Prepared in cooperation with the U.S. Department of Energy Office of Environmental Management, National Nuclear Security Administration, Nevada Site Office, under Interagency Agreement DE-EM0004969

\title{
Groundwater Characterization and Effects of Pumping in the Death Valley Regional Groundwater Flow System, Nevada and California, with Special Reference to Devils Hole
}

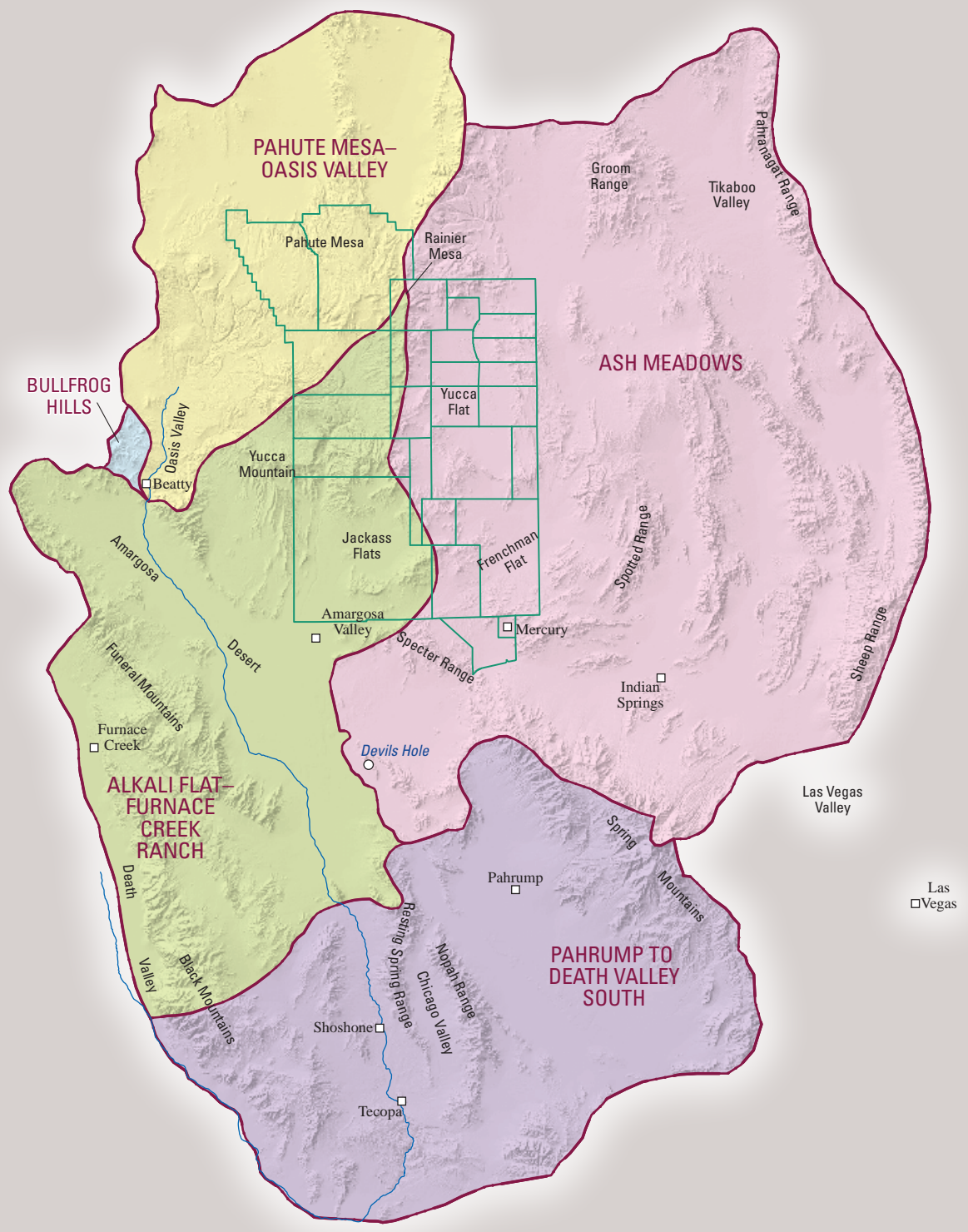

Professional Paper 1863

U.S. Department of the Interior

U.S. Geological Survey 
Cover: Map of study area showing Alkali Flat-Furnace Creek Ranch, Ash Meadows, Bullfrog Hills, Pahrump to Death Valley South, and Pahute Mesa-Oasis Valley groundwater basins; and Nevada National Security Site boundary and internal operations area, in the Death Valley regional flow system, Nevada and California. Source: U.S. Geological Survey. 


\section{Groundwater Characterization and Effects of Pumping in the Death Valley Regional Groundwater Flow System, Nevada and California, with Special Reference to Devils Hole}

By Keith J. Halford and Tracie R. Jackson

Prepared in cooperation with the U.S. Department of Energy Office of Environmental Management, National Nuclear Security Administration, Nevada Site Office, under Interagency Agreement DE-EM0004969

Professional Paper 1863 


\title{
U.S. Department of the Interior DAVID BERNHARDT, Secretary
}

\author{
U.S. Geological Survey \\ James F. Reilly II, Director
}

\section{U.S. Geological Survey, Reston, Virginia: 2020}

For more information on the USGS - the Federal source for science about the Earth, its natural and living resources, natural hazards, and the environment—visit https://www.usgs.gov or call 1-888-ASK-USGS.

For an overview of USGS information products, including maps, imagery, and publications, visit https://store.usgs.gov.

Any use of trade, firm, or product names is for descriptive purposes only and does not imply endorsement by the U.S. Government.

Although this information product, for the most part, is in the public domain, it also may contain copyrighted materials as noted in the text. Permission to reproduce copyrighted items must be secured from the copyright owner.

Suggested citation:

Halford, K.J., and Jackson, T.R., 2020, Groundwater characterization and effects of pumping in the Death Valley regional groundwater flow system, Nevada and California, with special reference to Devils Hole: U.S. Geological Survey Professional Paper 1863, 178 p., https://doi.org/10.3133/pp1863.

Associated data for this publication:

Jackson, T.R., and Halford, K.J., 2020, MODFLOW-2005 model and supplementary data used to characterize groundwater flow and effects of pumping in the Death Valley regional groundwater flow system, Nevada and California, with special reference to Devils Hole: U.S. Geological Survey data release, https://doi.org/10.5066/P9HIYVG2.

ISSN 1044-9612 (print) ISSN 2330-7102 (online) 


\section{Contents}

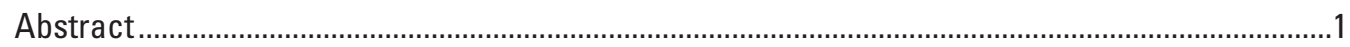

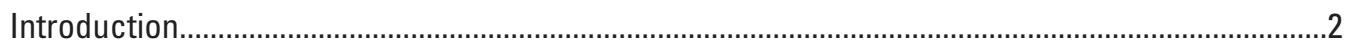

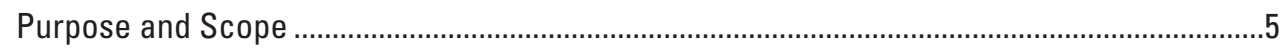

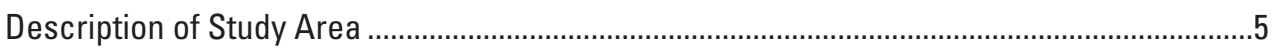

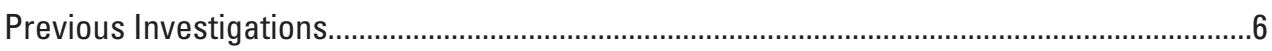

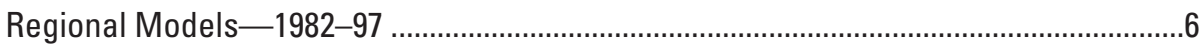

Regional Investigations_-1998-2004 .....................................................................

Predevelopment Discharge Investigations ..............................................................

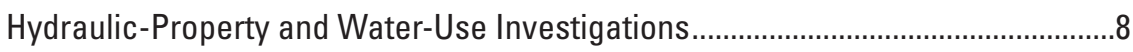

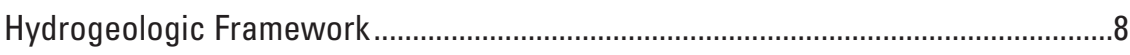

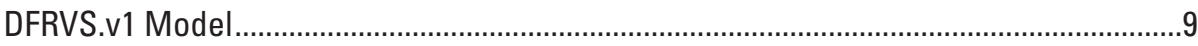

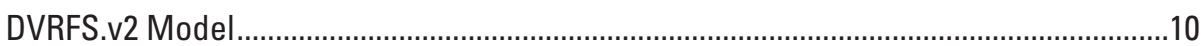

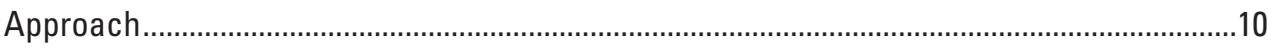

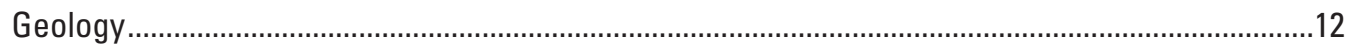

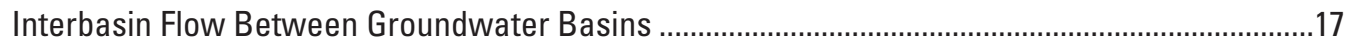

Predevelopment Groundwater Flow........................................................................................17

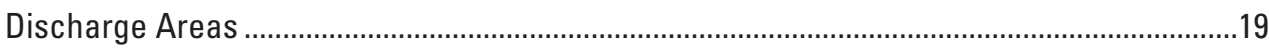

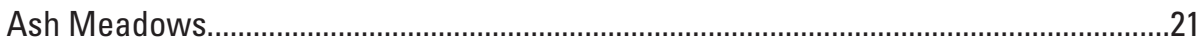

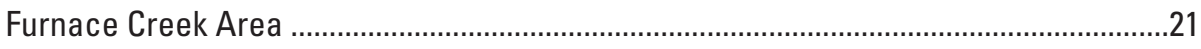

Previous Predevelopment Estimates And Conceptual Models ...............................21

DV3 Conceptual Model—Three Hydrologically Distinct Periods .............................25

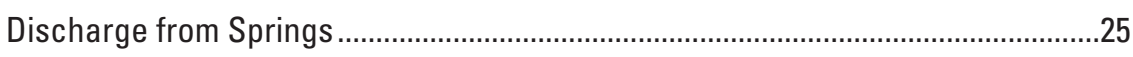

Discharge from Phreatophytes on Alluvial Fan ....................................................26

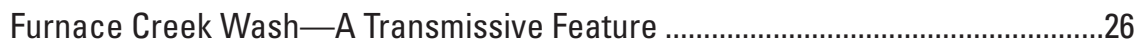

Mining-Tourism Period_A Steady-State Condition............................................28

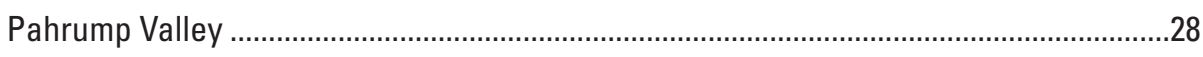

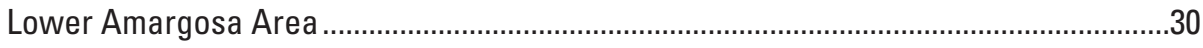

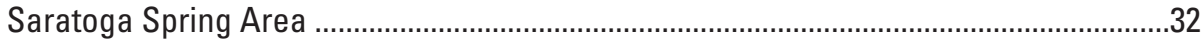

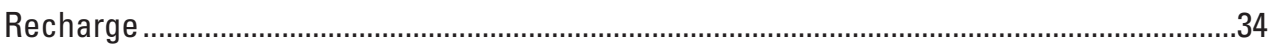

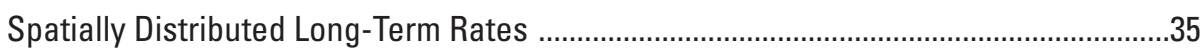

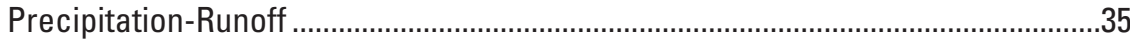

Perched and Semi-Perched Groundwater ……………..........................................36

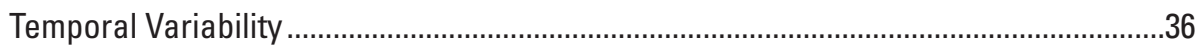

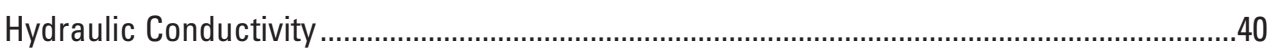

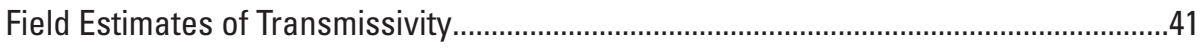

Transmissivity and Rock Type ...................................................................................4

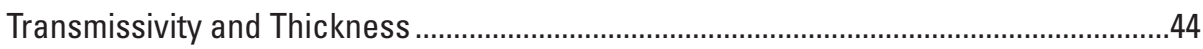

Hydraulic Conductivity and Depth ...............................................................................46

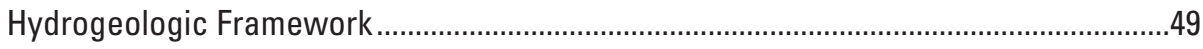

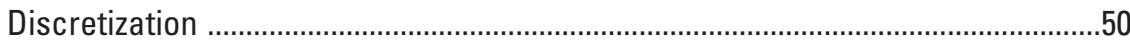

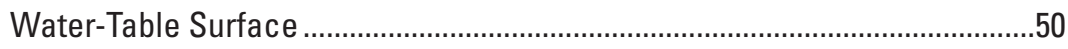

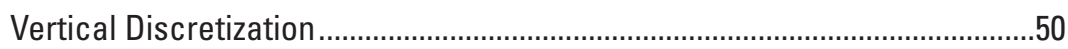

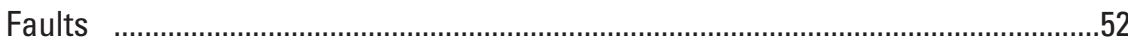




\section{Contents-Continued}

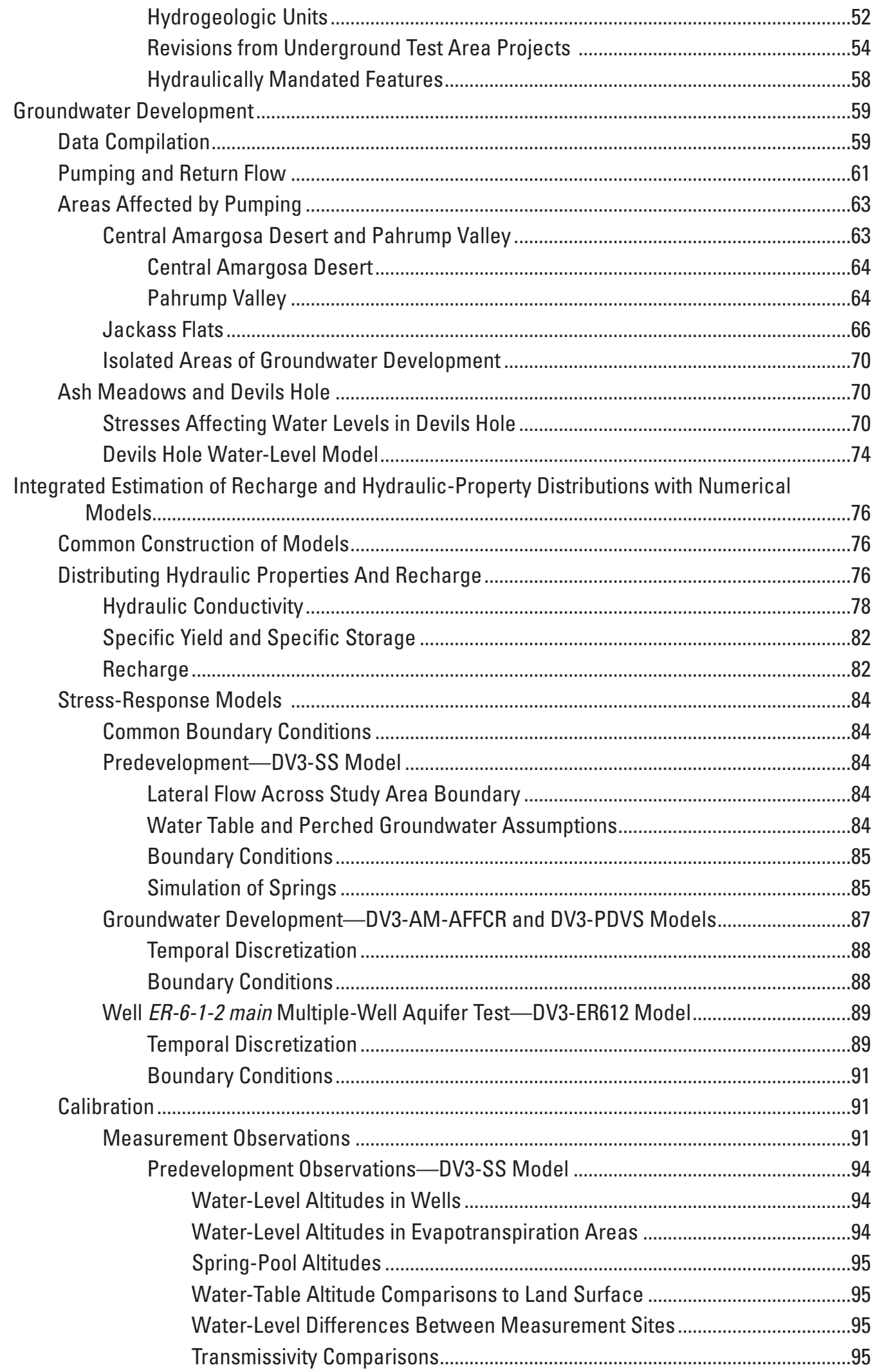




\section{Contents-Continued}

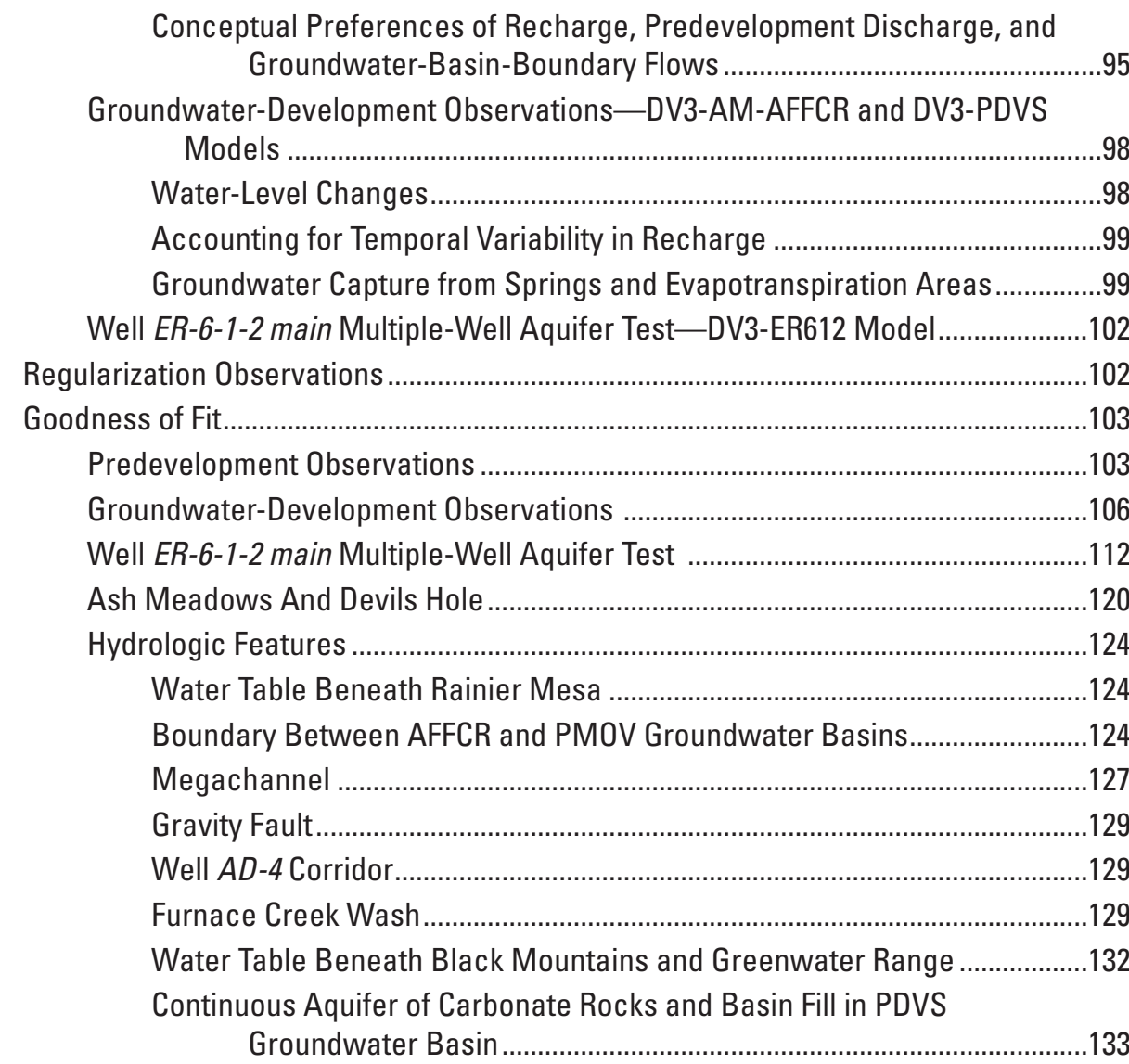

Simulated Predevelopment Groundwater Flow.........................................................................133

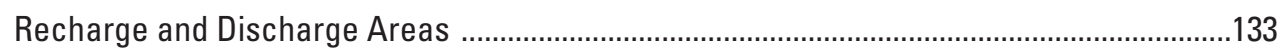

Flow from Ash Meadows Groundwater Basin to the Furnace Creek Area ..........................137

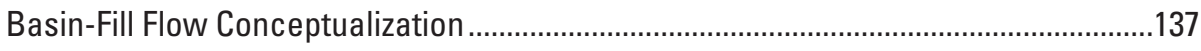

Flow Potential Through Well AD-4 Corridor ............................................................ 140

Flow Potential Through Basin Fill in the Central Amargosa Desert .......................141

Basin-Fill, Carbonate-Rock, and Volcanic-Rock Hydraulic Connections..............141

Geochemically Differentiated Sources of Furnace Creek Area Discharge ...........141

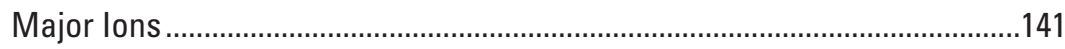

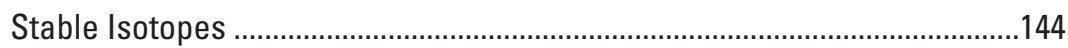

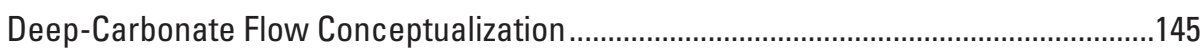

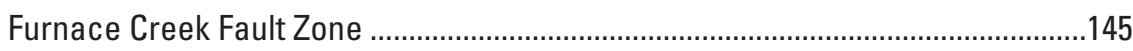

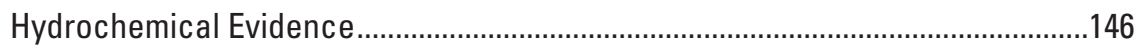

Contradictory Results from Drilling and Numerical Simulation .............................146

Basin-Fill Flow Path More Probable .....................................................................147

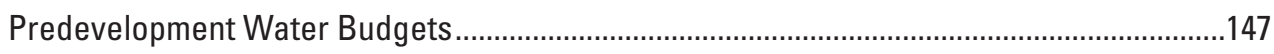

Pahute Mesa-Oasis Valley Groundwater Basin ........................................................147

Ash Meadows Groundwater Basin .............................................................................147

Alkali Flat-Furnace Creek Ranch Groundwater Basin ................................................150

Pahrump to Death Valley South Groundwater Basin...................................................150 


\section{Contents-Continued}

Rainier Mesa Groundwater Sub-Basin n
Effects of Groundwater Development
Extent of Water-Level Declines
Sources of Pumped Water
Reductions in Natural Discharges
Ash Meadows and Devils Hole

\section{Figures}

1. Map of study area showing groundwater basins and hydrographic areas in the Death Valley regional flow system, Nevada and California.

2. Map showing areal extent of previous regional groundwater models and the regional model [Death Valley version 3 (DV3)] used in this study, Nevada and California

3. Graph showing minimum, maximum, geometric mean, and 95-percent confidence interval of log-hydraulic conductivities in 9 hydrogeologic units in the Death Valley Regional Flow System version 2 model framework using 377 hydraulic-conductivity estimates, Nevada and California

4. Hydrograph showing measured and simulated water-level changes in Devils Hole from the Death Valley Regional Flow System versions 1 and 2 (DVRFS.v1 and DVRFS.v2) models, Nevada and California, 1930-2018.

5. Map showing major geologic structures, in the study area, Nevada and California .....16

6. Map showing groundwater basins and major discharge areas in the study area, Nevada and California ....................................................................................................18

7. Map showing springs and evapotranspiration areas in the Ash Meadows discharge area and vicinity, Nevada.

8. Conceptual model showing groundwater flow to springs and phreatophyte areas in the Ash Meadows discharge area, Nevada

9. Map showing discharge locations and the historical water-collection system in the Furnace Creek area, California

10. Hydrographs showing groundwater-level fluctuations in the Furnace Creek area from collection galleries in Furnace Creek Wash and water-supply wells, California, 2008-12.

11. Map showing discharge areas in Pahrump and Stewart Valleys, Nevada and California

12. Map showing discharge areas in the Lower Amargosa discharge area and extent of Pleistocene Lake Tecopa, Nevada and California 


\section{Figures-Continued}

13. Graph showing groundwater discharge to river and estimated evapotranspiration in the Amargosa River downstream of Borehole Spring, California, on February 27, 2014, and cumulative annual evapotranspiration

14. Map showing upgradient source and discharge areas for the Saratoga Spring area, California.

15. Graphs showing relation between precipitation rate and conceptual recharge rate from infiltration and runoff to the study area, and cumulative recharge resulting from this relation, in the study area, Nevada and California

16. Map showing conceptual recharge distribution, in the study area, Nevada and California

17. Graphs showing winter precipitation (October-March) and excess winter precipitation (recharge) using 125-percent threshold, and hypothetical water-level change under predevelopment (steady-state) conditions, in the study area, Nevada and California, 1900-2016

18. Hydrographs showing measured water levels and water-level models for wells U-19bk and USFWS DR-1, in the study area, Nevada and California, 1910-2018

19. Map showing transmissivity estimates from single-well aquifer tests and specific capacity, in the study area, Nevada and California

20. Graph showing volume of water pumped or displaced from single-well aquifer tests (pumping and slug tests) and specific capacity, in the study area, Nevada and California

21. Graphs showing minimum, maximum, median, and 95-percent confidence interval of log-transmissivities in four rock-type categories from 271 field estimates of transmissivity, in the study area, Nevada and California.

22. Graphs showing relation between transmissivity and thickness of carbonate rocks, volcanic rocks, basin fill, and low-permeability rocks, in the study area, Nevada and California

23. Graph showing relation between specific capacity and thickness of basin fill classified as permeable in the Amargosa Desert, Nevada

24. Graphs showing average, depth-dependent hydraulic conductivity in volcanic and carbonate rocks, in the study area, Nevada and California.

25. Map showing differences in the water-table surface between the Death Valley version 3 (DV3) and Death Valley Regional Flow System version 2 (DVRFS.v2) hydrogeologic framework, and areas where the DVRFS.v2 hydrogeologic framework was modified, in the study area, Nevada and California.

26. Example cross sections through intermediate grid of Death Valley Regional Flow System version 2 (DVRFS.v2) (Belcher and others, 2017; top cross section), and Death Valley version 3 (DV3; bottom cross section) hydrogeologic framework models, Nevada and California

27. Map showing extents of hydrogeologic framework models for Frenchman Flat, Yucca Flat-Climax Mine, Rainier Mesa-Shoshone Mountain, and Pahute Mesa corrective action units; extent of Frenchman Flat basin in Death Valley Regional Flow System version 2 model (DVRFS.v2) hydrogeologic framework; and areas where carbonate rocks at water table in DVRFS.v2 were revised to volcanic rocks, basin fill, or low-permeability rocks in Death Valley version 3 model (DV3) hydrogeologic framework based on lithologic well data, Nevada and California. 


\section{Figures-Continued}

28. Maps showing hydrogeologic units in Death Valley Regional Flow System version 2 model (DVRFS.v2), Death Valley version 3 model (DV3), and Fenelon and others (2012), at the water table beneath Yucca Flat, Nevada ...

29. Map showing pumping wells, areas affected by groundwater development, and hydraulic barriers, in the study area, Nevada and California

30. Graphs showing total annual groundwater withdrawals by water-use type, return flow, and predevelopment discharge by groundwater basin, in the study area, Nevada and California, 1910-2010, with withdrawal estimates from 2010 projected through 2018

31. Graph showing net groundwater withdrawals and return flow, in the study area, Nevada and California, 1910-2018. .64

32. Map showing observation wells affected by groundwater development and hydraulic barriers, in the study area, Nevada and California

33. Hydrographs showing water-level changes in well $A D-5$ in the central Amargosa Desert and well ESB1 in Pahrump Valley, Nevada, 1910-2018. 66

34. Graph showing net pumpage in the Alkali Flat-Furnace Creek Ranch groundwater basin, and hydrographs showing measured water levels in wells $B G M W-8$, NC-EWDP-Washburn-1X(deep), DVJ-02, and Travertine Point 1, in the central Amargosa Desert, Nevada and California,1910-2018.

35. Graph showing net pumpage in the Pahrump to Death Valley South groundwater basin, and hydrographs showing measured water levels in wells BLM Stewart Valley Well, Last Chance Well, Jeep Trail, 021NO10E04L01S, and Hwy 127 MM21-1, around Pahrump Valley, Nevada and California, 1910-2018

36. Graph showing annual pumping from Jackass Flats, and hydrographs showing measured water levels in wells JF-2, J-13 WW, and JF-3, in Jackass Flats, Nevada, 1950-2018

37. Map showing hydrogeologic units at the water table, wells, Devils Hole, springs, pumping wells, and injection well [Devils Hole Well (AM-5)] in the Ash Meadows discharge area and surrounding areas, Nevada .

38. Graph showing monthly pumping from northern wells, southern wells, and Spring Meadows 6 well and injection into Devils Hole Well (AM-5) by Cappaert Enterprises in the Ash Meadows discharge area, Nevada, 1968-82...

39. Graph showing monthly pumping and injection from the Ash Meadows discharge area, and hydrographs showing measured water levels in wells Devils Hole Well (AM-5), Point of Rocks North (AM-6), and Spring Meadows 7db2, during groundwater development by Cappaert Enterprises, Nevada, 1965-2000.

40. Graphs showing estimated natural water-level fluctuations, long-term natural trend of recharge and steady discharge, measured water levels, water-level model that includes all natural and pumping stresses, and pumping effects without natural fluctuations in Devils Hole, Nevada, 1900-2018

41. Map showing boundary of Death Valley version 3 (DV3) model and areas of finer discretization, in the study area, Nevada and California

42. Diagram showing process for distributing hydraulic conductivities from pilot points to U.S. Geological Survey finite-difference model (MODFLOW) layers through hydrogeologic units in a hydrogeologic framework.

43. Map showing conceptual transmissivity distribution in shallow carbonate rocks and hydraulic-conductivity pilot points for the shallow carbonate rocks, in the study area, Nevada and California 


\section{Figures-Continued}

44. Map showing extents of all hydrogeologic units and hydraulic-conductivity pilot points at the water table, in the study area, Nevada and California.

45. Map showing estimated recharge distribution and recharge pilot points, from the Death Valley version 3 steady-state model (DV3-SS), in the study area, Nevada and California

46. Map showing locations and types of boundary conditions and measurement observations used in the Death Valley version 3 steady-state model (DV3-SS), in the study area, Nevada and California

47. Map showing observation wells monitored during well ER-6-1-2 main multiple-well aquifer test, in the study area, Nevada and California.

48. Conceptual diagram showing the model-run process of the Death Valley version 3 model (DV3), which is an integrated stress-response model, in the study area, Nevada and California

49. Map showing lateral and vertical water-level difference observations used in the Death Valley version 3 steady-state model (DV3-SS), in the study area, Nevada and California

50. Map showing transmissivity observations from aquifer tests and specific capacities, in the study area, Nevada and California.

51. Hydrograph showing "raw" water-level measurements, measured water levels, which are annual averages of measured water-level data during an annual stress period, and simulated water levels in well ESB1, Nevada, 1910-2020

52. Hydrographs showing "raw" water-level measurements, measured (average) water-level changes, and simulated water-level changes in terms of depth to water level and water-level change, at well Travertine Point 1, California, 1950-2018

53. Map showing estimated transmissivity distribution from integrated Death Valley version 3 model, extent of megachannel, and wells with measured water levels noticeably affected by natural fluctuations from recharge, Nevada National Security Site and vicinity, Nevada

54. Graph showing comparison of measured and simulated water-level altitudes from the calibrated Death Valley Regional Flow System version 2 model (DVRFS.v2) and Death Valley version 3 steady-state model (DV3-SS), in the study area, Nevada and California

55. Map showing steady-state water-level altitude residuals in the Death Valley version 3 steady-state model (DV3-SS), in the study area, Nevada and California

56. Graph showing comparison of simulated and measured transmissivities from the Death Valley Regional Flow System version 2 model (DVRFS.v2) and Death Valley version 3 steady-state model (DV3-SS), in the study area, Nevada and California ......107

57. Map showing maximum simulated drawdown and selected observation sites with hydrographs shown in this report, in the study area, Nevada and California, 2018

58. Hydrographs showing "raw" water-level measurements and simulated and measured (average) water-level declines in wells AD-5, TG Well, and Inyo-BLM1, in the central Amargosa Desert, Nevada and California, 1950-2018.

59. Hydrographs showing "raw" water-level measurements and simulated and measured (average) water-level declines in wells $A D-1$, NC-EWDP-Washburn-1X (deep), DVJ-02, and WRPMW-4 that result from pumping in the central Amargosa Desert, Nevada and California, 1950-2018 


\section{Figures-Continued}

60. Hydrographs showing "raw" water-level measurements and simulated and measured (average) water levels in wells GSA, SD2, and JAW, in Pahrump Valley, Nevada, 1910-2020

61. Hydrographs showing "raw" water-level measurements and simulated and measured (average) water-level changes in wells BLM Stewart Valley Well, Last Chance Well, Jeep Trail, 021N010E04L01S, 022N007E13L01S, and Hwy 127 MM21-1 that result from pumping in Pahrump Valley, in the study area, Nevada and California, 1910-2020

62. Hydrographs showing comparison of simulated and measured discharges from Bennetts and Manse Springs, Pahrump Valley, Nevada, 1910-2018

63. Hydrographs showing "Raw" water-level measurements and simulated and measured (average) water-level changes in well WW-4 in CP basin, and USAF Well 3 in Indian Springs, Nevada, 1950-2018.

64. Map showing estimated specific-yield distribution and pilot points from integrated Death Valley version 3 model, in the study area, Nevada and California ....116

65. Map showing estimated storage-coefficient distribution, which is specific storage times thickness of model layers 2-6, and pilot points from integrated Death Valley version 3 model, in the study area, Nevada and California

66. Hydrographs showing periods when well ER-6-1-2 main pumped; simulated drawdowns from Death Valley version 3 model simulating Jackson and Halford, 2020 pumping during the ER-6-1-2 main multiple-well aquifer test (DV3-ER612); and measured drawdowns, which were estimated from water-level models (Jackson and Halford, 2019), in wells ER-3-1-2 (shallow), and ER-7-1, Nevada, 2004-05

67. Hydrographs showing periods when well ER-6-1-2 main pumped; simulated drawdowns from Death Valley version 3 model simulating Jackson and Halford, 2020 pumping during the ER-6-1-2 main multiple-well aquifer test (DV3-ER612); and measured drawdowns, which were estimated from water-level models (Jackson and Halford, 2019), in wells UE-1h, and Tracer Well 3, Nevada, 2004-05.

68. Map showing estimated transmissivity distribution from integrated Death Valley version 3 model (DV3), extent of megachannel, and observation sites during well ER-6-1-2 main multiple-well aquifer test, in the study area, California and Nevada.....119

69. Graphs showing measured, and DV3-SS- and DVRFS.v2-simulated pool altitudes and spring discharges, and total measured and simulated spring discharges, in the Ash Meadows discharge area, Nevada.

70. Hydrographs showing "raw" water-level measurements, measured (average) water-level changes, and simulated water-level changes in the megachannel, including wells Tracer Well 3, North Crystal Well, and Spring Meadows 12, and Devils Hole, Nevada, 1950-2018

71. Graph showing monthly pumping by Cappaert Enterprises; injection into Devils Hole Well (AM-5); total simulated capture in the Ash Meadows discharge area from DV3-AM-AFFCR model; and hydrographs showing measured and simulated (DV3-AM-AFFCR model) discharges from Jack Rabbit, Point of Rocks, and Big Springs, Nevada, 1968-82.

72. Map showing estimated transmissivity distribution from integrated Death Valley version 3 model and traces of water-level profiles through major hydrologic features, in the study area, Nevada and California 


\section{Figures-Continued}

73. Measured water-level profile and simulated water-level profiles from Death Valley Regional Flow System version 2 model (DVRFS.v2) and Death Valley version 3 steady-state model (DV3-SS), and transmissivity profile from the DV3-SS model, through Rainier Mesa, Nevada

74. Measured and simulated water-level profiles, and transmissivity profiles from the Death Valley version 3 steady-state model (DV3-SS), through boundary between Pahute Mesa-Oasis Valley and Alkali Flat-Furnace Creek Ranch groundwater basins, Nevada.

75. Measured and simulated water-level profiles, and transmissivity profiles from the Death Valley version 3 steady-state model (DV3-SS), through megachannel from Yucca Flat to the Ash Meadows discharge area, Nevada and California ...

76. Measured and simulated water-level profiles, and transmissivity profiles from the Death Valley version 3 steady-state model (DV3-SS), through the well $A D-4$ corridor, Nevada and California

77. Measured and simulated water-level profiles, and transmissivity profile from the Death Valley version 3 steady-state model (DV3-SS), through the Furnace Creek area, California

78. Measured and simulated water-level profiles, and transmissivity profile from the Death Valley version 3 steady-state model (DV3-SS), through the Black Mountains and Greenwater Range, California

79. Measured and simulated water-level profiles, and transmissivity profile from the Death Valley version 3 steady-state model (DV3-SS), from the Spring Mountains to the Amargosa River, Nevada and California

80. Map showing groundwater-flow paths to selected discharge areas and contributing recharge areas for discharge areas in Oasis Valley, Ash Meadows, Furnace Creek, Lower Amargosa, and Pahrump and Stewart Valleys, Nevada and California

81. Cross section along a simulated groundwater-flow path from the Spring Mountains to the Amargosa River, Nevada and California

82. Map showing basin-fill and deep-carbonate flow-path conceptualizations from the Ash Meadows groundwater basin to discharge areas in Furnace Creek, Nevada and California

83. Cross section along a simulated groundwater-flow path from the Ash Meadows groundwater basin to the Furnace Creek area through the well $A D-4$ corridor, Nevada and California

84. Map showing water-chemistry sites in the Alkali Flat-Furnace Creek Ranch and Ash Meadows groundwater basins, Nevada and California

85. Piper diagram showing major ion water chemistry for sites in the Alkali Flat-Furnace Creek Ranch and Ash Meadows groundwater basins, Nevada and California

86. Graph showing stable isotopes for sites in the Alkali Flat-Furnace Creek Ranch and Ash Meadows groundwater basins, Nevada and California

87. Maps showing flow-weighted paths from Furnace Creek discharge area to contributing recharge areas in the Death Valley Regional Flow System version 2 model (DVRFS.v2) and Death Valley version 3 steady-state model (DV3-SS), in the study area, Nevada and California. 


\section{Figures-Continued}

88. Map showing predevelopment water budgets within and between geographic areas in the study area from the Death Valley version 3 steady-state model (DV3-SS), Nevada and California

89. Graphs showing total annual groundwater withdrawals by groundwater-storage depletion, return flow, and capture of discharge from springs and evapotranspiration areas by groundwater basins Alkali Flat-Furnace Creek Ranch and Ash Meadows, Pahute Mesa-Oasis Valley, and Pahrump to Death Valley South, in the study area, 1910-2018, with withdrawal estimates from 2010 projected to 2018.

90. Hydrographs showing measured and simulated discharges from Travertine and Texas Springs in the Furnace Creek area, California, 1950-2018

91. Map showing pumping centers analyzed for affecting water levels in Devils Hole, Nevada and California

92. Graphs showing annual net pumpage by pumping center and water-level changes in Devils Hole by pumping center, as simulated with the Death Valley version 3 stress-response model simulating groundwater development in the Ash Meadows, Alkali Flat-Furnace Creek Ranch, and Pahute Mesa-Oasis Valley groundwater basins, Nevada and California, 1950-2018

93. Graphs showing groundwater withdrawals and injections; and measured water levels, and simulated water levels with and without injections, in Devils Hole Well (AM-5), Nevada, 1960-2000.

94. Hydrograph showing measured water levels without long-term natural fluctuations from recharge, and simulated water levels from DV3-AM-AFFCR and DV3-PRED models, in Devils Hole, Nevada, 1950-2100.

95. Map showing simulated 165 -year advective-flow paths from 296 underground nuclear tests detonated near or below the water table, in the study area, Nevada National Security Site, Nevada 


\section{Tables}

1. Predevelopment discharge estimates from previous and current investigations for Alkali Flat-Furnace Creek Ranch, Ash Meadows, and Pahute Mesa-Oasis Valley groundwater basins, Nevada and California, 1982-2018 ......................................8

2. Groundwater models developed for Death Valley version 3 model (DV3) project ..........12

3. Major lithology and occurrence descriptions of hydrogeologic units in the study area, as defined in the Death Valley Regional Flow System version 2 hydrogeologic framework, Nevada and California

4. Predevelopment discharge by discharge area for previous and current regional flow analyses of the study area, Nevada and California

5. Predevelopment and post-development discharge estimates for all sites in the Furnace Creek area, California, prior to 1880 to 2018

6. Relation between simple-rock types and previously defined hydrogeologic units in the Death Valley Regional Flow System version 2 model (DVRFS.v2) hydrogeologic framework, Nevada and California

7. Hydrogeologic units in the Death Valley version 3 model (DV3) hydrogeologic framework that were defined by rock type, depth, and previously defined hydrogeologic units from the Death Valley Regional Flow System version 2 model (DVRFS.v2) project, Nevada and California.

8. Fraction of return flow and velocity through unsaturated zone, in the study area, Nevada and California

9. Springs explicitly simulated in Death Valley version 3 steady-state model (DV3-SS), estimated predevelopment spring discharge, and the minimum measured discharge from springs during groundwater development, in the study area, Nevada and California

10. Summary of observations and Death Valley version 3 model (DV3) fit to simulated comparisons, in the study area, Nevada and California ....

11. Expected and simulated groundwater-flow rate observations, in the study area, Nevada and California

12. Summary of major hydrologic features simulated in the integrated Death Valley version 3 model (DV3), for the study area, Nevada and California.

13. Simulated discharges by discharge area for predevelopment (DV3-SS model), 2018 (DV3-AM-AFFCR or DV3-PDVS model), and projected future conditions in 2100 (DV3-PRED model), in the study area, Nevada and California

14. Pumping centers; net pumpage volumes, 1969-2018; and effect of pumping centers on water levels in Devils Hole, in the study area, Nevada and California 


\section{Conversion Factors}

U.S. customary units to International System of Units

\begin{tabular}{|c|c|c|}
\hline Multiply & By & To obtain \\
\hline \multicolumn{3}{|c|}{ Length } \\
\hline inch (in.) & 25.4 & millimeter (mm) \\
\hline foot (ft) & 0.3048 & meter $(\mathrm{m})$ \\
\hline mile (mi) & 1.609 & kilometer (km) \\
\hline \multicolumn{3}{|c|}{ Area } \\
\hline square foot $\left(\mathrm{ft}^{2}\right)$ & 0.09290 & square meter $\left(m^{2}\right)$ \\
\hline square mile $\left(\mathrm{mi}^{2}\right)$ & 2.590 & square kilometer $\left(\mathrm{km}^{2}\right)$ \\
\hline acre & 4,047 & square meter $\left(\mathrm{m}^{2}\right)$ \\
\hline \multicolumn{3}{|c|}{ Volume } \\
\hline gallon (gal) & 3.785 & Liter (L) \\
\hline acre-foot (acre-ft) & 1,233 & cubic meter $\left(\mathrm{m}^{3}\right)$ \\
\hline cubic mile $\left(\mathrm{mi}^{3}\right)$ & 4.168 & cubic kilometer $\left(\mathrm{km}^{3}\right)$ \\
\hline \multicolumn{3}{|c|}{ Flow rate } \\
\hline acre-foot per year (acre-ft/yr) & 1,233 & cubic meter per year $\left(\mathrm{m}^{3} / \mathrm{yr}\right)$ \\
\hline cubic foot per second $\left(\mathrm{ft}^{3} / \mathrm{s}\right)$ & 0.02832 & cubic meter per day $\left(\mathrm{m}^{3} / \mathrm{d}\right)$ \\
\hline gallon per minute (gal/min) & 0.06309 & liter per second $(\mathrm{L} / \mathrm{S})$ \\
\hline \multicolumn{3}{|c|}{ Velocity } \\
\hline foot per day (ft/d) & 0.3048 & meter per day (m/d) \\
\hline foot per year (ft/yr) & 0.3048 & meter per year (m/yr) \\
\hline \multicolumn{3}{|c|}{ Radioactivity } \\
\hline picocurie per liter (pCi/L) & 0.037 & becquerel per liter (B q/L) \\
\hline \multicolumn{3}{|c|}{ Specific capacity } \\
\hline gallon per minute per foot ([gal/min]/ft) & 0.2070 & liter per second per meter $([\mathrm{L} / \mathrm{s}] / \mathrm{m})$ \\
\hline \multicolumn{3}{|c|}{ Hydraulic gradient } \\
\hline foot per foot (ft/ft) & 1 & meter per meter $(\mathrm{m} / \mathrm{m})$ \\
\hline foot per mile (ft/mi) & 0.1894 & meter per kilometer $(\mathrm{m} / \mathrm{km})$ \\
\hline \multicolumn{3}{|c|}{ Transmissivity } \\
\hline foot squared per day (ft²/d) & 0.09290 & meter squared per day $\left(\mathrm{m}^{2} / \mathrm{d}\right)$ \\
\hline
\end{tabular}

International System of Units to U.S. customary units

\begin{tabular}{|c|c|c|}
\hline Multiply & By & To obtain \\
\hline \multicolumn{3}{|c|}{ Length } \\
\hline meter (m) & 3.281 & foot $(\mathrm{ft})$ \\
\hline \multicolumn{3}{|c|}{ Flow rate } \\
\hline cubic meter per day $\left(\mathrm{m}^{3} / \mathrm{d}\right)$ & 264.2 & gallon per day (gal/d) \\
\hline kilogram per second (kg/s) & 2.205 & pound per second (Ib/s) \\
\hline \multicolumn{3}{|c|}{ Chemical constituent concentration } \\
\hline $\mathrm{mg} / \mathrm{L}$ & 0.0001335 & ounce per U.S. gallon (oz/gal) \\
\hline \multicolumn{3}{|c|}{ Density } \\
\hline gram per cubic centimeter $\left(\mathrm{g} / \mathrm{cm}^{3}\right)$ & 62.4220 & pound per cubic foot (Ib/ft³) \\
\hline
\end{tabular}

Temperature in degrees Fahrenheit $\left({ }^{\circ} \mathrm{F}\right)$ may be converted to degrees Celsius as follows:

$\left({ }^{\circ} \mathrm{C}\right){ }^{\circ} \mathrm{C}=\left({ }^{\circ} \mathrm{F}-32\right) / 1.8$. 


\section{Datums}

Vertical coordinate information is referenced to the National Geodetic Vertical Datum of 1929 (NGVD29).

Horizontal coordinate information is referenced to the North American Datum of 1983 (NAD 83).

Altitude, as used in this report, refers to distance above NGVD29.

\section{Supplemental Information}

Concentrations of chemical constituents in water are given in milligrams per liter (mg/L).

Activities for radioactive constituents in water are given in picocuries per liter ( $\mathrm{pCi} / \mathrm{L})$.

Transmissivity: The standard unit for transmissivity is cubic foot per day per square foot times foot of aquifer thickness $\left[\left(\mathrm{ft}^{3} / \mathrm{d}\right) / \mathrm{ft}^{2}\right] \mathrm{ft}$. In this report, the mathematically reduced form, foot squared per day $\left(\mathrm{ft}^{2} / \mathrm{d}\right)$, is used for convenience.

\section{Abbreviations}

2D-FD two-dimensional finite difference

2D-FE two-dimensional finite element

AFFCR Alkali Flat-Furnace Creek Ranch

CAU corrective action unit

DEM digital elevation model

DVSS1 Death Valley steady-state version 1 model

DVSS2 Death Valley steady-state version 2 model

DVRFS Death Valley regional flow system

DVRFS.v1 Death Valley Regional Flow System version 1 model

DVRFS.v2 Death Valley Regional Flow System version 2 model

DV3 Death Valley version 3 model

DV3-AM-AFFCR Death Valley version 3 stress-response model simulating groundwater development in the Ash Meadows, Alkali Flat-Furnace Creek Ranch, and Pahute Mesa-Oasis Valley groundwater basins

DV3-ER612 Death Valley version 3 stress-response model simulating pumping during the well ER-6-1-2 main multiple-well aquifer test

DV3-PDVS Death Valley version 3 stress-response model simulating groundwater development in the Pahrump to Death Valley South groundwater basin

DV3-PRED Death Valley version 3 predictive model

DV3-SS Death Valley version 3 stress-response model simulating steady-state (predevelopment) conditions 


\section{Abbreviations-Continued}

$\begin{array}{ll}\text { ET } & \text { evapotranspiration } \\ \text { ET }_{\text {GW }} & \text { groundwater discharge by evapotranspiration } \\ \text { HUF } & \text { Hydrogeologic-Unit Flow package of MODFLOW } \\ \text { IT } & \text { IT Corporation } \\ \text { MODFLOW } & \text { USGS modular, finite-difference, groundwater-flow model } \\ \text { MWAT } & \text { multiple-well aquifer test } \\ \text { NNSS } & \text { Nevada National Security Site } \\ \text { PDVS } & \text { Pahrump to Death Valley South } \\ \text { PEST } & \text { Parameter ESTimation code } \\ \text { PRISM } & \text { Precipitation-elevation Regressions on Independent Slopes Model } \\ \text { PMOV } & \text { Pahute Mesa-Oasis Valley } \\ \text { RMS } & \text { root-mean-square } \\ r^{2} & \text { coefficient of determination } \\ \text { SDWA } & \text { Safe Drinking Water Act } \\ \text { UGTA } & \text { Underground Test Area } \\ \text { USGS } & \text { U.S. Geological Survey } \\ \text { VSU } & \text { volcanic-sedimentary unit }\end{array}$




\title{
Groundwater Characterization and Effects of Pumping in the Death Valley Regional Groundwater Flow System, Nevada and California, with Special Reference to Devils Hole
}

\author{
By Keith J. Halford and Tracie R. Jackson
}

\begin{abstract}
Groundwater flow and development were characterized in four groundwater basins of the Death Valley regional flow system in Nevada and California with calibrated, groundwater-flow models. Natural groundwater discharges in the Furnace Creek, L ower A margosa, and Saratoga Spring areas were defined and distributed consistently with a revised hydrogeologic framework. This simplified hydrogeologic framework was limited to four hydraulically unique, hydrogeologic units: (1) basin fill; (2) carbonate rocks; (3) volcanic rocks; and (4) low-permeability granitic and siliciclastic rocks. Hydrogeologic units and division of carbonate and volcanic rocks between shallow and deep were supported by results from 271 aquifer tests and specificcapacity estimates. Greater than 90 percent of field-estimated transmissivity occurred within 1,600 feet (ft) of the water table. Pumping in the study area from 1960 to 2010 averaged 46,000 acre-feet per year (acre-ft/yr), which is 80 percent of the predevelopment discharge. The central Amargosa Desert and Pahrump Valley were the two primary pumping centers and measurably affected water levels across 900 square miles in 2018.

Water levels in Devils Hole were a special focus because endangered Devils Hole pupfish (Cyprinodon diabolis) are affected by water-level declines. Pumping 42,100 acre-ft by Cappaert Enterprises, formerly Spring M eadows, Inc., caused a $2.3 \mathrm{ft}$ water-level decline in Devils Hole, which temporarily reduced habitat of Devils Hole pupfish by 85 percent in 1972. If no pumping occurred, water levels in Devils Hole would have risen naturally about $1 \mathrm{ft}$ between 1973 and 2018 from temporal variations in recharge. The $2.6-\mathrm{ft}$ range of measured
\end{abstract}

water-level changes in Devils Hole was simulated with a root-mean-square error of $0.2 \mathrm{ft}$ during the 70 -year period of record. Simulated water-level declines from pumping totaled $1.4 \mathrm{ft}$ in 2018, with 25 and 34 percent attributed to pumping by Cappaert Enterprises and the central A margosa Desert, respectively. Water levels in Devils Hole will decline at rates of $0.1-0.2 \mathrm{ft}$ per decade if pumping from $A$ sh $M$ eadows groundwater basin and the central A margosa D esert continue at current rates. Effects of future natural water-level fluctuations remain unknown.

A sh $M$ eadows and $A$ Ikali Flat-Furnace $C$ reek $R$ anch groundwater basins are hydraulically connected near well $A D-4$, about 5 miles south of the town of A margosa Valley, Nevada. About 40 percent of the discharge from the Furnace $C$ reek area is recharged in the $A$ sh $M$ eadows groundwater basin. Basin fill in the central Amargosa Desert hydraulically connects carbonate rocks east of well $A D-4$ with saturated carbonate rocks in the Funeral Range. A bout 7 percent of the 960,000 acre-ft pumped from A sh M eadows and A lkali Flat-Furnace Creek Ranch groundwater basins prior to 2019 was captured discharge from springs and phreatophytes. G reater than 40 percent of the 2,080,000 acre-ft pumped from Pahrump Valley between 1910 and 2019 was capture that primarily discharged from Bennetts and Manse Springs.

Simulated advective-flow distances and velocities from underground nuclear tests are within the range of advective transport calculations from tritium data and previous radionuclide transport investigations. Boundary conditions and flow rates from the regional model in this study are plausible for local-scale flow and radionuclide transport models. Simulated 165-year groundwater-flow paths do not extend into pumping areas and effects of regional pumping on advective transport are negligible. 


\section{Introduction}

Potential radionuclide transport, effects of groundwater pumping, and groundwater-basin boundary uncertainty are of interest in the Death Valley regional flow system, which includes four groundwater basins in Nevada and California: (1) Pahute Mesa-Oasis Valley (PMOV); (2) Alkali Flat-Furnace Creek Ranch (AFFCR); (3) Ash Meadows; and (4) Pahrump to Death Valley South (PDVS). These groundwater basins compose the $6,720,000$-acre study area (fig.1). Radionuclides were introduced into the groundwater system by underground nuclear testing beneath the Nevada National Security Site (NNSS). Groundwater has been pumped primarily for irrigation in Pahrump Valley and the central A margosa Desert ( $M$ oreo and J ustet, 2008), where groundwater withdrawals have considerably lowered water levels more than $10 \mathrm{mi}$ from each pumping center. Pumping for irrigation in the A sh $\mathrm{M}$ eadows discharge area during the 1970s directly affected water levels in Devils Hole ${ }^{1}$, the exclusive habitat of the Devils Hole pupfish, Cyprinodon diabolis (Dudley and Larson, 1976). [Discharge in this report refers to predevelopment (natural) groundwater discharge from springs and evapotranspiration areas, whereas pumping discharge is referred to as either groundwater development or pumping]. Observed water-level changes in Devils Hole have raised awareness about potential effects of groundwater pumping on other federally protected groundwater-dependent ecosystems in the regional flow system. Addressing groundwater-basin boundary uncertainty is of interest for estimating potential radionuclide transport from Pahute $M$ esa (Fenel on and others, 2016) and for determining hydraulic connections between pumping centers and groundwaterdependent ecosystems across groundwater-basin boundaries. These problems require regional analysis because considerable flow occurs between some groundwater basins (Winograd and Thordarson, 1975).

Investigation and long-term monitoring of radionuclides from 828 underground nuclear tests beneath the NNSS from 1951 to 1992 (U.S. Department of Energy, 2015) are the focus of the U.S. Department of Energy Underground Test Area activity (U.S. Department of Energy, 2010). An objective of the long-term activity is to assess potential transport downgradient of detonations. Radionuclide movement from F renchman Flat, Y ucca Flat-Climax M ine, Rainier M esaShoshone M ountain, and western and central Pahute M esa corrective action units (CAUs) has been investigated since the 1990s. Western and central Pahute M esa CAUs will be referred to as the Pahute $\mathrm{M}$ esa $\mathrm{CAU}$ in this report. Regional

\footnotetext{
${ }^{1} \mathrm{G}$ roundwater sites, including wells and springs, are italicized and hyperlinked to their respective data stored in the U.S. Geological Survey National Water Information System database.
}

analysis of groundwater flow remains necessary for hydrologic context around CAUs and to estimate advective movement beyond CAUs. Boundary conditions and flow rates from regional groundwater models also are used to support localscale CAU models of groundwater flow and radionuclide transport (Navarro-Intera, LLC, 2013). Because regional groundwater models implicitly estimate advective transport, showing advective movement along groundwater-flow paths is a relevant way to evaluate the reasonableness of using simulated flow rates from a regional model in local-scale models.

Substantial groundwater pumping for irrigation occurred after 1945 with the introduction of high-capacity, turbine pumps (Harrill, 1986; Moreo and others, 2003). Successful artesian wells were drilled initially in Pahrump Valley and the central A margosa Desert beginning in 1913 and 1916, respectively, but total irrigated acreage was less than 700 acres and annual pumping totaled 4,000 acre-ft prior to 1945 (M oreo and Justet, 2008). Total irrigated acreage increased more than tenfold to almost 10,000 acres and annual pumping from Pahrump Valley and the central A margosa D esert exceeded 46,000 acre-ft in 1965 (M oreo and others, 2003). A nnual pumping remains substantial, with 17,200 and 17,600 acre-ft pumped from Pahrump Valley and the central A margosa Desert, respectively, in 2010. More than 80 percent of pumpage in the central A margosa Desert supplied irrigation, whereas irrigation accounted for less than one-quarter of pumpage in Pahrump Valley during 2010 (Elliott and M oreo, 2018).

Groundwater development in the Ash Meadows discharge area and near Devils Hole during the late 1960s conflicted with preservation of an endangered species, the Devils Hole pupfish. Ash Meadows discharge area was developed considerably between 1967 and 1970 by a ranching corporation, Spring M eadows, Inc. (Dudley and Larson, 1976). Government and private conservationists forecasted extinction of the Devils Hole pupfish in response to expected water-level declines from pumping by Spring M eadows, Inc., which became Cappaert Enterprises after 1972 (Dudley and Larson, 1976; Williams and others, 1996). These concerns established a Desert Pupfish Task Force in 1969 that recommended identifying causes of water-level declines in Devils Hole. A scientific investigation by the U.S. Geological Survey (USGS) correlated pumping from eleven wells in the Ash Meadows discharge area with water-level declines in Devils Hole (Dudley and Larson, 1976). The established correlation was sufficient for the U.S Supreme Court, in the 1976 court case Cappaert v. United States (426 U.S. 128 [1976]), to limit pumping of groundwater so that a minimum pool elevation is maintained in Devils Hole (Williams and others, 1996). 


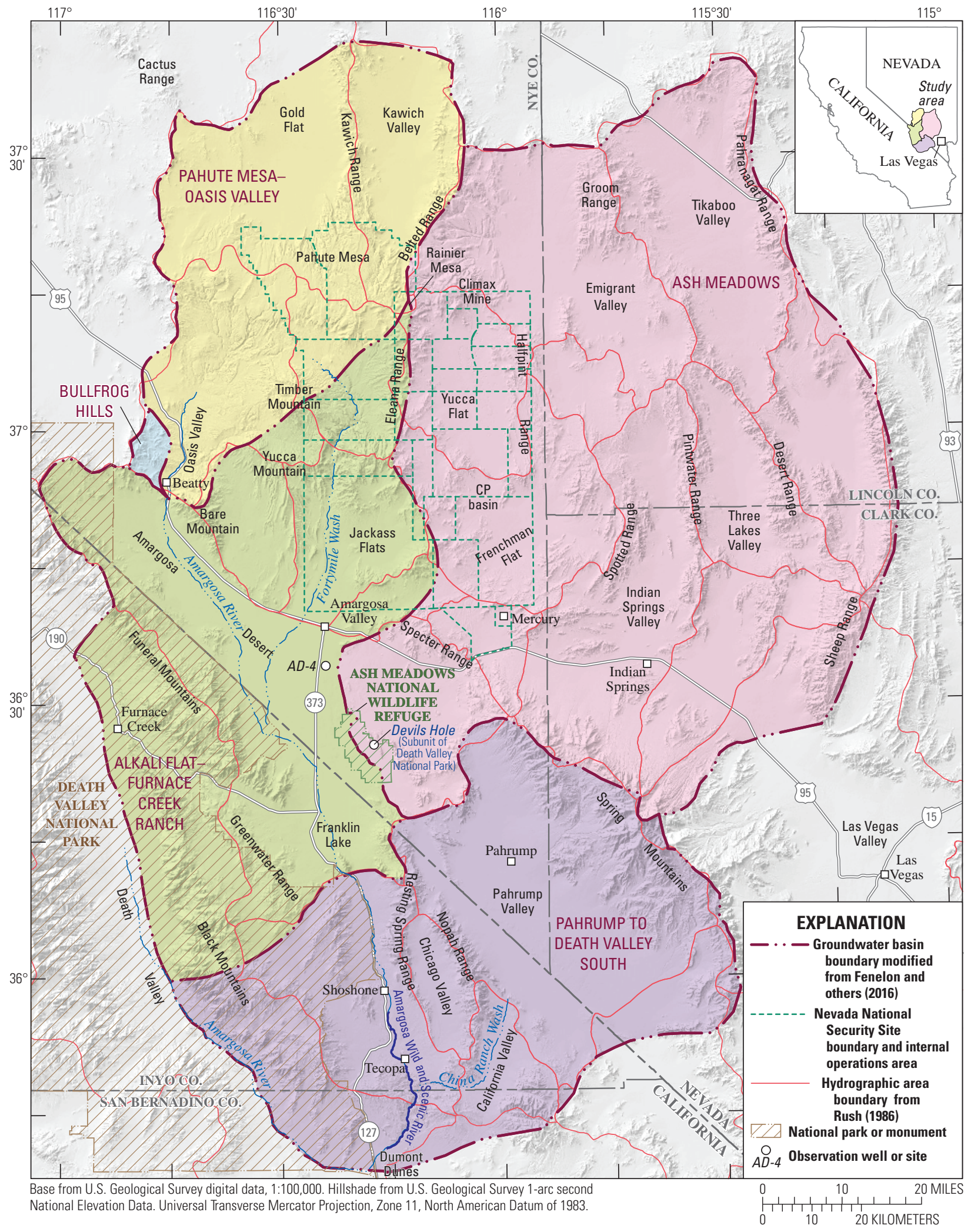

Figure 1. Study area showing groundwater basins and hydrographic areas in the Death Valley regional flow system, Nevada and California. 
Effects of pumping from areas distant from the Ash M eadows discharge area and Devils Hole were considered by State and Federal agencies after 1976 (Williams and others, 1996). This was because aquatic and riparian ecosystems in a desert environment depend on discharges from an aquifer that can encompass areas considerably larger than the local topographic basin. For example, recharge to a dozen topographic basins (shown as hydrographic areas in fig. 1) within the Ash Meadows groundwater basin covers 2,840,000 acres and supplies the 18,000 acre-ft/yr of discharge in the Ash Meadows discharge area (Winograd and Thordarson, 1975; Laczniak and others, 1999). Hydraulic connections exist between many topographic basins, where groundwater moves beneath topographic (surface-water) divides. These hydraulic connections increase the potential for pumping in a local topographic basin to affect discharges in other topographic basins.

Hydraulic connections have been recognized between two major pumping centers, the central Amargosa Desert and Pahrump Valley, and three federally protected groundwaterdependent ecosystems in the study area. The central Amargosa Desert is connected hydraulically to the Furnace Creek area in Death Valley National Park (Winograd and Thordarson, 1975, p. C112), and to the Ash Meadows National Wildlife Refuge (Claassen, 1985, p. F19; Fenelon and others, 2016, p. 6), which is near Devils Hole- a detached unit of Death Valley National Park. The Ash Meadows National Wildlife R efuge and Devils Hole are part of the A sh M eadows discharge area. Pahrump Valley is hydraulically connected to a 26-mi perennial reach of the Amargosa River between Shoshone, California, and Dumont Dunes (Malmberg, 1967; Harrill, 1986), which has been designated as a National Wild and Scenic River (Interagency Wild and Scenic Rivers Coordinating Council, 2018). Hydraulic properties that define degrees of connection and susceptibility to pumping effects have not been quantified plausibly, despite recognition of these hydraulic connections more than 40 years ago.

The location of one or more boundaries between the PM OV, AFFCR, A sh M eadows, and PDV S groundwater basins is uncertain. Some of these boundaries are defined by water-level altitudes in wells, where water-level declines from nearby pumping can affect the location of the boundary and degrees of connection between pumping centers and natural discharge areas. The southeastern boundary of the PMOV groundwater basin between Rainier M esa and B are M ountain is uncertain based on water-level data (fig. 1; Fenelon and others, 2016), and the boundary is susceptible to movement by nearby pumping. A ddressing boundary uncertainty for the PM OV groundwater basin will determine whether radionuclides migrating downgradient from Pahute M esa will move only downgradient toward Oasis Valley or, if the boundary is affected by pumping, radionuclides potentially will migrate southward into the A margosa Desert.

Characterization of predevelopment flow, advective movement, pumping effects, hydraulic connections, and basinboundary uncertainty are best investigated with groundwater models of the study area because complex geometries, heterogeneous hydraulic properties, and groundwater discharges from springs and evapotranspiration areas can be simulated consistently. These study objectives are addressable with a steady-state model of predevelopment conditions and transient models of pumping in the groundwater basins. A steady-state model can be used to estimate predevelopment water levels, groundwater-flow paths, recharge, spring discharges, and groundwater evapotranspiration within each groundwater basin. A steady-state model also can be used to consistently estimate water budgets between groundwater basins. Timing and magnitude of groundwater capture from springs and evapotranspiration areas by pumping, in addition to water-level changes from pumping, can be estimated consistently within each groundwater basin and between groundwater basins with a transient model. Steady-state and transient models should be developed simultaneously because they share common hydraulic properties and related boundary conditions in discharge areas.

Development of plausible groundwater models requires conceptualizations of predevelopment discharge and recharge that are consistent with geologic and hydrologic evidence. Groundwater conceptualizations have evolved as new data have been collected. Predevelopment discharge estimates should be evaluated for consistency with conceptualizations of groundwater movement through discharge areas based on the relation of discharge estimates to hydrogeologic data, water levels, transmissivity estimates, and locations of known discharge. Conceptual models of recharge, transmissivity, specific-yield, and specific-storage distributions should be developed that are consistent with data and observations. For example, recharge should be greater in permeable mountain ranges than on valley floors because available precipitation is greater in mountain ranges. Hydrogeologic framew ork models should be evaluated to determine whether hydrogeologic units have unique hydraulic variability and if major hydrologic features are incorporated. Testing of the hydrogeologic framew ork requires comparison of hydrogeologic units to transmissivity estimates from aquifer tests and specificcapacity estimates.

Plausible results from groundwater models depend on model calibration to data and conceptual frameworks. Definitive measurements such as water levels, water-level changes, predevelopment discharges, and spring capture must be replicated at a minimum. Simulated transmissivities must compare favorably with aquifer-test results, even if supporting volumes of aquifer investigated by pumping are defined subjectively, because replicating observed heterogeneity depends greatly on transmissivity estimates (Halford, 2016). Distributions of recharge, transmissivity, specific yield, and specific storage in numerical models also must agree with conceptual models of these hydraulic properties. Critical hydraulic features and responses must be replicated, such as water-level gradients in Yucca Flat and water-level changes in Devils Hole. 


\section{Purpose and Scope}

The purposes of this report are to:

1. Characterize predevelopment groundwater flow;

2. Evaluate effects of historical (1913-2018) groundwater development on water levels and spring discharges;

3. Estimate potential future (2019-2100) effects of groundwater development on water levels and spring discharges;

4. Evaluate advective flow from selected underground nuclear tests to determine if boundary conditions and flow rates from the regional model in this study are reasonable for local-scale flow and transport models; and

5. A ddress groundwater-basin boundary uncertainty in the study area, which comprises the A sh M eadows, AFFCR, PM OV, and PDV S groundwater basins.

Predevelopment groundwater flow, effects of groundwater development, advective movement from nuclear tests, and basin-boundary uncertainty were investigated with three-dimensional, groundwater models. Recharge, hydraulicconductivity, specific-yield, and specific-storage distributions were estimated by simultaneously calibrating a steady-state model of the study area to predevelopment conditions and transient models of groundwater development to waterlevel changes from pumping during 1913-2018. Hydraulicconductivity and specific-yield estimates were constrained from specific-capacity tests, aquifer-test results, and analysis of multiple-year water-level declines in the central Amargosa Desert, A sh M eadows discharge area, B eatty, B ullfrog Hills area, Emigrant Valley, Indian Springs, NNSS, Pahrump Valley, and Yucca M ountain. A total of four groundwater models, which are discussed in more detail in section, "A pproach," contributed information to calibrated distributions of hydraulic conductivity, specific yield, and specific storage. Potential future effects of groundwater development on water levels and spring discharges were simulated with a predictive groundwater model that used the calibrated distributions of hydraulic conductivity, specific yield, and specific storage. This predictive model simulated capture of discharge from springs and evapotranspiration areas by pumping, where total capture was limited to predevelopment discharge rates. All pertinent data, analyses, the hydrogeologic framework, and the calibrated and predictive groundwater models are published in a separate data rel ease (J ackson and Halford, 2020).

Conceptual models of predevelopment and groundwater development were required to accomplish the five purposes of this study. Characterization of predevelopment groundwater flow required conceptual models for recharge, discharge, and hydraulic-conductivity distributions within hydrogeologic units. Conceptual models integrated water-level data, transmissivity estimates, geologic data, water availability in recharge areas, and locations and estimates of predevelopment discharge. A hydrogeologic framework was used to distribute hydraulic properties within hydrogeologic units during simulation of predevelopment and groundwater development.

Conceptual and numerical models that were developed in this study were compared to results from previous investigations. Many comparisons were to results from the Death Valley Regional Flow System version 2 (DVRFS.v2) model because this study supersedes the DVRFS.v2 project.

\section{Description of Study Area}

The study area comprises the PMOV (940,000 acres), $\operatorname{AFFCR}(1,480,000$ acres), A sh M eadows (2,840,000 acres), and PDV S (1,460,000 acres) groundwater basins (Fenelon and others, 2016). The four groundwater basins are in Clark, Lincoln, and Nye Counties, southern Nevada, and Inyo and San B ernardino Counties, southern California (fig. 1). In-place recharge (Fenel on and others, 2016) principally occurs in Pahute Mesa; Spring Mountains; Timber Mountain; and B elted, Groom, Pahranagat, and Sheep R anges. Land-surface altitudes exceed 6,000 ft in these highland areas, which are in the northern and eastern quadrants of the study area. Natural discharge occurs primarily in the $A$ sh $M$ eadows discharge area, L ower A margosa area, D eath Valley, Oasis Valley, and Pahrump Valley, which are in the southern and western quadrants of the study area. A ltitudes range from - $282 \mathrm{ft}$ in Death Valley to $11,916 \mathrm{ft}$ in the Spring M ountains.

The study area mostly is isolated from surrounding groundwater basins by low-permeability boundaries and groundwater divides (Fenelon and others, 2016). About 290 mi of the 460 mi perimeter of the study area coincides with low-permeability rocks. A bout $80 \mathrm{mi}$ of boundary through carbonate rocks in the Spring M ountains and Sheep Range are classified as low permeability because of the occurrence of high-altitude springs. G reater than $80 \mathrm{mi}$ of low-permeability boundary coincides with the floor of Death Valley. Potentially permeable rocks are mapped north of K awich, E migrant, and Tikaboo Valleys (Heilweil and Brooks, 2011), but flow across these boundaries is expected to be limited. Flows of less than 1,000 acre-ft/yr into Kawich Valley have been estimated (Blankennagel and Weir, 1973; Fenelon and others, 2016). Penoyer Valley north of Emigrant and Tikaboo Valleys has been interpreted as a closed basin (Harrill and others, 1988). Potential flow between Tikaboo and Pahranagat Valleys is least certain, with previous estimates ranging from 5,000 acre-ft/yr into the study area (Winograd and Thordarson, 1975) to 800 acre-ft/yr out of the study area (B elcher and Sweetkind, 2010, appendix 2). 
The climate of the study area is arid to semi-arid, characteristic of a high desert region. The climate is characterized by hot summers and mild winters, large fluctuations in daily and annual temperatures, and low precipitation and humidity. Average summertime maximum temperatures at Furnace Creek are $120^{\circ} \mathrm{F}$ (National Climatic Data Center, 2017), and average wintertime minimum temperatures on Mount Charleston are about $20^{\circ} \mathrm{F}$ (National Climatic Data Center, 2017). Average annual precipitation in the study area ranges from about 2 in. in Death Valley to about 24 in. on Mount Charleston (National Climatic Data Center, 2017). Precipitation occurs primarily in late autumn through early spring and in mid-summer. Precipitation falls primarily as rain, and during the winter months at high altitudes, as snow. Most streams in the study area are ephemeral and flow only for brief periods after infrequent intense rainfall or during and shortly after spring snowmelt.

\section{Previous Investigations}

Regional groundwater models were first developed in the 1980s to estimate potential transport of radionuclides from proposed radioactive waste disposal beneath Yucca Mountain (Waddell, 1982; Rice, 1984). These models were areally extensive because, at the time, known discharge areas and assumed recharge areas were separated by more than $50 \mathrm{mi}$ (Winograd and Thordarson, 1975) and boundaries between groundwater basins were uncertain. In numerical models by Waddell (1982) and Rice (1984), simulated groundwater flow from Yucca Mountain discharged primarily to Franklin L ake (A lkali Flat in Czarnecki and Waddell, 1984) because available discharge estimates totaled 10,000 acre-ft/yr (Walker and Eakin, 1963). Revised Franklin Lake discharge estimates from field measurements and satellite imagery were about 1,000 acre-ft/yr (Laczniak and others, 2001). This altered the conceptual model of Franklin Lake from being the primary discharge area downgradient of Yucca M ountain to a mostly irrelevant discharge area (Fenelon and others, 2016).

Subsequent regional groundwater models were developed to estimate potential transport of radionuclides from Yucca M ountain (D'A gnese and others, 1997) and underground nuclear tests (IT Corporation, 1997). Areal extents of these subsequent models increased relative to Waddell (1982) so that uncertainty of boundaries between groundwater basins could be investigated (fig. 2). Simulated groundwater-flow paths and velocities from these revised models remained uncertain mostly because uncertainties in discharge estimates remained.

\section{Regional Models-1982-97}

The four regional models (Waddell, 1982; Rice, 1984; D'Agnese and others, 1997; IT Corporation, 1997) were calibrated to markedly different estimates of predevelopment discharge. Differences in model extents (fig. 2) prohibit comparison of discharge estimates from some discharge areas betw een models, such as discharges in the PDV S groundwater basin (fig. 1). Comparisons are possible for predevelopment discharges from Ash Meadows, AFFCR, and PMOV groundwater basins. Total predevelopment discharges from these three groundwater basins for the four regional models ranged from 34,400 to 82,000 acre-ft/yr (table 1). Some differences can be attributed to likely double counting of spring discharge and groundwater evapotranspiration. Groundwater pumping also was simulated erroneously in steady-state models where depletion of storage is a substantial part of the water budget (Rice, 1984; D'Agnese and others, 1997). Legitimate differences resulted from uncertainties in discharge estimates that required better measurements to reduce uncertainties (Waddell, 1982; IT Corporation, 1997).

\section{Regional Investigations-1998-2004}

A series of investigations were initiated by the USGS to address inadequacies of the existing regional models and develop another regional model, Death Valley Regional Flow System version 1 model (DVRFS.v1; Belcher, 2004; Belcher and Sweetkind, 2010). These investigations resulted in about three dozen publications from 1998 to 2004 that mapped geologic features, measured hydrologic components, and developed hydrologic models. Geologic cross sections were interpreted from mapped exposures, borehole data, and geophysical mapping of aeromagnetic, gravity, and seismic anomalies (Sweetkind and others, 2001). Hydrologic components such as predevelopment discharge, pumping, water levels, and aquifer-test results were defined better with additional measurements and scrutiny of existing measurements. Hydrologic models were developed to estimate recharge and simulate groundwater flow.

\section{Predevelopment Discharge Investigations}

Multiple investigations measured natural discharges to support the DVRFS.v1 model. Discharges from the Ash Meadows discharge area and Oasis Valley were defined well from 18, multiyear, micrometeorological measurement sites where groundwater discharge by evapotranspiration $\left(\mathrm{ET}_{\mathrm{GW}}\right)$ was estimated (Laczniak and others, 1999; Reiner and others, 2002). Discharges from Chicago Valley, California Valley, Franklin Well area, Franklin Lake, Shoshone-to-Tecopa area, and Stewart Valley were refined with $\mathrm{ET}_{\mathrm{GW}}$ rates extrapolated from $O$ asis Valley and $A$ sh $M$ eadows discharge areas (L aczniak and others, 2001). Discharges from D eath Valley were estimated similarly with a site-specific investigation that measured $\mathrm{ET}_{\mathrm{GW}}$ rates with four micrometeorological measurement sites (D eM eo and others, 2003). Discharge from 100,000 acres of playa in Death Valley remained uncertain because annual playa $\mathrm{ET}_{\mathrm{GW}}$ rates less than $0.3 \mathrm{ft}$ were within the measurement error of the B owen-ratio approach (J ackson and others, 2018). 


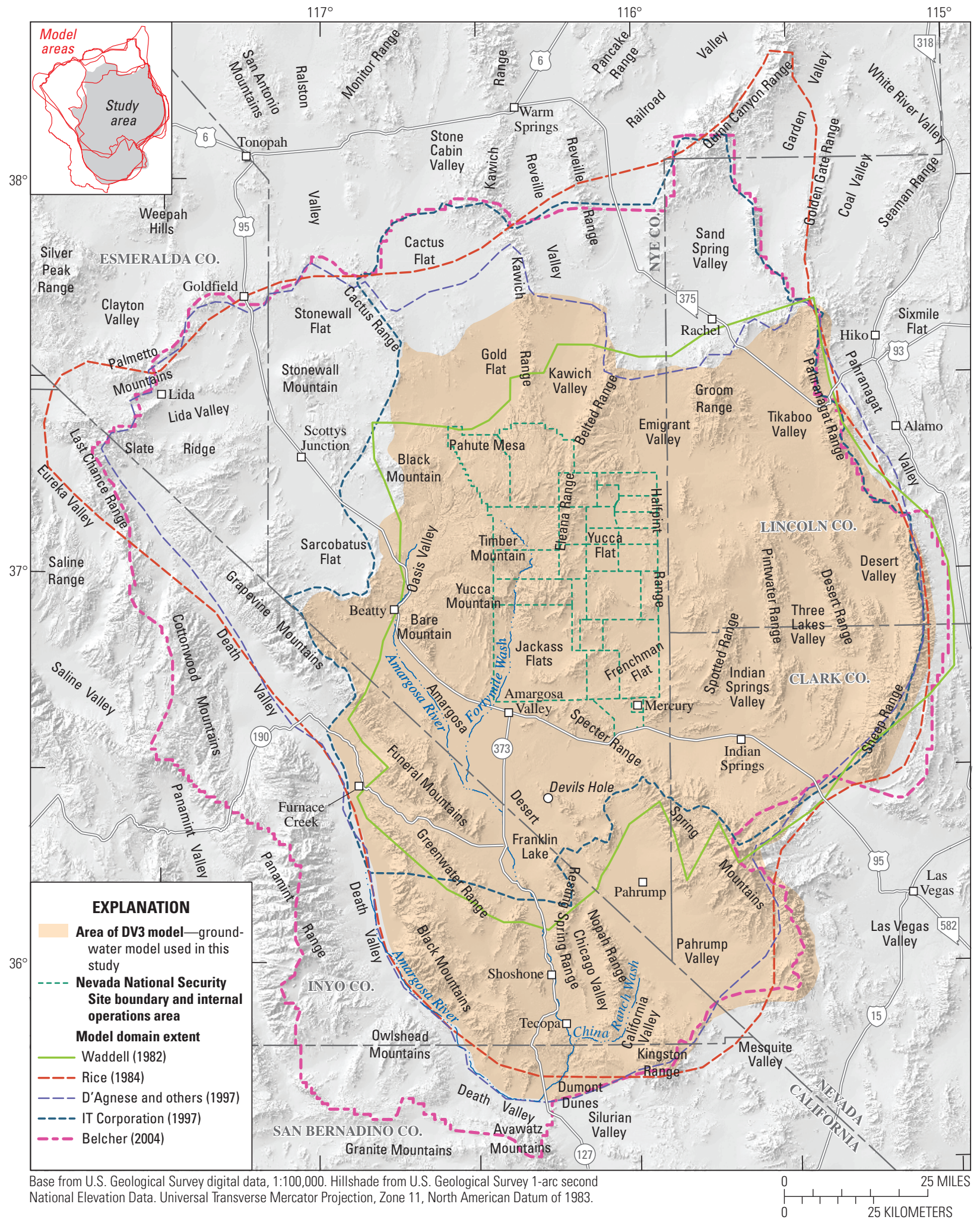

Figure 2. Areal extent of previous regional groundwater models and the regional model [Death Valley version 3 (DV3)] used in this study, Nevada and California. 
Table 1. Predevelopment discharge estimates from previous and current investigations for Alkali Flat-Furnace Creek Ranch, Ash Meadows, and Pahute Mesa-Oasis Valley groundwater basins, Nevada and California, 1982-2018.

[M odel: 2D-FD, two-dimensional finite difference; 2D-FE, two-dimensional finite element; DVSS1, Death Valley steady-state version 1 model; IT, IT Corporation; DVSS2, Death Valley steady-state version 2 model; DVRFS.v1, Death Valley Regional Flow System version 1 model; DVRFS.v2, Death Valley Regional Flow System version 2 model; DV3, Death Valley version 3 model. AFFCR: Alkali FlatFurnace Creek Ranch. PM OV: Pahute M esa-Oasis Valley]

\begin{tabular}{lllrccc}
\hline \multirow{2}{*}{ Year } & \multirow{2}{*}{ Model } & \multicolumn{1}{c}{ Citation } & \multicolumn{3}{c}{ Groundwater discharge (acre-feet per year) } \\
\cline { 3 - 6 } & & & AFFCR & Ash Meadows & PMOV & Total \\
\hline 1982 & 2D -FE & Waddell, 1982 & 15,600 & 16,800 & 2,000 & 34,400 \\
1984 & 2D-FD & Rice, 1984 & 20,000 & 50,000 & 4,000 & 74,000 \\
1997 & DV SS1 & D'A gnese and others, 1997 & 40,800 & 36,900 & 4,300 & 82,000 \\
1997 & IT & IT Corporation, 1997 & 23,000 & 31,200 & 6,500 & 60,700 \\
2002 & DV SS2 & D'A gnese and others, 2002 & 14,000 & 18,900 & 5,700 & 38,600 \\
2004 & DVRFS.v1 & Belcher, 2004 & 8,500 & 18,500 & 6,000 & 33,000 \\
2010 & DVRFS.v1 & Belcher and Sweetkind, 2010 & 8,500 & 18,500 & 6,000 & 33,000 \\
2017 & DVRFS.v2 & Belcher and others, 2017 & 8,500 & 18,500 & 6,000 & 33,000 \\
2018 & DV3 & This report & 7,500 & 19,000 & 6,000 & 32,500 \\
\hline
\end{tabular}

Changes in predevelopment discharge estimates substantially affected simulated transport results. For example, Franklin Lake was interpreted as the primary discharge area from the AFFCR groundwater basin with an initial estimate of 10,000 acre-ft/yr (Walker and Eakin, 1963), which was double the estimated discharge from the Furnace Creek area (Waddell, 1982; Czarnecki and Stannard, 1997). Revised discharge estimates from F ranklin L ake total ed 1,000 acre-ft/ yr, where 25 percent discharged from the playa (L aczniak and others, 2001). $\mathrm{ET}_{\mathrm{GW}}$ rates of $0.17 \mathrm{ft} / \mathrm{yr}$ for playas likely were overestimated and better approximated as near $0 \mathrm{ft} / \mathrm{yr}$ (Jackson and others, 2018). Discharge from Franklin Lake is best interpreted as less than 700 acre-ft/yr because most of the discharge is local recharge derived from flooding events on the Amargosa River, not regional discharge. Reduced discharge estimates changed Franklin L ake from being interpreted as a primary receptor to an improbable terminus for potential transport from Yucca M ountain.

\section{Hydraulic-Property and Water-Use Investigations}

A quifer-test results were compiled, and groundwater use was inventoried to improve regional datasets in support of the DVRFS.v1 model. A total of 377 transmissivity estimates from aquifer tests in southern Nevada and California were compiled (B elcher and others, 2001, appendix A). Transmissivity estimates were normalized to hydraulic conductivities by assuming that contributing thicknesses equaled screen lengths so that hydraulic conductivities could be classed by hydrogeologic units. Estimated pumping for the DVRFS.v1 model was an interpretive effort because minimal reporting existed prior to 1950 and permitted water rights are not correlated directly with wells (M oreo and others, 2003).

Annual pumping volumes and uncertainty were estimated for 9,300 wells in the extent of the DVRFS.v1 model.

\section{Hydrogeologic Framework}

A hydrogeologic framework model also was developed that was intended to improve the DVRFS.v1 groundwater model. The volume within the hydrogeologic framework was differentiated into hydrogeologic units on the basis of similar geologic and hydraulic properties (Winograd and Thordarson, 1975; Laczniak and others, 1996; Faunt, Sweetkind, and Belcher, 2010; Fenelon and others, 2010). Hydrogeologic units were assumed to represent volumes of fairly uniform hydraulic properties in structurally similar zones (F aunt, Blainey, and others, 2010, p. 280). Hydraulic properties were distributed throughout the DVRFS.v1 model by assigning a single value to each zone in a hydrogeologic unit (Faunt, Blainey, and others, 2010).

A $n$ unexpected result from another supporting investigation (Belcher and others, 2002) of the DVRFS.v1 model was that hydraulic conductivities were predicted and constrained poorly by hydrogeologic units in the DVRFS. v1 hydrogeologic framework. Probability distributions of hydraulic conductivity, which were estimated from aquifertest results, were computed for 18 of 27 hydrogeologic units in the DVRFS.v1 hydrogeologic framework. Hydraulic conductivities were highly heterogeneous rather than uniform for all analyzed hydrogeologic units. Hydraulic conductivities in each hydrogeologic unit ranged from three to seven orders of magnitude (fig. 3). The geometric mean hydraulic conductivity of the alluvial confining unit exceeded the geometric mean hydraulic conductivity of the alluvial aquifer, which contradicts conceptual models of aquifers and confining units (Belcher and others, 2002, table 1). Highly heterogeneous hydraulic conductivities contradict assumptions that hydrogeologic units in DVRFS.v1 approximate uniform hydraulic conductivities (Faunt, Blainey, and others, 2010, p. 280). 


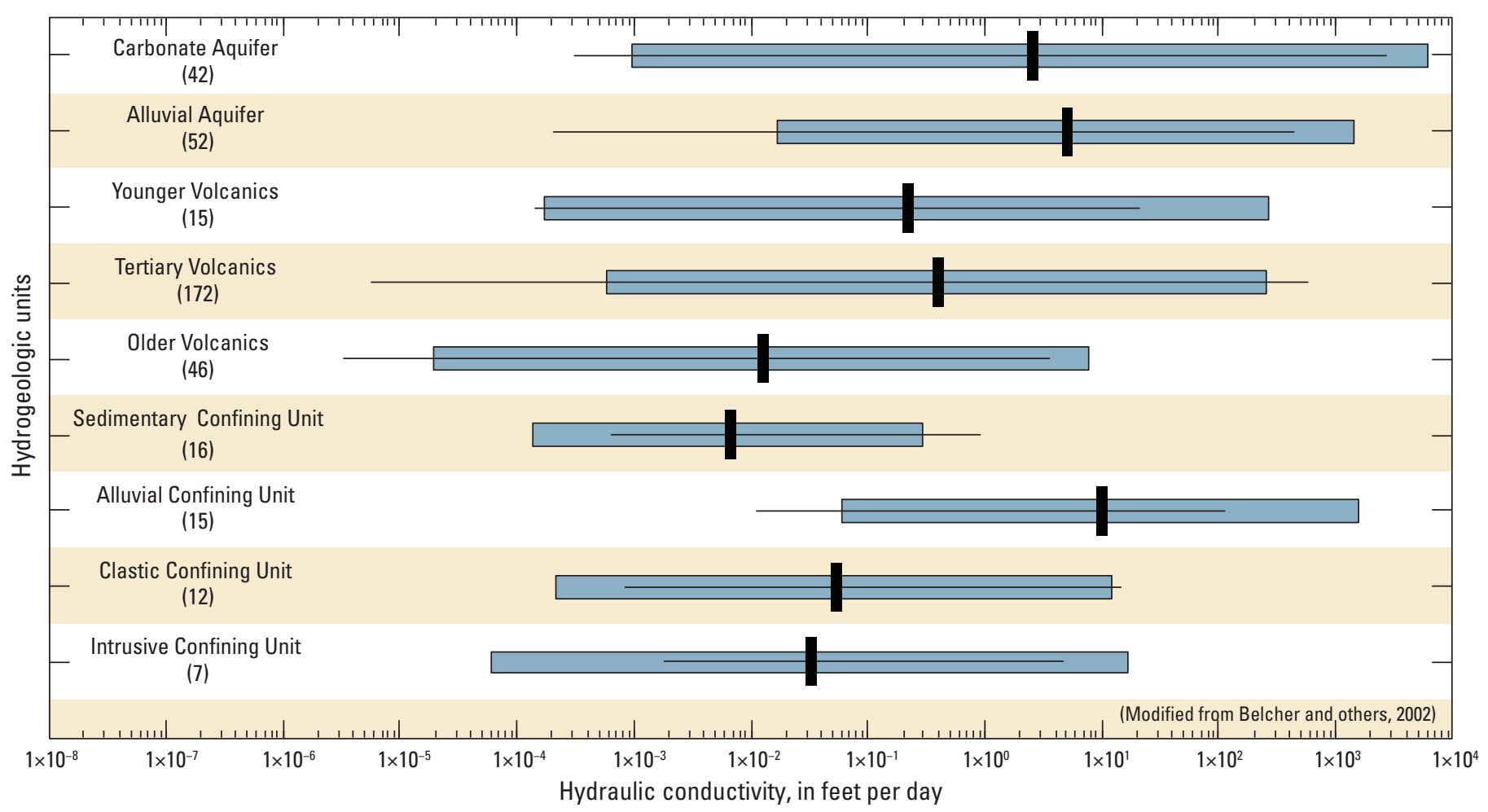

\section{EXPLANATION}

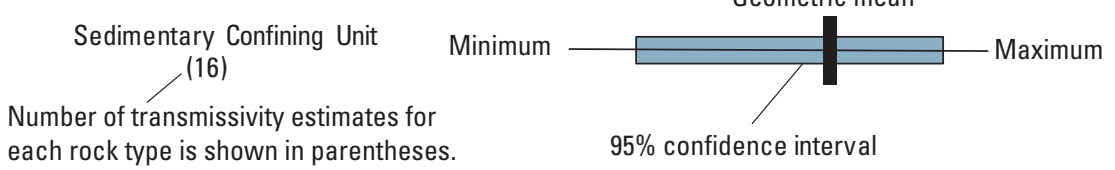

Figure 3. Minimum, maximum, geometric mean, and 95-percent confidence interval of log-hydraulic conductivities in 9 hydrogeologic units in the Death Valley Regional Flow System version 2 model framework using 377 hydraulic-conductivity estimates, Nevada and California.

\section{DFRVS.v1 Model}

The DVRFS.v1 model was developed to supply boundary conditions to CAU models that simulated radionuclide transport beneath the NNSS, and to simulate water-level changes in critical areas from pumping. These development goals were reported as appropriate uses of the DVRFS.v1 model: "The model can provide boundary conditions for the development of local-scale models, such as those being developed by the Department of Energy..." (B elcher, 2004, p. 348; Belcher and Sweetkind, 2010, p. 340) and " $[t]$ he model can be used for examining the effects of continued or increased pumpage on the regional ground-water flow system to effectively manage ground-water resources within conflicting land-use management policies." (Belcher, 2004, p. 349; Belcher and Sweetkind, 2010, p. 341.)

Boundary conditions from the DVRFS.v1 model that were applied to a local-scale CAU model of the carbonate aquifer beneath Y ucca Flat were not adequate for their stated purpose. The DVRFS.v1 model simulated a groundwaterflow rate of 14,000 acre-ft/yr into northern Yucca Flat through low-permeability shale, quartzite, granite, marble, and siltstone (B elcher and Sweetkind, 2010). A pplying 14,000 acre-ft/yr as the northern boundary condition for the Yucca Flat CAU model resulted in rapid groundwater velocities, large extents of simulated tritium plumes that were not supported by tritium data, and model-estimated hydraulic properties that exceeded aquifer-test results (Navarro-Intera, LLC, 2013). The 14,000 acre-ft/yr of northern flow is erroneously large because predevelopment flow through Yucca Flat ranges from 350 and 1,000 acre-ft/yr (Winograd and Thordarson, 1975; Harrill and others, 1988; Fenel on and others, 2016), and estimated flow through low-permeability rocks in northern Yucca Flat is less than 40 acre-ft/yr (Winograd and Thordarson, 1975, p. C93).

Groundwater resources within 25 mi of Devils Hole have been managed with an empirical rule (Nevada State Engineer, 2008b), instead of using the DVRFS.v1 model. The State Engineer administers water resources in Nevada and designated A margosa Desert hydrographic area 230 in 1979. Nevada State Engineer Order No. 724 manages pumping to maintain a minimum pool elevation in Devils Hole. The 
empirical rule was developed in response to proposed changes in points of diversion, where the protestant was the National Park Service (Nevada State Engineer, 2008a). The National Park Service also cooperatively developed and funded the DVRFS.v1 model (Belcher, 2004, p. 7) because conflicting land uses were anticipated (Belcher, 2004, p. 349). The protestant estimated effects of proposed changes in pumping on water levels in Devils Hole with a Theis analysis (Nevada State Engineer, 2008b), despite having cooperatively developed and funded the DVRFS.v1 model.

\section{DVRFS.v2 Model}

A revised regional model, DVRFS.v2, was developed to update the DVRFS.v1 model with new data and interpretations (B elcher and others, 2017). Two primary purposes of the DVRFS.v2 model were stated: “... (1) inform definition of boundary conditions for the Underground Test Area (UGTA) Corrective Action Units (CAUs) on the NNSS, (2) evaluate the effects of changes in groundwater-system fluxes, regardless of whether the changes are natural or human-induced..." (Belcher and others, 2017, p. 3). Revisions to the DVRFS. v1 model included altering the hydrogeologic framework, estimating annual variations in recharge, extending the simulated period 5 years to 2003, comparing transmissivities and water-budget terms in the objective function, and distributing hydraulic properties with pilot points in some basin-fill units. Despite revisions, the DVRFS.v2 model is inadequate for its reported purposes.

Simulated flow through Yucca Flat remained unrealistic even though flow into northern Yucca Flat was reduced from 14,000 to 1,400 acre-ft/yr between the DVRFS.v1 and DVRFS. v2 models, respectively (Navarro-Intera, LLC, 2013, table 5-7). The DVRFS.v2 model simulated 7,700 acre-ft/yr (300 $\mathrm{kg} / \mathrm{s}$ ) across the southern edge of the Yucca F lat-Climax M ine CA U model of carbonate rocks (Navarro-Intera, LLC, 2013, table 5-7). Regional water-balance analyses limited flow from southern Yucca Flat to about 1,000 acre-ft/yr (W inograd and Thordarson, 1975; Fenelon and others, 2016). Groundwaterflow estimates from hydraulic gradients and aquifer-test results ranged from 240 to 970 acre-ft/yr (Navarro, 2016a) between wells ER-7-1 and ER-6-1-2 main, where these estimates represent groundwater flow from approximately two-thirds of the Yucca Flat hydrographic area. UGTA investigators concluded: "This limit on flux through the high-transmissivity eastern corridor suggests that several models documented in $N-I$ (2013a) [Navarro-Intera, LLC, 2013]_including the base case and many Null Space Monte Carlo (NSMC) results with northern boundary fluxes greater than $50 \mathrm{~kg} / \mathrm{s}[1,300 \mathrm{acre}-\mathrm{ft} /$ yr]_are unrealistic." (Navarro, 2016a, p. 24.)

The DVRFS.v2 model poorly explains effects of natural changes and pumping on water levels in Devils Hole and spring discharges in the A sh M eadows discharge area, which precludes analyzing effects of either stress with the DVRFS. v2 model. Measured water levels in carbonate rocks naturally fluctuate from 0.5 to $3 \mathrm{ft}$ in wells and in Devils Hole, where these natural changes correlate with fluctuations in cumulative departure from mean precipitation (Fenel on and M oreo, 2002, p. 51). The DVRFS.v2 model simulated less than $0.02 \mathrm{ft}$ of natural water-level changes in Devils Hole (fig. 4). Simulated and measured water-level changes notably differ in Devils Hole, where maximum water-level declines from pumping, or drawdown, in the DVRFS.v2 model were simulated about 30 years after maximum measured draw down occurred (fig. 4). M easured spring discharges of 1,400 acre-ft/month $(10,700 \mathrm{gal} / \mathrm{min})$ decreased 34 percent during A ugust 1971 in response to pumping of about 1,000 acre-ft/month in the A sh M eadows discharge area (Dudley and Larson, 1976, p.22). Simulated capture in the DVRFS.v2 model from all springs and evapotranspiration areas totaled less than 1 percent of the predevelopment discharge, in response to pumping in the Ash $M$ eadows discharge area.

The stated goals of informing boundary conditions and estimating the effects of groundwater pumping were not achieved in the DVRFS.v1 and DVRFS.v2 projects because geologic differences were emphasized in the hydrogeologic framew orks and groundwater models. Results from the DVRFS.v1 and DVRFS.v2 projects indicate the need for hydrology to inform the hydrogeologic framework by empirically testing hydrogeologic units with results from aquifer tests. Achieving the stated goals requires a new approach that emphasizes hydrologic results.

\section{Approach}

The study area, purpose, and approach of this project differ from the DVRFS.v1 and DVRFS.v2 studies. The study area of this project is about 6,720,000 acres, which is less than one-third the areal extent of the approximately $24,710,000$ acre DVRFS.v2 model (fig. 2). B ecause the study area does not encompass the entire Death Valley regional flow system (Harrill and others, 1988), the general descriptor for this project has been simplified to Death Valley version 3 (DV3).

The DV3 study area encompasses the AFFCR, Ash M eadows, PM OV, and PDV S groundwater basins to address the study objectives. Potential radionuclide transport from historical underground nuclear tests at the NNSS occurs in the AFFCR, A sh M eadows, and PM OV groundwater basins. Groundwater development occurs in all four groundwater basins; however, extensive development occurs in the AFFCR, Ash Meadows, and PDVS groundwater basins. The outer boundaries of groundwater basins in the DV 3 study area mostly are separated from surrounding groundwater basins outside the study area by no-flow boundaries (Fenelon and others, 2016). However, within the DV3 study area, groundwater-basin boundary uncertainty needs to be addressed for the boundaries between the four groundwater basins.

Groundwater-basin boundary uncertainty affects estimation of potential radionuclide transport from underground tests, and degrees of hydraulic connection between pumping centers and areas of interest, such as Devils Hole, across groundwater divides. 


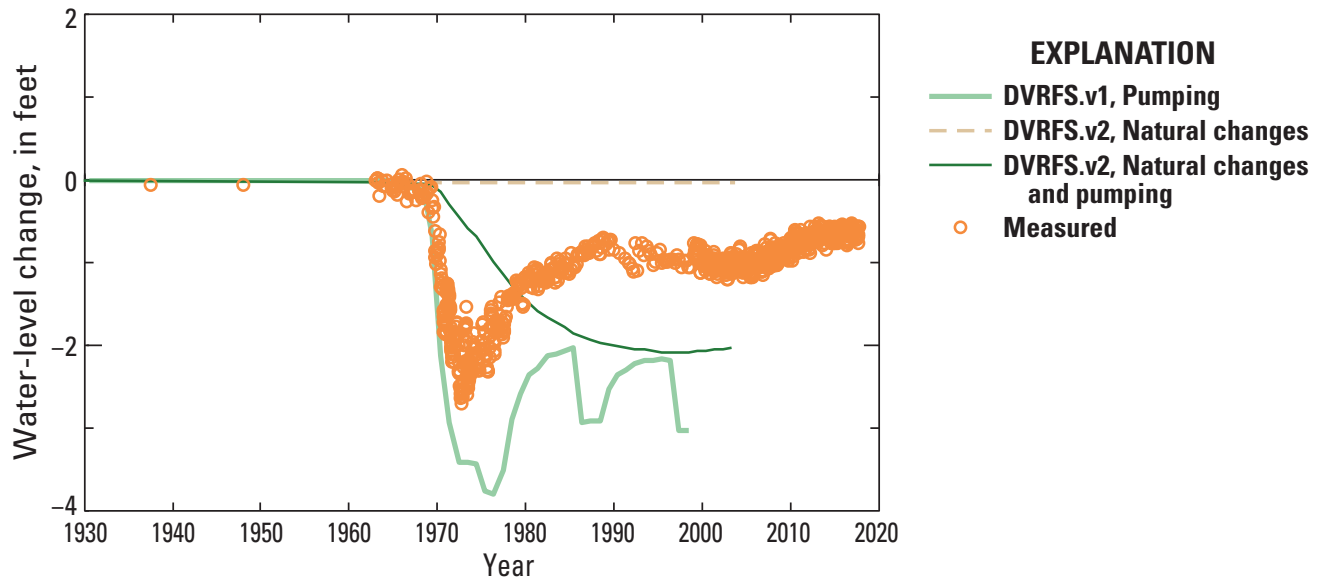

Figure 4. Measured and simulated water-level changes in Devils Hole from the Death Valley Regional Flow System versions 1 and 2 (DVRFS.v1 and DVRFS.v2) models, Nevada and California, 1930-2018.

Predevelopment conditions, historical groundwater development, and potential pumping effects from future development were simulated with multiple, stress-response groundwater models that honor hydraulic constraints. Stressresponse models are groundwater models that simulate an identifiable stress within the aquifer system. Average recharge is the stress during steady-state, predevelopment conditions and is better defined than time-varying recharge. Pumping for groundwater development is the stress in transient models and is highly identifiable relative to other hydraulic stresses. The primary assumption of the stress-response approach is that differentiating natural (recharge) and anthropogenic (pumping) stresses introduces less errors than compensating errors in a single model that attempts to simultaneously simulate all stresses.

Developing a set of stress-response models simplifies estimation of hydraulic properties because structural errors are easier to discern and remove where responses to steadystate and transient stresses are separated. A set of stressresponse models also better addresses multiple questions than a single groundwater model because boundary conditions are tailored to the effects of each stress. For example, models simulating both predevelopment flow (steady-state) and groundwater development (transient) should inform a calibrated transmissivity distribution. Spring discharge is best specified as a constant value for calibration to predevelopment conditions but must decrease in response to pumping as groundwater development is simulated (Halford and Plume, 2011). Spring discharge can be simulated advantageously as a specified discharge in a steady-state model and as a head-dependent discharge in a groundwater-development model. Both models have common hydraulic properties and are calibrated simultaneously so that all observations inform an estimated transmissivity distribution (Garcia and others, 2017).
Predictive utility of the DV3 model depends on plausibility of calibrated recharge, transmissivity, specificyield, and specific-storage distributions. Plausibility increases as simulated results better match as many relevant observations and concepts as possible. Predevelopment flow was simulated and compared to water-level altitudes, discharges, and transmissivity estimates from aquifer tests. Groundwater development in AFFCR, Ash Meadows, PMOV, and PDV S groundwater basins was simulated as changes from predevelopment and compared to measured changes in water levels and spring discharges. Pumping from well ER-6-1-2 main during a large-scale, multiple-well aquifer test (MWAT) in Yucca Flat also was simulated, where simulated drawdowns were compared to drawdown estimates in observation wells located 0-33 mi from the pumped well. Four stress-response models simulated predevelopment conditions, groundwater development in the PDVS groundwater basin, groundwater development in the PMOV, AFFCR, and Ash Meadows groundwater basins, and the large-scale MWAT (table 2). All models shared common recharge, transmissivity, specificyield, and specific-storage distributions, as needed, and were calibrated simultaneously.

Advective flow from nuclear tests and effects of groundwater pumping were estimated with separate models that were appropriate for addressing each question. Advective flow from selected nuclear tests was estimated with the DV3-SS model because flow paths from these tests do not extend into pumping areas (table 2). Potential effects of historical (1913-2018) and future (2019-2100) groundwater pumping were simulated directly as change from predevelopment conditions (Leake and others, 2010) with another model, DV3-PRED. This model is discretized temporally to annual pumping changes in all groundwater basins from 1913 to 2100 . Directly simulating potential effects of pumping with a separate predictive model has been effective elsewhere in Nevada (Halford and Plume, 2011). 
Table 2. Groundwater models developed for Death Valley version 3 model (DV3) project.

\begin{tabular}{|c|c|c|}
\hline Groundwater model & Description & Purpose \\
\hline DV 3-SS & Steady-state model of predevelopment flow & $\begin{array}{l}\text { Calibration and transport } \\
\text { estimates }\end{array}$ \\
\hline DV 3-AM-AFFCR & $\begin{array}{l}\text { Transient superposition model of groundwater development in the Alkali Flat-Furnace } \\
\text { Creek Ranch, A sh M eadows, and Pahute M esa- } 0 \text { asis Valley groundwater basins }\end{array}$ & Calibration \\
\hline DV 3-ER 612 & Well ER-6-1-2 main aquifer test, 2004 & Calibration \\
\hline DV 3-PDVS & $\begin{array}{l}\text { Transient superposition model of groundwater development in the Pahrump to Death } \\
\text { Valley South groundwater basin }\end{array}$ & Calibration \\
\hline DV 3-PRED & Capture-limited model for predicting pumping effects & Predict pumping effects \\
\hline
\end{tabular}

\section{Geology}

Geologic units were formed by magmatic activity, volcanism, and depositional processes in the study area. These rocks subsequently have been uplifted, thrusted, offset, and deformed. Depositional, magmatic, volcanic, and tectonic processes have juxtaposed geologic units into a complex threedimensional framework that affects groundwater flow. The geologic history is divided into six periods of deposition and tectonic deformation:

\section{Precambrian and Paleozoic marine and non-marine deposition;}

2. Late Paleozoic to Early Cenozoic folding, thrusting, and strike-slip faulting;

3. Mesozoic intrusion;

4. Cenozoic volcanism;

5. Cenozoic normal and strike-slip faulting; and

6. Cenozoic basin-fill deposition (table 3).

Precambrian and Paleozoic marine and orogenic processes resulted in two major sedimentation sequences of siliciclastic and carbonate rocks (Winograd and Thordarson, 1975; Laczniak and others, 1996; Slate and others, 2000; Sweetkind and others, 2010). The continental margin of the southwestern U nited States intersected the study area from the Neoproterozoic to Devonian (Sweetkind and others, 2010). $\mathrm{M}$ arine sedimentary rocks, primarily siltstones, were deposited from Neoproterozoic to Lower Cambrian (table 3), where deposits thicken westward in the study area. The siliciclastic rocks are overlain by thick sequences of Middle Cambrian to Devonian carbonate rocks. From the Late Devonian to M ississippian, siliciclastic rocks - predominantly shales and argillites-interrupted marine carbonate deposition in the eastern part of the study area. Siliciclastic sediments were derived from uplifted areas north of the study area (Sweetkind and others, 2010). M arine carbonate deposition continued from the L ate M ississippian to Permian (table 3 ).
Precambrian and Paleozoic rocks were subjected to compressional tectonic forces from the $L$ ate Paleozoic to Early Cenozoic. Siliciclastic and carbonate rocks were offset by regional thrust faulting (fig. 5), which emplaced Neoproterozoic to Lower Cambrian siliciclastic rocks over younger Pal eozoic rocks (Sweetkind and others, 2010). Many mountain ranges have exposed thrust faults, including the Belted, Eleana, Specter, Resting Spring, and Nopah Ranges, as well as B are M ountain and the Spring and Funeral M ountains (fig. 5; Sweetkind and others, 2010). Thrust faulting displaced rocks laterally more than $10 \mathrm{mi}$ away (Winograd and Thordarson, 1975). Siliciclastic and carbonate rocks also were subjected to folding and strike-slip faulting (Laczniak and others, 1996). Compressional tectonics have formed broad anticlines and synclines in the Precambrian and Paleozoic sequence within the A sh M eadows groundwater basin. M esozoic rocks mostly are absent because of uplift and erosion of Precambrian and Pal eozoic rocks (Sweetkind and others, 2010). Therefore, Mesozoic rocks are minor and occur as localized granitic intrusions.

Volcanic and associated sedimentary rocks formed during the Cenozoic (table 3). From the Oligocene to M iocene, thick sequences of volcanic rocks were deposited by calderaforming eruptions in the southwestern Nevada volcanic field, located in the northwestern part of the study area (Byers and others, 1976; Christiansen and others, 1977; Sawyer and others, 1994; Laczniak and others, 1996; Prothro and Drellack, 1997). Volcanic centers within the southwestern Nevada volcanic field caldera complex (fig. 5) erupted rhyolitic-todacitic lava flows, variably welded ash-flow tuffs, ash-fall tuffs, and volcaniclastic rocks (Winograd and Thordarson, 1975; Laczniak and others, 1996; Sweetkind and others, 2010). From the M iocene to Pliocene, localized rhyolitic and basaltic lava flows erupted from the central Death Valley volcanic field in Greenwater Valley (Sweetkind and others, 2010). During the Holocene, localized basaltic lava flows erupted from five cinder cones in the Crater Flat volcanic field (Wells and others, 1990). 
Table 3. Major lithology and occurrence descriptions of hydrogeologic units in the study area, as defined in the Death Valley Regional Flow System version 2 hydrogeologic framework, Nevada and California.

[Abbreviations: AM, Ash Meadows groundwater basin; AFFCR, Alkali Flat-Furnace Creek Ranch groundwater basin; CDVVF, Central Death Valley volcanic field; PDVS, Pahrump to Death Valley South groundwater basin; PMOV, Pahute Mesa-Oasis Valley groundwater basin; SAMM, Southern AMargosa Model; SWNVF, southwestern Nevada volcanic field. Table summarizes information obtained from Noble and others (1964, 1984); Blankennagel and Weir (1973); Winograd and Thordarson (1975); Byers and others (1976); Christiansen and others (1977); Simonds (1989); Sawyer and others (1994); Laczniak and others (1996); Prothro and Drellack (1997); Slate and others (2000); Sweetkind and others (2010); Taylor and Sweetkind (2014)]

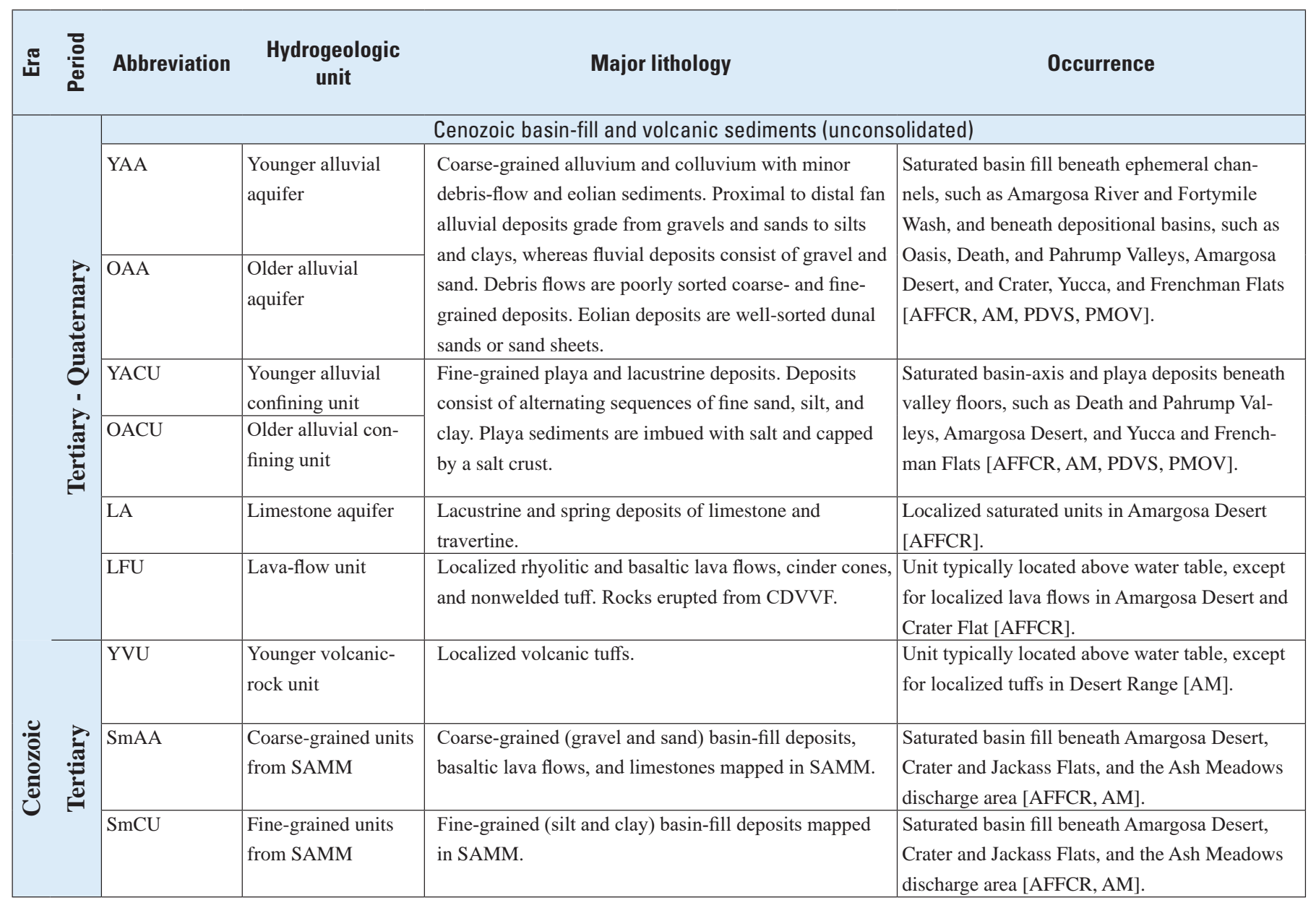


Table 3. Major lithology and occurrence descriptions of hydrogeologic units in the study area, as defined in the Death Valley Regional Flow System Version 2 hydrogeologic framework, Nevada and California.-Continued

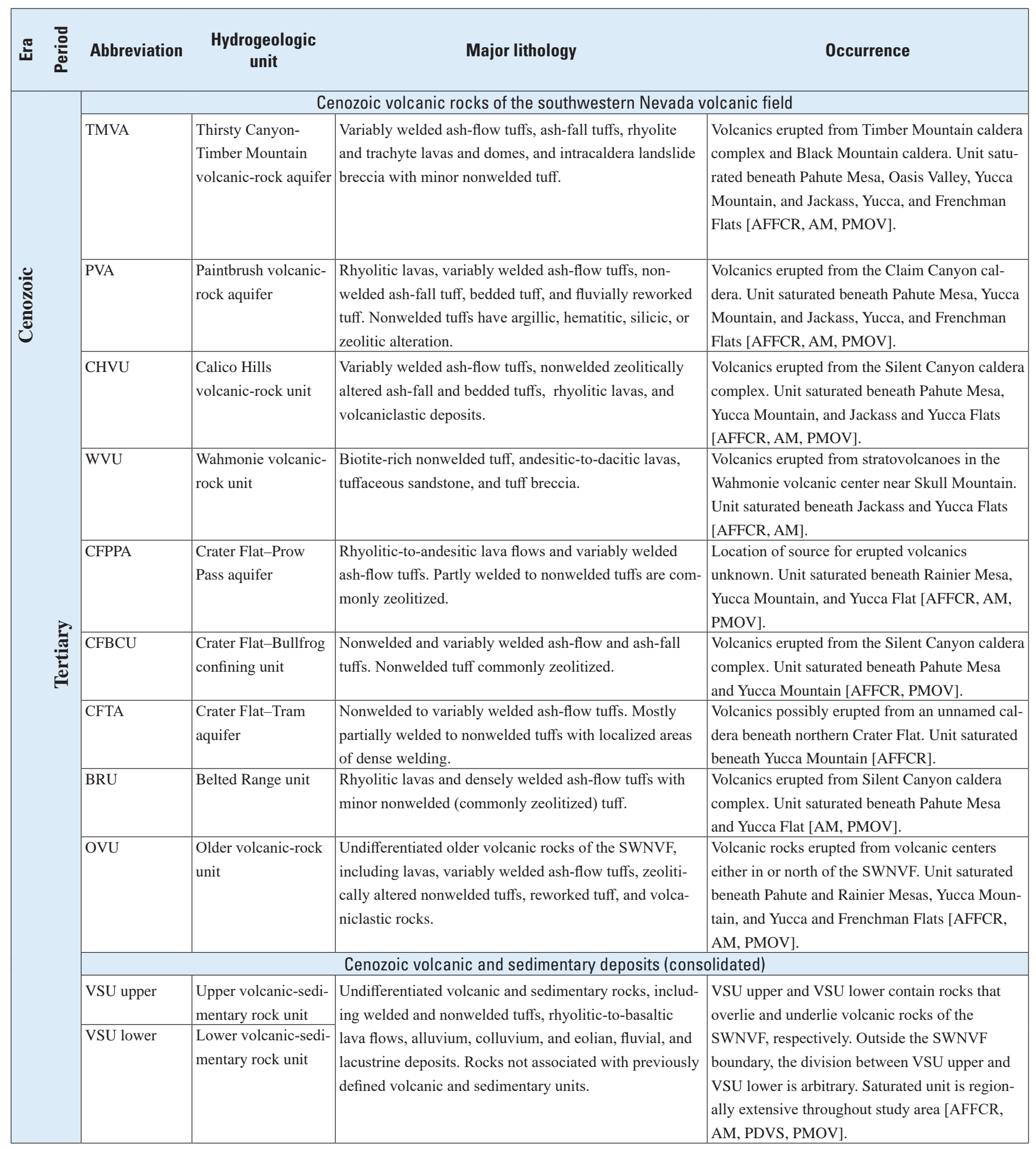


Table 3. Major lithology and occurrence descriptions of hydrogeologic units in the study area, as defined in the Death Valley Regional Flow System Version 2 hydrogeologic framework, Nevada and California.-Continued

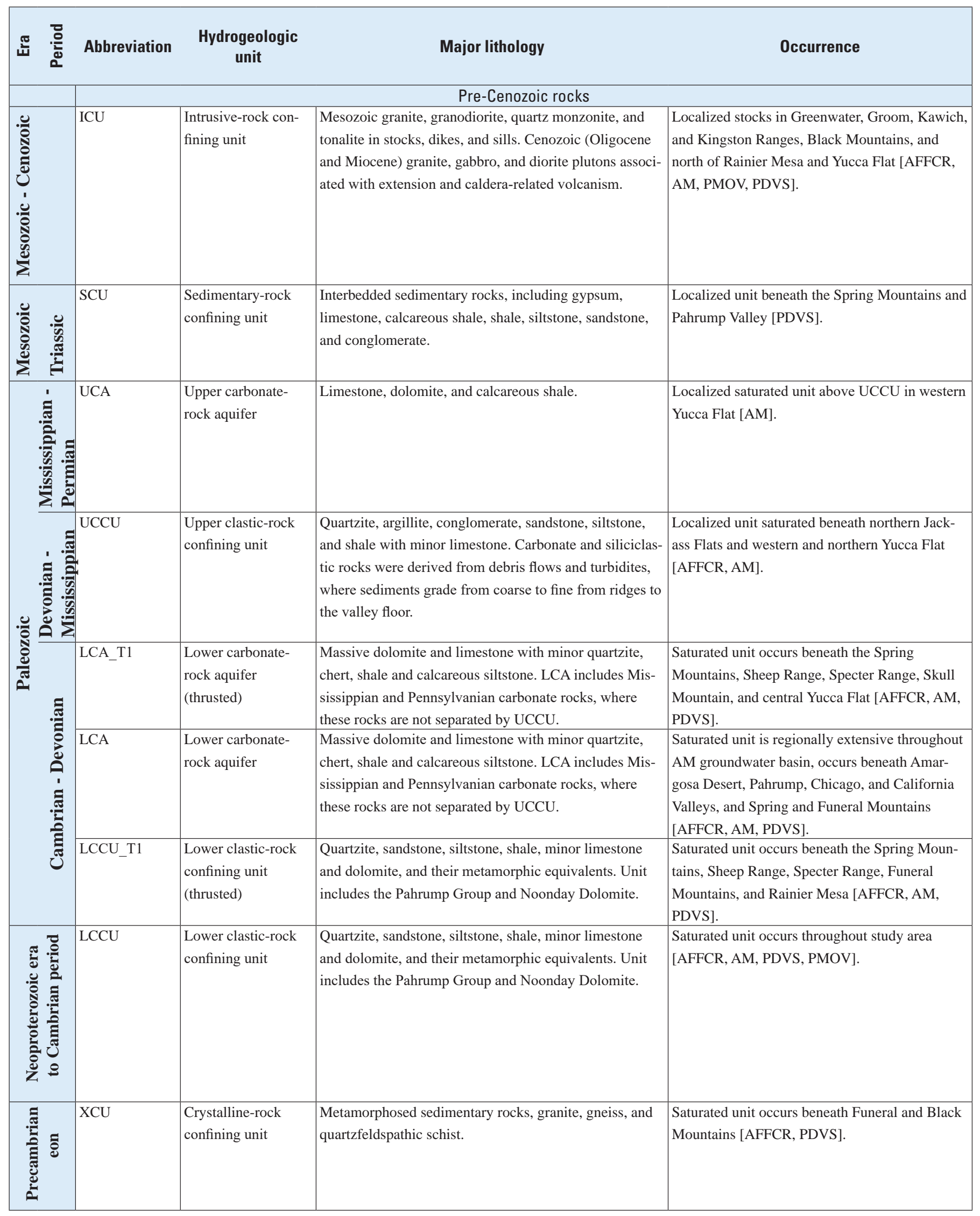




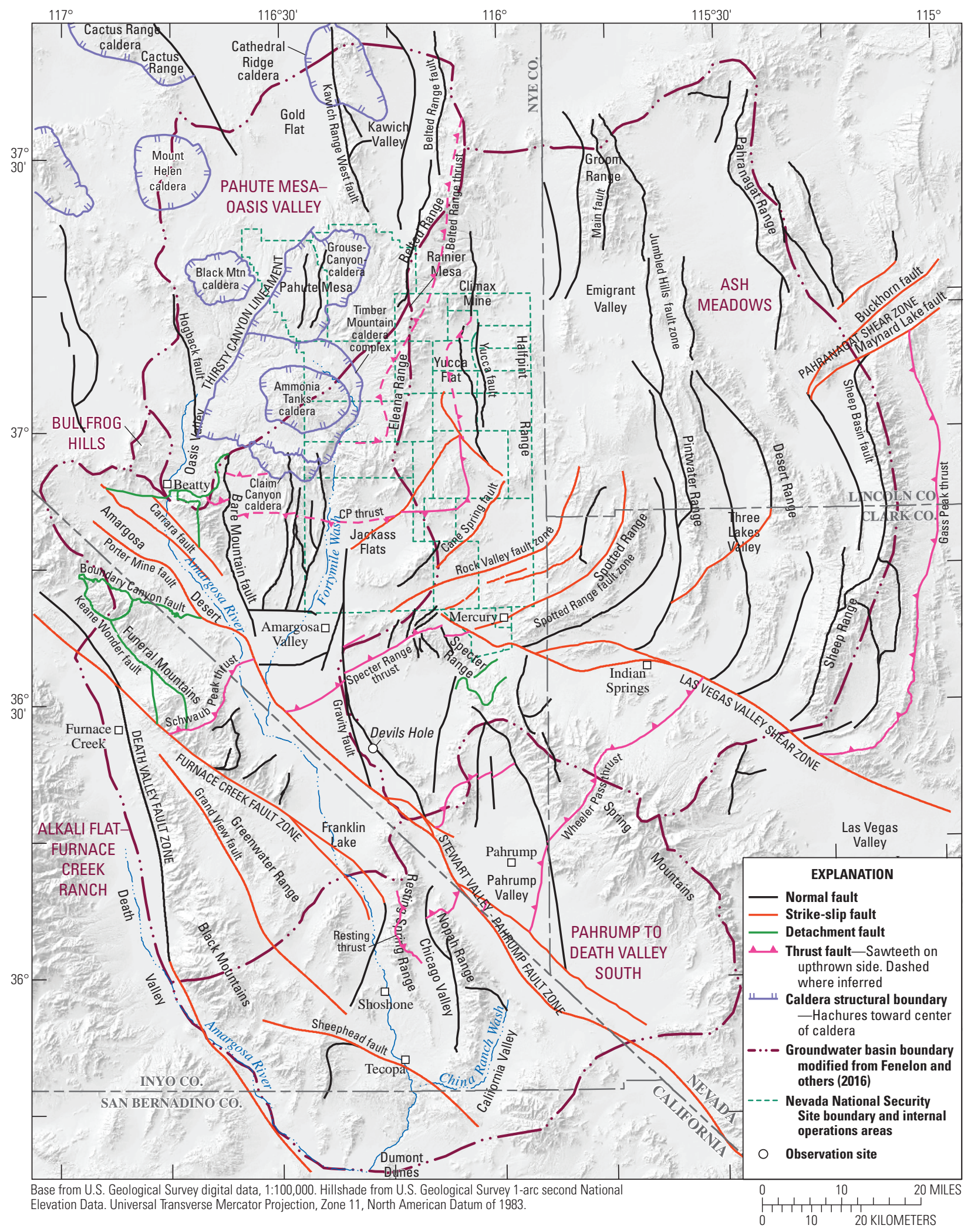

Figure 5. Major geologic structures, in the study area, Nevada and California. 
L arge-scale normal faulting occurred during and after the period of Cenozoic volcanism (Winograd and Thordarson, 1975; Laczniak and others, 1996; Prothro and Drellack, 1997; Sweetkind and others, 2010). From the Mid-Tertiary to Quaternary, normal faults (fig. 5) formed the Basin and Range topography of the Great Basin province. Normal faults are the most common structural feature in the study area and displacement along normal faults continues today (Winograd and Thordarson, 1975). Normal faults typically have displaced the Precambrian through Cenozoic section by less than $500 \mathrm{ft}$; however, in some cases, normal faults have displaced rocks more than $1,000 \mathrm{ft}$ (Winograd and Thordarson, 1975). Sedimentary rocks associated with volcanism occur throughout the study area, and consist of tuffaceous sandstone and siltstone, lacustrine tuff, and claystone.

Cenozoic unconsolidated basin fill occurs throughout the study area in intermontane basins (Sw eetkind and others, 2010; Taylor and Sweetkind, 2014). Coarse-grained basin fill typically consists of alluvial and colluvial deposits with minor fluvial, debris-flow, and eolian deposits. Fine-grained basin fill consists of playa and lacustrine sediments. Limestone and spring deposits also are present locally.

\section{Interbasin Flow Between Groundwater Basins}

Interbasin flow is the movement of groundwater across groundwater-basin boundaries. Groundwater-basin boundaries were delineated by Fenel on and others (2016) to minimize interbasin flow between groundwater basins. Therefore, interbasin flow is limited to four small areas in the study area. Expected flows between groundwater basins were derived from Darcy estimates through well-defined features, such as basin fill bounded by low-permeability rocks south of Beatty and near Eagle M ountain (fig. 6).

Groundwater moves from the Ash Meadows groundwater basin to the AFFCR groundwater basin through a 2-5-mi-wide corridor around well $A D-4$ (fig. 6). Permeable basin fill contacts permeable carbonate rock along the Gravity fault (fig. 5) in the well $A D-4$ corridor. This is atypical along the Gravity fault because, south of the well $A D-4$ corridor, low-permeability basin fill in the AFFCR groundwater basin has been juxtaposed against carbonate rocks in the Ash $M$ eadows groundwater basin. Groundwater upwells from underlying carbonate rocks to overlying basin fill in the well $A D-4$ corridor, and flows through permeable basin fill in the Amargosa Desert. Groundwater flows between groundwater basins and does not discharge at land surface because shallow basin fill is sufficiently permeable in the well $A D-4$ corridor (fig. 6).

Expected predevelopment flow from the Ash Meadows to the A FFCR groundwater basin through the well $A D-4$ corridor ranges from 2,000 (Fenelon and others, 2016) to $4,000 \mathrm{acre}-\mathrm{ft} / \mathrm{yr}$, where the expected flow rate likely is closer to 2,000 acre-ft/yr. Expected flow rates were computed from
Darcy's L aw assuming a hydraulic gradient of $0.01 \mathrm{ft} / \mathrm{ft}$, a transmissivity of $2,000 \mathrm{ft}^{2} / \mathrm{d}$ from specific-capacity tests, and a corridor width of 2-5 mi.

Groundwater moves from the PMOV groundwater basin to the AFFCR groundwater basin through basin fill of limited saturated thickness south of B eatty (fig. 6). Basin fill underlies the Amargosa River channel and is bounded by lowpermeability rocks from B ullfrog Hills and B are M ountain. Reiner and others (2002) estimated about 100 acre-ft/yr of groundwater flow from the PMOV to the AFFCR groundwater basins (fig. 6). The Amargosa River is perennial in Beatty and about 300 acre- $\mathrm{ft} / \mathrm{yr}$ of streamflow flows past USGS streamgage 10251217 (Amargosa River at Beatty, Nevada). Part of this streamflow infiltrates basin fill in the Amargosa River channel and recharges the AFFCR groundwater basin (Stonestrom and others, 2007).

Saturated basin fill beneath the Amargosa River near Eagle M ountain connects the A FFCR and PDV S groundwater basins (fig. 6). Basin fill has limited thickness, is less than 1-mi wide, and Eagle M ountain is an isolated block of carbonate rocks (Sweetkind and others, 2001). L ess than $300 \mathrm{acre}-\mathrm{ft} / \mathrm{yr}$ of predevelopment flow is estimated to move beneath the Amargosa River, assuming a hydraulic gradient of $29 \mathrm{ft} / \mathrm{mi}$ between wells Eagle Mtn North and

Hwy 127 MM21-1, a width of $1 \mathrm{mi}$, and an average transmissivity of $1,000 \mathrm{ft}^{2} / \mathrm{d}$.

Saturated basin fill between Stewart Valley and the A sh M eadows discharge area connects the PDV S and A sh $M$ eadows groundwater basins (fig. 6). Basin fill is less than 1 mi wide and bounded by low-permeability rocks (Sweetkind and others, 2001). Less than $200 \mathrm{acre}-\mathrm{ft} / \mathrm{yr}$ of predevelopment flow is estimated to move from the PDVS groundwater basin, assuming a hydraulic gradient of $14 \mathrm{ft} / \mathrm{mi}$ between wells BLM Stewart Valley Well and GS-1 Well (AD-12), a width of $1 \mathrm{mi}$, and an average transmissivity of $1,000 \mathrm{ft}^{2} / \mathrm{d}$.

\section{Predevelopment Groundwater Flow}

Groundwater flow prior to development can be characterized by distributions and rates of groundwater recharge and discharge, and by the hydraulic conductivities of saturated rocks in the study area. R echarge adds water to the groundwater system and locally elevates water levels. Water levels locally are depressed where groundwater discharges from the system. Recharge and discharge areas are controlled by topography, where more recharge occurs in highland areas, compared to valley floors, and moves downgradient to discharge areas. Topography and hydraulic conductivities of geologic units control the rate and distribution of recharge and discharge. Hydraulic conductivity and recharge control waterlevel altitudes, flow rates, and flow directions in the saturated rocks between recharge and discharge areas. Recharge, discharge, and hydraulic conductivities are distributed spatially throughout the flow system and their distributions characterize the four principal groundwater basins in the study area (Fenel on and others, 2016). 


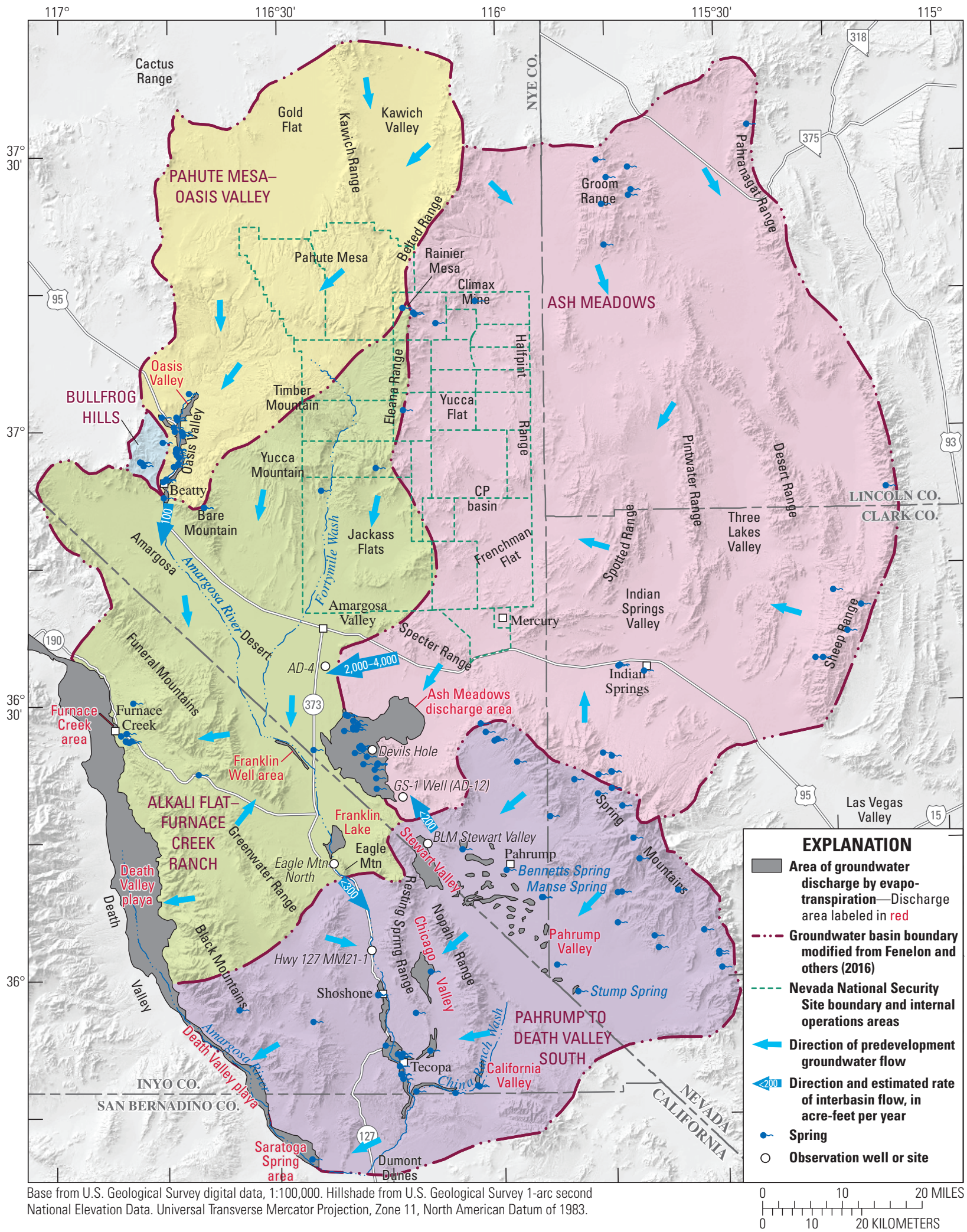

Figure 6. Groundwater basins and major discharge areas in the study area, Nevada and California. 


\section{Discharge Areas}

Discharges define groundwater budgets for undeveloped groundwater basins because (1) discharge is approximately equal to recharge prior to development; and (2) recharge is more difficult to quantify than discharge because recharge cannot be measured directly (B redehoeft, 2007). Imbalances betw een discharge and recharge estimates in the G reat $B$ asin typically are attributed to interbasin flow (Maxey and Eakin, 1951).

Spatial distribution of discharge is controlled by topography, hydraulic conductivity (transmissivity), and geologic features. Discharge typically occurs either at a break in slope of the topography or by strong contrasts in hydraulic conductivity between geologic units. Bennetts and Manse Springs in Pahrump Valley were formed by the break in slope between the Spring Mountains and valley floor, whereas springs in the Ash Meadows discharge area (fig. 6) were formed by a normal fault known as the Gravity fault (fig. 5). Discharge from A sh M eadows springs occurs from transmissive carbonate rocks because clayey basin fill downgradient of the Gravity fault limits flow. Locations and magnitudes of discrete discharges al so are controlled by estimated transmissivity distributions. For example, assuming two springs discharge from the same aquifer, the part of the aquifer contributing $6 \mathrm{ft}^{3} / \mathrm{s}$ to one spring must be considerably more transmissive than another part of the aquifer contributing $0.006 \mathrm{ft}^{3} / \mathrm{s}$ to another spring. In the study area, each regional discharge area is characterized individually because estimated hydraulic-property distributions affect local variations in discharge rates within each discharge area.

D ischarge typically occurs in topographically low areas where groundwater is at or near land surface by three processes: (1) spring flow and seepage; (2) transpiration by local phreatophytic vegetation; and (3) evaporation from soil and open water. Each of these processes can be measured directly or estimated. A s groundwater emerges from springs, it forms ponds or flows into free-flowing drainages or local reservoirs. Some of this water infiltrates downward into soils and possibly into an underlying aquifer, but most of the water ultimately is consumed by phreatophytic vegetation or is evaporated. The combined processes of evaporation and transpiration are referred to as evapotranspiration (ET), where only groundwater evapotranspiration is considered in this study. Major discharge areas in the study area occur in topographic lows of each groundwater basin (fig. 6).

The amount and rate of groundwater lost to the atmosphere by ET from discharge areas varies with vegetation type and density, soil characteristics, depth to water, and climate (L aczniak and others, 1999, 2001; Reiner and others, 2002; DeMeo and others, 2003; Moreo and others, 2007; Allander and others, 2009). ET rates generally increase as vegetation health, vegetation density, and soil moisture increase. Previous studies in Nevada have applied various remote-sensing techniques using satellite imagery in combination with field mapping and ET measurements to identify and group areas of similar vegetation and soil conditions within discharge areas (Smith and others, 2007; Allander and others, 2009; Garcia and others, 2014; Berger and others, 2016). Vegetation and soil groupings are referred to as ET units because they represent areas with similar ET rates. Typical ET units include areas of no vegetation (such as open water, dry playa, and moist bare soil) and areas with vegetation dominated by phreatophytic shrubs, grasses, rushes, and reeds.

Regional discharge is estimated by mapping ET units, estimating the total ET from all units, and subtracting nongroundwater contributions such as local precipitation and infiltrated floodwaters. Local precipitation and infiltrated floodwaters are assumed to evaporate locally, or supply plant needs when available (Laczniak and others, 1999). Total discharge can be approximated well by estimating ET rates at discrete locations and delineating ET areas, as was done in the A sh M eadows discharge area (L aczniak and others, 1999). Total discharge in Ash Meadows and Oasis Valley is defined well because groundwater discharge by $\mathrm{ET}\left(\mathrm{ET}_{\mathrm{GW}}\right)$ from different types of vegetative cover was estimated from 18 multiyear, micrometeorological measurement sites (L aczniak and others, 1999; Reiner and others, 2002).

Predevelopment discharge has been estimated for each discharge area in the study area (table 4). Estimates consisted of existing values within each discharge area (Maxey and Jameson, 1948; Malmberg, 1967; Laczniak and others, 1999, 2001, 2006; Reiner and others, 2002; DeMeo and others, 2003; and Fenelon and others, 2016). Estimates from the A sh M eadows discharge area (L aczniak and others, 1999), Indian Springs (M axey and Jameson, 1948), and Oasis Valley (Reiner and others, 2002) are accurate because of detailed, sitespecific, field studies (fig. 6). Discharges from Chicago Valley, California Valley, Franklin Well area, and Shoshone-to-Tecopa areas are less certain because $\mathrm{ET}_{\mathrm{GW}}$ rates were extrapolated from ET measurements in Oasis Valley and Ash Meadows discharge areas (L aczniak and others, 2001). Discharges from D eath Valley playa, Franklin L ake, Furnace C reek area, Pahrump Valley, and Saratoga Spring area were revised in this study because ET rates from playas have been previously overestimated, ET areas have been classified incorrectly, or discharges have been excluded inadvertently (Belcher, 2004; Belcher and Sweetkind, 2010; Belcher and others, 2017).

Discharges primarily differed between DVRFS.v2 and DV3 projects in areas with playas (table 4). Revised discharges were reduced markedly from previous estimates because plausible $\mathrm{ET}_{G W}$ rates from playas approach $0 \mathrm{ft} / \mathrm{yr}$ (Jackson and others, 2018). Previously estimated $\mathrm{ET}_{\mathrm{GW}}$ rates on playas in the study area ranged from 0.13 to $0.15 \mathrm{ft} / \mathrm{yr}$ (DeM eo and others, 2003). These $\mathrm{ET}_{\mathrm{GW}}$ rates were interpreted as annual averages, but better represent the detection limit on $\mathrm{ET}_{\mathrm{GW}}$ rates, given limitations of the Bowen-ratio method (Garcia and others, 2014). 
Table 4. Predevelopment discharge by discharge area for previous and current regional flow analyses of the study area, Nevada and California.

[G roundwater basin: AFFCR, Alkali Flat-Furnace Creek Ranch; PDVS, Pahrump to Death Valley South; PMOV, Pahute Mesa-Oasis Valley. DVR FS.v2: Death Valley Regional Flow System version 2 model (previous regional flow analysis). DV3, Death Valley version 3 model (current regional flow analysis)]

\begin{tabular}{|c|c|c|c|}
\hline \multirow[t]{2}{*}{ Groundwater basin } & \multirow[t]{2}{*}{ Discharge area } & \multicolumn{2}{|c|}{$\begin{array}{c}\text { Annual discharge } \\
\text { (acre-feet) }\end{array}$} \\
\hline & & DVRFS.v2 & DV3 \\
\hline \multirow[t]{4}{*}{ AFFCR } & Furnace Creek area ${ }^{1,2}$ & 5,700 & 6,100 \\
\hline & Franklin Well area & 340 & 340 \\
\hline & Franklin Lake ${ }^{1}$ & 1,000 & $0-700$ \\
\hline & Death Valley playa ${ }^{3,1}$ & 1,400 & $0-100$ \\
\hline \multirow[t]{2}{*}{ Ash M eadows } & A sh M eadows with A margosa Flat & 17,900 & 18,100 \\
\hline & Indian Springs & 660 & 700 \\
\hline PMOV & Oasis Valley & 6,000 & 6,200 \\
\hline \multirow[t]{7}{*}{ PDVS } & Pahrump and Stewart Valleys ${ }^{4}$ & 10,600 & 13,300 \\
\hline & Chicago Valley & 430 & 430 \\
\hline & Shoshone area & 2,100 & 2,100 \\
\hline & Tecopa/California Valley area & 6,200 & 6,300 \\
\hline & Saratoga Spring area ${ }^{5}$ & 2,460 & $0-400$ \\
\hline & Death Valley playa 3,1 & 6,800 & $0-100$ \\
\hline & TOTAL & 61,600 & $53,600-54,900$ \\
\hline
\end{tabular}

\footnotetext{
${ }^{1}$ Discharges differ because playas were assigned different groundwater-evapotranspiration rates

${ }^{2}$ Discharges differ because diversions from Furnace Creek wash were not included in DVRFS.v2 project.

${ }^{3}$ Comparison limited to playa area in DV 3 study area.

${ }^{4}$ Discharges differ because total discharge from Pahrump Valley in DVRFS.v2 project was limited to predevelopment discharges from Bennetts and Manse Springs.

${ }^{5}$ Discharges differ because DVRFS.v2 project used groundwater-evapotranspiration areas and rates that were classified incorrectly in DeMeo and others (2003) and did not subtract the 720 acre-feet per year (acre-ft/yr) (1 cubic foot per second) of return flow from the Amargosa River downstream of Dumont Dunes streamgage. The DV3 discharge estimate is a net discharge estimated from a water balance done for the Saratoga Spring topographic basin in this study. Predevelopment discharge ranges between 800 and 1,200 acre-ft/yr, where subtraction of the 720 acre-ft/yr of return flow results in a net discharge of less than 400 acre-ft/yr in this study.
}

Hydraulic-property estimates and predictions of groundwater discharges from springs depend greatly on specified locations and rates of discharges. Previous studies were designed to estimate the total predevelopment discharge from discharge areas, but not specifically to identify each discrete discharge location within a discharge area (L aczniak and others, 1999, 2001, 2006; Reiner and others, 2002; D eM eo and others, 2003). M ost groundwater either discharges discretely from springs or evapotranspires in ET units that are downgradient of the springs. Discharge rates differ markedly between springs and ET areas. For example, Crystal Pool in the $A$ sh $M$ eadows discharge area discharges $6.4 \mathrm{ft}^{3} / \mathrm{s}(4,600$ acre-ft/yr) from a 5 -ft-diameter spring pool (0.0018 acres), which equates to a discharge rate of more than 2,500,000 $\mathrm{ft} / \mathrm{yr}$. This discharge rate is much more intense than ET rates of $0.9-8.2 \mathrm{ft} / \mathrm{yr}$ from the 3,000 acres of ET units downgradient of Crystal Pool (L aczniak and others, 1999).
"D ouble counting" of discharge occurs when discharges from spring orifices feed downgradient spring runs, wetlands, and moist soils that support phreatophytic vegetation. Predevelopment discharge in a discharge area is double counted if spring discharge and ET are summed and the ET areas are fed by the springs. Spring orifices and ultimate ET locations can differ by more than $3 \mathrm{mi}$. To prevent double counting of discharge, differences in locations and rates of discharge were reconciled by delineating the ET area fed by each spring and attributing cumulative $\mathrm{ET}_{\mathrm{GW}}$ in excess of the spring discharge to the ET area. ET areas fed by springs were delineated by summing $\mathrm{ET}_{\mathrm{GW}}$ rates from $\mathrm{ET}$ units downgradient of the springs until cumulative $\mathrm{ET}_{\mathrm{GW}}$ equaled measured spring discharges. Differences in locations and rates from diversions, ET areas, and springs were reconciled in Ash M eadows, F urnace Creek, Pahrump Valley, L ower A margosa, and Saratoga Spring discharge areas (fig. 6). 


\section{Ash Meadows}

A sh M eadows discharge area includes A margosa Flat, more than 30 springs and seeps at Ash Meadows, and ET areas that extend downgradient from $A$ sh $M$ eadows springs to Carson Slough (fig. 7). Predevelopment discharge from the A sh M eadows discharge area totals 18,100 acre-ft/yr (L aczniak and others, 1999). M ost of the discharge occurs from 19 springs in A sh M eadows, which discharge a total of 16,150 acre-ft/yr (Dudley and Larson, 1976; Laczniak and others, 1999). Discharge by $\mathrm{ET}_{\mathrm{GW}}$ from ET units within A margosa Flat accounts for 1,700 acre-ft/yr of the total discharge, whereas estimated discharge from ET units downgradient of A sh M eadows springs is about 250 acre-ft/yr (Laczniak and others, 1999).

D ischarge from the A sh M eadows discharge area would be twice the predevelopment estimate of 18,100 acre-ft/yr if double counting of discharge is not reconciled. Total discharge from springs in A sh M eadows (16,150 acre-ft/yr) is similar to the 16,400 acre-ft/yr of $\mathrm{ET}_{\mathrm{GW}}$ (L aczniak and others, 1999) estimated from about 10,000 acres of ET units downgradient of the springs (fig. 7). Spring discharges and estimated $\mathrm{ET}_{\mathrm{GW}}$ from ET units are functionally equivalent within the uncertainty of the measurements (Laczniak and others, 1999). Attributing virtually all discharge to springs rather than to large areas of seeps implies that all discharge in the A sh $M$ eadows discharge area occurs through less than 1 acre of spring pools.

Some water that evapotranspires from ET units downgradient of Ash Meadows springs is sourced from diffuse seepage rather than runoff from spring discharge. Water seeps diffusely from the underlying carbonate rocks to the water table through overlying clay-rich, basin fill. Diffuse seepage of $0.02 \mathrm{ft} / \mathrm{yr}$ was estimated from local hydraulic gradients of $0.2 \mathrm{ft} / \mathrm{ft}$ and a hydraulic conductivity of $0.0003 \mathrm{ft} / \mathrm{d}$. Diffuse seepage discharges as $\mathrm{ET}_{\mathrm{GW}}$ from the water table in the $\mathrm{A}$ sh $M$ eadows discharge area and totals about $250 \mathrm{acre}-\mathrm{ft} / \mathrm{yr}$.

Springs in A sh M eadows discharge groundwater from underlying carbonate rocks that minimally interact with overlying basin fill prior to entering spring pools (fig. 8). Flows are controlled by heads decreasing between carbonate rocks and spring pools. Water levels in spring pools generally are higher than the water table around spring pools, as evidenced by the lack of vegetation far from spring pools and runs. Vegetation typically occurs in the A sh M eadows discharge area where the water table is within $10 \mathrm{ft}$ of land surface (Laczniak and others, 1999). Absence of vegetation far from spring pools and runs suggests that the water table is more than $10 \mathrm{ft}$ bel ow land surface, and thus, lower than the pools. M inimal spring discharge returns to the water table from spring runs because clay predominates in the basin fill. A delta-shaped area of phreatophytes downgradient of Crystal Pool is an exception where return flow occurs (fig. 7).

\section{Furnace Creek Area}

About 90 percent of predevelopment discharge from the AFFCR groundwater basin (fig. 6) exits in the Furnace Creek area (table 4), which extends from the alluvial fan of Furnace Creek Wash in the southwest to Nevares Springs in the northeast (fig. 9). Prior to development in the Furnace Creek area, groundwater either discharged from springs upgradient of Furnace Creek Wash or moved as subsurface flow through Furnace Creek Wash and discharged by $\mathrm{ET}_{\mathrm{GW}}$ from phreatophytes on the alluvial fan (fig. 9). Groundwater development began with the alteration of springs and installation of collection galleries that act as French drains in Furnace Creek Wash. Furnace Creek Wash has three collection galleries: (1) a sump; (2) buried tile; and (3) the Furnace Creek Inn tunnel (fig. 9), which collect and divert groundwater in the wash principally for irrigation at The Oasis at Death Valley, formerly known as Furnace Creek Ranch. Discharge from Travertine and Texas Springs also is collected and diverted for water supply in the Furnace Creek area.

Predevelopment discharge from the Furnace Creek area totals $8.5 \mathrm{ft}^{3} / \mathrm{s}(6,200$ acre-ft/yr). Nevares, Travertine, Texas, and undeveloped springs discharge $2.8 \mathrm{ft}^{3} / \mathrm{s}(2,000$ acre-ft/ $\mathrm{yr})$ and ungaged $\mathrm{ET}_{\mathrm{GW}}$ near Travertine Springs discharges about $0.1 \mathrm{ft}^{3} / \mathrm{s}$ ( $\left.70 \mathrm{acre}-\mathrm{ft} / \mathrm{yr}\right)$. A total of $2.0 \mathrm{ft}^{3} / \mathrm{s}$ (1,400 acre-ft/ yr) of subsurface flow in Furnace Creek Wash is diverted by three collection galleries, whereas the remaining subsurface flow passes through the wash and discharges as $\mathrm{ET}_{\mathrm{GW}}$ on the alluvial fan (fig. 9).

Predevelopment discharge from the Furnace Creek area was estimated by reevaluating previous water-budget estimates and conceptual models. Rates and locations of predevelopment discharge differed primarily because of conceptual models that either included or excluded collection galleries in Furnace Creek Wash. The conceptual model used in this study is based on the evaluation of data during three hydrologically distinct periods: (1) predevelopment; (2) mining-tourism; and (3) restoration.

\section{Previous Predevelopment Estimates And Conceptual Models}

Previously published water budgets of the Furnace Creek area synoptically total ed discharge during two periods: 1956-63 (Pistrang and Kunkel, 1964; Hunt and others, 1966) and 1990-2000 (B elcher and Sweetkind, 2010). Estimates of total discharge from the Furnace Creek area ranged from $5.6 \mathrm{ft}^{3} / \mathrm{s}\left(4,100\right.$ acre-ft/yr; Hunt and others, 1966) to $7.9 \mathrm{ft}^{3} / \mathrm{s}$ (5,700 acre-ft/yr; Belcher and Sweetkind, 2010). Estimates of total discharge from the Furnace Creek area differed because conceptual models differed. Miller (1977) is not included because reported discharges were limited to Travertine and Texas Springs. 


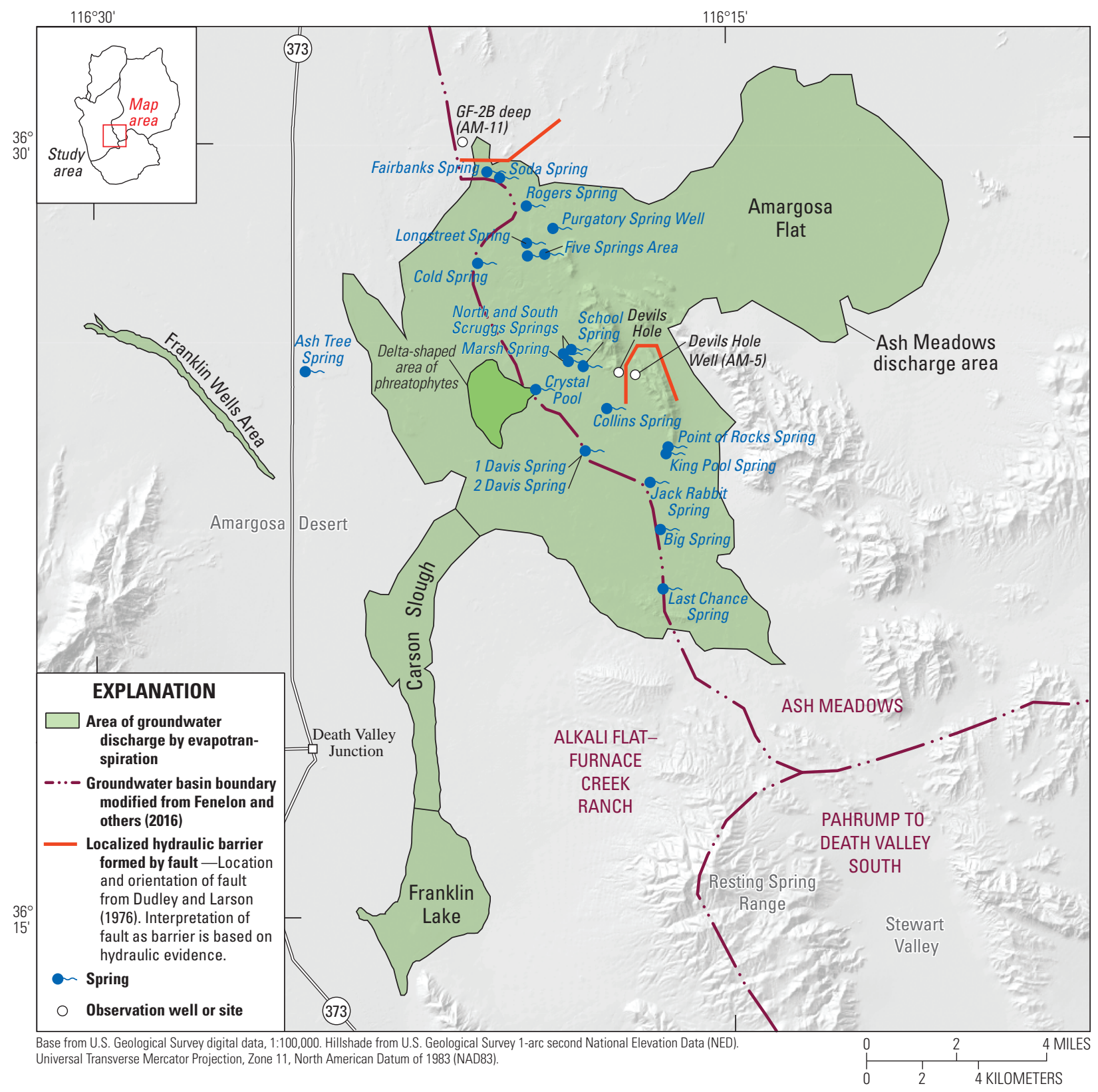

Figure 7. Springs and evapotranspiration areas in the Ash Meadows discharge area and vicinity, Nevada. 


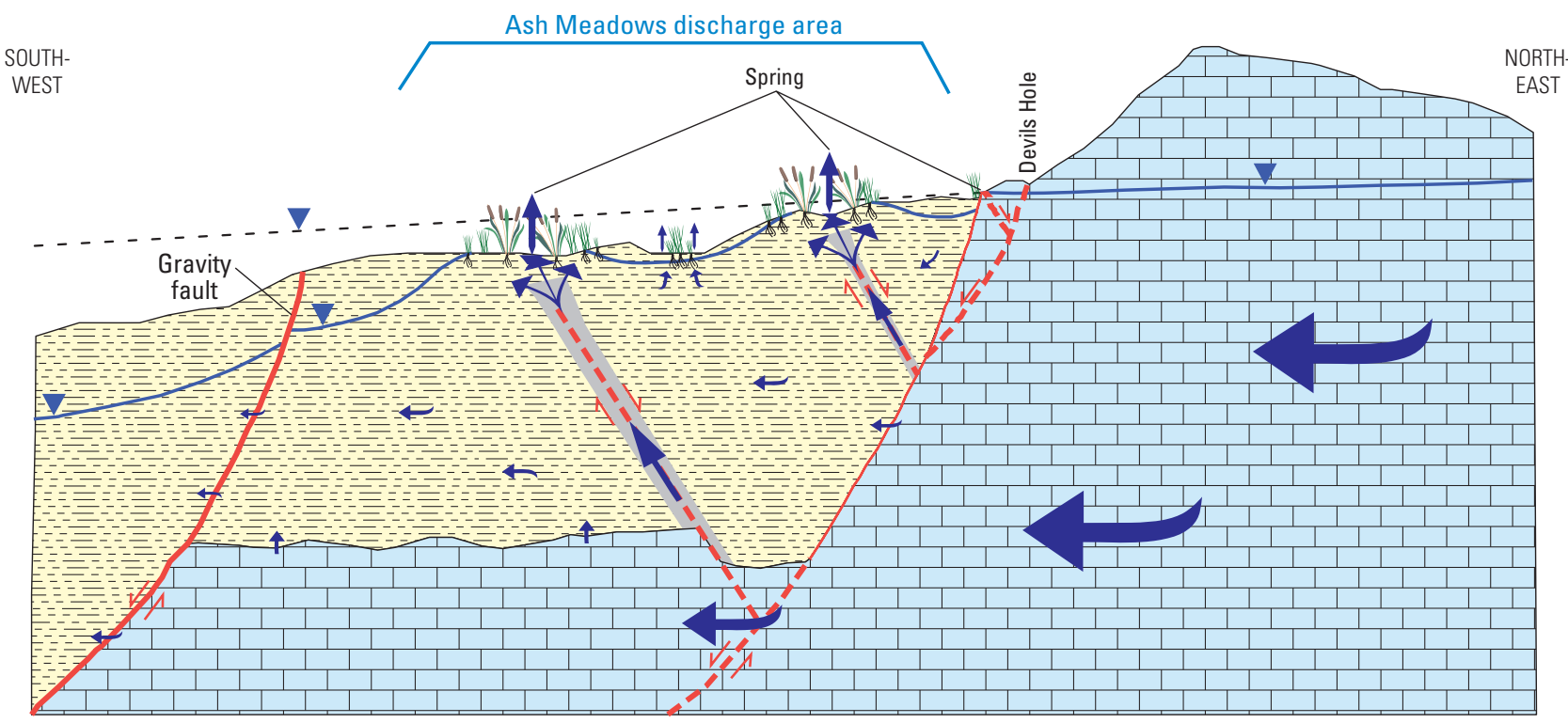

Diagram not to scale, vertical dimension greatly exaggerated.

\section{EXPLANATION}
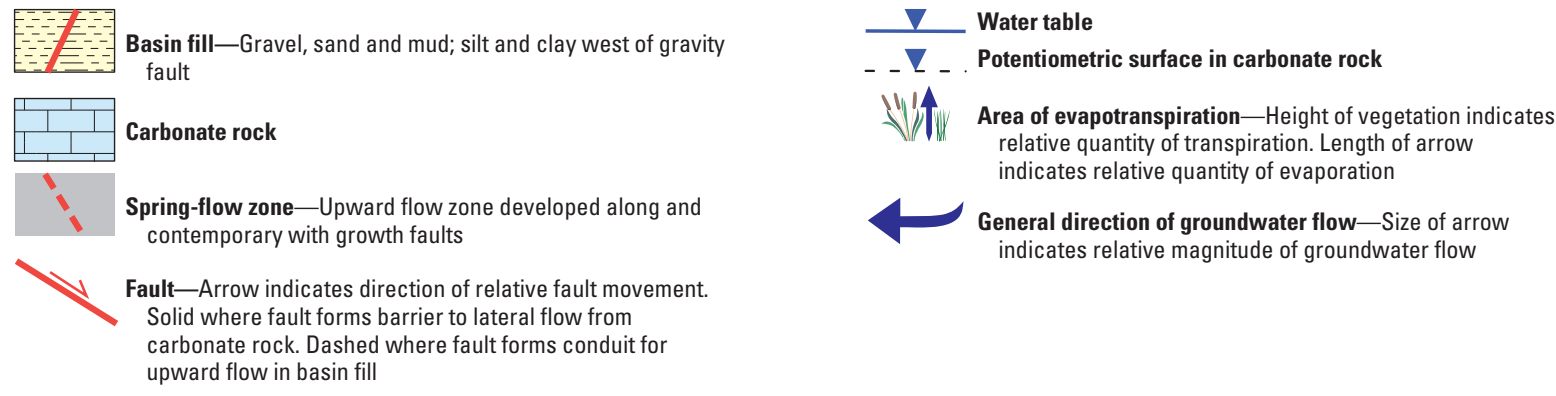

Figure 8. Groundwater flow to springs and phreatophyte areas in the Ash Meadows discharge area, Nevada. Figure modified from Laczniak and others (1999). 


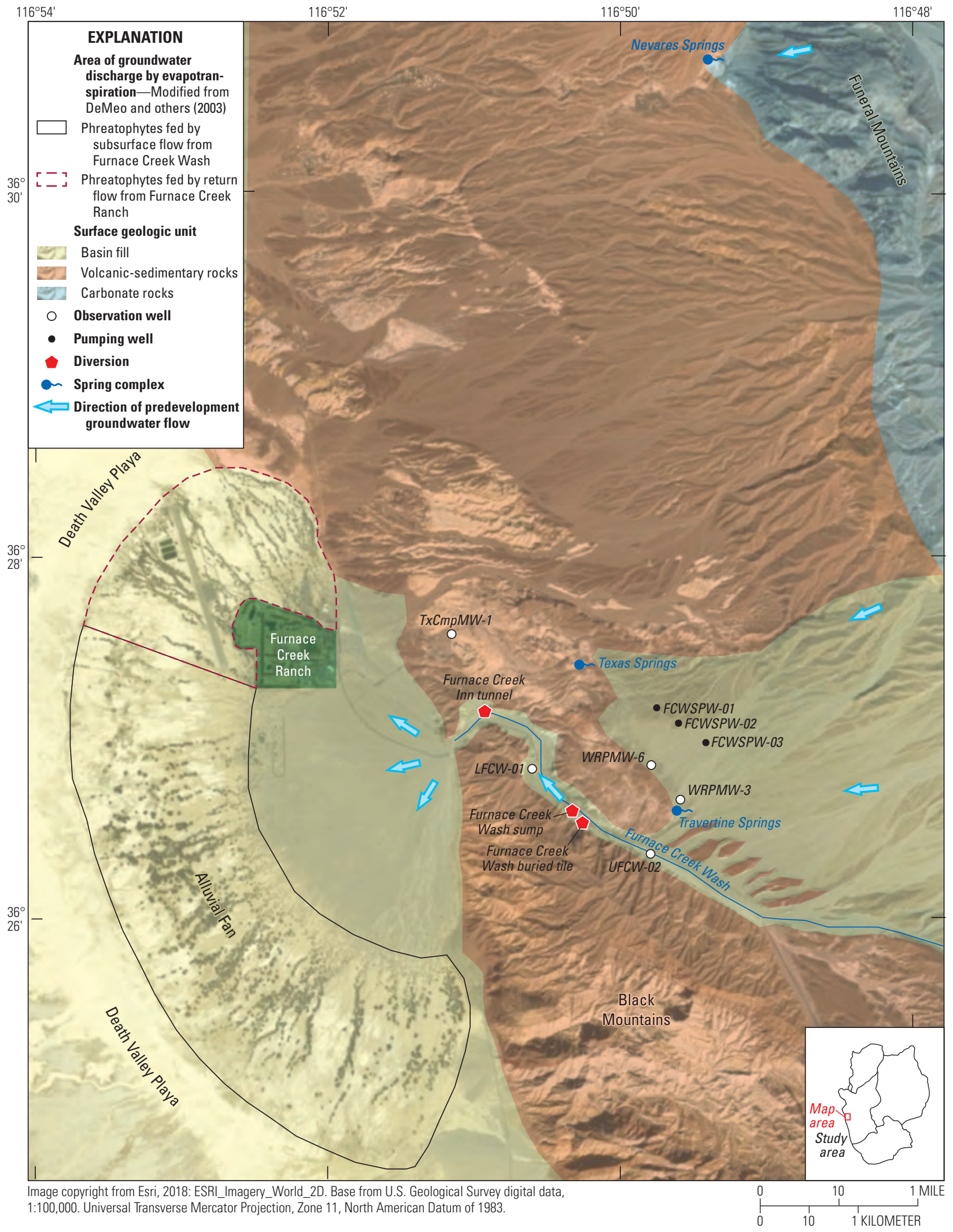

Figure 9. Discharge locations and the historical water-collection system in the Furnace Creek area, California. 
Predevelopment-discharge estimates from the Furnace Creek area during 1956-63 (Pistrang and Kunkel, 1964; Hunt and others, 1966) were similar (table 5) and assumed that all discharge occurred in Furnace Creek Wash upgradient of Furnace Creek Inn tunnel (fig. 9). Water collected by a sump, buried tile, and the Furnace Creek Inn tunnel for irrigation at Furnace Creek Ranch (fig. 9) were included as part of the predevelopment discharge because collected groundwater would have passed through the wash prior to development. Discharge by $\mathrm{ET}_{\mathrm{GW}}$ on the alluvial fan was not included because this discharge was assumed to be reinfiltrated spring discharge and return flow from irrigation at Furnace Creek Ranch, which was sourced from diverted groundwater in Furnace Creek Wash (Hunt and others, 1966, p. B 37). Discharge from Nevares Springs during 1956-63 differed by $0.1 \mathrm{ft}^{3} / \mathrm{s}$ (70 acre-ft/yr; table 5) because small springs downgradient of Nevares Springs were interpreted as reinfiltrated spring discharge and not included by Pistrang and K unkel (1964, p. Y 19), whereas all discharges were totaled by Hunt and others (1966, p. B35). The low permeability of the underlying mudstones, classified as volcanic-sedimentary rocks in figure 9, downgradient of carbonate rocks supports the interpretation of Pistrang and K unkel (1964).

Predevelopment conditions were approximated during the 1990-2000 period (B elcher and Sweetkind, 2010) by summing discharges from Travertine, Texas, and Nevares Springs, and $\mathrm{ET}_{\mathrm{GW}}$ areas on the alluvial fan (table 5). Average discharges from Travertine and Texas Springs were estimated from measurements during the periods 1956-72 and 1989-96, respectively (Belcher and Sweetkind, 2010, table C-2). Discharge from Nevares Springs was the sum of average discharge from the main spring area during the period 1956-57 and discharges from other nearby springs. B elcher and Sweetkind (2010) did not include discharge from the collection galleries in Furnace $\mathrm{Creek}$ Wash because predevelopment conditions were being simulated (Belcher and Sweetkind, 2010). The conceptual model used by Belcher and Sweetkind (2010) assumes that $4.7 \mathrm{ft}^{3} / \mathrm{s}$ (3,400 acre-ft/yr) bypasses Travertine and Texas Springs, moves downgradient, and enters the head of the alluvial fan.

Differences in conceptual models of the natural system understandably arise because all discharges were measured 60 or more years after the Furnace Creek area was developed and total predevelopment discharges differed little in previous investigations. Travertine and Texas Springs were diverted to collection galleries in Furnace Creek Wash between 1880, when mining commenced, and 1920 when tourism was introduced (G reene and $L$ atschar, 1981). A single discharge measurement was reported for Texas Springs and the sump during 1941, but frequent, repeatable measurements of discharge from springs and collection galleries in the Furnace Creek area were not reported until 1956 (Pistrang and K unkel, 1964). $\mathrm{ET}_{G W}$ areas on the alluvial fan were not estimated systematically until more than 100 years after the F urnace Creek area was developed (DeMeo and others, 2003).

\section{DV3 Conceptual Model-Three Hydrologically Distinct Periods}

Predevelopment, mining-tourism, and restoration are three hydrologically distinct periods in the Furnace Creek area that occurred prior to 1880, and during 1880-2008 and 2009-18, respectively. Groundwater flow prior to development was inferred to total $8.6 \mathrm{ft}^{3} / \mathrm{s}(6,200 \mathrm{acre}-\mathrm{ft} / \mathrm{yr})$ where Nevares, Travertine, Texas, and undeveloped springs discharged $2.9 \mathrm{ft}^{3} / \mathrm{s}(2,100$ acre-ft/yr), and the remaining 5.6 $\mathrm{ft}^{3} / \mathrm{s}(4,100$ acre-ft/yr) flowed through Furnace Creek Wash to the alluvial fan (table 5). Development during the miningtourism period diverted a total of $4.1 \mathrm{ft}^{3} / \mathrm{s}(3,000 \mathrm{acre}-\mathrm{ft} / \mathrm{yr})$ from springs and collection galleries in Furnace Creek Wash. Diversions from Travertine and Texas Springs redirected 2.1 $\mathrm{ft}^{3} / \mathrm{s}$ (1,500 acre-ft/ yr) from flowing down washes and across the alluvial fan. Collection galleries in Furnace Creek Wash diverted $2.0 \mathrm{ft}^{3} / \mathrm{s}(1,400$ acre- $\mathrm{ft} / \mathrm{yr})$ of subsurface flow that would have entered the alluvial fan; therefore, discharge from the alluvial fan was reduced from 5.6 to $3.6 \mathrm{ft}^{3} / \mathrm{s}$ (table 5). Most of the diverted water was applied at Furnace Creek Ranch for irrigation of date palms and a golf course, and to support tourism. Flow through the Furnace C reek area was al tered during the restoration period by (1) restoring $1.7 \mathrm{ft}^{3} / \mathrm{s}$ (1,200 acre-ft/yr) to spring runs downgradient of Travertine and Texas Springs; (2) pumping $0.4 \mathrm{ft}^{3} / \mathrm{s}$ (300 acre-ft/yr) from water-supply wells FCW SPW-01, FCW SPW -02, and FCW SPW-03 north of Travertine Springs; and (3) collecting non-potable groundwater from collection galleries in Furnace Creek Wash (fig. 9).

Changing discharge from any location affects all other discharges in the Furnace Creek area, as shown by pumping. Supply wells FCW SPW-01, FCW SPW-02, and FCW SPW-03 began pumping in March 2009 and averaged $0.4 \mathrm{ft}^{3} / \mathrm{s}(300$ acre-ft/yr) during 3 years of pumping (fig. 10). Combined discharge from Travertine and Texas Springs decreased by 0.3 $\mathrm{ft}^{3} / \mathrm{s}$ (200 acre- $\mathrm{ft} / \mathrm{yr}$ ) during the first 2 years of pumping before a local equilibrium was established (J ackson and Halford, 2020). The additional $0.1 \mathrm{ft}^{3} / \mathrm{s}$ (100 acre-ft/yr) of pumped water that did not come from spring capture was supplied from storage in the basin fill.

\section{Discharge from Springs}

Discharges from Travertine, Texas, and undeveloped springs are assumed to minimally infiltrate Furnace Creek Wash and the alluvial fan, and do not contribute to discharge by $\mathrm{ET}_{\mathrm{GW}}$ from phreatophytes on the alluvial fan. This was true during the mining-tourism period because all spring discharges were collected and applied to Furnace Creek R anch. D uring the restoration period, this assumption is supported by discharge from Travertine Springs flowing across the alluvial fan. A sufficient fraction of the $1.3 \mathrm{ft}^{3} / \mathrm{s}$ ( $940 \mathrm{acre}-\mathrm{ft} / \mathrm{yr}$ ) from the restored Travertine Springs flows across the alluvial fan to form ponds and wetlands on the floor of Death Valley (Richard Friese, National Park Service, oral commun., 2015). 
Table 5. Predevelopment and post-development discharge estimates for all sites in the Furnace Creek area, California, prior to 1880 to 2018.

[“-” indicates that the site existed and was measured, but measurements were not included based on the conceptual model. No data indicates that the site existed but was not measured during the period of study. A bbreviations: acre-ft/yr, acre-feet per year; $\mathrm{ft}^{3} / \mathrm{s}$, cubic feet per second; N/A, not applicable]

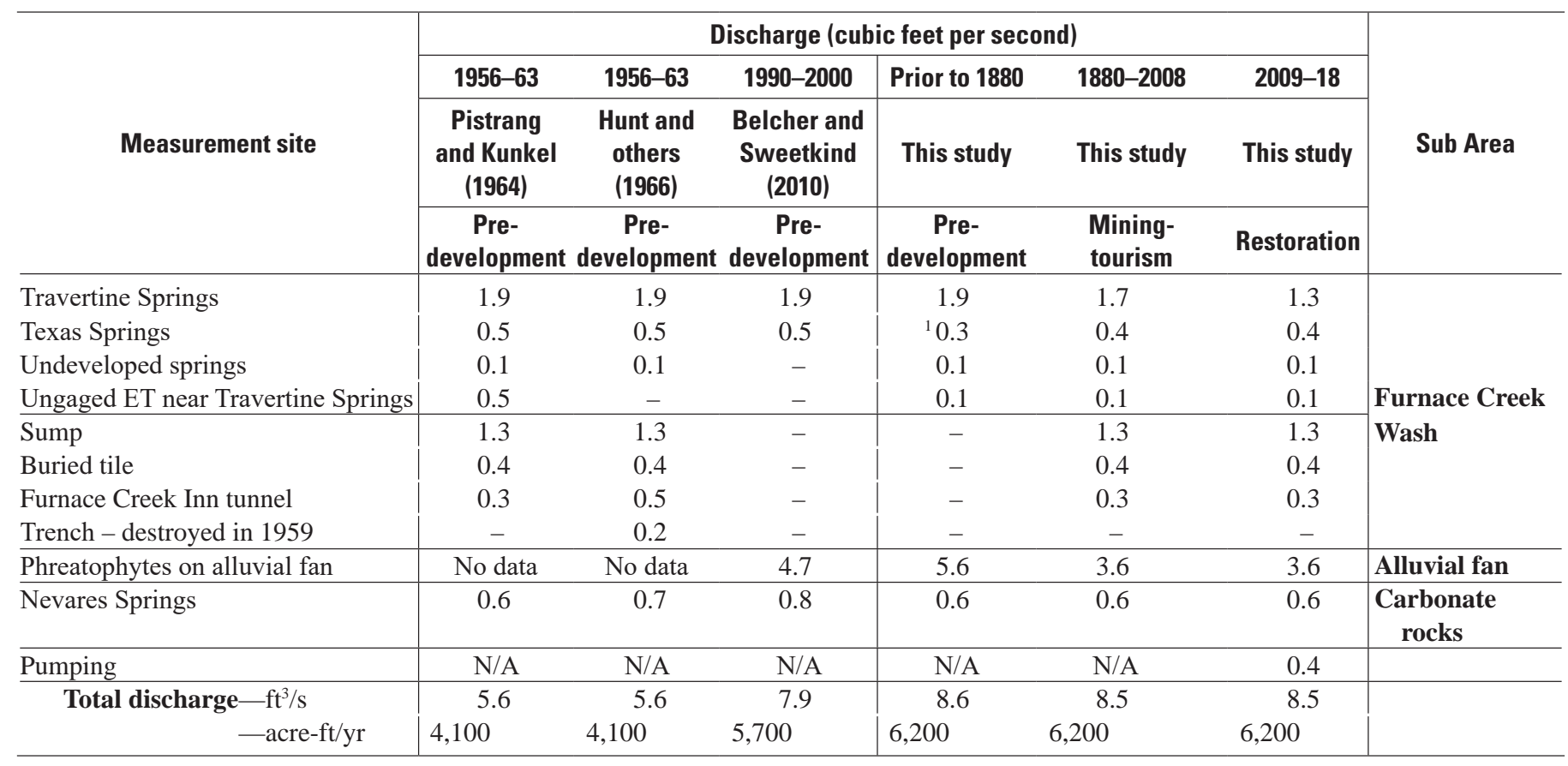

${ }^{1}$ Discharge measured in 1926 prior to construction of tunnel at Texas Spring.

Discharge from Phreatophytes on Alluvial Fan

$\mathrm{ET}_{\mathrm{GW}}$ on the alluvial fan downgradient of Furnace Creek Ranch is sustained in part by return flow. Irrigation and water features at F urnace $C$ reek R anch are supplied by diversions from Travertine Springs, Texas Springs, and collection galleries in Furnace Creek Wash that total 4.1 $\mathrm{ft}^{3} / \mathrm{s}$ (3,000 acre- $\left.\mathrm{ft} / \mathrm{yr}\right)$. Some of the diverted water becomes return flow and infiltrates the alluvial fan to the westnorthwest of Furnace Creek Ranch (fig. 9). All discharge from phreatophytes to the west-northwest of F urnace Creek Ranch totals about $1 \mathrm{ft}^{3} / \mathrm{s}$ ( 720 acre- $\mathrm{ft} / \mathrm{yr}$ ).

In this study, predevelopment discharge from phreatophytes on the alluvial fan totaled $5.6 \mathrm{ft}^{3} / \mathrm{s}(4,100$ acre-ft/yr; table 5), which accounts for return flow and other factors. DeM eo and others (2003) reported a discharge of $4.7 \mathrm{ft}^{3} / \mathrm{s}(3,400$ acre-ft/yr) from the alluvial fan, which was used in the DVRFS.v2 project (Belcher and Sweetkind, 2010; table 5). The $4.7 \mathrm{ft}^{3} / \mathrm{s}$ (3,400 acre-ft/yr) was revised by adding the $2.0 \mathrm{ft}^{3} / \mathrm{s}(1,400 \mathrm{acre}-\mathrm{ft} / \mathrm{yr})$ of diverted water from collection galleries in Furnace Creek Wash, and then subtracting discharge from the Death Valley playa $\left(0.1 \mathrm{ft}^{3} / \mathrm{s}\right.$; $70 \mathrm{acre}-\mathrm{ft} / \mathrm{yr})$ and return flow $(1 \mathrm{ft} / \mathrm{s} ; 720 \mathrm{acre}-\mathrm{ft} / \mathrm{yr})$.

A predevelopment-discharge estimate of $5.6 \mathrm{ft}^{3} / \mathrm{s}(4,100$ acre-ft/yr) from the alluvial fan assumes that all discharge from phreatophytes to the west-northwest of F urnace Creek Ranch ( $1 \mathrm{ft}^{3} / \mathrm{s} ; 720$ acre-ft/yr) is entirely attributed to return flow. More likely only a fraction of the water diverted for Furnace Creek Ranch becomes return flow. About $1 \mathrm{ft}^{3} / \mathrm{s}$ of discharge from the alluvial fan occurs downgradient of Furnace Creek Ranch. Therefore, subsurface flow through Furnace Creek Wash during predevelopment could range from 5.6 to $6.6 \mathrm{ft}^{3} / \mathrm{s}(4,100$ to $4,800 \mathrm{acre}-\mathrm{ft} / \mathrm{yr})$, and subsurface flow through Furnace Creek Wash during the mining-tourism period could range from 3.6 to $4.6 \mathrm{ft}^{3} / \mathrm{s}$ $(2,600$ to 3,300 acre-ft/yr).

\section{Furnace Creek Wash—A Transmissive Feature}

Permeable sediments in Furnace $C$ reek Wash connect basin-fill deposits upgradient of Travertine Springs to the alluvial fan on the floor of Death Valley (fig. 9). Furnace Creek Wash consists of coarse-grained sediments as evidenced by lithologic well logs from wells LFCW-01 and UFCW-02, which are open to gravels and sands in Furnace Creek Wash. Rocks surrounding Furnace Creek Wash are predominantly low-permeability mudstones, as evidenced by a low hydraulic conductivity of 0.0001 $\mathrm{ft} / \mathrm{d}$ in well TxCmpMW-1 (J ackson and Halford, 2020). L ow-permeability mudstones surrounding Furnace Creek Wash and the radial shape of the alluvial fan indicate that most, if not all, groundwater enters the alluvial fan from the mouth of Furnace Creek Wash. The conceptual model depends greatly on $5.6 \mathrm{ft}^{3} / \mathrm{s}$ (4,100 acre-ft/yr) passing through Furnace Creek Wash as subsurface flow, which requires an average transmissivity of $40,000 \mathrm{ft}^{2} / \mathrm{d}$. This assumes a channel width of $300 \mathrm{ft}$ and hydraulic gradient of $0.04 \mathrm{ft} / \mathrm{ft}$. 

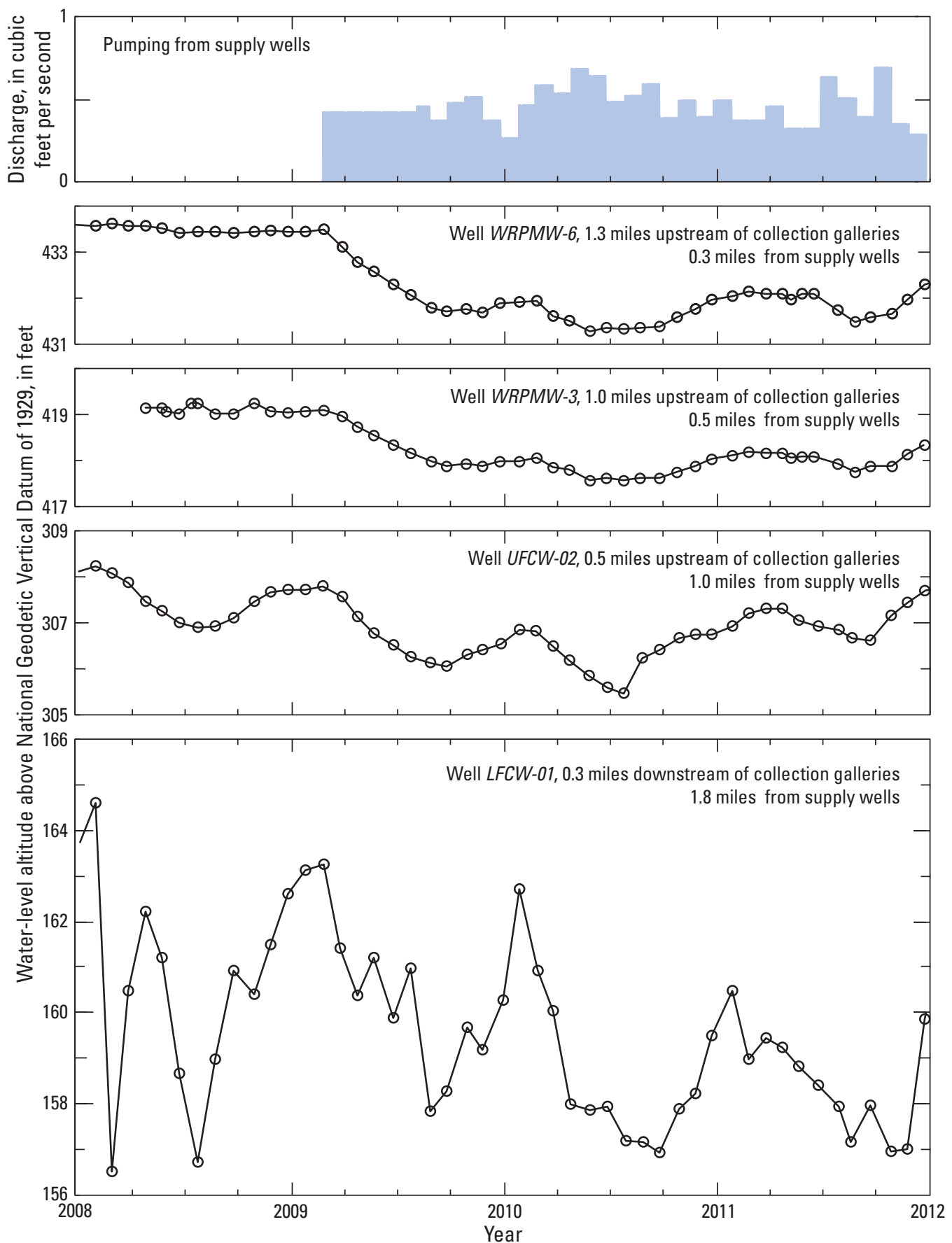

Figure 10. Groundwater-level fluctuations in the Furnace Creek area from collection galleries in Furnace Creek Wash and water-supply wells, California, 2008-12. 
Conveying $5.6 \mathrm{ft}^{3} / \mathrm{s}(4,100$ acre- $\mathrm{ft} / \mathrm{yr})$ requires that Furnace Creek Wash between Travertine Springs and the Furnace Creek Inn tunnel be very transmissive. Annual fluctuations of $8 \mathrm{ft}$ in well LFCW-01 are consistent with Furnace Creek Wash being very transmissive (fig. 10). This is because seasonal water-level changes are attenuated minimally between the well and the sump and tile collectors that are 0.3mi upgradient. Seasonal fluctuations were observed upgradient of the sump and tile collectors in well UFCW-02 prior to pumping of the supply wells (fig. 10). Seasonal fluctuations were attenuated in wells WRPMW-3 and WRPMW-6 by less transmissive coarse-grained sediments upgradient of Travertine Springs.

\section{Mining-Tourism Period-A Steady-State Condition}

Discharge estimates during the mining-tourism period (1880-2008; table 5) best represent steady-state conditions for this investigation. Total predevelopment discharge from phreatophytes on the alluvial fan is uncertain because no information is available regarding the density of phreatophytes prior to development. Collection galleries in Furnace Creek Wash behave as French drains that divert a steady source of groundwater moving through the wash, resulting in little change in groundwater storage but the capture of discharge from phreatophytes on the alluvial fan. Phreatophyte density and $\mathrm{ET}_{\mathrm{GW}}$ rates decreased with time in response to capture, but steady-state conditions likely were established by the end of the 128-year mining-tourism period.

Use of the predevelopment (prior to 1880) period for steady-state model calibration also is infeasible because of limited data. The mining-tourism period has concurrent measurements of discharges and water levels, unlike the predevelopment period. Earliest groundwater levels were measured during 1958 (Pistrang and Kunkel, 1964) or about 80 years after the hydrology of the Furnace Creek area was modified for mining (Greene and Latschar, 1981). Most wells in the Furnace Creek area were drilled after 2000. Discharges from Nevares, Travertine, Texas, and undeveloped springs and $\mathrm{ET}_{\mathrm{GW}}$ on the alluvial fan were measured or estimated concurrently and totaled $6.4 \mathrm{ft}^{3} / \mathrm{s}$ (4,600 acre-ft/yr). Water diverted by collection galleries in Furnace Creek Wash was measured during 1956 and 1963 (Pistrang and K unkel, 1964). Total diversions of $2.0 \mathrm{ft}^{3} / \mathrm{s}(1,400 \mathrm{acre}-\mathrm{ft} / \mathrm{yr})$ were assumed to be unchanged between 1960 and 2018.

\section{Pahrump Valley}

The Pahrump Valley discharge area includes Bennetts, Manse, and Stump Springs, and $\mathrm{ET}_{\mathrm{GW}}$ areas in Pahrump and Stewart Valleys (fig. 11). Predevelopment discharge from the Pahrump Valley discharge area totaled 13,300 acre-ft/yr.
Bennetts and Manse Springs discharged 9,800 acre-ft/yr (13.5 $\mathrm{ft}^{3} / \mathrm{s}$ ) prior to development in 1910 and accounted for more than 70 percent of predevelopment discharge. Most discharge from Bennetts and Manse Springs reinfiltrated the shallow basin fill and was consumed by downgradient phreatophytes in central Pahrump Valley (M almberg, 1967). Phreatophytes in northern Pahrump, southern Pahrump, and Stewart Valleys were sustained directly from shallow groundwater, not spring runs (Harrill, 1986). Discharge from these areas, which were not dependent on Bennetts and Manse Springs, totaled 3,500 acre-ft/yr (fig. 11).

Predevelopment discharges from Pahrump and Stewart Valleys for this investigation were revised by evaluating groundwater budgets from previous investigations. Quantities and distributions of discharge from Harrill (1986) were accepted as reported, with a few exceptions. Discharges from Bennetts and Manse Springs total ed 9,800 acre-ft/yr $\left(13.5 \mathrm{ft}^{3} / \mathrm{s}\right)$, but issued from spring orifices rather than being distributed downgradient across phreatophyte areas as was simulated by Harrill (1986). Remote sensing estimates of discharge from Stewart Valley, which totaled 1,000 acre-ft/ yr (L aczniak and others, 2001), replaced estimates from Harrill (1986). Revised discharge estimates for Stump Spring (J ackson and $\mathrm{Halford}, 2020$ ) and inclusion of phreatophytes 1-8 mi south of Manse Spring (M almberg, 1967), which were inadvertently excluded by Harrill (1986) (fig. 11), added 300 acre-ft/yr to previous estimates by Harrill (1986). M apped discharge areas (and predevelopment-discharge rates) from the previous investigations that are used in this project are shown in figure 11.

Discharge prior to development in Pahrump Valley was underestimated by M almberg (1967). Evapotranspired discharge and extent of phreatophytes downgradient of Bennetts and Manse Springs in 1961 were assumed by M almberg (1967) to be similar to predevelopment conditions. $\mathrm{ET}_{\mathrm{GW}}$ from these phreatophytes totaled 7,000 acre-ft/yr (9.7 $\mathrm{ft}^{3} / \mathrm{s}$ ) in 1961 and originated as return flow from irrigation and Manse Spring (Malmberg, 1967, p. 28-29). The assumption of similar $\mathrm{ET}_{\mathrm{GW}}$ rates and phreatophyte extents prior to development and during 1961 is inconsistent with intensive groundwater development in Pahrump Valley. Between 1916 and 1961, pumping increased from 4,300 to 28,500 acre-ft/yr and spring discharges decreased from 9,800 to 1,500 acre-ft/ yr (2.1 ft³/s; M almberg, 1967, p. 31). $\mathrm{ET}_{\mathrm{GW}}$ by phreatophytes from shallow groundwater in northern Pahrump, southern Pahrump, and Stewart Valleys totaled 3,300 acre-ft/yr (M almberg, 1967, p. 29) and has differed little in subsequent estimates (Harrill, 1986; Laczniak and others, 2001) because these phreatophyte areas are farther from pumping than phreatophytes downgradient of Bennetts and Manse Springs. 


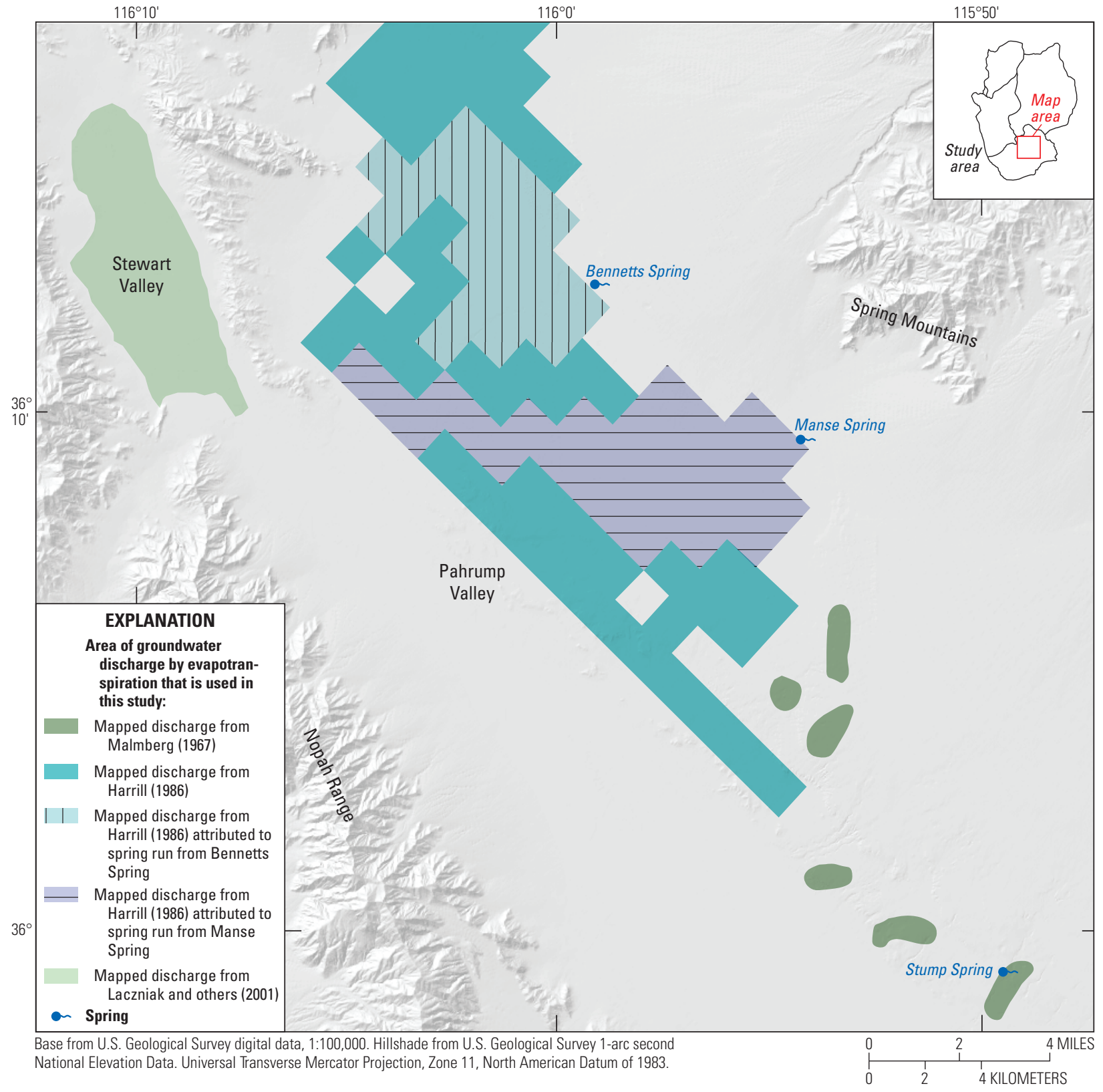

Figure 11. Discharge areas in Pahrump and Stewart Valleys, Nevada and California. 
Predevelopment discharge of 9,800 acre-ft/yr $\left(13.5 \mathrm{ft}^{3} / \mathrm{s}\right)$ from Bennetts and Manse Springs is accurate (Harrill, 1986). This discharge combined reported discharges of 7.5 and 6 $\mathrm{ft}^{3} / \mathrm{s}$ from Bennetts and Manse Springs, respectively, during 1875 and 1877 (Maxey and Jameson, 1948, p. 10). These measurements were corroborated by measured discharges during 1916 from springs and flowing wells that were drilled between 1910 and 1916 (Waring, 1921). Discharge from Bennetts and Manse Springs totaled 5,800 acre-ft/yr ( 8.0 $\mathrm{ft}^{3} / \mathrm{s}$ ), whereas discharge from 8 of 13 flowing wells totaled 2,600 acre-ft/yr (3.6 ft $\left.\mathrm{t}^{3} / \mathrm{s}\right)$ during 1916 (Waring, 1921, p. 64). Discharge from springs and flowing wells exceeded $8,400$ acre-ft/yr ( $11.6 \mathrm{ft} 3 / \mathrm{s})$ and would equal measured predevelopment discharge from Bennetts and Manse Springs if flow from each of the five unmeasured wells equaled average discharge of the eight measured wells.

Predevelopment discharges from Pahrump Valley in the DVRFS.v2 project differed from those reported by Malmberg (1967) and Harrill (1986) and totaled 10,600 acre-ft/yr (table 4). Predevelopment discharge from Bennetts and Manse Springs total ed 9,600 acre-ft/yr (B elcher and Sweetkind, 2010; 32,400 m $/ \mathrm{d}$ in table C-2). The $200 \mathrm{acre}-\mathrm{ft} / \mathrm{yr}\left(0.3 \mathrm{ft}^{3} / \mathrm{s}\right)$ difference between Belcher and Sweetkind (2010) and Harrill (1986) likely resulted from rounding as discharge units were converted from cubic feet per second to cubic meters per day. All discharge from Pahrump Valley was simulated diffusely as $\mathrm{ET}_{\mathrm{GW}}$ from phreatophyte areas with the DVRFS.v2 model, including Bennetts and Manse Springs.

\section{Lower Amargosa Area}

L ower A margosa discharge area includes springs and ET areas between Shoshone, California, and Dumont Dunes, and in Chicago and California Valleys (fig.12). The discharge area is divided into three subareas: (1) Chicago Valley; (2) Shoshone area; and (3) Tecopa/California Valley area. The Shoshone area spans the Amargosa River from the Shoshone Spring complex to north of B orehole Spring and extends east to include Chappo Spring. The Tecopa/California Valley area spans the Amargosa River from Borehole Spring to Dumont Dunes and extends east to include springs and ET areas in California Valley, China Ranch Wash, and at the southern part of the Resting Spring Range.

Predevelopment discharge from the Lower Amargosa discharge area total ed 8,830 acre-ft/yr. Discharge from Twelvemile Spring and $\mathrm{ET}_{\mathrm{GW}}$ areas within Chicago Valley accounted for 430 acre-ft/yr of the total discharge. Predevelopment discharge from the Shoshone area and Tecopa/California Valley area totaled 2,100 and 6,300 acre-ft/ yr, respectively.

Predevelopment discharge from the Lower Amargosa discharge area was estimated with remote sensing and extrapolated $\mathrm{ET}_{\mathrm{GW}}$ rates (L aczniak and others, 2001). Reported predevelopment discharges have differed by less than 100 acre-ft/yr between previous investigations (Laczniak and others, 2001, p. 36; B elcher and Sweetkind, 2010, p. 103). These minor differences can be attributed to rounding and not simulating small discharges in model cells on the periphery of the L ower A margosa discharge area (Faunt, B lainey, and others, 2010, p. 269).

Shoshone and Tecopa/California Valley areas are the functional terminus of discharge within the PDVS groundwater basin (fig. 1) because the Greenwater Range and Ibex Hills west of the Amargosa River and Sperry Hills south of Tecopa are mostly impermeable (fig. 12). Low-permeability quartzite and Miocene sedimentary, volcanic, and intrusive rocks are present beneath the water table from the A margosa River to the ridges of the Greenwater Range and Ibex Hills (Sweetkind and others, 2001, plate 3). Sperry Hills consist of low-permeability siliciclastic and M iocene rocks (Sw eetkind and others, 2001, plate 3). M iocene rocks are correlated with mudstones of the Furnace Creek area that have a hydraulic conductivity of $0.0001 \mathrm{ft} / \mathrm{d}$ in well TxCmpMW-1 (fig. 9). All these geologic units have expected transmissivities of less than $10 \mathrm{ft}^{2} / \mathrm{d}$.

The extent of the ancestral Lake Tecopa also is consistent with the area west of the Amargosa River and south of Tecopa being relatively impermeable. Lake Tecopa occupied Tecopa Valley, reached a maximum depth of $500 \mathrm{ft}$, and was drained 186,000 years ago after the Amargosa River breached the Sperry Hills (M orrison, 1999). D owngradient features such as Dublin Hills and Sperry Hills cannot be transmissive and sustain a 500 -ft-deep lake.

The terminus of regionally transmissive units south of Tecopa was delineated using synoptic discharge measurements at temporary streamgage sites (seepage run) in the A margosa River on February 27, 2014 (Belcher and others, 2019). When storm-runoff gains are minimal, streamflow gains between synoptic measurements identify reaches where groundwater flow into the river exceeds evaporative losses. These conditions existed because $\mathrm{ET}_{\mathrm{GW}}$ is less in winter and the last runoff event in the Amargosa River at Tecopa, California (USGS streamgage 10251300) occurred 60 days prior to the seepage run.

Flow in the Amargosa River increased by $3.5 \mathrm{ft}^{3} / \mathrm{s}$ (2,500 acre-ft/yr) between Borehole Spring (USGS streamgage 10251290) and site A R 11 (USGS streamgage 354903116130401), a 5.5-mi reach (fig. 13). Increases from areas 3-5.5 mi downstream of B orehole Spring came from springs discharging from conglomerates, sandstones, and localized megabreccia (China Ranch beds) at the contact with underlying siliciclastic rocks on the east side of the A margosa River canyon (B elcher and others, 2019). This contact occurs from 50 to $100 \mathrm{ft}$ above the channel of the Amargosa River. 


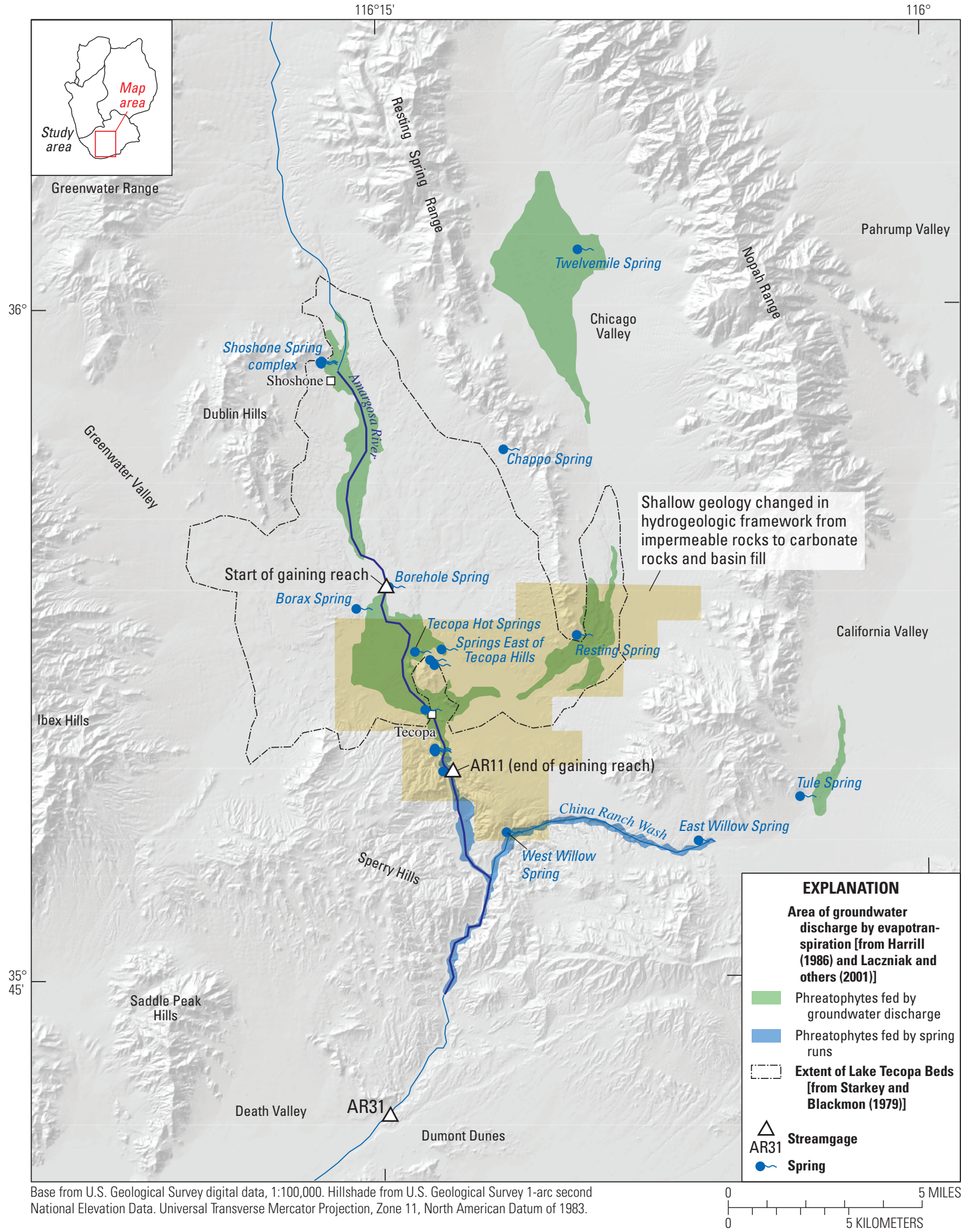

Figure 12. Discharge areas in the Lower Amargosa discharge area and extent of Pleistocene Lake Tecopa, Nevada and California. 


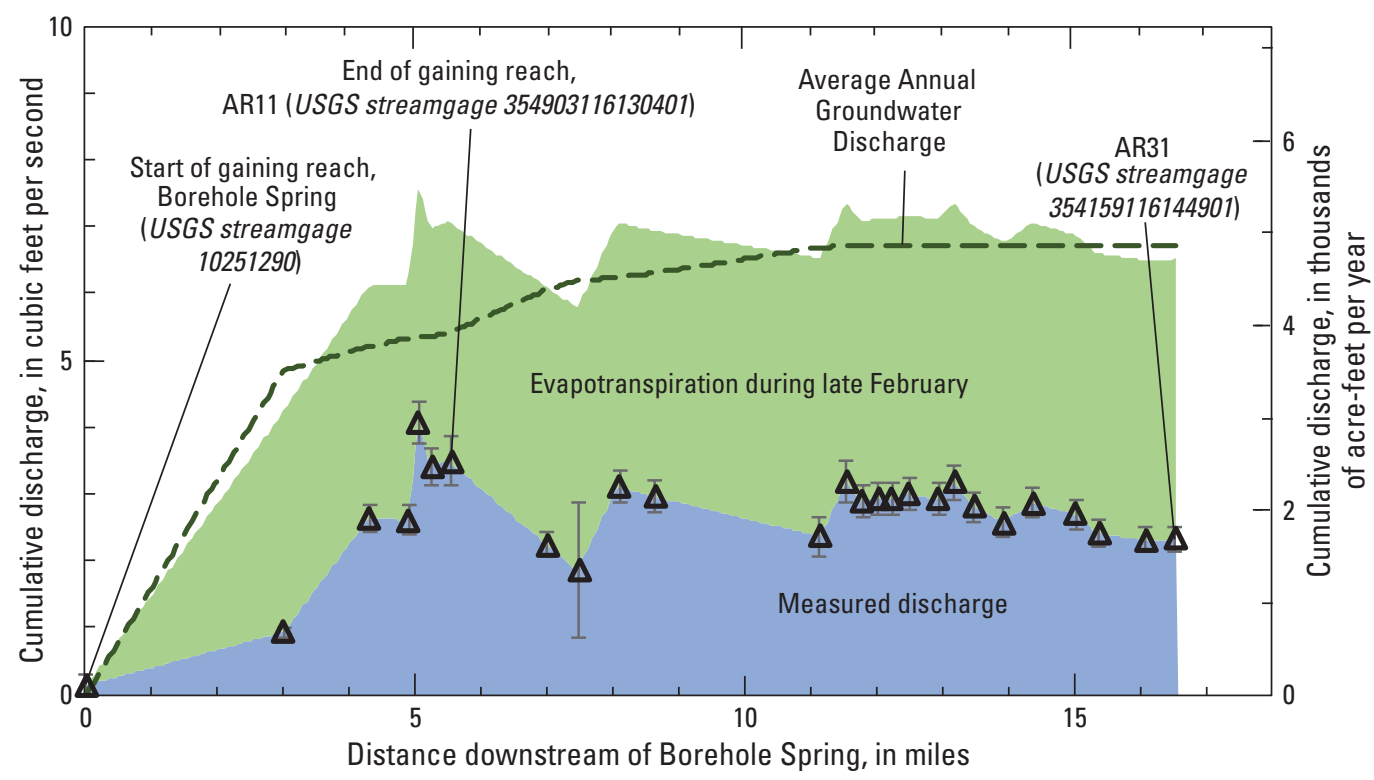

Figure 13. Groundwater discharge to river and estimated evapotranspiration in the Amargosa River downstream of Borehole Spring, California, on February 27, 2014, and cumulative annual evapotranspiration.

Site A R 11 (USGS streamgage 354903116130401 ) marked the terminus of the groundwater system because streamflow decreased downstream of site AR11 (fig. 13), indicating no additional groundwater gains. Flow in the Amargosa River decreased by about $1 \mathrm{ft} / \mathrm{s}$ ( 720 acre- $\mathrm{ft} / \mathrm{yr})$ between sites A R 11 (USGS streamgage 354903116130401) and A R 31 (USGS streamgage 354159116144901 ) near Dumont Dunes (fig. 12). Observed conditions were consistent with relatively large evaporative losses during late February and negligible groundwater/surface-water interaction.

Not all groundwater flow into the Amargosa River downstream of B orehole Spring was measured because substantial $\mathrm{ET}_{\mathrm{GW}}$ occurred during the seepage run (fig. 13). $M$ aximum daily temperatures in Shoshone range from 60 to $81^{\circ} \mathrm{F}$ during late February (National Climatic Data Center, 2017). $\mathrm{ET}_{G W}$ rates during late February average 60 percent of annual average $\mathrm{ET}_{\mathrm{GW}}$ rates (L aczniak and others, 1999, 2001). Estimated $\mathrm{ET}_{\mathrm{GW}}$ along the Amargosa River on February 27, 2014 , was computed by multiplying average winter $\mathrm{ET}_{\mathrm{GW}}$ rates by the acreage of ET units for each ET unit, and summing total $\mathrm{ET}_{\mathrm{GW}}$ between streamflow measurement sites. Similarly, annual average discharge along the Amargosa River was computed using annual average $\mathrm{ET}_{G W}$ rates. $\mathrm{ET}_{\mathrm{GW}}$ totaled 3,000 acre-ft/yr ( $\left.4.2 \mathrm{ft}^{3} / \mathrm{s}\right)$ during the seepage run because $\mathrm{ET}_{\mathrm{GW}}$ rates during late February averaged $1.16 \mathrm{ft} / \mathrm{yr}$ across 2,600 acres of ET units.

Annual average discharge and total discharge agree in magnitude and distribution on February 27, 2014 during the seepage run (fig. 13). Total discharge from the Amargosa River downstream of Borehole Spring averages 4,900 acre-ft/yr or
$6.8 \mathrm{ft}^{3} / \mathrm{s}$ (Laczniak and others, 2001). Discharge (streamflow) in the Amargosa River and $\mathrm{ET}_{\mathrm{GW}}$ during late February totaled $7.0 \mathrm{ft}^{3} / \mathrm{s}(5,100 \mathrm{acre}-\mathrm{ft} / \mathrm{yr}$ ) at site A R 11 (USGS streamgage 354903116130401). Combined discharge and $\mathrm{ET}_{G W}$ varied little between sites A R 11 and A R 31 (fig. 13). These results partially validate estimates from Laczniak and others (2001) and are consistent with site A R 11 being the terminus of the groundwater system.

$\mathrm{ET}_{\mathrm{GW}}$ areas sourced from upgradient springs were not simulated in this investigation to prohibit double counting of discharge. $\mathrm{ET}_{\mathrm{GW}}$ areas in the Amargosa River canyon downstream of site A R 11 had discharges totaling 1,100 acre-ft/yr $\left(1.5 \mathrm{ft}^{3} / \mathrm{s}\right)$, which were attributed to springs discharging from the China Ranch beds upstream of site A R 11 (fig. 12). Discharges in $\mathrm{ET}_{\mathrm{GW}}$ areas downgradient of springs in China Ranch Wash similarly was totaled and attributed to upgradient springs. Discharges from West Willow and East Willow Springs totaled 300 and 200 acre-ft/yr (0.4 and 0.3 $\mathrm{ft}^{3} / \mathrm{s}$ ), respectively.

\section{Saratoga Spring Area}

G roundwater in the Saratoga Spring area is supplied by a small topographic basin that mostly is isolated within the PDV S groundwater basin (fig. 14). Recharge to the Saratoga Spring area is derived from infiltration of streamflow from the Amargosa River, local recharge, and subsurface bedrock leakage to basin fill. Discharge from the Saratoga Spring area occurs from one spring and about 1,450 acres of phreatophytic vegetation. 


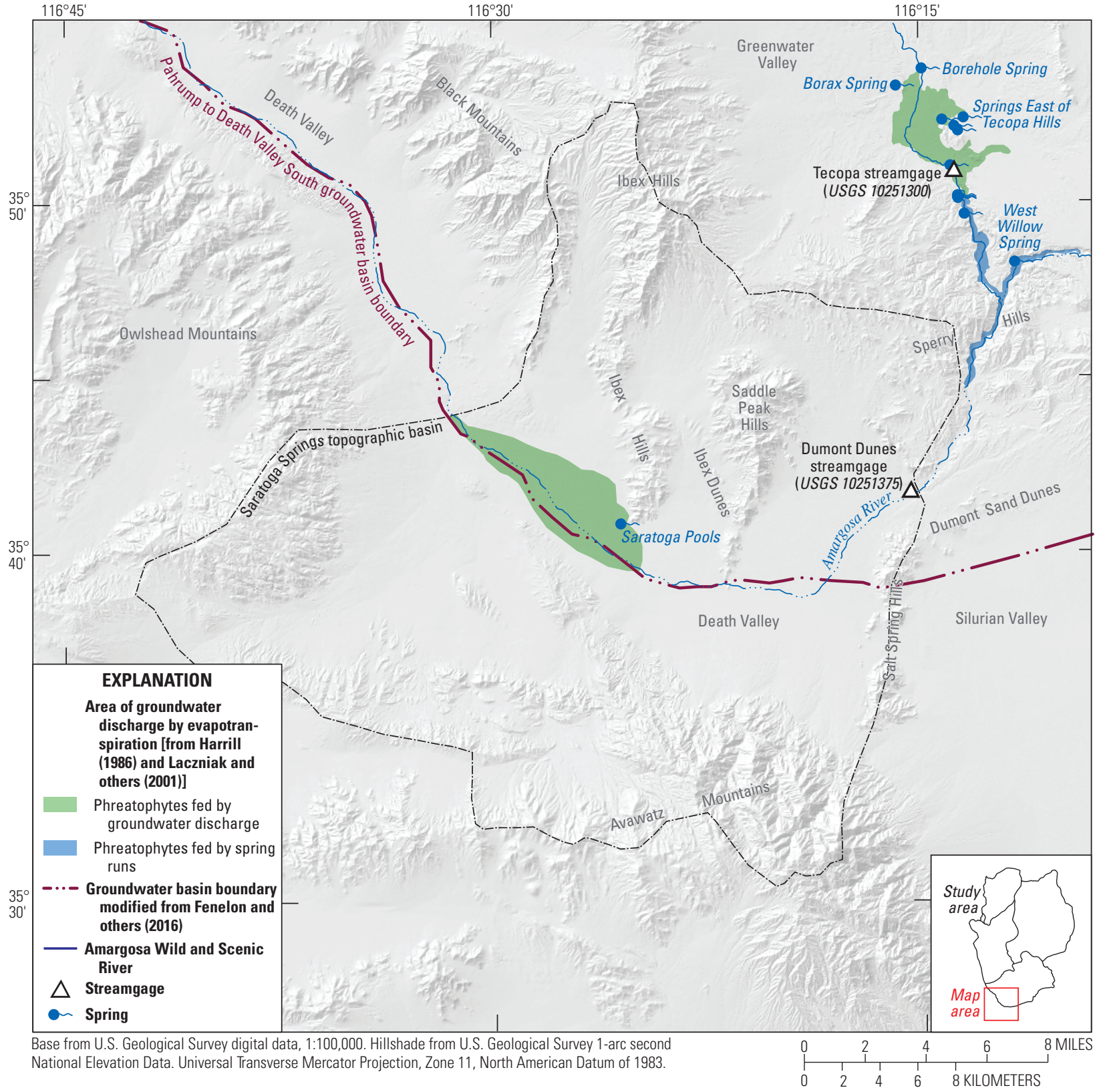

Figure 14. Upgradient source and discharge areas for the Saratoga Spring area, California. 
Saratoga Spring topographic basin principally is recharged by infiltration from the Amargosa River downstream of the Dumont Dunes streamgage (fig. 14). In the period of record (1999-2001) at Dumont Dunes streamgage (USGS 10251375), base flow in the Amargosa River averaged $720 \mathrm{acre}-\mathrm{ft} / \mathrm{yr}\left(1.0 \mathrm{ft}^{3} / \mathrm{s}\right)$. This base flow is assumed to infiltrate basin-fill deposits in the river channel, assuming minimal evaporative losses, prior to entering Saratoga Spring topographic basin as subsurface flow.

Recharge to Saratoga Spring topographic basin also occurs from flood events. During flood events, part of the streamflow that enters Saratoga Spring topographic basin infiltrates the Amargosa River channel (fig. 14). Average streamflow during flood events is needed to estimate floodevent recharge to Saratoga Spring topographic basin. Dumont Dunes streamgage (USGS 10251375) has an insufficient period of record (2 years) to estimate average streamflow during flood events. The nearest streamgage with long-term streamflow measurements occurs at Tecopa, California (USGS streamgage 10251300), where streamflow during flood events averaged 1,100 acre-ft/yr $\left(1.5 \mathrm{ft}^{3} / \mathrm{s}\right)$ from 1961 to 2017 . This average was computed from daily streamflows that exceed base flow but are less than 100,000 acre-ft/yr $\left(138 \mathrm{ft}^{3} / \mathrm{s}\right)$. Infrequent, extreme flood events with streamflows of more than 100,000 acre-ft/yr likely do not infiltrate the Amargosa River channel. Instead, this runoff flows downstream of Saratoga Springs topographic basin and floods the Death Valley floor with large volumes of water during extreme events (D eM eo and others, 2003). Recharge to Saratoga Spring topographic basin during flood events would average about 220 acre-ft/yr $\left(0.3 \mathrm{ft}^{3} / \mathrm{s}\right)$ if infiltration rates, computed as a percentage of streamflow, in the Amargosa River channel are similar to measured infiltration in Fortymile Wash (Savard, 1998).

A dditional sources of water to the Saratoga Spring area are local recharge and subsurface bedrock leakage to basin fill. The Saratoga Spring topographic basin is 220,000 acres in size. The annual precipitation volume totals 23,000 acre-ft for precipitation rates that exceed $0.4 \mathrm{ft} / \mathrm{yr}$ from the 1981-2010 Precipitation-elevation Regressions on Independent slopes M odel (PRISM) precipitation distribution (PRISM Climate Group, 2012). A local M axey-Eakin relation estimates recharge as 0.9 percent of annual precipitation volume in excess of $0.4 \mathrm{ft} / \mathrm{yr}$ (Fenelon and others, 2016) or 200 acre-ft. Subsurface bedrock leakage from surrounding low-permeability rocks to basin fill is less than 50 acre-ft/yr assuming a transmissivity of less than $5 \mathrm{ft}^{2} / \mathrm{d}$, a width of $10 \mathrm{mi}$, and a gradient of $100 \mathrm{ft} / \mathrm{mi}$.

Previous predevelopment discharge estimates from Saratoga Spring have differed by an order of magnitude, but primarily resulted from different areas being labeled Saratoga Spring. Saratoga Spring initially was identified as an area of 23 acres that discharges 200 acre-ft/yr (K unkel and Robinson, 1966) and is discussed as Saratoga Pools in this report

(fig. 14). Saratoga Spring also has been identified as a much larger area consisting of Saratoga Pools and mapped ET units
(Faunt, Blainey, and others, 2010, p. 269, table F-4). Reported discharge from the larger Saratoga Spring area totaled 2,460 acre-ft/yr (Faunt, Blainey, and others, 2010), which was estimated with remote sensing and extrapolated $\mathrm{ET}_{\mathrm{GW}}$ rates (DeMeo, and others, 2003). This estimate was biased high and likely occurred because $\mathrm{ET}_{G \mathrm{WW}}$ rates were extrapolated from areas with denser vegetation than in the Saratoga Spring area.

D ischarge from Saratoga Pools totaled 150 acre-ft/yr in this investigation. Kunkel and Robinson (1966) overestimated discharge (200 acre-ft/yr) from Saratoga Pools by applying an $\mathrm{ET}_{\mathrm{GW}}$ rate of $13 \mathrm{ft} / \mathrm{yr}$ to reeds, whereas rates of $8 \mathrm{ft} / \mathrm{yr}$ are more likely (L aczniak and others, 1999). DeM eo and others (2003) underestimated discharge (50 acre-ft/yr) from Saratoga Pools because about 13 acres of open water and reeds were not mapped. Discharge from Saratoga Pools was corrected in this investigation by assigning an $\mathrm{ET}_{\mathrm{GW}}$ rate of $8 \mathrm{ft} / \mathrm{yr}$ to the unmapped 13 acres, which increased total discharge from Saratoga Pools from 50 to 150 acre-ft/yr.

Predevelopment discharge from the Saratoga Spring area totaled 800-1,200 acre-ft/yr from a local water budget, and net discharge was less than $400 \mathrm{acre}-\mathrm{ft} / \mathrm{yr}$ (table 4). Discharge from Saratoga Spring topographic basin was estimated by summing estimated inputs (recharge) and assuming that discharge equal ed recharge. M inimum discharge was supported mostly by 720 acre-ft/yr of base flow infiltrating the Amargosa River channel downstream of Dumont Dunes, California (USGS streamgage 10251375). Estimated recharge from flood events (220 acre-ft/yr), local recharge (200 acre-ft/yr), and subsurface bedrock leakage (50 acre-ft/yr) is uncertain, but minor compared to base-flow infiltration. Because the 720 acre-ft/yr of base-flow infiltration is derived from springs and seeps along the Amargosa River between Shoshone and Tecopa, including base-flow infiltration in the Saratoga Spring water budget would result in double-counting of groundwater between L ower A margosa and Saratoga Spring discharge areas. Subtracting base-flow infiltration results in a net discharge of less than 400 acre-ft/yr for the Saratoga Spring area.

\section{Recharge}

Recharge is spatially and temporally variable in the study area. Spatially varying recharge is dependent on unsaturated zone depth, hydraulic conductivities of unsaturated and saturated rocks, and the distribution of precipitation, where higher altitudes receive more precipitation. Time-varying, or episodic, recharge is precipitation-derived and occurs during brief intermittent periods that cause distinct waterlevel rises in well hydrographs. Conceptual models of spatial and temporal recharge in the study area are discussed in the following sections. 


\section{Spatially Distributed Long-Term Rates}

A recharge distribution was estimated for the study area based on a conceptual model of water availability and permeability of rocks in recharge areas. Rates of infiltration below the root zone were assumed related to precipitation rates and increased as precipitation rates increased. R echarge rates were assumed equal to infiltration rates below the root zone, except where runoff occurs from surface-water flow or subsurface flow. Precipitation-runoff (surface-water flow) occurs when snowmelt runoff or high-intensity rainfall flows downgradient from low-permeability rocks in highland areas and infiltrates adjacent, permeable, alluvial-fan deposits or basin fill in ephemeral channels. Subsurface flow occurs when discontinuous low-permeability rocks form perched intervals above the regional water table. Subsurface flow is assumed to move laterally within the perched system until sufficiently permeable, saturated rocks of the regional system are encountered that can be recharged by the infiltrated water.

The conceptual model of total annual recharge to the study area is a modified Maxey-Eakin (Maxey and Eakin, 1951) approach that honors the annual predevelopment discharge, which ranges from 53,600 to 54,900 acre-ft/yr (table 4). Distributed recharge is conceptualized as a piecewise linear function of total annual precipitation, as defined by the 1981-2010 PRISM precipitation distribution (PRISM Climate Group, 2012). A three-stage relation is assumed to exist betw een precipitation and total potential recharge. Potential recharge includes in-place infiltration, precipitation-runoff, and runoff by subsurface flow. The assumed relation exists for a precipitation rate of $0.3-2.5 \mathrm{ft} / \mathrm{yr}$, which is the range of annual precipitation estimates in the study area (fig. 15). The water available for recharge was estimated from precipitation, where stages are demarcated by inflection points at annual precipitation rates of 1.0 and $1.5 \mathrm{ft} / \mathrm{yr}$ (fig. 15A). Proportions of recharge increase from 0 to $0.9,0.9$ to 4.6 , and 4.6 to 41 percent of annual precipitation in the ranges $0.3-1.0,1.0-1.5$, and $1.5-2.5 \mathrm{ft} / \mathrm{yr}$ of precipitation. Relations between total conceptual recharge and precipitation in excess of 1.0 and $1.5 \mathrm{ft} / \mathrm{yr}$ were adjusted for each groundwater basin so that the cumulative volume of annual recharge equaled net discharge from each groundwater basin and the study area as a whole.

The three-stage relation approximates conceptual differences in water availability even if the inflection points of 1.0 and $1.5 \mathrm{ft} / \mathrm{yr}$ for changes in slope are arbitrary. Infiltration of runoff from summer storms is the primary mechanism for generating recharge at low elevations, where precipitation rates are less than $1 \mathrm{ft} / \mathrm{yr}$. Summer storms occur infrequently and much of the water is lost to ET, resulting in a low ratio of precipitation converted to recharge. About 20 percent $(12,000$ acre-ft/yr) of the total recharge in the study area occurs in areas with precipitation rates of less than $1 \mathrm{ft} / \mathrm{yr}$ (fig. 15B). At higher altitudes where precipitation rates are more than $1 \mathrm{ft} / \mathrm{yr}$, winter snow pack generates most of the recharge and a higher ratio of the precipitation is converted to recharge. Efficiencies increase where precipitation rates are more than $1.5 \mathrm{ft} / \mathrm{yr}$ because ET losses decrease as altitude increases. All water that infiltrates below the root zone is assumed to migrate to the water table in the absence of low-permeability bedrock at the water table.

Except for surface-water channels, recharge is assumed not to occur on valley floors (F rench and others, 1996), which were defined as areas with land-surface slopes less than 1.5 percent. The valley floors have clay-rich soils, low precipitation rates, and warm air temperatures, which promote retention of soil water and ET.

Recharge volumes are limited where hydraulic conductivity of bedrock is less than infiltration rates. Recharge rates cannot exceed hydraulic conductivity of saturated rocks, which results in excess infiltration being displaced laterally downgradient (Fenel on and others, 2008) in Cactus, K awich, B elted, Groom, Eleana, and Greenwater Ranges and areas of the Spring M ountains (fig. 16).

\section{Precipitation-Runoff}

Infiltration is limited where low-permeability rocks occur at land surface and precipitation-runoff flows laterally downgradient until more permeable rocks are encountered. Recharge rates of $0.004 \mathrm{ft} / \mathrm{yr}(0.00001 \mathrm{ft} / \mathrm{d})$ were assumed for low-permeability bedrock and excess infiltration was displaced downgradient to where more permeable rocks could accept the water. The excess infiltration available for recharge from precipitation-runoff was halved and then applied to permeable rocks because additional evaporative losses occur in alluvial channels.

Focused recharge occurs beneath channels of the Amargosa River and Fortymile Wash during infrequent flood events (fig. 16). Annual volumes of infiltration have been estimated for reaches of the Amargosa River from Beatty to the central A margosa Desert, from Eagle M ountain to Shoshone, and from Dumont Dunes to the Saratoga Spring area. Infiltration to the Amargosa River from Beatty to the central A margosa Desert ranges from 80 to $100 \mathrm{acre}-\mathrm{ft} / \mathrm{yr}^{2}$ (Stonestrom and others, 2007). Infiltration to the Amargosa River from Eagle Mountain to Shoshone is less than 700 acre-ft/yr (Osterkamp and others, 1994). Infiltration to the Amargosa River from Dumont Dunes to the Saratoga Spring area totals $920 \mathrm{acre}-\mathrm{ft} / \mathrm{yr}$, where about $720 \mathrm{acre}-\mathrm{ft} / \mathrm{yr}$ is reinfiltrated groundwater that originally discharged into the Amargosa River upstream of Dumont Dunes, California (USGS streamgage 10251375). Infiltration estimates to Fortymile Wash plausibly are about 900 acre-ft/yr (Osterkamp and others, 1994) and have ranged from 90 to 6,550 acre-ft/yr (Czarnecki and Waddell, 1984; French and others, 1996; Savard, 1998).

\footnotetext{
${ }^{2}$ Infiltration rates were miscalculated in Stonestrom and others (2007) because recharge-rate fractions of 12 and 15 percent were multiplied by the 4-year (1998-2001) total of streamflow from table 3 of that report, rather than by the annual average streamflow.
} 

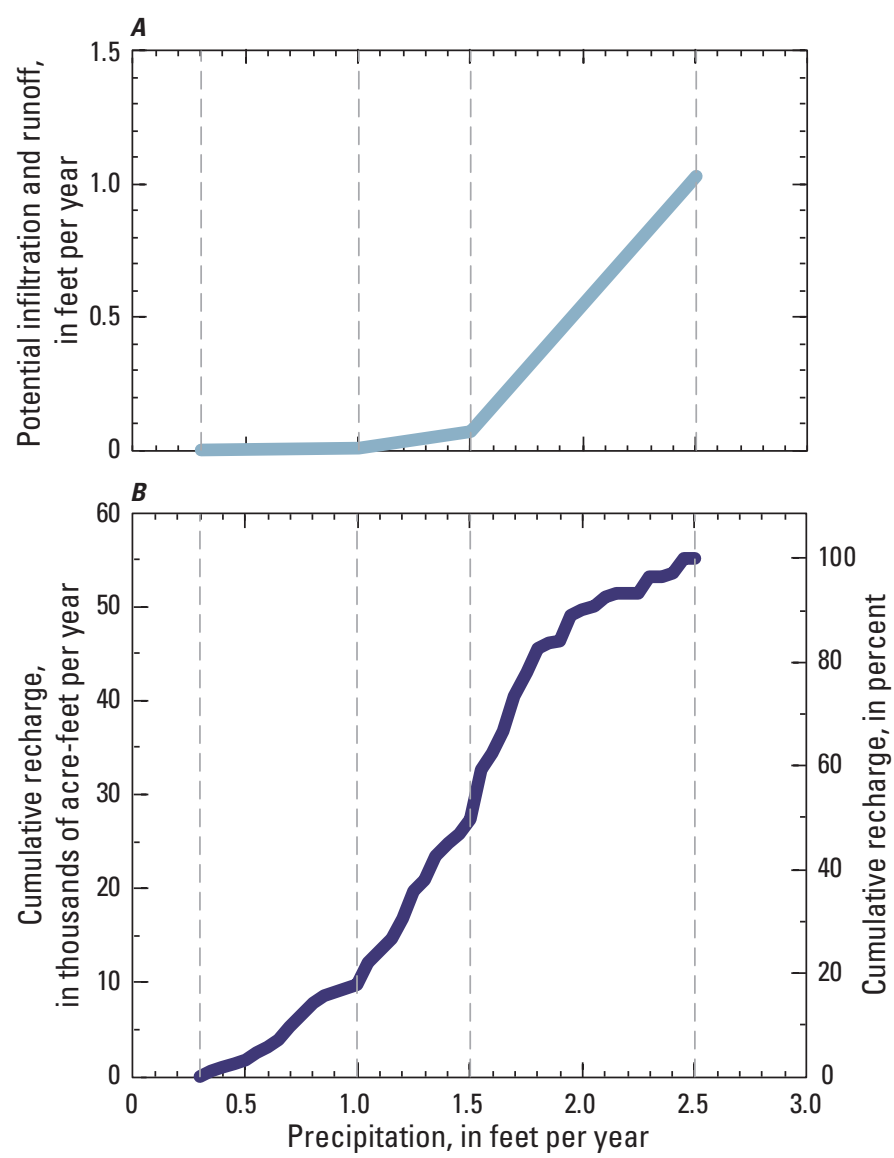

Figure 15. Relation between precipitation rate and $(A)$ conceptual recharge rate from infiltration and runoff to the study area, and $(B)$ cumulative recharge resulting from this relation, in the study area, Nevada and California.

\section{Perched and Semi-Perched Groundwater}

Infiltrated water moves laterally in the subsurface where more permeable rocks permit infiltration near land surface and less permeable rocks at depth limit recharge, resulting in perched or semi-perched conditions. Perched groundwater is a localized, unconfined, saturated volume of groundwater that is separated from the underlying regional groundwater system by an unsaturated zone of discontinuous low-permeability rocks. Semi-perched groundwater is similar to perched groundwater, except that the discontinuous low-permeability rocks are saturated. Perched (and semi-perched) intervals impede infiltration because vertical hydraulic conductivities of underlying low-permeability rocks are less than local infiltration rates, which impounds water and laterally diverts flow. Subsurface flow moves downgradient atop discontinuous low-permeability rocks until permeable saturated rocks of the regional groundwater system are encountered. Perched and semi-perched intervals conceptually redistribute recharge, with less recharge beneath and more at the peripheries of the perched and semi-perched intervals. Recharge rates of $0.004 \mathrm{ft} / \mathrm{yr}(0.00001 \mathrm{ft} / \mathrm{d})$ were assumed for low-permeability bedrock and excess infiltration from subsurface flow was displaced downgradient to where more permeable rocks could accept the water.
In this investigation, the water table encompasses the uppermost occurrence of saturation, which includes perched and semi-perched intervals. Inclusion of perched and semiperched intervals affects conceptual models of recharge and is a practical necessity to simulate advective flow from the locations of nuclear tests beneath Rainier M esa (U.S. Department of Energy, 2018). Advective movement from Rainier M esa cannot be addressed if the locations of nuclear tests are not in the groundwater model of the study area.

\section{Temporal Variability}

Predevelopment conditions are analyzed as steady state in this investigation, which assumes recharge and natural discharge differ negligibly. This steady-state assumption is true if time-varying recharge is averaged over centuries. A long-term average is used because multi-decade water-level rises in wells have resulted from short-term imbalances between recharge and discharge (Fenelon and Moreo, 2002; Elliott and Fenelon, 2010; Fenelon and others, 2012; Jackson and Fenelon, 2018). Short-term (decadal) water-level changes generally can be ignored because spatial gradients are affected minimally, and water-level changes from natural stresses are small relative to pumping effects. Water-level changes in Devils Hole and wells throughout the A sh M eadows discharge area were the exception because natural changes were similar in magnitude to pumping effects. These natural changes were simulated and differentiated analytically from pumping effects with water-level models (Halford and others, 2012). Natural water-level changes were not simulated numerically because hydraulic-property estimates would have been degraded.

A water-level model simulates measured water levels in a well by summing analytically solved water-level changes from recharge, natural discharge, and pumping. This technique has been used effectively by Jackson and Fenelon (2018) to determine stresses affecting water-level trends and can be used to subtract time-varying recharge from the water-level trend in a well. The water-level modeling approach requires a conceptual model of recharge to explain rising water-level trends based on recharge patterns in the study area.

A conceptual model of time-varying recharge and natural discharge was used to explain the behavior of waterlevel trends in the study area prior to development. Water levels fluctuate naturally in response to short-term (hourly to seasonal) hydrologic stresses; therefore, a sufficiently long timescale is required to achieve steady-state conditions. As a rule of thumb, small groundwater basins have short steadystate timescales, whereas large groundwater basins, such as those within the study area, have long steady-state timescales. J ackson and Fenel on (2018) assumed that steady-state conditions occur on a century timescale in the study area based on available water-level data. The conceptual model requires a long-term (century-scale) precipitation record to represent recharge patterns in the study area, and this precipitation record is used to construct a hypothetical water-level record to explain steady-state water-level trends. 


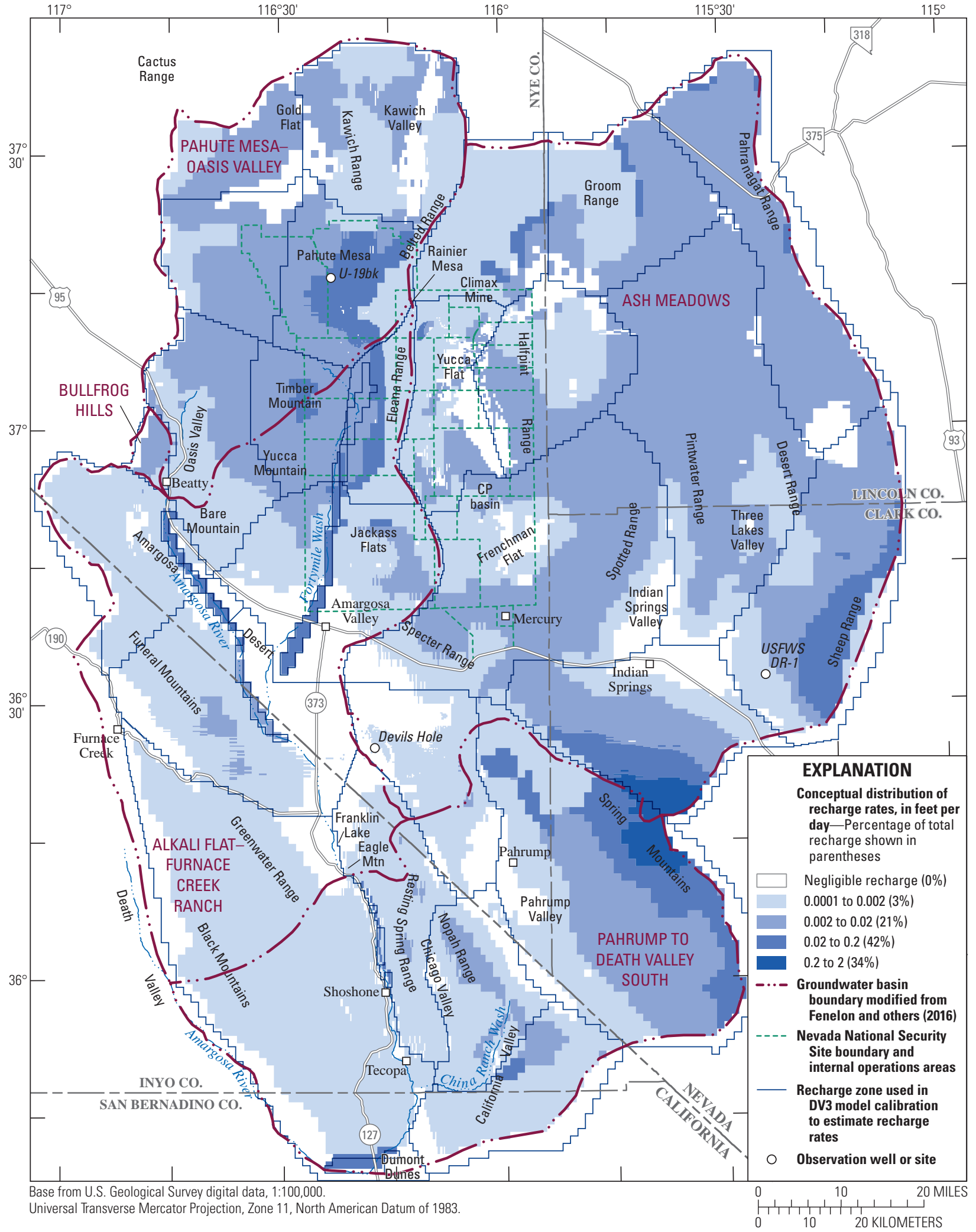

Figure 16. Conceptual recharge distribution, in the study area, Nevada and California. 
The conceptual model postulates that long-term waterlevel fluctuations in predevelopment groundwater systems indicate changes in storage that result from differences between recharge entering the system and discharge leaving the system. In the Great Basin and the study area, more specifically, most natural discharge occurs at springs, seeps, and phreatophyte areas distant from the recharge areas. This regional discharge is nearly constant from year to year because the regional gradient that controls changes in discharge is insensitive to local water-level fluctuations of less than 50 $\mathrm{ft}$ in recharge areas relative to greater than 1,000-ft-head differences along flow paths between recharge areas and distant discharge areas. Unlike discharge, recharge varies temporally, and is the primary cause of annual-to-decadal, water-level fluctuations in the aquifer, as measured in wells.

Recharge principally occurs during winter months between $O$ ctober and $M$ arch, in years with greater-thanaverage precipitation. This is because minimal ET occurs during the winter, which allows infiltrating precipitation to exceed the storage capacity of the root zone and infiltrate below the root zone (Smith and others, 2017). M ore recharge also occurs during winter months because surface runoff is less in areas where snow falls, and the slow melting of snow pack allows more time for infiltration compared to relatively brief rainfall events. Stable-isotope analyses of precipitation and shallow groundwater at Rainier M esa (Russell and others, 1987; Hershey and others, 2008) and the Spring Mountains (Winograd and others, 1998) have indicated that most recharge is derived from winter precipitation. During a winter with less-than-average to slightly above-average precipitation, infiltrating precipitation mostly or entirely contributes to the soil-moisture reservoir depleted by ET during the previous summer. In these years, little to no water infiltrates beyond the root zone. Following winters with greater-than-average precipitation (wet winters), snowmelt infiltrates the root zone, wetting the soil sufficiently to exceed its field capacity and allows percolation downward to recharge the groundw ater system (Smith and others, 2017).

A simple conceptual model of steady discharge and episodic recharge explains expected water-level trends prior to groundwater development (Jackson and Fenelon, 2018). Discharges are conceptualized as steady because water-level gradients and regional discharges are relatively invariant between decades. Episodic recharge events are approximated with precipitation during winter months that exceeds a threshold. Estimated recharge events from the precipitationthreshold model were correlated with infiltration below the root zone. Winter precipitation greater than a defined threshold infiltrates below the root zone, passes through the unsaturated zone, and ultimately becomes recharge at the water table in the conceptual model (Smith and others, 2017).
A precipitation index of monthly precipitation for south-central Nevada (Western Regional Climate Center, 2016) was used to examine century-scale precipitation trends and resultant recharge trends. Although the precipitation index does not represent the true magnitude of precipitation in the study area, the relative patterns of wet and dry years in south-central Nevada are similar. Recharge is defined as winter precipitation in excess of a threshold that approximates the volume of the root zone. This simple water balance assumes that all moisture evaporates from the root zone prior to October of each year. In the example for south-central Nevada, excess winter precipitation (recharge) during wet winters is defined as 125 percent of the long-term average (1900-2016), where long-term average precipitation is $4.8 \mathrm{in}$. (fig. 17A). A threshold of 125 percent ( $6 \mathrm{in}$.) resulted in the occurrence of wet winters about 20 percent of the time from 1900 to 2016 (fig. 17B). Notably, wet conditions after 1968 generated nearly 70 percent of the recharge for the 117-year period. The 125-percent threshold used is arbitrary. Thresholds of 100 or 150 percent of the long-term average produce similar long-term recharge patterns.

J ackson and Fenel on (2018) derived a hypothetical long-term water-level record to explain expected steady-state water-level trends in the study area. The hypothetical waterlevel record is the sum of two components: water-level change resulting from recharge and water-level change resulting from aquifer discharge. The water-level change from recharge was calculated as the sum of excess winter precipitation using a 125-percent threshold divided by an effective porosity of 10 percent. Selection of a larger or smaller effective porosity would result in a smaller or larger magnitude of water-level change, respectively. However, the hypothetical waterlevel trend would remain unchanged. Cumulative waterlevel increase from recharge equals about $30 \mathrm{ft}$ over 117 years. Cumulative aquifer discharge was assumed equal in magnitude to cumulative recharge during the 117-year period; therefore, water-levels declined $0.26 \mathrm{ft} / \mathrm{yr}$ from discharge. Hypothetical water levels declined prior to 1970 because aquifer discharge exceeded recharge during persistent dry conditions. Hypothetical water levels rose from 1970 to 2016 because recharge exceeded discharge in response to frequent wet winters (fig. 17).

In areas distant from groundwater development, the longest consistent water-level records (1990s to 2018) show that water levels have been rising in the study area and throughout southern Nevada (Fenelon and Moreo, 2002; Elliott and Fenelon, 2010; Fenelon and others, 2012; Jackson and Fenelon, 2018). For example, rising water-level trends are observed in well $U-19 b k$, open to volcanic rocks in Pahute M esa, and well USFWS DR-1, open to carbonate rocks near the Sheep Range (figs. 16 and 18). 

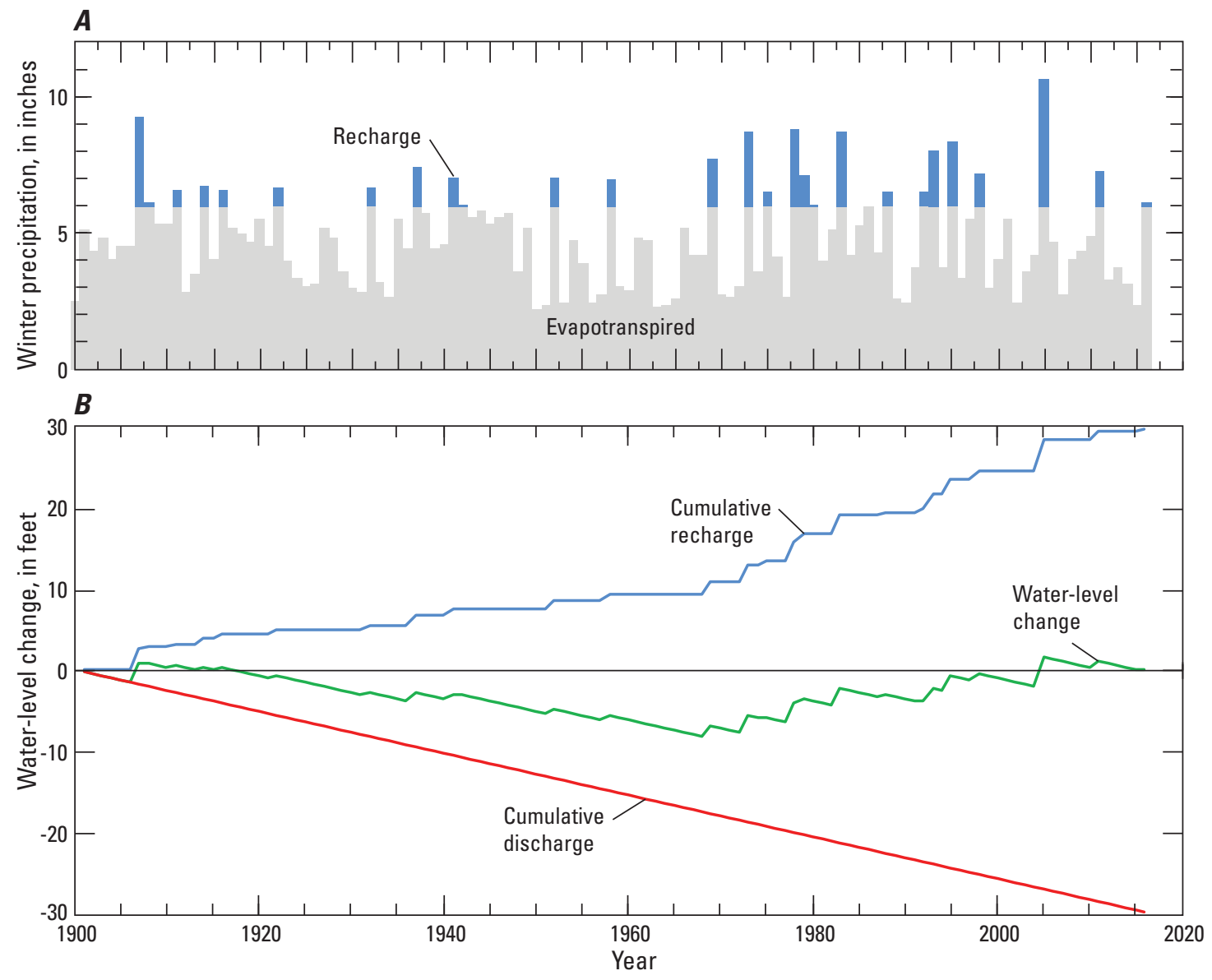

Figure 17. Winter precipitation (October-March) and excess winter precipitation (recharge) using 125-percent threshold $(A)$, and hypothetical water-level change under predevelopment (steady-state) conditions $(B)$, in the study area, Nevada and California, 1900-2016. Threshold of 125 percent of long-term average is an arbitrary threshold used to designate a "wet winter." Hypothetical waterlevel change under predevelopment conditions is the sum of cumulative recharge from 1900 to 2016 and constant discharge. Precipitation data from south-central Nevada precipitation index (Western Regional Climate Center, 2016). DV3, Death Valley version 3. Figure modified from Jackson and Fenelon (2018). 


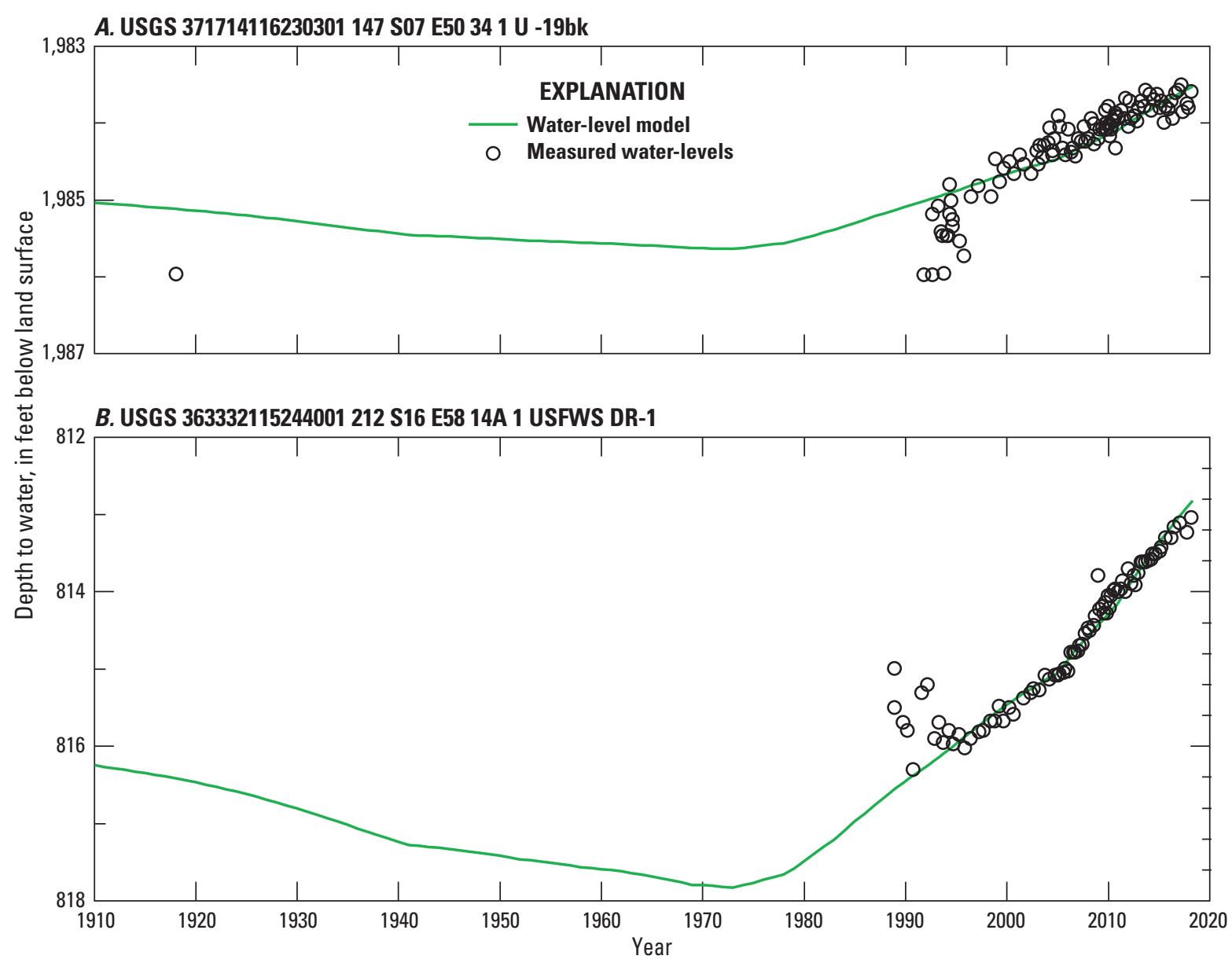

Figure 18. Measured water levels and water-level models for wells U-19bk and USFWS DR-1, in the study area, Nevada and California, 1910-2018.

Water-level models show that rising trends in wells $U-19 b k$ and USFWS DR-1 can be attributed to precipitationderived recharge from a series of wet winters (Jackson and Fenelon, 2018). Water-level models simulated rising trends by fitting an analytical model of recharge and discharge to measured water levels. Recharge was simulated using winter precipitation ( 0 ctober- $M$ arch) in excess of 6 in. from the south-central Nevada precipitation index (fig. 17AA). Discharge was assumed to be constant and was simulated as a linear decline. The fit of the water-level models to the measured data in wells $U-19 b k$ and USFWS DR-1 compare favorably (fig. 18), indicating that rising trends can be explained by recharge and discharge. The poor fit in both models prior to 1996 is attributed to less accurate $( \pm 1 \mathrm{ft})$ water-level measurements (Elliott and Fenelon, 2010).
Water levels in most, if not all, wells would have rising trends if groundwater development never occurred in the study area. Water levels in wells within pumping areas have declining trends because the magnitude of water-level decline from pumping has exceeded water-level rises from recharge.

\section{Hydraulic Conductivity}

Spatial variations in hydraulic conductivities of saturated rocks control water-level gradients and flow rates between recharge and discharge areas. Spatially distributed hydraulic conductivities must be estimated throughout the study area to simulate groundwater flow. The hydraulic-conductivity distribution encompasses the lateral and vertical extent of saturated rocks in the aquifer system. 
Hydraulic conductivities are estimated indirectly from pumping aquifer tests. Each aquifer test is a controlled field experiment (Stallman, 1971) because water is pumped at a known rate and resulting water-level declines, or drawdowns, can be interpreted with an analytical or numerical model. Transmissivity estimates are the most prevalent and reliable aquifer-test result. Hydraulic conductivity equals transmissivity divided by aquifer thickness or well screen length. A quifer thickness is assumed to be equal to well screen length in areas where transmissivity is less than $1,000 \mathrm{ft}^{2} / \mathrm{d}$ or small volumes of water are pumped (less than 100,000 gal), whereas the aquifer thickness is used for saturated rocks where transmissivity exceeds $1,000 \mathrm{ft}^{2} / \mathrm{d}$ or large volumes of water are pumped (more than 100,000 gal, such as pumping at $100 \mathrm{gal} / \mathrm{min}$ for 1 day) (H alford and others, 2006). A quifer thickness frequently is unknown at a field site, which is a source of uncertainty; however, aquifer thickness is defined in a hydrogeologic framework model, which is based on geologic data and interpretations. Relating the product of groundwatermodel-estimated hydraulic conductivities and assigned hydrogeologic framework model thicknesses to field-estimated transmissivities reduces this uncertainty.

Transmissivity estimates from aquifer tests can be extrapolated throughout the study area by correlating hydraulic conductivity with mappable hydrogeologic units. These hydrogeologic units theoretically have unique hydraulic variability or transport properties compared to other units (M irus and others, 2016). Unique hydraulic variability within a hydrogeologic unit is defined as a hydrogeologic unit having a hydraulic-conductivity probability distribution that does not sufficiently overlap with the hydraulic-conductivity probability distributions of other hydrogeologic units.

More hydrogeologic units have been defined than can be supported hydrologically in previous studies (fig. 3). This was suggested by disagreement between estimated geometric mean hydraulic conductivities and their conceptual ranking, where geometric means indicate that some confining units are more permeable than aquifers (fig. 3). Furthermore, probability distributions of hydraulic conductivity significantly overlap between multiple hydrogeologic units, indicating non-uniqueness in hydraulic variability. Relations between geologic units, hydraulic conductivity, and transmissivity are examined so that resulting hydrogeologic units have unique hydraulic variability in this investigation.

Reducing the number of hydrogeologic units is practical for the stated purpose of this investigation. Numerous hydrogeologic units originally were defined within complex hydrostratigraphic frameworks to allow for comprehensive evaluation of uncertainty in radionuclide transport predictions. However, these framework models have more hydrogeologic units than are needed to calibrate groundwater models. M ore hydrogeologic units hinder the calibration process because of incomplete data and computational burden.

\section{Field Estimates of Transmissivity}

Transmissivity can be estimated from single-well or multiple-well aquifer tests and from specific capacities. Single-well aquifer tests include pumping tests and slug tests. Multiple-well aquifer tests involve pumping one well and measuring water levels within the pumped well and nearby observation wells. Specific capacity is the pumping rate divided by drawdown at an unspecified time.

In this report, the terms "borehole" and "well" have specific definitions. A borehole refers to the mapped $(\mathrm{X}, \mathrm{Y})$ location where a hole was drilled, and the borehole may have more than one well. A well is a single, temporary or permanent, screened (or open) completion in a borehole. M any wells in the study area have multiple reported transmissivity estimates because multiple aquifer tests occurred, or an aquifer test was analyzed by multiple investigators (Frus and Halford, 2018).

A single, representative transmissivity is estimated for each well in this investigation. Multiple-well aquifer test results are limited to a transmissivity that is attributed to the pumping well. In individual boreholes beneath Pahute Mesa, transmissivities were estimated from pumping aquifer tests, where the entire borehole was pumped, and from slug tests of 200-ft intervals of the open hole that were isolated with packers (Blankennagel and Weir, 1973). Transmissivities from only pumping aquifer tests were compared, where a pumping aquifer test and multiple slug tests occurred within a borehole. This was appropriate for characterization of geologic units and calibration of a regional groundwater model. Wells, construction, aquifer-test results, sources, and representative transmissivity estimates used in this study are summarized in Jackson and Halford (2020).

Transmissivities have been estimated from aquifer tests at 113 wells within the study area (fig. 19), where nearly all aquifer tests supported NNSS activities. Exploratory boreholes were drilled and tested in the 1960s primarily to identify low-permeability rocks suitable for the testing of nuclear devices underground (Blankennagel and Weir, 1973). Radionuclides potentially could migrate from underground nuclear tests and hydrologic studies began investigating potential migration within a few years of the first underground nuclear test in 1957 (Winograd and Thordarson, 1975, p. C1). Regional aquifers and confining units from Yucca Flat to the A sh M eadows discharge area were characterized with drilling and aquifer testing that included 10 wells completed in carbonate rocks (Winograd and Thordarson, 1975, p. C20). Aquifers and confining units in the nearby Yucca Mountain area also were characterized with drilling and aquifer testing for a proposed nuclear waste repository to store high-level radioactive waste and spent nuclear fuel (Craig and Robison, 1984). Additional wells have been drilled and tested for water supplies that supported NNSS operations. After nuclear testing ceased in 1992, most aquifer tests have supported subsurface characterization to better estimate potential migration of radionuclides for the U.S. Department of Energy UGTA activity. 


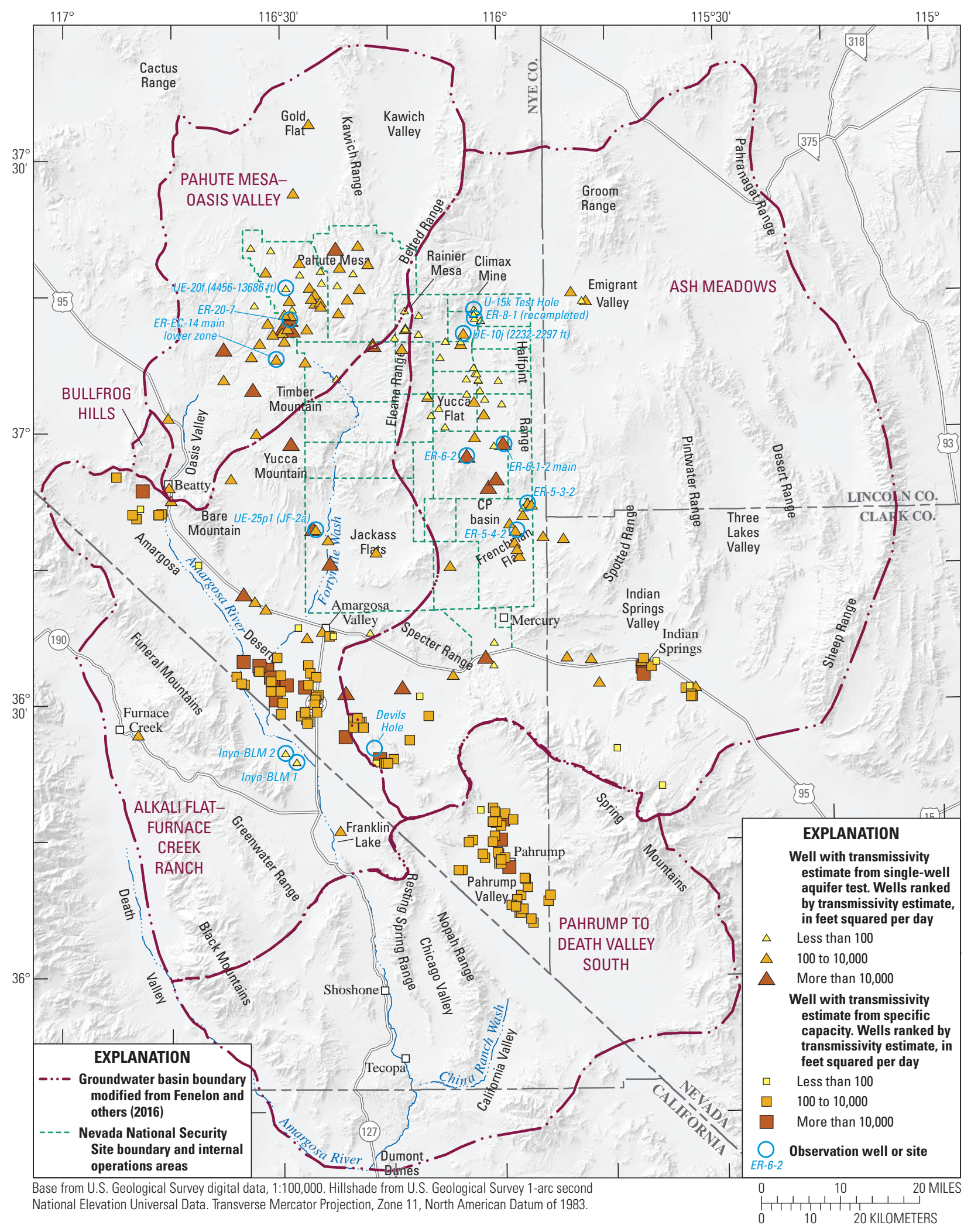

Figure 19. Transmissivity estimates from single-well aquifer tests and specific capacity, in the study area, Nevada and California. 
Transmissivity estimates characterize a volume of aquifer rather than a point. The volume of aquifer sampled generally is proportional to the volume of water pumped or displaced. For example, 2,400,000 gal were pumped from w ell ER-20-7 (fig. 19) and draw downs were detected as far away as $2 \mathrm{mi}$ from the pumping well. Likewise, 7,000,000 gal were pumped from well ER-EC-14 main lower zone (fig. 19) and drawdowns were detected more than $4 \mathrm{mi}$ from the pumping well. In a simplistic example, if it was assumed that the 4-mi drawdown distance in the latter aquifer test represented the radius of a spherical capture volume, then the transmissivity estimated from this test would characterize a $268-\mathrm{mi}^{3}$ volume of aquifer. Of the 113 aquifer tests, 83 were pumping aquifer tests, where a median volume of 700,000 gal was pumped during each test (fig. 20).

Transmissivities from low-permeability units were estimated primarily with slug tests because only limited volumes of water could be removed. Transmissivities of $0.00002-1 \mathrm{ft}^{2} / \mathrm{d}$ were estimated exclusively with slug tests. The median volume displaced from slug testing was about 400 gal (fig. 20), which is large relative to typical slug-test volumes of less than 1 gal. Relatively large displacement volumes resulted from initial displacements exceeding 1,000 ft (Frus and $\mathrm{H}$ alford, 2018) or evacuation of wells with diameters greater than 50 in. during slug tests. Recovery periods for many slug tests exceeded 1 year, with the longest period exceeding 20 years in well U-15k Test Hole (fig. 19). Investigated radial distances of slug tests remained considerably less than the influence of pumping aquifer tests (Frus and Halford, 2018). A transmissivity estimated from tidal-forcing of water levels in well Inyo-BLM 1 (fig. 19; Cutillo and Bredehoeft, 2011) was classified as a slug test because less than 1 gal of water was displaced.

Transmissivity estimates from pumping aquifer tests in siliciclastic rocks and zeolitized tuffs likely represent permeable inclusions in otherwise low-permeability rocks. Biased results were suggested by transmissivity estimates decreasing during later analysis periods and locally inconsistent water levels. For example, well ER-5-4-2 (fig. 19) is open to zeolitized tuff 4,850-7,000 ft below Frenchman Flat and 2,200,000 gal were pumped during a 10-day test. Transmissivities of 200 and $60 \mathrm{ft}^{2} / \mathrm{d}$ were estimated during periods $0-1$ and 2-6 days after pumping started, respectively, with Cooper-J acob (1946) analyses. Transmissivities of 13 and $6 \mathrm{ft}^{2} / \mathrm{d}$ were estimated during periods $0.3-4$ and 4-15 years after pumping stopped, respectively, with Cooper-Jacob recovery analyses. The water-level altitude in well ER-5-4-2 exceeds 2,480 ft, which is 70 and $90 \mathrm{ft}$ higher than waterlevel altitudes in overlying basin fill and adjacent carbonate rocks, respectively. The water-level altitude in well ER-5-4-2 unlikely represents predevelopment conditions within the last 500 years and is best explained as incomplete drainage from past pluvial conditions. Sustaining 70 - to $90-\mathrm{ft}$ head differences during a 10,000-yr period of drainage requires an average hydraulic conductivity of less than $0.00001 \mathrm{ft} / \mathrm{d}$, or 300 times less than the smallest estimate from the aquifer test, when converted to a hydraulic conductivity $(0.003 \mathrm{ft} / \mathrm{d})$.

Transmissivities also were estimated empirically from 158 specific-capacity estimates using a local powerlaw relation for Pahute M esa (Frus and Halford, 2018). Transmissivity (foot squared per day) equaled 380 times specific capacity (gallons per minute per foot) and was developed with results from 39 Pahute Mesa pumping aquifer tests. Greater than 80 percent of 39 transmissivities estimated with the Pahute-M esa relation were within a factor of five from aquifer-test results. The Pahute-Mesa relation functionally differs little from other empirical relations developed in California and northern Nevada (Thomasson and others, 1960; Yager and others, 2012). Greater than 70 percent of the 158 specific-capacity estimates sampled large volumes of aquifer because more than 100,000 gal were pumped (fig. 20).

Transmissivities outside the NNSS were estimated predominantly from specific capacities using well logs (Nevada Division of Water Resources, 2018). Reported pumping rates (gallons per minute) and water-level declines (feet) were used to minimize spurious specific-capacity estimates from domestic wells. For example, specific-capacity estimates were reported for 4,442 of 12,226 well logs in Pahrump Valley, where 3,582 wells had a reported pumping rate of $20 \mathrm{gal} / \mathrm{min}$ with a drawdown of $4 \mathrm{ft}$. To eliminate questionable specific-capacity estimates, wells with pumping rates less than $30 \mathrm{gal} / \mathrm{min}$ or water-level declines less than $10 \mathrm{ft}$ were not used in this study, which reduced the number of specific-capacity estimates from 4,442 to about 300 . The number of useful specific capacities declined from about 300 to 129 , after each of the remaining well logs were read. M ost of the specific capacities were rejected because bailed volumes were reported as pumping rates, such as the removal of 5 gal of water being reported as a pumping rate of $5 \mathrm{gal} / \mathrm{min}$. The 129 specific-capacity estimates primarily were from irrigation wells in the central A margosa Desert and Pahrump Valley (fig. 19). The 129 specific-capacity estimates were computed from pumping rates that averaged $700 \mathrm{gal} / \mathrm{min}$, with a maximum of 3,500 gal/min. Specific capacities ranged from 0.01 to $400 \mathrm{gal} / \mathrm{min} / \mathrm{ft}$ and transmissivities from specific capacities ranged from 4 to $160,000 \mathrm{ft}^{2} / \mathrm{d}$. 


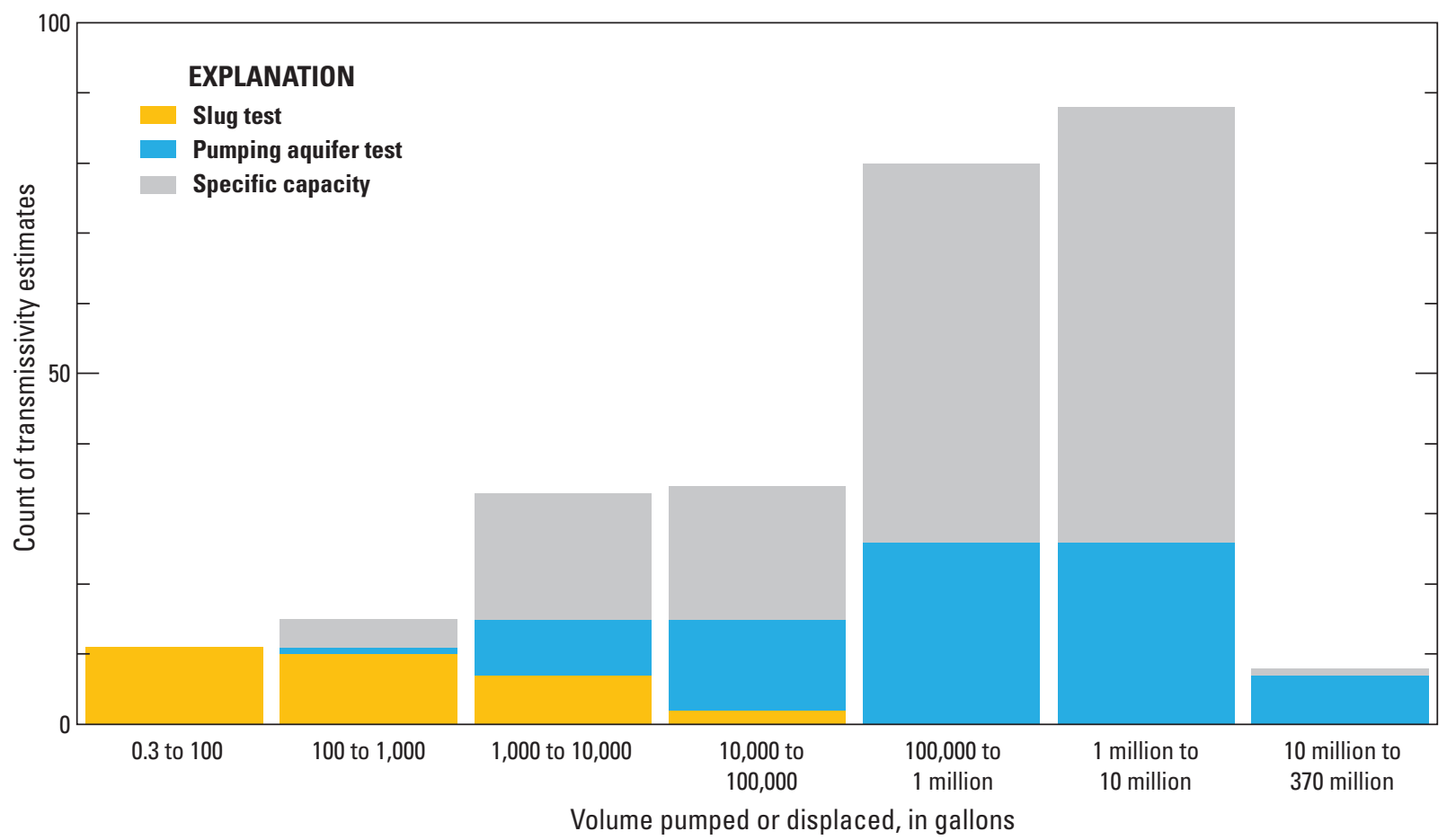

Figure 20. Volume of water pumped or displaced from single-well aquifer tests (pumping and slug tests) and specific capacity, in the study area, Nevada and California.

\section{Transmissivity and Rock Type}

Relations between transmissivity and rock type were investigated using four broad categories that group previously defined hydrogeologic units from DVRFS.v2 (table 6).

Previous investigations (fig. 3) and limited data for some hydrogeologic units suggest that only four broad categories of rock type can be related to transmissivity: (1) carbonate rocks; (2) volcanic rocks; (3) basin fill; and (4) low-permeability rocks. Carbonate rocks were not further subdivided because few wells penetrate the local ized, upper carbonate aquifer. Volcanic rocks were not subdivided because distributions of log-hydraulic conductivity were similar in younger volcanic and Tertiary volcanic units (fig. 3). Probability distributions overlapped considerably where the Tertiary volcanic unit was differentiated into eight hydrogeologic units (Belcher and others, 2002; p. 12). Log-hydraulic conductivity distributions of alluvial aquifer and alluvial confining unit differed little (fig. 3); therefore, units were grouped into a single category of basin fill. Low-permeability rocks consist of granitic rocks, siliciclastic rocks, and older volcanic rocks, which form the basement of the study area. Low-permeability rocks were not further subdivided because there were only a small number of transmissivity estimates.

Log-transmissivity distributions for carbonate rocks, volcanic rocks, basin fill, and low-permeability rocks do not sufficiently overlap, indicating hydraulic uniqueness (fig. 21). Median transmissivities of carbonate rocks, volcanic rocks, and basin fill are all near 1,000 ft'/d but variability differs markedly. Transmissivity of basin fill was the most predictable, with a 95-percent confidence interval that ranged from 40 to $20,000 \mathrm{ft}^{2} / \mathrm{d}$. Transmissivity of volcanic rocks was the least predictable, with a 95-percent confidence interval that ranged from 0.006 to $60,000 \mathrm{ft}^{2} / \mathrm{d}$. R ock type most reliably establishes a maximum transmissivity that likely would be present at a site (fig. 21). Transmissivity estimates were analyzed, in preference to hydraulic conductivity, because contributing aquifer thickness generally was unknown.

\section{Transmissivity and Thickness}

Thickness and transmissivity are not correlated regardless of definition of thickness or rock type (fig. 22). Thickness alternatively was defined by length of open interval or thickness of rock type penetrated by the well. Thicknesses of rock types were the summation of hydrogeologic unit thicknesses for each rock type from the DVRFS. v2 hydrogeologic framework (Belcher and others, 2017). Observed rock types in 25 of 271 wells were misclassified in the hydrogeologic framework. Misclassification errors occurred too infrequently to explain the lack of correlation. Spatial variability in transmissivity can be attributed almost exclusively to variability in hydraulic conductivity. This suggests that refining thicknesses of hydrogeologic units further will minimally benefit future hydrologic investigations. 
Table 6. Relation between simple-rock types and previously defined hydrogeologic units in the Death Valley Regional Flow System version 2 model (DVRFS.v2) hydrogeologic framework, Nevada and California.

[Source: B elcher and others (2017)]

\begin{tabular}{|c|c|c|}
\hline Rock type & DVRFS.v2 abbreviation & DVRFS.v2 hydrogeologic unit \\
\hline \multirow[t]{3}{*}{ C arbonate rocks } & UCA & Upper carbonate-rock aquifer \\
\hline & LCA T1 & L ower carbonate-rock aquifer (thrusted) \\
\hline & $\mathrm{LCA}$ & L ow er carbonate-rock aquifer \\
\hline \multirow[t]{10}{*}{ Volcanic rocks } & LFU & Lava-flow unit \\
\hline & YVU & Younger volcanic-rock unit \\
\hline & TMVA & Thirsty Canyon-Timber Mountain volcanic-rock aquifer \\
\hline & PVA & Paintbrush volcanic-rock aquifer \\
\hline & CHVU & Calico Hills volcanic-rock unit \\
\hline & WVU & Wahmonie volcanic-rock unit \\
\hline & CFPPA & Crater Flat-Prow Pass aquifer \\
\hline & CFBCU & Crater Flat-Bullfrog confining unit \\
\hline & CFTA & Crater Flat-Tram aquifer \\
\hline & BRU & B elted $R$ ange unit \\
\hline \multirow[t]{6}{*}{ Basin fill } & YAA & Younger alluvial aquifer \\
\hline & YACU & Younger alluvial confining unit \\
\hline & OAA & Older alluvial aquifer \\
\hline & OACU & Older alluvial confining unit \\
\hline & LA & Limestone aquifer \\
\hline & VSU upper & Upper volcanic-sedimentary rock unit \\
\hline \multirow[t]{8}{*}{ Low-permeability rocks } & OVU & Older volcanic-rock unit \\
\hline & VSU lower & Lower volcanic-sedimentary rock unit \\
\hline & ICU & Intrusive-rock confining unit \\
\hline & SCU & Sedimentary-rock confining unit \\
\hline & UCCU & Upper clastic-rock confining unit \\
\hline & LCCU_T1 & Lower clastic-rock confining unit (thrusted) \\
\hline & LCCU & Lower clastic-rock confining unit \\
\hline & $\mathrm{XCU}$ & Crystalline-rock confining unit \\
\hline
\end{tabular}

Basin fill in the Amargosa Desert was differentiated previously for the stated reason of "....improved understanding of the hydrogeologic system." (Taylor and Sweetkind, 2014, p. 1.) Grain size, sorting, and texture were inferred from 210 drillers' logs to define 28 unique lithologic classes. These refined lithologic classes replaced previously defined basinfill hydrogeologic units in the DVRFS.v2 model and were assigned relative permeabilities of low, moderately low, or high (B elcher and others, 2017, p. 13). High-permeability classes were composed of gravel, sand, or freshwater limestone, which presumably would be correlated with high specific capacities or transmissivities. Specific capacities were reported on 50 of the drillers' logs and used to test the hydrologic utility of finely differentiating basin fill.
Finely differentiated basin fills poorly predicted specific capacities in the A margosa Desert, regardless of how permeable classes were assigned (fig. 23). High permeability from Belcher and others $(2017$, p. 13) defined a test group. A second test group combined all classes dominated by gravel or sand. Effective thicknesses of each of the 24 lithologic classes were estimated independently in a third test group, where the effective thickness was the coarse-grained fraction of the saturated thickness. Coefficient of determination $\left(\mathrm{r}^{2}\right)$ was less than 0.01 regardless of whether thicknesses were compared to specific capacities or log-specific capacities. Independently estimating an effective thickness for each of 24 classes improved $\mathrm{r}^{2}$ to 0.39 , but the results were nonsensical. This was because specific capacity increased as effective thickness of permeable sediments decreased (fig. 23). 


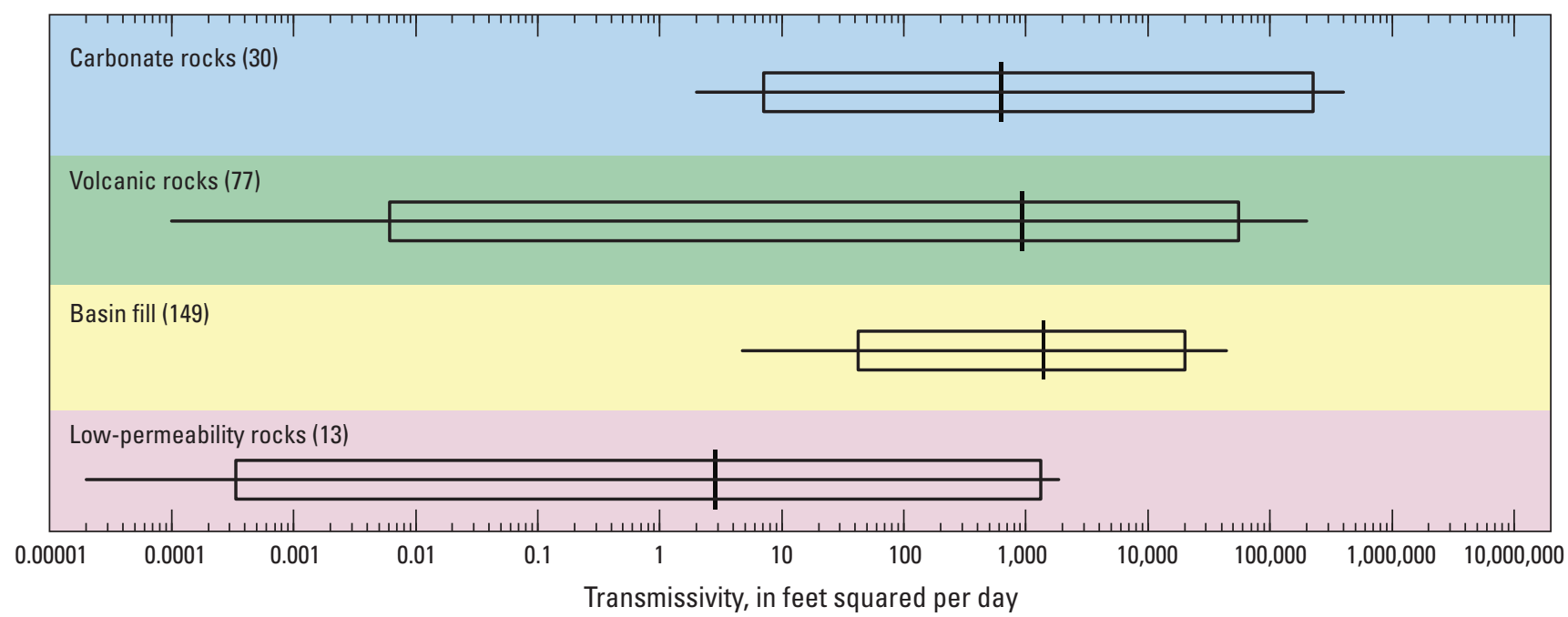

\section{EXPLANATION}

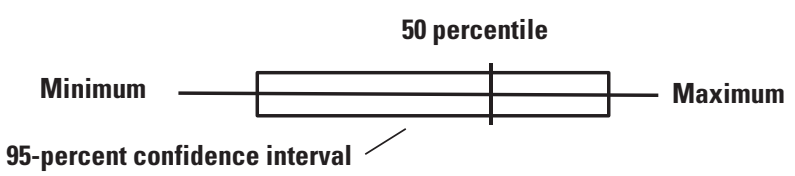

Note: Number of transmissivity estimates for each rock type is shown in parentheses.

Figure 21. Minimum, maximum, median, and 95-percent confidence interval of log-transmissivities in four rock-type categories from 271 field estimates of transmissivity, in the study area, Nevada and California.

\section{Hydraulic Conductivity and Depth}

Hydraulic conductivity is distributed heterogeneously with depth in carbonate and volcanic rocks, where few permeable intervals contribute most of the transmissivity in a well. Few flowing intervals have been detected with flow logs in carbonate rocks beneath Yucca F lat in wells ER-6-1-2 main (Garcia and others, 2010), ER-6-2 (Stoller-Navarro Joint Venture, 2005a), and $U E-10 j$ (2232-2297 ft) (IT Corporation, 1995) (fig. 19). A bout 10 percent of the combined 3,200 $\mathrm{ft}$ of saturated thickness from the three wells contributed greater than 80 percent of flow. Depth-dependent variations in volcanic rocks beneath Pahute Mesa are well defined in 17 boreholes, where these boreholes have an average depth of 6,200 ft below land surface (B lankennagel and Weir, 1973). For each of these boreholes, interval transmissivities were estimated from packer testing 200 -ft intervals and total transmissivities were defined by pumping aquifer tests. Most of the permeability occurred in about 2 percent of $74,800 \mathrm{ft}$ of saturated borehole that was tested (F rus and Halford, 2018). Hydraulic variations are consistent with complex bedded and fractured rocks, which have been observed in boreholes and outcrops in the study area (Sweetkind and others, 2010, p. 71). These observable hydraulic and structural heterogeneities cannot be represented adequately by simulating groundwater flow through thick, homogeneous, hydrogeologic units.

G reater than 90 percent of estimated hydraulic conductivity in carbonate and volcanic rocks occurs within $1,600 \mathrm{ft}(500 \mathrm{~m})$ of the water table (fig. 24). To estimate hydraulic conductivity with depth, transmissivities from pumping aquifer tests were binned into $330-\mathrm{ft}$ (100-m) saturated intervals of the wells for consistency in comparing carbonate and volcanic rocks. For example, consider a well open to $2,000 \mathrm{ft}$ of carbonate rocks with a transmissivity of $1,000 \mathrm{ft}^{2} / \mathrm{d}$. The $2,000 \mathrm{ft}$ saturated open interval would be binned into six 330 -ft saturated intervals, where each interval would have a hydraulic conductivity of about $0.5 \mathrm{ft} / \mathrm{d}$. Transmissivity was distributed uniformly across open intervals in carbonate rocks because depth-dependent contributions were unknown in 23 of 26 wells. However, depth-dependent contributions have been estimated in volcanic rocks (Frus and Halford, 2018) and distributed accordingly. Interval-averaged hydraulic conductivity was the average transmissivity in each interval divided by interval thickness (fig. 24). 


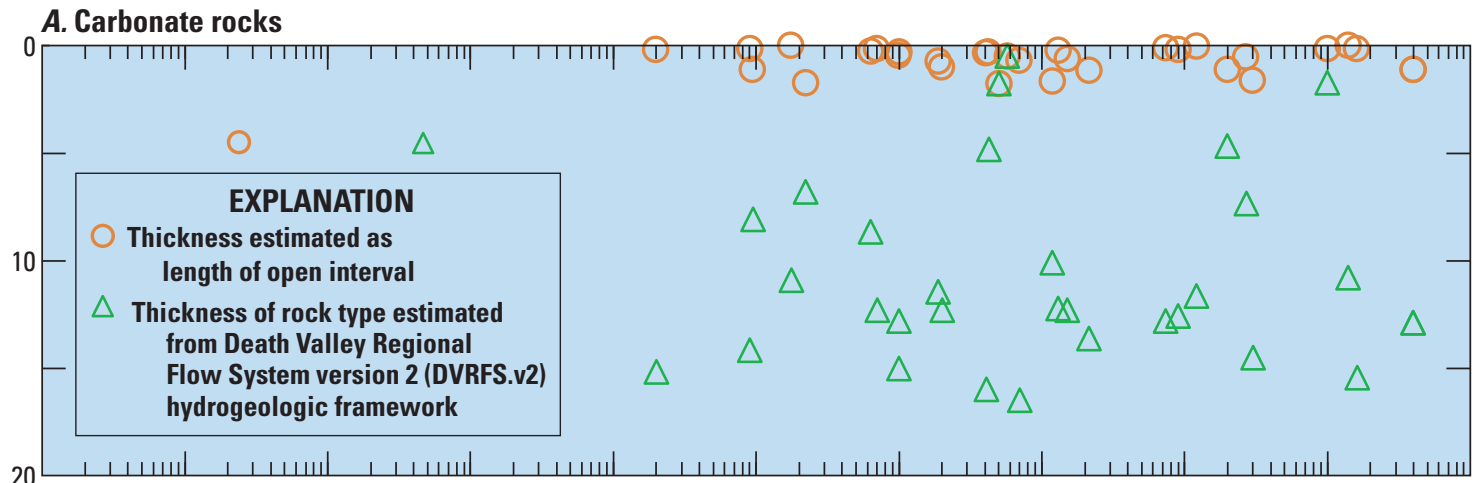

B. Volcanic rocks

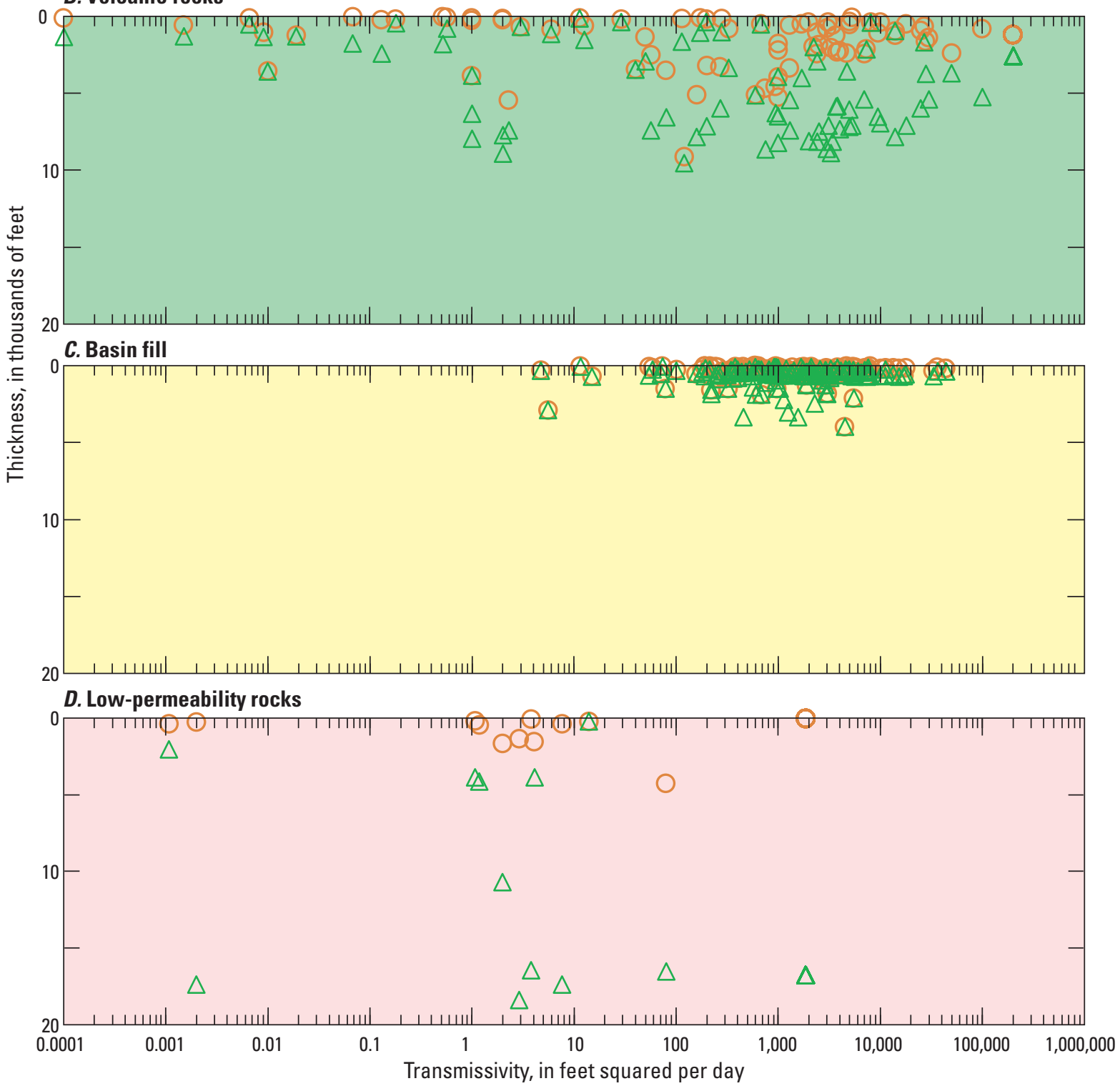

Figure 22. Relation between transmissivity and thickness of carbonate rocks, volcanic rocks, basin fill, and low-permeability rocks, in the study area, Nevada and California. 


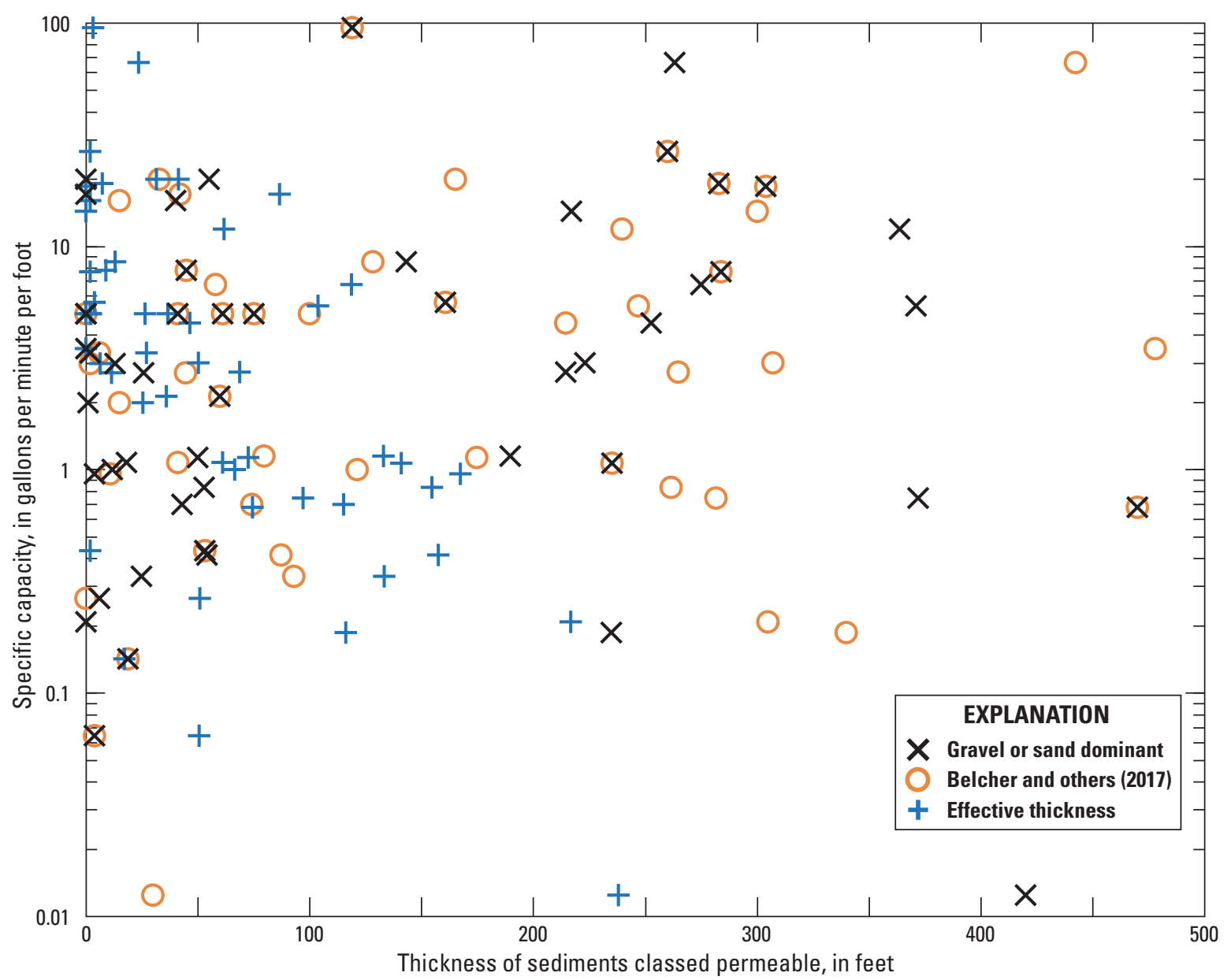

Figure 23. Relation between specific capacity and thickness of basin fill classified as permeable in the Amargosa Desert, Nevada.

Hydraulic conductivity does not decrease smoothly as a function of depth below land surface as conceptualized in depth-decay models. These models assume that permeability decreases with depth as geostatic and hydrostatic load increases, which decreases widths of pore spaces and fracture apertures. Hydraulic conductivity previously has been correlated weakly with depth below land surface, where average hydraulic conductivity decreased by an order of magnitude with a 2,300-ft decrease in depth below land surface (Stoller-Navarro Joint Venture, 2004a, p. 5-30). The weak correlation had no predictive value because individual hydraulic-conductivity estimates ranged from 0.02 to $100,000 \mathrm{ft} / \mathrm{d}$ within 2,300 ft of land surface (Stoller-Navarro J oint Venture, 2004a, p. 5-28). Unpredictable hydraulicconductivity variations at depth differences of less than 2,000 $\mathrm{ft}$ bel ow the water table and less than $5,000 \mathrm{ft}$ bel ow land surface are consistent with previous observations in carbonate rocks (Winograd and Thordarson, 1975, p. C20) and volcanic rocks (B lankennagel and Weir, 1973). Previous groundwater models in the study area (Belcher, 2004; Stoller-Navarro Joint Venture, 2009; Navarro-Intera, LLC, 2013; Belcher and others, 2017) have simulated vertical variations in hydraulic conductivity with depth-decay models despite available data.

Carbonate and volcanic rocks can be divided into shallow and deep rocks as an alternative to a depth-decay model. The division between shallow and deep rocks at 1,600 $\mathrm{ft}(500 \mathrm{~m})$ below the water table is supported by depth-dependent hydraulic-conductivity data (fig. 24). Transmissive shallow rocks transmit most of the groundwater between recharge and discharge areas, whereas deep rocks have low-permeability and transmit a small component of the flow. The shallowdeep concept does not negate part of the groundwater budget because all flow from the active part of the groundwater system is included. The shallow-deep concept has been used previously within the study area (Fenelon and others, 2008, 2010, 2012). 


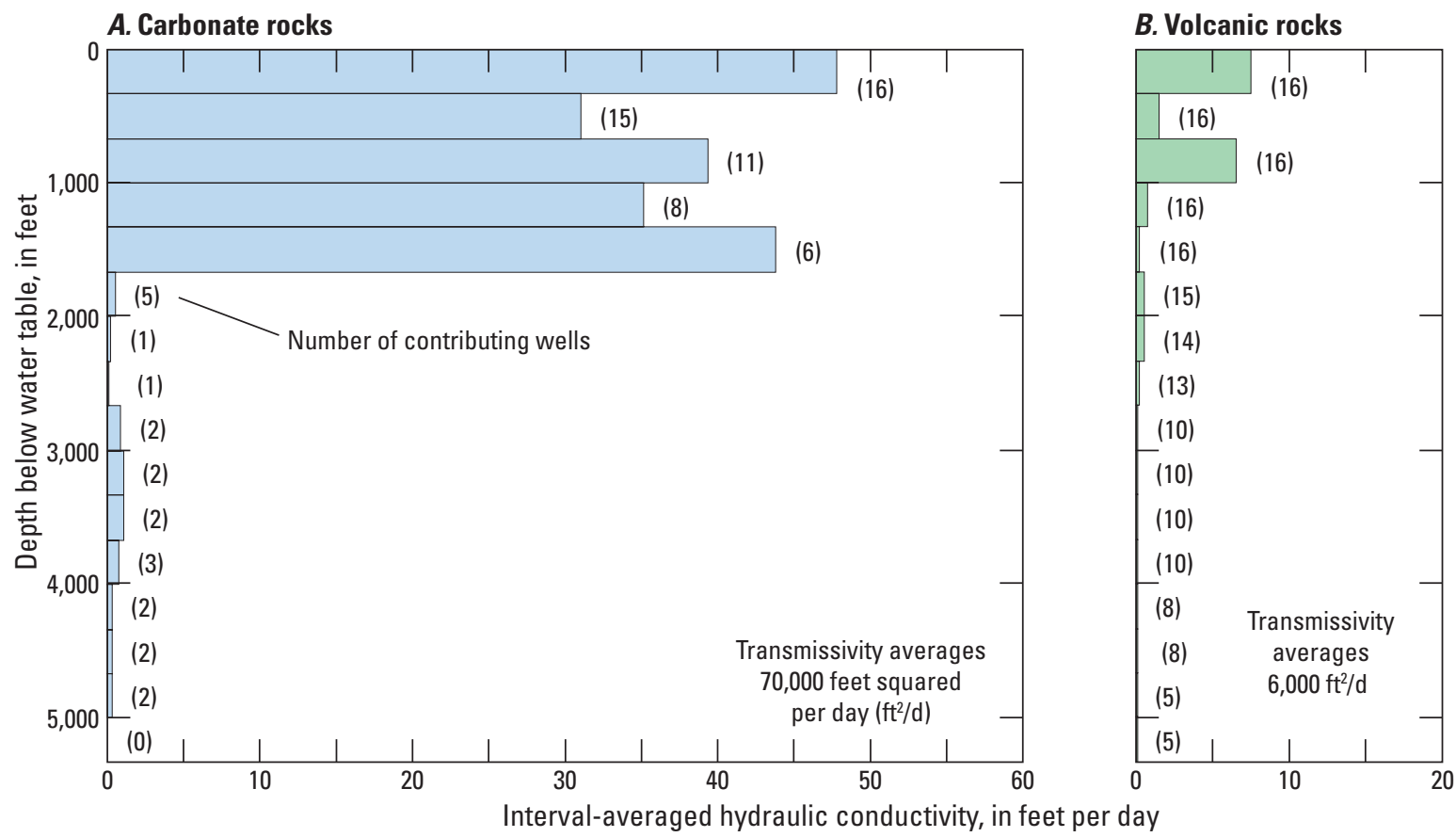

Figure 24. Average, depth-dependent hydraulic conductivity in volcanic and carbonate rocks, in the study area, Nevada and California.

The limited number of deep carbonate wells does not negate the concept of low-permeability carbonate rocks more than $1,600 \mathrm{ft}$ bel ow the water table. Six wells were completed in carbonate rocks at depths greater than 1,600 feet below the water table. Transmissivities in deep carbonate rocks ranged from 2 to 2,200 $\mathrm{ft}^{2} / \mathrm{d}$ and averaged 10 times less than transmissivities in shallow carbonate rocks. Wells ER-5-32, Inyo-BLM 1, and UE-25pl (JF-2a) (fig. 19) were drilled to test the concept of transmissive carbonate rocks at depth. However, the carbonate rocks encountered by these wells were not very transmissive, with transmissivities of 100-900 $\mathrm{ft}^{2} / \mathrm{d}$. Wells ER-5-4-2, ER- 8-1 (recompleted), and Inyo-BLM 2 (fig. 19) targeted, but never penetrated, transmissive carbonate rocks, and encountered low-permeability volcanic and granitic rocks. Although a rigorous evaluation of deep carbonate rocks is not possible, failed attempts to find transmissive intervals in deep carbonate rocks support the shallow-deep concept. The shallow-deep concept is supported by the substantial decrease in hydraulic conductivity with depth in 17 Pahute Mesa boreholes, where 16 of the 17 boreholes were completed in volcanic rocks at depths greater than $1,600 \mathrm{ft}$ below the water table (fig. 24).

\section{Hydrogeologic Framework}

The hydrogeologic framework of the DV3 project is a simplification of the hydrogeologic framework from the DVRFS.v2 project (Belcher and others, 2017). The DVRFS.v2 hydrogeologic framework integrates a regional hydrogeologic framew ork with CAU-scale frameworks for Frenchman Flat (Bechtel Nevada, 2005a), Yucca Flat-Climax Mine (Bechtel Nevada, 2006; Fenelon and others, 2012), Rainier Mesa-Shoshone Mountain (National Security Technologies, LLC, 2007; Fenelon and others, 2008), and Pahute Mesa (Bechtel Nevada, 2002; Garcia and others, 2017). The DV3 hydrogeologic framework simplifies the DVRFS. v2 hydrogeologic framework (Belcher and others, 2017) by grouping hydraulically similar hydrogeologic units and limiting vertical discretization.

Unlike the DVRFS.v2 hydrogeologic framework, the DV 3 hydrogeologic framework included hydrologically mandated features and incorporated revisions to frameworks for Frenchman Flat, Yucca Flat-Climax M ine, and Rainier M esa-Shoshone M ountain CA U s. A n example of including a hydrologically mandated feature is explicitly mapping Furnace Creek Wash in the DV3 hydrogeologic framework. The DVRFS.v2 framework, polygons for modifying hydrogeologic unit extents by DV 3 model layer, and the DV 3 framework are available in Jackson and Halford (2020). 


\section{Discretization}

The DV3 hydrogeologic framework grid is consistent with the numerical grid used in the groundwater models created for the DV3 project. The hydrogeologic framework for the DV3 project extends from the water table to 3,280 $\mathrm{ft}(1,000 \mathrm{~m})$ below the National Geodetic Vertical Datum of 1929 (NGVD 29), which encompasses all rocks with considerable permeability. This volume was discretized laterally into 268 rows of 221 columns of variably spaced, rectangular cells that ranged from $820 \mathrm{ft}(250 \mathrm{~m})$ to $4,920 \mathrm{ft}$ $(1,500 \mathrm{~m})$ on a side. The volume was discretized vertically with deformed layers, where each cell was assigned a unique hydrogeologic unit. Hydraulically similar rock types with depth and computed vertical hydraulic gradients indicated that known gradients and hydrologic conditions can be simulated sufficiently with five layers.

\section{Water-Table Surface}

The DV3 hydrogeologic framework was developed to distribute hydraulic properties within the saturated rocks in the groundwater-flow models. The top of the hydrogeologic framework is the water table. In this report, the water table encompasses the uppermost occurrence of saturation, which includes perched intervals. The water-table surface was estimated from potentiometric maps and water levels in low-permeability ranges (IT Corporation, 1997; Fenelon and others, 2008, 2010, 2016).

The top of the saturated flow system in the DVRFS. v2 project was defined differently than in the DV3 project (fig. 25). An undefined "idealized" potentiometric surface was the top of the saturated flow system in the DVRFS.v2 project (Belcher and others, 2017, p. 17) that excluded higher altitudes of saturation in low-permeability ranges. Compared to the DVRFS.v2 project, the top of saturation of the DV3 framework is 1,000 to $3,200 \mathrm{ft}$ higher (fig. 25). U sing the uppermost occurrence of saturation as the top surface of the DV 3 hydrogeologic framework allowed for the simulation of major groundwater divides in the groundwater models. Unlike the DVRFS.v2 project, groundwater divides can be represented in the DV3 project in Bare Mountain, Eleana Ridge, north of Climax M ine, Skull M ountain, Sheep Range, Greenwater Range, and B lack M ountains (fig. 25). Inclusion of perched groundwater al so allowed for the simulation of advective flow from nuclear test locations in Rainier Mesa and Shoshone M ountain, which were detonated within the perched system (fig. 25).
Vertical Discretization

Vertical discretization of the DV 3 hydrogeologic framework was the same as the groundwater-flow model. This differed from the DVRFS.v2 hydrogeologic framework, which was discretized independently of the groundwater-flow model grid. Hydrogeologic units were distributed in the DVRFS.v2 framework by specifying tops and thicknesses. This permitted multiple hydrogeologic units to be present in each model cell. Hydraulic conductivities distributed with the DVRFS.v2 hydrogeologic framework were translated to the groundwater model grid with the Hydrogeologic-U nit Flow (HUF) package of MODFLOW - a USGS modular hydrologic model software (A nderman and Hill, 2000). In each groundwater model cell, hydraulic conductivities from multiple hydrogeologic units were reduced to an equivalent hydraulic conductivity by assuming parallel flow in the horizontal direction and series flow in the vertical direction between hydrogeologic units.

The strength of the HUF package is the ability to use a hydrogeologic framework that has a different spatial discretization from the groundwater model. However, this strength is also a weakness because using different spatial grids introduces (sometimes unwarranted) complexity and can easily cause errors if not implemented correctly. When multiple hydrogeologic units occupy a M ODFL OW model cell, the estimated effective hydraulic conductivity does not provide information on the hydrogeologic units that are behaving as aquifers or confining units. Parallel and series flow assumptions for computing equivalent hydraulic conductivities fail where dips of hydrogeologic-unit contacts and M ODFLOW model layers depart more than a few degrees. This can transpose conceptual flow barriers and conduits in the groundwater model. Specifying tops and thicknesses of hydrogeologic units in the HUF package also can erroneously allow multiple hydrogeologic units to occupy identical volumes of aquifer, which is physically impossible and not checked by the HUF package.

The DV3 hydrogeologic framework was developed by first mapping hydrogeologic units from the DVRFS.v2 framework (B elcher and others, 2017) to an intermediate grid. The intermediate grid was discretized vertically into uniform 164-ft-thick (50-m-thick) layers. This assured that the volumes of the individual units would sum correctly to the total volume of the framework. The thickest hydrogeologic unit in each 164-ft-thick cell was assigned to the cell. Hydrogeologic unit assignment was altered minimally because less than 3 percent of the 164-ft-thick cells were intersected by more than one of the original hydrogeologic units from the DVRFS.v2 framework. 


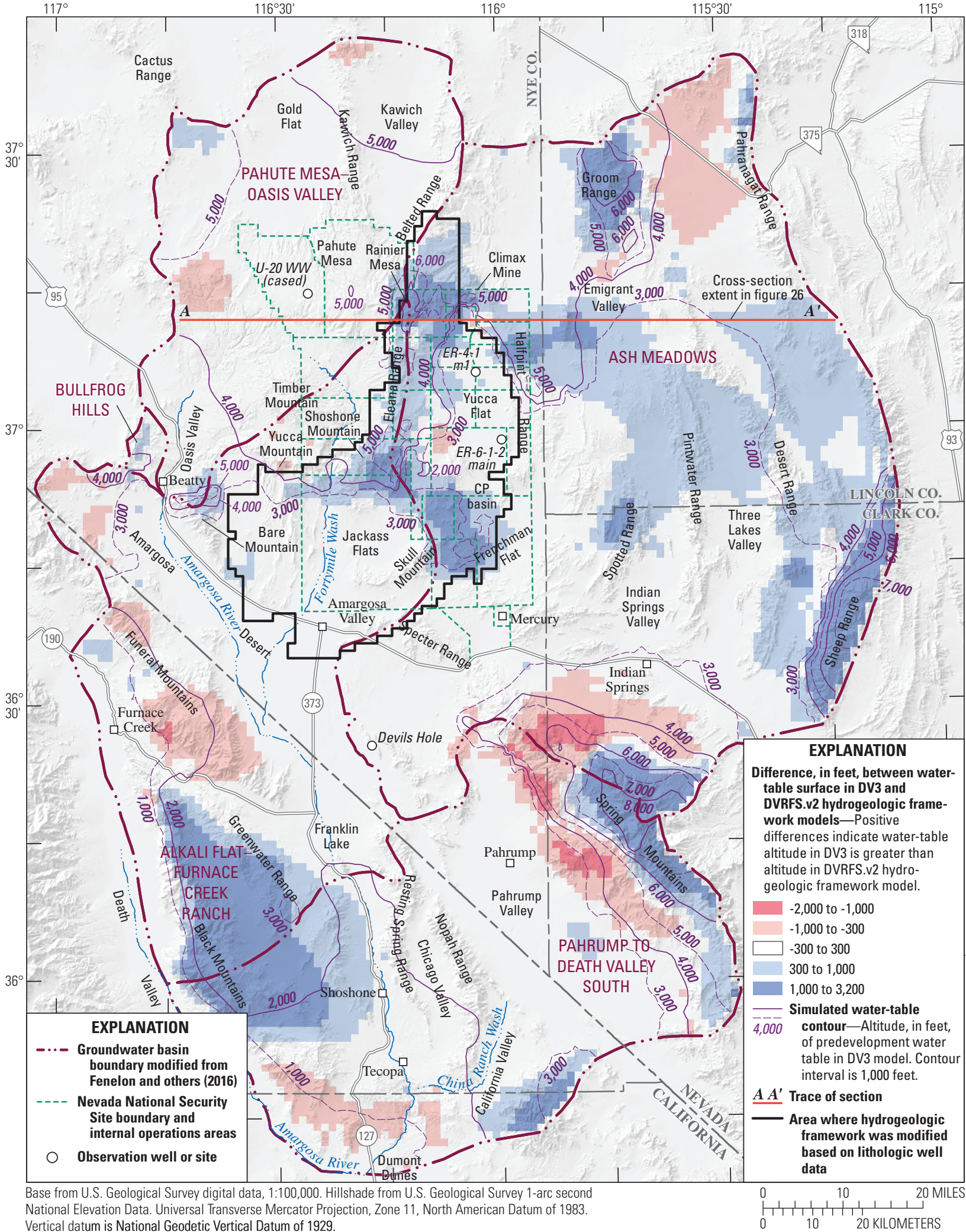

Figure 25. Differences in the water-table surface between the Death Valley version 3 (DV3) and Death Valley Regional Flow System version 2 (DVRFS.v2) hydrogeologic framework, and areas where the DVRFS.v2 hydrogeologic framework was modified, in the study area, Nevada and California. See figure 26 for cross section $A-A^{\prime}$. 
Faults

Faults and caldera margins have been conceptualized as forming barriers or conduits to groundwater flow. Few geologic structures have sufficient hydraulic information to determine their behavior as a barrier or conduit. For example, lithologic data and aquifer-test results indicate that the Gravity fault (fig. 5) forms a hydraulic barrier (Dudley and Larson, 1976). The Gravity fault causes groundwater to move from underlying carbonate rocks into overlying basin fill and discharge at land surface from spring pools in the Ash M eadows discharge area (L aczniak and others, 1999). The northern part of the Timber Mountain caldera complex (fig. 5) is a transmissive feature, with transmissivities exceeding $100,000 \mathrm{ft}^{2} / \mathrm{d}$ (G arcia and others, 2017). The southern part of the Claim Canyon caldera (fig. 5) likely forms a hydraulic barrier, as indicated by the steepening of lateral hydraulic gradients between Timber Mountain and Yucca Mountain (IT Corporation, 1999; Fenelon and others, 2010, plate 3; Navarro-Intera, LLC, 2013). Attributing these hydraulic properties to caldera margins or adjacent rocks remains ambiguous.

Many faults are not hydraulically distinct from adjacent host rocks and have no direct hydraulic significance. Y ucca fault (fig. 5) has been conceptualized as a conduit to groundwater flow in a local-scale CAU model of the carbonate aquifer beneath Yucca Flat (Navarro-Intera, LLC, 2013).

However, drawdown analyses from multiple-well aquifer tests in wells ER-6-1-2 main (fig. 25; Jackson and Halford, 2019) and ER-4-1 m1 (fig. 25; Jackson, 2017) showed that pumping signals propagated across Yucca fault. The calibrated Yucca F lat CAU model of the carbonate aquifer also interpreted Yucca fault as an inconsequential hydraulic feature (NavarroIntera, LLC, 2013). In another example, the West Greeley fault in Pahute $M$ esa has been conceptualized as a conduit for groundwater flow and radionuclide transport (StollerNavarro Joint Venture, 2009). This interpretation was tested during analysis of a multiple-well aquifer test in well $U-20$ $W W$ (cased) (fig. 25), and results showed that estimated hydraulic conductivities of the fault were similar to those of the surrounding volcanic rocks, indicating that West Greeley fault is neither a conduit nor barrier to flow (Garcia and others, 2011).

Faults were implemented explicitly by the offset of juxtaposed hydrogeologic units in the DV3 framework. J uxtaposition of a low-permeability hydrogeologic unit against a permeable unit causes a fault to function as a hydraulic barrier. J uxtaposition of permeable units along a fault allows for the movement of groundwater flow across the fault. Behavior of a fault as a barrier or conduit to groundwater flow was determined during calibration of the DV3 model by fitting simulated results to predevelopment water levels, water-level declines from pumping, and aquifer-test results.

\section{Hydrogeologic Units}

The DV3 framework was divided into ten hydrogeologic units (table 7) based on rock type, depth, and previously defined hydrogeologic units from the DVRFS.v2 project (table 6). Hydrogeologic units were consolidated initially for this study into four rock types (fig. 21). Two of the rock types contain thick sequences of carbonate and volcanic rocks, which were divided in the DV3 framework into shallow and deep intervals at $1,600 \mathrm{ft}(500 \mathrm{~m})$ below the water table based on analysis of hydraulic conductivity with depth (fig. 24). The shallow-deep concept (see section, "Hydraulic Conductivity and Depth") was used as an alternative to a depth-decay model. Shallow carbonate rocks were further subdivided by separating Pennsylvanian (UCA, upper carbonate-rock aquifer) and fault-thrusted [(LCA_T1, lower carbonaterock aquifer (thrusted)] carbonate rocks, which have low permeabilities, from other carbonate rocks in the shallow interval so that expected transmissivity contrasts could be simulated (table 7). Deep volcanic rocks are relatively impermeable and were included in the low-permeability rock type (table 7). For example, transmissivity was $30 \mathrm{ft}^{2} / \mathrm{d}$ around well UE-20f (4456-13686ft) in deep volcanic rocks, or an average hydraulic conductivity of $0.003 \mathrm{ft} / \mathrm{d}$ (fig. 19).

Basin fill was differentiated into shallow and deep intervals to accommodate known hydrologic variability in the central A margosa D esert and Pahrump Valley (table 7). Pronounced seasonal water-level fluctuations from seasonal irrigation pumping in the central A margosa Desert suggest that less permeable sediments overlie the pumped interval. For example, water levels fluctuate seasonally and distinctly in wells $A D-3 a$ and $A D-9$ in response to seasonal irrigation, which requires a confining unit that is laterally extensive at distances greater than $1 \mathrm{mi}$ from pumped wells. Refined lithologic classes for basin fill in the Amargosa Desert (Taylor and Sweetkind, 2014) were not considered when defining the extent of the less permeable sediments because hydraulic properties were predicted poorly (fig. 23). Instead, basin-fill sediments were defined based on lithologic well logs, locations of flowing wells, and water-level trends in wells. Continuity of fine-grained sediments that confine deeper, coarse-grained basin fill in Pahrump Valley was indicated by historically flowing wells near Bennetts Spring and 4 mi south-southwest of Manse Spring (Waring, 1921). Wells such as $H \& H$, which was capped and had a water level of $57 \mathrm{ft}$ above land surface in 1948, extended the area of confinement at least 4 mi north of Bennetts Spring (Harrill, 1986). 
Table 7. Hydrogeologic units in the Death Valley version 3 model (DV3) hydrogeologic framework that were defined by rock type, depth, and previously defined hydrogeologic units from the Death Valley Regional Flow System version 2 model (DVRFS.v2) project, Nevada and California.

[Source: Belcher and others (2017). Description: AFFCR, Alkali Flat-Furnace Creek Ranch; AM, Ash Meadows; PDVS, Pahrump to Death Valley South; PM OV, Pahute M esa-Oasis Valley. DVR F S.v2 hydrogeologic unit: BRU, Belted Range unit; CFBCU, Crater Flat-Bullfrog confining unit; CFPPA, Crater Flat-Prow Pass aquifer; CFTA, Crater Flat-Tram aquifer; CHVU, Calico Hills volcanic-rock unit; ICU, Intrusive-rock confining unit; LA, Limestone aquifer; LCA, Lower carbonate-rock aquifer; LCA_T1, Lower carbonate-rock aquifer (thrusted); LCCU, Lower clastic-rock confining unit; LCCU_T1, Lower clastic-rock confining unit (thrusted); LFU, Lava-flow unit; OAA, Older alluvial aquifer; OACU, Older alluvial confining unit; OVU, Older volcanic-rock unit; PVA, Paintbrush volcanic-rock aquifer; SCU, Sedimentary-rock confining unit; TMVA, Thirsty Canyon-Timber Mountain volcanic-rock aquifer; UCA, Upper carbonate-rock aquifer; UCCU, Upper clastic-rock confining unit; VSU upper, Upper volcanic-sedimentary rock unit; VSU lower, Lower volcanic-sedimentary rock unit; WVU, Wahmonie volcanic-rock unit; XCU, Crystalline-rock confining unit; YAA, Younger alluvial aquifer; YACU, Younger alluvial confining unit; YVU, Younger volcanic-rock unit]

\begin{tabular}{|c|c|c|c|}
\hline Rock type & $\begin{array}{l}\text { DV3 hydrogeo- } \\
\text { logic unit }\end{array}$ & Description & $\begin{array}{c}\text { DVRFS.v2 } \\
\text { hydrogeologic unit }\end{array}$ \\
\hline \multirow[t]{2}{*}{ C arbonate rocks } & $\begin{array}{l}\text { Shallow, low-per- } \\
\text { meability carbonate } \\
\text { rocks }\end{array}$ & $\begin{array}{l}\text { Occur primarily beneath Rainier M esa, western Yucca Flat, Specter Range, } \\
\text { and Sheep Range. }\end{array}$ & UCA, LCA_T1 \\
\hline & $\begin{array}{l}\text { Shallow carbonate } \\
\text { rocks }\end{array}$ & $\begin{array}{l}\text { Regionally extensive in the AM basin. Spans from Pahrump Valley to the } \\
\text { Amargosa River in the PDVS basin and occurs in the southern Funeral } \\
\text { M ountains in the AFFCR basin. }\end{array}$ & LCA_T1, LCA \\
\hline Volcanic rocks & $\begin{array}{l}\text { Shallow volcanic } \\
\text { rocks }\end{array}$ & $\begin{array}{l}\text { Extends north-south from Pahute M esa and Black M ountain to Yucca M oun- } \\
\text { tain and J ackass Flats, and extends west-east from Oasis Valley to Rainier } \\
\text { M esa in the PM OV and A FFCR basins. Forms localized units beneath Yucca } \\
\text { Flat, Frenchman Flat, and Emigrant Valley in the AM basin. }\end{array}$ & $\begin{array}{l}\text { LFU, YVU, TMVA, PVA, } \\
\text { CHVU, WVU, CFPPA, } \\
\text { CFBCU, CFTA, BRU }\end{array}$ \\
\hline \multirow{2}{*}{ Basin fill } & $\begin{array}{l}\text { Confining unit in } \\
\text { Pahrump Valley }\end{array}$ & $\begin{array}{l}\text { Saturated basin fill between } 200 \text { and } 400 \mathrm{ft} \text { below the water table in Pahrump } \\
\text { Valley. Basin fill divided into three units, where this is the intermediate unit, } \\
\text { which was used to provide hydraulic separation between shallow (uncon- } \\
\text { fined) basin fill and deep (confined) basin fill. }\end{array}$ & $\begin{array}{l}\text { YAA, YACU, OAA, OACU, } \\
\text { LA, VSU upper }\end{array}$ \\
\hline & Deep basin fill & $\begin{array}{l}\text { Remainder of saturated basin fill beneath valleys, including the Amargosa } \\
\text { D esert, D eath Valley, Pahrump Valley, Oasis Valley, Emigrant Valley, Y ucca } \\
\text { Flat, and Frenchman Flat. }\end{array}$ & $\begin{array}{l}\text { YAA, YACU, OAA, OACU, } \\
\text { LA, VSU upper }\end{array}$ \\
\hline $\begin{array}{l}\text { Volcanic-sedimentary } \\
\text { rocks }\end{array}$ & $\begin{array}{l}\text { Volcanic-sedimen- } \\
\text { tary rocks }\end{array}$ & $\begin{array}{l}\text { Shallow volcanic-sedimentary rocks. Rocks are saturated in northern PMOV } \\
\text { basin from the Cactus Range to Kawich Valley. These rocks form the low- } \\
\text { permeability "tuff pile" beneath Rainier Mesa, Yucca Flat, and Frenchman } \\
\text { Flat, and extend beneath E migrant Valley in the AM basin. Rocks extend } \\
\text { from A margosa Desert to Greenwater Range in AFFCR basin, and occur } \\
\text { beneath Pahrump Valley and Sperry Hills in PDVS basin. }\end{array}$ & OVU, VSU upper \\
\hline Low-permeability rocks & $\begin{array}{l}\text { Granitic and silici- } \\
\text { clastic rocks }\end{array}$ & $\begin{array}{l}\text { Clastic sediments (and their metamorphosed equivalents), and granite, } \\
\text { granodiorite, quartz monzonite, and tonalite in stocks, dikes, sills, and } \\
\text { plutons. Rocks extend from the Resting Spring Range and California Valley } \\
\text { to D eath Valley in the PDV S basin, and between Pahrump Valley and the A sh } \\
\text { M eadows discharge area. Rocks occur beneath the Greenwater Range, Black } \\
\text { M ountains, and northern Funeral M ountains in the AFFCR basin. Rocks } \\
\text { are saturated to the west, north, and east of Yucca Flat in the Eleana Range, } \\
\text { Climax Stock, and Halfpint Range, respectively. }\end{array}$ & $\begin{array}{l}\text { ICU, SCU, UCCU, LCCU_T1, } \\
\text { LCCU, XCU }\end{array}$ \\
\hline
\end{tabular}


Deep basin fill mostly was differentiated from shallow basin fill in the DVRFS.v2 framework and classified as lower volcanic-sedimentary rock unit (VSU lower; table 3). These deep, volcanic-sedimentary rocks are clay-rich and cemented, and are otherwise impermeable (Sweetkind and others, 2010). For example, well Inyo-BLM 2 is open to deep, volcanic-sedimentary rocks that have a hydraulic conductivity of $3 \times 10^{-6} \mathrm{ft} / \mathrm{d}$ (fig. 19). G reater cementation, occurrence of evaporites, and other less-permeable basin fill have been observed at depths greater than 1,600 ft below the water table elsewhere in the Great Basin (Halford and Plume, 2011). The VSU lower was classified as part of the low-permeability rock type in the DV 3 framework (table 7).

Shallow volcanic-sedimentary rocks were retained as a unique hydrogeologic unit in the DV 3 framework because hydraulic isolation was needed between overlying and underlying aquifers and because rocks in some basins and ranges were undifferentiated. Volcanic-sedimentary rocks consist of tuffs; lavas; alluvium; colluvium; and eolian, fluvial, and lacustrine deposits (Sweetkind and others, 2010). Volcanic-sedimentary rocks function as confining units that hydraulically isolate basin fill from underlying carbonate rocks in CP basin (fig. 25), Frenchman Flat, and Yucca Flat. Basin fill in Gold Flat and Kawich Valley and consolidated rocks in the surrounding mountain ranges mostly were undifferentiated because these rocks were grouped into volcanic-sedimentary unit. Expected differences between transmissivity of basin fill and mountain ranges were addressed when hydraulic conductivities were distributed in groundwater models during calibration.

The intermediate hydrogeologic framework grid, which consisted of uniform 164-ft-thick (50-m-thick) layers, was reduced to 5 layers for the DV 3 hydrogeologic framework. Hydrogeologic units from DV 3 were substituted for previously defined hydrogeologic units from DVRFS.v2 (table 7). L ayer contacts were assigned nominally at depths of $164,328,820$, and $1,640 \mathrm{ft}(50,100,250$, and $500 \mathrm{~m})$ below the water table. A n exception occurred if lithologic well data provided sufficient control to align the contacts between layers at the contacts between hydrogeologic units (fig. 26). Sufficient hydrologic control was limited to an area in the NNSS that was bounded by Yucca Mountain, Rainier Mesa, and Yucca Flat (fig. 25). L ayer contacts were nominal depths bel ow the water table outside the limited area, which was sufficient to preserve contacts between hydrogeologic units because units typically thinned or thickened by less than $330 \mathrm{ft}$ $(100 \mathrm{~m})$. The thickest hydrogeologic unit was assigned where multiple hydrogeologic units intersected a cell. This primarily occurred in the deepest layer because average thicknesses exceeded $4,000 \mathrm{ft}$.

\section{Revisions from Underground Test Area Projects}

Hydrogeologic frameworks for F renchman Flat, Y ucca Flat-Climax M ine, Rainier M esa-Shoshone M ountain, and Pahute M esa CA U s (fig. 27) were created and revised to support the UGTA project. Hydrogeologic frameworks for CAUs were developed after the DVRFS.v1 hydrogeologic framework was developed (Belcher, 2004; Belcher and Sweetkind, 2010). Hydrogeologic units beneath Frenchman Flat (Bechtel Nevada, 2005a), Yucca Flat (Bechtel Nevada, 2006; Fenelon and others, 2012), and Rainier MesaShoshone Mountain (National Security Technologies, LLC, 2007; Fenelon and others, 2008) were revised in the DV3 framework. Revisions were warranted because details were missing in the DVRFS.v2 framework, such as aquifers that are known to be isolated where volcanic tuffs intervened between underlying carbonate rocks and overlying basin fill or volcanic rocks.

Revisions to hydrogeologic frameworks for CAUs were informed by additional data collection through the drilling of wells. Geologic and hydrologic uncertainties were reduced as a result of the UGTA project; 34 new boreholes were drilled and 119 new wells were completed during 2000-16, with most boreholes having multiple completions referred to as wells. Features such as Frenchman Flat basin were revised extensively because data from wells superseded surface mapping and geophysical inferences (Bechtel Nevada, 2005a). Well ER-5-3-2 (fig. 27) drilled through 4,000 ft of saturated basin fill before encountering carbonate rocks (Bechtel Nevada, 2005b), in contrast to the DVRFS.v2 framework, which interprets the basin fill contact with carbonate rocks as occurring above the water table. The edge of Frenchman Flat basin, where saturated basin fill occurs, was moved 3 mi north because of additional well control (fig. 27). Carbonate rocks were expected 6,000 ft below land surface in well ER-5-4-2 but were not encountered after drilling 7,000 ft below land surface (Bechtel Nevada, 2005c). Data from wells quintupled the volume of saturated basin fill in Frenchman Flat basin from the DVRFS.v2 framework to the DV3 framework.

Revisions to the DV3 framework were hydraulically important in northern Yucca Flat, and for local basin-fill aquifers and adjacent volcanic-sedimentary rocks in the eastern NNSS. Quartzite Ridge and Climax Mine, upgradient of wells WW-2 (3422 ft) and ER-8-1 (recompleted), are mapped as low-permeability rocks (DV 3 framew ork) rather than as carbonate rocks (DVRFS.v2 framework), which is consistent with surface geology, well logs, and elevated water levels (fig. 28; Winograd and Thordarson, 1975; Fenelon and others, 2012). B etter mapping extents and thicknesses of basin fill and volcanic rocks in Yucca Flat improved representation of local aquifers (fig. 28). Local basin-fill aquifers in Yucca Flat supplied pumping wells $W W-A$ and $W W-3$ with 2,700 and 620 acre-ft, respectively, from 1952-1988 (fig. 28; Elliott and Moreo, 2011). Revising these local basin-fill aquifers improved simulation of water-level declines in pumping wells $W W-A$ and $W W-3$ because these basin-fill aquifers were absent in the DVRFS.v2 framework (fig. 28) and incorrectly simulating pumping from volcanic rocks of limited extent imposes an artificial hydraulic barrier, resulting in larger simulated water-level declines in wells $W W-A$ and $W W-3$ than otherwise occurs based on water-level data. 


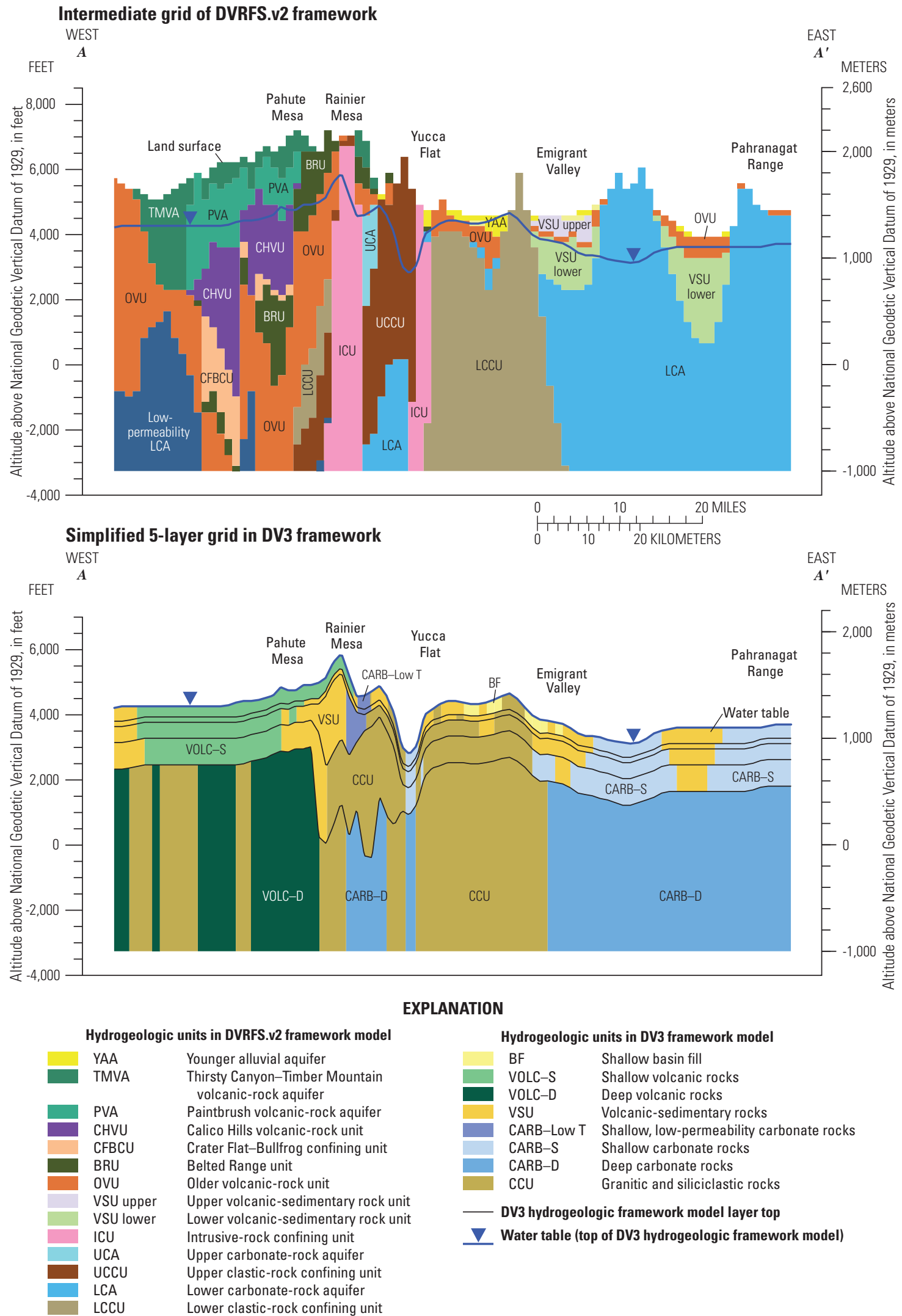

Figure 26. Example cross sections through intermediate grid of Death Valley Regional Flow System version 2 (DVRFS.v2) (Belcher and others, 2017; top cross section), and Death Valley version 3 (DV3; bottom cross section) hydrogeologic framework models, Nevada and California. Trace of cross section $A-A^{\prime}$ is shown in figure 25 . 


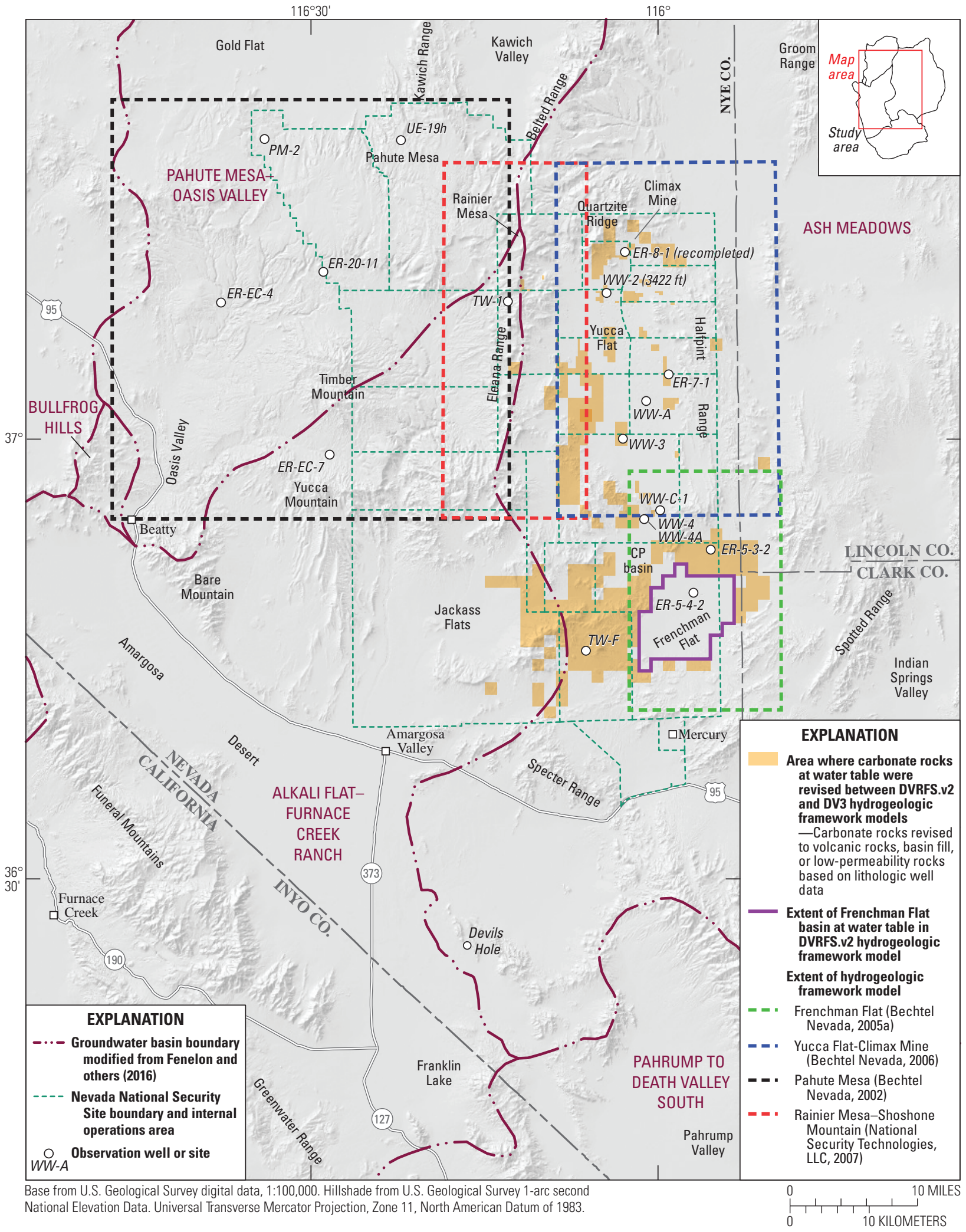

Figure 27. Extents of hydrogeologic framework models for Frenchman Flat, Yucca Flat-Climax Mine, Rainier MesaShoshone Mountain, and Pahute Mesa corrective action units; extent of Frenchman Flat basin in Death Valley Regional Flow System version 2 model (DVRFS.v2) hydrogeologic framework; and areas where carbonate rocks at water table in DVRFS.v2 were revised to volcanic rocks, basin fill, or low-permeability rocks in Death Valley version 3 model (DV3) hydrogeologic framework based on lithologic well data, Nevada and California. 


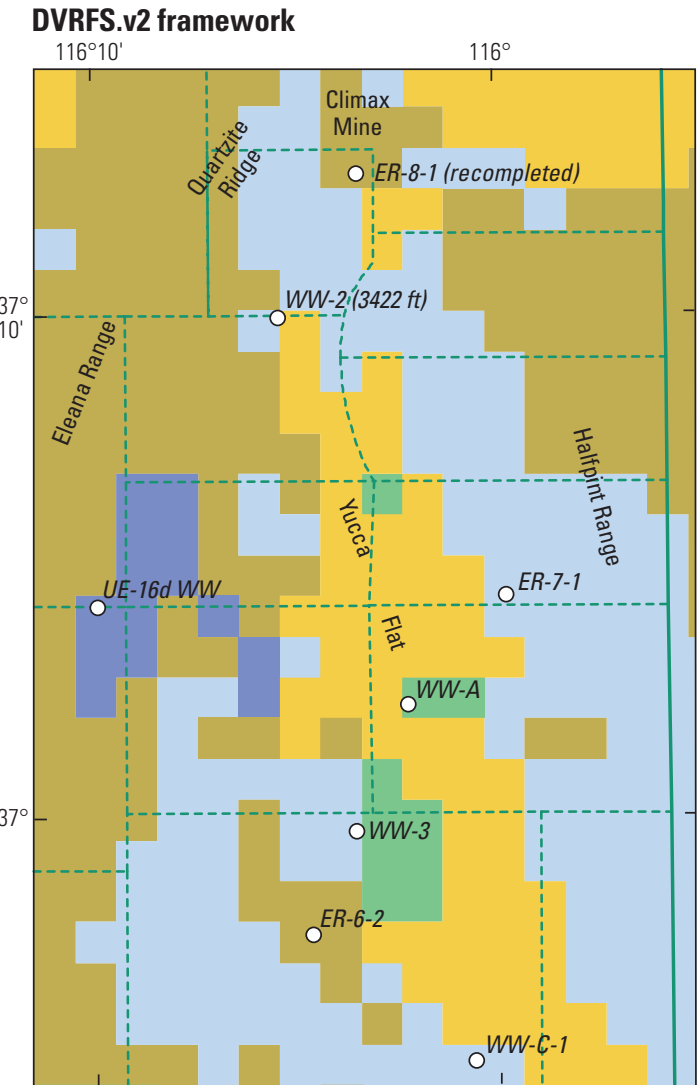

\section{Fenelon and others (2012)}

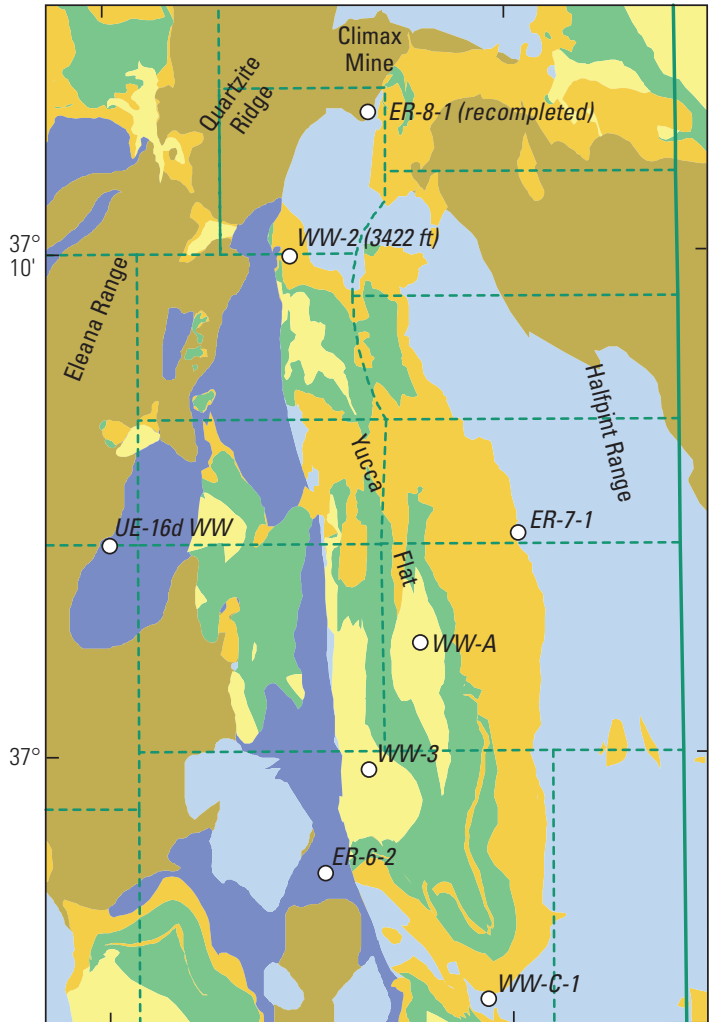

DV3 framework

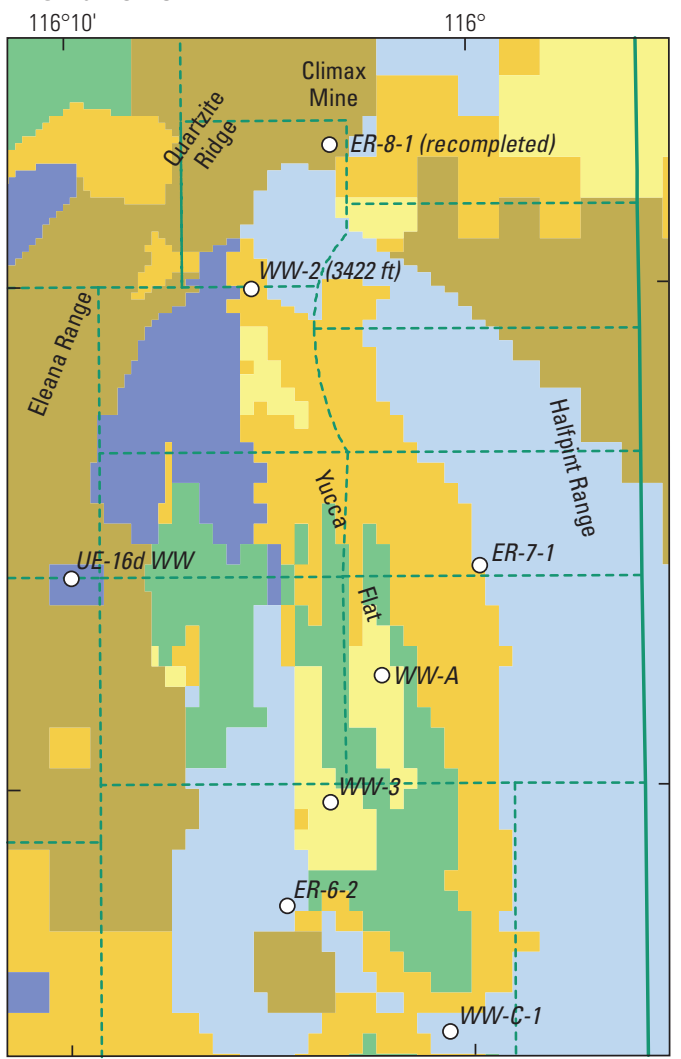

Universal Transverse Mercator Projection, Zone 11, North American Datum of 1983.
EXPLANATION

Hydrogeologic units

Shallow basin fill

Shallow volcanic rocks

Volcanic-sedimentary rocks

Shallow, low-permeability

carbonate rocks

Shallow carbonate rocks

Granitic and siliciclastic rocks

Nevada National Security Site

boundary-Internal operations areas dashed

$\underset{E R-7-1}{O}$ Well and identifier

Figure 28. Hydrogeologic units in Death Valley Regional Flow System version 2 model (DVRFS.v2; top left map), Death Valley version 3 model (DV3; top right map), and Fenelon and others (2012) (bottom map), at the water table beneath Yucca Flat, Nevada. 
Extents of permeable rocks in CP basin and surrounding low-permeability rocks (fig. 27) were revised for similar reasons because $\mathrm{CP}$ basin is isolated hydraulically (Fenelon and others, 2010, p. 21). Water levels in well WW-4, in $\mathrm{CP}$ basin (fig. 27), declined more than $10 \mathrm{ft}$ in response to pumping 7,300 acre-ft of water from wells $W W-4$ and $W W-4 A$ during 1981-2017. The transmissivity of basin fill at well $W W-4 A$ is $27,000 \mathrm{ft}^{2} / \mathrm{d}$, indicating that water levels in well $W W-4$ would have declined less than $1 \mathrm{ft}$ if $\mathrm{CP}$ basin were not isolated.

Hydrogeologic frameworks for the Pahute M esa CAU were not incorporated in the DV 3 framework because Pahute Mesa consists primarily of thick sequences of volcanic rocks (Fenel on and others, 2016). Uniqueness of hydraulic variability between hydrogeologic units from the original and a revised framework for Pahute Mesa CAU (Bechtel Nevada, 2002; Garcia and others, 2017) was tested by simultaneously interpreting 8-16 interfering MWATs. Hydraulic-conductivity estimates varied more within hydrogeologic units than between hydrogeologic units (Belcher and others, 2002; Mirus and others, 2016; Garcia and others, 2017). Another interpretation using a single MWAT at well ER-20-11 (fig. 27) reached a similar conclusion: "The hydraulic conductivities of the aquifers, confining units, and composite units show considerable overlap in their estimated values with no discernible trend among the different rock types," (Navarro, 2016a, p. 5-35).

\section{Hydraulically Mandated Features}

In the DV 3 framew ork, discharge areas were connected to upgradient aquifers by changing shallow hydrogeologic units in the Furnace Creek area, L ower A margosa area, and Saratoga Spring area. Potential local ized hydraulic barriers were introduced in the A sh $M$ eadows discharge area based on hydraulic data and attenuated responses to local pumping. Revisions to the DV3 framework, from the DVRFS.v2 framework, were warranted based on geologic evidence and hydrologic data.

A localized hydraulic barrier was introduced into shallow carbonate rocks in the A sh M eadows discharge area north of Fairbanks Spring (fig. 7) because a steep horizontal hydraulic gradient exists. Water-level altitudes declined from 2,361 ft in well GF-2B deep (AM-11) to 2,250 ft at Fairbanks Spring over a distance of 3,500 ft, a gradient of $160 \mathrm{ft} / \mathrm{mi}$. Hydraulic gradients north of well GF-2B deep (AM-11) are less than $2 \mathrm{ft} / \mathrm{mi}$ and transmissivities exceed 100,000 $\mathrm{ft}^{2} / \mathrm{d}$. This high hydraulic gradient can be explained by a low-permeability feature, such as a fault, north of Fairbanks Spring that offsets thin permeable horizons in shallow carbonate rocks (Dudley and Larson, 1976, p. 49). Groundwater would need to flow through shallow carbonate rocks south of the low-permeability feature to discharge from Fairbanks Spring. The location and orientation of the low-permeability feature were interpreted from a fault map of the A sh M eadows discharage area (Dudley and Larson, 1976).
A nother potential localized hydraulic barrier is suggested by attenuated responses to injection in Devils Hole Well (AM5), which is $900 \mathrm{ft}$ east of Devils Hole (fig. 7). A bout 1,700 acre-ft of water was injected in Devils Hole Well (AM-5) from J uly 1973 to A ugust 1977 at rates of $400 \mathrm{gal} / \mathrm{min}$, with the intent of mitigating water-level declines in Devils Hole (Larson, 1974a, 1974b, 1975; Carson, 1979). A detectable rise of $1 \mathrm{ft}$ would be expected in Devils Hole if transmissivity and specific yield reasonably averaged $50,000 \mathrm{ft}^{2} / \mathrm{d}$ and 0.02 , respectively, around Devils Hole Well (AM-5). No discernable response was observed in Devils Hole (Dudley and L arson, 1976), which suggests a low-permeability feature exists in the shallow carbonate rocks between Devils Hole Well (AM-5) and Devils Hole. A fault was postulated and introduced in the shallow carbonate rocks (fig. 7) along previously mapped lineaments and faults (Dudley and Larson, 1976, p. 49).

Furnace Creek Wash was revised in the DV3 framework for consistency with the conceptualization of discharge from the Furnace Creek area (fig. 9). Furnace Creek Wash consists of basin-fill deposits based on well logs but was mapped as undifferentiated volcanic-sedimentary rocks in the DVRFS. v2 framework. These undifferentiated volcanic-sedimentary rocks were changed to basin fill in the DV3 framework so that groundwater flow could be simulated through Furnace Creek Wash between upgradient Travertine Springs and downgradient alluvial fan on the Death Valley floor (fig. 9).

L ow-permeability rocks formed an unwarranted hydraulic barrier in the Lower Amargosa area. The DVRFS. v2 framework mapped low-permeability rocks at the water table between the Nopah Range and Amargosa River, which impeded the movement of groundwater downgradient of Chicago Valley to discharge areas near Tecopa (fig. 12). L owpermeability rocks between the Nopah Range and Amargosa River were remapped, based on geologic interpretations, as carbonate rocks and basin fill, which was needed to allow westward flow to be simulated to Resting Spring and Tecopa (fig. 12). Basin fill added near Tecopa primarily represents saturated China Ranch beds in the area bounded by Resting Spring, Tecopa, and West Willow Spring.

Spatial distribution of discharge in the L ower A margosa area differs between the DVRFS.v2 project and this investigation because low-permeability rocks were remapped in the DV 3 framew ork. Discharges were simulated in the DVRFS.v2 project (Faunt, Sweetkind, and Belcher, 2010) at locations where ET units were mapped by Laczniak and others (2001). However, more than 30 percent of the ET units occurred from rocks mapped as impermeable in the DVRFS.v2 hydrogeologic framework. Mapped ET in these instances should overlie basin fill in the Amargosa River downstream of Tecopa and China Ranch Wash (fig. 12). Errors occurred in the DVRFS.v2 hydrogeologic framework because basin-fill deposits in these channels have limited extents and are bounded by impermeable rocks. Shallow geology of the Tecopa/California Valley area was changed in this investigation so that discharges from ET units are simulated from basin-fill deposits (fig. 12). 
The Amargosa River channel was revised in the DV3 framew ork for consistency with the conceptual ization of flow in the Saratoga Spring area. The Amargosa River channel between Dumont Dunes and the Saratoga Spring area (fig. 14) consists of basin fill; however, the DVRFS.v2 framework mapped the channel as low-permeability rocks. Incorrectly mapped low-permeability rocks at the water table were remapped as basin fill between Dumont Dunes and the Saratoga Spring area. Basin fill is required upgradient of Saratoga Pools for the simulation of flood infiltration and base flow downstream of the Amargosa River at Dumont Dunes, California (USGS streamgage 10251375).

\section{Groundwater Development}

Groundwater development entails pumping wells and nonpumping flowing wells, which affect groundwater flow as water is withdrawn from the aquifer system. When a pump is first turned on, water is supplied from storage. Eventually, if pumping continues for sufficient time, some of the pumped water will be supplied by natural discharge. Sources of water to wells were summarized originally by Theis (1940, p. 10) as follows: "All water discharged by wells is balanced by a loss of water somewhere. This loss is always to some extent and in many cases largely from storage in the aquifer. Some groundwater is always mined," and "After sufficient time has elapsed...further discharge by wells will be made up in part by a diminution in the natural discharge." Decreased discharge to springs, wetlands, and phreatophytes as a result of pumping is termed capture (K onikow and L eake, 2014).

Water-level declines and capture that result from groundwater development are affected by the rate and volume pumped, distance to pumping centers, distance to discharge areas, and aquifer hydraulic properties. In pumped wells, water levels decline proportionally with increasing pumping rates. Pumping centers where large volumes of water are withdrawn have greater magnitudes and extents of water-level declines compared to pumping centers where small volumes are withdrawn. Pumping centers distant from discharge areas have greater magnitudes and extents of water-level declines compared to pumping centers within discharge areas. Water-level declines and capture also are affected by hydraulic properties of the rocks. The ratio of transmissivity to storativity (specific yield plus specific storage times thickness), known as hydraulic diffusivity, controls the magnitude and lateral extent of water-level declines from groundwater development. Water-level declines propagate farther and faster from pumping centers as hydraulic diffusivities increase.

Groundwater development in the study area principally has removed water from storage because pumping has been relatively distant from discharge areas (fig. 29). L arge groundwater withdrawals primarily have occurred in the central A margosa Desert and Pahrump Valley, but discharge areas greater than $10 \mathrm{mi}$ from these pumping centers have not been affected measurably. For example, local pumping wells in the Ash Meadows discharge area affected spring discharges within 5 mi during 1968-80 (Dudley and L arson, 1976), but effects of distant pumping from the central Amargosa Desert were not discernable. A bout one-half of the discharge in A sh M eadows is from Crystal Pool, Fairbanks Spring, and Big Spring, which averaged $12.7 \mathrm{ft}^{3} / \mathrm{s}(9,200 \mathrm{acre}-\mathrm{ft} / \mathrm{yr})$ prior to 1969 (D udley and Larson, 1976). Combined discharge from these springs averaged $12.6 \mathrm{ft}^{3} / \mathrm{s}(9,100 \mathrm{acre}-\mathrm{ft} / \mathrm{yr})$ from 2008-2017 (U.S. Geological Survey, 2018a), which is no change relative to measurement standard deviations of $0.1-0.4$ $\mathrm{ft}^{3} / \mathrm{s}(100-300$ acre-ft/yr).

Predicted effects of groundwater development depend on estimated pumping rates, water-level changes, and capture (B redehoeft, 2002). Uncertainty in these quantities propagates into estimated distributions of transmissivity and storativity. Estimates of pumping prior to 1950 are uncertain because most groundwater was withdrawn from nonpumped flowing wells where data are sparse. L ong-term ( $>50$ years) waterlevel data are limited in the central Amargosa Desert and Pahrump Valley despite long pumping histories. For example, groundwater development has occurred in Pahrump Valley from 1913 to present (2018); however, only five wells in Pahrump Valley have long-term (1950-2018) water-level measurements and no wells provide information about water-level declines from 1913-1950. Based on comparison of historical and current spring discharges, 15-20 percent of predevelopment discharge has been captured in response to more than 100 years of groundwater development in the study area.

\section{Data Compilation}

Groundwater-withdrawal data and return-flow estimates used in this report are provided in a supplemental data release (J ackson and Halford, 2020). Groundwater-withdraw al data from 1913 to 2010 were compiled from Elliott and M oreo (2018), which is an updated database that supersedes previous databases (Moreo and others, 2003; Moreo and Justet, 2008). In this report, more-recent groundwater withdrawals were estimated by projecting 2010 pumping rates through 2018 .

Groundwater-withdrawal data used in this report incorporate minor revisions to Elliott and Moreo (2018). For example, in the Elliott and M oreo (2018) database, pumping for dewatering the B arrick-Bullfrog mine incorrectly was attributed to wells 3 and 4 mi south of the Barrick-Bullfrog pit. This pumpage was assigned to temporary dewatering wells within 1,000 ft of the north edge of the B arrick-Bullfrog pit in this study. Injection in Devils Hole Well (AM-5) of about 1,700 acre-ft from J uly 1973 to A ugust 1977 (L arson, 1974a, 1974b, 1975; Carson, 1979) was not inventoried in Elliott and Moreo (2018) and was added for this study. 


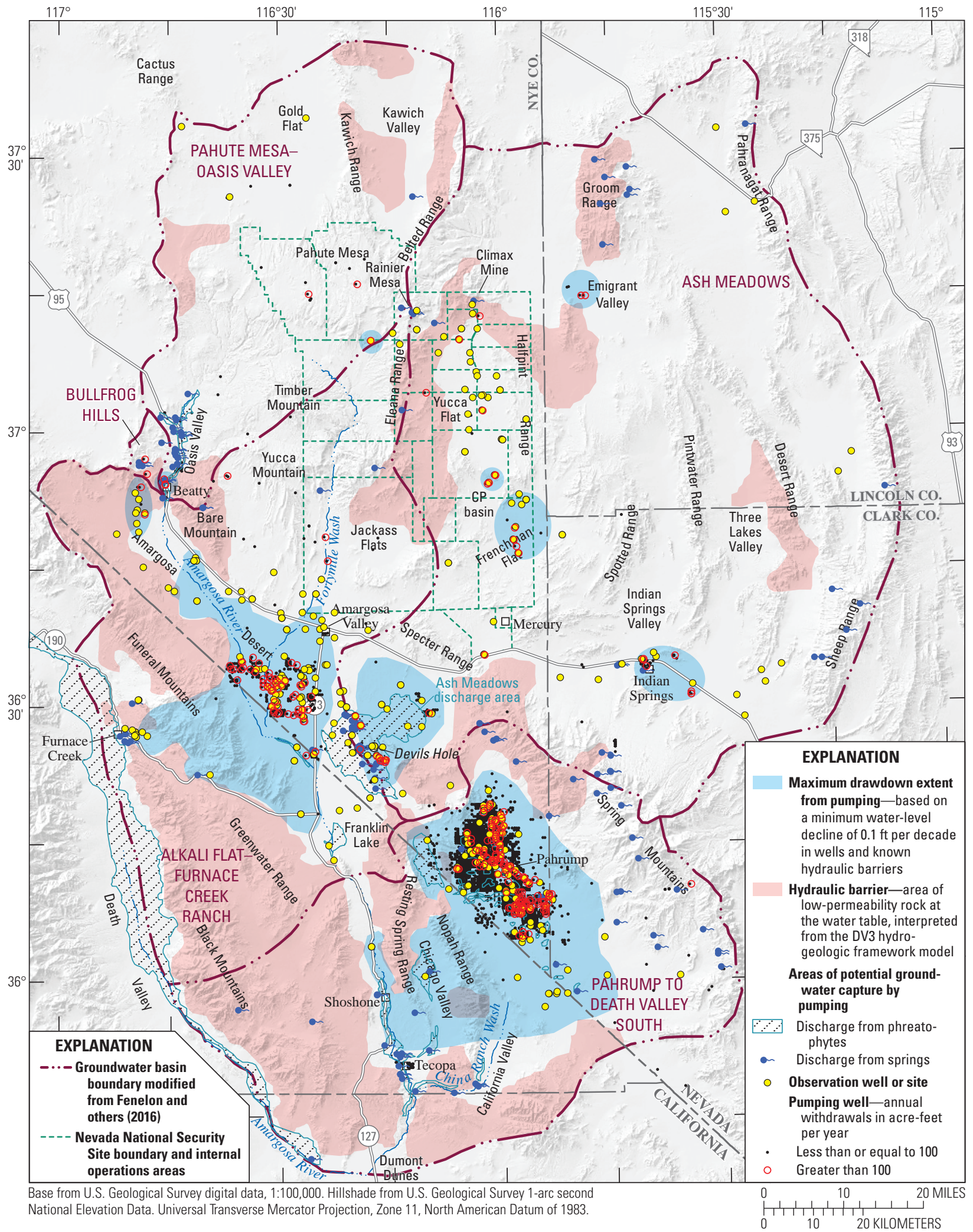

Figure 29. Pumping wells, areas affected by groundwater development, and hydraulic barriers, in the study area, Nevada and California. DV3, Death Valley version 3. 


\section{Pumping and Return Flow}

Pumping in the study area has been inventoried and estimated by water-use type because water-use type is correlated strongly with measurement uncertainty ( $M$ oreo and others, 2003). This is because pumping is estimated differently for irrigation, domestic, and metered water-use groups. I rrigation pumping was estimated by multiplying irrigated acreage by annual crop application rates that averaged $7 \mathrm{ft} / \mathrm{yr}$ (M oreo and J ustet, 2008). D omestic pumping was estimated by multiplying the number of wells by an annual pumping volume of 0.7 acre- $\mathrm{ft}$ for each well (Moreo and others, 2003). Pumping estimates for domestic and irrigation water uses have an uncertainty of about 20 percent (M oreo and J ustet, 2008). $M$ etered pumping includes commercial, industrial, mining, and public-supply wells, and is known within 10 percent. M ost metered pumping is for public supply, which includes NNSS and Department of Defense supply wells (M oreo and others, 2003).

Total groundwater withdrawals from irrigation, domestic, and metered water use were compared to predevelopment discharge estimates for each groundwater basin (fig. 30). AFFCR and A sh M eadows groundwater basins were combined because pumping from either basin can affect predevelopment discharges in both basins (see section, "Groundwater-B asin B oundary U ncertainty"). A nnual groundwater withdrawals exceeded predevelopment discharge in the PDVS groundwater basin from 1952-2002 (fig. 30). As of 2018, groundwater withdrawals have never exceeded predevelopment discharges in the A FFCR, A sh M eadows, or PM OV groundwater basins (fig. 30).

Groundwater withdrawals primarily have occurred in the AFFCR and PDVS groundwater basins where, historically, withdrawals principally supplied irrigation (fig. 30). Groundwater withdrawals in the A FFCR groundwater basin have increased from 1950 to present (2018) where, on average, withdrawals for irrigation account for about 90 percent of total withdrawals. M aximum groundwater withdrawals in the PDV S groundwater basin occurred between 1960 and 2000, when withdrawals for irrigation averaged 30,100 acre-ft/yr and total withdrawals averaged 32,600 acre-ft/yr.

Substantial pumping from domestic wells was limited to Pahrump Valley in the PDV S groundwater basin (fig. 30). Pumping from domestic wells in the PDV S groundwater basin was minor prior to 1970 and totaled 8,100 acre-ft/yr during
2010. D omestic pumping in Pahrump Valley accounted for 95 percent of all pumping from domestic wells in the study area during 2010.

M ost metered pumping in the study area was for public supply, with episodic periods when mining usage was prevalent. About 60 percent of metered pumping in the study area supported activities at the NNSS between 1960 and 1980 (Moreo and Justet, 2008). Pumping for NNSS activities occurred in the AFFCR, Ash Meadows, and PMOV groundwater basins (fig. 30). Pumping at the NNSS declined after 1990 and averaged 800 acre-ft/yr from 2000-2010 (Elliott and M oreo, 2011). Pumping for mine dewatering south of Bullfrog Hills and in Crater Flat averaged 1,800 acre-ft/ yr from 1984-2004 (Elliott and M oreo, 2018), where this pumping occurred in the AFFCR and PM OV groundwater basins. Ninety percent of metered pumping in the AFFCR and $A$ sh $M$ eadows groundwater basins during 2010 was for commercial and public supply (fig. 30). Public supply accounted for greater than 90 percent of metered pumping in the PDV S groundwater basin between 1980 and 2010 (M oreo and J ustet, 2008).

A fraction of pumped groundwater infiltrates below the root zone and recharges the saturated groundwater system as return flow (Harrill, 1986). Return flow is computed as a fraction of total groundwater withdrawals, where fractions differed between metered, domestic, and irrigation water use (table 8). Of the three water-use components, return flows from irrigation wells were the smallest decimal fraction (0.17) of annual pumping volumes (Stonestrom and others, 2007). However, return flows from irrigation wells accounted for 60 percent of total return-flow volumes in the study area from 1913-2010 (fig. 30). Return flows from metered wells averaged one-half of annual pumping volumes (Harrill, 1986). Moreo and Justet (2008) estimated an annual pumping volume of 0.7 acre-ft per domestic well, whereas the revised estimate of annual net consumptive use is 0.5 acre-ft/yr (Geter, 2015, p. 2). Return flow for each domestic well was 0.2 acre-ft/yr, which was computed from the product of $0.7 \mathrm{acre}-\mathrm{ft} / \mathrm{yr}$ and 0.29 (table 8). A domestic well return-flow rate of 0.2 acre-ft/ $\mathrm{yr}$ is the difference between the revised net consumptive-use $(0.5 \mathrm{acre}-\mathrm{ft} / \mathrm{yr})$ and the previously published pumping estimate ( 0.7 acre-ft/yr). Annual return-flow volumes from domestic wells exceeded 2,000 acre-ft after 2005 in the study area.

Return flow for mining was reported as injection to wells or infiltration in basins (Moreo and Justet, 2008). 


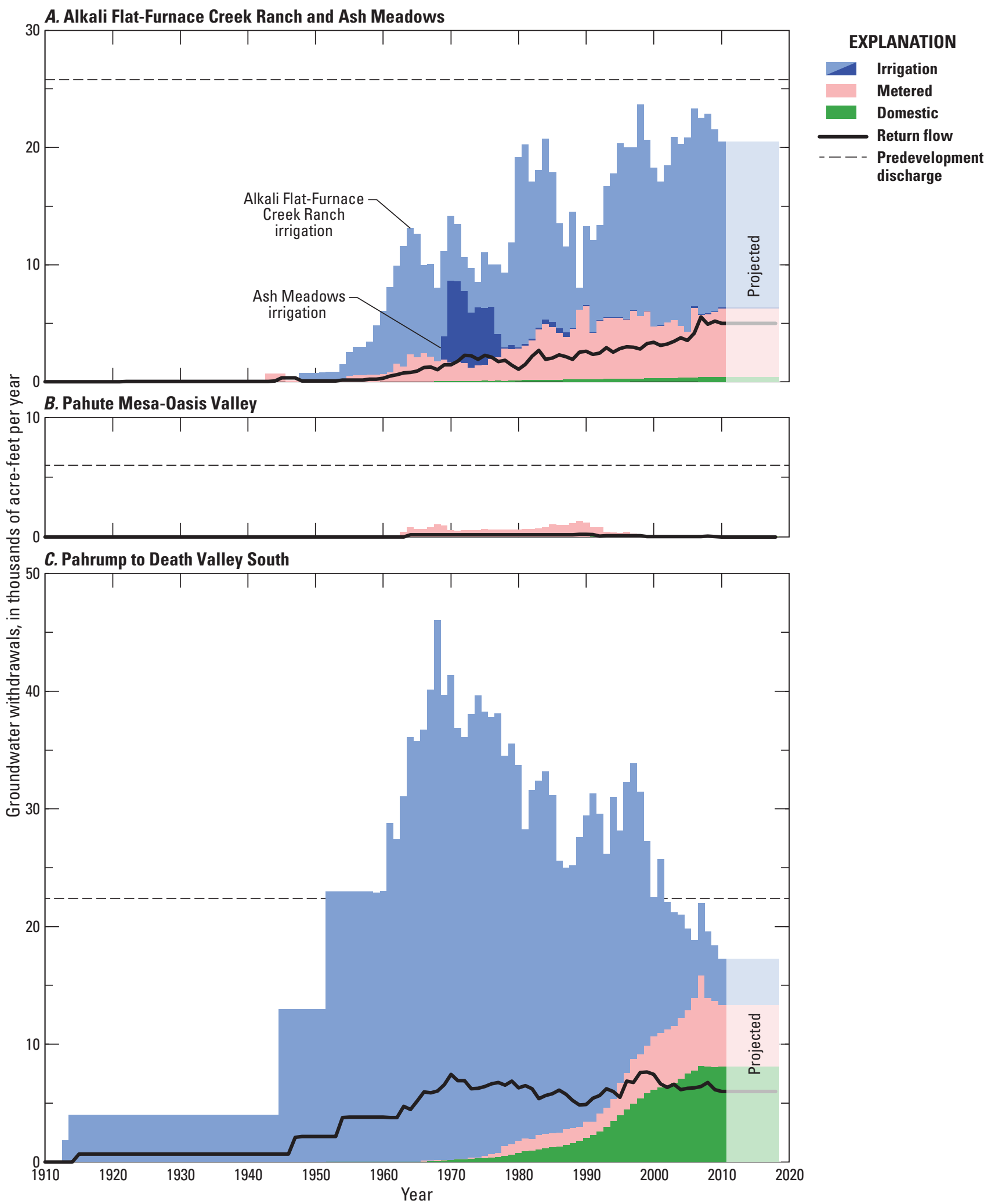

Figure 30. Total annual groundwater withdrawals by water-use type, return flow, and predevelopment discharge by groundwater basin, in the study area, Nevada and California, 1910-2010, with withdrawal estimates from 2010 projected through 2018. Irrigation water use is differentiated between Alkali FlatFurnace Creek Ranch and Ash Meadows groundwater basins, whereas metered and domestic use are combined totals. 
Table 8. Fraction of return flow and velocity through unsaturated zone, in the study area, Nevada and California.

[Water-use group: M etered includes commercial, industrial, mining, and public-supply wells]

\begin{tabular}{lccl}
\hline Water-use group & Return flow fraction & $\begin{array}{c}\text { Pore velocity } \\
\text { (feet per year) }\end{array}$ & \multicolumn{1}{c}{ Reference } \\
\hline M etered & 0.50 & 20 & Harrill (1986) \\
Domestic & 0.29 & 30 & Geter (2015), Naranjo and others (2013) \\
Irrigation & 0.17 & 5 & Stonestrom and others (2007) \\
\hline
\end{tabular}

Recharge to the saturated groundwater system is delayed as return flow passes through the unsaturated zone between the root zone and water table. A nnual delay time between application of return flow and recharge was estimated at each well. A nnual delay time was the depth to water table divided by pore velocity, which varied by water-use group (table 8) because return flow occurred over different areas. For example, assuming 130 acres are irrigated with an application rate of $7 \mathrm{ft} / \mathrm{yr}$, the return-flow volume applied to the irrigated acreage is about $1 \mathrm{ft} / \mathrm{yr}$ and the return-flow rate, assuming a porosity of 0.2 , is $5 \mathrm{ft} / \mathrm{yr}$. Pumped water from domestic wells primarily returned through leach fields in septic systems, which restricted application areas and increased pore velocities, compared to irrigation wells (Naranjo and others, 2013). Return-flow volume per domestic well is 0.2 acre- $\mathrm{ft} / \mathrm{yr}$ $(0.7 \mathrm{acre}-\mathrm{ft} / \mathrm{yr} \times 0.29$ fraction). Dividing the return-flow volume by a leach-field area of about 0.034 acres $\left(1,500 \mathrm{ft}^{2}\right)$ (Naranjo and others, 2013) and a porosity of 0.2 , the returnflow rate is $30 \mathrm{ft} / \mathrm{yr}$. Average pumping for commercial and public supply from 1913-2010 was 47 acre-ft/yr (Elliott and M oreo, 2018) and, assuming a 5-acre reclamation area, the return-flow rate is about $20 \mathrm{ft} / \mathrm{yr}$. Delays between application of return flow and recharge generally were less than 10 years because depths to water table were less than $70 \mathrm{ft}$ for about 90 percent of pumped wells (fig. 30). Delays greater than 10 years affect about 10 percent of wells where depths to the water table range from 200 to $2,060 \mathrm{ft}$.

Groundwater pumped, consumed, and lost to the saturated system is the net pumpage, which is the difference between groundwater pumping and return flow (fig. 31). Net pumpage in the study area averaged 39,100 acre-ft/yr from 1960 to 2000, or 83 percent of total groundwater withdrawals. Net pumpage averaged 71 percent of total groundwater withdrawals during 2010 because irrigation pumping decreased as a fraction of all groundwater withdrawals.

Return flow mitigates the effects of pumping on capture from discharge areas. In the absence of return flow, total groundwater withdrawals would have exceeded total predevelopment discharge in the study area during 6 years between 1960 and 2000 (fig. 31). Instead, return flow has resulted in an average net pumpage of 39,100 acre-ft/ yr between 1960 and 2000, which is 73 percent of the predevelopment discharge.
Net pumpage (pumping and return flow) causes localized effects on water-level declines and capture from discharge areas. Pumped intervals in wells and recharge from return flow can differ vertically by $50-500 \mathrm{ft}$ and laterally by as much as $0.6 \mathrm{mi}$ (Moreo and others, 2003). These spatial differences can affect local groundwater levels and capture by reducing the rate of water-level decline from pumping or the rate of capture from discharge areas. These effects are unimportant at distances greater than 1-2 mi from areas of pumping and return flow (fig. 29).

\section{Areas Affected by Pumping}

Areas affected by pumping were delineated with a minimum water-level decline of $0.1 \mathrm{ft}$ per decade (fig. 29). Delineated areas were compared to the density of pumping well locations and volumes pumped (fig. 29). Delineated areas also were compared to locations of observation wells with observed water-level declines in pumping centers and geologic controls, such as low-permeability rocks that function as hydraulic barriers (fig. 29). Declining water-level trends in wells within the delineated areas are caused by pumping. Net pumpage, rather than total groundwater withdrawals, better explains water-level declines in wells because net pumpage better indicates the actual stresses affecting water levels. Therefore, water-level trends from pumping are discussed in terms of net pumpage in this section.

\section{Central Amargosa Desert and Pahrump Valley}

The central Amargosa Desert and Pahrump Valley are the two principal pumping centers in the study area (fig. 32) and had maximum measured water-level declines of 50 and 80 $\mathrm{ft}$, respectively (fig. 33). Water levels declined continuously in well $A D-5$ in the central A margosa D esert (fig. 32), where pumping generally has increased from 1950 to 2010 (fig. 33). Water levels in well ESB1 in Pahrump Valley (fig. 32) declined $80 \mathrm{ft}$ by 1980 and recovered $60 \mathrm{ft}$ by 2010 (fig. 33), to about $20 \mathrm{ft}$ below predevelopment water levels. The water-level trend in Pahrump Valley is a response to net pumping that peaked at 40,000 acre-ft/yr in 1968 and decreased to about $12,000 \mathrm{acre}-\mathrm{ft} / \mathrm{yr}$ in 2010. 


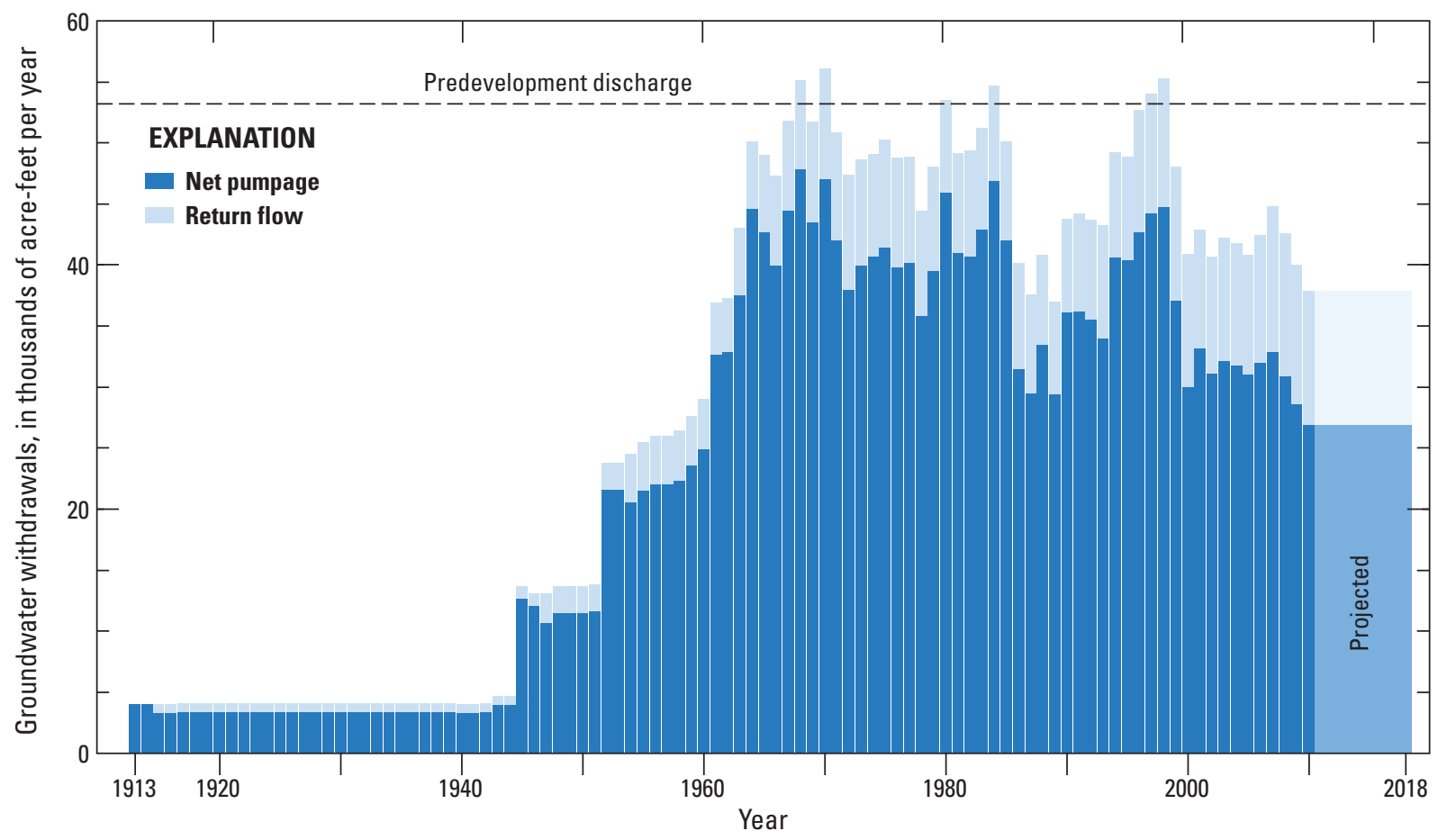

Figure 31. Net groundwater withdrawals and return flow, in the study area, Nevada and California, 1910-2018.

Pumping from the central A margosa Desert and Pahrump Valley affected areas of 300 and $600 \mathrm{mi}^{2}$, respectively (fig. 32). Extents of pumping effects were delineated using decadal rates of water-level declines in wells. Decadal rates of water-level declines in wells are successively smaller as distance from the pumping center increases. A reas within each delineated pumping center (fig. 32) had rates of decline of greater than $0.1 \mathrm{ft}$ per decade, whereas groundwater levels either had rising trends (fig. 18) or no trend (neither upward or downward) in areas affected minimally or not at all by pumping.

\section{Central Amargosa Desert}

Pumping in the central A margosa Desert has propagated north toward J ackass F lats and B are M ountain and south toward D eath Valley J unction (fig. 32), as determined from water-level declines in wells. Small water-level declines in well BGMW-8 (fig. 34B) are not observable $1 \mathrm{mi}$ west in well $B G M W-6$ (fig. 32). Likewise, water-level declines evident in well NC-EWDP-Washburn-1X (deep) (fig. 34C) do not extend 2 mi north to well NC-EWDP-22PA (shallow) (fig. 32), where water levels have risen $0.8 \mathrm{ft}$. Water-level declines in well DVJ-02 (fig. 34D) are expected to be limited farther south because of the occurrence of low-permeability rocks (fig. 32).

The maximum westward extent of pumping from the central A margosa Desert is uncertain. Pumping has propagated into the Funeral M ountains because substantial drawdowns of $3 \mathrm{ft}$ per decade were observed in well Travertine Point 1 (fig. 34). Distal pumping effects, if any, from the central
A margosa Desert would be masked in Furnace Creek area wells by water-level declines from local pumping. Water levels have been declining in well WRPMW-5, about $10 \mathrm{mi}$ northwest of well Travertine Point 1 (fig. 32), at $1.2 \mathrm{ft}$ per decade since 2008. These water levels are affected by local pumping for F urnace Creek water supply, where pumped wells are less than $1 \mathrm{mi}$ south of well WRPMW-5.

\section{Pahrump Valley}

Pumping from Pahrump, Nevada, has propagated to the northern and southern extent of Pahrump Valley, into Stewart and Chicago Valleys, and north of Shoshone, California (fig. 32). Water levels declined at rates of 2.2 and $3.1 \mathrm{ft}$ per decade in Last Chance Well and BLM Stewart Valley Well, respectively (fig. $35 B-C$ ), which are 5 mi northwest of pumping wells (fig. 29). Pumping effects did not propagate north of these wells because of the occurrence of lowpermeability rocks (Winograd and Thordarson, 1975, p. C91-C92; fig. 32). Groundwater levels in wells Jeep Trail and 021N010E04L01S, $10 \mathrm{mi}$ south and southeast of pumping wells (fig. 29), declined at rates of $9 \mathrm{ft}$ per decade between 1960 and 1980, which coincides with the period of largest groundwater withdrawals from Pahrump Valley (fig 35D-E). Water levels were recovering in Jeep Trail well after 2004 from reduced pumping in Pahrump Valley (fig. 35D). Water levels in well Hwy 127 MM21-1, about 16 mi west of Pahrump Valley pumping wells and 6 mi north of Shoshone (fig. 32), declined at a rate of $0.5 \mathrm{ft}$ per decade (fig. 35E). 


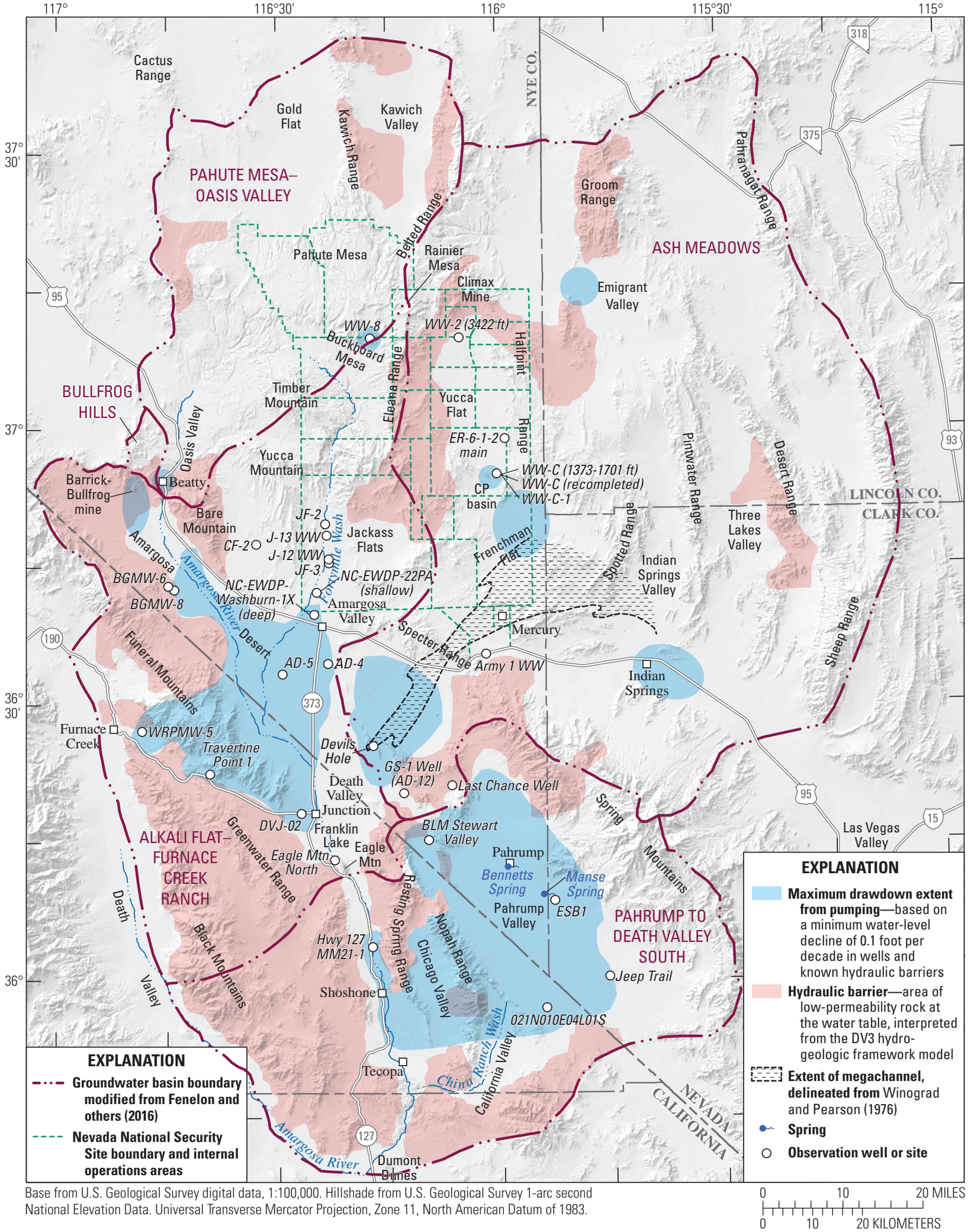

Figure 32. Observation wells affected by groundwater development and hydraulic barriers, in the study area, Nevada and California. 


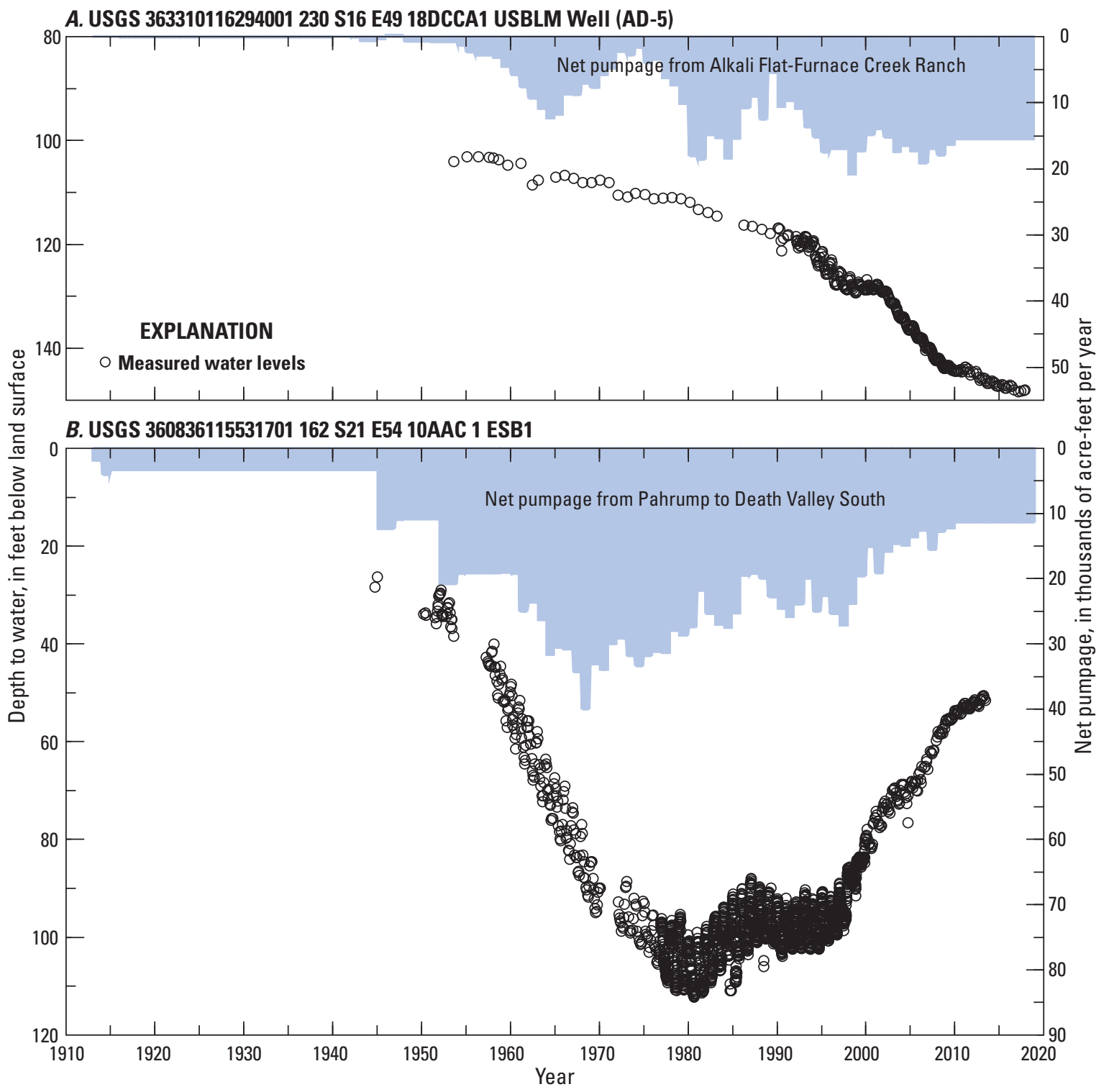

Figure 33. Water-level changes in $(A)$ well $A D-5$ in the central Amargosa Desert and $(B)$ well $E S B 1$ in Pahrump Valley, Nevada, 1910-2018. DV3, Death Valley version 3.

Low-permeability rocks west of the Amargosa River limited pumping effects from Pahrump Valley from extending west of well Hwy 127 MM21-1 (fig. 32).

Discharges from Bennetts and Manse Springs (fig. 32) were captured by pumping in Pahrump Valley. A II 5,400 acre-ft/yr (7.5 ft $3 / \mathrm{s})$ of discharge from Bennetts Spring was captured by 1959 (Harrill, 1986). Bennetts Spring has remained dry through 2018. Predevelopment discharge from Manse Spring was 4,400 acre-ft/yr ( $6 \mathrm{ft}^{3} / \mathrm{s}$ ) and declined gradually after development. All discharge from Manse Spring was captured by 1977 (Harrill, 1986). Discharge from Manse Spring resumed by the late 1990s (B uqo, 2004). Pumping declines and rising water levels restored Manse Spring, and discharge averaged 1,500 acre-ft/yr $\left(2.1 \mathrm{ft}^{3} / \mathrm{s}\right)$ in 2011.

\section{Jackass Flats}

Pumping in Jackass Flats, about 15 mi north of the central A margosa Desert (fig. 32), has affected groundwater levels but natural water-level rises from recharge mask pumping effects (fig. 36). D uring 1957-2018, total withdrawals from wells $J-12 \mathrm{WW}$ and $J-13 \mathrm{WW}$ were 2,250 and 4,050 acre-ft, respectively, and these wells supplied about 90 percent of the 7,000 acre-ft that was pumped from J ackass Flats (fig. 36). Water levels in wells $J F-2, J-13 \mathrm{WW}$, and $J F-3$ rose $1.5 \mathrm{ft}$ in unison from 1997 to 2015 (fig. 36), which is consistent with water-level rises from recharge throughout the study area (Fenelon and Moreo, 2002; Elliott and Fenelon, 2010; Fenelon and others, 2012; Jackson and Fenelon, 2018). Measured water-level rises were not recoveries from reduced pumping because recovery rates would differ between wells. 


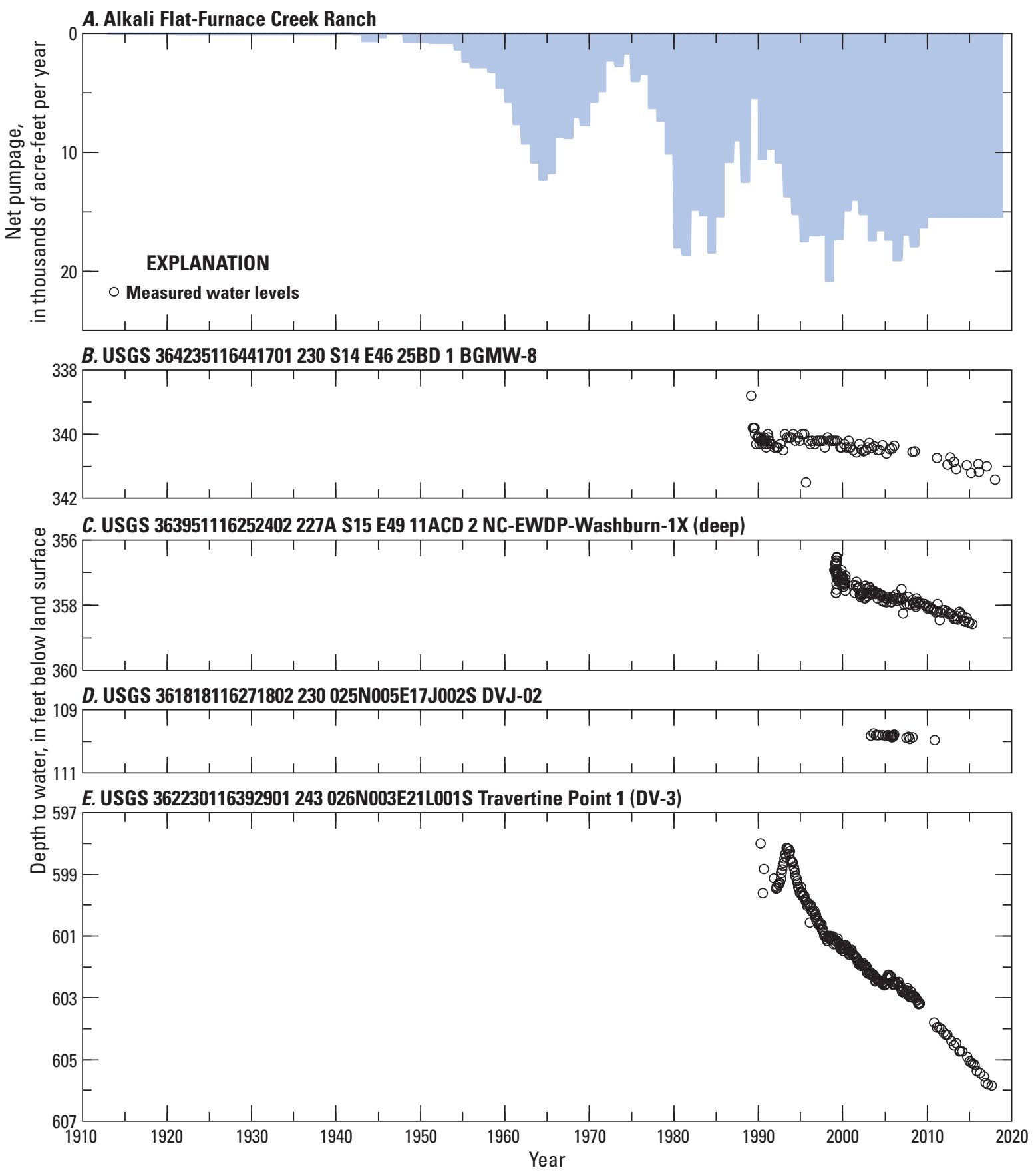

Figure 34. Net pumpage in the Alkali Flat-Furnace Creek Ranch groundwater basin $(A)$, and hydrographs showing measured water levels in wells BGMW-8 (B), NC-EWDP-Washburn-1X(deep) (C), DVJ-02 (D), and Travertine Point 1 (E), in the central Amargosa Desert, Nevada and California, 1910-2018. 

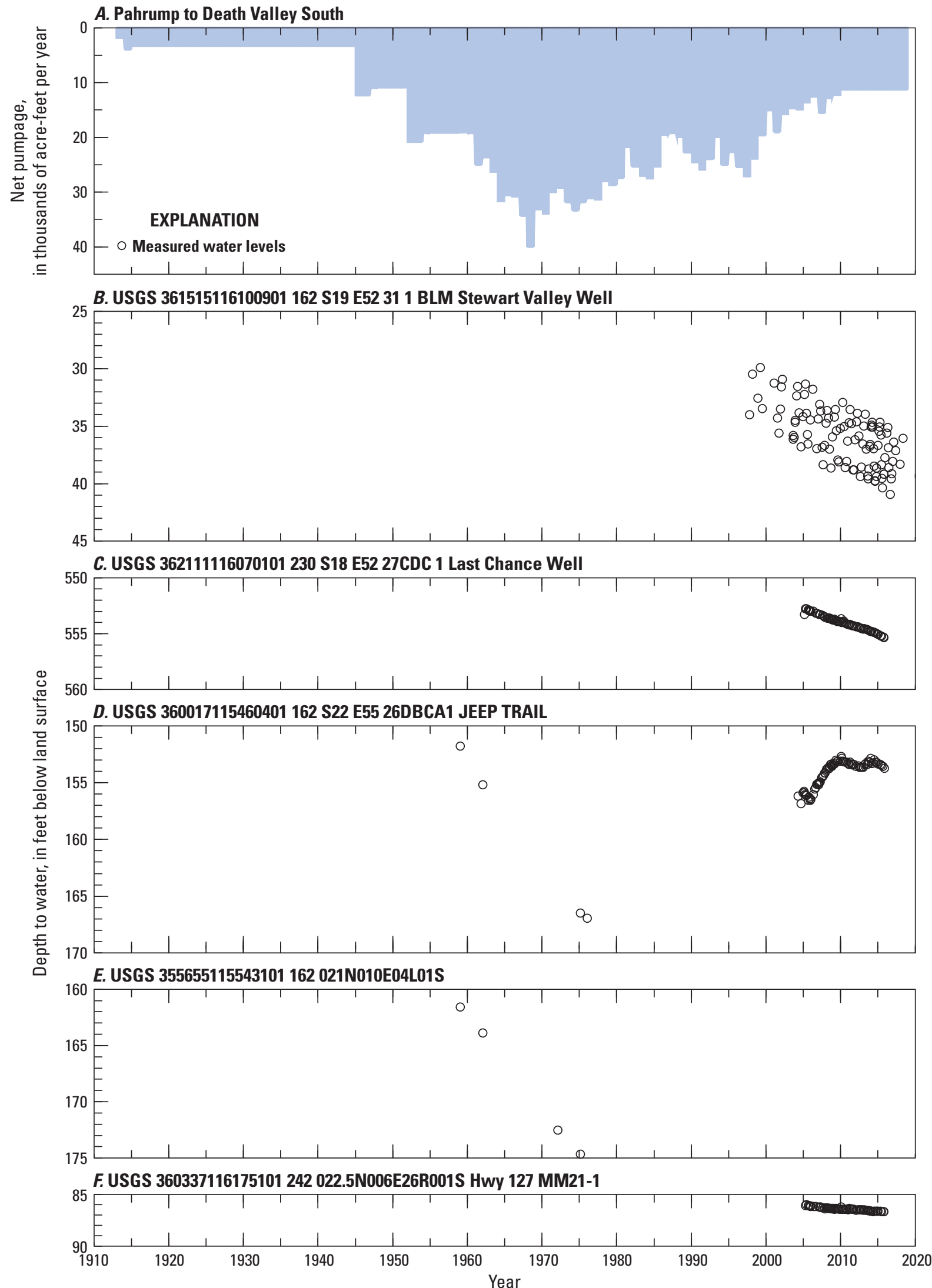

Figure 35. Net pumpage in the Pahrump to Death Valley South groundwater basin $(A)$, and hydrographs showing measured water levels in wells BLM Stewart Valley Well (B), Last Chance Well (C), Jeep Trail (D), 021N010E04L01S (E), and Hwy 127 MM21-1 (F), around Pahrump Valley, Nevada and California, 1910-2018. 


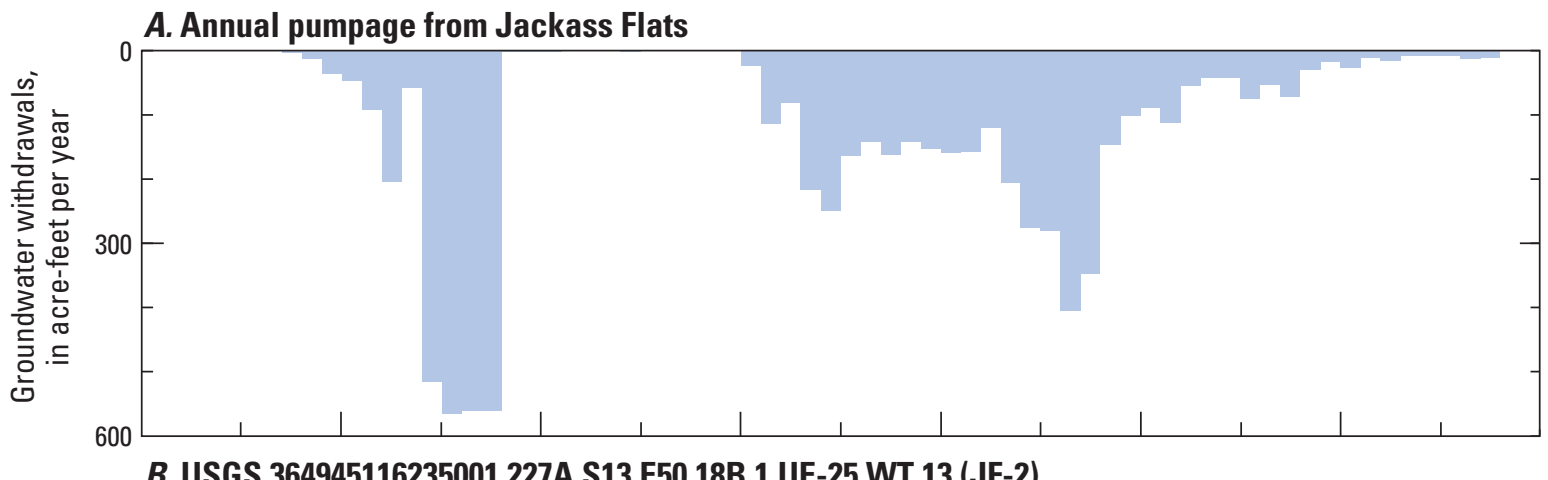

B. USGS 364945116235001 227A S13 E50 18B 1 UE-25 WT 13 (JF-2)
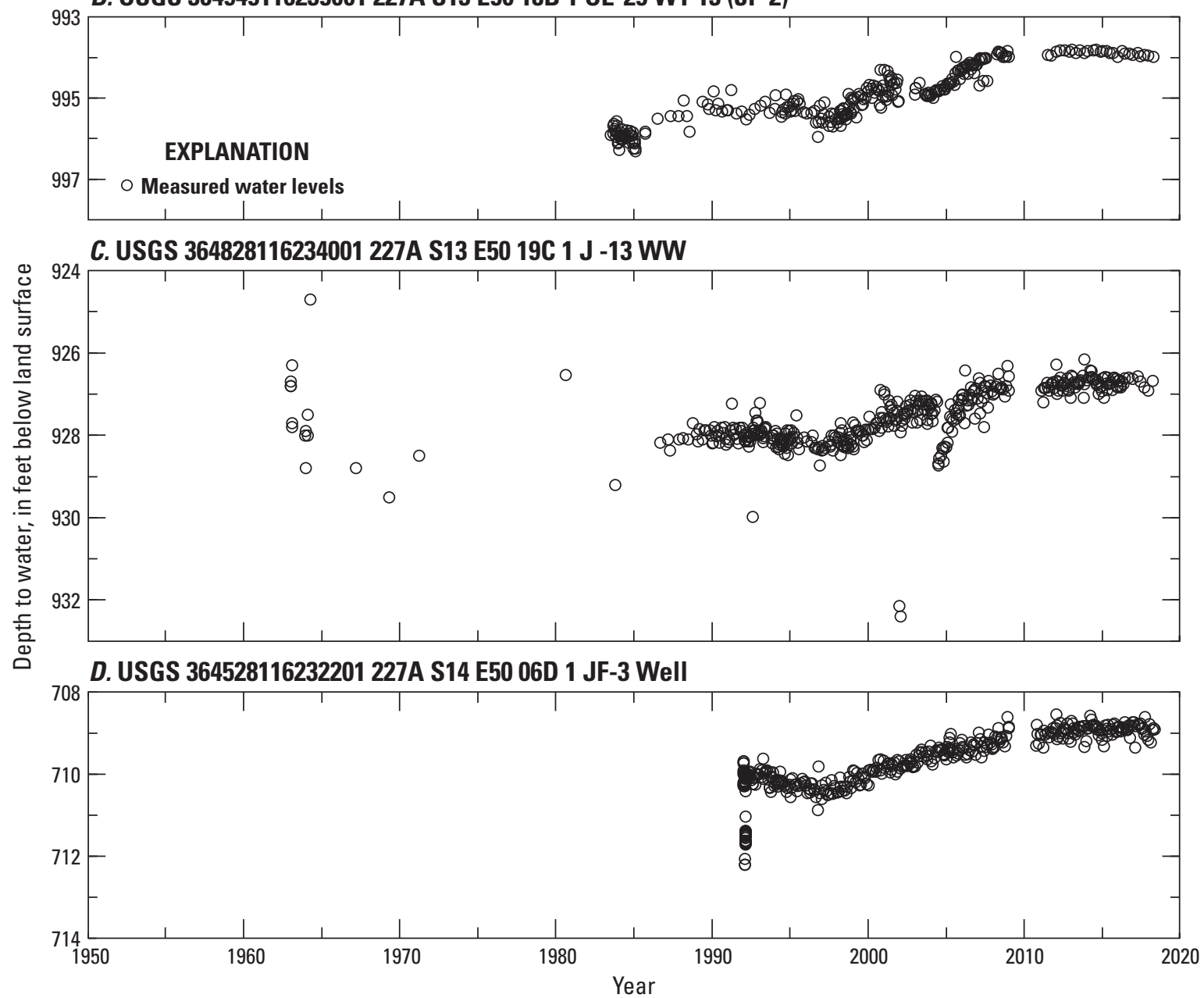

Figure 36. Annual pumping from Jackass Flats $(A)$, and hydrographs showing measured water levels in wells JF-2 $(B), J-13 W W(C)$, and JF-3 $(D)$, in Jackass Flats, Nevada, 1950-2018. 
Differences in recovery rates would be exaggerated further by heterogeneous transmissivities as occurs beneath Jackass Flats, where aquifer-test results yield transmissivity estimates that ranged from 2,400 to $200,000 \mathrm{ft}^{2} / \mathrm{d}$ (U.S. Geological Survey, 2018b).

\section{Isolated Areas of Groundwater Development}

Isolated areas of groundwater development occur in Indian Springs, Frenchman Flat, B uckboard M esa, CP basin, south of Bullfrog Hills, B eatty, Emigrant Valley, and the F urnace Creek area (fig. 32). Water-level declines in these areas were observed primarily in the pumped wells and at distances less than $6 \mathrm{mi}$ from a pumping well. Indian Springs is the earliest isolated area, developed in 1942, and pumping averaged 600 acre-ft/yr from 1942 to 2010. Groundwater development began in Frenchman Flat, Buckboard Mesa, and CP basin in 1951, 1963, and 1981, respectively, as water supplies for the NNSS. Pumping averaged 470, 120, and 210 acre-ft/yr from F renchman Flat, B uckboard M esa, and CP basin, respectively, from the start of development to 2010 . Pumping rates averaged 1,600 acre-ft/yr south of Bullfrog Hills between 1990 and 2000 as the B arrick Bullfrog mine (fig. 32) was dewatered. Pumping averaged 2,600 acre-ft/ yr during 1963-2010 from six B eatty Water and Sanitation District wells, which supply water for the town of B eatty. Pumping averaged 3,900 acre-ft/yr from four water-supply wells in Emigrant Valley from 1955-2010. G roundwater in the Furnace Creek area was developed during 2009 for public supply, where pumping averaged $330 \mathrm{acre}-\mathrm{ft} / \mathrm{yr}$ from 2009 to 2014.

\section{Ash Meadows and Devils Hole}

Effects of historic pumping from the Ash Meadows discharge area were notew orthy because pumping wells were within $5 \mathrm{mi}$ of Devils Hole (fig. 37). Groundwater was pumped from 1969 to 1982 by Cappaert Enterprises, which was Spring M eadows, Inc. prior to 1972 (Dudley and Larson, 1976). In this report, Spring M eadows, Inc. and Cappaert Enterprises pumping is jointly referred to as Cappaert Enterprises pumping. A total of 42,100 acre-ft were pumped over 14 years (Westenburg, 1993), which is less than 7 percent of the 630,000 acre-ft pumped between 1950 and 2010 from AFFCR and A sh M eadows groundwater basins (figs. 30 and 32). Water-level declines from pumping by Cappaert Enterprises immediately affected water levels in Devils Hole and recovery from this local pumping has persisted for two decades (Williams and others, 1996). Groundwater levels declined $2.3 \mathrm{ft}$ in Devils Hole (fig. 4). This would seem like a minor change relative to declines of more than $50 \mathrm{ft}$ in other pumping centers (fig. 33) except that, prior to pumping in
1969 , less than $2.5 \mathrm{ft}$ of water covered the shelf where Devils Hole pupfish feed and reproduce (Dudley and Larson, 1976). Water covered only 15 percent of the shelf when water levels were lowest in Devils Hole during J une of 1972 (Dudley and Larson, 1976).

Water levels in Devils Hole were affected by nine nearby pumping wells and one injection well (fig. 37). Pumping from individual wells uniquely affected Devils Hole depending on locations and pumping rates, which were measured frequently from 1969 to 1982. Electric-power consumption was measured to estimate pumping volumes. Pumped volumes and electricpower consumption were correlated for each well, where multipliers ranged from 0.0023 to $0.0041 \mathrm{acre}$-ft/kilowatt-hour (Westenburg, 1993). Pumping rates principally were estimates of pumped volumes divided by elapsed times between site visits. Electric-power consumption was measured during site visits more than 10 times per month from March to July of 1971, but most measurements between 1969 and 1982 were monthly (fig. 38). M ore than 90 percent of the pumpage was from southern wells within 1 mi of Point of Rocks Spring (fig. 37). M onthly pumping rates from all pumping wells ranged from $400 \mathrm{gal} / \mathrm{min}\left(0.8 \mathrm{ft}^{3} / \mathrm{s}\right)$ in the winter to $7,500 \mathrm{gal} /$ $\min \left(16.8 \mathrm{ft}^{3} / \mathrm{s}\right)$ in the summer (fig. 38).

Groundwater levels and spring discharges were monitored intensively in the Ash Meadows discharge area in response to declining water levels in Devils Hole during the 1970s (Dudley and Larson, 1976). Water levels in Devils Hole have been measured regularly from an established reference point since 1962 but little else was monitored until 1970. Water levels in Devils Hole declined about $0.1 \mathrm{ft}$ during 1968 and at a rate of $0.7 \mathrm{ft} / \mathrm{yr}$ during 1969, 1970, and 1971 (fig. 4). Monitoring of water levels in wells and discharges from a few springs began in 1970; however, intensive monitoring of most springs and wells in the A sh M eadows discharge area occurred during 1971 and 1972 (Dudley and Larson, 1976). Water levels in wells Spring Meadows 7db2 and Point of Rocks North (AM-6), near Point of Rocks Spring (fig. 37), had maximum declines of 20 and $50 \mathrm{ft}$, respectively, during the summer from 1970 to 1977 (fig. 39). Water levels in pumping wells near Point of Rocks Spring al so likely had similar trends to pumping well Point of Rocks North (AM-6). Persistent recovery was observed in most wells between 1978 and 2000.

\section{Stresses Affecting Water Levels in Devils Hole}

Pumping by Cappaert Enterprises was the principal stress that affected water levels in Devils Hole, but not the only stress. Local injection, regional pumping, and natural water-level fluctuations measurably changed water levels in Devils Hole during the 1970s. R egional pumping and natural water-level fluctuations were dominant effects after 1990. All stresses must be considered to correctly explain measured water-level changes in Devils Hole. 


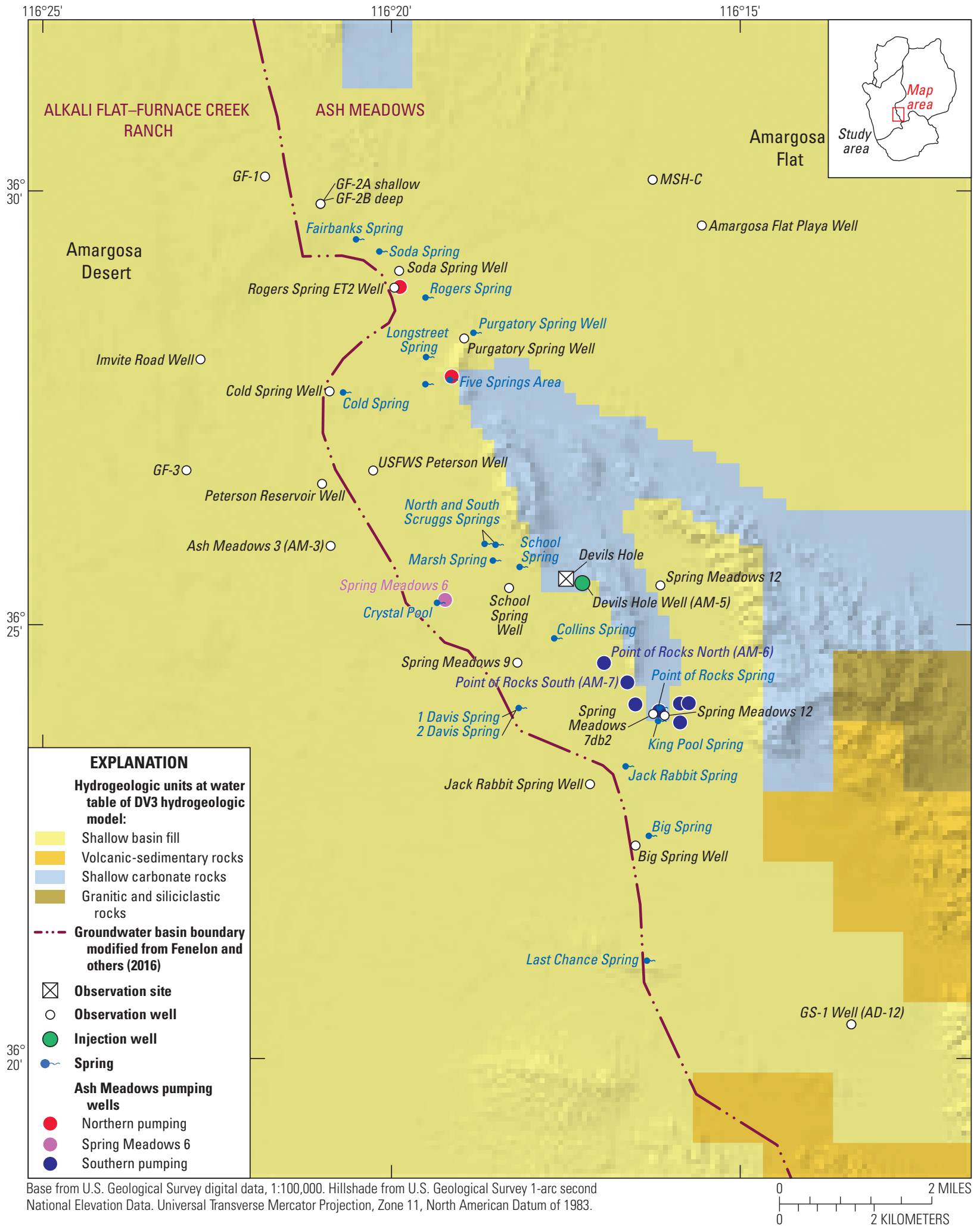

Figure 37. Hydrogeologic units at the water table, wells, Devils Hole, springs, pumping wells, and injection well [Devils Hole Well (AM-5)] in the Ash Meadows discharge area and surrounding areas, Nevada. DV3, Death Valley version 3. 


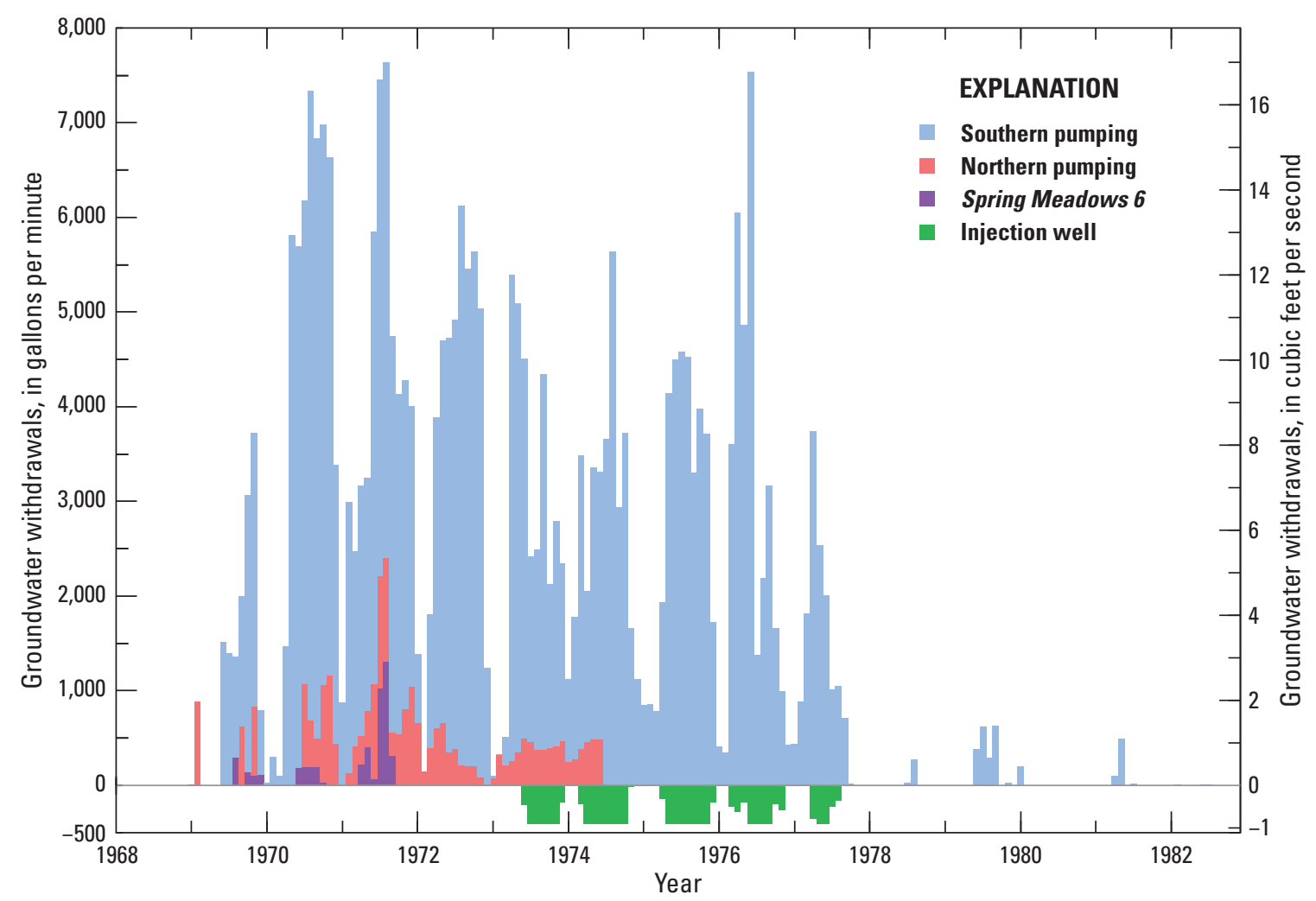

Figure 38. Monthly pumping from northern wells, southern wells, and Spring Meadows 6 well and injection into Devils Hole Well (AM-5) by Cappaert Enterprises in the Ash Meadows discharge area, Nevada, 1968-82.

Water was injected into Devils Hole Well (AM-5) to mitigate declines in Devils Hole from pumping by Cappaert Enterprises during the peak irrigation season (fig. 38). Devils Hole Well (AM-5) is $900 \mathrm{ft}$ east of Devils Hole (fig. 37).

Injection began in June 1973 and continued seasonally through 1977 (fig. 38). The source of injected water was spring discharge diverted from King Pool Spring that would not have readily returned to the groundwater system otherwise. A single injection rate of $400 \mathrm{gal} / \mathrm{min}$ was reported during summer 1973 (Larson, 1974a), which caused water levels to rise $20 \mathrm{ft}$ in Devils Hole Well (AM-5) (fig. 39). Water levels rose between 30 and $40 \mathrm{ft}$ during injection periods from 1974 to 1977 (fig. 39). The increase in water-level rises from $20 \mathrm{ft}$ to betw een 30 and $40 \mathrm{ft}$ were attributed to "... partial plugging of the perforations in the well by algae, air entrainment, or physical change in the well" (Larson, 1975).

Water levels in Devils Hole fluctuate naturally in response to Earth tides, barometric-pressure changes, earthquakes, and episodic recharge. Water levels fluctuate less than $0.4 \mathrm{ft}$ in response to short-term tidal and barometric stresses, where Earth tides are the dominant stress (Dudley and L arson, 1976, p. 11). The range of short-term Earth tidal fluctuations can be observed with less than a month of continuous water-level measurements. Seismic waves from nuclear detonations and earthquakes have perturbed water levels in Devils Hole, but effects typically dissipate in less than a few hours (Dudley and Larson, 1976). Coseismic water-level responses to crustal deformation can persist for years, but ultimately dissipate (Cutillo and Ge, 2006). L anders/L ittle Skull M ountain and Hector Mine earthquakes initially displaced water levels in Devils Hole by 0.4 and $0.1 \mathrm{ft}$, respectively (Cutillo and $\mathrm{Ge}, 2006$ ). Episodic recharge caused long-term water-level fluctuations in Devils Hole. Cycles of long-term fluctuations exceed 120 years, where multiple-decade periods of declining or rising water levels are the result of dry or wet periods (fig. 17). 


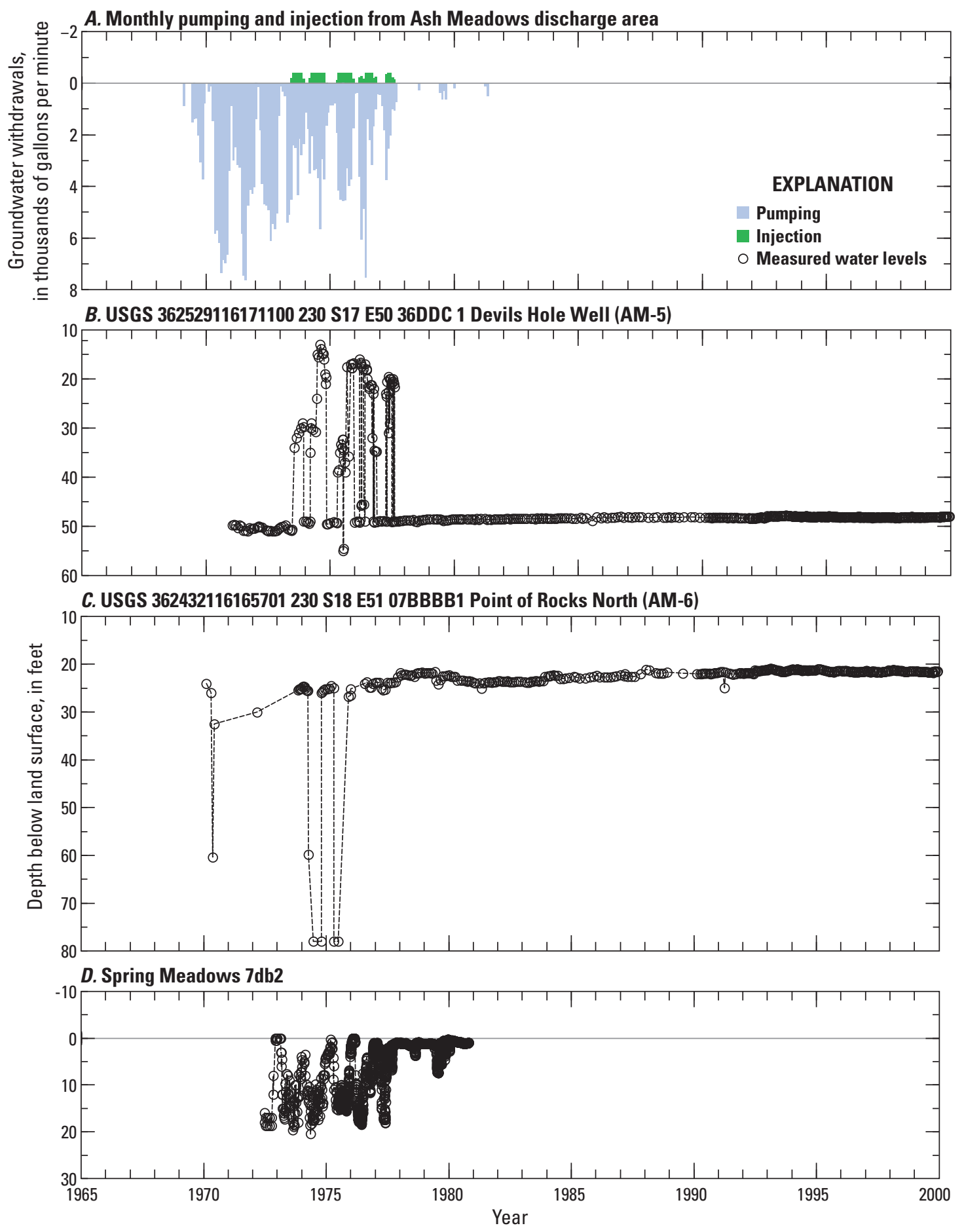

Figure 39. Monthly pumping and injection from the Ash Meadows discharge area $(A)$, and hydrographs showing measured water levels in wells Devils Hole Well $(A M-5)(B)$, Point of Rocks North $(A M-6)(C)$, and Spring Meadows $7 \mathrm{db} 2(D)$, during groundwater development by Cappaert Enterprises, Nevada, 1965-2000. 


\section{Devils Hole Water-Level Model}

Water levels in Devils Hole were simulated with a water-level model in this study (Jackson and Halford, 2020) so that natural water-level fluctuations could be estimated and differentiated from pumping effects (fig. 40). Waterlevel changes in Devils Hole from natural fluctuations must be explained in addition to changes from pumping. This is because the U.S Supreme Court (Cappaert v. United States) mandated a minimum pool elevation of $2.7 \mathrm{ft}$ below the reference point, whether or not water-level changes are due solely to pumping (Williams and others, 1996). Timevarying natural fluctuations were estimated with the waterlevel model and subtracted from water-level measurements in Devils Hole to obtain a Devils Hole hydrograph affected by pumping only for calibration of numerical groundwater models. Groundwater models were used to differentiate effects from different pumping centers on water levels in Devils Hole. Long-term natural fluctuations were removed because groundwater models in this study do not simulate time-varying recharge or earthquakes.

Natural fluctuations simulated include Earth tides, earthquakes, episodic recharge, and steady discharge. L anders/ Little Skull M ountain and Hector M ine earthquakes were simulated because displacement and dissipation affected water levels for multiple years (Cutillo and Ge, 2006). Recharge was simulated using winter precipitation (October- $M$ arch) in excess of 6 in. from the south-central Nevada precipitation index (fig. 17) and natural discharge from springs and phreatophytes was assumed steady. In this report, longterm natural fluctuations refer to water-level fluctuations in response to time-varying recharge and steady discharge.

The assumption of steady natural discharge is violated near Devils Hole, but does not affect water-level model results. Spring discharge was not steady during pumping by Cappaert Enterprises (Dudley and Larson, 1976). Spring capture and pumping by Cappaert Enterprises were correlated highly for monthly pumping estimates. Net effects of pumping by Cappaert Enterprises and spring capture were estimated in the analytical model of water levels in Devils Hole.

Effects from injection into Devils Hole Well (AM-5), local pumping, and regional pumping were approximated with Theis transforms (Halford and others, 2012). Combined pumping effects were estimated and cannot be attributed to individual pumping wells or pumping centers because of correlation between Theis transforms.

Pumping from the AFFCR groundwater basin and NNSS wells in carbonate rocks (figs. 29 and 39) was a regional stress that affected water levels in Devils Hole. Effects of pumping more than 600,000 acre-ft from the AFFCR groundwater basin are attenuated in the $A$ sh $M$ eadows groundwater basin because a relatively small corridor near well $A D-4$ (fig. 32) connects the two basins (Claassen, 1985 p. F19; Fenelon and others, 2016, p. 6). Pumping from NNSS wells Army 1 $W W$, ER-6-1-2 main, WW-2 (3422 ft), WW-C (1373-1701 ft), $W W-C$ (recompleted), and $W W-C-1$ (fig. 32) totaled 18,000 acre-ft and likely affected water levels in Devils Hole. This is because these NNSS wells pump water from carbonate rocks near a confined transmissive feature, the megachannel (fig. 32; Winograd and Pearson, 1976). Pumping from Indian Springs also likely affected water levels in Devils Hole, but effects of pumping from NNSS and Indian Springs cannot be differentiated with an analytical water-level model (Bedinger and Harrill, 2006).

Episodic recharge had to exceed steady discharge to explain annually averaged water levels rising $0.43 \mathrm{ft}$ in Devils Hole from 2005-2015 (fig. 40). Water levels in Devils Hole declined between 1990 and 2005 as regional pumping from AFFCR and A sh M eadows groundw ater basins increased (fig. 30). Nevada Division of Water Resources inventories of pumpage from the A margosa Desert hydrographic area show less than 2 percent change during 2006- 10 and 2011-15. B ecause regional pumping changed little from 2005-2015, water levels in Devils Hole would have stabilized or declined after 2005 in the absence of episodic recharge events. Recharge exceeding steady discharge after 2005 is consistent with ubiquitous rising water levels throughout the study area (Fenelon and Moreo, 2002; Elliott and Fenelon, 2010; Fenelon and others, 2012; Jackson and Fenelon, 2018).

Estimated long-term natural fluctuations suggest that water levels in Devils Hole would have risen about $1 \mathrm{ft}$ from 1973-2018 in the absence of pumping and injection (fig. 40). Water-level rise estimates are interpretative because pumpingrecovery effects and recharge are correlated. Rises from recharge of as much as $2.7 \mathrm{ft}$ from 1973-2018 were estimated with alternative water-level models of Devils Hole. Estimated rises greater than $1 \mathrm{ft}$ were rejected because comparable water-level rises in distant wells bounded estimates in Devils Hole. Proximity to discharge locations subdues water-level fluctuations and Devils Hole is within 1-5 mi of all major springs in the A sh M eadows groundwater basin (fig. 37). Estimated rises between 1973 and 2018 in wells $U$-19bk and USFWS DR-1 were 2 and $5 \mathrm{ft}$, respectively (fig. 18). These wells are 20 and $50 \mathrm{mi}$ from their respective discharge areas (fig. 16) and are not affected by pumping. Natural water-level fluctuations from recharge in Devils Hole should be less than in wells far removed from discharge areas such as wells U-19bk and USFWS DR-1. 

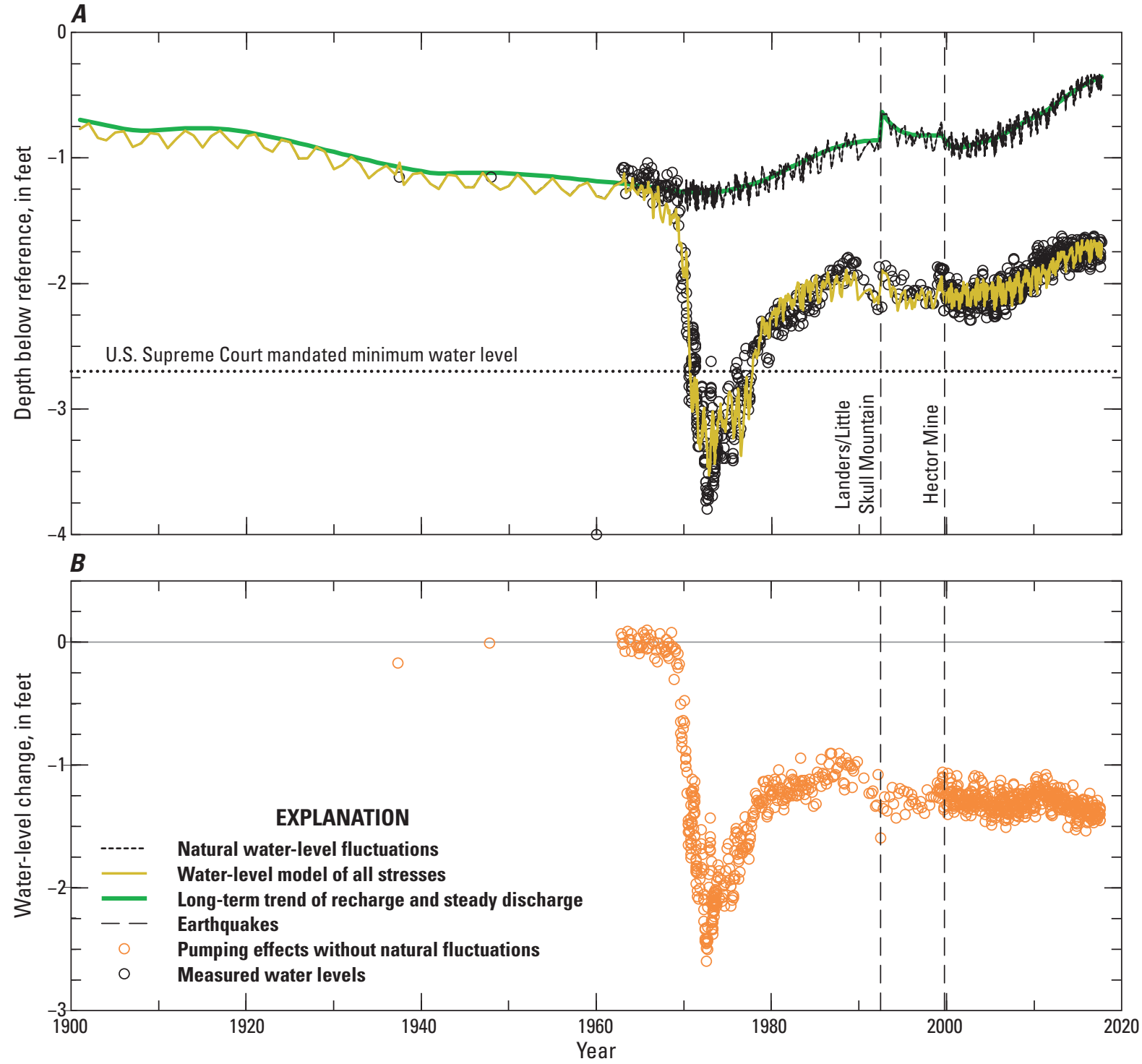

Figure 40. Estimated natural water-level fluctuations (includes short-term and long-term natural stresses), long-term natural trend of recharge and steady discharge, measured water levels, water-level model that includes all natural and pumping stresses, and pumping effects without natural fluctuations in Devils Hole, Nevada, 1900-2018. 


\section{Integrated Estimation of Recharge and Hydraulic-Property Distributions with Numerical Models}

Recharge and hydraulic-property distributions were estimated by simultaneously calibrating four, threedimensional, numerical groundwater models of the study area. When the four models are coupled, the integrated model is referred to as the DV 3 model. M ultiple models with identical spatial extents were constructed to simulate and differentiate the effects of predevelopment flow; changes from groundwater development (two models); and changes from a large-scale, multiple-well aquifer test (MWAT; table 2). Interpretation of measured stress-response pairs with separate models introduced fewer errors than simulation of all responses with a single generalized model. This was because boundary conditions could be better constrained to known stresses and corresponding simulated responses could be compared to appropriate observations. For example, discharge from Big Spring averaged $2.4 \mathrm{ft}^{3} / \mathrm{s}$ prior to development, with a pool altitude of 2,240 ft. M ultiple models allowed simulation of Big Spring as a specified discharge of $2.4 \mathrm{ft}^{3} / \mathrm{s}$ prior to development and as a head-dependent boundary during groundwater development. This prevented misfits between simulated and measured pool altitudes from affecting simulated capture during groundwater development.

Groundwater-flow equations were solved using the USGS finite-difference model, MODFLOW (Harbaugh, 2005). The four coupled (stress-response) groundwater models were calibrated simultaneously using the Parameter ESTimation code (PEST; Doherty, 2010a). Archives of the integrated DV3 model containing executables, PEST calibration files, stressresponse models, and utilities for drawing maps are available in J ackson and $\mathrm{H}$ alford (2020).

\section{Common Construction of Models}

All groundwater models that were developed for the DV3 project shared a common domain, gridding, hydrogeologic framework, and hydraulic properties. M odel domains extended laterally to the edges of the study area (fig. 41). Each model was divided areally into 268 rows of 221 columns of variably spaced, rectangular cells that ranged from $820 \mathrm{ft}(250 \mathrm{~m})$ to $4,920 \mathrm{ft}(1,500 \mathrm{~m})$ on a side. Furnace Creek area, Devils Hole area, Rainier Mesa, and Yucca Flat were areas of finer discretization (fig. 41). The model grid is oriented north-south in Universal Transverse Mercator (UTM), zone 11, North American Datum of 1983 (NAD 83) projection, and the X and $Y$ coordinates of the northwest corner are 494,000 and $4,175,500 \mathrm{~m}$, respectively.
All groundwater model grids were divided into six layers and coincided with the grid of the hydrogeologic framework, which extended vertically from the water table to $3,300 \mathrm{ft}$ $(1,000 \mathrm{~m})$ below the National Geodetic Vertical Datum of 1929 (NGVD29) (fig. 26). L ayer 1 of the groundwater models was 1 -ft thick to better simulate groundwater/surface-water interaction and drainage at the water table. Groundwater model layers 2-6 coincided with hydrogeologic framework layers 1-5. Hydrogeologic units in groundwater model layers 1 and 2 were identical. Tops of layers 3-6 nominally occurred at depths of $164,330,800$, and $1,600 \mathrm{ft}(50,100,250$, and $500 \mathrm{~m}$ ) below the water table or followed contacts between hydrogeologic units where well control was sufficient (fig. 26). The bottom of layer 6 extended to $3,300 \mathrm{ft}(1,000 \mathrm{~m})$ below NGVD29.

Saturated thicknesses of all model layers were specified and did not change in response to simulated pumping. Therefore, the simulated water table does not deform or move through layers. This approach was adopted because models with specified thicknesses converge and execute quickly compared to models that simulate transmissivity as a function of head (Sheets and others, 2015). The central Amargosa Desert and Pahrump Valley were the only areas where this approach could be questioned, with maximum declines of 50 and $100 \mathrm{ft}$, respectively (fig. 33). M aximum change in saturated thickness was less than 30 percent of model cell thicknesses, which affects simulated drawdowns less than 20 percent (Sheets and others, 2015).

\section{Distributing Hydraulic Properties And Recharge}

H eterogeneous hydraulic-property (and recharge) distributions were estimated with PEST using pilot points. Hydraulic-property values of hydraulic conductivity, specific yield, and specific storage were estimated at pilot points (RamaR ao and others, 1995), where the locations of pilot points were user-specified. In this study, more pilot points occurred in areas where more data are available to constrain hydraulic-property estimates. Estimated hydraulic-property values at user-specified locations were translated into continuous hydraulic-property fields by interpolation with kriging using variograms (Doherty, 2010b).

Isotropic, exponential variograms defined spatial variability of log-hydraulic properties, where spatial correlation was specified with user-defined ranges (distances). Spatial correlation is assumed non-existent where distances between the interpolated location (cell center) and known value (pilot point) exceed the range. A hydraulic-property value at a cell functionally was an inverse-distance weighted average of the eight nearest pilot-point values if all distances betw een cell center and pilot points were less than the range. A hydraulic-property value at a cell is a simple average if distances between a cell center and the eight nearest pilot points all exceed the range. 


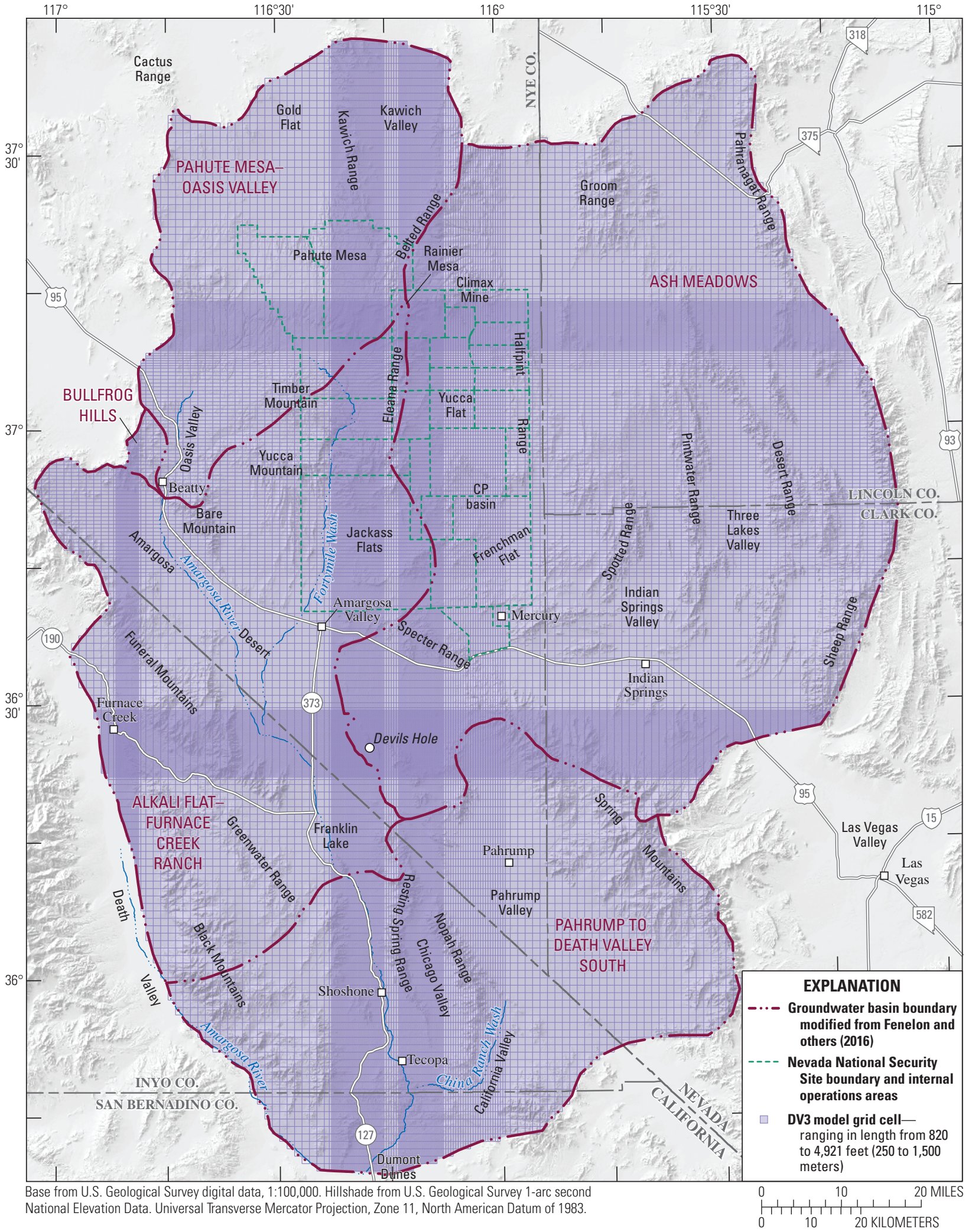

Figure 41. Boundary of Death Valley version 3 (DV3) model and areas of finer discretization, in the study area, Nevada and California. 
Interpolated hydraulic properties varied laterally but were uniform with depth in multiple-layer hydrogeologic units. For example, consider the distribution of hydraulic-conductivity values within a hypothetical framework consisting of basin fill, volcanic rocks, and carbonate rocks (fig. 42). The thickness of carbonate rocks varies with depth but is collapsed into a two-dimensional array of the laterally mapped extent (fig. 42). In this study, each hydrogeologic unit is a unique zone in MODFLOW and the pilot points were grouped by zone. This means that only pilot points within the hydrogeologic unit (zone) were used in the interpolation of hydraulic-property values at model cells within the hydrogeologic unit. The hypothetical carbonate rocks (fig. 42) have three pilot points that only are used in the lateral interpolation of hydraulic conductivities within the carbonate rocks. The estimated hydraulic-conductivity values at each lateral $(\mathrm{X}, \mathrm{Y})$ location in the carbonate rocks are assigned to all model layers where the carbonate rocks occur. Therefore, hydraulic properties are estimated at pilot points, interpolated lateral ly within each hydrogeologic unit, and then assigned the same value for all layers where the hydrogeologic unit occurs. $M$ ap extents of hydrogeologic units and pilot points for each hydrogeologic unit are provided as spatial coverages in Jackson and Halford (2020).

Hydraulic properties are assumed to be laterally and vertically isotropic because of practical limitations. Outcrops clearly indicate that bedding occurs at every conceivable dip and orientation (Sweetkind and others, 2010). Flow logs (Garcia and others, 2010) and packer tests (Frus and Halford, 2018) show extreme anisotropy or heterogeneity across intervals of less than $200 \mathrm{ft}$. None of these details are indicated in the hydrogeologic units, which are featurel ess groups of rocks. Heterogeneity is simulated entirely by contrasts in hydraulic properties within and between hydrogeologic units. L ateral contrasts were simulated by adding pilot points to hydrogeologic units, where greater pilot-point density allows for increased heterogeneity. Vertical contrasts were simulated exclusively by differences in hydraulic properties between hydrogeologic units as occurred beneath Rainier M esa (fig. 26). Basin fill in Amargosa Desert and Pahrump Valley was differentiated with depth by subdividing basin fill into three units (table 7) to simulate water table (unconfined) and confined conditions. Heterogeneity and anisotropy are correlated, where large degrees of anisotropy can be simulated with large contrasts in hydraulic properties.

\section{Hydraulic Conductivity}

Hydraulic conductivities and layer thicknesses define simulated transmissivities and were assigned with the Layer-Property Flow package in M ODFL OW (Harbaugh, 2005). Heterogeneous hydraulic-conductivity distributions were estimated for each hydrogeologic unit. Hydraulic conductivities are estimable at pilot points in areas where data exist because the parameters are sensitive to and informed by the data. However, in areas where no data exist, hydraulicconductivity estimates were constrained by conceptual transmissivity distributions. A conceptual transmissivity distribution was estimated for each hydrogeologic unit from aquifer-test results. Hydraulic conductivities for a hydrogeologic unit initially were conceptual transmissivities divided by model thicknesses of a hydrogeologic unit. For example, broad areas of uniform transmissivity were postulated for shallow carbonate rocks to provide initial hydraulic conductivities for this hydrogeologic unit (fig. 43).

Hydraulic conductivities were distributed with pilot points so that observed spatial variability could be simulated in hydrogeologic units (fig. 21). I sotropic, exponential variograms were used to define spatial variability of loghydraulic conductivities with ranges of 1.5-9 mi. Ranges of variograms were less than $3 \mathrm{mi}$ in areas of high pilot-point densities (fig. 44) so that interpolated hydraulic conductivities could vary more. Distributed hydraulic conductivities in hydrogeologic units were mapped to the hydrogeologic framework and parsed to a two-dimensional array for each model layer (fig. 42). All groundwater models used the same arrays of hydraulic conductivity.

Hydraulic conductivities were specified with 2,476 pilot points and pilot-point density increased in areas where waterlevel measurements, spring discharges, and transmissivity estimates were more prevalent (fig. 44). Pahute M esa, Rainier M esa, Y ucca Flat, central A margosa D esert, A sh M eadows discharge area, Furnace Creek area, and northern Pahrump Valley were areas with high data densities (figs. 19 and 29).

Pilot-point occurrence differed between model layers. Pilot-point occurrence at the water table adequately shows variations in pilot-point density, even though only 45 percent of pilot points occur at the water table (fig. 44). A dditional pilot points in deeper hydrogeologic units are not shown in figure 44. For example, shallow carbonate rocks are overlain by basin fill, volcanic rocks, and volcanic-sedimentary rocks in Yucca Flat and the A sh M eadows discharge area (figs. 43 and 44). Compared to other hydrogeologic units, more hydraulic data exist for these shallow carbonate rocks, which supports adding more pilot points because more data are available to inform hydraulic-conductivity estimates during model calibration. Hydraulic data include measured water levels in more than 100 wells, discharges and pool altitudes from 19 springs, water-level changes and spring captures from pumping by Cappaert Enterprises, and drawdowns from the well ER-6-1-2 main MWAT.

Hydraulic conductivities were specified at pilot points where knowledge of the mapped lithology constrained hydraulic-conductivity estimates despite an absence of hydraulic data. For example, the floor of Death Valley is classified as basin fill in the hydrogeologic framework (fig. 44). The upper $1,000 \mathrm{ft}$ of sediments consist of alternating layers of salt and clay in boreholes north and south of the Furnace Creek area (Hunt and others, 1966, p. B 42). Hydraulic conductivities of salt and clay are variable, but generally do not exceed $0.0001 \mathrm{ft} / \mathrm{d}$ (J ackson and others, 2018). Representative hydraulic conductivities were assigned, not estimated, during model calibration. 


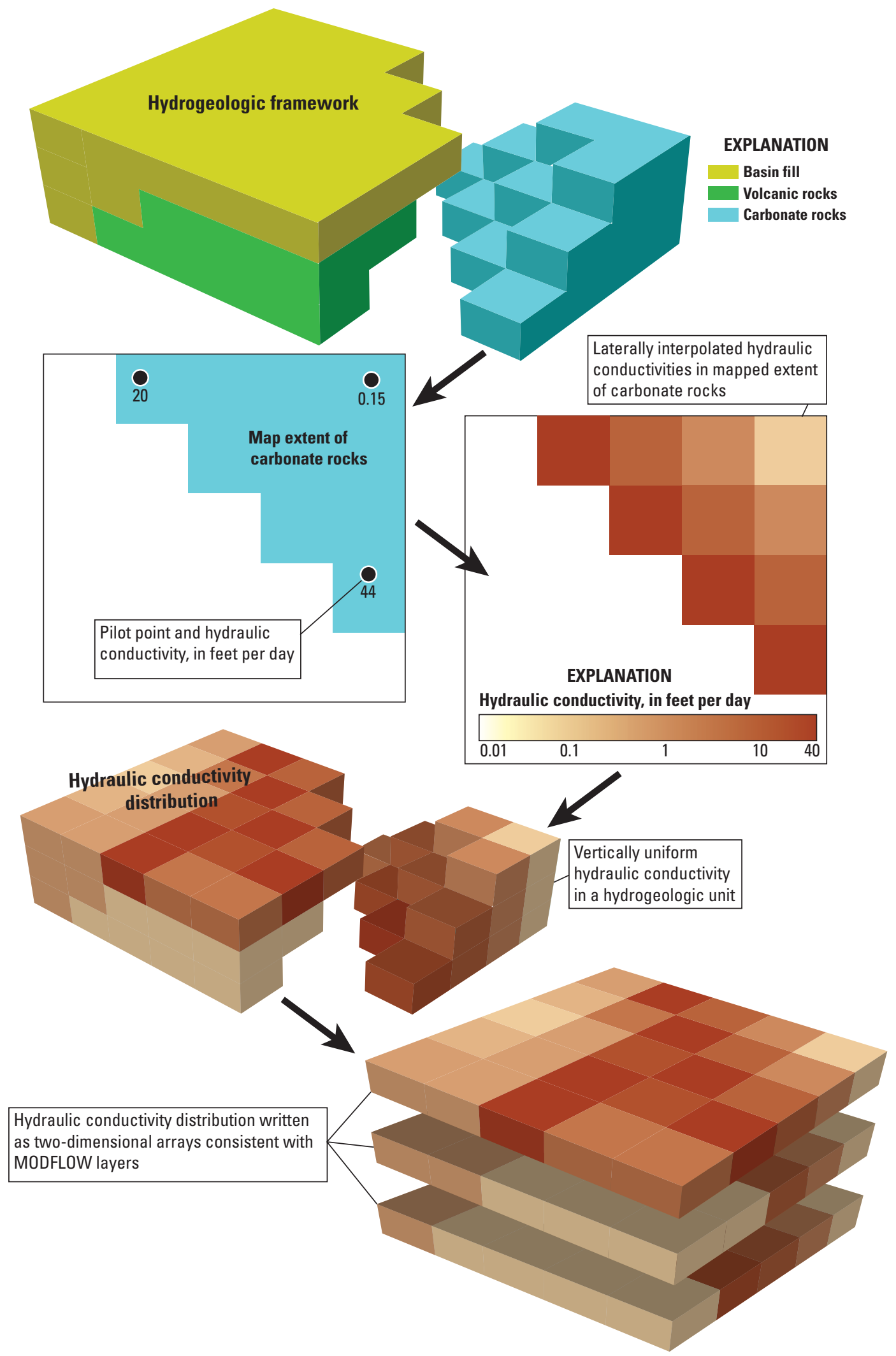

Figure 42. Process for distributing hydraulic conductivities from pilot points to U.S. Geological Survey finite-difference model (MODFLOW) layers through hydrogeologic units in a hydrogeologic framework. 


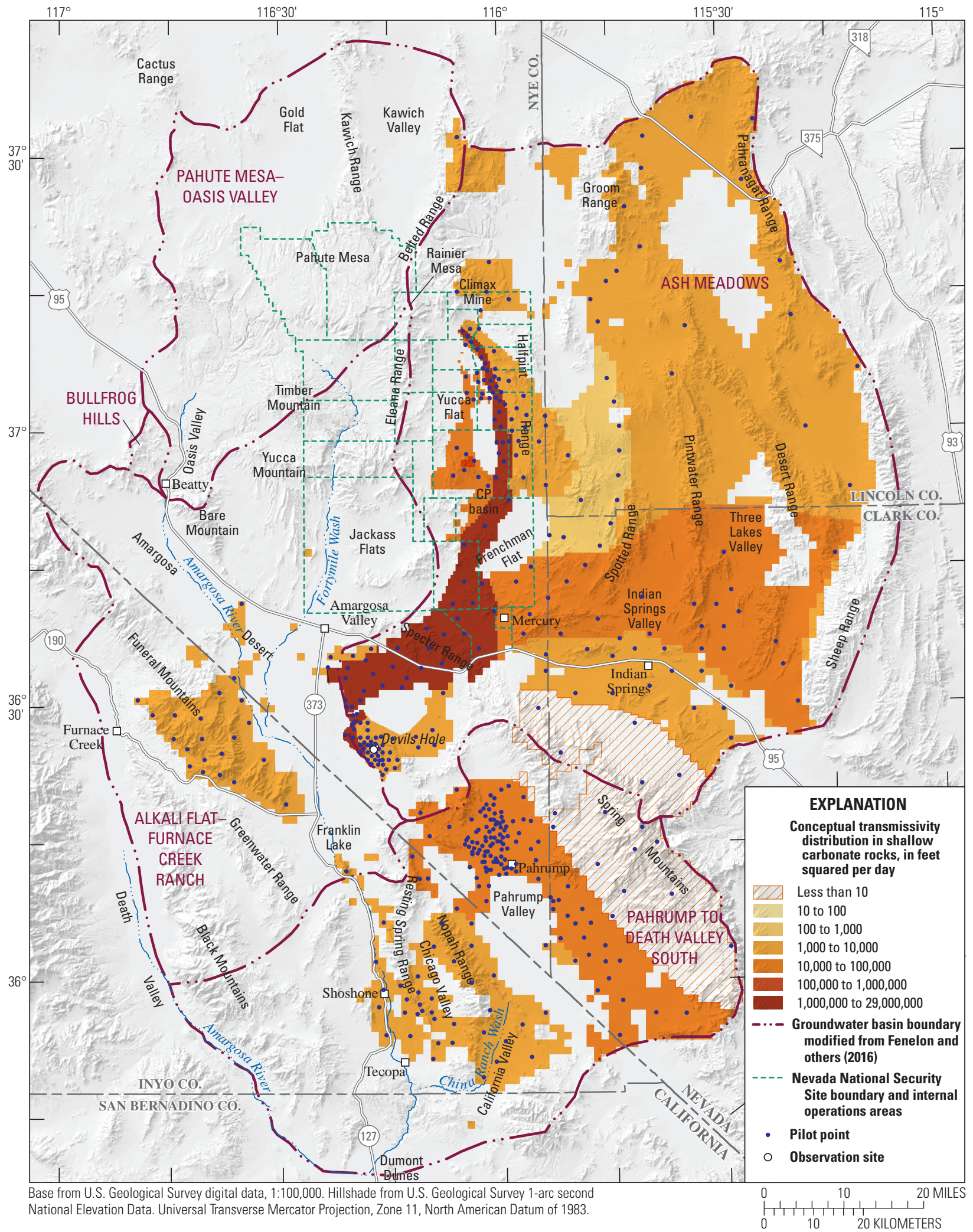

Figure 43. Conceptual transmissivity distribution in shallow carbonate rocks and hydraulic-conductivity pilot points for the shallow carbonate rocks, in the study area, Nevada and California. 


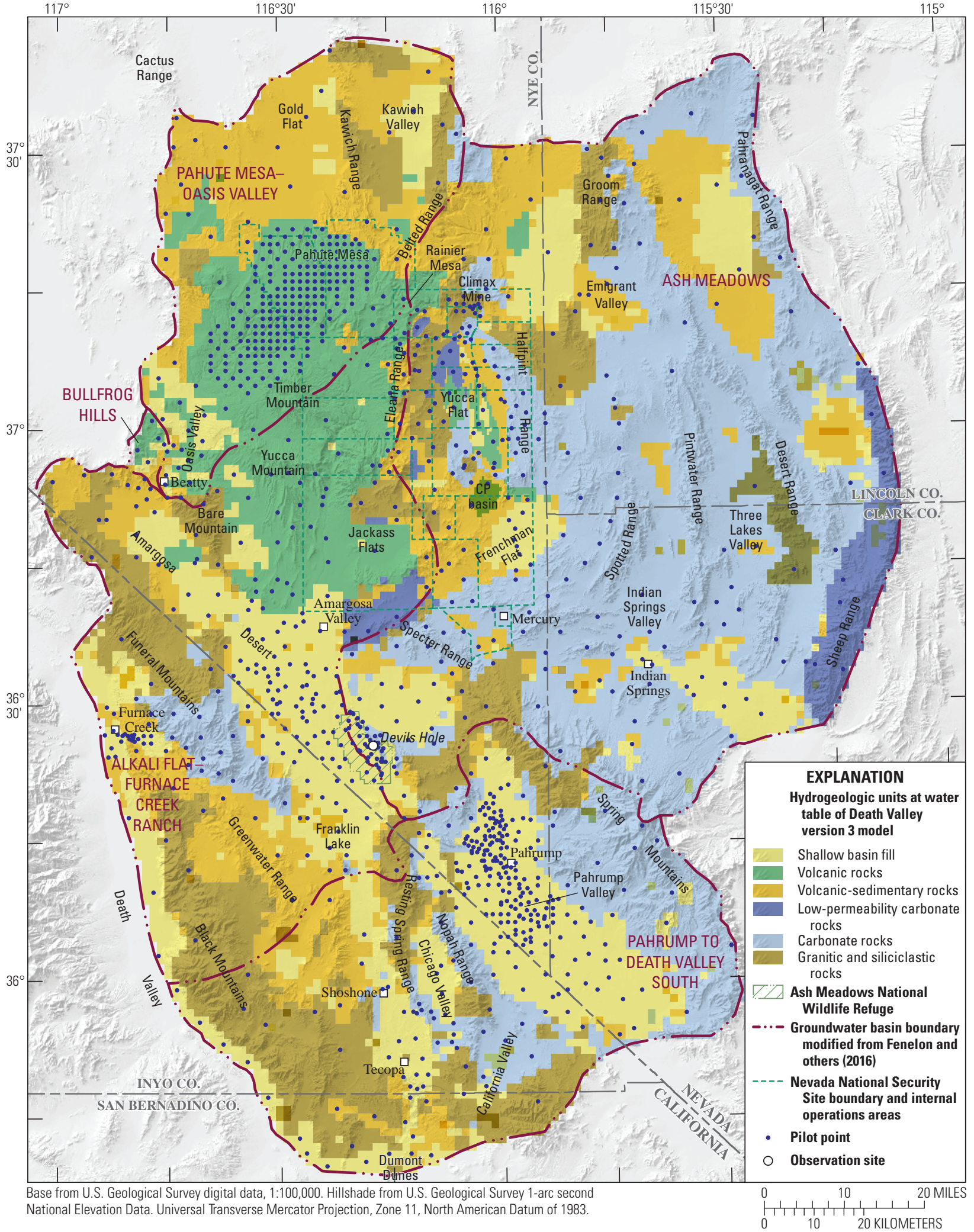

Figure 44. Extents of all hydrogeologic units and hydraulic-conductivity pilot points at the water table, in the study area, Nevada and California. 


\section{Specific Yield And Specific Storage}

Storativity distributions were estimated for hydrogeologic units by categorizing these units in the DV 3 hydrogeologic framework as either basin fill or consolidated rocks. The basin fill categorization includes basin fill and volcanicsedimentary rocks, whereas consolidated rocks consist of carbonate, volcanic, and low-permeability rocks (table 7). A simplified framework of basin fill and consolidated rocks was used because storativities are less variable than hydraulic conductivities. Storativity is specific yield plus specific storage times thickness. Specific yields typically range from 0.05 to 0.25 in basin fill and from 0.01 to 0.05 in consolidated rocks. Specific-storage values typically range from $1 \times 10^{-6}$ to $5 \times$ $10^{-6} \mathrm{l} / \mathrm{ft}$, regardless of hydrogeologic unit. Specific-yield and specific-storage values only were estimated (with PEST) in areas where saturated rocks were affected by pumping (fig. 29). In areas where aquifers were unaffected by pumping, specific yields of 0.1 and 0.02 were assigned to basin fill and consolidated rocks, respectively, and a specific-storage value of $2 \times 10^{-6} 1 / \mathrm{ft}$ was assigned.

Storativities were estimated (or assigned) using either specific yield or specific storage in MODFLOW layers. Storativities in layer 1 were interchangeable with specific yields because layer 1 is 1 - $\mathrm{ft}$ thick and specific storage is at least three orders of magnitude smaller than specific yield. Specific storages were used in layers $2-6$ and reported as storage coefficients, which is specific storage times thickness. Specific storages estimated (in pumping areas) and assigned (in nonpumping areas) were uniform with depth and independent of hydrogeologic units because specific storages range from $1 \times 10^{-6}$ to $5 \times 10^{-6} 1 / f t$ for all hydrogeologic units. For example, the estimated specific storage at an $(\mathrm{X}, \mathrm{Y})$ location is assigned to model layers 2-6 and the storage coefficient is computed by multiplying the specific storage by the total thickness of layers $2-6$. Therefore, the specificstorage distribution has lateral $(X, Y)$ heterogeneity where estimated, but is uniform with depth at each spatial $(X, Y)$ location.

Specific-storage values estimated with PEST ranged from $2 \times 10^{-9}$ to $1 \times 10^{-5} 1 / \mathrm{ft}$, which are beyond expected values of $1 \times 10^{-6}$ and $5 \times 10^{-6} 1 / \mathrm{ft}$. Extreme underestimation of specific storages likely compensated for overestimating contributing thicknesses of consolidated rocks. For example, if a 10-ft-thick unit with a specific storage of $2 \times 10^{-6} 1 / \mathrm{ft}$ was simulated incorrectly with a 1,000-ft-thick layer, then the correct storage coefficient would be simulated if a specific storage of $2 \times 10^{-8}$ $1 / \mathrm{ft}$ is estimated. Correction of hydrogeologic unit thicknesses was beyond the scope of this study.

Specific yields and specific storages were estimated with 420 pilot points so that spatial variability could be simulated in hydrogeologic units. Interpolated specific yields varied laterally within basin fill and consolidated rocks in model layer 1. Interpolated specific storages varied laterally in model layers 2- 6 but were uniform with depth. I sotropic, exponential variograms defined spatial variability of log-specific yields and log-specific storages with a range of $12 \mathrm{mi}$. Distributed specific yields and specific storages were mapped to the hydrogeologic framework and parsed to two-dimensional arrays for each M ODFLOW model layer as was done with hydraulic conductivities (fig. 42). All transient (pumping) groundwater models used the same array of specific yield and arrays of specific storages.

\section{Recharge}

Recharge was distributed throughout the steady-state model simulating predevelopment flow with a total of 521 pilot points (fig. 45). Recharge rates were estimated at pilot points with PEST, then interpolated from pilot points to model cells with kriging, similar to the interpolation method used for distributing hydraulic properties (D oherty, 2010b). Spatial variability of recharge was defined with an isotropic, exponential variogram, where nugget and range were 0 and $30,000 \mathrm{ft}$, respectively.

Recharge zones (fig. 16) were used for estimating heterogeneous recharge-rate distributions (fig. 45), similar to the hydrogeologic unit zones used for estimating heterogeneous hydraulic-property distributions. Recharge zones were delineated for runoff areas downgradient of low-permeability rocks, channels of the Amargosa River and Fortymile Wash, and other geographic areas (fig. 16). Recharge zones informed the objective function at sufficiently large scales that relative water availability was well defined between zones. For example, annual recharge volumes from the Spring Mountains greatly exceed annual recharge volumes from the Funeral Mountains. Annual recharge volumes to these zones are well defined relative to cell-by-cell estimates in the conceptual recharge distribution (fig. 16). 


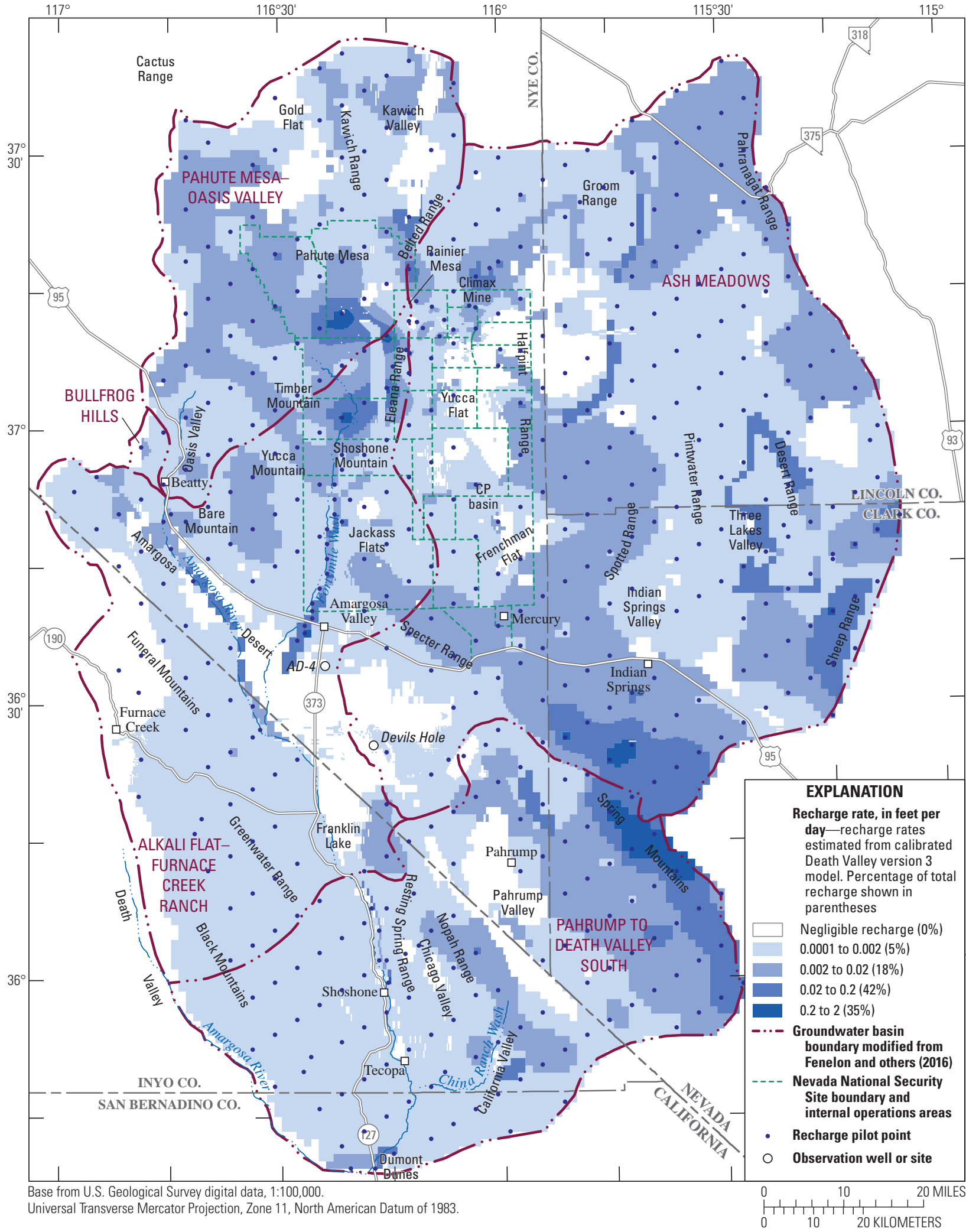

Figure 45. Estimated recharge distribution and recharge pilot points, from the Death Valley version 3 steady-state model (DV3-SS), in the study area, Nevada and California. 


\section{Stress-Response Models}

Predevelopment conditions; the well ER-6-1-2 main MWAT; groundwater development in Ash Meadows, AFFCR, and PMOV groundwater basins; and groundwater development in the PDVS groundwater basin were simulated with four separate, but coupled, stress-response models (table 2). The DV3-SS (steady-state) model simulated predevelopment conditions and informed estimates of recharge rates and hydraulic conductivities. The DV3-ER612 model simulated drawdowns from pumping during the well ER-6-1-2 main MWAT, and informed estimates of hydraulic properties between northern Yucca Flat and the A sh M eadows discharge area. The DV3-AM-AFFCR model simulated changes from groundwater development from 1950-2018 in the A sh M eadows, AFFCR, and PM OV groundwater basins. The DV3-PDVS model simulated changes from groundwater development from 1913-2018 in the PDVS groundwater basin. Transient DV3-ER612, DV3-AM-AFFCR, and DV3PDVS models informed estimates of hydraulic conductivity, specific yield, and specific storage in areas where pumping measurably changed groundwater levels or spring discharges.

\section{Common Boundary Conditions}

The outer edges of the study area (fig. 41) and the bottom of layer 6 at 3,300 ft $(1,000 \mathrm{~m})$ below NGVD29 are no-flow boundaries in all groundwater models. Internal boundaries between groundwater basins were not simulated explicitly as no-flow boundaries. Instead, hydrogeologic units formed hydraulic barriers or conduits to groundwater flow based on estimated hydraulic properties. Hydraulic-property estimates were informed by water-level altitudes, lateral and vertical water-level differences, recharge, predevelopment discharges, water-level changes from pumping, captures of spring discharges, captures of discharge from ET areas, transmissivity estimates from aquifer-test results and specific capacity, and hydraulic inferences from lithologic data, such as siliciclastic and granitic rocks functioning as hydraulic barriers.

The top surface of each groundwater model was the water table. The DV3-SS model simulated recharge to the top surface of layer 1 across the entire model domain. The transient DV 3-ER 612, DV 3-A M -A FFCR, and DV 3-PDV S model s are superposition models, where the top of layer 1 is the predevelopment water table (Halford and Plume, 2011). Transient superposition models have initial heads of $0 \mathrm{ft}$, which are conceptualized as no change or drawdown from predevelopment conditions. Simulated water-level changes are relative to predevelopment heads.

\section{Predevelopment—DV3-SS Model}

Steady-state flow during predevelopment conditions was simulated so that recharge and transmissivities (through hydraulic conductivities) could be estimated. Annual recharge volumes were defined primarily by predevelopment discharges. Elevated water levels in areas of limited recharge identified low-permeability rocks. Transmissivities of areas betw een Devils Hole and Army 1 WW (fig. 32) were defined primarily by discharges from springs in the A sh M eadows discharge area. Volume and water chemistry of discharges from the Furnace Creek area defined transmissivities upgradient in the central A margosa Desert (Winograd and Thordarson, 1975, p. C112). Transmissivities of areas between the Nopah Range and Amargosa River were defined by discharges from the Lower Amargosa area. Transmissivities between Oasis Valley and Pahute Mesa were defined by discharges from 0 asis Valley and aquifer-test results.

Transmissivities in Yucca Mountain, Jackass Flats, Yucca Flat, Frenchman Flat, Indian Springs, Emigrant Valley, the central A margosa D esert, and Pahrump Valley were informed by aquifer-test results and specific capacities (fig. 19); however, the transient groundwater models further refined transmissivities in these areas.

\section{Lateral Flow Across Study Area Boundary}

The study area primarily is isolated from surrounding groundwater basins by low-permeability rocks and groundwater divides (Fenelon and others, 2016), as discussed in the section, "D escription of Study A rea." The outer boundaries of the study area are simulated as no-flow boundaries. Groundwater flow across the northern and eastern boundaries between Gold Flat and Pahranagat Valley has been suggested previously (Winograd and Thordarson, 1975; Heilweil and Brooks, 2011; Fenelon and others, 2016), but flow across these boundaries is expected to be limited.

Potential groundwater flow across the lateral studyarea boundary was not precluded by no-flow boundaries because potential lateral flow was accommodated in simulated recharge estimates. For model cells al ong the periphery of the model domain, adding recharge to tops of model cells or specifying flow at any depth would similarly affect simulated water levels. Differentiating recharge and lateral flow along the study-area boundary was not possible because little data exist. Less than a dozen wells are available within $10 \mathrm{mi}$ of the northern and eastern boundaries of the study area. Estimated recharge al ong the periphery of the study area should be interpreted as undifferentiated recharge and lateral flow.

\section{Water Table and Perched Groundwater Assumptions}

The top surface of all groundwater models is the water table, which encompasses the uppermost occurrence of saturation and includes perched and semi-perched intervals. Inclusion of perched groundwater in the DV 3-SS model allows for the simulation of groundwater-flow paths from nuclear test locations in Rainier M esa and Shoshone M ountain, which were detonated within the perched system. Perched and semi-perched groundwater also was included in B are M ountain, Eleana Ridge, north of Climax M ine, Skull M ountain, Sheep Range, Greenwater Range, and Black M ountains (fig. 25). 
E rrors introduced by simulating the unsaturated zone beneath perched intervals with a saturated groundwater model are assumed to be negligible at the regional scale. Infiltration is vertical through the unsaturated zone from overlying perched intervals into the underlying saturated flow system. When the unsaturated zone beneath a perched zone is simulated as saturated, minor amounts of vertical flow are simulated erroneously as lateral flow. For example, in Rainier Mesa, open intervals in wells ER-12-3 piezometer and ER-12-3 main are at average depths of 1,700 and 4,000 $\mathrm{ft}$ below land surface, respectively, with about $1,000 \mathrm{ft}$ of unsaturated zone between the two open intervals. The vertical gradient averages $0.8 \mathrm{ft} / \mathrm{ft}$, whereas lateral gradients range from $0.08 \mathrm{ft} / \mathrm{ft}$ in volcanic tuffs at the perched water table to $0.008 \mathrm{ft} / \mathrm{ft}$ in the saturated carbonate rocks at the regional water table (U.S. D epartment of Energy, 2018). By simulating the 1,000-ft unsaturated zone as part of the saturated flow system, less than $100 \mathrm{ft}$ of lateral movement would be simulated in the unsaturated zone assuming a vertical gradient of $0.8 \mathrm{ft} / \mathrm{ft}$ and a maximum lateral gradient of $0.08 \mathrm{ft} / \mathrm{ft}$. E rroneously simulating less than $100 \mathrm{ft}$ of lateral movement in the unsaturated zone is not materially different than the conceptually correct $0 \mathrm{ft}$. Perched intervals and underlying saturated rocks coal esce into a single, thick saturated zone within $1 \mathrm{mi}$ of outcrops beneath Rainier M esa (U.S. Department of Energy, 2018), which suggests perched intervals are areally limited in the study area.

\section{Boundary Conditions}

More than 96 percent of the predevelopment discharge was specified in the DV3-SS model (fig. 46) using the well package in MODFLOW (Harbaugh, 2005). Specified discharges from springs totaled 30,300 acre-ft/yr as measured (table 9), where 18 of 27 springs were in the A sh M eadows discharge area (fig. 46). Diversions from Furnace Creek Wash also were included in the spring category (table 9). The remaining 23,400 acre-ft/yr of specified discharge was evapotranspired discharge in the Ash Meadows discharge area, O asis Valley, Furnace Creek area, Franklin Well area, Stewart Valley, Pahrump Valley, L ower A margosa area, and Saratoga Spring area, which were simulated as specified discharges from layer 1 (fig. 46). Evapotranspired discharge in each model cell was computed by mapping all ET unit areas in each cell and multiplying the ET areas by their respective discharge rates. U nlike the A sh $M$ eadows discharge area, spring discharges and $\mathrm{ET}_{\mathrm{GW}}$ from downgradient phreatophytes were not differentiated in Oasis Valley and the Lower Amargosa area because springs and their downgradient ET units typically occurred within a cell. Therefore, total discharge from each model cell in Oasis Valley and the L ower A margosa area is the sum of all discharge from springs and ET areas within each cell. Discharge from ET areas was specified from the southern two-thirds of the alluvial fan south of Furnace Creek Ranch where diverted water was not applied (figs. 9 and 46). Infiltration from the Amargosa River downstream of Dumont Dunes, California (USGS streamgage 10251375) (fig. 14) averaged 720 acre- $\mathrm{ft} / \mathrm{yr}\left(1.0 \mathrm{ft}^{3} / \mathrm{s}\right)$ and was specified with the well package in M ODFL OW (Harbaugh, 2005) (fig. 46).

Discharges from high-altitude springs in recharge areas were not simulated in the DV 3-SS model (fig .46) because the springs are perched. Discharge from perched springs is not part of the regional groundwater system because infiltrated precipitation enters and exits from the perched groundwater system. Spring-pool altitudes from perched springs were used as measurement observations to constrain the top of the simulated water table, which is the uppermost occurrence of saturation and includes perched intervals.

Remaining discharges in ET areas not simulated as specified discharges were simulated as specified heads (fig. 46) because discharge estimates were uncertain and reference water levels were needed. Discharges from Franklin Lake and Death Valley playa were uncertain relative to watertable altitudes and hydraulic conductivities in these areas (table 4). Discharge by $\mathrm{ET}_{\mathrm{GW}}$ from the northern third of the alluvial fan downgradient of Furnace Creek Ranch (fig. 9) was simulated with specified heads (fig. 46) because amounts of return flow in discharge estimates were unknown. Discharge near site A R 11 (USGS streamgage 354903116130401) on the Amargosa River (fig. 12) was simulated with a specified head (fig. 46) for numerical stability and is the functional terminus of the PDVS groundwater system. The DV3-SS model converged slowly prior to introducing a specified-head cell near site AR11 because small differences between specified recharge and discharge were not reconciled easily. A flow observation near site AR11 assured that simulated discharge matched the measured discharge of 1,100 acre-ft/yr.

\section{Simulation of Springs}

Conduits between spring pools and the most transmissive layer beneath springs were inferred and not simulated, except in the A sh M eadows discharge area. Spring discharge was specified directly from the most transmissive layer in Indian Springs, Pahrump Valley, and the Furnace Creek area (table 9). The most transmissive layer coincides with the hydrogeologic unit that is the source of spring water, which typically is carbonate rock. 


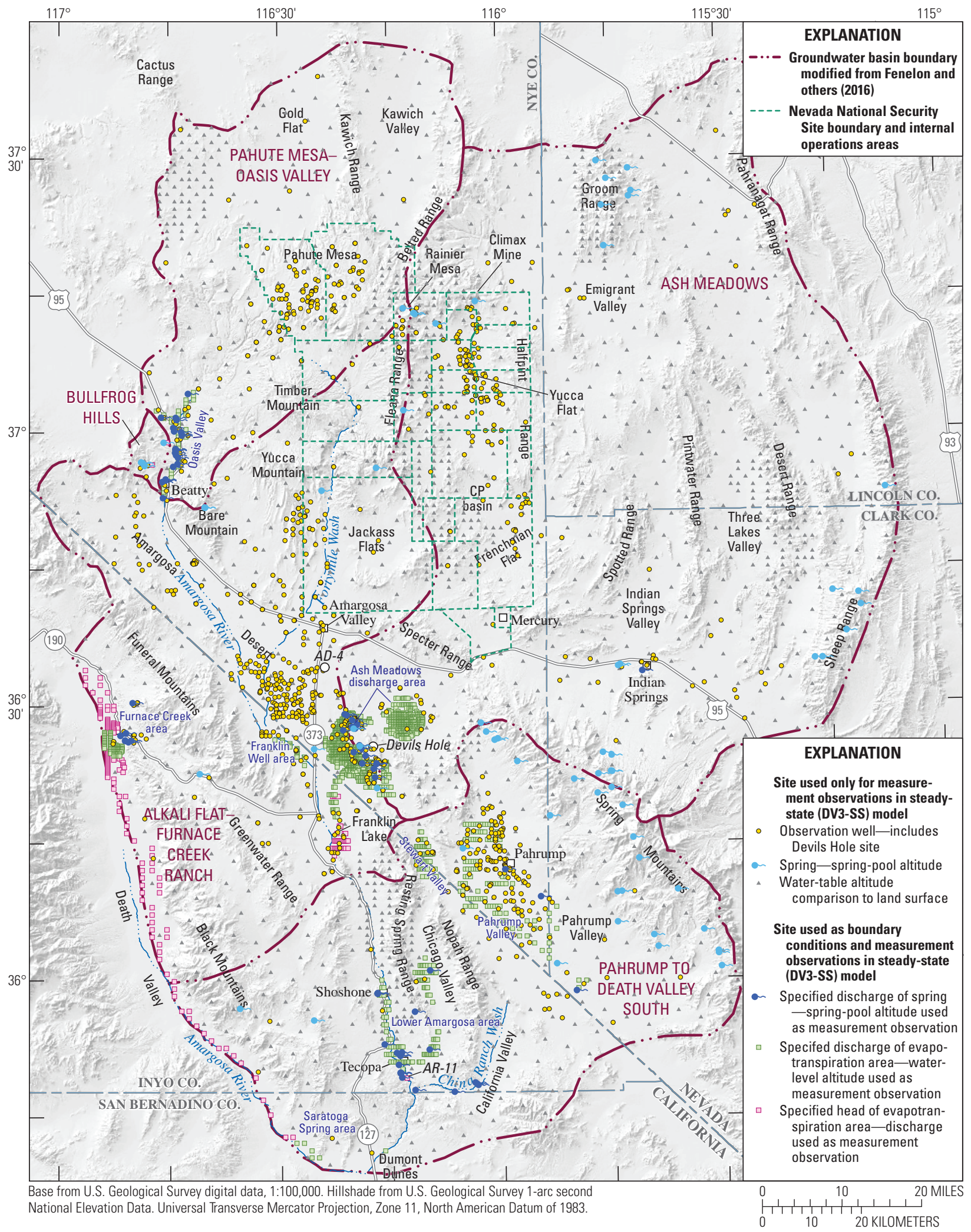

Figure 46. Locations and types of boundary conditions and measurement observations used in the Death Valley version 3 steady-state model (DV3-SS), in the study area, Nevada and California. 
Table 9. Springs explicitly simulated in Death Valley version 3 steady-state model (DV3-SS), estimated predevelopment spring discharge, and the minimum measured discharge from springs during groundwater development, in the study area, Nevada and California.

[Discharge estimates compiled in J ackson and Halford (2020). M inimum measured discharge during groundwater development: M inimum discharge that is less than one-half of predevelopment spring discharge is highlighted in bold. "-" indicates that minimum measured discharge is unknown.

Abbreviations: acre-ft/yr, acre-feet per year; ft³/s, cubic feet per second; NGVD29, National Geodetic Vertical Datum of 1929]

\begin{tabular}{|c|c|c|c|c|c|c|}
\hline $\begin{array}{l}\text { Discharge } \\
\text { area }\end{array}$ & Spring name & Site identifier & $\begin{array}{l}\text { Model } \\
\text { layer }\end{array}$ & $\begin{array}{l}\text { Pool altitude } \\
\text { (feet above } \\
\text { NGVD29) }\end{array}$ & $\begin{array}{c}\text { Predevelopment } \\
\text { discharge, } \\
\left.\text { acre-ft/yr (ft }{ }^{3} / s\right)\end{array}$ & $\begin{array}{c}\text { Minimum measured } \\
\text { discharge during } \\
\text { groundwater devel- } \\
\text { opment, } \\
\text { acre-ft/yr }\left(\mathrm{ft}^{3} / \mathrm{s}\right)\end{array}$ \\
\hline Indian Springs & Indian Springs & 363354115400601 & 2 & 3,183 & $700(0.96)$ & - \\
\hline \multirow[t]{2}{*}{ Pahrump Valley } & Manse Spring & 360919115541501 & 5 & 2,776 & $4,350(6.00)$ & $0(0.00)$ \\
\hline & Bennetts Spring & 361222115585801 & 5 & 2,680 & $5,430(7.50)$ & $0(0.00)$ \\
\hline \multirow[t]{18}{*}{ A sh M eadows } & Five Springs Area & 362723116184101 & 1 & 2,345 & $310(0.43)$ & $0(0.00)$ \\
\hline & Purgatory Spring Well & 362822116193801 & 1 & 2,336 & $80(0.11)$ & $10(0.02)$ \\
\hline & School Spring & 362532116181501 & 1 & 2,323 & $10(0.01)$ & - \\
\hline & Point of Rocks Spring & 362405116161300 & 1 & 2,320 & $620(0.85)$ & $330(0.46)$ \\
\hline & Collins Spring & 362450116174001 & 1 & 2,320 & $20(0.02)$ & $10(0.01)$ \\
\hline & King Pool Spring & 362407116162401 & 1 & 2,314 & $1,960(2.70)$ & $1,920(2.65)$ \\
\hline & Longstreet Spring & 362751116192701 & 1 & 2,310 & $1,090(1.50)$ & $830(1.14)$ \\
\hline & North Scruggs Spring & 362601116182800 & 1 & 2,305 & $100(0.14)$ & $70(0.10)$ \\
\hline & South Scruggs Spring & 362554116184101 & 1 & 2,300 & $30(0.04)$ & - \\
\hline & Jack Rabbit Spring & 362324116163900 & 1 & 2,280 & $1,010(1.40)$ & $0(0.00)$ \\
\hline & Rogers Spring & 362835116192101 & 1 & 2,275 & $940(1.30)$ & $690(0.95)$ \\
\hline & Soda (Bell) Spring & 362848116195901 & 1 & 2,254 & $130(0.18)$ & $0(0.00)$ \\
\hline & Fairbanks Spring $(A M-1 a)$ & 362924116203001 & 1 & 2,250 & $2,750(3.80)$ & $1,860(2.57)$ \\
\hline & Big Spring (AM-8) & 362230116162001 & 1 & 2,247 & $1,590(2.20)$ & $1,160(1.60)$ \\
\hline & 2 Davis Spring & 362401116181102 & 1 & 2,245 & $10(0.01)$ & - \\
\hline & 1 Davis Spring & 362401116181101 & 1 & 2,243 & $640(0.88)$ & - \\
\hline & Cold Spring & 362740116204201 & 1 & 2,235 & $120(0.16)$ & $110(0.15)$ \\
\hline & Crystal Pool (AM-5a) & 362502116192301 & 1 & 2,203 & $4,750(6.55)$ & $2,630(3.63)$ \\
\hline \multirow[t]{6}{*}{ Furnace Creek } & Nevares Springs & 363045116491601 & 2 & 946 & $430(0.60)$ & - \\
\hline & Travertine Springs & 362630116494701 & 2 & 415 & $1,380(1.90)$ & - \\
\hline & Texas Springs & 362728116501101 & 2 & 397 & $360(0.50)$ & - \\
\hline & Furnace Creek Wash sump & 362627116494901 & 2 & 320 & $940(1.30)$ & - \\
\hline & Furnace Creek Wash buried tile & 362632116501201 & 2 & 265 & $290(0.40)$ & - \\
\hline & Furnace Creek Inn tunnel & 362709116505201 & 2 & 73 & $220(0.30)$ & - \\
\hline
\end{tabular}

Spring discharges from the A sh M eadows discharge area were specified from layer 1 . Vertical conduits were simulated explicitly between spring pools in layer 1 and underlying carbonate rocks as high-hydraulic conductivity paths through basin fill. These conduits were isolated from surrounding basin fill by minimizing cell-by-cell conductances between the conduits and adjacent basin fill with horizontal-flow barriers (Hsieh and Freckleton, 1993). The approach for simulating A sh M eadows springs is consistent with the L aczniak and others (1999) conceptual model (fig. 8). The conceptual model shows that these springs discharge groundwater from underlying carbonate rocks through permeable conduits that minimally interact with overlying basin fill prior to entering spring pools (fig. 8). The conduits may be permeable travertine deposits or lenses of gravels and sands within clay-rich basin fill. The precise geometry of the conduits within basin fill is unknown because these conduits have not been differentiated in hydrogeologic frameworks and previous studies provide little guidance on their occurrence and extent. Therefore, a simplistic approach was used by simulating conduits as vertical, high-hydraulic conductivity paths from carbonate rocks to spring pools.

\section{Groundwater Development—DV3-AM-AFFCR and DV3-PDVS Models}

Groundwater development was simulated so that transmissivities, specific yields, and specific storages could be estimated in areas where water levels and spring discharges have been affected by pumping (fig. 29). The central A margosa D esert, A sh M eadows discharge area, and Pahrump Valley are the principal areas affected by groundwater development. Groundwater development also was simulated in Yucca Mountain and on the NNSS, including Pahute Mesa, 
Buckboard M esa, Yucca Flat, Frenchman Flat, CP basin, and

Jackass Flats. Isolated areas of groundwater development were simulated to refine hydraulic-property estimates around Indian Springs, Emigrant Valley, south of Bullfrog Hills, Beatty, and the Furnace Creek area (fig. 29). Water-level fluctuations from time-varying (episodic) recharge were not simulated because estimating episodic recharge would detract from estimating transmissivities and specific yields.

Groundwater development was simulated with two models because the PDV S groundwater basin is hydraulically isolated from the A sh M eadows, A FFCR, and PM OV groundwater basins. Separate models better accommodated differences in pumping histories and reduced computational time. Pumping from the PDV S groundwater basin began in 1913, whereas irrigation pumping from the central A margosa Desert began in the 1950s (fig. 30). Groundwater development in the central A margosa D esert, A sh M eadows discharge area, Yucca Mountain, the NNSS, and isolated areas was simulated with the DV3-AM-AFFCR model. Groundwater development in Pahrump Valley was simulated with the DV 3-PDVS model.

\section{Temporal Discretization}

Temporal discretization of pumping in the DV3AM-AFFCR and DV3-PDVS models differed because the temporal resolution of groundwater-level and spring-discharge measurements differed between groundwater-development areas. Groundwater levels and spring discharges were measured infrequently in Pahrump Valley during the first 40 years of pumping and regularly during limited periods after 1960. Groundwater levels were measured seasonally and consistently in the central A margosa Desert since pumping began during the 1950s (fig. 30). Groundwater levels and spring discharges were measured frequently in the A sh $M$ eadows discharge area during the period when groundwater was pumped by Cappaert Enterprises (fig. 39).

Seasonal and monthly pumping were simulated in the DV 3-AM-AFFCR model so that measured waterlevel changes and spring captures could be matched in the central A margosa Desert and the A sh M eadows discharge area. Seasonal pumping was approximated by assuming all irrigation pumping occurred between mid-M arch and midSeptember. M onthly pumping was simulated from 1969 to 1977, when discharges were measured from the nine pumping wells and one injection well in the Ash Meadows discharge area near Devils Hole (fig. 38). Pumping from all other water uses and return flows were unchanged during each year. This included pumping from Indian Springs, Emigrant Valley, Yucca Mountain, the NNSS, south of Bullfrog Hills, Beatty, and the F urnace Creek area (fig. 29).
A nnual pumping was simulated in the DV 3-PDV S model because pumping, water-level changes, and spring captures are relatively uncertain. Pumping estimates are less certain in Pahrump Valley, compared to the central A margosa Desert, because about 30 percent of the water in Pahrump Valley was pumped prior to crops being inventoried annually. Water levels in Jeep Trail and Hwy 127 MM21-1 wells are typical, with limited measurements prior to 2000 (fig. 35). Simulating seasonal pumping for irrigation is not beneficial to calibration without commensurate water-level measurements.

\section{Boundary Conditions}

DV 3-AM-AFFCR and DV 3-PDV S models simulated changes from predevelopment conditions and directly simulated drawdowns and spring captures. Initial heads were all zero, which represented no drawdown relative to predevelopment conditions. Discharges from springs and ET areas that had been simulated as specified discharges in the DV 3-SS model were simulated as capture-limited boundaries (Halford and Plume, 2011; p. 35) in the DV3-AM-AFFCR and DV 3-PDV S models (fig. 46).

A capture-limited boundary limits the total capture of discharge from springs and ET areas to their predevelopmentdischarge estimates. MODFLOW does not have a boundarycondition package that simulates limited capture. Therefore, two M ODFL OW packages were combined in each model cell where discharge occurs that simulates limited capture. One package simulates the injection of water into the model cell, whereas the other package simulates the removal of water from the model cell. The water injected during each stress period is the predevelopment discharge. The water removed is controlled by a head-dependent boundary package, such as the drain package (Harbaugh, 2005). In the drain package, the elevation is equal to the extinction depth and the conductance is equal to the predevelopment discharge divided by the extinction depth. The extinction depth is the depth below the predevelopment water level at which the spring will go dry or ET ceases (phreatophytes die). When these packages are coupled and the simulated water level at the drain is equal to the initial head of zero, indicating the spring is unaffected by pumping, then the water injected is equal to the water removed and no capture occurs. As the simulated water level declines at the drain, the water injected remains the same, but the water removed (discharging from spring) decreases, causing capture, which is computed as injection minus water removed. Once the simulated water level at the drain is at or below the extinction depth, no water is removed from the drain and all injected water is captured, which equals the predevelopment discharge. 
Capture-limited boundaries were simulated with a combination of the river and drain packages in MODFLOW (Harbaugh, 2005). Water was injected with the river package, instead of the well package, so that only pumping was simulated and tracked with the well package and the river package only simulated and tracked the injection component of capture when using ZONEBUDGET (Harbaugh, 1990). Predevelopment discharges were injected with the river package, where riverbed conductance is the predevelopment discharge divided by the difference between the river stage and river bottom. The river-stage parameter was set equal to $1 \mathrm{ft}$ above the river-bottom altitude so that the riverbed conductance equaled the predevelopment discharge. River stages and bottom altitudes were sufficiently high above the top of the model so that the river cells always behaved as losing river cells, which allowed simulated river leakage to be a constant injection rate. Drain elevations equaled extinction depths and conductances equaled predevelopment-discharge rates divided by extinction depths. Differences between injected and drained water simulated limited groundwater capture, meaning that simulated captures cannot exceed measured discharges.

Extinction depths were estimated in Pahrump Valley and the $A$ sh $M$ eadows discharge area because spring discharges had been captured (table 9). Springs such as Bennetts and Manse Springs in Pahrump Valley and Jack Rabbit Spring, Five Springs Area, and Soda (Bell) Spring in the A sh $M$ eadows discharge area had to be simulated as capturelimited because all springs ceased flowing in response to nearby pumping. Extinction depths were estimable in these springs and a dozen others because declines in discharge had been measured (table 9). A uniform extinction depth of $5 \mathrm{ft}$ was assumed for all other discharges by springs and ET areas.

Discharges from ET areas that had been simulated as specified heads in the DV3-SS model (fig. 46) were simulated as specified heads of $0 \mathrm{ft}$ in the DV3-AM-AFFCR and DV3-PDVS models. These specified heads simulated unconstrained no-draw down boundaries in Franklin Lake, Death Valley playa, and near site A R 11 (USGS streamgage 354903116130401) on the Amargosa River (fig. 46). These specified heads were not converted to capture-limited boundaries because capture never exceeded $80 \mathrm{acre}-\mathrm{ft} / \mathrm{yr}$ relative to simulated predevelopment discharges of 1,840 acre-ft/yr from specified heads in the DV3-SS model.

\section{Well ER-6-1-2 main Multiple-Well Aquifer Test- DV3-ER612 Model}

A large-scale, multiple-well aquifer test (MWAT) was simulated with the DV 3-ER612 model to better constrain transmissivity, specific yields, and specific storages in the shallow carbonate aquifer. A separate stress-response model,
DV 3-ER 612, was used to simulate the well ER-6-1-2 main MWAT, instead of using either the DV3-AM-AFFCR or DV3-PDVS models, because finer temporal discretization is required to adequately simulate drawdown responses to pumping. Well ER-6-1-2 main was pumped and drawdowns were estimated in 13 observation wells that were $0-33$ mi from the pumping well. Drawdowns were detected in observation wells, open to carbonate rocks, as far away as $33 \mathrm{mi}$ from the pumping well (Jackson and Halford, 2019). Detected drawdowns are within an irregular $5 \times 50-\mathrm{mi}$ corridor of carbonate rocks between northern Yucca Flat and the A sh M eadows discharge area (fig. 47).

Drawdowns from pumping in well ER-6-1-2 main were estimated from measured water-level data in 13 observation wells (J ackson and Halford, 2019). D rawdowns were not equivalent to measured water levels because natural waterlevel fluctuations, such as barometric pressure and Earth tides, masked water-level changes from well ER-6-1-2 main pumping. Water levels were measured continuously in pumping well ER-6-1-2 main and eight observation wells:

(1) ER-3-1-2 (shallow); (2) ER-6-1 main (lower zone); (3) ER-6-1 main (upper zone); (4) ER-6-1-1; (5) ER-6-1-2 piezometer; (6) ER-7-1; (7) UE-1h; and (8) Tracer Well 3 (fig. 47). Drawdowns in these wells were differentiated from natural fluctuations and effects of other pumping wells with water-level models (Halford and others, 2012). Water levels were measured periodically with tape downs in five additional wells: (1) Army $1 \mathrm{WW}$; (2) $U-3 c n 5$; (3) UE-7nS; (4) UE-10j (2232-2297 ft); and (5) WW-2 (3422 ft) (fig. 47). All drawdown analyses are reported in J ackson and $\mathrm{Halford}$ (2019).

\section{Temporal Discretization}

Well ER-6-1-2 main pumped 75 million gal (230 acre-ft) from February 5 to July 23, 2004, during a MWAT and tracer test in southern Yucca Flat (Stoller-Navarro Joint Venture, 2005a). Well development, step-drawdown tests, and a preliminary 9-day constant-rate test occurred during February 5-21, 2004. The 90-day constant-rate test occurred during A pril 24-July 23, 2004, when well ER-6-1-2 main pumped 64 million gal at $524 \mathrm{gal} / \mathrm{min}$ (Stoller-Navarro Joint Venture, 2005a). Pumping was deliberately ceased during J uly 8-12, 2004, which introduced a calibration point for tracer transport analyses (Stoller-Navarro Joint Venture, 2005a).

Stress periods in the DV 3-ER612 model matched the periods of well development, step-drawdown testing, constantrate pumping, and the 4-day shut-off because these pumping changes clearly were observed in drawdowns (Jackson and Halford, 2019). Seasonal or annual stress periods used in the DV3-AM-AFFCR and DV3-PDVS models, respectively, would not have been adequate to simulate these responses. 


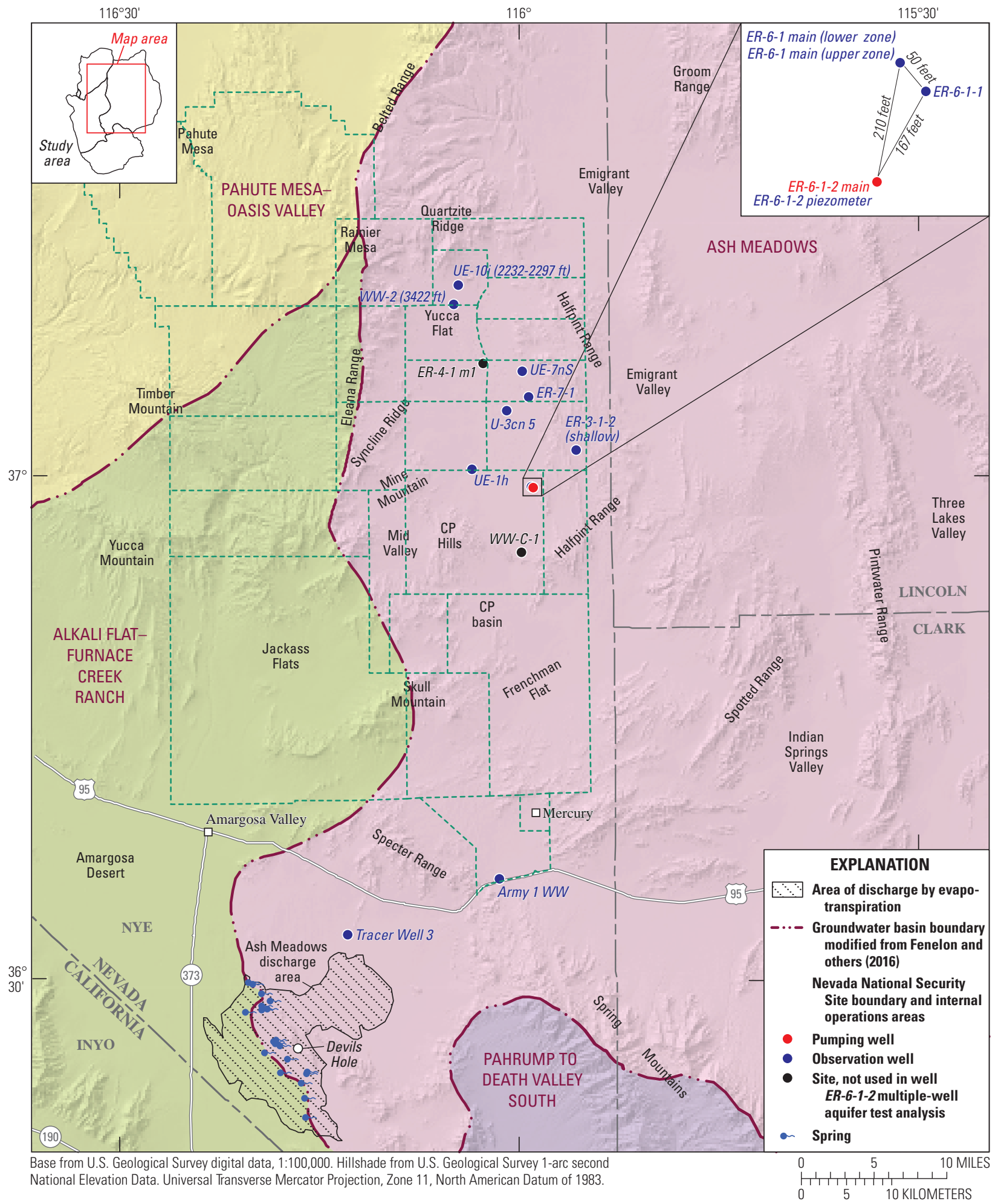

Figure 47. Observation wells monitored during well ER-6-1-2 main multiple-well aquifer test, in the study area, Nevada and California. 


\section{Boundary Conditions}

Pumping in well ER-6-1-2 main was simulated using the well package in M ODFL OW (Harbaugh, 2005). Groundwater discharge from springs and ET areas (fig. 46) were simulated in the DV 3-ER612 model as capture-limited boundaries, using the same method described for use in the DV 3-AM -AFFCR and DV 3-PDV S models.

\section{Calibration}

Hydraulic-conductivity, specific-yield, specific-storage, and recharge distributions, and spring-extinction depths in the A sh M eadows discharge area were estimated by minimizing a weighted composite, sum-of-squares objective function. Hydraulic-property and recharge distributions were defined with 3,415 pilot points, where about 60 percent of the parameters were adjusted with PEST (Doherty, 2010a). Differences between measured observations and simulated responses formally defined the goodness-of-fit or improvement of calibration. This formal definition also was informed by qualitative assessment of estimated hydraulic-property distributions and biases in residuals.

Stress responses were simulated with the integrated DV 3 model, which was called by PEST (fig. 48). The DV3 model initially translated estimated hydraulic conductivities, specific yields, specific storages, and recharge rates at pilot points into two-dimensional M ODFL OW arrays. Stress-response models were executed sequentially, where each model used the same hydraulic-property arrays stored in a common directory (fig. 48). Simulated responses from all four stressresponse models were compared to measured observations. Results from all models simultaneously informed PEST, and parameter changes were estimated iteratively until the objective function had been minimized, resulting in calibration of the DV3 model. The objective function was informed by measurement and regularization observations.

The objective function defines misfit between measured data and simulated equivalents so that parameters can be changed to minimize this misfit. Data used to inform parameters are measurement observations. Adjustable parameters include hydraulic conductivities, specific yields, specific storages, recharge rates, and spring-extinction depths. Parameters are estimable at pilot points in areas where simulated results are sensitive to parameter changes and data exist to judge goodness of fit. However, parameter estimation is not effective at pilot points where no data are available.

Regularization informs the objective function of conceptual models for parameters relatively insensitive to measurement observations. Tikhonov regularization provides information in the form of either preferred values of parameters or preferred relations betw een parameters (Doherty, 2010a). These preferred values or relations are regularization observations, which are added as prior information to the PEST control file (Doherty, 2010a). A hypothetical example of a preferred condition is the assumption of a homogeneous transmissivity of $1,000 \mathrm{ft}^{2} / \mathrm{d}$ in a hydrogeologic unit. For each hydraulic-conductivity pilot point in the hydrogeologic unit, the regularization observation would be the transmissivity $\left(1,000 \mathrm{ft}^{2} / \mathrm{d}\right)$ divided by the hydrogeologic unit thickness. During calibration with PEST, measurement and regularization objective functions are minimized simultaneously by allowing measurement observations to inform parameters where data exist and regularization observations (preferred conditions) to inform parameters where measured observations are deficient.

\section{Measurement Observations}

Measured observations characterized predevelopment flow and pumping effects. Water-level altitudes, water-level differences between wells, transmissivities, and discharge rates characterized predevelopment flow (table 10). M easured water-level altitudes included groundwater levels in wells, spring-pool altitudes, water levels in ET areas, and water-table altitude comparisons to land surface. Water-level differences between wells, including water-level differences between wells and spring pools in the A sh M eadows discharge area, constrained vertical and lateral hydraulic gradients. Simulated transmissivities were compared to transmissivities estimated from aquifer tests and specific capacities. Predevelopment discharges primarily informed the objective function of conceptual preferences, such as flows across groundwaterbasin boundaries, because most measured discharges were specified in the DV3-SS model. Water-level changes and spring captures characterized pumping effects. Waterlevel changes principally were responses to groundwater development, but also included drawdown from the well ER-6-1-2 main MWAT. Spring captures primarily were responses to pumping from C appaert Enterprises in the A sh M eadows discharge area.

Groundwater levels, spring-pool altitudes, and transmissivities were measured at 1,409 unique sites in the study area (Jackson and Halford, 2020). Water levels were measured in 1,070 wells and 164 spring pools, with predevelopment levels available for 881 wells and 162 spring pools (table 10). Transmissivities were estimated from aquifer tests and specific capacities in 271 wells, with less than 40 percent of these wells also supplying water-level data. Site identifier, station name, location, and observation group for each unique site are reported in J ackson and $\mathrm{H}$ alford (2020). 


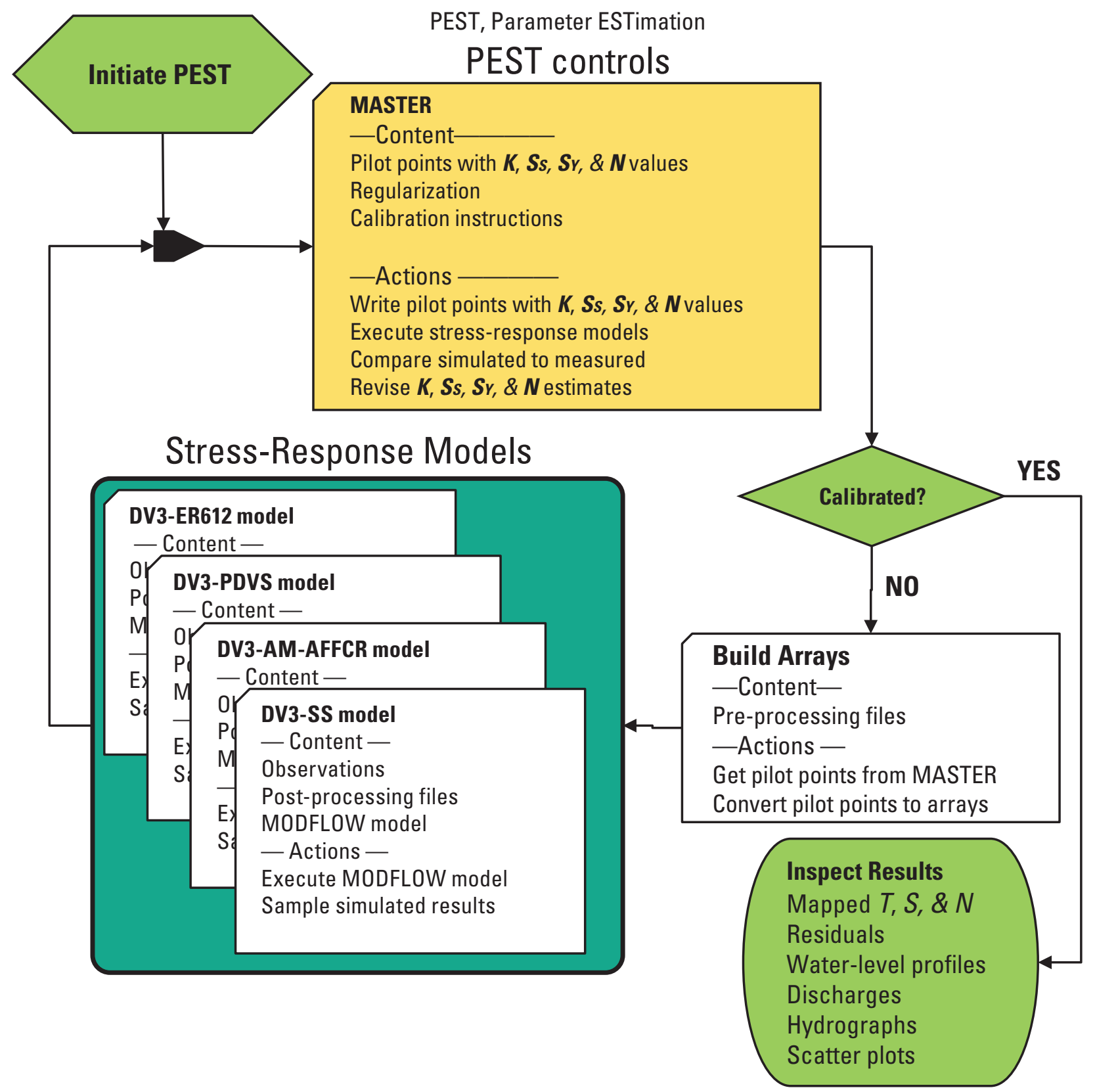

Figure 48. Model-run process of the Death Valley version 3 model (DV3), which is an integrated stress-response model, in the study area, Nevada and California. DV3-AM-AFFCR, Death Valley version 3 model simulating groundwater development in the Ash Meadows, Alkali Flat-Furnace Creek Ranch, and Pahute Mesa-Oasis Valley groundwater basins; DV3-ER612, Death Valley version 3 model simulating pumping during the ER-6-1-2 main multiple-well aquifer test; DV3-PDVS, Death Valley version 3 model simulating groundwater development in the Pahrump to Death Valley South groundwater basin; DV3-SS, Death Valley version 3 steady-state model; $K$, hydraulic conductivity; $N$, recharge; $S$, storativity; $S$ s, specific storage; $S Y$, specific yield; and $T$, transmissivity. 
Table 10. Summary of observations and Death Valley version 3 model (DV3) fit to simulated comparisons, in the study area, Nevada and California.

[M odel: DV3-SS, Death Valley version 3 stress-response model simulating steady-state (predevelopment) conditions; DV3-AM-AFFCR, Death Valley version 3 stress-response model simulating groundwater development in the Ash Meadows, Alkali Flat-Furnace Creek Ranch, and Pahute Mesa-Oasis Valley groundwater basins; DV3-PDVS, Death Valley version 3 stress-response model simulating groundwater development in the Pahrump to Death Valley South groundwater basin; DV3,ER612, Death Valley version 3 stress-response model simulating pumping during the well ER-6-1-2 main multiple-well aquifer test. Sum-ofweights squared: (ft/ft) ${ }^{2}$, foot per foot squared; $\left[\mathrm{ft} / \log \left(\mathrm{ft}^{2} / \mathrm{d}\right)\right]^{2}$, square of foot per log of square foot per day; (ft/acre-ft/yr) ${ }^{2}$, foot per acre-foot per year squared; [ft/(gal/min)] $]^{2}$, foot per gallon per minute squared. R M S error: Root-mean-square error; ft, foot; log(ft $\left.2 / \mathrm{d}\right), \log$ of square foot per day; acre-ft/yr, acre-foot per year; gal/min, gallon per minute; $\mathrm{ft}^{3} / \mathrm{s}$, cubic foot per second. A bbreviation: NA, not applicable]

\begin{tabular}{|c|c|c|c|c|c|}
\hline Model & Observation group & $\begin{array}{c}\text { Number of } \\
\text { observations }\end{array}$ & $\begin{array}{l}\text { Sum of squares of } \\
\text { weighted residuals } \\
\text { (foot squared) }\end{array}$ & $\begin{array}{c}\text { Sum-of-weights } \\
\text { squared }\end{array}$ & RMS error \\
\hline \multirow[t]{8}{*}{ DV 3-SS } & Water-level altitude in wells & 881 & $2,005,251$ & $9 . \mathrm{E}+2(\mathrm{ft} / \mathrm{ft})^{2}$ & $49 \mathrm{ft}$ \\
\hline & Water-level altitude in evapotranspiration areas & 1,657 & 20,027 & 2. $\mathrm{E}+1(\mathrm{ft} / \mathrm{ft})^{2}$ & $35 \mathrm{ft}$ \\
\hline & Spring-pool altitude & 162 & 114,580 & 3. $\mathrm{E}+1(\mathrm{ft} / \mathrm{ft})^{2}$ & $64 \mathrm{ft}$ \\
\hline & Water-table altitude comparison to land surface & 1,675 & 14,001 & 4. $\mathrm{E}+0(\mathrm{ft} / \mathrm{ft})^{2}$ & $58 \mathrm{ft}$ \\
\hline & Transmissivity from specific capacities & 129 & 57,367 & 8.E $+4\left[\mathrm{ft} / \log \left(\mathrm{ft}^{2} / \mathrm{d}\right)\right]^{2}$ & $0.9 \log \left(\mathrm{ft}^{2} / \mathrm{d}\right)$ \\
\hline & Water budget volumes & 23 & 169,317 & 1.E-2 (ft/acre-ft/yr) ${ }^{2}$ & 30 acre-ft/yr \\
\hline & Conceptual recharge volumes & 31 & 546,236 & 3.E-3 (ft/acre-ft/yr) ${ }^{2}$ & 110 acre-ft/yr \\
\hline & Erroneous recharge from specified heads & 3 & 1,475 & 7.E-6 (ft/acre-ft/yr) ${ }^{2}$ & 120 acre-ft/yr \\
\hline $\begin{array}{r}\text { DV 3-AM - } \\
\text { AFFCR }\end{array}$ & A margosa Desert draw down & 3,782 & $1,700,713$ & 2.E+7 $(\mathrm{ft} / \mathrm{ft})^{2}$ & $0.31 \mathrm{ft}$ \\
\hline DV 3-PDVS & Pahrump Valley spring capture & 203 & 79,419 & 8.E $+4\left(\mathrm{ft} / \mathrm{ft}^{3} / \mathrm{s}\right)^{2}$ & $\left.1.0 \mathrm{ft}^{3} / \mathrm{s} \mathrm{(444} \mathrm{gal} / \mathrm{min}\right)$ \\
\hline \multirow[t]{2}{*}{ DV3-ER 612} & Well ER-6-1-2 main drawdown & 1,514 & 498,180 & $1 . \mathrm{E}+9(\mathrm{ft} / \mathrm{ft})^{2}$ & $0.02 \mathrm{ft}$ \\
\hline & Totals & 14,990 & $8,581,929$ & NA & NA \\
\hline
\end{tabular}

Many more observations exist than unique sites primarily because water levels and discharges have been measured many times in wells and springs. About 11,600 observations from wells and springs are compared in the objective function (table 10), which is nearly 10 times greater than the number of unique sites. Water-level changes (drawdowns) and springdischarge changes (capture) resulting from pumping were compared to simulated equivalents for more than 60,000 observations, but only about 10,000 observations had weights greater than 0 (table 10). More than 60,000 observations are reported by PEST because simulated hydrographs were sampled continuously regardless of measurement frequency. For example, well Jeep Trail has 15 water-level measurements from 1959 to 2015, but includes an additional 107 sampling observations ( 1 for each year from 1913 to 2018) to view a continuous simulated hydrograph from 1913 to 2018. These additional sampling observations were given weights of 0 and, therefore, did not affect the objective function. More observations than unique sites also exist because multiple observations - such as a water-level altitude and water-level changes- were measured in a well. For example,

Tracer Well 3 has four types of observations: (1) waterlevel altitude; (2) water-level changes from groundwater development; (3) drawdowns from the well ER-6-1-2 main MWAT; and (4) a transmissivity estimate.

Simulated water levels were sampled from a single MODFLOW layer for comparison to measured water-level altitudes and changes. Open intervals are less than $246 \mathrm{ft}$ $(75 \mathrm{~m})$ in length for 63 percent of the wells, which functionally precludes assigning more than a single M ODFLOW layer. Open intervals penetrating multiple MODFLOW layers were assigned to the most transmissive layer, as conceptualized in the hydrogeologic framework. This is because water levels in wells most closely represent water levels in the most transmissive interval of a formation. Less than 17 percent of 1,070 w ells fully penetrated multiple M ODFL OW layers and were assigned to the most transmissive layer. 
Simulated water levels at wells and springs were interpolated laterally between model cell centers in assigned layers, except where hydraulic discontinuities made lateral interpolation inappropriate. Simulated water levels mostly were interpolated from nodes of surrounding cells to points of measurement with M OD20BS (D oherty, 2010b). Well locations of a small number of wells were shifted from their true locations to the model cell centers in M OD2OBS input files and the shifted locations are shown in spatial coverages of model results (J ackson and Halford, 2020). For example, instead of discretizing the model grid finer, locations of Devils Hole and Devils Hole Well (AM-5) were manually shifted from their true locations to attenuate the effect of an intervening discontinuity in shallow carbonate rocks on simulated water levels. This shift was an approximate difference of $400 \mathrm{ft}$ west and $400 \mathrm{ft}$ east from the true locations of Devils Hole and Devils Hole Well (AM-5), respectively. Simulated spring pools in the A sh M eadows discharge area were sampled from cell centers because their conduits from carbonate rocks to land surface were simulated explicitly, and spring-pool cells were isolated hydraulically from adjoining cells.

Weights were assigned to observations to represent expected observation accuracy and importance of each observation to model fit. For example, water-level altitude observations were weighted progressively less as observations were more uncertain, which resulted in water levels in wells being weighted more than water levels in ET areas. Weights accounted for differences in the number of observations between wells, where a well with 100 water levels will be weighted more than a well with 10 water levels if all water levels are weighted equally. Weights also accounted for the range of measurement values between observation groups. For example, log-transmissivities from 142 aquifer-tests ranged from -4.7 to $5.6 \log \left(\mathrm{ft}^{2} / \mathrm{d}\right)$, whereas water-level altitudes in 881 wells ranged from -281 to 8,504 ft above NGVD29. Transmissivity observations would not affect calibration if logtransmissivities from aquifer-tests and water-level altitudes in wells were weighted equally.

Weights were adjusted iteratively so all observation groups affected model calibration. Mismatches in scatter plots of water-level altitudes and transmissivities, spatial distributions of water-level residuals, profiles of predevelopment water levels, and hydrographs of waterlevel changes and spring captures directly informed relative importance of observation groups on model calibration. Simulated water levels; drawdown extents; and transmissivity, specific-yield, specific-storage, and recharge distributions were examined for conceptual inconsistencies. For example, transmissivities exceeding 1,000 ft'/d in low-permeability rocks are conceptually problematic. This problem typically identified a misclassified hydrogeologic unit, a compensating error, or an insensitive parameter that drifted to an upper limit. Influence of each observation group on calibration was best summarized by sum-of-squares (table 10). This was because the weighted sum-of-squares residuals for each observation group integrates the number of observations, range of measurement values, and relative weighting.

\section{Predevelopment Observations-DV3-SS Model}

Measurement observations used in the calibration of the DV3-SS model were categorized into 10 observation groups (table 10). The following sections describe: (1) the different types of measurement observations; (2) methods used to estimate observations, where appropriate; (3) reasoning for weight assignment during calibration; and (4) how measurements were implemented in the DV 3-SS model and used in model calibration.

\section{Water-Level Altitudes in Wells}

Measured and simulated water-level altitudes were compared from 1,033 wells (fig. 46) in the study area, where 881 wells have weights greater than $1 \times 10^{-6}$ (table 10). M ost measured water levels were relatively shallow, with 961 wells being screened in layers 2,3 , or 4 . Only 26 wells were screened in layer 6, 80 percent of which were in the NNSS. Small weights were assigned to water levels in 152 wells, which limited sensitivity of comparisons between measured and simulated water levels during parameter estimation. Small weights were assigned because water levels either were redundant or were affected by transient (nuclear testing or pumping) conditions. These water-level observations were assigned small weights, rather than excluded from the DV 3 model, because these data provided censored information during calibration. For example, if a measured water level is affected by pumping, then the simulated predevelopment water level should be higher.

\section{Water-Level Altitudes in Evapotranspiration Areas}

Water-level altitudes were estimated at 1,657 ET locations (fig. 46; table 10) and compared to water levels simulated with the DV3-SS model. Water levels are within 30 $\mathrm{ft}$ of land surface in discharge areas. Water levels exceed land surface at spring pools and remain below land surface in ET areas. Water levels in ET locations were estimated with landsurface altitudes from a digital elevation model (DEM) that sampled 1:24,000-scale maps every $30 \mathrm{~m}$ and reported to the nearest whole meter (Gesch and others, 2009). DEM altitudes typically spanned $10 \mathrm{ft}$ in model cells where discharge by $\mathrm{ET}_{\mathrm{GW}}$ occurred. Water levels were assumed equal to average land-surface altitudes because variability of land surface exceeds measured differences between land surface and water levels. These observations are less certain than measured water-level altitudes in wells and were weighted less. During DV3-SS model calibration, if measured water-level data from wells exist in the discharge area, the measured water-level data have greater weights than DEM-averaged water levels in ET locations and parameters have greater sensitivity to the measured data. 
Spring-Pool Altitudes

M easured and simulated spring-pool altitudes were compared from 162 springs in the study area (table 10). Altitudes were well known for 27 springs where discharges were simulated (table 9). A ltitudes of springs in the Eleana Range, Groom Range, Sheep Range, Spring M ountains, and Black M ountains were less certain because altitudes were estimated from the DEM used to calculate water-level altitudes in ET areas. Spring altitudes estimated from the DEM were weighted less than springs where altitudes were known. Despite the low weight assigned to DEM -estimated spring altitudes, water-table altitudes in mountain ranges depended on these spring-pool altitudes because wells were absent (figs. 6 and 46).

\section{Water-Table Altitude Comparisons to Land Surface}

Simulated water-table altitudes were compared to landsurface altitudes to ensure that the simulated water table remained below land surface. L and-surface altitudes were sampled at 1,675 locations from the DEM used to calculate water-level altitudes in ET areas. Water-table altitudes were evaluated after each MODFLOW simulation and simulated altitudes either remained unchanged or were assigned to the land-surface altitude. The simulated water-table altitude was set equal to the land-surface altitude if the simulated water table was below land surface so that the residual equaled zero and did not affect model calibration. For example, a simulated water-table altitude that initially equal ed $4,500 \mathrm{ft}$ would be changed to 5,000 ft, where land-surface altitude is $5,000 \mathrm{ft}$, and the residual would be $0 \mathrm{ft}$. Alternatively, a simulated water-table altitude that initially equal ed $5,500 \mathrm{ft}$ at the same location would not be changed and the residual would be 500 $\mathrm{ft}$. Water-table altitude comparisons to land surface had small weights because these observations are highly non-linear. Water-table altitude comparisons also had small weights, compared to water-level altitudes in wells and spring-pool altitudes, so that calibration was sensitive to measured water levels.

\section{Water-Level Differences Between Measurement Sites}

Measured and simulated water-level differences between wells (or between wells and spring pools) were compared to preserve vertical and lateral differences (fig. 49). Water-level differences between volcanic rocks at the water table and underlying low-permeability carbonate rocks beneath Rainier Mesa were the primary vertical differences of concern. The greatest vertical difference exceeded $1,800 \mathrm{ft}$ between wells ER-12-3 piezometer and ER-12-3 main in Rainier M esa. Small water-level differences in shallow carbonate rocks between Yucca Flat and the A sh M eadows discharge area were the primary lateral differences of concern. Water levels decline $32 \mathrm{ft}$ between well ER-6-1-2 main and Devils Hole and are separated by $42 \mathrm{mi}$ (fig.49).

\section{Transmissivity Comparisons}

Transmissivity estimates from aquifer-test results and specific capacities were compared to simulated transmissivities. Simulated transmissivities were computed by defining the area investigated by each aquifer test (fig. 50), averaging hydraulic conductivities of all model cells that occur within the area investigated, and then multiplying by the contributing thickness (Halford, 2016). The area investigated was defined where drawdowns exceeded $0.07 \mathrm{ft}$ at the end of each aquifer test, but the radius of investigation was not allow ed to exceed 6,600 ft. For aquifer tests where transmissivity was less than $1,000 \mathrm{ft}^{2} / \mathrm{d}$ or small volumes of water were pumped, the contributing thickness was limited to the well screen length. For aquifer tests where transmissivity exceeded 1,000 $\mathrm{ft}^{2} / \mathrm{d}$ or large volumes (more than 100,000 gal) of water were pumped (Halford and others, 2006), the contributing thickness was the aquifer thickness from the DV3 hydrogeologic framework model. If the area investigated spanned multiple model layers, the simulated transmissivity was computed by averaging hydraulic conductivities in each model layer, multiplying by their respective model layer thicknesses, and then summing layer-averaged transmissivities (Halford, 2016, p. 10). Estimated transmissivities from aquifer tests and specific capacities are discussed herein as measured transmissivities for comparison to simulated transmissivities from the DV 3-SS model.

Conceptual Preferences of Recharge, Predevelopment Discharge, and Groundwater-Basin-Boundary Flows

Expected and simulated groundwater-flow rates that were compared included recharge to groundwater basins, flow across divides between groundwater basins, interbasin flow through corridors between groundwater basins, and discharges from specified heads (table 11). Expected recharge to groundwater basins was the annual volume from the conceptual recharge distribution (fig. 16), which was estimated from predevelopment discharge. No flow was expected across boundaries that form divides between groundwater basins. Expected interbasin flows through corridors between groundwater basins were derived from Darcy estimates (fig. 6). Expected discharges from specified heads primarily are maximum estimated discharges from playas (table 11). Discharge south of Tecopa is an exception where a discharge of 1,100 acre-ft/yr was known, but simulated with a single, specified head for numerical stability. Simulated flow rates were sampled from the DV3-SS model with ZONEBUDGET (Harbaugh, 1990). 


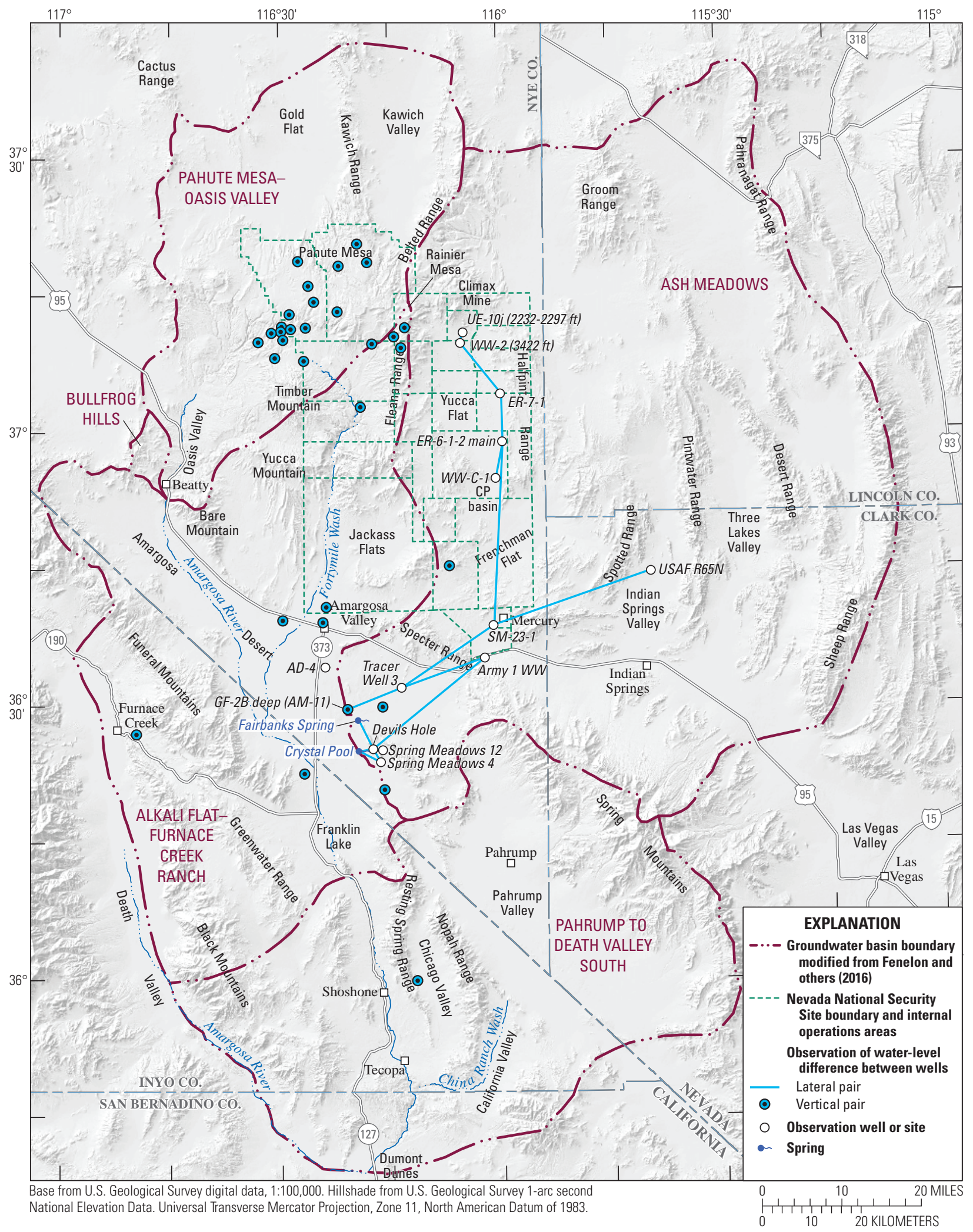

Figure 49. Lateral and vertical water-level difference observations used in the Death Valley version 3 steady-state model (DV3-SS), in the study area, Nevada and California. 


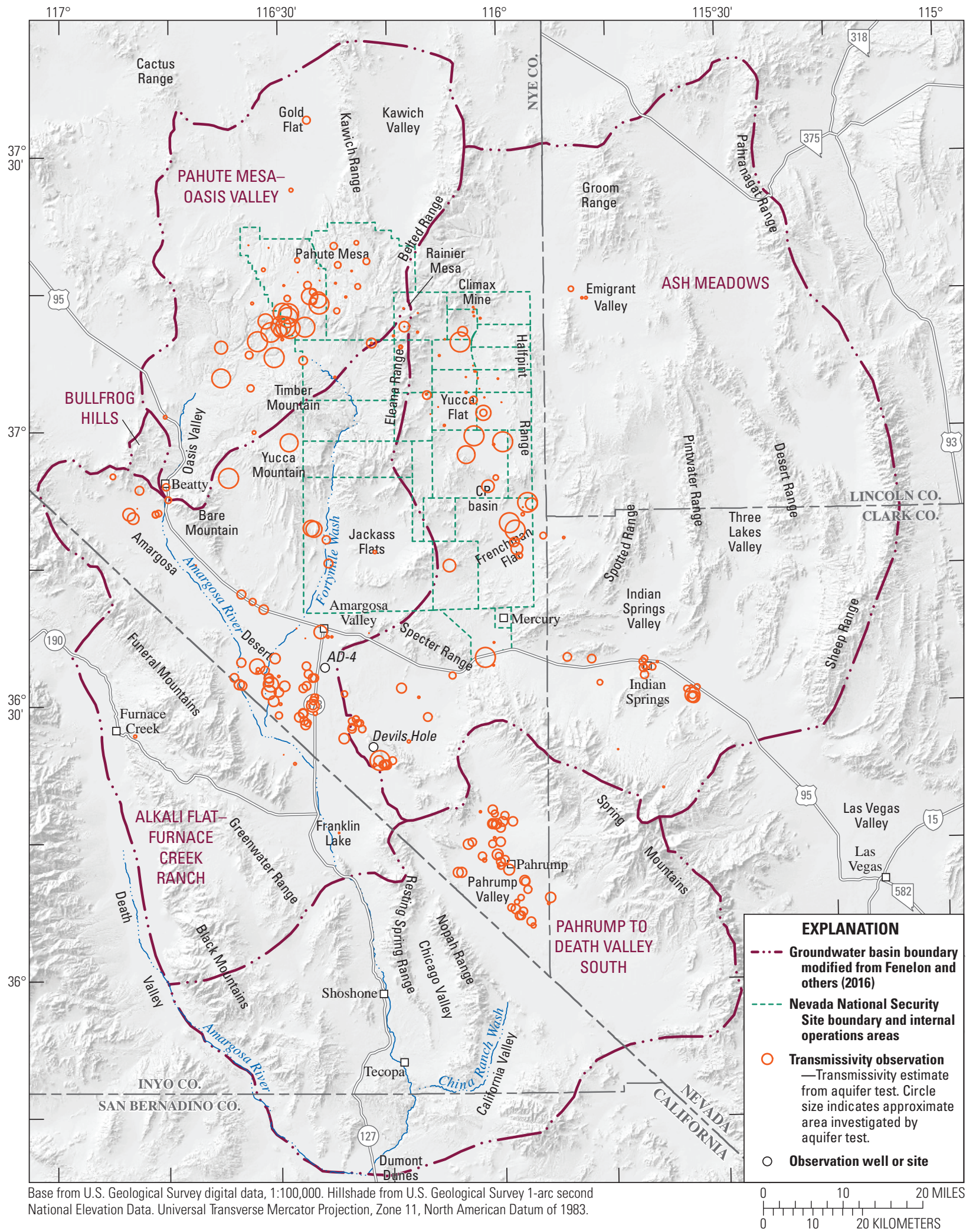

Figure 50. Transmissivity observations from aquifer tests and specific capacities, in the study area, Nevada and California. 
Table 11. Expected and simulated groundwater-flow rate observations, in the study area, Nevada and California.

[G roundwater basin: AFFCR, Alkali Flat-Furnace Creek Ranch; PDVS, Pahrump to Death Valley South; PMOV, Pahute Mesa-Oasis Valley. Flow volume component: Recharge and discharge flow volume components are colored blue and red, respectively. Symbol: <, less than.]

\begin{tabular}{|c|c|c|c|}
\hline \multirow{2}{*}{$\begin{array}{c}\text { Groundwater } \\
\text { basin }\end{array}$} & \multirow{2}{*}{ Flow volume component } & \multicolumn{2}{|c|}{ Flow volume (acre-feet per year) } \\
\hline & & Expected & Simulated \\
\hline \multirow[t]{6}{*}{ PMOV } & Recharge to PM OV & 6,000 & 5,900 \\
\hline & Divide between PMOV and Ash Meadows & 0 & 20 \\
\hline & Divide between AFFCR and PMOV & 0 & 230 \\
\hline & Interbasin flow from PMOV to AFFCR & 100 & 110 \\
\hline & Recharge to Bullfrog Hills & 100 & 80 \\
\hline & Interbasin flow from Bullfrog Hills to PMOV & 100 & 60 \\
\hline A sh & Recharge to A sh M eadows & 21,100 & 21,600 \\
\hline \multirow[t]{4}{*}{ M eadows } & Divide between Ash Meadows and AFFCR north of well $A D-4$ & 0 & 50 \\
\hline & Interbasin flow from Ash Meadows to AFFCR near well $A D-4$ & $2,000-4,000$ & 2,550 \\
\hline & L eakage from A sh M eadows to AFFCR south of well $A D-4$ & 200 & 270 \\
\hline & Divide between Ash Meadows and PDVS & 0 & 70 \\
\hline \multirow[t]{6}{*}{ AFFCR } & Recharge to AFFCR & 4,800 & 4,850 \\
\hline & Divide between AFFCR and PDVS & 0 & 20 \\
\hline & Interbasin flow from AFFCR to PDVS near Eagle Mountain & $<300$ & 60 \\
\hline & Discharge from Franklin Lake & $<700$ & 440 \\
\hline & Discharge from specified heads on alluvial fan in Furnace Creek area & $<300$ & 300 \\
\hline & Discharge from floor of Death Valley in AFFCR & $<200$ & 120 \\
\hline \multirow[t]{5}{*}{ PDVS } & Recharge to PDVS & 22,100 & 22,200 \\
\hline & Interbasin flow from PDVS to Ash Meadows north of Stewart Valley & $<200$ & 180 \\
\hline & Discharge from specified head south of Tecopa & 1,100 & 1,000 \\
\hline & D ischarge from Saratoga Spring area & $800-1,100$ & 950 \\
\hline & Discharge from floor of Death Valley in PDVS & $<200$ & 40 \\
\hline
\end{tabular}

Expected annual volumes from the conceptual recharge distribution were divided into 31 zones (fig. 16) and compared to simulated annual volumes. Zones were small enough that the objective function was informed of expected spatial variability in annual volumes of recharge. Zones were large enough that annual volumes of recharge were minimally affected by displacement of infiltration by low-permeability rocks and delineation of zones. Four zones in Pahute M esa, Sheep Range, and Spring M ountains generated more than 70 percent of all recharge. Annual volumes of recharge were limited elsewhere and less than 500 acre-ft/yr in 17 of 31 zones.

Penalizing simulated water-table al titudes higher than land surface (table 10), minimizing flow across groundwaterbasin boundaries (table 11), and matching water-budget volumes were conceptual observations (table 11). These conceptual observations, which defined well-understood terms that were quantified poorly through other observation groups, were compared as measurement observations in the objective function. Conceptual observations were weighted minimally because expected values are uncertain.

\section{Groundwater-Development Observations-DV3-AM- AFFCR and DV3-PDVS Models}

Measurement observations used in the calibration of the DV 3-A M -AFFCR and DV 3-PDV S models were categorized into observation groups of water-level changes and captures (table 10). The following sections describe how (1) waterlevel change measurement observations were computed, implemented in groundwater-development models, and used in model calibration; (2) long-term natural fluctuations from variations in recharge were accounted for or removed from measured water-level changes; and (3) groundwater captures were computed in the groundwater-development models.

\section{Water-Level Changes}

Measurement times and water levels were averaged to a single value for each stress period prior to estimating waterlevel changes. Water levels were averaged in a total of 308 wells for the DV 3-A M-A FFCR and DV 3-PDV S models. For modeling purposes, each of the averages is referred to as a "measured water level". Averaging eliminated high-frequency fluctuations that were not simulated. For example, water levels in well ESB1 were averaged annually because 1-year stress periods were simulated in the DV 3-PDV S model (fig. 51). Simulated water-level changes in well ESB1 were fit to changes in these annually averaged water levels. 
Measured and simulated water-level changes were compared relative to a reference water level in each well (fig. 52). Reference water levels established a time when simulated water levels were set equal to measured water levels. Simulated changes were relative to the reference water level and pivoted about the reference water level. This occurred during calibration as transmissivities, specific yields, and specific storages were estimated (fig. 52). Reference water levels were necessary because most water-level records began 10-50 years after groundwater development started and changes from predevelopment water levels generally were unknown. This approach has been applied previously to negate unknown effects of entry losses in pumping wells (Halford and Yobbi, 2006).

Reference water levels were established so that measured water-level changes from pumping primarily were compared. Initial water levels commonly were not used because these measurements frequently are from well logs and do not represent equilibrated conditions after drilling. Water levels that have not equilibrated in low-permeability rocks or are affected by crustal deformation from earthquakes also were not used as reference water levels and were assigned small weights. For example, water levels in well Travertine Point 1 were affected by the Landers earthquake in 1992 (Fenelon and Moreo, 2002). A 2005 water level was the reference and water levels prior to 1997 were not compared in the objective function (fig. 52). Reference water levels also were established during the last 10 years of record, after pumping had ceased, to mitigate effects of pumping in supply wells such as Army $1 W W$ and $W W-8$.

\section{Accounting for Temporal Variability in Recharge}

Time-varying recharge was not simulated in the DV3 model because of the complexity of the groundwater system. The behavior of rising water-level trends from recharge is dependent on annual variations in precipitation, distance from the recharge source, unsaturated zone depth, and the hydraulic conductivity of unsaturated and saturated rocks. Instead of simulating time-varying recharge to account for rising waterlevel trends, the recharge component of the water-level trend was differentiated from the pumping component at selected sites using water-level models (Halford and others, 2012).

Long-term natural fluctuations from variations in recharge were removed from measured water-level changes in Devils Hole and nearby wells because they were substantial relative to pumping effects. This was most apparent from 1990 to 2018 when episodic recharge affected water levels in Devils Hole more than pumping (fig. 40). L ong-term waterlevel fluctuations from recharge estimated in Devils Hole were assumed pervasive throughout the shallow carbonate because other nearby wells had water-level trends similar to Devils Hole. Therefore, long-term recharge trends also were removed from wells $A D-8$, Point of Rocks North (AM-6), Point of Rocks South (AM-7), Devils Hole Well (AM-5), North Crystal Well,
SM-23-1, Spring Meadows 12, Spring Meadows 9, Tracer Well 3 (AD-6), and $T W-5$ (RV-1) (fig. 53).

Wells along the periphery of pumping centers with small rising water-level trends are affected by episodic recharge and minimally are affected by pumping, if at all. These water-level rises have been attributed to recharge from multiple waterlevel trend studies (Elliott and Fenelon, 2010; Fenelon and Moreo, 2002; Fenelon and others, 2012; Jackson and Fenelon, 2018). Water levels typically have risen about $0.8 \mathrm{ft}$ per decade since the 1980s in wells along the periphery of pumping centers, such as well CF2 (fig. 32). Small water-level rises in these wells may have masked small water-level declines from pumping. Because water levels in these wells are rising and the magnitude of water-level declines from pumping is unknown, recharge could not be differentiated from pumping. Instead, measured and simulated water-level changes were inspected visually in wells with rising water levels, such as well USFWS DR-1 (fig. 18), to determine whether pumping likely has been masked by rising trends. Observations from 51 wells with rising trends were weighted near zero, where the rising trend enforces a minimal drawdown boundary at these wells.

Measured water-level changes were assumed to be from pumping exclusively for wells within the main pumping centers. The pumping-only assumption likely was adequate where water-level declines exceeded $1 \mathrm{ft}$ per decade, which includes most wells in the central A margosa Desert and all 109 wells in the PDVS groundwater basin. The only exceptions were water levels in Devils Hole and in nearby wells open to shallow carbonate rocks.

\section{Groundwater Capture from Springs and Evapotranspiration Areas}

M easured and simulated captures were compared at 18 springs in the A sh M eadows discharge area and two springs in Pahrump Valley (table 9). Limited capture was simulated by combining the river and drain packages in MODFLOW (H arbaugh, 2005). Simulated captures were computed by subtracting the predevelopment discharge injected in the river package from the water removed in the drain package. Simulated flow rates from the river and drain packages were extracted with a variation of ZONEBUDGET (Harbaugh, 1990) to compute capture. Simulated capture could not be computed directly from ZONEBUDGET because only flows across zone faces and flows from individual MODFLOW packages for each zone are reported in ZONEBUDGET, and rates from multiple packages are not combined. The modified program, M OD2BUD, was used to compute capture by reading the output file from ZONEBUDGET. MOD2BUD sums rates from multiple packages, converts units, interpolates rates between time steps, and reports time series for each zone. Source code for MOD2BUD is provided in the data release for this report (J ackson and Halford, 2020). 


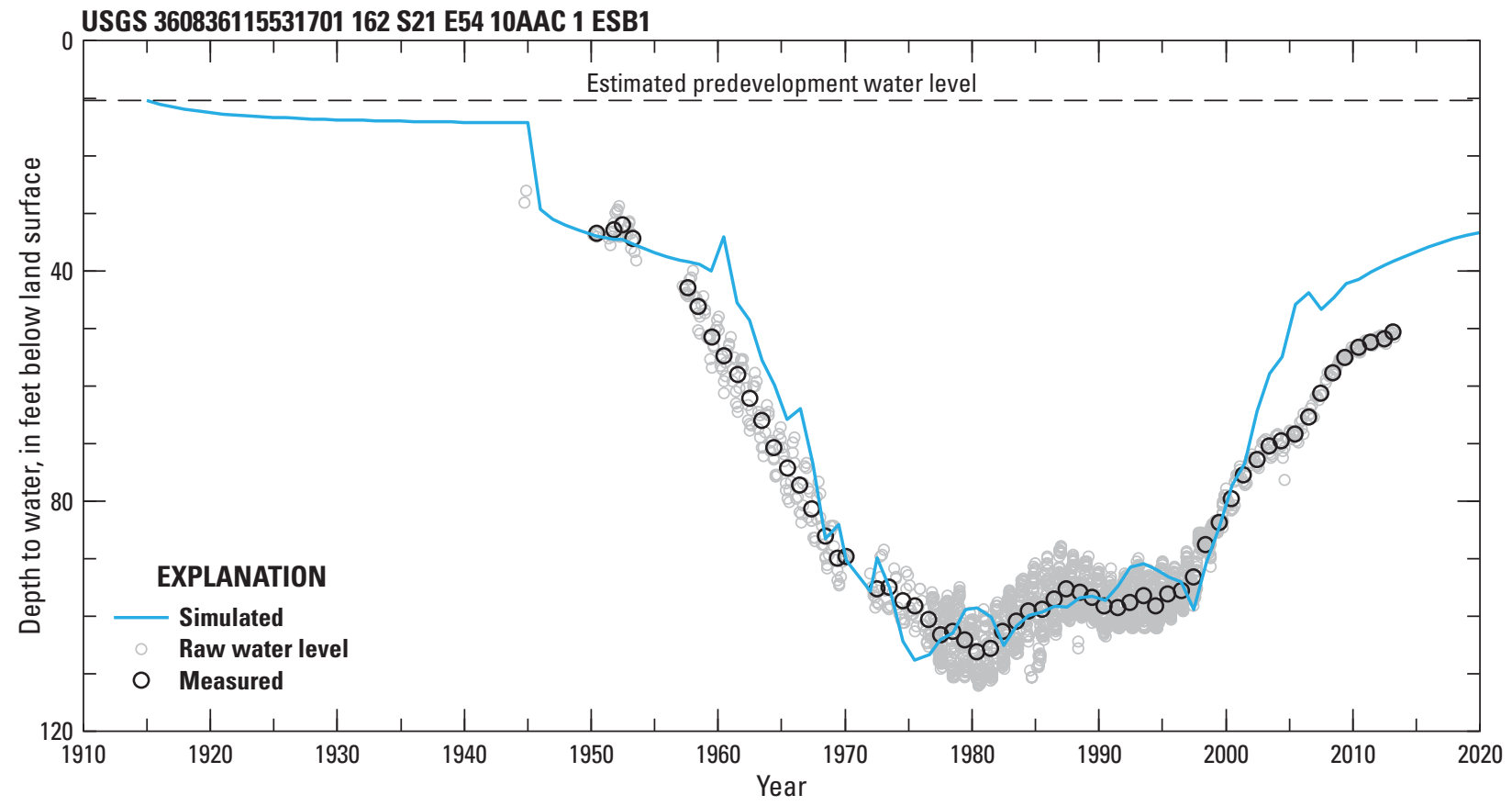

Figure 51. "Raw" water-level measurements, measured water levels, which are annual averages of measured waterlevel data during an annual stress period, and simulated water levels in well ESB1, Nevada, 1910-2020.
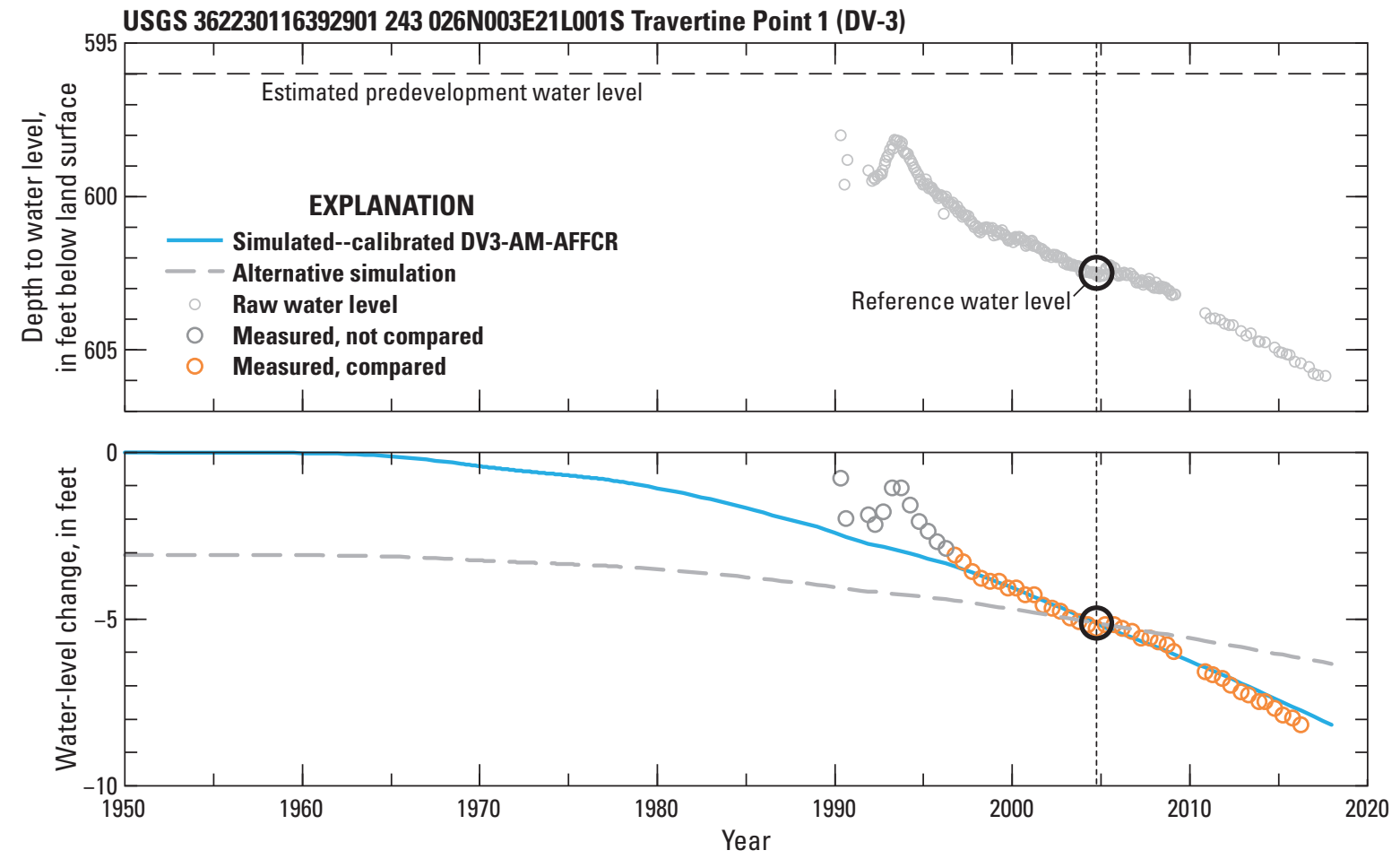

Figure 52. "Raw" water-level measurements, measured (average) water-level changes, and simulated water-level changes in terms of depth to water level (top graph) and water-level change (bottom graph), at well Travertine Point 1, California, 1950-2018. DV3-AM-AFFCR, Death Valley version 3 model simulating groundwater development in the Ash Meadows, Alkali Flat-Furnace Creek Ranch, and Pahute Mesa-Oasis Valley groundwater basins. 


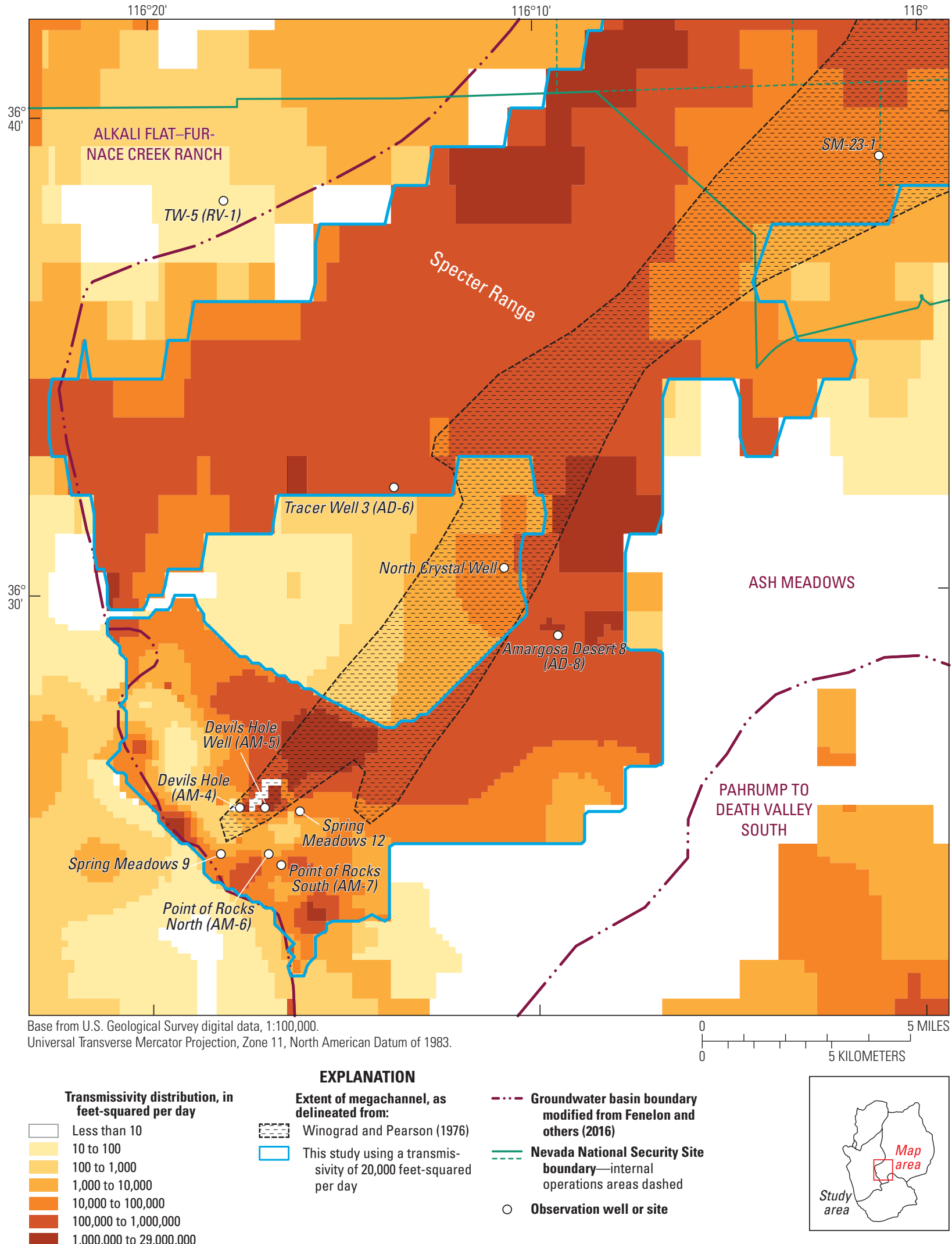

Figure 53. Estimated transmissivity distribution from integrated Death Valley version 3 model, extent of megachannel, and wells with measured water levels noticeably affected by natural fluctuations from recharge, Nevada National Security Site and vicinity, Nevada. 


\section{Well ER-6-1-2 main Multiple-Well Aquifer Test- DV3-ER612 Model}

Drawdowns from the well ER-6-1-2 main MWAT differed from water-level changes during groundwater development because drawdowns were attributed exclusively to pumping in well ER-6-1-2 main. This was possible because estimates of these drawdowns in observation wells were isolated from other water-level changes using water-level models (Halford and others, 2012). Water-level models removed effects of barometric and Earth tidal fluctuations, and effects of pumping from wells $W W-C-1$ and Army $1 W W$ from measured water levels (Jackson and Halford, 2019). Estimated drawdowns solely were from pumping of well ER-6-1-2 main. Drawdowns from the MWAT could be isolated because they were not correlated with water-level changes from all other stresses.

Long-term trends in observation wells were not accounted for, but minimally affected drawdown estimates from the well ER-6-1-2 main MWAT. Effects of long-term trends were minimal because less than 1 year of water-level record was analyzed for each well, except in Tracer Well 3. Long-term trends were not estimated with water-level models because background water levels were unavailable. Long-term rising trends in wells ER-7-1 and ER-3-1-2 (shallow) were both an increase of $0.07 \mathrm{ft} / \mathrm{yr}$. These trends equate to rises of $0.04 \mathrm{ft}$ during the period of analysis, which are small relative to draw downs greater than $0.3 \mathrm{ft}$ in these wells (J ackson and Halford, 2019). The long-term trend in Tracer Well 3 was less than a 0.02-ft increase during 2004. Removing the long-term trend would increase the maximum drawdown in Tracer Well 3 by less than $0.01 \mathrm{ft}$, which equals the root-mean-square (RM S) error in the drawdown estimates (J ackson and Halford, 2019).

\section{Regularization Observations}

Tikhonov regularization informed parameters insensitive to measurement observations (Doherty, 2010a). Parameters were values of hydraulic conductivity (foot per day), specific yield (decimal percent), specific storage (1 per foot), and recharge rate (foot per day) at pilot points.

Tikhonov regularization observations were equations that defined either a preferred value at a pilot point or a preferred relation between pilot points. In the preferred-value approach, a single equation is provided for each adjustable parameter (pilot point) that equates the parameter to the preferred value. Preferred relations between pilot points were specified as ratios of preferred (or expected) values between pilot points, which guided relative differences rather than absolute values. For example, preferred hydraulic conductivities of 0.3 and 30 $\mathrm{ft} / \mathrm{d}$ at two pilot points would specify a preferred ratio of 100 . Hydraulic-conductivity estimates of 5 and $500 \mathrm{ft} / \mathrm{d}$ at the two pilot points would perfectly agree with the preferred relation because the ratio is 100 .

If the preferred relation is homogeneity, then pilot points within a zone are assigned the same initial preferred value and the preferred ratio between pilot points is 1 . By invoking homogeneity, Tikhonov regularization limits differences between pilot points by penalizing sharp differences, and thereby ensuring relatively continuous distributions (Doherty and Johnston, 2003). Contrasts within hydrogeologic units and recharge zones were penalized minimally in areas where data informed the objective function.

The preferred relation between pilot points for the recharge distribution was ratios of the conceptual average annual recharge (fig. 16). Initial recharge estimates at pilot points were sampled from the conceptual recharge distribution (fig. 16). Recharge rates were estimated independently at all pilot points, but preferred ratios of conceptual recharge rates did not change between pilot points during calibration. A maximum of 30,000 regularization observations initially constrained recharge estimates with these preferred relations.

For each hydrogeologic unit, zones of conceptualized homogeneous transmissivity were the preferred relation between pilot points for hydraulic-conductivity distributions. Preferred hydraulic conductivity equaled preferred transmissivity of a zone divided by thickness of the hydrogeologic unit at a pilot point. For example, conceptual transmissivity of shallow carbonate rocks was distributed with homogeneous zones (fig. 43). Simulated hydraulic conductivities were interpolated smoothly between zones throughout each hydrogeologic unit because zones of homogeneity were speculative. Homogeneous transmissivity zones were incorporated as regularization observations instead of as parameters, so transmissivity in a hydrogeologic unit could differ where dictated by measurement observations. About 30,000 regularization observations constrained hydraulic-conductivity estimates with these preferred relations.

Homogeneity was the preferred relation between pilot points for specific yield and specific storage. Preferred values of specific yield for basin fill and consolidated rocks were 0.1 and 0.02 , respectively. Preferred values of specific storage were $2 \times 10^{-6} 1 / \mathrm{ft}$. About 2,000 regularization observations constrained specific-yield and specific-storage values with these preferred relations.

Regularization observations were weighted so that preferred relations were emphasized where measurement observations were few. Regularization observations were weighted relative to separation distances between pilot points and the nearest measurement sites. Regularization-observation weights between pilot-point pairs were equal to 1 where the distance between the two pilot points was less than the separation between a measured water level and the nearest pilot point. Weights between pilot-point pairs decreased as the distance between the pilot points was more than the distance between a measured water level and the nearest of the two pilot points. Distances between measurement sites were less than 1 mi through Pahute M esa, Rainier M esa, Y ucca Flat, Oasis Valley, Yucca M ountain, Frenchman Flat, the central A margosa D esert, A sh M eadows discharge area, and Pahrump Valley, and exceeded $10 \mathrm{mi}$ in northern Three Lakes Valley and the Black M ountains (fig. 46). 
U nrealistic hydraulic-property distributions were avoided partially by preventing overfitting of measurement observations (Fienen and others, 2009). Goodness-of-fit was limited so that the weighted, sum-of-squares error could not be reduced to less than irreducible measurement and numerical model errors. This expected measurement error is a weighted, sum-of-squares error and is the variable PHIMLIM in a PEST control file (Doherty, 2010a). A PHIMLIM of 8,000,000 $\mathrm{ft}^{2}$ was specified, which is equivalent to an RMS error of about 50 $\mathrm{ft}$ for water-level measurements and approximates the average allowable misfit between the simulated and measured water level at each well.

\section{Goodness of Fit}

Goodness of fit was evaluated with scatter plots, a map of residuals (simulated minus measured), water-level profiles, hydrographs, and hydraulic-property distributions. Steady-state calibration primarily was evaluated with scatter plots of simulated and measured water-level altitudes and transmissivities. A map of predevelopment (steady-state) water-level residuals identified systematic spatial biases. Agreement between vertical and lateral gradients was checked with profiles of measured and simulated water levels. Calibration of groundwater-development and MWAT models was evaluated by agreement between measured and simulated hydrographs of water-level changes in each well. Calibration of groundwater-development models also was evaluated by agreement between measured and simulated changes in spring discharges from pumping (table 9). Major hydrologic features have been identified in conceptual models from water-level profiles, hydrographs, transmissivity estimates, and a refined hydrogeologic framework. Simulation of these hydrologic features was evaluated qualitatively by comparing measured water-level profiles and hydrographs to simulated equivalents and examining simulated hydraulic-property distributions.

\section{Predevelopment Observations}

Simulated water levels compare favorably to measured water levels in the DV3-SS model (fig. 54). Average and RMS water-level errors of +1 and $49 \mathrm{ft}$, respectively, are not large relative to the $8,800-\mathrm{ft}$ range of measured water levels (fig. 54). Measured water-level altitudes range from -281 to $8,504 \mathrm{ft}$ in Death Valley playa and the Spring M ountains, respectively. Differences between simulated and measured water levels from the DV3-SS model have been reduced by about a factor of 5, compared to the DVRFS.v2 model (fig. 54).

Water-level residuals show little spatial pattern of significance, suggesting a good overall fit between simulated and measured water levels (fig. 55). Water-level residuals average about $20 \mathrm{ft}$ in transmissive areas such as Jackass
Flats, the central A margosa D esert, A sh M eadows discharge area, Furnace C reek area, and northern Pahrump Valley. Water-level residuals exceed $100 \mathrm{ft}$ in high-altitude, highrelief, low-transmissivity areas such as Eleana Range, Groom Range, Sheep Range, and Spring Mountains. These residuals are interspersed positive and negative values that exhibit little spatial bias (fig. 55). Water-level residuals of more than 100 $\mathrm{ft}$ are expected in high-relief areas because simulated water levels are very sensitive to small amounts of recharge across low-permeability rocks, land-surface altitudes span more than $500 \mathrm{ft}$ across these model cells, and the simulated water levels computed at cell centers are averages that are being compared to average land-surface altitudes across the model cell.

Spring-pool altitudes are underestimated and overestimated at perched springs in Groom Range, Sheep Range, and Spring M ountains, whereas nearby water-table altitude observations are overestimated (above land surface) (fig. 55). This occurred because land-surface altitudes span more than $500 \mathrm{ft}$ across these model cells, water-table observations have disproportionate sensitivity, and recharge pilot points did not coincide with the locations of watertable observations. Water-table observations are inequalities, where water-table altitudes can be only overestimated because the altitudes were set equal to land surface for each optimization iteration if the water table was below land surface. This means that the water-table residual can be $0 \mathrm{ft}$ after the first optimization iteration and $500 \mathrm{ft}$ after the next iteration. The simulated water table is very sensitive to small changes in recharge in these areas of low-permeability rock, but parameter estimation only can "see" the parameters that overestimate the water table. Because recharge pilot points did not coincide with water-table observations, reductions or additions of recharge at pilot points lowered or raised the simulated water table near these spring pools while attempting to lower the water table at the water-table observations. Future modeling efforts should ensure that recharge pilot points and water-table observations occur at the same locations.

Simulated water levels in ET areas were within $50 \mathrm{ft}$ of measured values at 86 percent of the sites. Spatial patterns generally were absent in simulated water levels in these ET areas, except in the A sh $\mathrm{M}$ eadows discharge area, Chicago Valley, and north and east of Tecopa (fig. 55). Simulated water levels in ET areas ranged from 50 to $60 \mathrm{ft}$ greater than measured values in the Ash Meadows discharge area. Future modeling efforts should focus on better calibration to remove the spatial bias in the A sh M eadows discharge area. Simulated water levels are overestimated and underestimated in northern and southern Chicago Valley. Simulated water levels are underestimated east of Tecopa and overestimated north of Tecopa. Measured and simulated spring-pool altitudes differ by less than $30 \mathrm{ft}$ around Tecopa (fig. 55). Spatial biases in Chicago Valley and near Tecopa are structural model errors that cannot be resolved with the limited data available. 


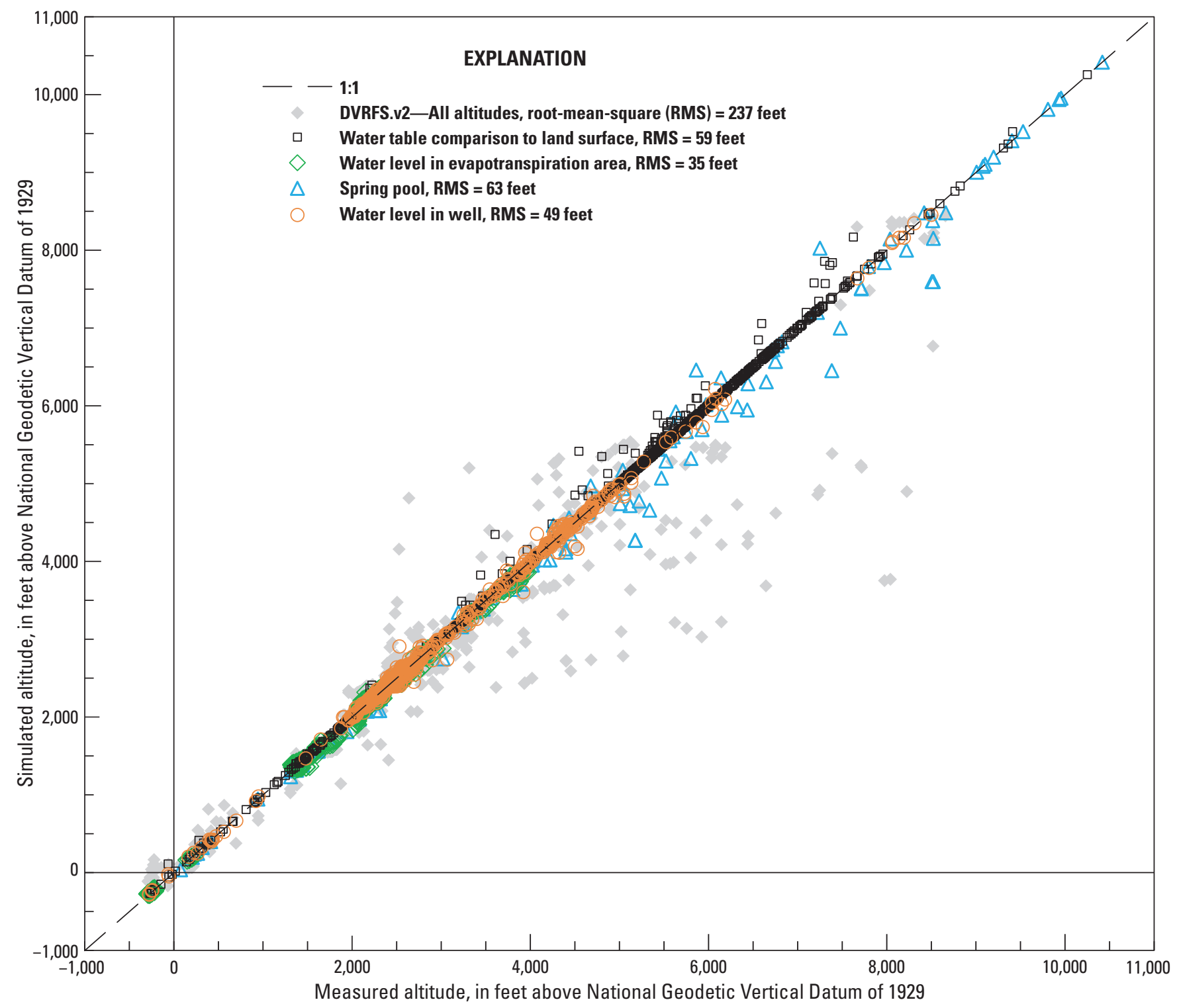

Figure 54. Comparison of measured and simulated water-level altitudes from the calibrated Death Valley Regional Flow System version 2 model (DVRFS.v2) and Death Valley version 3 steady-state model (DV3-SS), in the study area, Nevada and California. Measured observations include estimated land-surface altitudes, estimated water-level altitudes in evapotranspiration areas, spring-pool altitudes, and measured water levels in wells. The four types of observations are combined from the DVRFS.v2 model and shown as one symbol. 


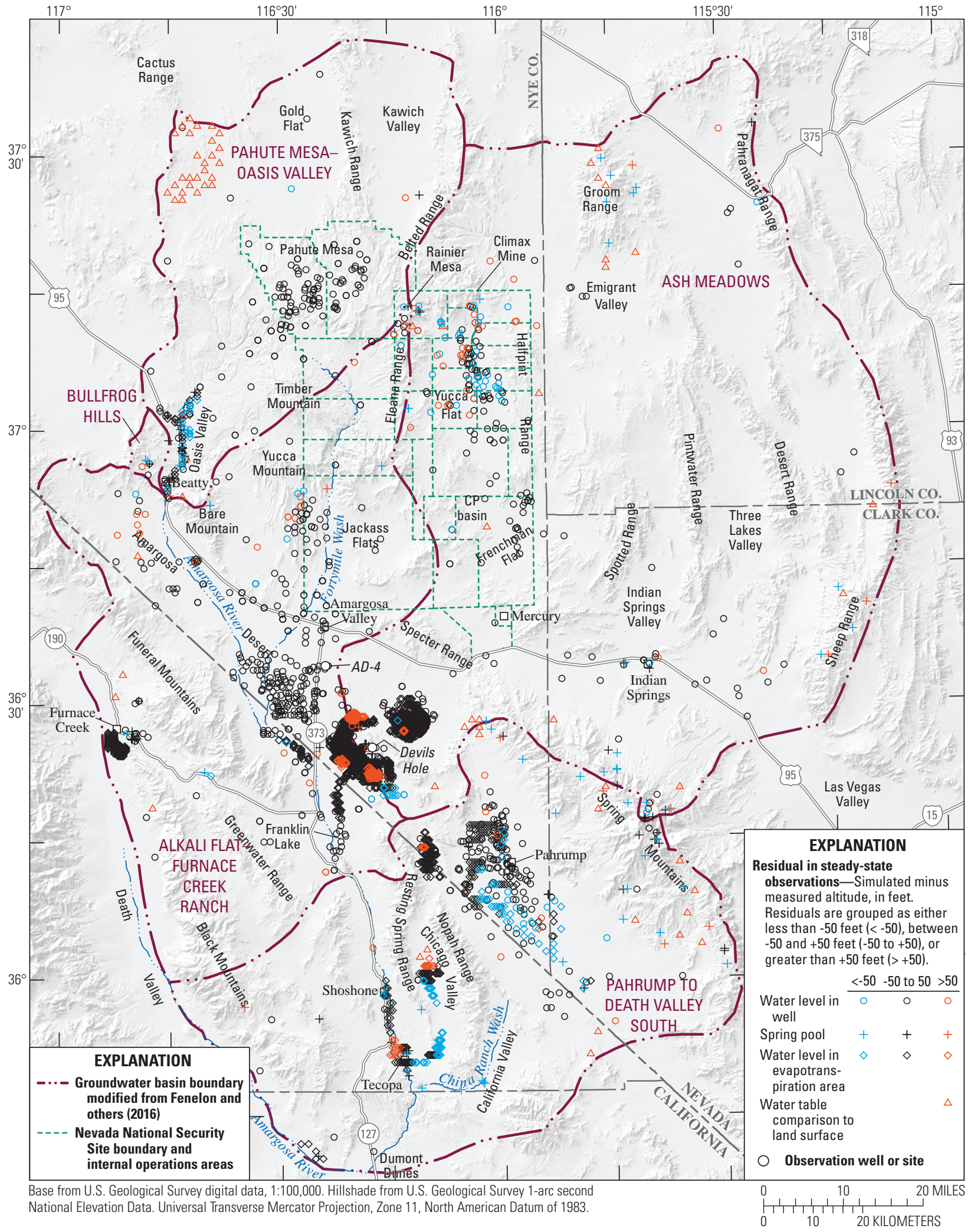

Figure 55. Steady-state water-level altitude residuals in the Death Valley version 3 steady-state model (DV3-SS), in the study area, Nevada and California. 
Simulated and measured transmissivities generally agree, with 76 percent of sites within the 95-percent confidence interval (fig. 56). Simulated and measured transmissivities geometrically average 440 and $650 \mathrm{ft}^{2} / \mathrm{d}$, respectively. The log standard deviation of residuals from all observations of aquifer-test transmissivity, which excludes specific-capacity estimates, is 0.9 or a multiplier of 8 . Simulated transmissivities range from $6 \times 10^{-4}$ to $1 \times 10^{6} \mathrm{ft}^{2} / \mathrm{d}$, or nine orders of magnitude. This is similar to measured transmissivities that range from $2 \times 10^{-5}$ to $4 \times 10^{5} \mathrm{ft}^{2} / \mathrm{d}, 10$ orders of magnitude. Simulated transmissivities from the DV3-SS model agree with aquifer-test results an order of magnitude better than simulated transmissivities from the DVRFS.v2 model.

Simulated predevelopment discharge estimates totaled 54,700 acre-ft, which agree with expected discharge estimates from 53,600 to 54,900 acre-ft/yr (table 4). Simulated and measured discharges agree in rate and location because 52,500 acre-ft/yr or 97 percent, was specified. The remainder of discharges that were simulated with specified heads agreed with measured discharges or were within estimated ranges (table 11). South of Tecopa was the location of the greatest discharge simulated with a specified head in the DV3-SS model, where measured and simulated discharges were 1,100 and 1,000 acre-ft/yr, respectively.

\section{Groundwater-Development Observations}

Calibration of groundwater-development models primarily was evaluated with hydrographs and mapped extents of simulated drawdown. Differences between simulated and measured water-level changes in hydrographs were the quantitative measure of model fit. Measured and simulated hydrographs also were examined qualitatively for agreement between trends. M apped extents of simulated drawdown (fig. 57) were compared to areas that were affected by groundwater development (figs. 29 and 32). Comparisons between previously estimated and simulated extents were necessarily qualitative but provided a useful guide for consistency between numerical and conceptual models of groundwater flow.

Measured and simulated water-level declines in the central A margosa Desert pumping center closely match, with RM S errors of $3 \mathrm{ft}$ (fig. 58). Measured water-level declines in well $A D-5$ were replicated closely except for the steeper measured declines after 2010. Departure between simulated and measured water-level changes could have resulted from erroneous pumping estimates or from effects of dewatering the basin fill that were not simulated. Unknown rates of pumping during 2011-18 were assumed equal to pumping estimates for 2010 (fig. 30). Transmissivity near well $A D-5$ likely is decreasing as basin fill is desaturated, but this process was not simulated. Potential desaturation seems a more likely reason for the poor fit at well $A D-5$, given consistent agreement between measured and simulated levels in TG Well and other wells where cumulative water-level declines were less than 30 $\mathrm{ft}$ (fig. 58). Simulated and measured water-level declines agree within carbonate wells Inyo-BLM 1 (fig. 58C) and Travertine Point 1 (fig. 52), which are 7 and $15 \mathrm{mi}$, respectively, from maximum simulated draw down in the central A margosa Desert (fig. 57). Hydrograph fits improved with RMS errors of less than $1 \mathrm{ft}$ as observation wells were more distant from pumping wells. This was because water levels were affected less by seasonal pumping and assignment of pumping well locations.

M easured and simulated hydrographs agree from wells at the perimeter of the area affected by the central Amargosa Desert pumping, with RM S errors of 0.05- $0.5 \mathrm{ft}$ (fig. 59). Simulated water-level declines in well $A D-1$ agree with the measured decline from 1990-2018. The simulated rate of water-level decline in well NC-EWDP-Washburn-1X (deep) is about 20 percent steeper than the measured decline from 2000-2015. A steeper simulated trend is conceptually acceptable because rising water-level trends exist in wells north of well NC-EWDP-Washburn-1X (deep). Naturally rising trends in these wells likely mask the northern extent of the area affected by pumping in the central Amargosa Desert (fig. 57). Slight declines were measured and simulated in wells DVJ-02 and WRPMW-4 along the southern and western extents, respectively, of the area affected by pumping in the central A margosa Desert (fig. 59). Water-levels in well $W R P M W-4$ also were affected by local pumping in the Furnace Creek area that began during 2009 and a recharge event in 2010 (fig. 59D). Both regional and local pumping effects are simulated correctly (fig. 59).

Measured and simulated water-level trends in Pahrump Valley match, with RM S errors of 5-10 ft in hydrographs near pumping wells. Misfits increased with proximity to assigned pumping wells, as observed in wells $G S A, S D 2$, and $J A W$ that were less than $1,1.5$, and $5 \mathrm{mi}$, respectively, from the nearest pumping well (fig. 60). Misfits were less than $1 \mathrm{ft}$ in well $J A W$, which was farthest from pumping wells. Near the center of pumping, fits between measured and simulated water-level changes were sufficiently close relative to measured changes in excess of $80 \mathrm{ft}$, such as was observed in well ESB1 (fig. 51).

$B$ etter agreement exists betw een simulated and measured water levels in the central Amargosa Desert (fig. 58), compared to Pahrump Valley (fig. 60). Differences in model fit between pumping centers possibly were caused by differences in estimated pumping in the central Amargosa Desert and Pahrump Valley. About 30 percent of the volume pumped in Pahrump Valley occurred prior to the first pumpage inventory of Pahrump Valley in 1959 (Nevada Division of Water Resources, 2018). M ultiyear periods of estimated uniform pumping indicate uncertainty of pumping estimates from Pahrump Valley prior to 1959 (fig. 30). Pumpage from the central Amargosa Desert was inventoried intermittently from 1965-1983 and verified with imagery after 1973 (Moreo and others, 2003). Pumpage was inventoried consistently in the study area after 1984, when pumping from the central A margosa Desert increased generally and Pahrump Valley decreased (fig. 30). 


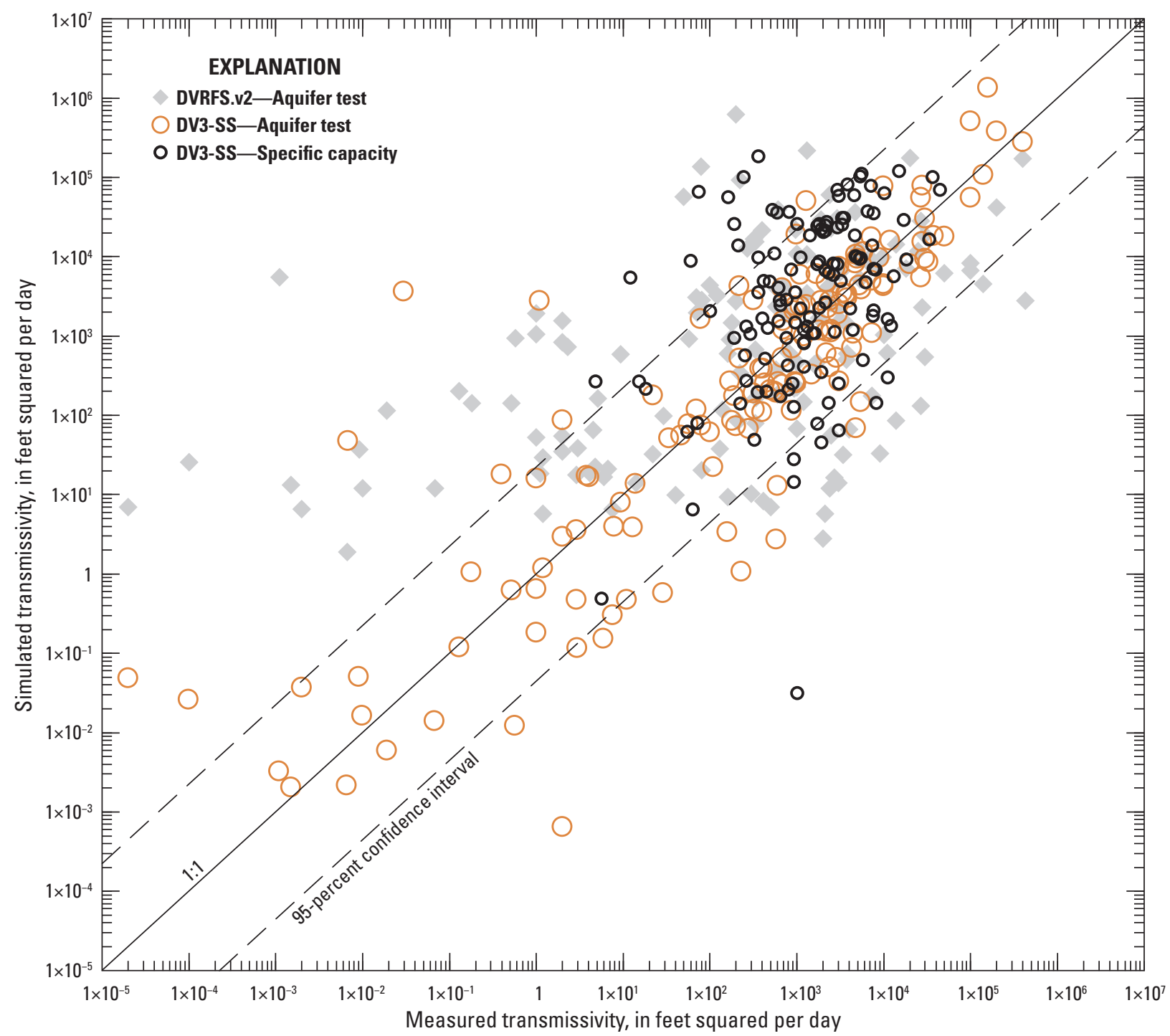

Figure 56. Comparison of simulated and measured transmissivities from the Death Valley Regional Flow System version 2 model (DVRFS.v2) and Death Valley version 3 steady-state model (DV3-SS), in the study area, Nevada and California. 


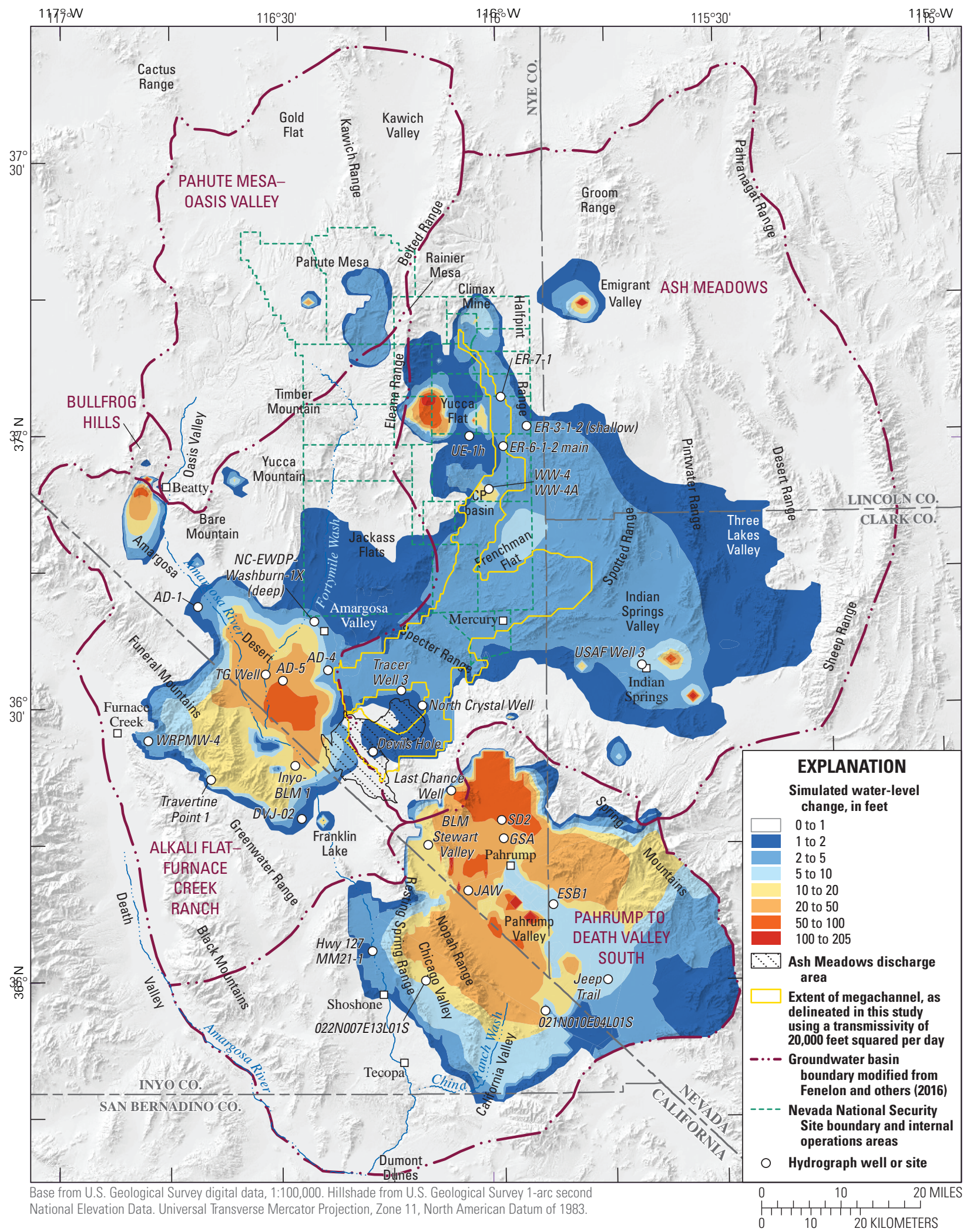

Figure 57. Maximum simulated drawdown and selected observation sites with hydrographs shown in this report, in the study area, Nevada and California, 2018. 
A. USGS 363310116294001230 S16 E49 18DCCA1 USBLM Well (AD-5)

Simulated predevelopment depth to water is $\mathbf{1 0 0}$ feet below land surface

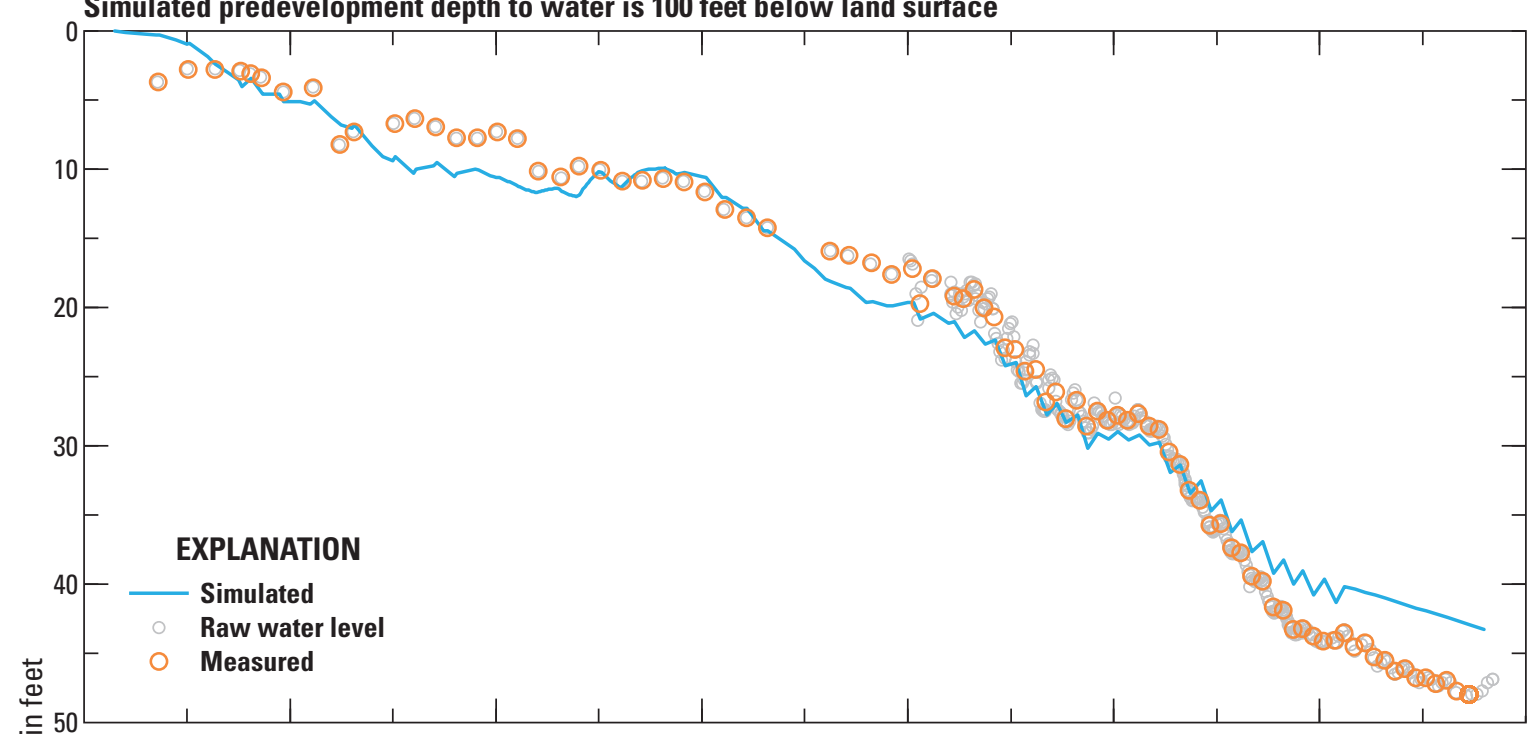

B. USGS 363346116322801230 S16 E48 14BAAA1 TG Well

Simulated predevelopment depth to water is 98 feet below land surface

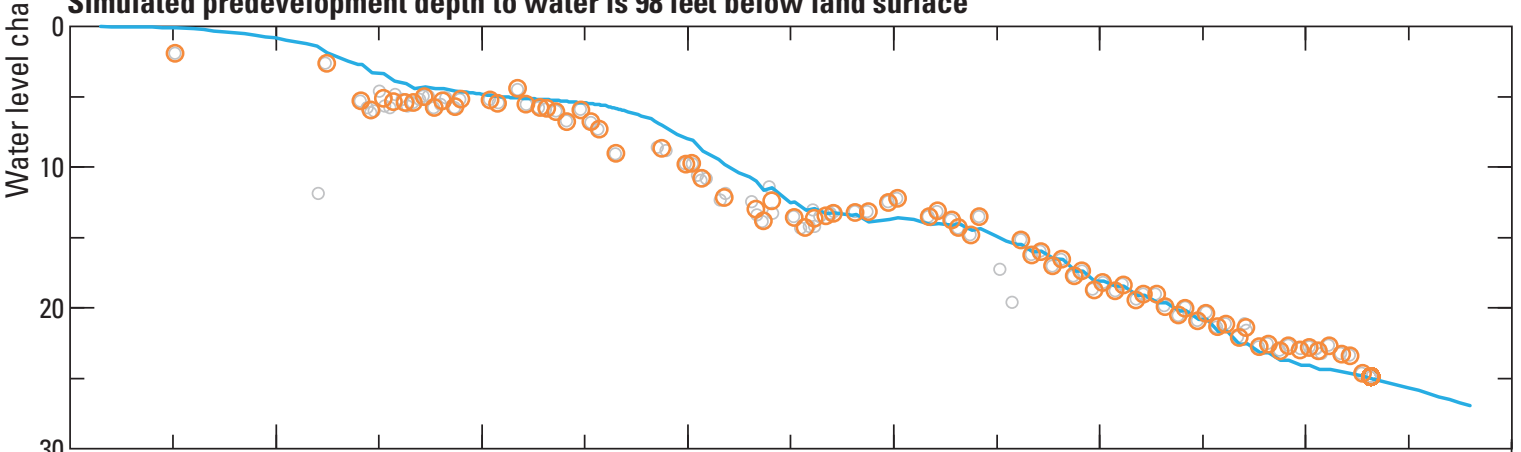

C. USGS 362402116280901230 026N005E07R001S Inyo-BLM 1

Simulated predevelopment depth to water is 79 feet below land surface

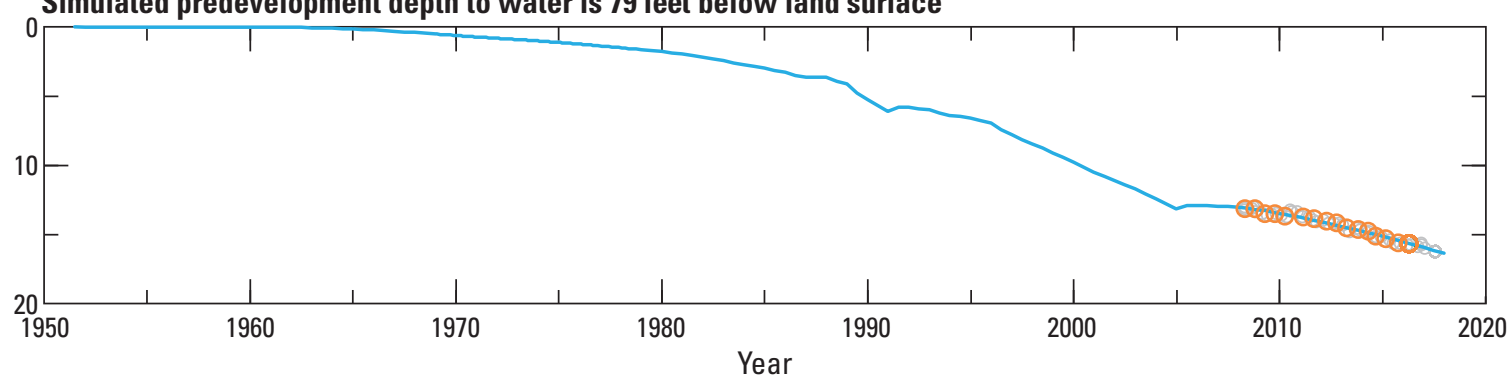

Figure 58. "Raw" water-level measurements and simulated and measured (average) water-level declines in wells $A D-5(A), T G W e / l(B)$, and Inyo-BLM $1(C)$, in the central Amargosa Desert, Nevada and California, 1950-2018. 
A. USGS 364141116351401230 S14 E47 32DA 1 NA-6 Well BGMW-10 (AD-1)

Simulated predevelopment depth to water is 269 feet below land surface

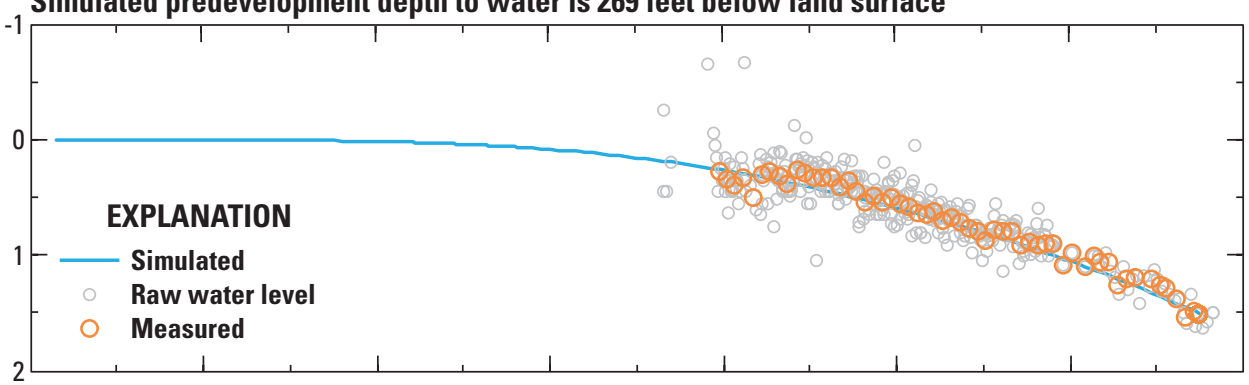

B. USGS 363951116252402 227A S15 E49 11ACD 2 NC-EWDP-Washburn-1X (deep)

Simulated predevelopment depth to water is 356 feet below land surface

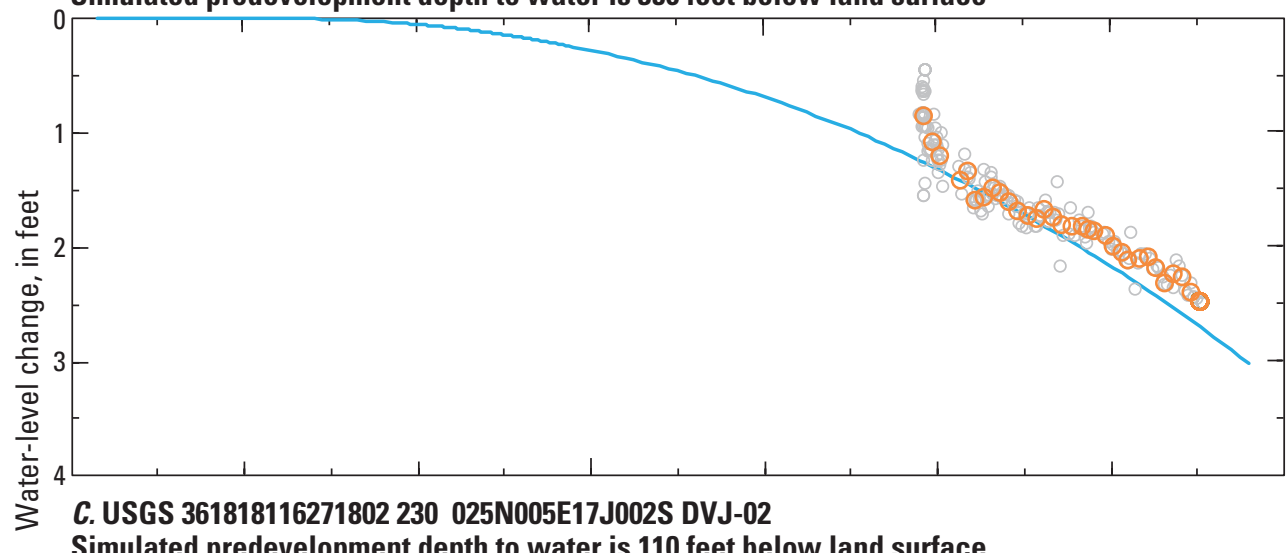

Simulated predevelopment depth to water is 110 feet below land surface

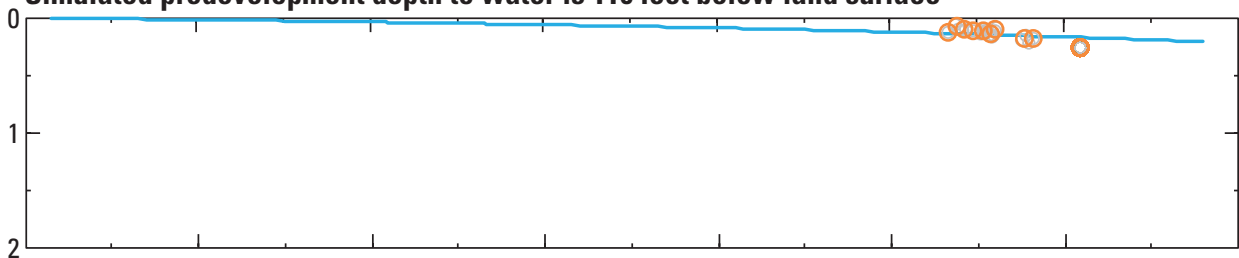

D. USGS 362646116480401243 027N002E190001S WRPMW-4

Simulated predevelopment depth to water is 352 feet below land surface

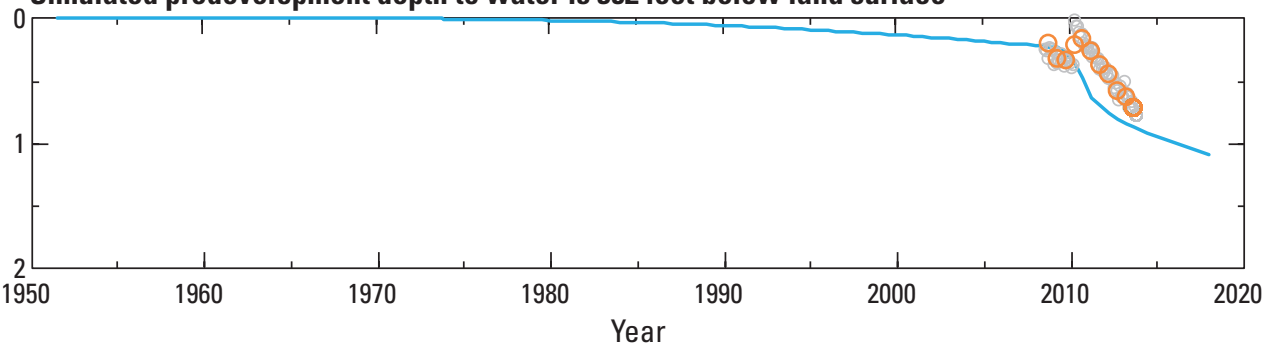

Figure 59. "Raw" water-level measurements and simulated and measured (average) water-level declines in wells $A D-1(A), N C$-EWDP-Washburn-1X (deep) (B), DVJ-02 (C), and WRPMW-4 $(D)$ that result from pumping in the central Amargosa Desert, Nevada and California, 1950-2018. 
A. USGS 361554115595501162 S19 E53 27DD 1 GSA

Simulated predevelopment depth to water is 30 feet below land surface
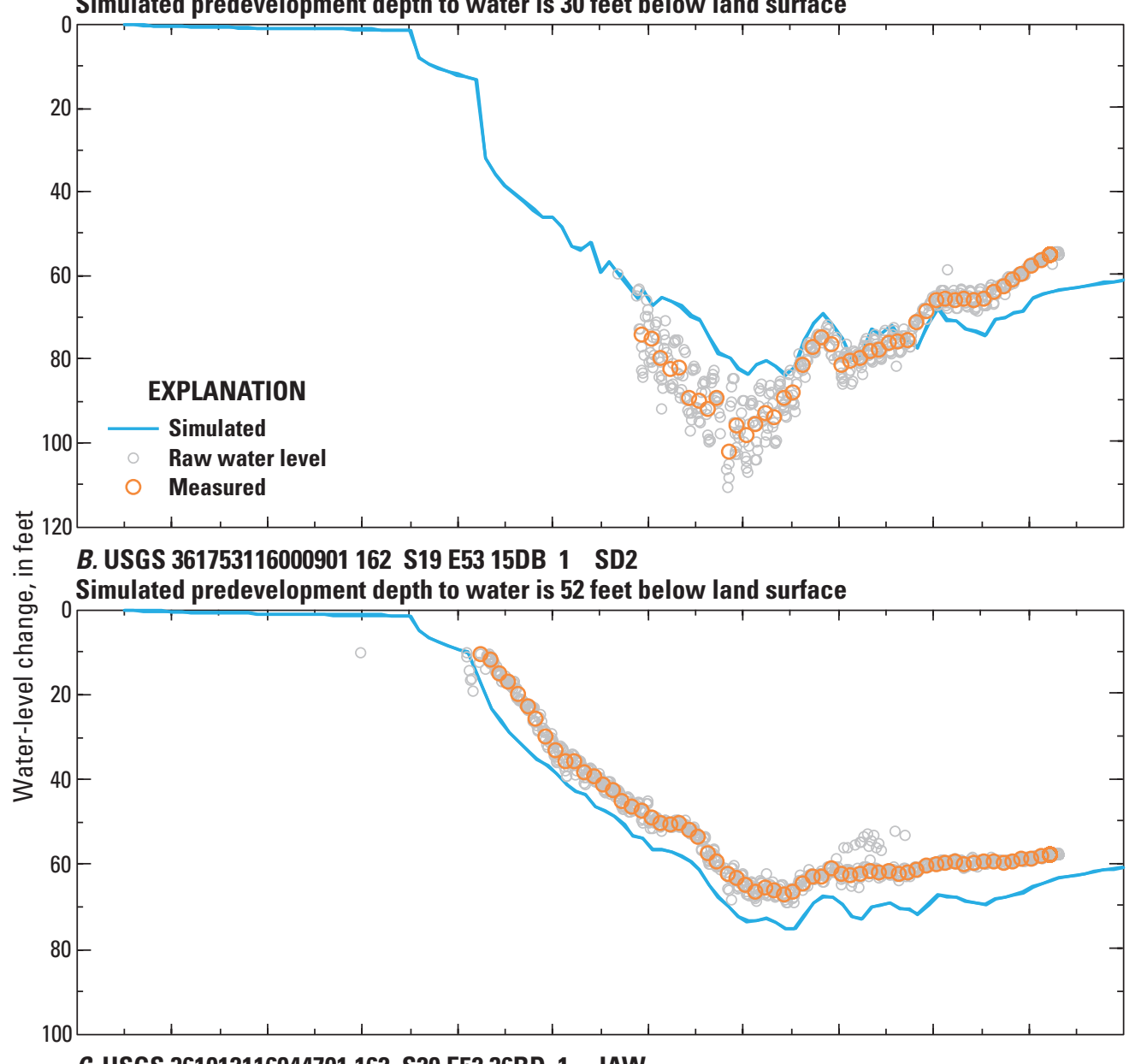

C. USGS 361012116044701162 S20 E52 36BD 1 JAW

Simulated predevelopment depth to water is 24 feet below land surface

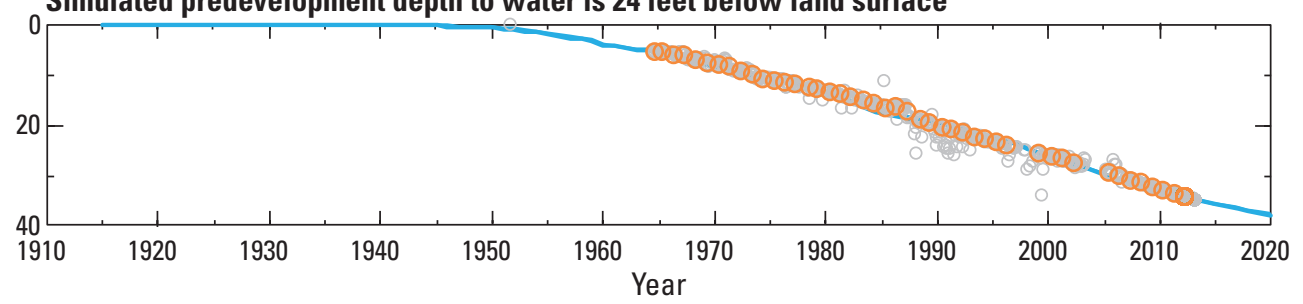

Figure 60. "Raw" water-level measurements and simulated and measured (average) water levels in wells $G S A(A), S D 2(B)$, and JAW $(C)$, in Pahrump Valley, Nevada, 1910-2020. 
M easured and simulated hydrographs agree from wells at the perimeter of the area affected by Pahrump Valley pumping, with RM S errors between 0.1 and $1 \mathrm{ft}$ (fig. 61). M easured water levels consistently declined from 2005 to 2015, with total declines of 3.3 and $2.5 \mathrm{ft}$ in wells BLM Stewart Valley Well and Last Chance Well, respectively. Measured waterlevel decline and recovery of $15 \mathrm{ft}$ were matched within $1 \mathrm{ft}$ in well Jeep Trail (fig. 61). Water levels were not measured from 1976 to 2004 in well Jeep Trail, but the pattern of simulated water levels declining gradually and recovering rapidly after 1997 is similar to the measured water-level trend in well ESB1 (fig. 51). Simulated and measured water-level declines from 1959 to 1975 were both $13 \mathrm{ft}$ in well 021N010E04L01S, which was the southernmost well in Pahurmp Valley with water-level data (fig. 57). Simulated and measured water-level declines from 2005 to 2015 were both $0.6 \mathrm{ft}$ in well Hwy 127 MM21-1, west of the Amargosa River.

$M$ easured and simulated discharges from Bennetts and Manse Springs compare favorably, but goodness of fit is more qualitative (fig. 62). A 2,400 acre-ft/yr (3.3 ft3/s) increase in discharge from Bennetts Spring between 1927 and 1937 suggests an undocumented alteration occurred. The orifice of Bennetts Spring was cleaned and deepened in 1941 and discharge increased 1,400 acre-ft/yr (2 ft³/s) (Harrill, 1986). Simulating these alterations would require estimating multiple pool altitudes and drain conductances that the available dataset cannot reasonably inform. Simulated discharges from both Bennetts and Manse Springs were sensitive to poorly known pumping rates and locations (fig. 62). Pahrump Valley spring observations accordingly were weighted less than other observation groups and contributed less than 1 percent of the error in the objective function (table 10).

Measured and simulated water-level trends in wells near isolated pumping centers agree but measured water levels are noisier (fig. 63). RMS errors approach cumulative waterlevel declines. These water levels were measured less than $1 \mathrm{mi}$ from the pumping well or in the pumped well itself. For example, wells $W W-4$ and $W W-4 A$ are $1,200 \mathrm{ft}$ apart and pumped alternately for water supply in CP basin (fig. 57). Measured water levels frequently are recovering from recent pumping, where pumping and recovery cause water levels to be 10 s of feet lower than the long-term water-level trend (fig. 63). The long-term declining trend in well $W W-4$ is caused by the slow dewatering of basin fill in CP basin (fig. 63). Head losses in the well from periods of pumping and recovery were not simulated, but yearly changes have been matched. Similar noise exists near other isolated pumping centers, such as in well USAF Well 3 in Indian Springs (fig. 63).

Estimated specific-yield and specific-storage distributions are better informed when more information is available. Specific-yield estimates of basin fill in the central Amargosa Desert and Pahrump Valley ranged from 0.1 to 0.3 (fig. 64). Specific yields less than 0.05 generally were estimated where consolidated rocks occurred at the water table. Storage coefficients (specific storage times thickness of layers 2-6) generally ranged from 0.0001 to 0.01 , where estimable (fig. 65). Storage coefficients exceeded 0.01 in Pahrump Valley, where specific-storage estimates were constrained by an upper limit of $1 \times 10^{-5} 1 / \mathrm{ft}$ and basin fill was thicker than $1,000 \mathrm{ft}$.

Overestimated specific yields and storage coefficients in Pahrump Valley are compensating errors that likely resulted from not explicitly simulating subsidence. Thick clay sequences occur in the basin fill of Pahrump Valley. These clays have compacted inelastically in response to declining water levels, which resulted in land subsidence (Harrill, 1986, p. 11). Inelastic specific storages of $4 \times 10^{-5}$ to $1 \times 10^{-3} 1 / \mathrm{ft}$ have been estimated for similar clays in Las Vegas Valley (Harrill, 1976; Pavelko, 2004). Overestimating a storage coefficient by 0.1 would be similar to explicitly simulating a $500-\mathrm{ft}$ thick clay with an inelastic specific storage of $2 \times 10^{-4} 1 / \mathrm{ft}$.

\section{Well ER-6-1-2 main Multiple-Well Aquifer Test}

Heterogeneous transmissivity and specific-yield distributions in shallow carbonate rocks beneath Yucca Flat were required to match drawdowns from the well ER-6-1-2 main MWAT within the limits of measurement uncertainty. A maximum drawdown of $1.9 \mathrm{ft}$ was estimated in well ER-7-1 (fig. 66), with little attenuation or delay, $6 \mathrm{mi}$ north of well ER-6-1-2 main (fig. 47). M aximum draw down was limited to less than $0.3 \mathrm{ft}$ in well ER-3-1-2 (shallow) (fig. 66), $4 \mathrm{mi}$ northeast of well ER-6-1-2 main (fig. 47). Pumping 75 million gallons from well ER-6-1-2 main did not affect water levels in well $U E-1 h$ (fig. 67), about 4 mi west of well ER-6-1-2 main (fig. 47). Drawdowns in wells ER-7-1, ER-3-1-2 (shallow), and $U E-1 h$ are consistent with a north-south trending corridor of transmissive, shallow carbonate rocks that are bounded on the east and west by low-transmissivity rocks (fig. 68).

Lack of draw down in shallow carbonate rocks in western Yucca Flat was replicated in the DV 3-ER 612 model. M easured and simulated drawdowns in well $U E-1 h$ indicate no response to pumping well ER-6-1-2 main, where the RM S error of 0.01 $\mathrm{ft}$ can be attributed entirely to drawdown-estimation error (fig. 67). Lack of drawdown was created by the juxtaposition of high-transmissivity carbonate rocks near well ER-6-1-2 main, with low-transmissivity volcanic-sedimentary rocks and underlying deep carbonate rocks at well UE- $1 h$.

M easurable draw downs in Tracer Well 3 (fig. 67), which are caused by pumping well ER-6-1-2 main (fig. 68), indicate that a hydraulic connection exists between Yucca Flat and Tracer Well 3. This hydraulic connection has been reproduced plausibly because simulated and measured drawdowns in Tracer Well 3 agree with an RM S error of $0.01 \mathrm{ft}$ (fig. 67). A high-transmissivity corridor extending from Yucca Flat to the A sh M eadows discharge area was conceptual ized to exist to better simulate draw downs in Tracer Well 3, more than $33 \mathrm{mi}$ from pumping well ER-6-1-2 main (fig. 68). This estimated high-transmissivity corridor is a consistent extension of the previously postulated megachannel (fig. 68; Winograd and Pearson, 1976). 
A. USGS 361515116100901162 S19 E52 $31 \quad 1$ BLM Stewart Valley Well Simulated predevelopment depth to water is 27 feet below land surface

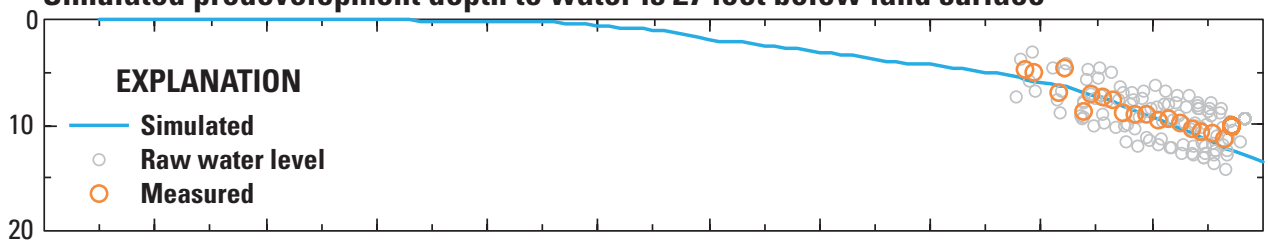

B. USGS 362111116070101230 S18 E52 27CDC 1 Last Chance Well

Simulated predevelopment depth to water is 541 feet below land surface

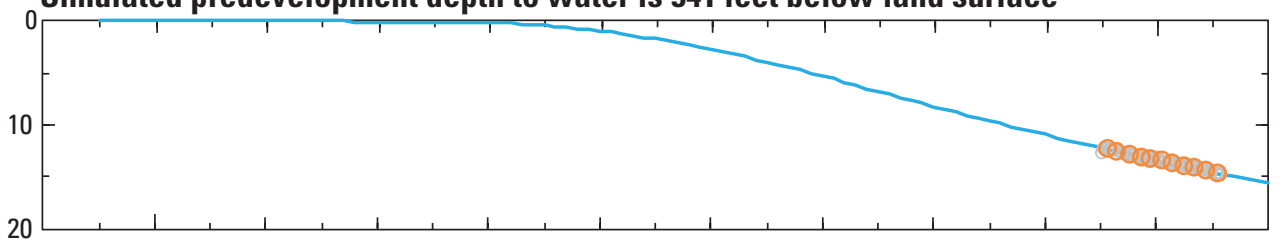

C. USGS 360017115460401162 S22 E55 26DBCA1 JEEP TRAIL

Simulated predevelopment depth to water is 144 feet below land surface

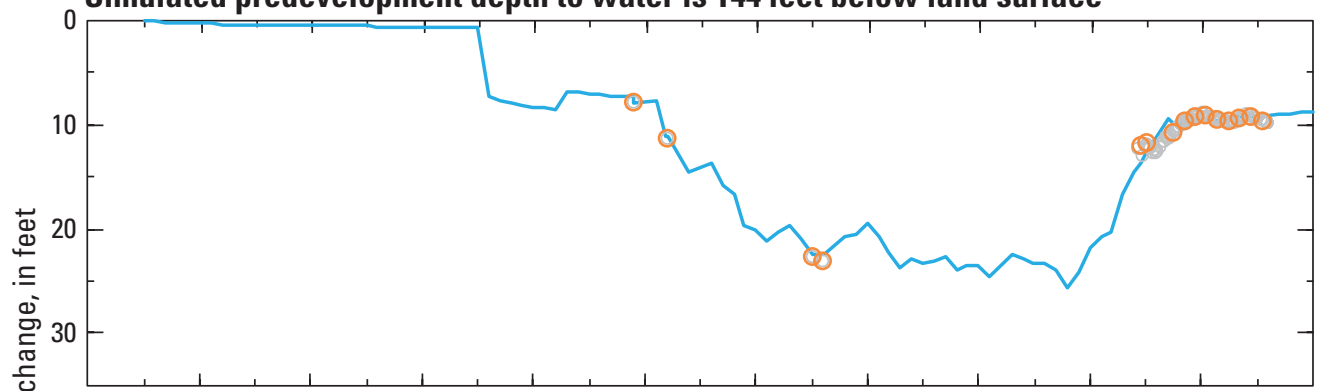

D. USGS 355655115543101162 021N010E04L01S

Simulated predevelopment depth to water is 157 feet below land surface

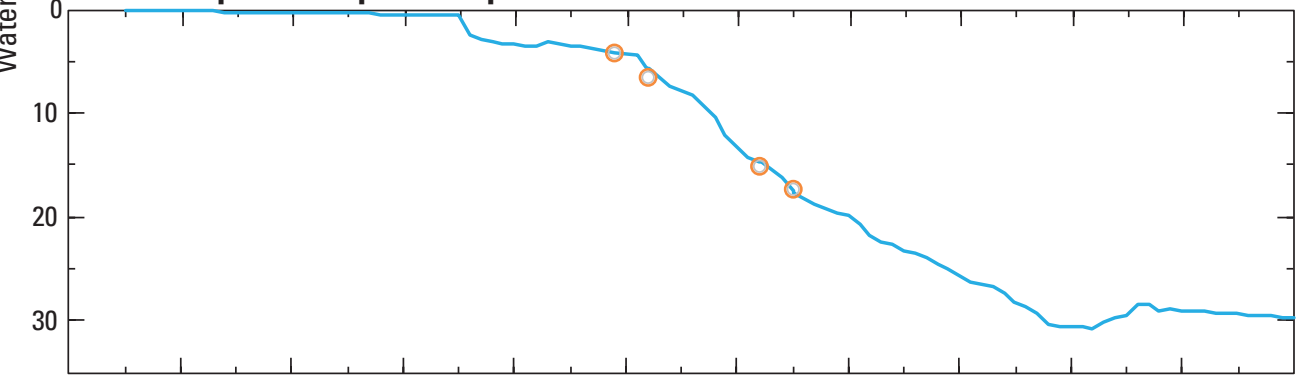

E. USGS 360020116103701240 022N007E13L01S

Simulated predevelopment depth to water is 17 feet below land surface

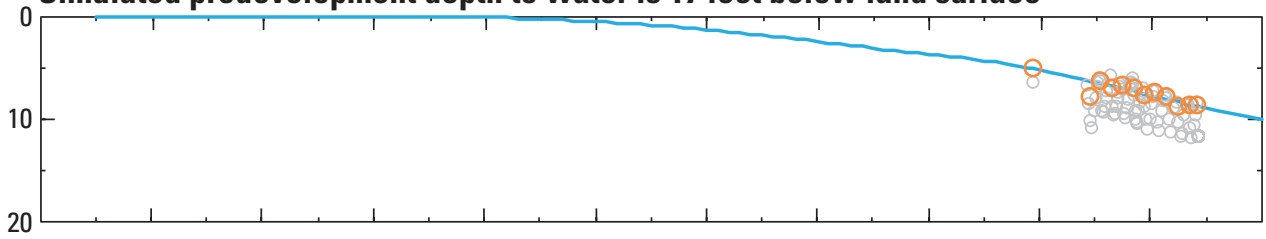

F. USGS 360337116175101 Hwy 127 MM21-1

Simulated predevelopment depth to water is 84 feet below land surface

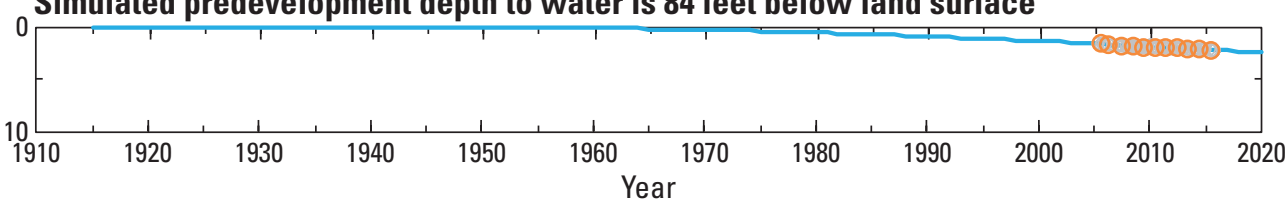

Figure 61. "Raw" water-level measurements and simulated and measured (average) waterlevel changes in wells BLM Stewart Valley Well $(A)$, Last Chance Well(B), Jeep Trail (C), 021N010E04LO1S (D), 022N007E13L01S (E), and Hwy 127 MM21-1 (F) that result from pumping in Pahrump Valley, in the study area, Nevada and California, 1910-2020. 


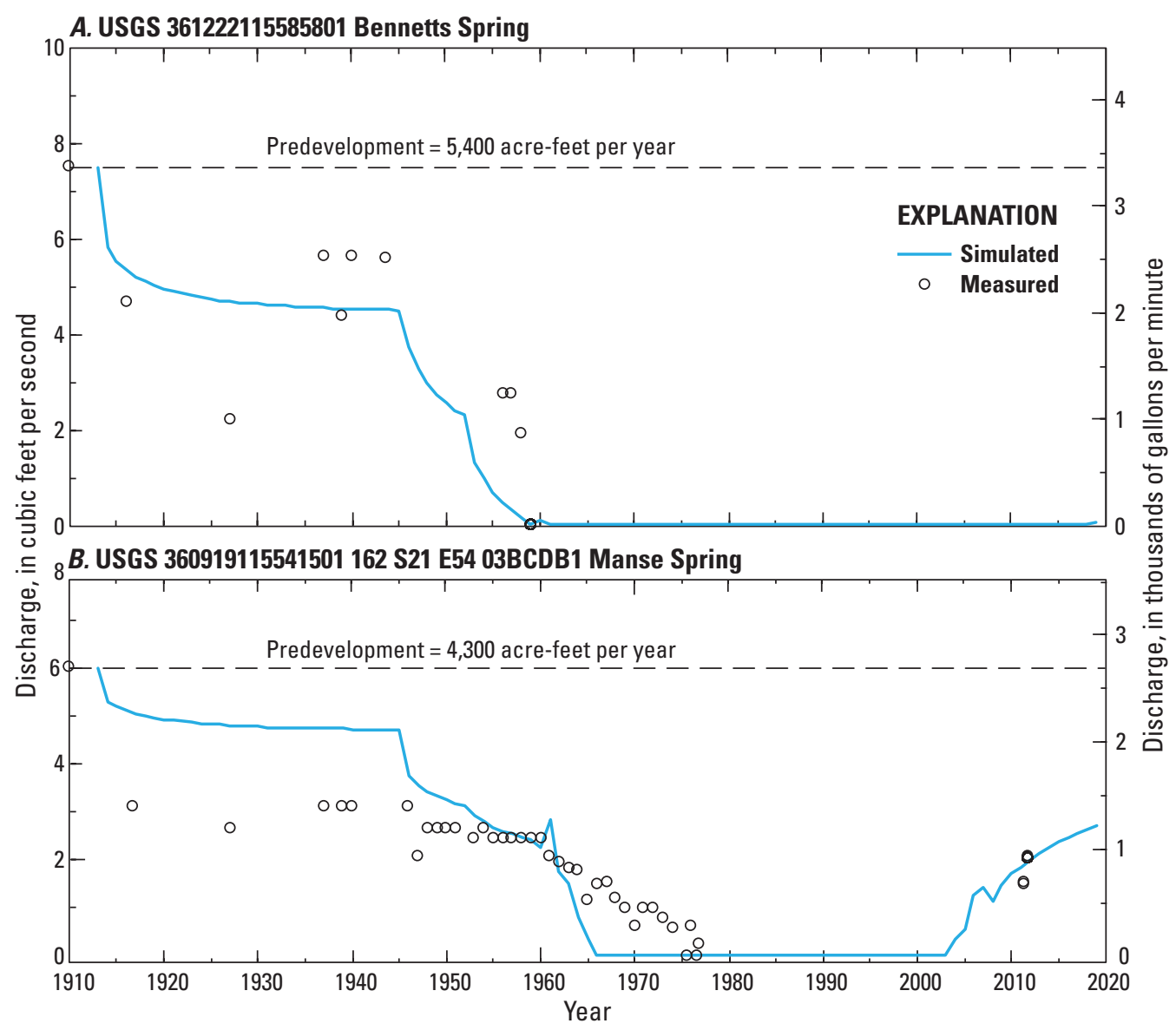

Figure 62. Comparison of simulated and measured discharges from Bennetts $(A)$ and Manse $(B)$ Springs, Pahrump Valley, Nevada, 1910-2018. 


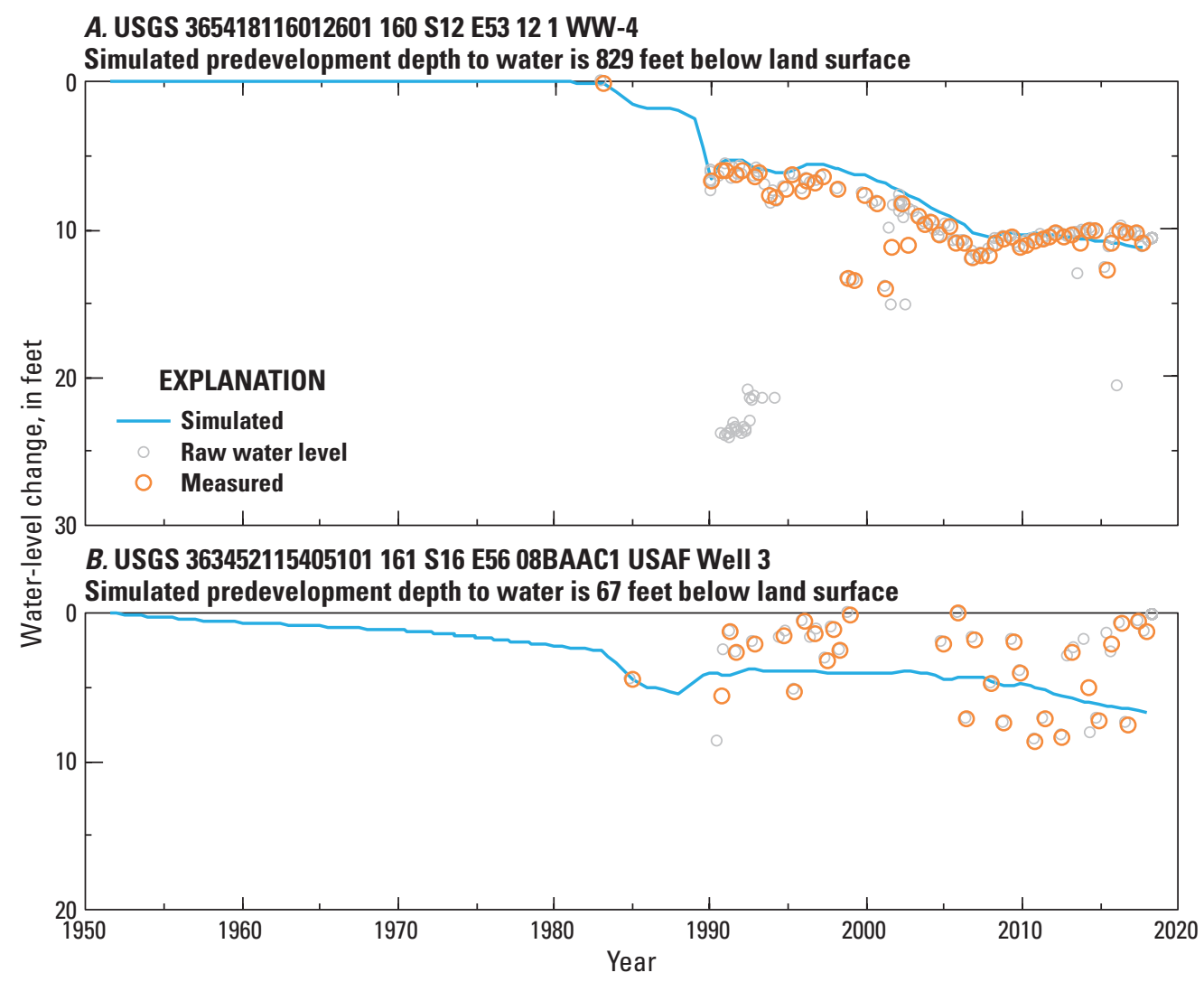

Figure 63. "Raw" water-level measurements and simulated and measured (average) waterlevel changes in well WW-4 in CP basin $(A)$, and USAF Well 3 in Indian Springs $(B)$, Nevada, 1950-2018. 


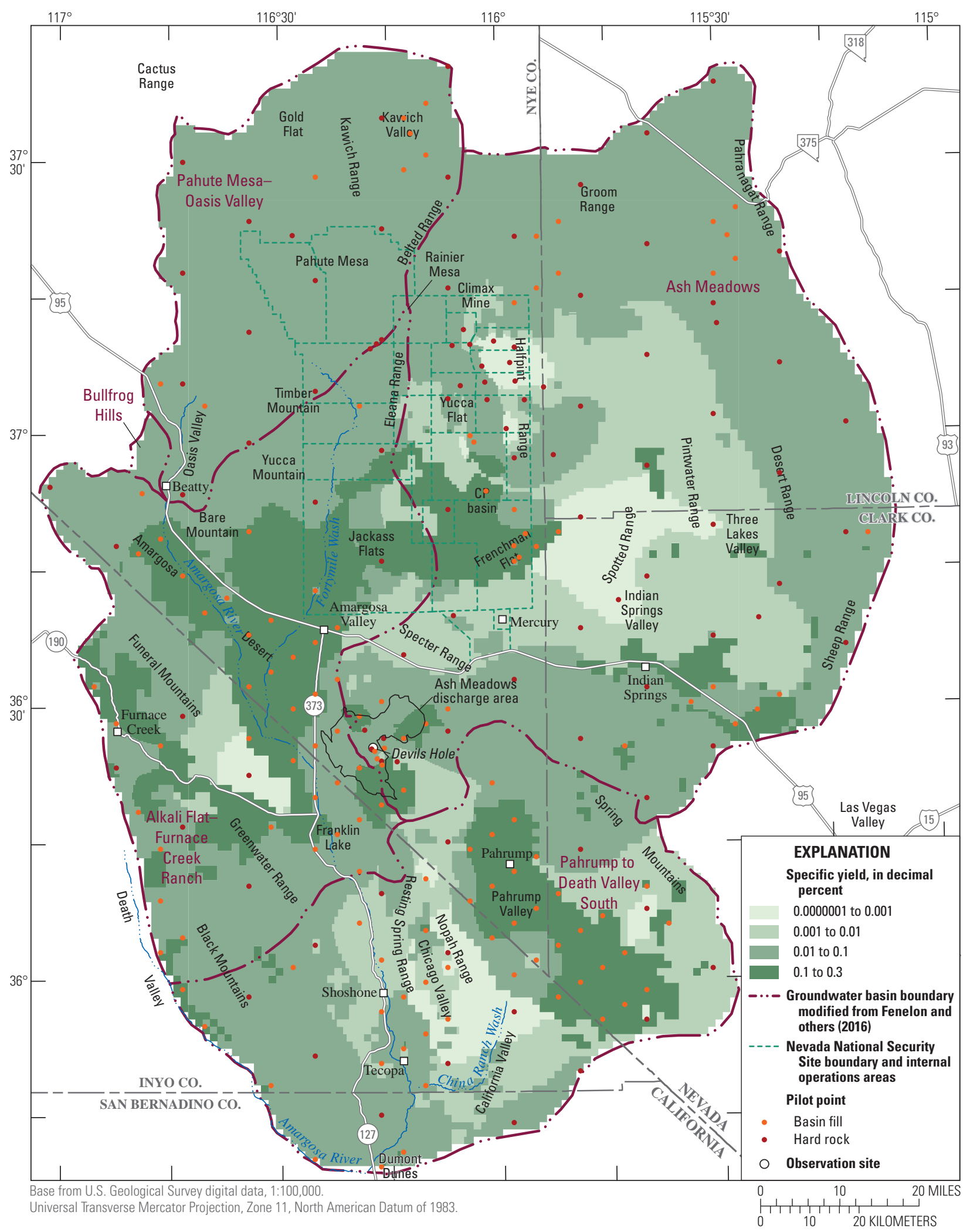

Figure 64. Estimated specific-yield distribution and pilot points from integrated Death Valley version 3 model, in the study area, Nevada and California. 


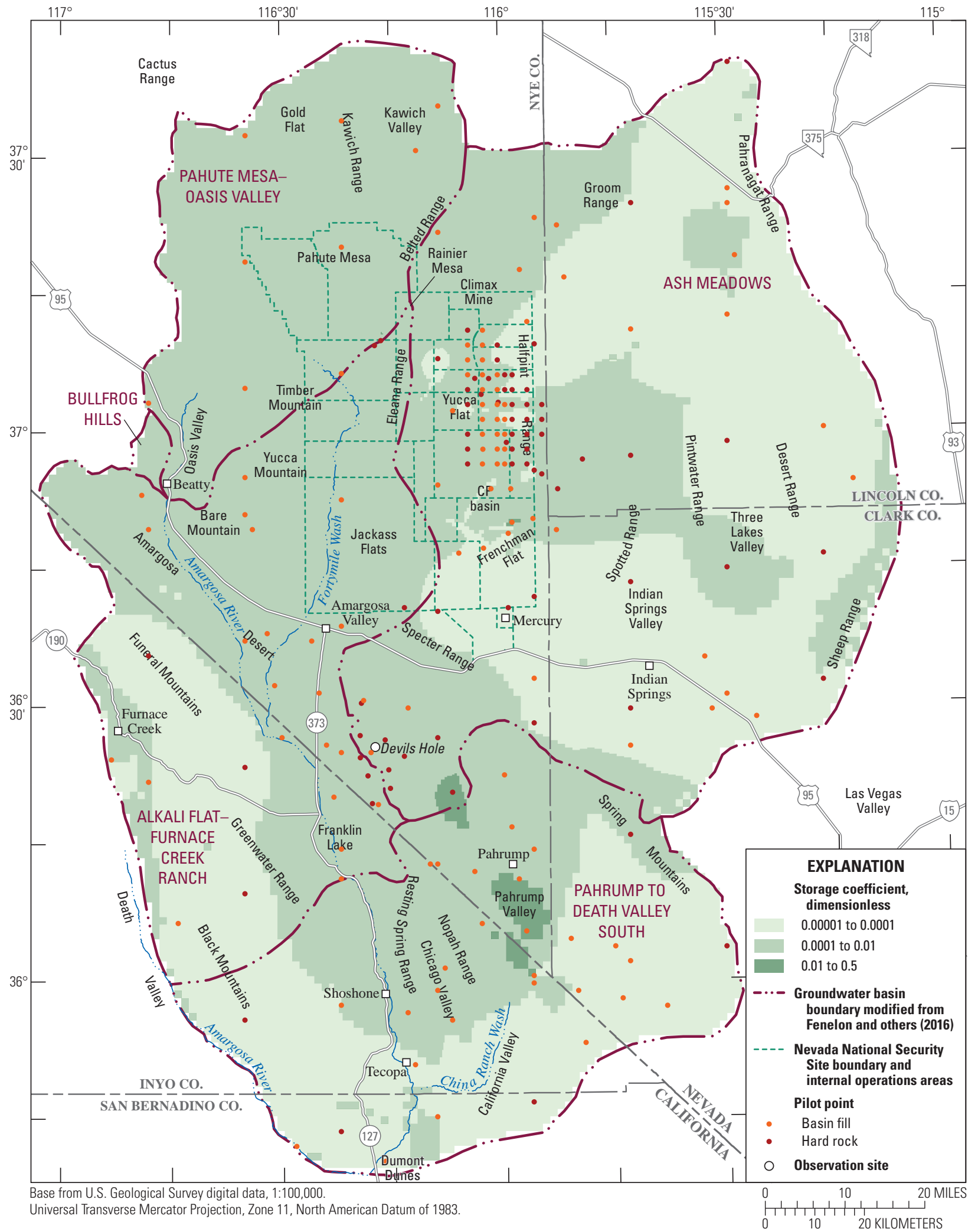

Figure 65. Estimated storage-coefficient distribution, which is specific storage times thickness of model layers 2-6, and pilot points from integrated Death Valley version 3 model, in the study area, Nevada and California. 


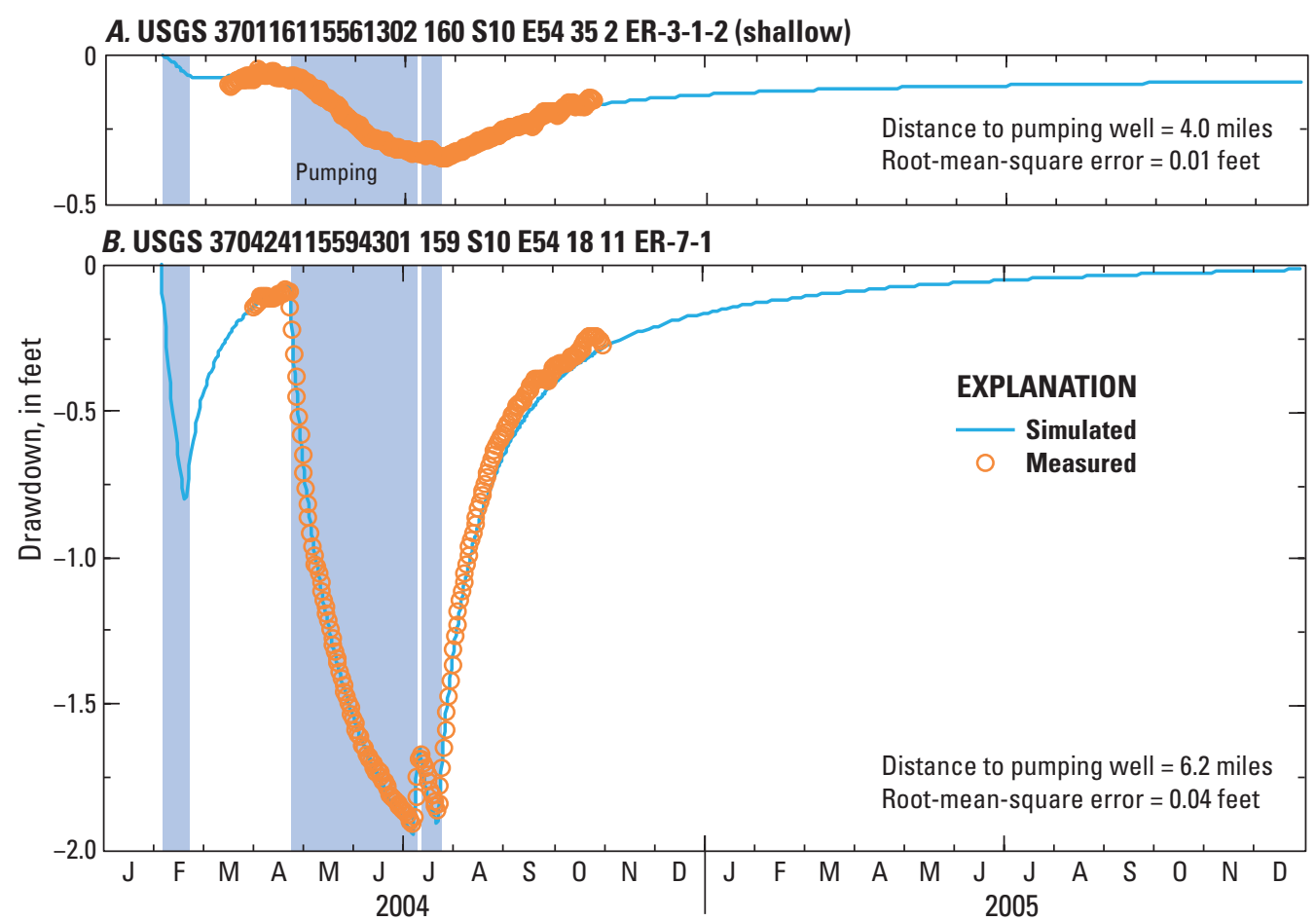

Figure 66. Periods when well ER-6-1-2 main pumped; simulated drawdowns from Death Valley version 3 model simulating pumping during the ER-6-1-2 main multiple-well aquifer test (DV3-ER612); and measured drawdowns, which were estimated from water-level models (Jackson and Halford, 2019), in wells ER-3-1-2 (shallow) (A), and ER-7-1 (B), Nevada, 2004-05.

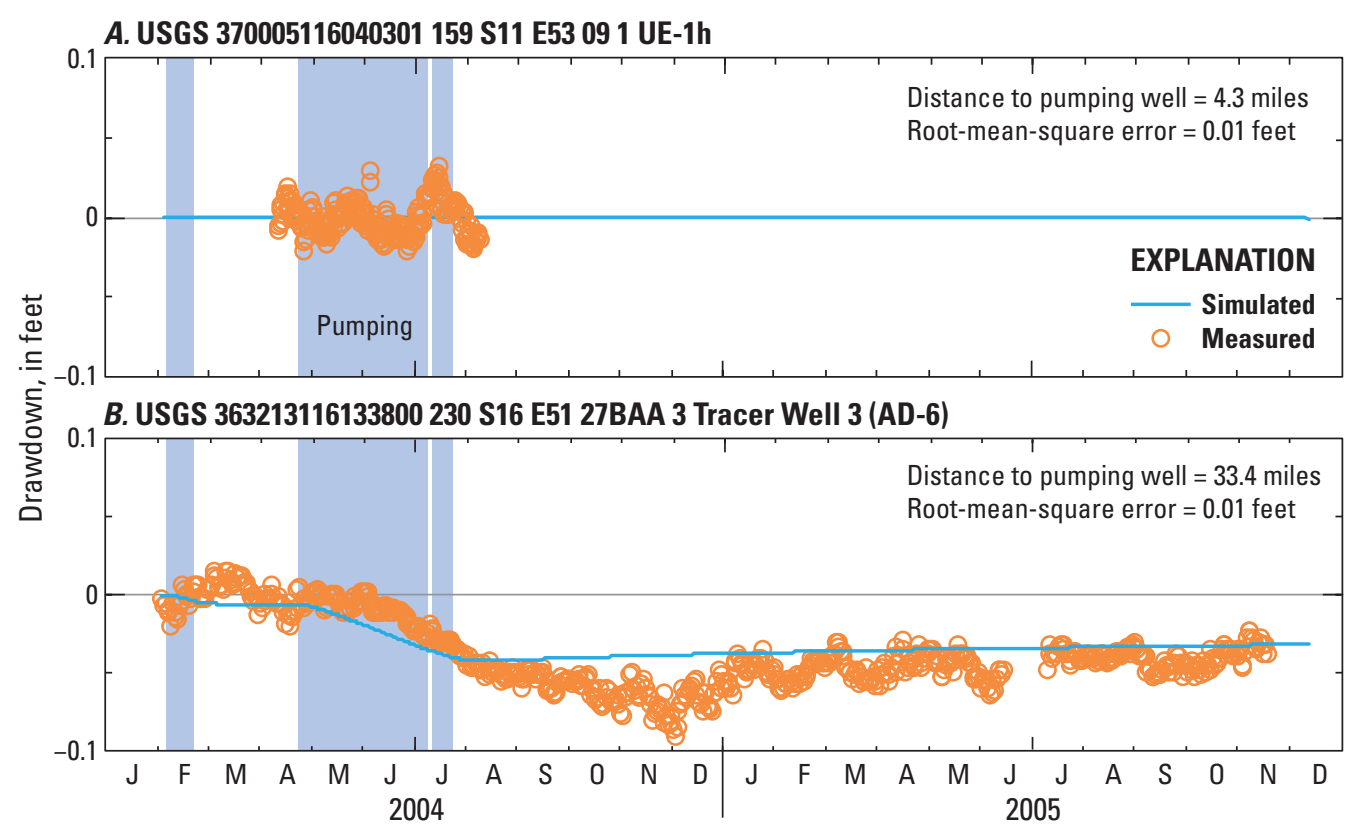

Figure 67. Periods when well ER-6-1-2 main pumped; simulated drawdowns from Death Valley version 3 model simulating pumping during the ER-6-1-2 main multiple-well aquifer test (DV3-ER612); and measured drawdowns, which were estimated from water-level models (Jackson and Halford, 2019), in wells UE-1h(A), and Tracer Well 3(B), Nevada, 2004-05. 


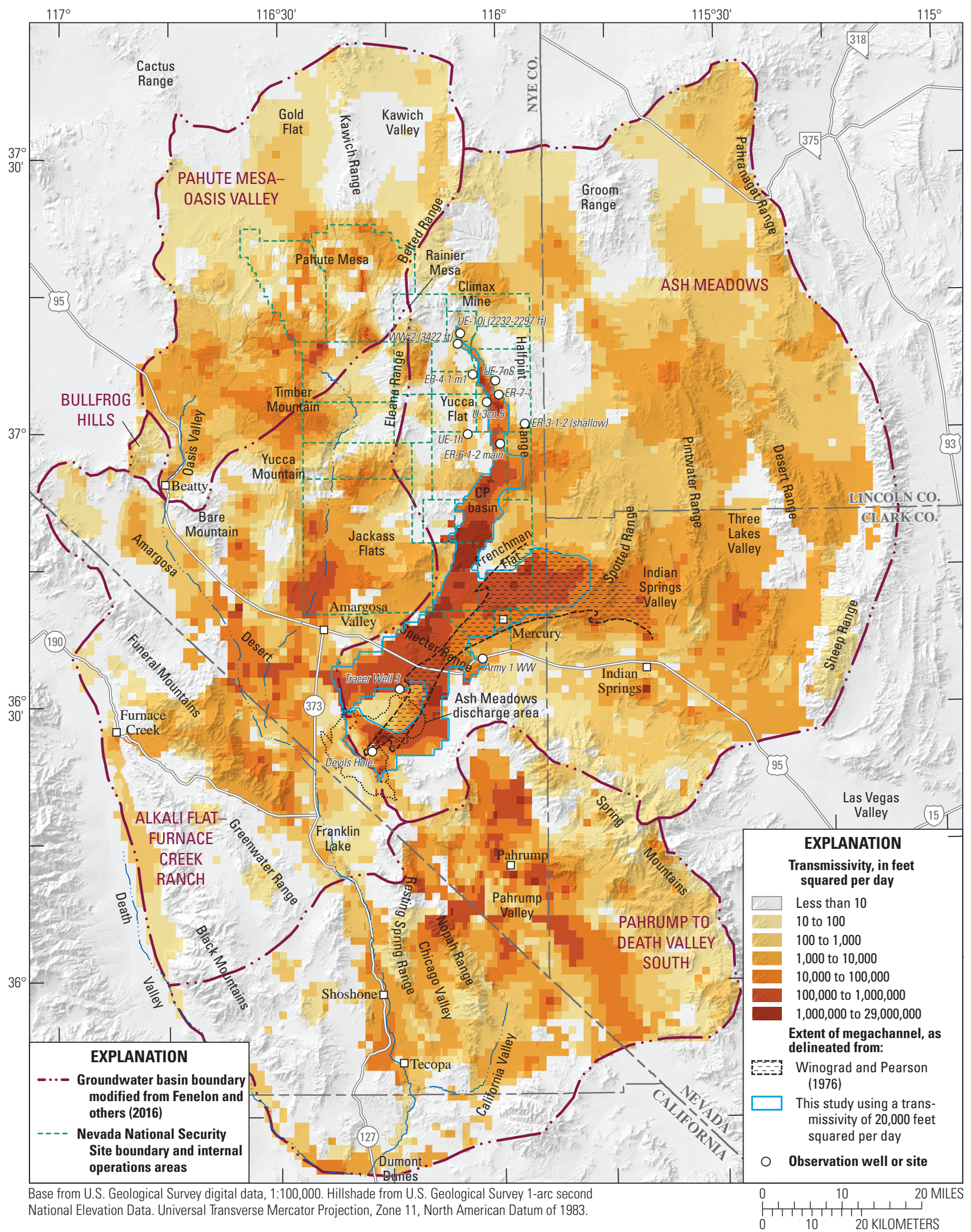

Figure 68. Estimated transmissivity distribution from integrated Death Valley version 3 model (DV3), extent of megachannel, and observation sites during well ER-6-1-2 main multiple-well aquifer test, in the study area, California and Nevada. 


\section{Ash Meadows And Devils Hole}

Simulated and measured predevelopment discharges, spring-pool altitudes, water-level changes from pumping, and spring captures were compared in the A sh M eadows discharge area to evaluate goodness of fit. Predevelopment discharges total ed 10,000 gal/min (16,150 acre-ft/yr) from all springs in the $A$ sh $M$ eadows discharge area, which is more than 60 percent of all predevelopment discharges from both AFFCR and $A$ sh $M$ eadows groundwater basins (table 4). Average and RMS spring-pool altitude errors of -8 and $32 \mathrm{ft}$, respectively, are acceptable errors, even though the errors are noticeable relative to a $160 \mathrm{ft}$ head difference between Devils Hole and Crystal Pool (fig. 69). Distributions of simulated hydraulic conductivities in the Ash Meadows discharge area could be improved, but errors mostly affect simulated water-level changes and spring captures from local pumping.

Predevelopment spring-pool altitudes and discharges in the A sh M eadows discharge area were better simulated with the DV3-SS model than the DVRFS.v2 model (fig. 69). $M$ easured and simulated discharges agreed perfectly for each spring in the A sh M eadows discharge area because discharges were specified in the DV3-SS model (fig. 69). However, measured and simulated discharges are dissimilar at each spring and in aggregate for the DVRFS.v2 model. Simulated discharges from the DVRFS.v2 model varied little between springs compared to measured spring discharges that ranged from 5 to 2,940 gal/min (0.01 and $6.55 \mathrm{ft}^{3} / \mathrm{s}$; table 9). Simulated discharge from Crystal Pool in the DVRFS.v2 model differed most and was 15 percent of measured discharge (fig. 69). Simulated discharges from the DVRFS.v2 model summed to slightly more than one-half of measured discharge from all springs in the Ash Meadows discharge area. Average and RM S spring-pool altitude errors of - 54 and $68 \mathrm{ft}$ from DVRFS.v2 are substantial errors. Misfits were larger where measured spring-pool altitudes exceeded 2,280 ft (fig. 69).

Water-level changes in Devils Hole and other wells in the megachannel (fig. 53) were evaluated differently during calibration from water-level changes in the remaining wells in the DV3-AM-AFFCR model. A different type of evaluation was required because long-term, natural water-level fluctuations were substantial in the Devils Hole area relative to effects of groundwater development. Simulated waterlevel changes in Devils Hole and nearby wells were fit in the objective function to measured water-level changes minus long-term, natural water-level fluctuations from recharge. The difference between measured and long-term natural fluctuations from recharge is assumed to represent pumping effects. Effects of pumping were simulated with the DV3-AMAFFCR model and long-term, natural water-level fluctuations were simulated with an analytical water-level model for Devils Hole (fig. 40) and other nearby wells (fig. 53). Hydrographs are presented with the original water-level measurements and simulated water levels that are the summation of numerical (DV 3-A M -A FFCR) and analytical models (fig 70).

Measured and simulated water-level changes in Devils Hole agree, with an RM S error of $0.2 \mathrm{ft}$ (fig. 70). Overall, water-level trends and responses to pumping stresses agreed well throughout the nearly 70-year period of record. Misfits between measured and simulated water-level changes were greatest during initial recovery from cessation of pumping by Cappaert E nterprises after 1976 (fig. 38). This misfit most likely resulted from underestimating spring capture and overestimating specific yield in the Ash Meadows discharge area of the DV 3-A M -AFFCR model (fig. 64). Errors in estimated long-term natural fluctuations from recharge also contributed to misfits between measured and simulated waterlevel changes in Devils Hole.

Measured water-level changes in wells Spring Meadows 12, North Crystal Well, and Tracer Well 3 are similar to changes in Devils Hole and are matched by their respective simulated water-level changes in the DV3-AM-AFFCR model (figs. 53 and 70). A systematic decline of about $1 \mathrm{ft}$ occurred in all wells between 1965 and 1995. Simulated water levels suggested that water levels in all wells responded to pumping by Cappaert Enterprises and declined prior to 1980. All wells were inferred to be affected strongly by the megachannel because water levels respond consistently to pumping and earthquake stresses. Simulated water-level changes in these wells agree with the conceptual model of the megachannel as an areally extensive, highly transmissive feature in the shallow-carbonate rocks (fig. 53).

Changes in measured and simulated spring discharges agree in the A sh M eadows discharge area of the DV 3-AM AFFCR model. M easured and simulated spring discharges in Ash Meadows agreed with an average RMS error of $120 \mathrm{gal} /$ $\min \left(0.3 \mathrm{ft}^{3} / \mathrm{s}\right)$. This error is similar to seasonal fluctuations in the absence of pumping (fig. 71) and is small relative to measured discharges that ranged from 5 to $2,900 \mathrm{gal} / \mathrm{min}(0.01$ and $6.6 \mathrm{ft}^{3} / \mathrm{s}$ ). Periods of complete capture in Jack Rabbit Spring were simulated correctly during the summer from 1970 to 1977 . Simulated recovery lagged behind measured recovery in Jack Rabbit Spring from 1978 to 1980 and likely resulted from locally overestimated specific yields. Capture was overestimated in Point of Rocks Spring but seasonal fluctuations were simulated correctly (fig. 71). Simulated changes in spring discharges in Big Spring replicated measured seasonal fluctuations and recovery within the uncertainty of measured discharges (fig. 71). 

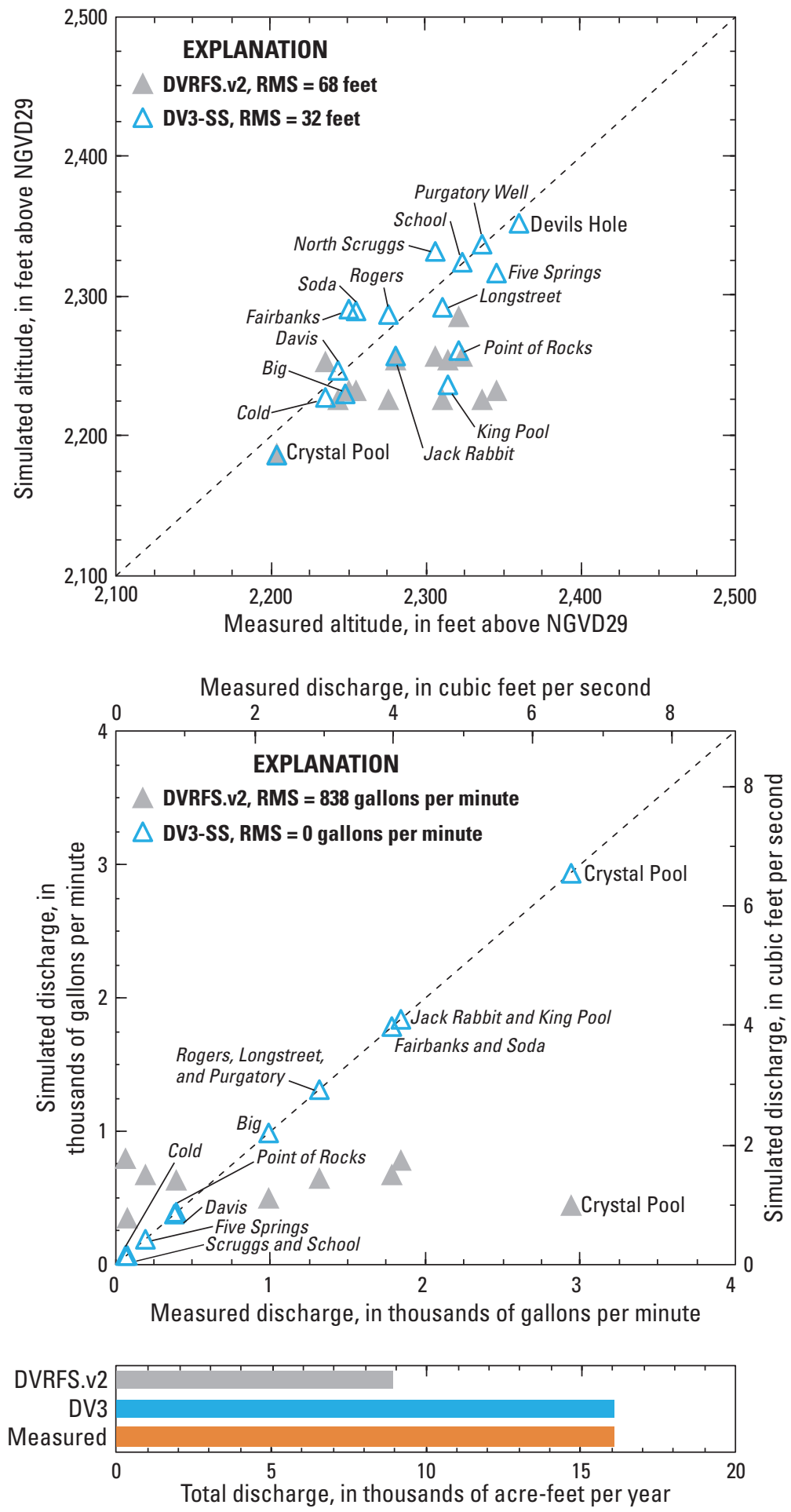

Figure 69. Measured, and DV3-SS- and DVRFS.v2-simulated pool altitudes (top graph) and spring discharges (middle graph), and total measured and simulated spring discharges (bottom graph), in the Ash Meadows discharge area, Nevada. DV3-SS, Death Valley version 3 steady-state model; DVRFS.v2, Death Valley Regional Flow System version 2 model; NGVD29, National Geodetic Vertical Datum of 1929; RMS, Root-mean-square error. 
A. USGS 363213116133800230 S16 E51 27BAA 3 Tracer Well 3 (AD-6)

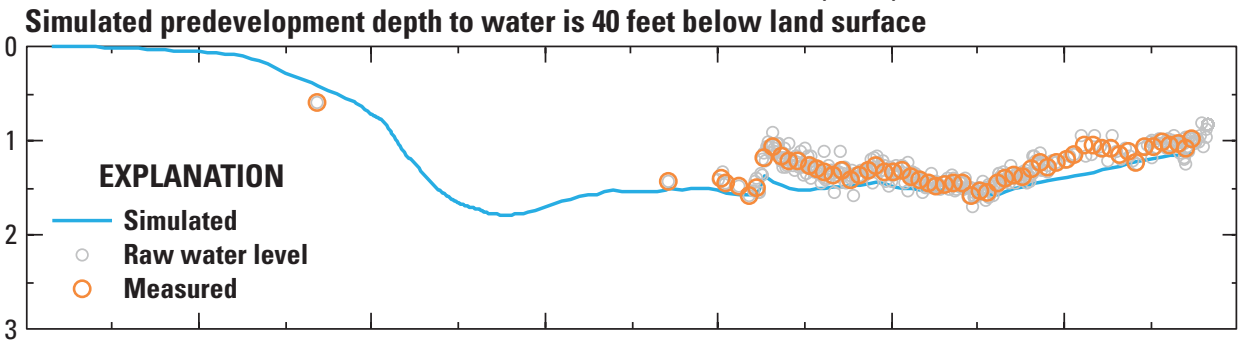

B. USGS 363030116104501230 S17 E51 01AAAB1 North Crystal Well

Simulated predevelopment depth to water is 59 feet below land surface

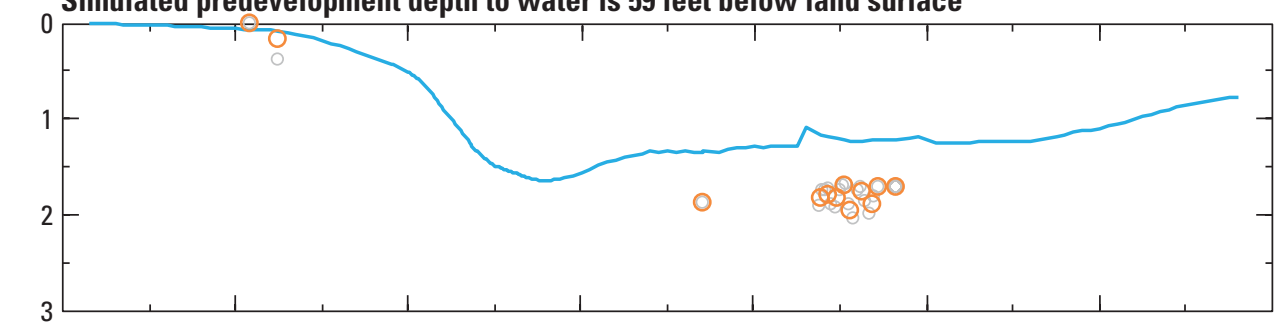

C. USGS 362529116160501230 S18 E51 06AAB 1 Spring Meadows 12

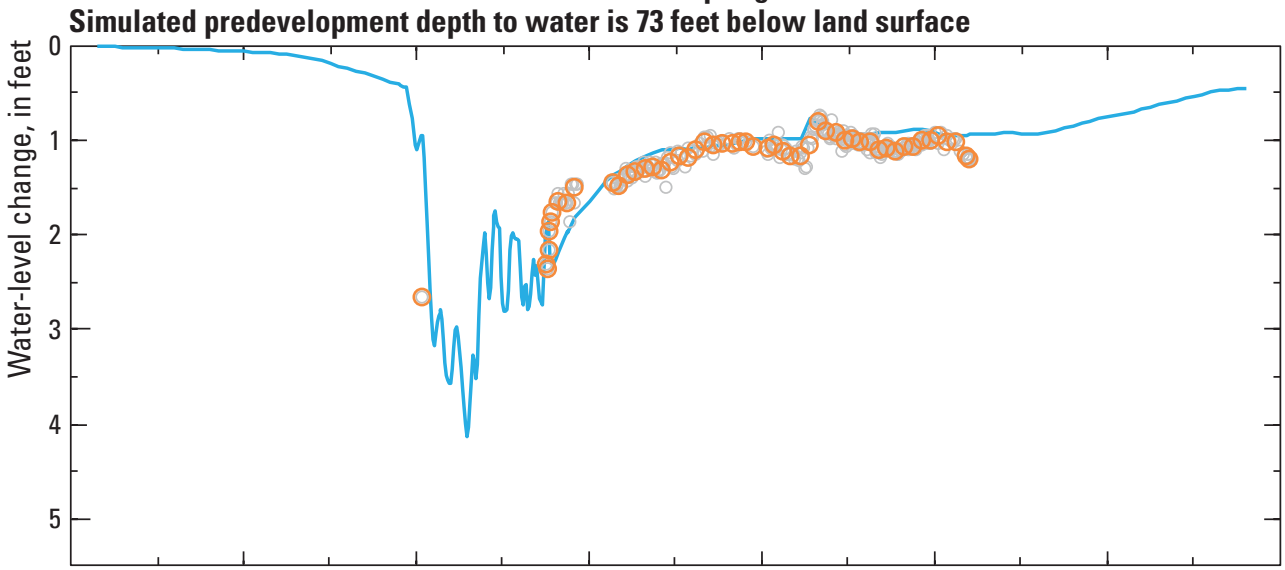

D. USGS 362532116172700230 S17 E50 36DC 1 Devils Hole (AM-4)

Simulated predevelopment depth to water is 1.0 feet below reference

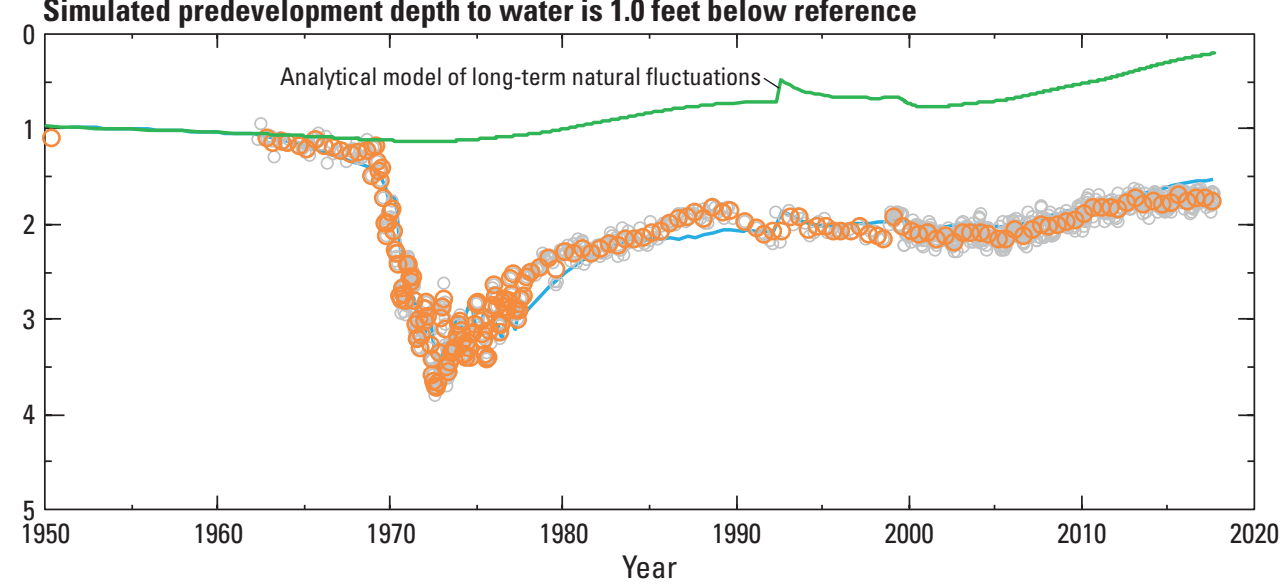

Figure 70. "Raw" water-level measurements, measured (average) water-level changes, and simulated water-level changes (summation of pumping from DV3-AM-AFFCR model and long-term natural fluctuations - recharge, steady discharge, and earthquakes - from analytical water-level model) in the megachannel, including wells Tracer Well 3(A), North Crystal Well (B), and Spring Meadows $12(C)$, and Devils Hole (D), Nevada, 1950-2018. DV3-AM-AFFCR, Death Valley version 3 model simulating groundwater development in the Ash Meadows, Alkali Flat-Furnace Creek Ranch, and Pahute Mesa-Oasis Valley groundwater basins. 


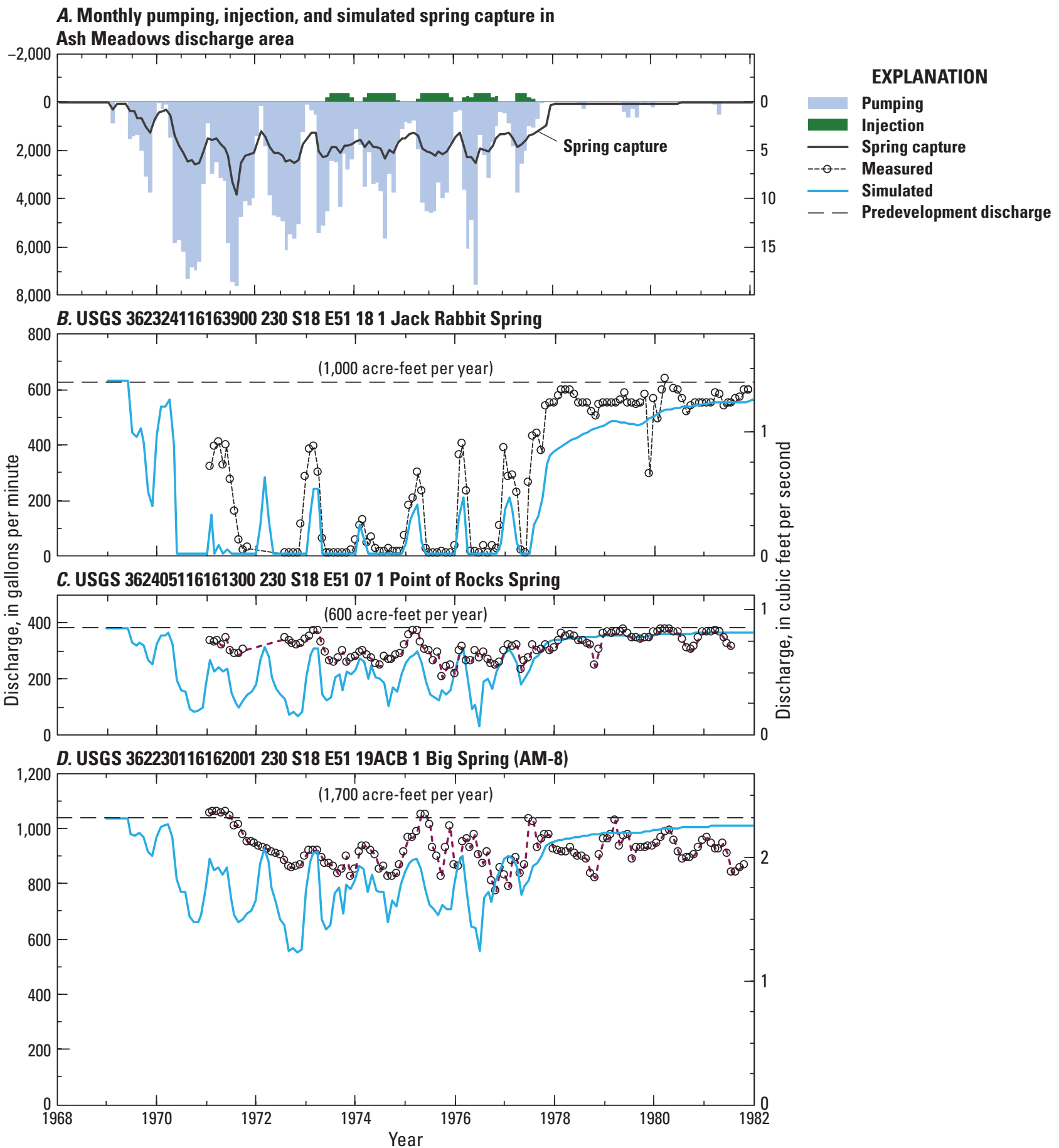

Figure 71. Monthly pumping by Cappaert Enterprises; injection into Devils Hole Well (AM-5); total simulated capture in the Ash Meadows discharge area from DV3AM-AFFCR model $(A)$; and hydrographs showing measured and simulated (DV3AM-AFFCR model) discharges from Jack Rabbit (B), Point of Rocks (C), and Big (D) Springs, Nevada, 1968-82. DV3-AM-AFFCR, Death Valley version 3 model simulating groundwater development in the Ash Meadows, Alkali Flat-Furnace Creek Ranch, and Pahute Mesa-Oasis Valley groundwater basins. 
Groundwater flow in the Ash Meadows discharge area is better simulated with the DV 3 model than the DVRFS.v2 model partly because the DV3 model was calibrated as an integrated stress-response model (fig. 48). Separately simulating predevelopment flow and changes from groundwater development constrained calibration and minimized compensating errors. For example, predevelopment discharge of $630 \mathrm{gal} / \mathrm{min}(1.4 \mathrm{ft} / \mathrm{s})$ from Jack Rabbit Spring was simulated correctly with the DV 3-SS model, but the simulated spring pool was $22 \mathrm{ft}$ lower than the measured altitude (fig. 69). Capture from Jack Rabbit Spring was simulated correctly with a $2 \mathrm{ft}$ extinction depth in the DV 3AM-AFFCR model (fig. 71). Simulating these conditions with a drain in a single model would create compensating errors. Predevelopment discharge would be 0 with an extinction depth of $2 \mathrm{ft}$ or little capture would be simulated with an extinction depth greater than $22 \mathrm{ft}$. Extinction depths seem overestimated in the DVRFS.v2 model because simulated capture from all springs in the Ash Meadows discharge area never exceeded $40 \mathrm{gal} / \mathrm{min}\left(0.09 \mathrm{ft}^{3} / \mathrm{s}\right)$, whereas maximum measured capture totaled $3,800 \mathrm{gal} / \mathrm{min}(8.5 \mathrm{ft} / \mathrm{s})$.

\section{Hydrologic Features}

Major hydrologic features have been identified in the study area that the DV 3 model must replicate (table 12). Simulated adequacy of these major hydrologic features was evaluated qualitatively because many aspects of these features remain conceptual. Conceptual models of these hydrologic features were developed from limited measurements from wells and springs, which limits the ability to quantify model misfit. Quantification was limited further where conceptual models depended on water quality and other measured quantities that were not simulated explicitly. For example, existence of a megachannel upgradient of the $A$ sh $M$ eadows discharge area was postulated primarily on anomal ous ${ }^{14} \mathrm{C}$ concentrations in discharge from Crystal Pool (W inograd and Pearson, 1976).

A greement between numerical and conceptual models of major hydrologic features was evaluated with water-level profiles, transmissivity estimates, and hydrographs. Numerical model results were considered improved where measured and simulated gradients between wells along a profile agreed (fig. 72). Total simulated transmissivities along a profile explained water-level gradients, characterized groundwaterbasin boundaries, and identified extremely transmissive and impermeable hydrologic features.
Water Table Beneath Rainier Mesa

Nuclear tests in tunnels beneath Rainier Mesa occurred within $300 \mathrm{ft}$ of the shallow (perched and semi-perched) water table (U.S. Department of E nergy, 2018), which makes the shallow water table a major hydrologic feature. Perched and semi-perched water-table mounds cause elevated water levels in the study area. M aximum altitude of the shallow watertable mound is about 6,200 ft above NGVD29 (fig. 73, A- $A^{\prime}$ ) and is within 0.5 miles of well ER-12-3 piezometer (shown as borehole ER-12-3 on fig. 72). L imited recharge to the shallow water table moves through volcanic rocks that primarily are zeolitized tuffs with hydraulic conductivities of $1 \times 10^{-5} \mathrm{ft} / \mathrm{d}$ $(0.004 \mathrm{ft} / \mathrm{yr})$. This recharge ultimately will discharge in either the PM OV, A FFCR, or A sh M eadows groundwater basin (U .S. Department of Energy, 2018).

M easured and simulated water tables beneath Rainier M esa generally agree (fig. 73, $A-A^{\prime}$ ), which is a prerequisite for correctly associating recharge with the location of its ultimate discharge. Elevated water levels in the study area generally coincide with areas of low transmissivity, except beneath the perched water table where higher transmissivity occurs in deep carbonate rocks beneath the low-transmissivity volcanic rocks (fig. 73, $A-A^{\prime}$ ). For example, the top of the perched water table near well ER-12-3 piezometer in zeolitized tuff is about $1,800 \mathrm{ft}$ higher than water levels in well ER-12-3 main (shown as borehole ER-12-3 in fig. 72), open to underlying carbonate rocks. The perched water table is controlled by vertical movement through low-permeability volcanic tuff. Correctly simulating the perched water table beneath Rainier Mesa became an objective because this hydrologic feature had not been simulated adequately by the DVRFS.v2 model.

\section{Boundary Between AFFCR and PMOV Groundwater Basins}

The boundary between PMOV and AFFCR groundwater basins is a major hydrologic feature. The boundary between PM OV and AFFCR groundwater basins from B are M ountain to Rainier M esa (fig. 72) has been interpreted as a no-flow boundary along a groundwater-flow path (Fenelon and others, 2016), which has implications for radionuclide transport. If this boundary is a no-flow boundary, then contamination from nuclear testing beneath Pahute $M$ esa in the northwestern part of the NNSS will not migrate into the AFFCR groundwater basin. The boundary between PMOV and AFFCR groundwater basins was less certain than other PM OV boundaries because this boundary was defined based on predevelopment water levels and discharges, rather than a topographic or groundwater divide (Fenelon and others, 2016). This boundary was not simulated explicitly as a no-flow boundary; instead, predevelopment water levels and discharges were matched to simulated equivalents to determine whether a no-flow boundary is substantiated based on groundwater-flow paths. 
Table 12. Summary of major hydrologic features simulated in the integrated Death Valley version 3 model (DV3), for the study area, Nevada and California.

[A bbreviations: AFFCR, Alkali Flat-Furnace Creek Ranch; PDVS, Pahrump to Death Valley South; PMOV, Pahute Mesa-Oasis Valley]

\begin{tabular}{|c|c|c|}
\hline Significant hydrologic feature & Reason for significance & $\begin{array}{l}\text { Relevant } \\
\text { water-level } \\
\text { profiles }\end{array}$ \\
\hline $\begin{array}{l}\text { Perched water-table mound beneath } \\
\text { Rainier M esa }\end{array}$ & $\begin{array}{l}\text { Nuclear tests in tunnels beneath Rainier Mesa occur within } 300 \text { feet of the shallow } \\
\text { (perched) water-table mound. }\end{array}$ & $A-A^{\prime}$ \\
\hline $\begin{array}{l}\text { B oundary between PM OV and AFFCR } \\
\text { groundwater basins }\end{array}$ & $\begin{array}{l}\text { Contamination from nuclear testing beneath Pahute M esa potentially can migrate } \\
\text { into AFFCR groundwater basin if the boundary is not a no-flow boundary. A no-flow } \\
\text { boundary was determined in DV3 model based on fitting predevelopment water } \\
\text { levels and discharges to simulated equivalents. }\end{array}$ & $B-B^{\prime}$ and $C-C^{\prime}$ \\
\hline $\begin{array}{l}\text { M egachannel in shallow carbonate } \\
\text { rocks betw een northern Y ucca Flat and } \\
\text { A sh M eadows discharge area }\end{array}$ & $\begin{array}{l}\text { Conceptual feature initially postulated immediately upgradient of A sh M eadows dis- } \\
\text { charge area that explained hydrochemical variations between Ash Meadows springs. } \\
\text { High hydraulic diffusivity of the shallow-carbonate megachannel causes drawdowns } \\
\text { to propagate quickly and recover slowly. }\end{array}$ & $D-D^{\prime}$ and $E-E^{\prime}$ \\
\hline $\begin{array}{l}\text { Gravity fault in Ash Meadows dis- } \\
\text { charge area }\end{array}$ & $\begin{array}{l}\text { Gravity fault causes the juxtaposition of low-permeability basin fill (clay, silt, and } \\
\text { fine-grained sand) in central Amargosa Desert with highly transmissive carbonate } \\
\text { rocks in Ash Meadows discharge area. Gravity fault impedes groundwater flow and } \\
\text { causes water to discharge from springs in A sh M eadows discharge area. }\end{array}$ & $E-E^{\prime}$ \\
\hline Well $A D$-4 corridor & $\begin{array}{l}\text { Well } A D-4 \text { corridor hydraulically connects A sh M eadows and AFFCR groundwater } \\
\text { basins. Most of the flow that enters the AFFCR basin occurs through this corridor. } \\
\text { Transmissive basin fill and carbonate rocks along the Gravity fault north of Ash } \\
\text { Meadows discharge area allow for upwelling water in the carbonate to move into } \\
\text { basin fill in the Amargosa Desert. }\end{array}$ & $F-F^{\prime}$ and $G-G^{\prime}$ \\
\hline Furnace Creek Wash & $\begin{array}{l}\text { Furnace Creek Wash allows regional groundwater flow to be conveyed to the alluvial } \\
\text { fan on the Death Valley floor, where groundwater discharges by evapotranspiration } \\
\text { from phreatophytes. }\end{array}$ & $H-H^{\prime}$ \\
\hline $\begin{array}{l}\text { Water table beneath B lack M ountains } \\
\text { and G reenwater R ange }\end{array}$ & $\begin{array}{l}\text { B lack M ountains and G reenwater R ange are interpreted as barriers to groundwater } \\
\text { flow based on most recent water-table interpretations from all available data. The } \\
\text { barrier impedes groundwater movement from central Amargosa Desert to Death Val- } \\
\text { ley through the Black M ountains and G reenwater Range. In the PDV S groundwater } \\
\text { basin, the barrier impedes groundwater flow beneath the Amargosa } \\
\text { River to Death Valley through the Black Mountains. }\end{array}$ & $I-I^{\prime}$ \\
\hline
\end{tabular}




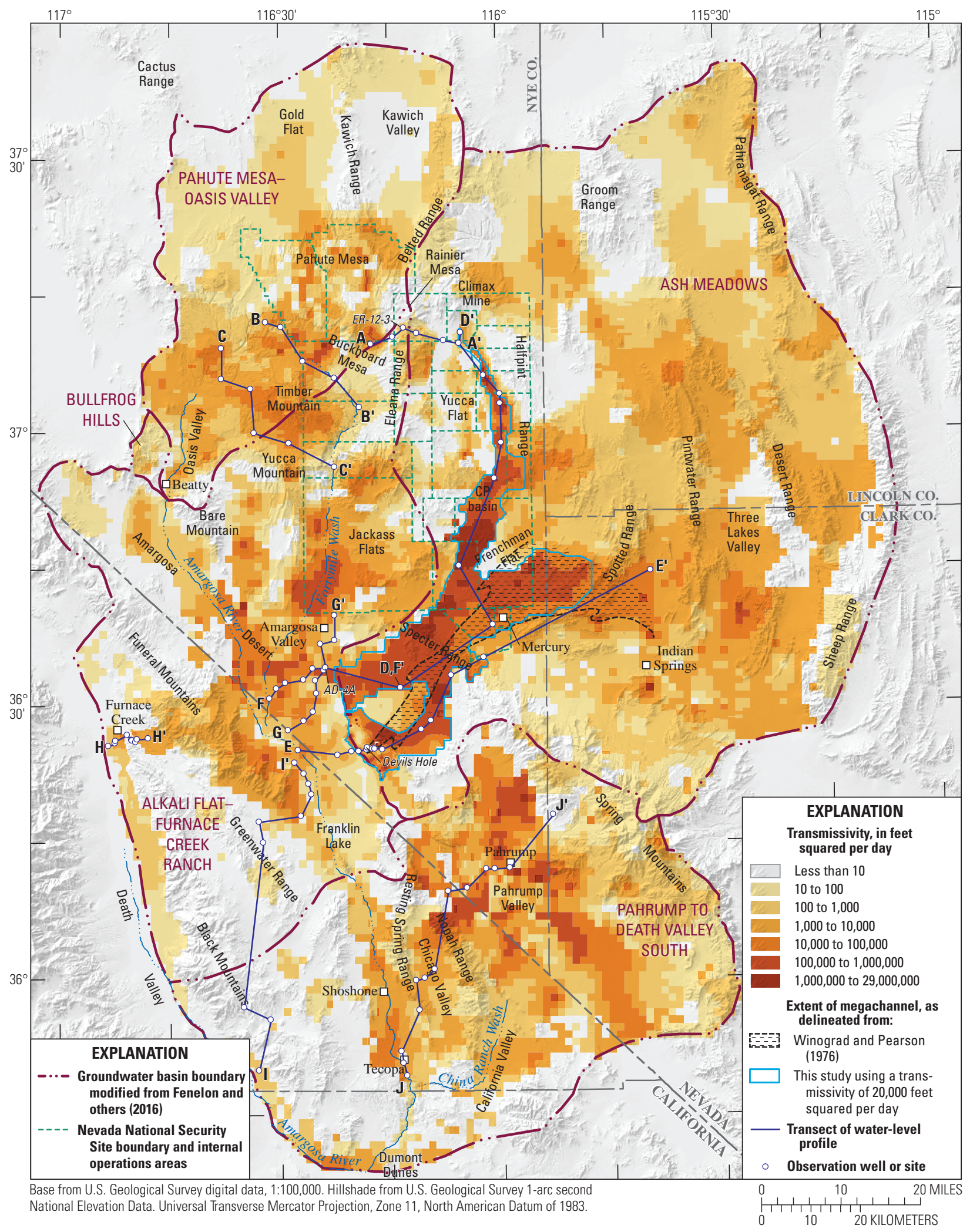

Figure 72. Estimated transmissivity distribution from integrated Death Valley version 3 model and traces of water-level profiles through major hydrologic features, in the study area, Nevada and California. See figures 73-79 for water-level profiles $A-A^{\prime}$ through $J-J^{\prime}$. 

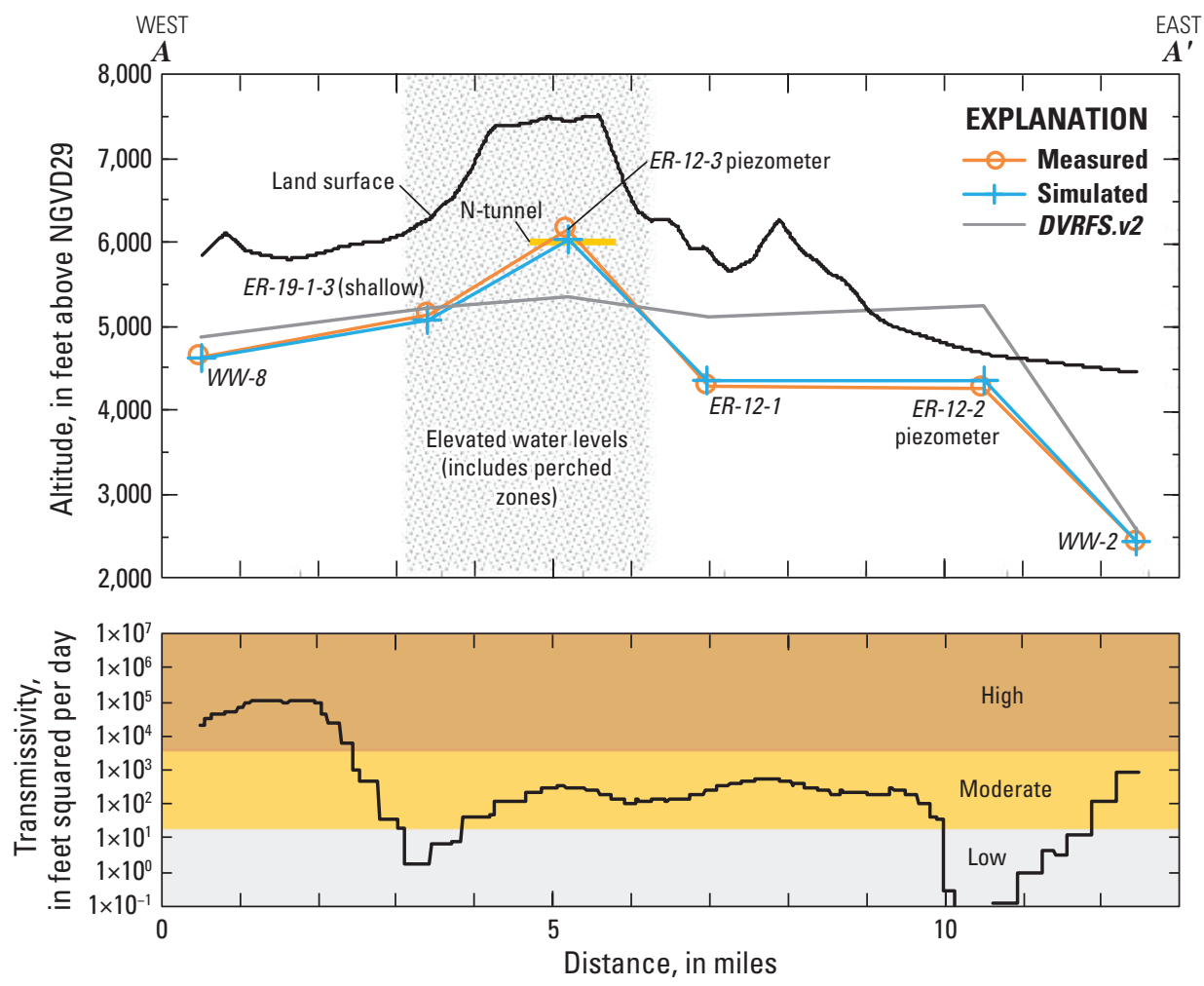

Figure 73. Measured water-level profile and simulated water-level profiles from Death Valley Regional Flow System version 2 model (DVRFS.v2) and Death Valley version 3 steady-state model (DV3-SS) (top graph), and transmissivity profile from the DV3-SS model (bottom graph), through Rainier Mesa, Nevada. Trace of water-level profile $A-A^{\prime}$ is shown in figure 72.

Interpreting the boundary between PM OV and AFFCR groundwater basins as a no-flow boundary differs from previous conceptualizations (Waddell, 1982; Laczniak and others, 1996). In previous conceptualizations, groundwater flowed southward from Pahute Mesa, across the current boundary between PM OV and A FFCR groundwater basins, and towards Yucca M ountain (L aczniak and others, 1996). The conceptualization was developed with fewer wells and inaccurate predevelopment-discharge estimates from Oasis Valley and Franklin Lake of 2,000 and 10,000 acre-ft/ yr, respectively (Walker and Eakin, 1963; Waddell, 1982; Czarnecki and Waddell, 1984). Current discharge estimates from 0 asis Valley and Franklin Lake total about 6,200 and no more than 700 acre-ft/yr, respectively (table 4).

The DV3-SS model implicitly simulated a no-flow boundary between the PMOV and AFFCR groundwater basins from B are M ountain to Rainier M esa (fig. 72). The measured water-level profile perpendicular to the boundary in Buckboard Mesa shows a notable difference in lateral gradients from well ER-18-2 (fig. 74, $B$ - $B^{\prime}$ ), indicating groundwater movement to the north and south of the boundary. Measured and simulated water levels have similar altitudes perpendicular to the boundary south of Timber M ountain (fig. $74, C-C^{\prime}$ ), indicating a lack of potential for flow across the boundary. Simulated flow perpendicular to the PM OV and AFFCR boundary is restricted by low transmissivity (fig. $74, B-B^{\prime}$ ) or small lateral gradients (fig. 74, $C-C^{\prime}$ ) relative to gradients parallel to the boundary.

\section{Megachannel}

The megachannel (fig. 72) is a major hydrologic feature of the A sh M eadows groundwater basin because drawdowns within this feature propagate quickly and recover slowly. The megachannel initially was presented as a conceptual feature that explained hydrochemical variations between large springs in the A sh M eadows discharge area (fig. 72; Winograd and Pearson, 1976). The megachannel was delineated in this report as a contiguous extent of shallow carbonate rocks where transmissivity exceeds $20,000 \mathrm{ft}^{2} / \mathrm{d}$ (fig. 72). The boundary of the megachannel was generalized around areas of low transmissivity in the Ash Meadows discharge area and extended into northern Yucca Flat (fig. 72). The northern extent includes well UE-10j (2232-2297 ft) because drawdowns from pumping well ER-4-1 $\mathrm{m} 1$ were detected 5.7 mi north in well $U E-10 j$ (2232-2297 ft) (fig. 68; Jackson, 2017). The megachannel as delineated in this report primarily differs from Winograd and Pearson (1976) by extending into Yucca Flat (fig. 72). This extension is well defined by measurable drawdowns in Tracer Well 3 from pumping well ER-6-1-2 main (figs. 67-68). 

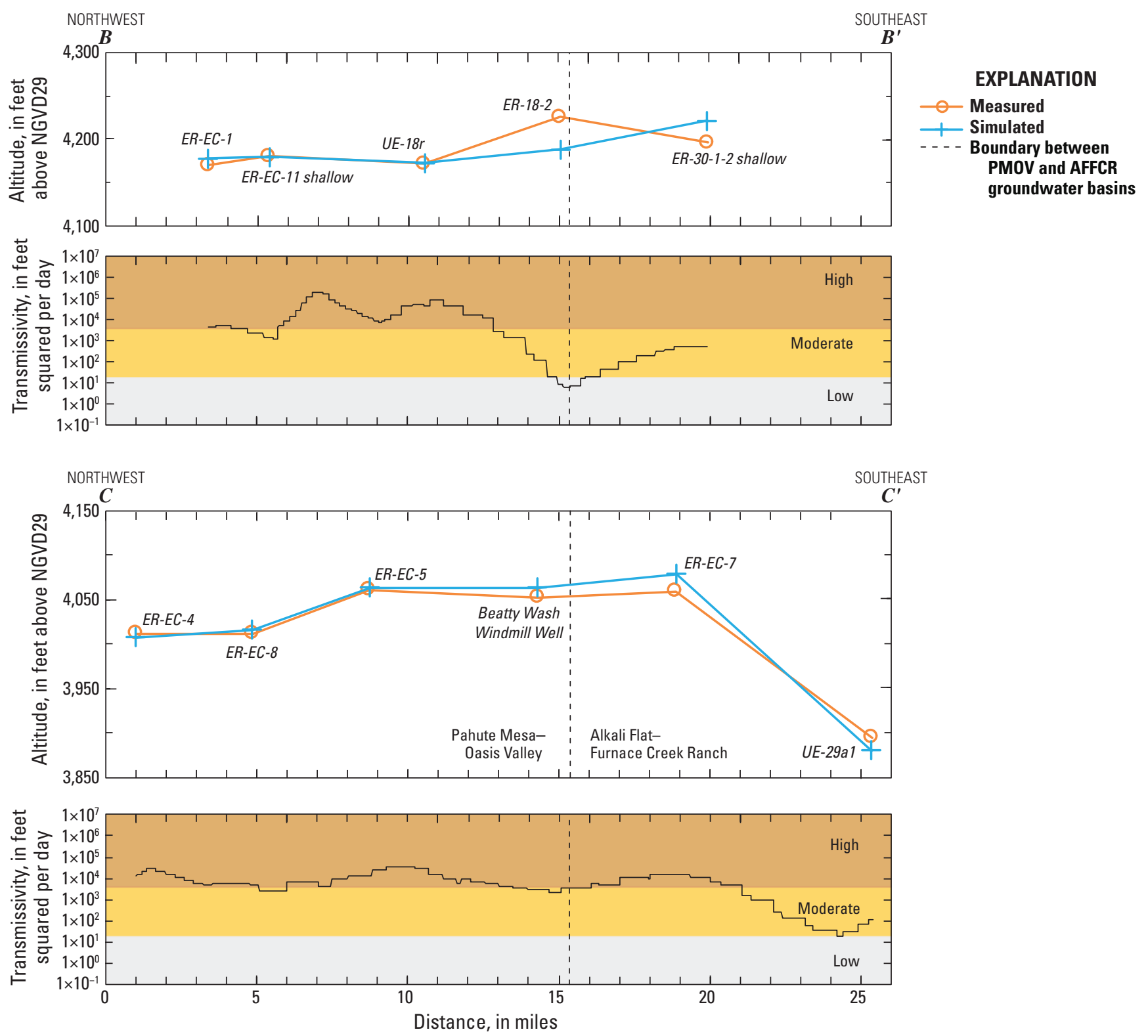

Figure 74. Measured and simulated water-level profiles (top graph and third graph from top), and transmissivity profiles from the Death Valley version 3 steady-state model (DV3-SS) (second and fourth graphs from top), through boundary between Pahute MesaOasis Valley (PMOV) and Alkali Flat-Furnace Creek Ranch (AFFCR) groundwater basins, Nevada. NGVD29, National Geodetic Vertical Datum of 1929. Traces of water-level profiles $B-B^{\prime}$ and $C-C^{\prime}$ are shown in figure 72. 
The megachannel is characterized by carbonate rock with high transmissivities and low storativities (specific yield plus storage coefficient). In unconfined areas of the shallow-carbonate megachannel, specific yields were spatially variable and averaged 0.04 . In confined areas of the megachannel, confined storage coefficients averaged 0.0001 . High transmissivities and low storativities resulted in broad areas with hydraulic diffusivities greater than $1,000,000 \mathrm{ft}^{2} / \mathrm{d}$. Hydraulic diffusivities increased where overlying saturated basin fill locally reduced hydraulic connection between carbonate rocks and the water table.

High hydraulic diffusivities caused relatively uniform declines of $2 \mathrm{ft}$ in the megachannel between 1970 and 1980 from pumping by Cappaert Enterprises (fig. 70). A bout 20,000 acre-ft of water drained from 250,000 acres in the megachannel between 1970 and 1980, which about equals net pumpage from Cappaert Enterprises minus spring capture in the A sh M eadows discharge area (fig. 38). Water levels in the megachannel recovered slowly during the ensuing decades after 1980 because surrounding rocks had low hydraulic diffusivities and did not readily release additional water (fig. 70).

Measured and simulated water-level profiles through the megachannel agree closely (fig. 75). M easured and simulated gradients between wells WW-2 (3422 ft) and Tracer Well 3 both averaged $1.0 \mathrm{ft} / \mathrm{mi}$ between northern Yucca Flat and A margosa Flat (fig. 75, D- $D^{\prime}$ ). Simulated gradients between well Army $1 \mathrm{WW}$ and Devils Hole averaged $0.9 \mathrm{ft} / \mathrm{mi}$, but were not as flat as measured gradients of $0.3 \mathrm{ft} / \mathrm{mi}$ (fig. $75, E-E^{\prime}$ ). Corresponding simulated transmissivities of the megachannel ranged from 10,000 to $10,000,000 \mathrm{ft}^{2} / \mathrm{d}$. M aximum simulated transmissivities locally exceed aquifer-test results in the megachannel by twentyfold, which would seem troubling if transmissivities between wells were not considered. Simulated transmissivity results were questioned and compared to Darcy estimates of transmissivity between well Army 1 WW and Devils Hole. Darcy estimates of transmissivity ranged from $1,000,000$ to $2,000,000 \mathrm{ft}^{2} / \mathrm{d}$, which is consistent with simulated transmissivities. Steep gradients between Devils Hole and Crystal Pool were simulated correctly with both simulated and measured gradients averaging $5 \mathrm{ft} / \mathrm{mi}$ (fig. 75, $\left.E-E^{\prime}\right)$. Steepening gradients were simulated with a three-orderof-magnitude decrease in transmissivities.

\section{Gravity Fault}

Water levels and simulated transmissivities from Crystal Pool to Franklin Well are consistent with basin fill west of the Gravity fault in the Ash Meadows discharge area impeding groundwater flow (fig. 75, E-E'). Basin fill in this area consists of clay, silt, and fine-grained sand of lacustrine origin (Walker and Eakin, 1963). Clay content exceeds 80 percent through more than 1,000 ft of basin fill (Oatfield and Czarnecki, 1989), with extensive deposits of bentonite and zeolite being mined north and south of section $E-E^{\prime}$ (Castor and others, 2006). Simulated water levels, discharges, and transmissivities are consistent with previous interpretations of the Gravity fault being a groundwater barrier that "...is caused by normal faulting of the poorly permeable Cenozoic rocks against the lower carbonate aquifer," (Winograd and Thordarson, 1975; p. (82).

\section{Well AD-4 Corridor}

The well $A D-4$ corridor is a major hydrologic feature that hydraulically connects $A$ sh $M$ eadows and A FFCR groundwater basins (fig. 72; fig. 76, $F-F^{\prime}, G-G^{\prime}$ ). Most groundwater that flows from the Ash Meadows groundwater basin to the AFFCR groundwater basin flows through a 5-mi-wide corridor around well $A D-4$, where water upwells from underlying carbonate rocks to overlying basin fill. The area of upw elling water extends west to east about $2 \mathrm{mi}$ between wells $H A-A D 68$ and $A D-4$ (fig. 76, $F-F^{\prime}$ ) and south to north about $5 \mathrm{mi}$ between wells $H A-A D 67$ and NC-GWEFELDERHOFF 25-01PA (fig. 76, G-G'). Water levels in the well $A D-4$ corridor are elevated 50-90 ft higher than water levels in wells immediately south, west, and north of the area of upwelling (fig. 76), which precludes all other sources of water other than flow from the underlying carbonate rocks.

Measured and simulated water levels through the well $A D-4$ corridor agree in profiles west to east and south to north (fig. 76). Simulated transmissivities are consistent with a corridor of limited lateral extent. Continuously transmissive rocks were simulated from west to east (fig. 76, $F-F^{\prime}$ ) and from south to north (fig. 76, G- $G^{\prime}$ ) through the 5-mi-wide corridor beneath well $A D-4$. These transmissivity profiles are qualitative and do not represent all hydraulic components because vertical flow is not depicted explicitly and flow through the well $A D-4$ corridor is limited by lower transmissivities of basin fill farther west of the $F-F^{\prime}$ profile. Simulated transmissivities west of well $A D-4$ ranged from 300 to 3,000 $\mathrm{ft}^{2} / \mathrm{d}$, which are consistent with measured specific capacities of 3-5 ([gal/min]/ft).

\section{Furnace Creek Wash}

Furnace Creek Wash is a major hydrologic feature that allows regional groundwater flow to discharge from the alluvial fan on the Death Valley floor (fig. 9; fig. 72, $H-H^{\prime}$ ). Measured and simulated water-level profiles closely agree (fig. 77), which was required to match the predevelopment water budget in the Furnace Creek area. The DV3-SS model simulated $5.8 \mathrm{ft}^{3} / \mathrm{s}(4,170$ acre-ft/yr) of groundwater entering Furnace Creek Wash, which is within a few percent of the predevelopment estimate of $5.6 \mathrm{ft}^{3} / \mathrm{s}$ (4,100 acre-ft/yr) being conveyed into Furnace Creek Wash (fig. 77). Simulated, predevelopment-groundwater flow leaves Furnace Creek Wash either from diversions or as subsurface flow. Furnace Creek Wash buried tile and sump, and the Furnace Creek Inn Tunnel (fig. 77) diverted $2.0 \mathrm{ft}^{3} / \mathrm{s}$ (1,500 acre-ft/yr). Subsurface flow of $3.8 \mathrm{ft}^{3} / \mathrm{s}(2,700$ acre-ft/yr) exits Furnace Creek Wash near Furnace Creek Inn Tunnel, flows downgradient, and discharges by $\mathrm{ET}_{\mathrm{GW}}$ from the alluvial fan (fig. 77). 

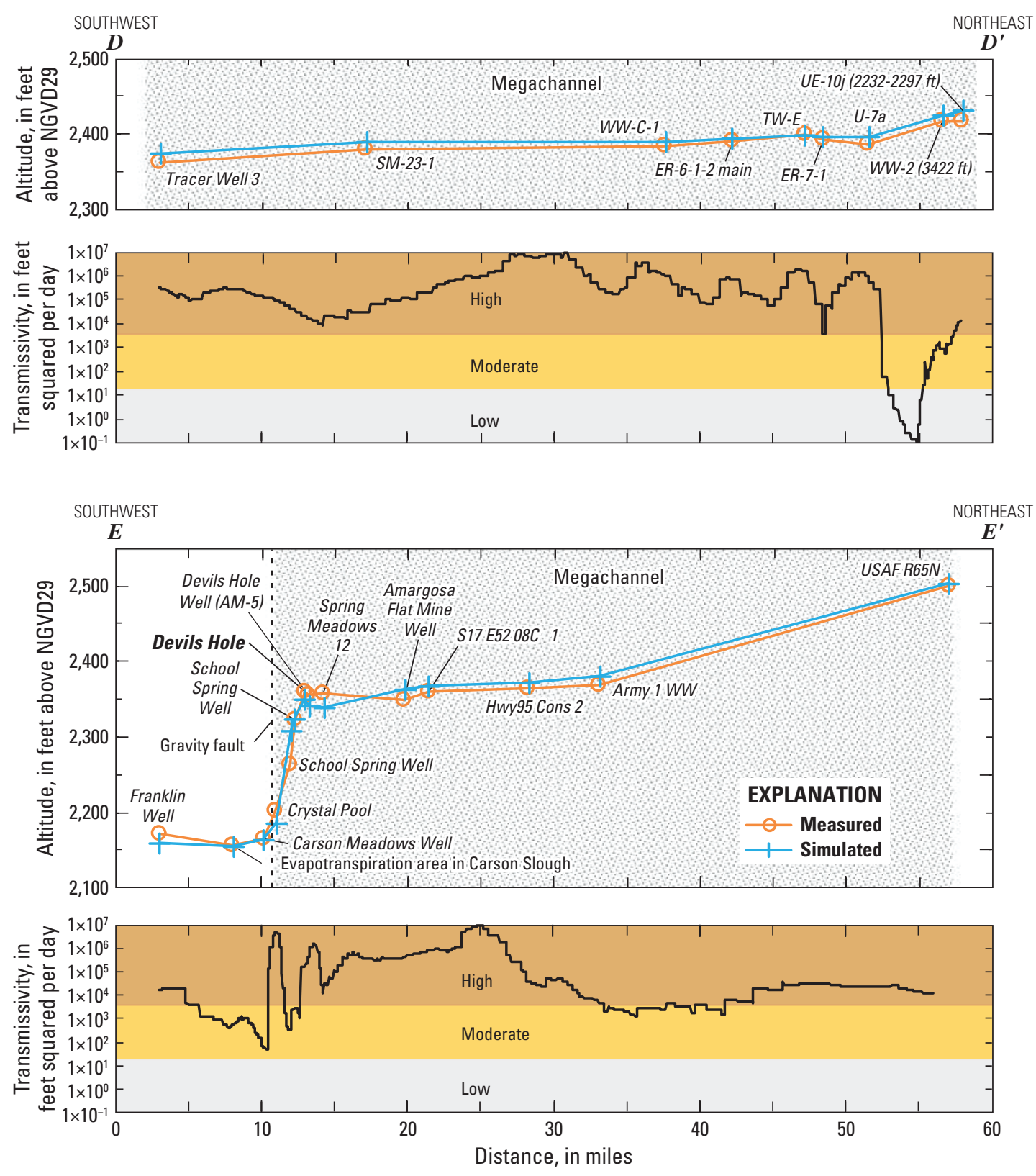

Figure 75. Measured and simulated water-level profiles (top graph and third graph from top), and transmissivity profiles from the Death Valley version 3 steady-state model (DV3-SS) (second and fourth graphs from top), through megachannel from Yucca Flat to the Ash Meadows discharge area, Nevada and California. NGVD29, National Geodetic Vertical Datum of 1929. Traces of water-level profiles $D-D^{\prime}$ and $E-E$ are shown in figure 72. 

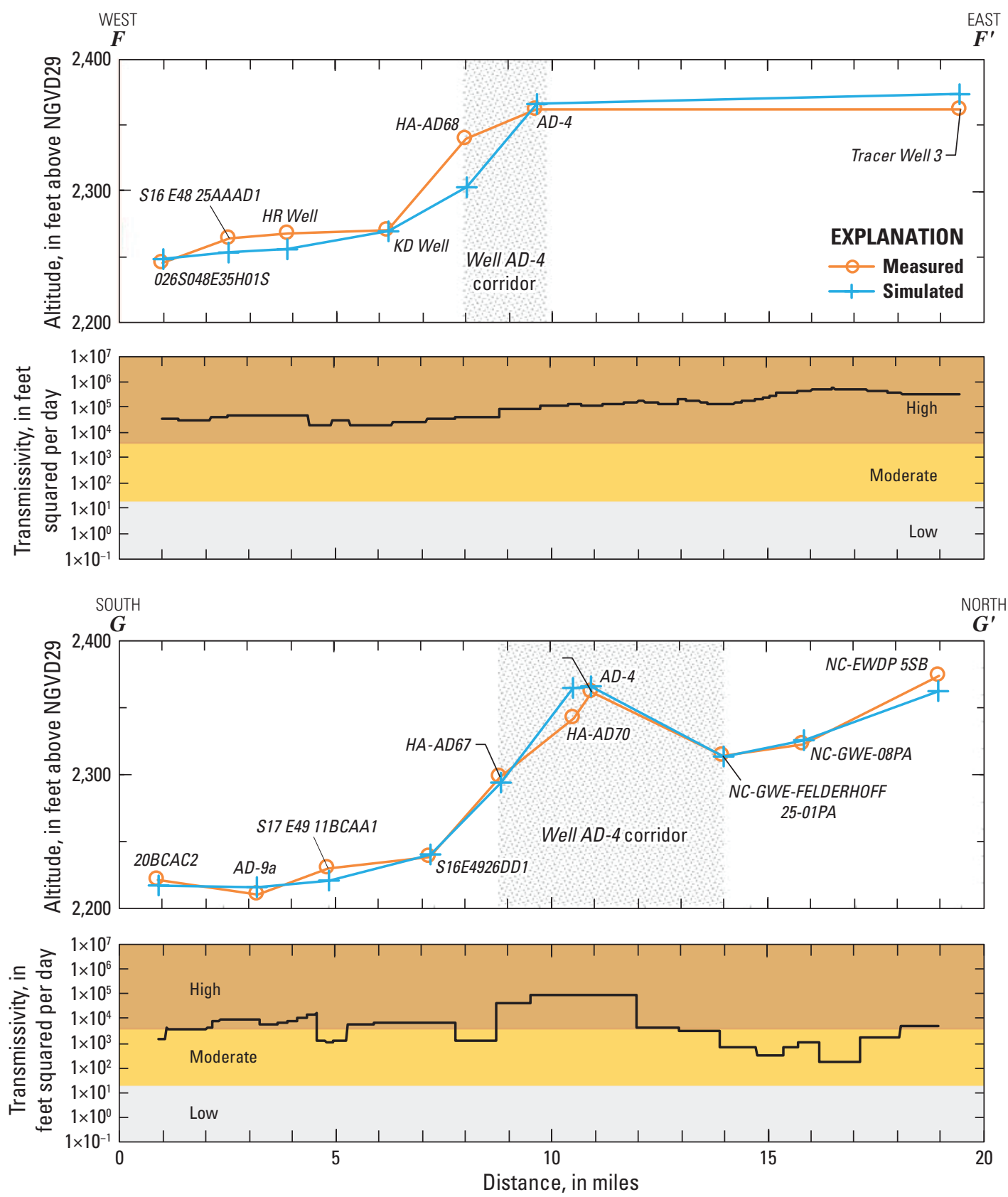

Figure 76. Measured and simulated water-level profiles (top graph and third graph from top), and transmissivity profiles from the Death Valley version 3 steady-state model (DV3-SS) (second and fourth graphs from top), through the well $A D-4$ corridor, Nevada and California. NGVD29, National Geodetic Vertical Datum of 1929. Traces of water-level profiles $F-F^{\prime}$ and $G-G^{\prime}$ are shown in figure 72 . 

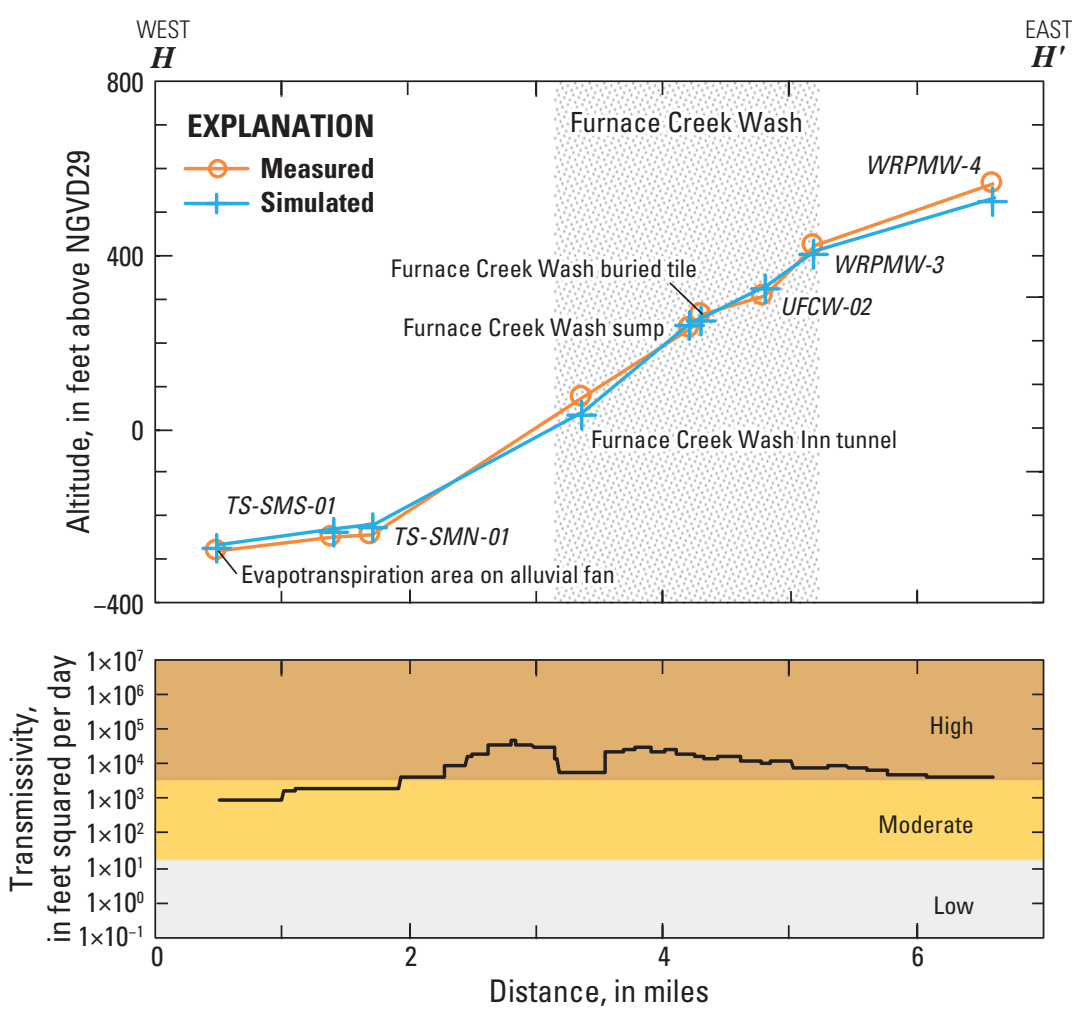

Figure 77. Measured and simulated water-level profiles (top graph), and transmissivity profile from the Death Valley version 3 steady-state model (DV3-SS) (bottom graph), through the Furnace Creek area, California. NGVD29, National Geodetic Vertical Datum of 1929. Trace of water-level profile $H-H^{\prime}$ is shown in figure 72.

\section{Water Table Beneath Black Mountains and Greenwater Range}

The Black Mountains and Greenwater Range are major hydrologic features that have been interpreted inconsistently. The water table beneath the Black Mountains and Greenwater Range was interpreted initially as a smoothly sloping surface from the Amargosa River on the east to the floor of Death Valley on the west (fig. 72) and originated from "...a handcontoured ground-water elevation map interpreted by the Denver Office of the USGS and transferred to PNL on March 31, 1982" (Rice, 1984, p. 22). The sloping water table was simulated with the DVSS2 model (table 1; D'Agnese and others, 2002, p. 88).

The water table alternatively has been interpreted as a perched mound beneath the Black M ountains and Greenwater Range (D'A gnese and others, 1998, plate 1). A dditional wells were inventoried in the Greenwater Range since 1982 and influenced the reinterpretation (Kilroy, 1991, plate 1). The mounded water table was the conceptual model for flow beneath the Black Mountains and Greenwater Range in DVRFS.v1 (Faunt, D'Agnese, and O'Brien, 2010, p. 139), but was simulated as a sloping water table. A mounded water table of limited north-south extent was simulated with the DVRFS. v2 model (Belcher and others, 2017, p. 44), but the conceptual model was a sloping water table (Belcher and others, 2017, plate 1). In the DVRFS.v2 model, the limited north-south extent of the perched water-table mound did not preclude flow through the Black M ountains and Greenwater Range because about 5,000 acre-ft/yr of discharge was simulated from the Death Valley floor south of the Furnace Creek area. Simulated groundwater flow in the DVRFS.v2 model moved around the limited extent of the perched water-table mound. However, more recent data indicate that the $B$ lack M ountains and Greenwater Range more likely behave as hydraulic barriers.

The Black Mountains and Greenwater Range are interpreted in this study as barriers to groundwater flow based on the most recent water-table interpretations from all available data. The barrier impedes groundwater movement from the central A margosa D esert to D eath Valley through the Black M ountains and Greenwater R ange. In the PDV S groundwater basin, the barrier also impedes movement of groundwater flow beneath the Amargosa River to Death Valley through the Black M ountains (fig. 72). The Black Mountains and Greenwater Range consist of bedded tuffs and clastic, crystalline, and intrusive rocks (Sweetkind and others, 2001, plate 3), which are typically impermeable rocks. 
Steep hydraulic gradients and potential for limited local recharge indicate that the Black M ountains and Greenwater Range are low-transmissivity features. For example, water levels increase 2,475 ft between well 020N004E09K001S and Virgin Spring in the B lack M ountains (fig. 78, $I-I^{\prime}$ ), which are a mapped distance of $8 \mathrm{mi}$ apart (fig. 72), resulting in a hydraulic gradient greater than $300 \mathrm{ft} / \mathrm{mi}$. Black M ountains and Greenwater Range are conceptualized as lowtransmissivity features, which limits the amount of recharge. L ocal recharge rates do not exceed $0.001 \mathrm{ft} / \mathrm{yr}$ (fig. 16) and can generate no more than 9 acre- $\mathrm{ft} / \mathrm{yr} / \mathrm{mi}(0.2 \mathrm{ft} / \mathrm{d} / \mathrm{ft})$ between well KJ-2 and 021N004E15R002S. This limits average transmissivity to less than $10 \mathrm{ft}^{2} / \mathrm{d}$ in the Black M ountains and $G$ reenwater $R$ ange and is consistent with simulated transmissivities (fig. 78, $I-I^{\prime}$ ).

Continuous Aquifer of Carbonate Rocks and Basin Fill in PDVS Groundwater Basin

Carbonate rocks and basin fill form a continuous aquifer between recharge in the Spring M ountains and discharge along the Amargosa River (fig. 72; fig. 79, $J-J^{\prime}$ ). This conceptualization differs little from previous interpretations (Harrill, 1986, p. 27). Transmissive intervals primarily are hosted by carbonate rocks in the mountain blocks and basin fill in the valleys. Bennetts and Manse Springs occur at the contact between the alluvial fan and valley floor primarily because of a break in slope, not a reduction in transmissivity (fig. 79, $J-J^{\prime}$ ). Transmissivity generally decreases from east to west between the Nopah Range and Amargosa River regardless of host rocks (fig. 72; fig. 79, $J-J^{\prime}$ ). Measured and simulated water-level profiles from the Spring Mountains to the Amargosa River generally agree (fig. $79, J-J^{\prime}$ ).

\section{Simulated Predevelopment Groundwater Flow}

Predevelopment groundwater flow was characterized with the calibrated DV 3-SS model. Recharge-source areas were mapped for each major discharge area with particle tracking. Groundwater flow was simulated from the Ash Meadows groundwater basin to the Furnace $\mathrm{Creek}$ area through the well $A D-4$ corridor. The Furnace Creek flow conceptualization is presented, which integrates results from previous investigations and compares the DV3 conceptualization to alternative conceptualizations. Simulated predevelopment water budgets were extracted for subareas in each groundwater basin. The simulated water budget also was extracted for the Rainier M esa groundwater sub-basin because radionuclides from underground nuclear tests can migrate farther into the A FFCR, A sh M eadows, and (or) PM OV groundwater basins.

\section{Recharge and Discharge Areas}

Recharge and discharge areas were paired for predevelopment flow with particle tracking (Pollock, 2012). Particles were backward-tracked from Bennetts, Manse, and Stump Springs in Pahrump Valley and from discharge areas in Oasis Valley, A sh M eadows, L ower A margosa, and Furnace $C$ reek to contributing recharge areas. Particles were seeded on the faces of cells where simulated discharge occurred. Each particle represented 50 acre-ft/yr, where the number of particles apportioned to each cell face was based on the total simulated discharge from each cell. Discharge from all analyzed areas totaled 47,000 acre-ft/yr and was backwardtracked with 940 particles. Connections between the initial particle location in the discharge area and the terminus at the water table in a recharge area are shown with pathlines (fig. 80). A reas with greater pathline densities represented areas with higher groundwater-flow rates. Pathlines were generated using an assigned effective porosity of 10 percent for basin fill and volcanic-sedimentary rocks, and an assigned effective porosity of 1 percent for fractured carbonate, volcanic, and low-permeability rocks.

Recharge also was mapped and differentiated between five major discharge areas by forward-tracking from the water table to discharge areas. The five major discharge areas were Oasis Valley, A sh M eadows, Furnace Creek, L ower A margosa, and Pahrump and Stewart Valleys. The contributing recharge area for Pahrump and Stewart Valleys included all discharge from springs and ET areas. Particles were seeded at the water table in model cell centers where simulated recharge rates exceeded $0.0001 \mathrm{ft} / \mathrm{d}$ (fig. 45). Each cell at the water table was mapped to one of the five discharge areas (fig. 80). Recharge areas were not mapped if they contributed to minor discharge areas, such as D eath Valley, Franklin L ake, and Saratoga Spring area. M apped recharge areas supply 86 percent of discharge from the study area. Groundwater-flow paths cal culated by backward-tracking from discharge areas (pathlines) and forward-tracking from recharge areas (shading) are shown in figure 80.

Pahute $M$ esa is the primary recharge area contributing to discharge from 0 asis Valley (fig. 80). O ther highland areas that contribute recharge in the PM OV groundwater basin include Black Mountain, Timber Mountain, Cactus Range, and $\mathrm{K}$ awich Range. Simulated contributing recharge areas for Oasis Valley generally agree with the previously delineated PM OV groundwater basin (Fenel on and others, 2016). M inor differences exist beneath Bare Mountain, east of the Belted Range, and north of Rainier M esa (fig. 80). 

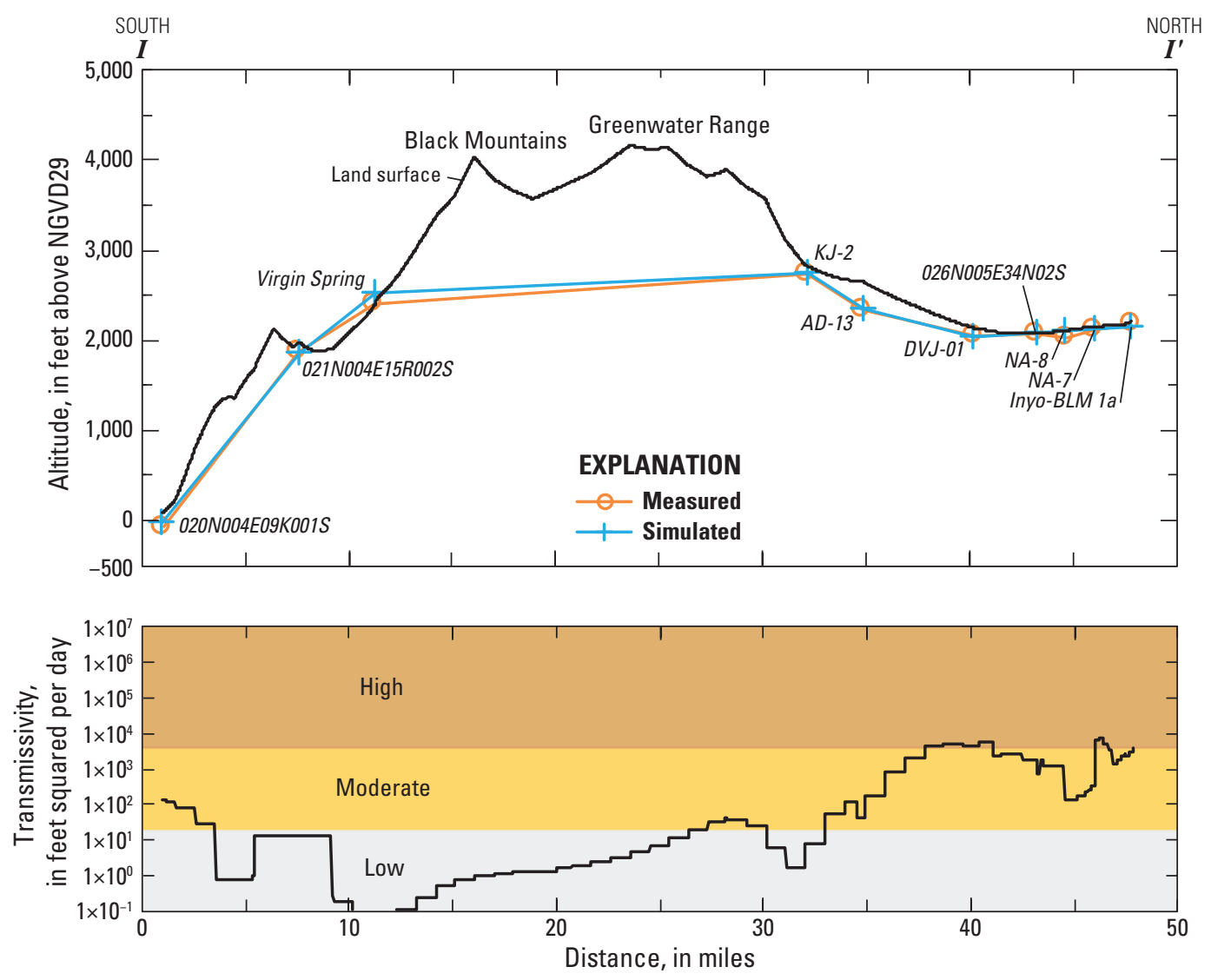

Figure 78. Measured and simulated water-level profiles (top graph), and transmissivity profile from the Death Valley version 3 steady-state model (DV3-SS) (bottom graph), through the Black Mountains and Greenwater Range, California. NGVD29, National Geodetic Vertical Datum of 1929. Trace of water-level profile I-I' is shown in figure 72. 

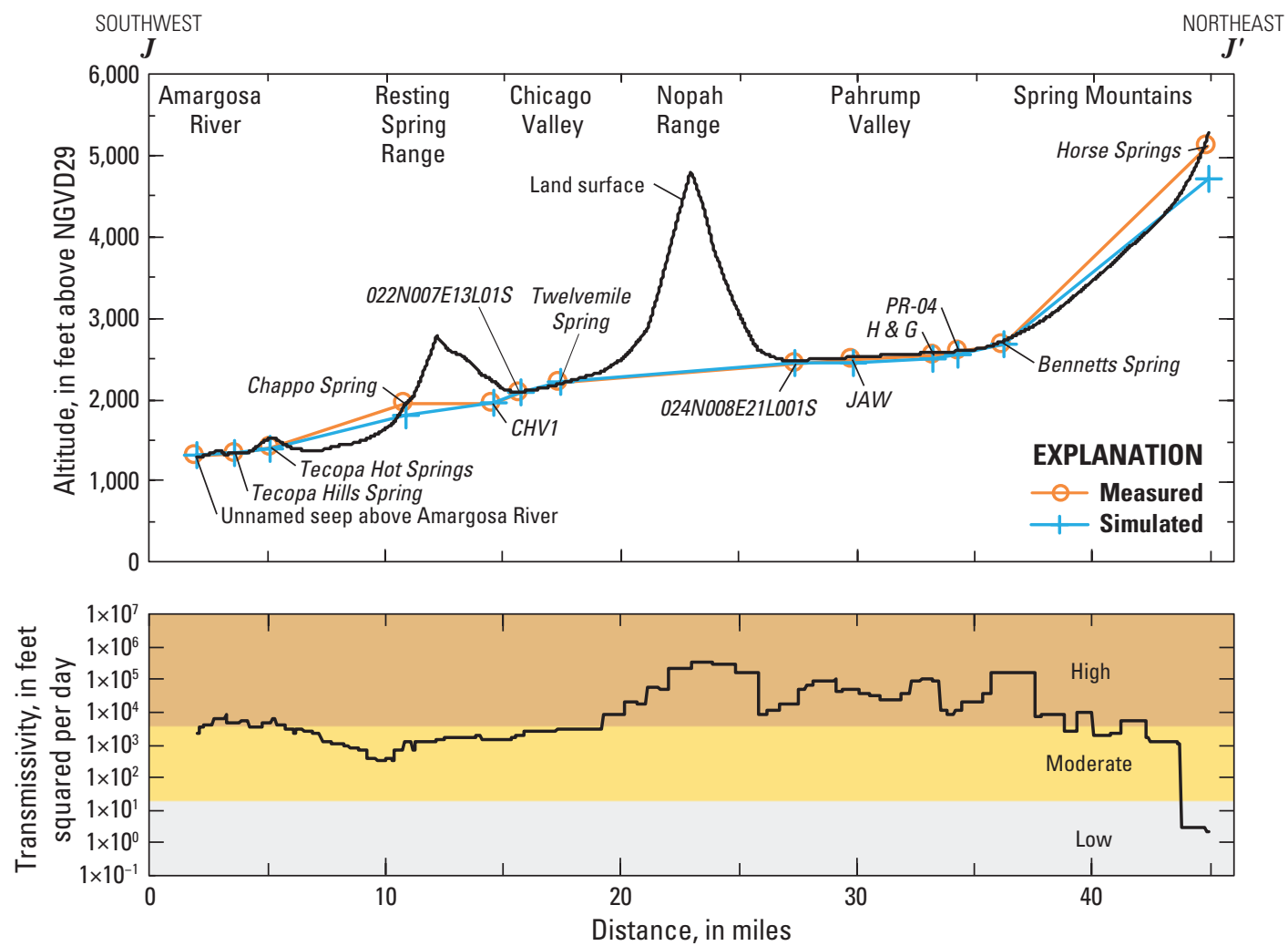

Figure 79. Measured and simulated water-level profiles (top graph), and transmissivity profile from the Death Valley version 3 steady-state model (DV3-SS) (bottom graph), from the Spring Mountains to the Amargosa River, Nevada and California. NGVD29, National Geodetic Vertical Datum of 1929. Trace of water-level profile $J-J$ ' is shown in figure 72. 


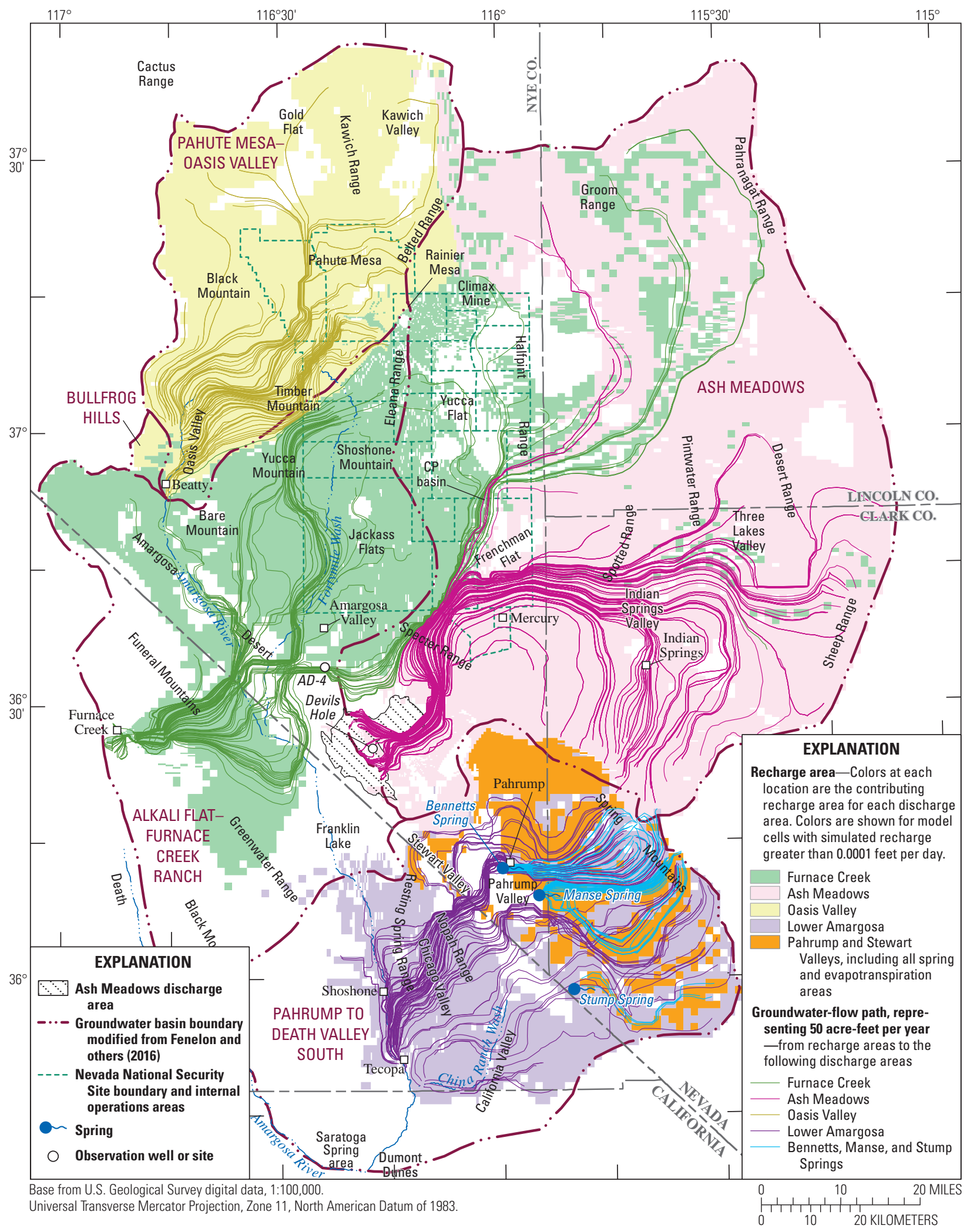

Figure 80. Groundwater-flow paths to selected discharge areas and contributing recharge areas for discharge areas in Oasis Valley, Ash Meadows, Furnace Creek, Lower Amargosa, and Pahrump and Stewart Valleys, Nevada and California. 
The Ash Meadows discharge area predominantly is recharged from the Spring M ountains and Sheep Range in the southern and eastern $A$ sh $M$ eadows groundwater basin (fig. 80). Less than 5 percent of the discharge is recharged from the Desert, Pintwater, Spotted, Pahranagat, and Groom Ranges. B etween the Pahranagat and Groom Ranges (fig. 80), groundwater in shallow carbonate rocks contributes to discharge in the AFFCR groundwater basin, whereas groundwater in deep carbonate rocks contributes to discharge in Ash Meadows groundwater basin. Flow from basin fill in southeast Frenchman Flat into shallow carbonate rocks ultimately will discharge in the A sh M eadows discharge area. Simulated flow through shallow carbonate rocks is consistent with hydrochemical interpretations of calcium-magnesiumsodium-bicarbonate type waters that discharge from springs in the Ash Meadows discharge area (Winograd and Thordarson, 1975).

Bennetts and Manse Springs were primary discharges in Pahrump Valley prior to development and were recharged from the central Spring M ountains in the northern PDV S groundwater basin (fig. 80). Stump Spring is a relatively minor discharge of less than 300 acre-ft/yr that is recharged in the southwestern Spring M ountains (fig. 80). A II recharge for springs in Pahrump Valley flowed through carbonate rocks prior to discharging from Bennetts, Manse, or Stump Springs.

D ischarge in the L ower A margosa area primarily is recharged in the Spring M ountains (fig. 80). Contributing recharge areas to the L ower A margosa area extend north and south of the recharge areas for Bennetts and Manse Springs in the central Spring M ountains. A bout 10 percent of the discharge from the L ower A margosa area is recharged in the Nopah, Resting Spring, and Greenwater Ranges. More flow was simulated through the northern Nopah Range into Chicago Valley than through the southern Nopah Range near California Valley (fig. 80).

Pathlines from recharge in the Spring M ountains to discharge along the Amargosa River show that carbonate rocks and basin fill form a continuous aquifer in the PDVS groundwater basin. Water recharges the carbonate rocks in the Spring Mountains, moves through basin fill and shallow carbonate rock beneath Pahrump Valley, and leaves Pahrump Valley through carbonate rocks in the Nopah Range (fig. 81). Groundwater flows through the northern part of the Nopah Range, Chicago Valley, and the southern part of the Resting Spring Range, and discharges near the Amargosa River. Groundwater flow functionally ceases west of the Amargosa River because of the exclusive occurrence of low-permeability rocks (fig. 32). Increasing occurrence of low-permeability rocks from east to west affects groundwater flow more than whether carbonate rocks or basin fill occur along the flow path.

\section{Flow from Ash Meadows Groundwater Basin to the Furnace Creek Area}

Discharge in the Furnace Creek area is atypical in the study area because a substantial part of the discharge is recharged in another groundwater basin (fig. 80). The Furnace Creek area is in D eath Valley on the western edge of the AFFCR groundwater basin. M ore than 40 percent of the discharge in the Furnace Creek area is sourced from the $A$ sh $M$ eadows groundwater basin, with the remaining Furnace Creek discharge derived from the AFFCR groundwater basin (Fenelon and others, 2016).

Hydraulic connection between A sh M eadows groundwater basin and the Furnace Creek area has been explained with two alternative flow-path conceptualizations (fig. 82). The path through basin fill in the central Amargosa Desert is an alternative that has been presented piecemeal in previous investigations. This flow-path conceptualization assumes that most of the discharge sourced from the A sh $M$ eadows groundwater basin passes through the well $A D-4$ corridor to reach the Furnace Creek area (figs. 80 and 82). The alternative path is flow through deep carbonate rocks that extend between the A sh M eadows discharge area and the southeastern Funeral Mountains, where flow moves northwest along the Furnace Creek fault zone to discharge areas in Furnace Creek (fig. 82; Hunt and Robinson, 1960; Belcher and others, 2009). These two alternatives will be discussed hereinafter as basin-fill and deep-carbonate flow paths. Lithology, hydraulic properties, chemical evidence, and numerical simulation results indicate that the basin-fill flow path is more likely than the deep-carbonate flow path.

\section{Basin-Fill Flow Conceptualization}

The basin-fill flow conceptualization assumes that basin fill in the central Amargosa Desert hydraulically connects the Furnace Creek area with carbonate rocks in A sh M eadows groundwater basin (fig. 83). Groundwater recharged in the A sh Meadows groundwater basin flows west-southwest through shallow carbonate rocks and converges on the well $A D-4$ corridor (fig. 80). Groundwater flows upward from carbonate rocks to basin fill in the well $A D-4$ corridor, moves west through the central Amargosa Desert, flows from basin fill to carbonate rocks in the Funeral M ountains, and continues to flow westward (fig. 83). Some of the westward-flowing groundwater discharges directly from carbonate rocks at Nevares Springs and the rest passes through shallow basin fill in the Furnace Creek area before discharging at land surface. 


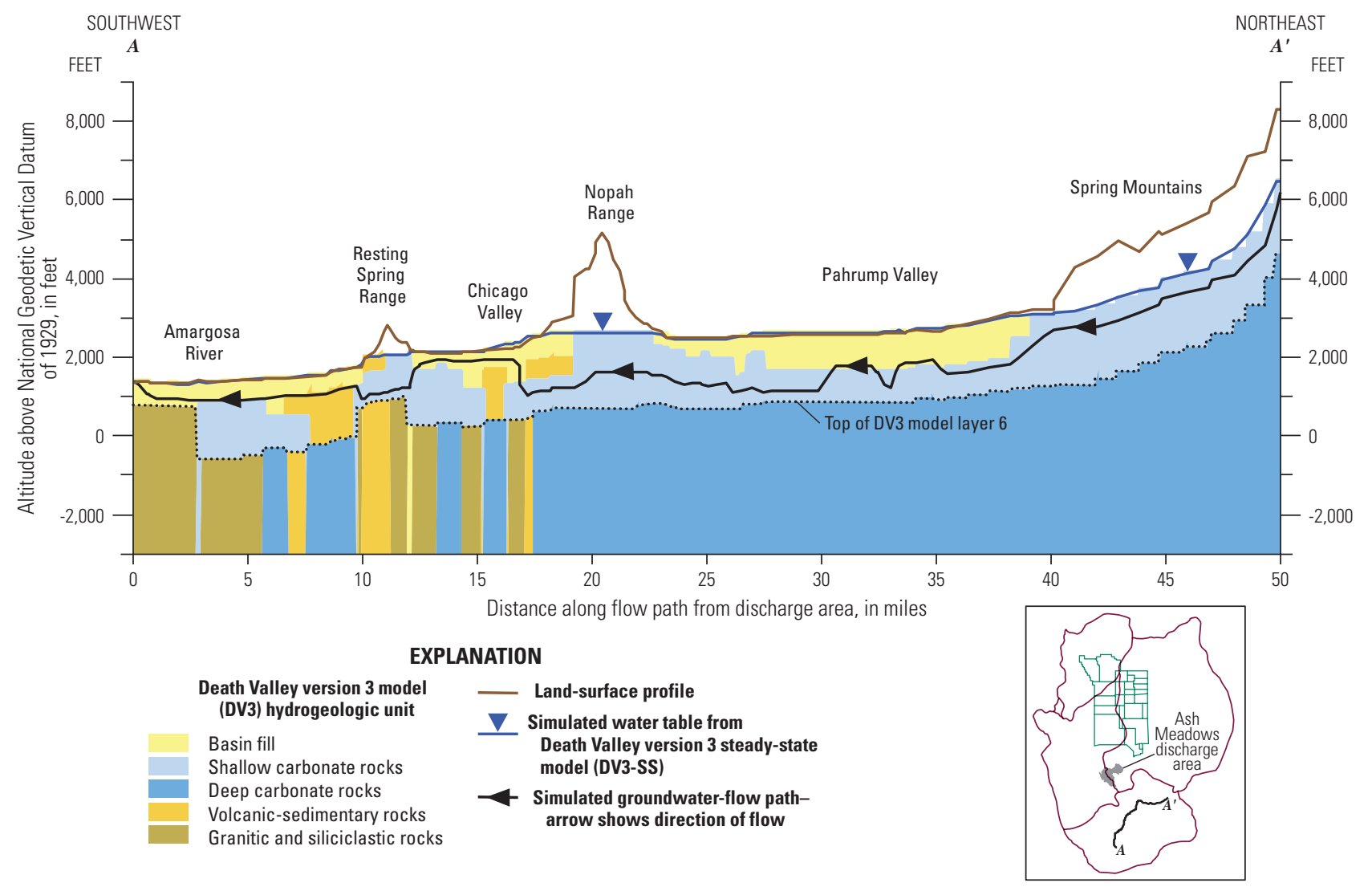

Figure 81. Cross section along a simulated groundwater-flow path from the Spring Mountains to the Amargosa River, Nevada and California. 


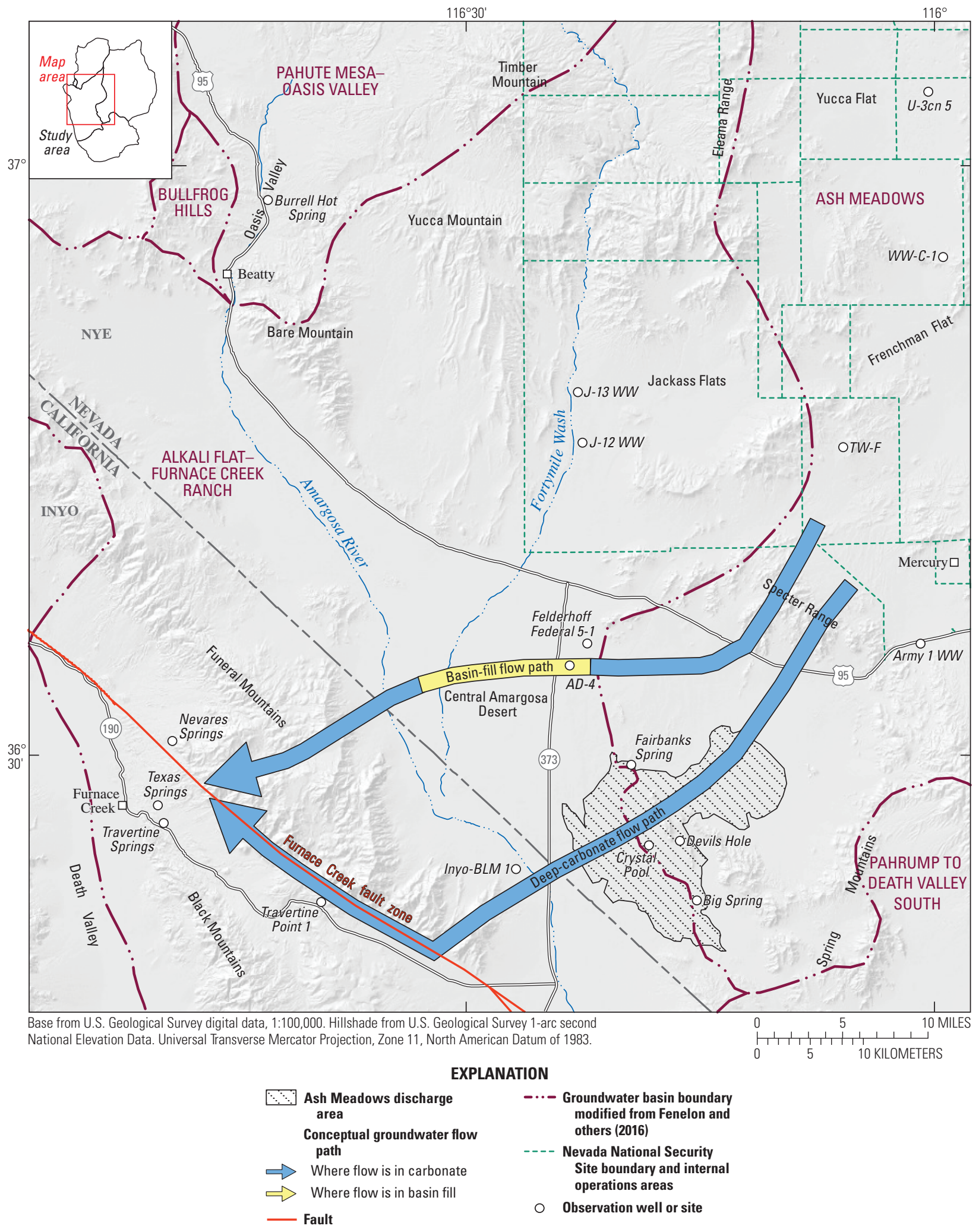

Figure 82. Basin-fill and deep-carbonate flow-path conceptualizations from the Ash Meadows groundwater basin to discharge areas in Furnace Creek, Nevada and California. 


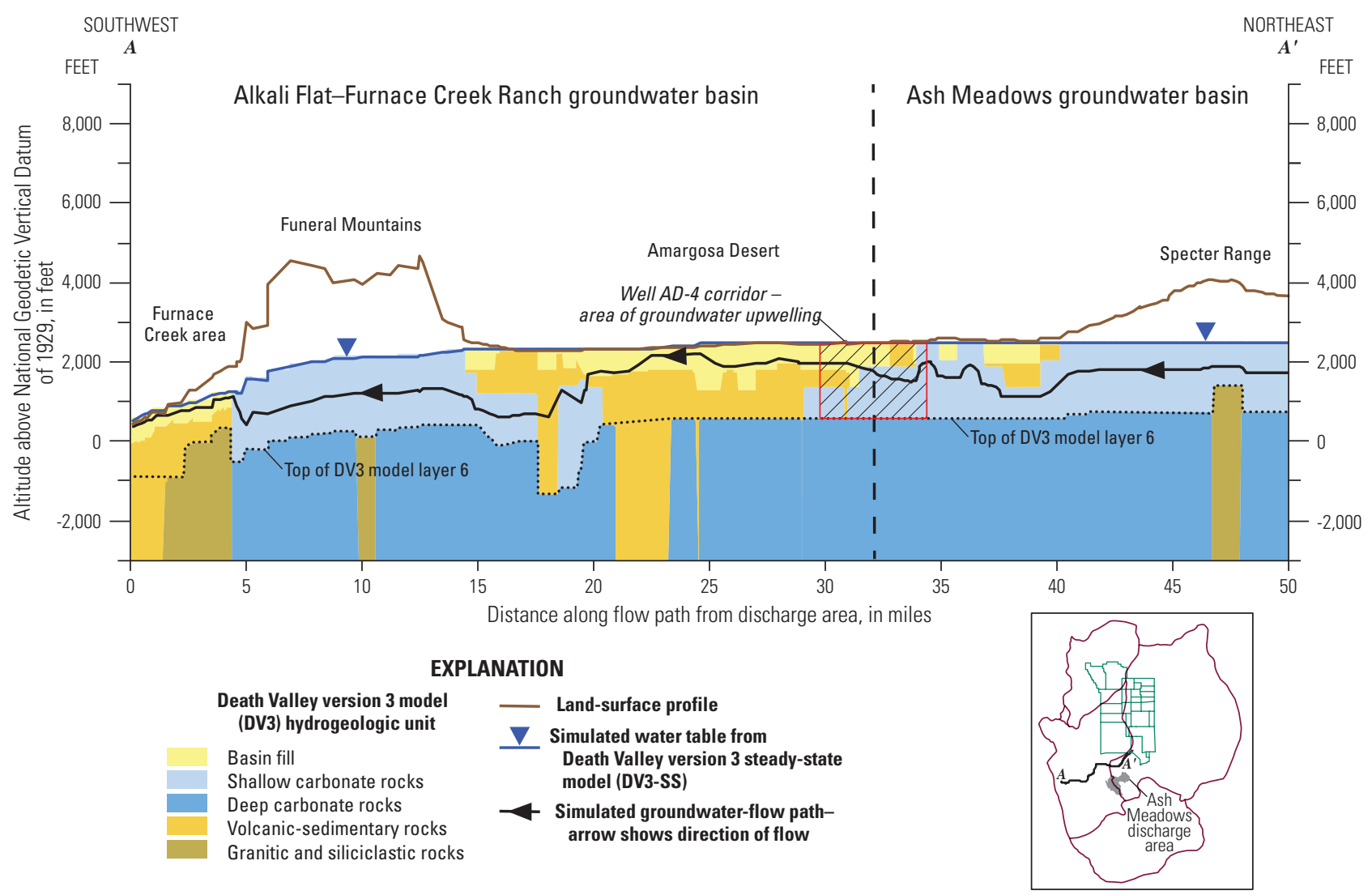

Figure 83. Cross section along a simulated groundwater-flow path from the Ash Meadows groundwater basin to the Furnace Creek area through the well $A D-4$ corridor, Nevada and California.

\section{Flow Potential Through Well AD-4 Corridor}

Potential for flow from Ash Meadows groundwater basin into basin fill in the well $A D-4$ corridor has been recognized for 55 years, but estimated flow rates have differed greatly. Predevelopment water-level contours show a potentiometric high around the well $A D-4$ corridor that radially decreases into the central A margosa Desert (Walker and Eakin, 1963, plate 3). A potentiometric high can occur from mounding from recharge, which is unlikely on a desert valley floor, or from groundwater upwelling. U pwelling of groundwater from carbonate rocks into overlying basin fill along the Gravity fault is supported by water-chemistry data. Water chemistry in wells open to basin fill within $0.4 \mathrm{mi}$ of well $A D-4$ and springs in the A sh M eadows discharge area was classed as chemically similar ("A sh M eadows" and "E ast-central A margosa Desert" in Winograd and Thordarson, 1975, p. C100). Winograd and Thordarson (1975, p. C87) dismissed substantial flow from carbonate rocks to basin fill near well $A D-4$ (figs. 82 and 83 ) because low-permeability siliciclastic rocks were assumed prevalent east of well $A D-4$. Claassen (1985 p. F19) analyzed drillers' logs and additional wells, and concluded that, "...[hydraulic] potential difference and the presence of more permeable sand and gravel in the valley fill in the vicinity of site 27 [well $A D-4$ ] support the presence of significant upward leakage from the carbonate aquifer." A bout 2,000 acre-ft/yr of flow through the corridor was estimated from transmissivity and hydraulic-gradient estimates in the basin fill west of well $A D-4$ (Fenel on and others, 2016).

D rilling history of wildcat oil and gas well Felderhoff Federal 5-1 qualitatively supports the ability of shallow carbonate rock to transmit substantial flow through the well $A D-4$ corridor. Felderhoff Federal 5-1 was drilled $1.6 \mathrm{mi}$ northeast of well $A D-4$ (fig. 82), encountered carbonate rocks $850 \mathrm{ft}$ bel ow land surface, and reached a total depth of 1,466 $\mathrm{ft}$ below land surface (Carr and others, 1995). The well was abandoned before reaching its target depth of $5,000 \mathrm{ft}$ bel ow land surface because circulation using the mud-rotary drilling method could not be maintained. During October 22-25, 1991, less than $100 \mathrm{ft}$ of hole was drilled near the bottom of the borehole (1,466 ft) while about 100,000 gal (2,500 barrels) of mud and cement were injected. Fluid-level altitudes of 2,354 ft were unchanged during injection and are consistent with expected water levels in shallow carbonate rocks at this location. Lack of circulation despite injection of large fluid volumes and unchanged water levels suggest hydraulic connection of the borehole with highly transmissive features in the carbonate rock. Geophysical measurements in the carbonate-rock sidewall of the borehole had bulk densities of $1.1 \mathrm{~g} / \mathrm{cm}^{3}$, which is low compared to average bulk densities that typically exceed $2.6 \mathrm{~g} / \mathrm{cm}^{3}$ for carbonate rocks. L ow 
measured bulk densities and a fully expanded caliper log between 1,410 and 1,445 ft below land surface are highly suggestive of large voids in the carbonate rocks (Carr and others, 1995).

\section{Flow Potential Through Basin Fill in the Central Amargosa Desert}

Transmissivities of basin fill in the central Amargosa Desert are sufficient to convey greater than 6,000 acre-ft/yr of groundwater to carbonate rocks in the Funeral M ountains. This groundwater is sourced from carbonate rocks east of the well $A D-4$ corridor, volcanic rocks at and upgradient of Yucca M ountain and J ackass Flats, and local recharge from the Amargosa River and Fortymile Wash (fig. 80). Specific capacities equal or exceed $20 \mathrm{gal} / \mathrm{min} / \mathrm{ft}$ in 11 wells in the basin fill that overlie dense pathlines through the central A margosa Desert (fig. 80). Pumping rates exceed 2,000 gal/ min in five wells that were reported in Nevada well logs 4379, 4821, 7633, 9510, and 27276 (Nevada Division of Water Resources, 2018). Simulated transmissivities of basin fill in the central A margosa Desert ranging from 10,000 to 100,000 $\mathrm{ft}^{2} / \mathrm{d}$ are consistent with empirical evidence from well logs (fig. $76, F-F^{\prime}$ ).

\section{Basin-Fill, Carbonate-Rock, and Volcanic-Rock Hydraulic Connections}

The basin-fill flow conceptualization assumes basin fill, carbonate rocks, and volcanic rocks are hydraulically connected between recharge areas and the F urnace Creek discharge area. Recharge derived from Yucca Mountain and nearby upland areas in the AFFCR groundwater basin enters primarily volcanic rocks, moves downgradient into basin fill in the central A margosa D esert, and passes through carbonate rocks in the Funeral M ountains (fig. 80). Recharge derived from Ash Meadows groundwater basin moves downgradient through carbonate rocks, enters basin fill in the central A margosa Desert through the well $A D-4$ corridor, and moves into carbonate rocks in the Funeral M ountains (fig. 83). Recharge derived from the Amargosa River and Fortymile Wash infiltrates basin fill beneath the ephemeral channels and then moves into carbonate rocks in the Funeral Mountains. Water entering the Funeral Mountains from these different source areas moves westward to discharge in the Furnace Creek area (fig. 80).

Water-level data support west-southwest movement of groundwater through basin fill, carbonate rocks, and (or) volcanic rocks toward Furnace Creek. Predevelopment waterlevel contour maps show west-southwest groundwater flow toward the Furnace Creek area (Walker and Eakin, 1963, plate 3; Fenelon and others, 2010, plates 3-6; Fenelon and others, 2016, plate 1). Fenel on and others (2010, plates 3-4) show groundwater-flow potential between alluvial-volcanic and carbonate-rock aquifers based on lateral and vertical head gradients between wells.
Water-level declines with time in wells Inyo-BLM 1 and Travertine Point 1 confirm that basin fill in the central A margosa Desert and carbonate rocks of the Funeral Mountains are connected hydraulically. The hydraulic connection was first reported in Fenelon and Moreo (2002, fig. 26). Both wells are completed in carbonate rocks, but on opposites sides of the Funeral M ountains (fig. 82). Well Travertine Point 1 is more than 10 mi west of well Inyo-BLM 1 , which is adjacent to basin fill in the central Amargosa Desert. Water levels declined $4 \mathrm{ft}$ per decade in well InyoBLM 1 (fig. 58C) and $3 \mathrm{ft}$ per decade in well Travertine Point 1 (fig. 52). In basin fill on the western side of the Amargosa Desert, water levels in NA-9 Shallow Well declined $5 \mathrm{ft} /$ decade (J ackson and Halford, 2020). Consistent declines through the Funeral M ountains that diminish with distance from pumping in the A margosa Desert (fig. 57) indicate a strong hydraulic connection with the central A margosa Desert. Similar arguments confirm that basin fill in the central Amargosa Desert and volcanic rocks in Jackass Flats are hydraulically connected (fig. 57).

\section{Geochemically Differentiated Sources of Furnace Creek Area Discharge}

Major-ion and stable-isotope water chemistry can be used to identify potential source areas that contribute to Furnace Creek area discharge. Major-ion chemistry evolves from source areas to the discharge area, where dissolved-solid content typically increases along groundwater-flow paths (Drever, 1988). Stable isotopes of deuterium and oxygen-18 can be used to evaluate sources of Furnace Creek discharge. Deuterium and oxygen-18 concentrations are lighter (more negative) where recharge occurs at higher altitudes or cooler temperatures. Deuterium and oxygen-18 concentrations are affected minimally by water-rock interactions and evolve along flow paths by simple mixing (Thomas and others, 1997; p. (31).

\section{Major lons}

The spatially variable, major-ion chemical character of groundwater across the study area results mostly from reaction with and dissolution of different rock types along flow paths. Groundwater in the Ash Meadows groundwater basin is characterized as a calcium-magnesium-sodiumbicarbonate type water (figs. 84 and 85). Well sites in A sh $M$ eadows groundwater basin are open to carbonate rock and $A$ sh $M$ eadows springs are sourced from carbonate rock (fig. 84). The groundwater chemistry can be explained by long flow paths through carbonate rock that mix with groundwater derived from volcanic rocks. Calcium-magnesium-bicarbonate type groundwater is characteristic of carbonate rocks, whereas sodium-potassium-bicarbonate type groundwater is characteristic of volcanic rocks in the study area (Winograd and Thordarson, 1975). The addition of sodium likely is derived from downward leakage of groundwater through overlying volcanic rocks into carbonate rocks (Winograd and Thordarson, 1975, C104). 


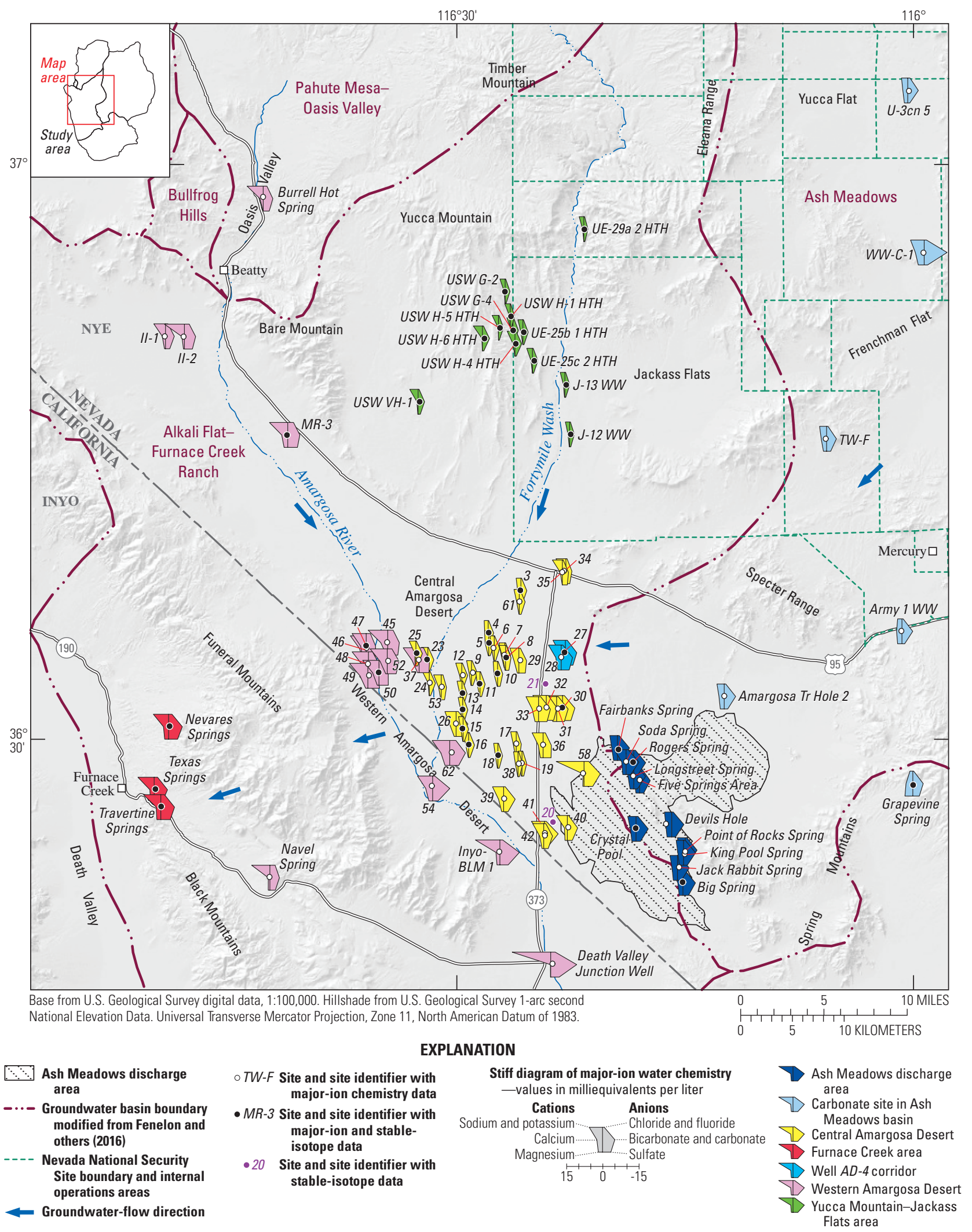

Figure 84. Water-chemistry sites in the Alkali Flat-Furnace Creek Ranch and Ash Meadows groundwater basins, Nevada and California. Water-chemistry data are compiled from Claassen (1973, 1985), Dudley and Larson (1976), and Thomas and others (1997), and are reported in Jackson and Halford (2020). 


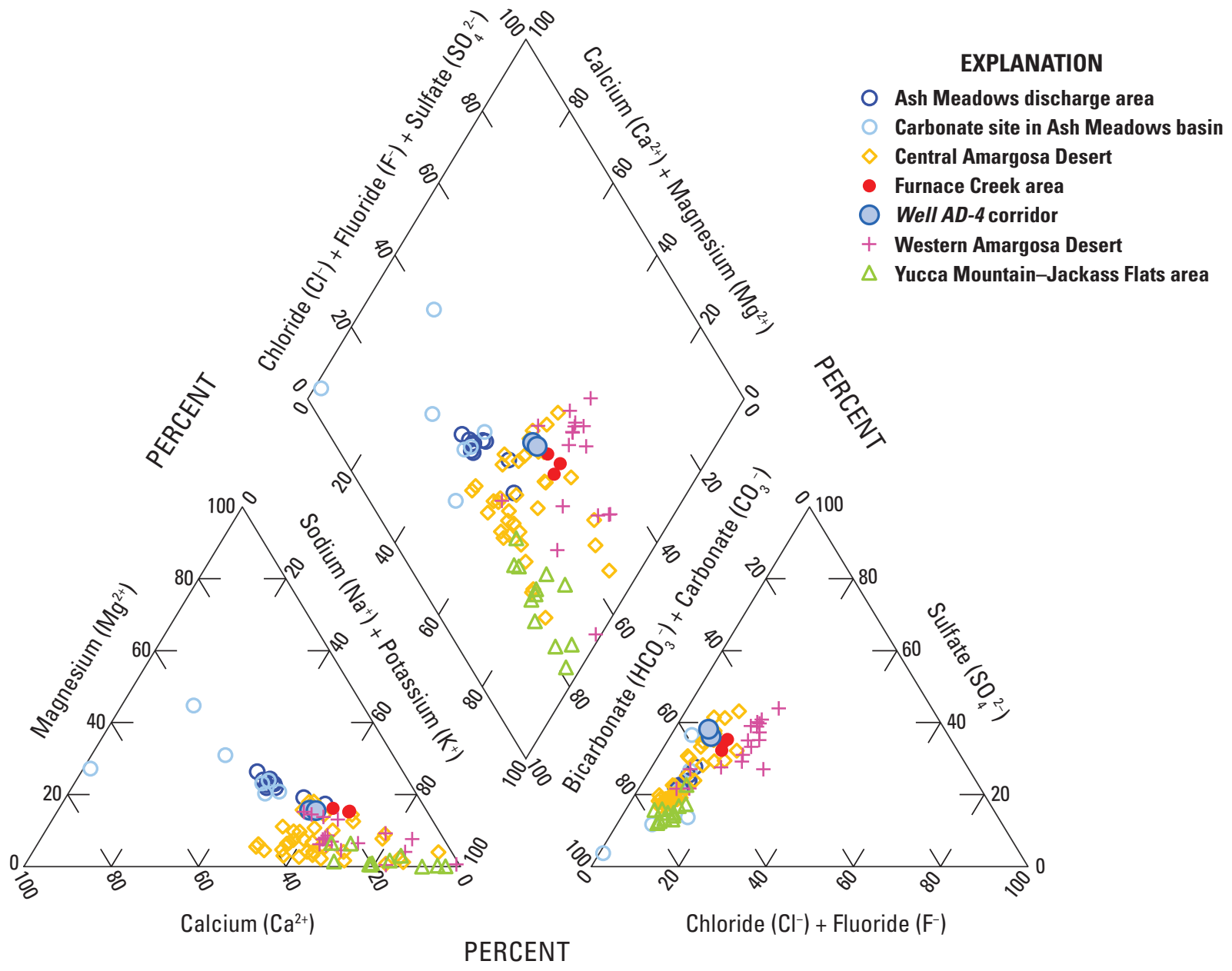

Figure 85. Major ion water chemistry for sites in the Alkali Flat-Furnace Creek Ranch and Ash Meadows groundwater basins, Nevada and California. Water-chemistry data are compiled from Claassen (1973, 1985), Dudley and Larson (1976), and Thomas and others (1997), and are reported in Jackson and Halford (2020).

Groundwater in the well $A D-4$ corridor is chemically similar to Ash Meadows springs (Winograd and Thordarson, 1975, p. C100). Wells 27 (also known as 230 S16 E50 07 1) and 28 (also known as HA-A D 70) in the well $A D-4$ corridor (fig. 84) are a calcium-magnesium-sodium-bicarbonate type (fig. 85), but have greater dissolved-solid concentrations (660 $\mathrm{mg} / \mathrm{L}$ ) compared to A sh M eadows springs (520-580 mg/L). Increased dissolved-solid concentrations are attributed to the addition of sodium and sulfate from mixing with groundwater in basin fill, where the likely source of sulfate is evaporite deposits, such as gypsum, within the basin fill (Winograd and Thordarson, 1975).

Major-ion chemistry varies spatially in the AFFCR groundwater basin because groundwater is derived from different sources (fig. 84). The chemical character of groundwater from volcanic rocks in Yucca Mountain and J ackass Flats and groundwater near Fortymile Wash (fig. 84) is a dilute sodium-potassium-bicarbonate type (fig. 85; Winograd and Thordarson, 1975) with dissolved-solid concentrations ranging from 200 to $315 \mathrm{mg} / \mathrm{L}$. This chemical character is similar to groundwater from wells farther south in the central A margosa Desert, such as Well 4 (also known as 230 S16 E49 05ACC 1) and Well 11 (also known as HR Well) in figure 84. Recharge derived from flood events along the Amargosa River infiltrates basin fill south of Bullfrog Hills and in western A margosa Desert (fig. 84). Near the river channel, groundwater in underlying basin fill, carbonate rocks, and volcanic rocks is a sodium-chloride-sulfate-bicarbonate type (fig. 85) with dissolved-solid concentrations ranging between 700 and $950 \mathrm{mg} / \mathrm{L}$. 
A considerable fraction of discharge from the Furnace Creek area has long been attributed to recharge in A sh M eadows groundwater basin based on the water chemistry of Furnace $\mathrm{Creek}$ spring discharges (Hunt and Robinson, 1960; Hunt and others, 1966; Winograd and Thordarson, 1975; Steinkampf and Werrell, 2001; Belcher and others, 2009). Discharge from the Furnace Creek area also has been proposed to derive exclusively from basin fill in the Amargosa Desert. Winograd and Thordarson (1975, p. C112) concluded: "Therefore, on the basis of chemical quality of water, the spring discharge at the Furnace Creek Wash-Nevares springs area seems to come from water in the valley-fill aquifer of the central and northwestern Amargosa Desert rather than directly from Pahrump Valley or from Pahrump Valley via Ash Meadows." The chemical character of discharge in the Furnace Creek area is a sodium-sulfate-bicarbonate type with dissolved-solid concentrations ranging from 760 to $820 \mathrm{mg} / \mathrm{L}$ (fig. 85), which is distinct from the water chemistry of A sh $M$ eadows springs (fig. 84). This discharge is a mixture of calcium-magnesium-sodium-bicarbonate type groundwater with additional sulfate and chloride (W inograd and Thordarson, 1975, p. C99).

Examination of the available major-ion data plausibly suggests that F urnace $\mathrm{Creek}$ area discharge is a chemical evolution, or mixture, of groundwater derived from both the A sh M eadows and AFFCR groundwater basins (fig. 84). The component coming from the $A$ sh $M$ eadows groundwater basin is calcium-magnesium-sodium-bicarbonate type water moving from shallow carbonate rocks west of well Army 1 $W W$ into the AFFCR groundwater basin through the well $A D-4$ corridor (fig. 84). The components coming from the AFFCR groundwater basin are dilute sodium-potassium-bicarbonate type groundwater originating near Yucca M ountain and Jackass Flats and a higher dissolved-solid, sodium-chloridesulfate-bicarbonate type groundwater near the Amargosa River in the western A margosa Desert (fig. 85). Continued mineral dissolution along flow paths is observed in the increase of dissolved-solid content from the well $A D-4$ corridor (660 $\mathrm{mg} / \mathrm{L}$ ) and Yucca M ountain and J ackass Flats area (200-315 $\mathrm{mg} / \mathrm{L}$ ), to west-central A margosa Desert (700-950 mg/L ) and springs at Furnace Creek (760-820 mg/L) (figs. 84 and 85 ). F urthermore, the central A margosa D esert groundwater has a chemical character that is intermediate between springs in the F urnace Creek and A sh M eadows discharge areas (fig. 85).

Based on major-ion compositions, Furnace Creek area discharge also could result from chemical evolution of Ash Meadows springs discharge. Limited data are available to evaluate the chemical evolution of groundwater from A sh $M$ eadows springs to the $F$ urnace $C$ reek discharge area by way of a deep-carbonate flow path. Inyo-BLM 1 is the only well open to carbonate rocks in the central A margosa Desert (fig. 84), but this 2,900-ft-deep well should represent conditions along the deep-carbonate flow path (fig. 82). Water from well Inyo-BLM 1 has a higher dissolved-solids concentration ( $995 \mathrm{mg} / \mathrm{L}$ ) than Furnace C reek area discharge, which means that groundwater near this well would have to mix with a considerable fraction of more-dilute groundwater to result in the chemical composition of groundwater observed in the Furnace Creek area. In the deep-carbonate flow conceptualization, mixing between concentrated and dilute groundwater would have to occur in only carbonate rocks. This scenario seems less likely than the basin-fill flow conceptualization, which postulates that Furnace Creek area discharge originates from $A$ sh $M$ eadows groundwater basin through the well $A D-4$ corridor and from the A margosa Desert. However, major-ion compositions in carbonate rocks beneath the Amargosa Desert are insufficient to conclusively exclude a flow path between Ash Meadows springs and Furnace Creek discharge.

Stable Isotopes

Deuterium and oxygen-18 concentrations in Furnace Creek cannot be differentiated from the Ash Meadows discharge area, Yucca M ountain-J ackass Flats wells, or A margosa Desert wells. Deuterium concentrations of -104.0, -102.0, and -102.0 permil from Nevares, Travertine, and Texas Springs, respectively, are bracketed by potential sources from A sh M eadows and AFFCR groundwater basins (fig. 86). D euterium concentrations range from -104.0 to -103.0 in the A sh M eadows discharge area, from -108.0 to -93.2 permil in the Y ucca M ountain-J ackass Flats area, from -104.0 to -97.5 permil in the central A margosa Desert, and from -105.0 to - 92.5 permil from carbonate sites in A sh M eadows groundwater basin (fig. 86). Oxygen-18 concentrations of -13.6, -13.7, and -13.7 permil from Nevares, Travertine, and Texas Springs, respectively, also are within the range of sites in the A sh M eadows discharge area, Yucca M ountain-J ackass Flats area, and the western and central A margosa Desert (fig. 86).

The wide range of isotopic values representing Yucca M ountain-J ackass F lats groundwaters indicate the large size and range of altitude covered by this area. The range of isotopic values in the central Amargosa Desert likely occurs because of groundwater mixing. Pumping in the central A margosa Desert generally has increased between 1950 and 2010 (fig. 30). I rrigation pumping has withdrawn about 555,000 acre-ft of groundwater from storage during 1950-2010, when about 94,000 acre-ft of water re-infiltrated as return flow. Samples with oxygen-18 concentrations ranging from - 13.2 to -12.4 permil in the central A margosa Desert wells (sites 3, 13-16, 18, and 20 in fig. 86) appear evaporatively enriched, which may be attributed to pumping and return flow. 


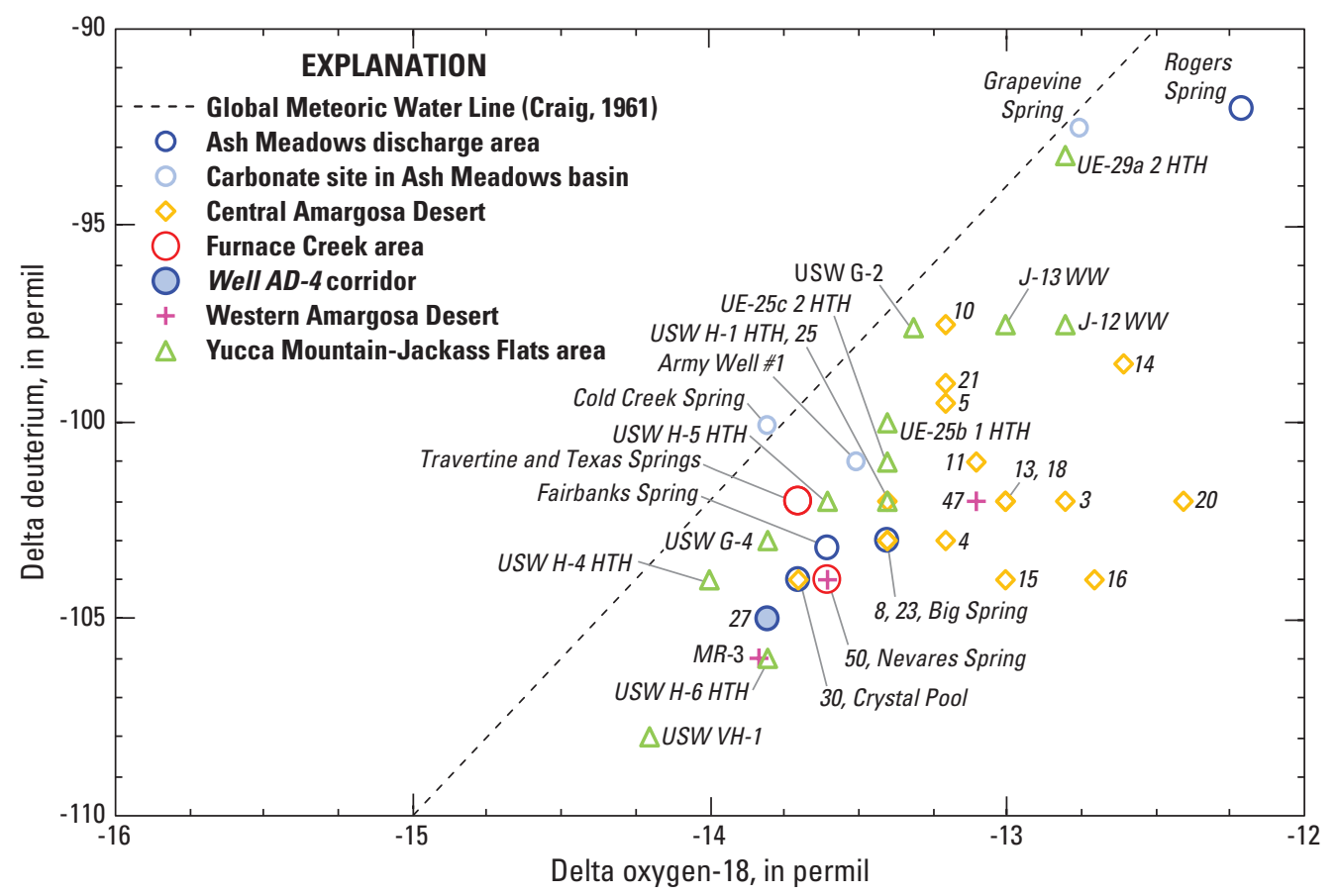

Figure 86. Stable isotopes for sites in the Alkali Flat-Furnace Creek Ranch and Ash Meadows groundwater basins, Nevada and California. Water-chemistry data are compiled from Claassen (1973, 1985), Dudley and Larson (1976), and Thomas and others (1997), and are reported in Jackson and Halford (2020).

\section{Deep-Carbonate Flow Conceptualization}

The deep-carbonate flow conceptualization assumes that deep carbonate rocks beneath the central A margosa D esert hydraulically connect the Furnace Creek area with the A sh $M$ eadows discharge area (fig. 82). This conceptualization principally was developed using hydrochemical data with limited hydrologic evidence. Hydrochemical evidence from previous investigations is reiterated and followed by hydrologic and hydrochemical results from subsequent investigations that contradict the deep-carbonate flow path conceptualization.

\section{Furnace Creek Fault Zone}

The deep-carbonate flow path has been conceptualized as a permeable feature in IT, DVRFS.v1, and DVRFS.v2 models (table 1). Conceptualization and implementation of the deepcarbonate flow path was articulated clearly for the IT model: "The Furnace Creek fault is interpreted to act as a conduit to groundwater flow from the Amargosa Desert to Death Valley." (IT Corporation, 1997, p. 6-15; fig. 82).

The deep-carbonate flow path from Ash Meadows groundwater basin to Furnace $\mathrm{Creek}$ was attributed initially to the Furnace Creek fault zone (fig. 5), which was conceptualized as a conduit through deep carbonate rocks from the A sh M eadows discharge area to F urnace Creek (Hunt and Robinson, 1960). The flow path was postulated in a quarterpage of text, based solely on hydrochemical similarities of spring waters between the Furnace $C$ reek and $A$ sh $M$ eadows discharge areas. This argument was reiterated and expounded upon by assuming Furnace $C$ reek discharge was sourced from Pahrump Valley, based on hydrochemical similarities and decreasing hydraulic potential from Pahrump to the A sh $M$ eadows discharge area and to Furnace Creek (Hunt and others, 1966, p. B40). Arguments for flow from Pahrump to the Furnace Creek area through A sh M eadows were dismissed with a more exhaustive hydrochemical analysis and observation that a thick clastic confining unit isolates Pahrump Valley from A sh M eadows discharge area (fig. 29; W inograd and Thordarson, 1975, p. C91, C112). Furthermore, analysis of major-ion water chemistry (fig. 85) shows that springs in the Furnace Creek area are hydrochemically distinct from springs in the A sh M eadows discharge area (fig. 84). Therefore, no hydrologic or hydrochemical data exist to support the Furnace Creek fault zone as a conduit to groundwater flow. 


\section{Hydrochemical Evidence}

The basis for incorporating the deep-carbonate flow path in the DVRFS.v1 model was as follows: "Hydrochemical data indicate that spring flow in the major springs at the Furnace Creek area likely derives from the carbonate-rock aquifer (Winograd and Thordarson, 1975, p. C95). Similar hydrochemistry between spring waters at Ash Meadows and the Furnace Creek area (Czarnecki and Wilson, 1991; Steinkampf and Werrell, 2001) indicate a hydraulic connection between these two discharge areas through the regional carbonate-rock aquifer by way of large-scale fractures or channels in the carbonate-rock aquifer (Winograd and Pearson, 1976)" (Faunt, D'A gnese, and O 'B rien, 2010, p. 151). Previous arguments were accepted for the DVRFS.v2 model with the statement, "DVRFS v. 2.0 is consistent with the accepted hydrogeologic interpretations of groundwater flow from Ash Meadows to the Furnace Creek springs through the southern Funeral Mountains..." (B elcher and others, 2017, p. 53).

The argument that "[h]ydrochemical data indicate that spring flow in the major springs at the Furnace Creek area likely derives from the carbonate-rock aquifer" (Faunt, D'Agnese, and O'Brien, 2010, p. 151) is not evidence for a deep-carbonate flow path. Springs in the Furnace Creek area are sourced from carbonate rocks. However, the fact that Furnace Creek springs are sourced from carbonate rocks does not mean that groundwater flow from recharge areas to the F urnace Creek discharge area is solely through carbonate rocks. Winograd and Thordarson (1975, p. C113) state clearly that "[f]low from the central Amargosa Desert into Death Valley is the most likely source of the major spring discharge in east-central Death Valley." Winograd and Thordarson (1975, p. C112) al so concluded as follows: "Therefore, on the basis of chemical quality of water, the spring discharge at the Furnace Creek Wash-Nevares springs area seems to come from water in the valley-fill aquifer of the central and northwestern Amargosa Desert."

The argument that "[s]imilar hydrochemistry between spring waters at Ash Meadows and the Furnace Creek area...indicate a hydraulic connection between these two discharge areas through the regional carbonate-rock aquifer" (Faunt, D'A gnese, and O'B rien, 2010, p. 151) is not valid based on available data. The chemical character of Furnace $C$ reek discharge is a sodium-sulfate-bicarbonate type that is distinct from A sh M eadows springs, which are a calcium-magnesium-sodium-bicarbonate type. Central A margosa Desert groundwater has a chemical character that is intermediate between springs in the Furnace Creek and A sh Meadows discharge areas. Chemical evolution of groundwater from A sh M eadows springs to Furnace Creek by way of a deep-carbonate flow path is less plausible, based on the limited data available, compared to a basin-fill flow path. The source of discharge in Furnace Creek is inconclusive based on stable-isotope results. F urthermore, an argument of similar hydrochemistry between springs does not, by itself, indicate a hydraulic connection between the two discharge areas.

The basin-fill flow path was excluded previously because water chemistry of the central A margosa Desert was characterized with limited numbers of wells. For example, in a rare earth el ement study to characterize the source of Furnace C reek springs (J ohannesson and others, 1997), water chemistry of the central A margosa Desert was characterized using only two wells (sites 3 and 35 in fig. 84). Characterization of all central A margosa Desert groundwater using only two wells is not representative because the water chemistry varies greatly (fig. 84). U sing limited data from the central A margosa Desert resulted in the conclusion that "... [rare earth element] signatures of Ash Meadows ground waters are similar to those of springs in the Furnace Creek region of Death Valley but different from shallow ground waters from predominantly tuffaceous alluvial deposits in the Amargosa Desert, perched ground waters from felsic volcanic rocks, and ground waters that have only flowed through the regional Paleozoic carbonate aquifer" (J ohannesson and others, 1997, p. 807). Heterogeneous water chemistry and complex flow fields in the Amargosa Desert indicate that a comprehensive and integrated hydrologic and geochemical analysis is necessary to conclusively characterize flow to Furnace C reek springs.

\section{Contradictory Results from Drilling and Numerical} Simulation

Wells Inyo-BLM 1 and Inyo-BLM 2 (fig. 19) were intended to characterize the deep-carbonate flow path beneath the A margosa Desert (Inyo County Y ucca M ountain Repository Assessment Office, 2005). Well Inyo-BLM 1 was drilled to a depth of 2,900 ft below land surface and penetrated $450 \mathrm{ft}$ of carbonate rocks. A small transmissivity of $100 \mathrm{ft}^{2} / \mathrm{d}$ was estimated from a tidal-forcing analysis (Cutillo and $B$ redehoeft, 2011). Well Inyo-BLM 2 was drilled to a depth of 3,340 ft bel ow land surface without encountering carbonate rocks (Inyo County Y ucca M ountain R epository A ssessment Office, 2007). Results from targeted drilling in the Amargosa Desert contradicted expectations that permeable carbonate rocks occur at depth.

Similar results also occurred with other wells in the study area, where transmissive carbonate rocks at depth were targeted. Wells ER-5-3-2 and UE-25pl (JF-2a) (fig. 19) were drilled to depths of 5,683 and 5,923 ft bel ow land surface, respectively, and penetrated low-transmissivity (100-900 ft $2 / \mathrm{d})$ carbonate rocks. Wells ER-5-4-2 and ER-8-1 (recompleted) (fig. 19) were drilled to depths of 7,000 and 2,863 ft below land surface, respectively, and penetrated low-transmissivity (less than $1 \mathrm{ft}^{2} / \mathrm{d}$ ) volcanic and granitic rocks, respectively, instead of carbonate rocks. Even though a rigorous evaluation of deep carbonate rocks is not possible, failed attempts to find transmissive intervals in deep carbonate rocks indicate that a deep flow path through carbonate rocks is unlikely. 
The deep-carbonate flow path was not simulated by the DVRFS.v2 model (fig. 87), despite being discussed as the preferred conceptual model (B elcher and others, 2017, p. 53). No discharge in the Furnace Creek area originated in the Ash $M$ eadows groundwater basin as simulated with the DV RFS. v2 model. The DV3-SS model simulated groundwater flow to the Furnace Creek area from the Yucca M ountain area in the AFFCR groundwater basin and predominantly from Yucca Flat and the Groom Range in A sh M eadows groundwater basin (fig. 87).

\section{Basin-Fill Flow Path More Probable}

The basin-fill flow path between Ash Meadows groundwater basin and the Furnace Creek area is more plausible, based on available data, than a deep-carbonate flow path for discharge in the Furnace Creek area. The basin-fill flow path, which extends from the well $A D-4$ corridor, through the central A margosa Desert, and into the Funeral M ountains, is consistent with hydraulic and hydrochemical evidence. The deep-carbonate flow path is not supported by hydraulic or geochemical evidence. The water chemistry of discharge in the Furnace Creek area clearly has evolved from the chemistry in the $A$ sh $M$ eadows discharge area and requires mixing with water from a non-carbonate source. Conceptual and numerical models of the basin-fill flow path are consistent in this study. In contrast, the deep-carbonate flow path conceptualization for the DVRFS.v2 study is not consistent with the DVRFS.v2 model (fig. 87).

\section{Predevelopment Water Budgets}

Groundwater basins were subdivided to simulate water budgets where estimated flow rates were needed. Groundwater-flow estimates generally are needed to constrain groundwater-velocity estimates from underground nuclear tests in CAUs at the NNSS. Estimated flow rates also inform water availability in subareas. Groundwater basins were divided into subareas, where flow across subarea divides was minimal, to minimize sensitivity of flow-rate estimates to specific divides (fig. 88). These divisions were suggested by mapped pathlines (fig. 80), water-level contours, and existing mapped groundwater-basin boundaries. Flow rates were simulated and balanced using zones that extended vertically from the water table to the model base in each subarea. Simulated recharge, discharge, and net flows between subareas were totaled with ZONEBUDGET (Harbaugh, 1990) and reported for each subarea.

\section{Pahute Mesa-Oasis Valley Groundwater Basin}

M ost of the recharge in the PM OV groundwater basin is derived from Pahute Mesa (fig. 45). Total simulated recharge in the PM OV groundwater basin is 5,900 acre-ft/yr (table 11; fig. 88). Simulated recharge in the Pahute Mesa and Timber
M ountain areas is 4,130 acre-ft/yr, whereas simulated recharge in the northwestern subarea is 1,060 acre-ft/yr. A smaller amount (600 acre-ft/yr) of recharge occurs in K awich Valley from the B elted and K awich Ranges. A small amount of recharge also is generated locally in the 0 asis Valley discharge area (110 acre-ft/yr).

$M$ ore than 90 percent of the groundwater discharging in Oasis Valley is derived from recharge sourced at Pahute Mesa and Timber Mountain (fig. 88). Total simulated discharge in Oasis Valley is 6,130 acre-ft/yr. The 5,530 acre-ft/yr of groundwater inflow from Pahute Mesa and Timber Mountain areas accounts for locally derived recharge and inflows from the north, west, and east. Bullfrog Hills contributes a small amount (60 acre-ft/yr) of groundwater flow to Oasis Valley.

\section{Ash Meadows Groundwater Basin}

Total simulated recharge in the Ash Meadows groundwater basin is about 21,600 acre-ft/yr (table 11; fig. 88). A bout 80 percent $(17,400$ acre-ft/yr) of the recharge in A sh $M$ eadows groundwater basin occurs in the Spring M ountains and Sheep Range, which are the highest altitude ranges in the study area. Less than 20 percent $(3,670 \mathrm{acre}-\mathrm{ft} / \mathrm{yr})$ of the total recharge is derived from highland areas in the northern part of the $A$ sh $M$ eadows groundwater basin.

Less than 3 percent of predevelopment flow in Ash Meadows groundwater basin moves through Yucca Flat (fig. 88). About 190 acre-ft/yr of groundwater moves into northern Yucca Flat from Emigrant Valley. Groundwater flow through the Eleana Range into western Yucca Flat is about 60 acre-ft/yr, whereas groundwater flow through the Halfpint Range into eastern Yucca Flat is about 10 acre-ft/yr. Simulated recharge derived from highland areas that bound Yucca Flat totals 230 acre-ft/yr. Total simulated groundwater flow from southern Yucca Flat through carbonate rocks is about 530 acre-ft/yr.

Groundwater flow in the Ash Meadows groundwater basin converges near the Specter Range (fig. 88). A bout $17,000 \mathrm{acre}-\mathrm{ft} / \mathrm{yr}$ moves westward from recharge areas spanning from the Spring M ountains in the south to the Sheep Range in the east. A bout 3,700 acre-ft/yr of groundwater moves south-southwest from Yucca Flat and the Pahranagat and G room Ranges.

Simulated water budgets indicate that the A sh M eadows discharge area receives groundwater primarily from the Ash $M$ eadows groundwater basin, with a minor contribution from the PDV S groundwater basin (fig. 88). A bout 18,290 acre-ft/ $\mathrm{yr}$ of groundwater moves southwest into the Ash Meadows discharge area. Simulation results indicate that about 180 acre-ft/yr of groundwater moves northward from Pahrump Valley to the Ash Meadows discharge area. This result is speculative and uncertain because of a lack of water-level data in wells to constrain flow between Pahrump Valley and the A sh M eadows discharge area. 


\section{DVRFS.v2 model}

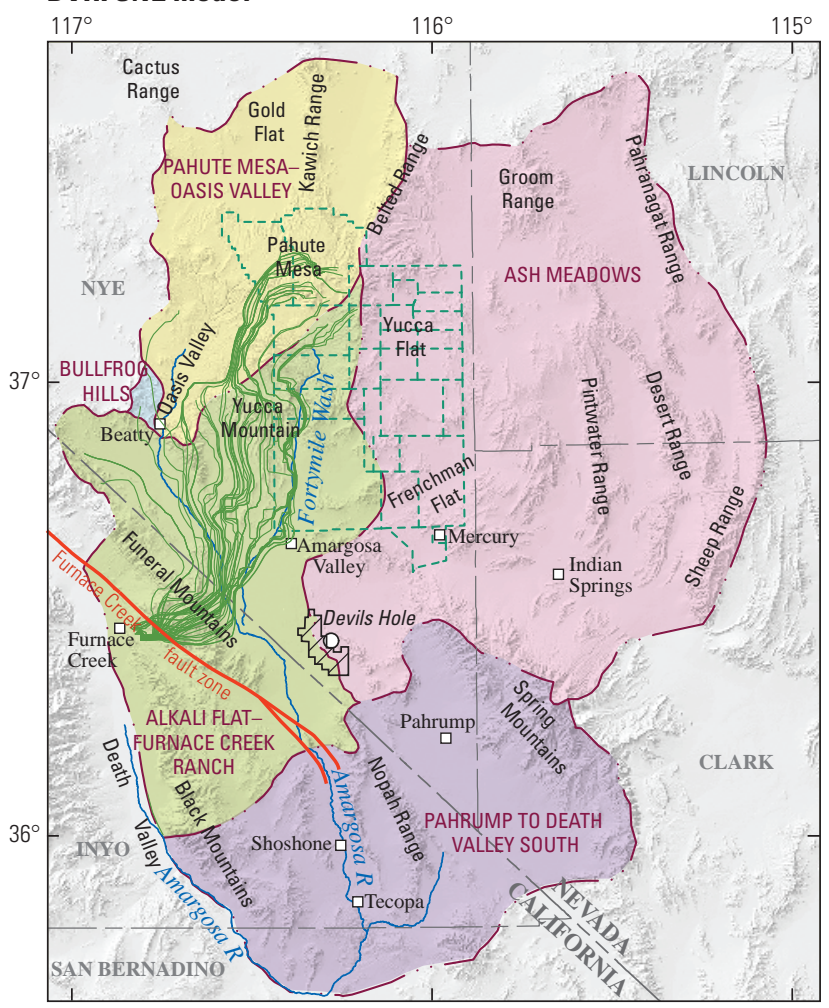

Base from U.S. Geological Survey digital data, 1:100,000. Hillshade from U.S. Geological Survey 1-arc second National Elevation Data. Universal Transverse Mercator Projection, Zone 11, North American Datum of 1983.

\section{DV3-SS model}

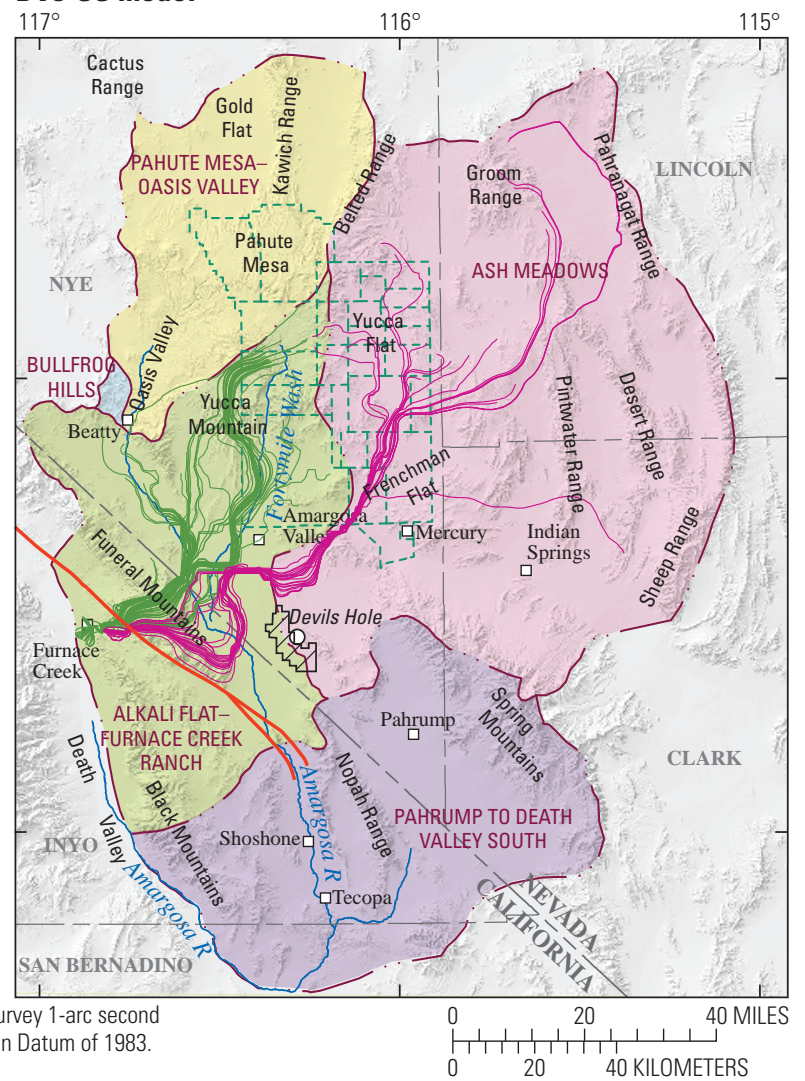

EXPLANATION

$\square \backslash$ Ash Meadows National Wildlife
Refuge
Fault
$-\cdots-$ Groundwater basin boundary
modified from Fenelon and
others (2016)
$---\begin{aligned} & \text { Nevada National Security } \\ & \text { Site boundary and internal } \\ & \text { operations areas }\end{aligned}$

Groundwater-flow path, represent-
ing 50 acre-feet per year-from
Furnace Creek discharge area to
the following recharge areas
Path that originates in Ash
Meadows groundwater basin
Path that originates in Alkali
Flat-Furnace Creek Ranch or
Pahute Mesa-Oasis Valley
groundwater basin

Figure 87. Flow-weighted paths from Furnace Creek discharge area to contributing recharge areas in the Death Valley Regional Flow System version 2 model (DVRFS.v2) and Death Valley version 3 steady-state model (DV3-SS), in the study area, Nevada and California. 


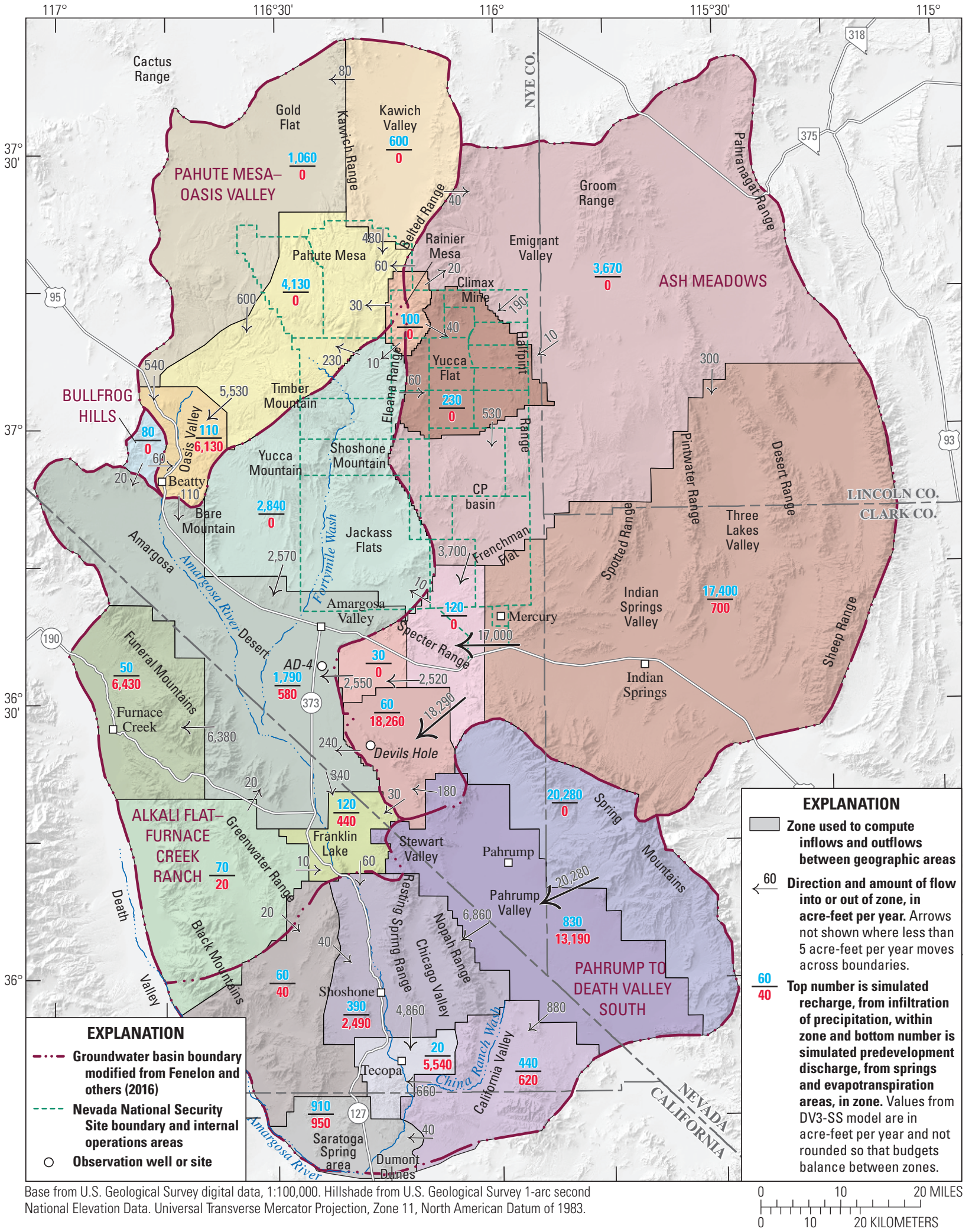

Figure 88. Predevelopment water budgets within and between geographic areas in the study area from the Death Valley version 3 steady-state model (DV3-SS), Nevada and California. 


\section{Alkali Flat-Furnace Creek Ranch Groundwater Basin}

Total simulated recharge in the AFFCR groundwater basin is less than 5,000 acre-ft/yr (table 11; fig. 88). Slightly more than one-half $(2,840$ acre-ft/yr) of the recharge occurs on Timber, Yucca, and Shoshone Mountains (fig. 45). A bout $1,800 \mathrm{acre}-\mathrm{ft} / \mathrm{yr}$ infiltrates along the Amargosa River and Fortymile Wash during ephemeral flows in the Amargosa Desert (figs. 45 and 88).

Groundwater moves laterally into the Amargosa Desert across six of the eight boundaries between adjacent zones (fig. 88). Simulated flow into the Amargosa Desert (AFFCR groundwater basin) principally comes from the A sh M eadows groundwater basin (2,790 acre-ft/yr) and Yucca and Shoshone M ountain areas (2,570 acre-ft/yr). Flow from the PM OV groundwater basin near Beatty, Bullfrog Hills, the Gravity Fault south of the well $A D-4$ corridor, and Greenwater Range are minor and contribute less than 400 acre-ft/yr to the A margosa Desert.

M ost groundwater that enters the A margosa D esert moves westward toward the Furnace Creek area (fig. 88). Total simulated discharge in the Furnace C reek area is 6,430 acre-ft/ yr. About 6,380 acre-ft/yr of groundwater moves from the A margosa Desert through the Funeral M ountains to discharge at Furnace Creek. A bout 50 acre-ft/yr is recharged locally in the F uneral M ountains near Furnace $C$ reek.

Groundwater movement into Franklin Lake occurs from the A margosa Desert, Greenwater Range, and A sh M eadows discharge area (fig. 88). Total simulated discharge at Franklin $\mathrm{L}$ ake is 440 acre-ft/yr, with most of this discharge sourced from the Amargosa Desert. The Greenwater Range and Ash $M$ eadows discharge area directly contribute less than 10 percent of the discharge at Franklin L ake.

\section{Pahrump to Death Valley South Groundwater Basin}

Simulated recharge in the PDV S groundwater basin totals 22,930 acre-ft/yr (fig. 88), but net recharge totals 22,210 acre-ft/yr (table 11) after 720 acre-ft/yr of re-infiltrated surface flow near Dumont Dunes is subtracted. Most of the recharge occurs in the Spring M ountains. A bout 400 acre-ft/ $\mathrm{yr}$ is recharged in the Nopah and Resting Spring Ranges, with most recharge occurring in the Nopah Range (fig. 45). M ost of the discharge from the Saratoga Spring area is re-infiltrated surface flow near Dumont Dunes (fig. 45), and the functional terminus of the PDV S groundwater system is the L ower A margosa area.
M ore than 60 percent of the groundwater entering Pahrump and Stewart Valleys is discharged locally at springs and in evapotranspiration areas (fig. 88). Groundwater inflow to Pahrump and Stewart Valleys from local recharge and upgradient flow from the Spring Mountains totals 20,280 acre-ft/yr. Total simulated discharge in Pahrump and Stewart Valleys is slightly more than 13,000 acre-ft/yr.

L ess than 40 percent $(7,740$ acre-ft/yr) of groundwater entering Pahrump and Stewart Valleys moves southwest to discharge areas downgradient of the Nopah Range (fig. 88). Most of the groundwater moves through the Nopah Range into Chicago Valley. This groundwater either discharges in Chicago Valley or moves southward to discharge along the Amargosa River. Groundwater that enters California Valley either discharges at springs locally in the valley or moves downgradient to discharge areas near Tecopa, California.

Simulation results indicate that groundwater discharging in the Saratoga Spring area is derived from California Valley and from re-infiltrated surface flow near Dumont Dunes (fig. 88). M ore than 70 percent of the discharge in the Saratoga Spring area is local recharge from re-infiltrated surface flow from the Amargosa River. California Valley contributes about 40 acre-ft/yr of groundwater flow to the Saratoga Spring area.

\section{Rainier Mesa Groundwater Sub-Basin}

Recharge to Rainier M esa is limited to 100 acre-ft/ yr across a $50 \mathrm{mi}^{2}$ area (fig. 88), even though Rainier Mesa receives high rates of precipitation. Most of the precipitation is not recharged locally because of low-permeability rocks, which cause most recharge to be redistributed downslope (fig. 16). Recharge rates in Rainier Mesa averaged $0.003 \mathrm{ft} / \mathrm{yr}$ and were limited by low permeabilities of the zeolitized tuffs. This in-place recharge moves downgradient and about 30,60, and 10 acre-ft/yr moves into the PMOV, Ash Meadows, and AFFCR groundwater basins, respectively.

\section{Effects of Groundwater Development}

Effects of groundwater development were characterized with calibrated DV 3-A M -A FFCR and DV 3-PDV S models. Extents of water-level declines from pumping were mapped throughout the study area. Sources of pumped water were differentiated between groundwater-storage depletion, capture of discharge from springs and ET areas, and return flow. Reductions in natural discharges from predevelopment to 2018 were quantified by discharge areas in Oasis Valley, Ash M eadows, Furnace Creek area, Pahrump Valley, and L ower Amargosa area. Effects of pumping centers and local injection on water levels in Devils Hole were differentiated between 1950 and 2018. 


\section{Extent of Water-Level Declines}

Extents of water-level declines throughout the study area in 2018 are shown where simulated declines equal ed or exceeded $1 \mathrm{ft}$ (fig. 57). U sing simulation results to estimate the extent of pumping effects was necessary where effects have not been measured or are obscured. For example, simulated water levels declined in California Valley where no wells have been inventoried or drilled (fig. 57). Simulated declines of 1-2 ft in J ackass Flats likely occurred (fig. 57) but are masked by water-level rises from recharge that exceed declines from pumping (fig. 36). Estimating extents of pumpingaffected areas with simulated water levels is less certain than measuring water levels in wells and primarily suggests where monitoring is needed.

D raw downs from pumping in the central A margosa Desert, Jackass Flats, eastern NNSS, and Indian Springs have coalesced into a 2,200 $\mathrm{mi}^{2}$ area (fig. 57). This area extends west to east from the Furnace Creek area to the base of the Sheep Range and south to north from the southern Funeral $M$ ountains to northern Yucca Flat. D raw downs from multiple pumping centers have combined because relatively contiguous areas have transmissivities greater than $10,000 \mathrm{ft}^{2} / \mathrm{d}$ (fig. 68). Basin fill of the central Amargosa Desert, volcanic and carbonate rocks of J ackass Flats, and the carbonate-rock megachannel are three notable areas where simulated transmissivities are high and empirically confirmed with aquifer-test results.

Drawdowns from pumping in Pahrump Valley have affected most, if not all, transmissive basin fill and carbonate rocks in the PDVS groundwater basin, where drawdowns extend over an area of 1,400 $\mathrm{mi}^{2}$ (fig. 57). D rawdowns were constrained to the southwest by low-permeability rocks that bound transmissive rocks between the Amargosa River and the Spring M ountains (fig. 32). Simulated draw dow ns north of Shoshone and in Chicago Valley are relatively accurate based on comparisons with measured declines in wells 022N007E13L01S and Hwy 127 MM21-1 (fig. 61). Simulated drawdowns do not extend into the Tecopa area (fig. 57). This result is less certain because groundwater levels have not been measured near Tecopa.

D raw downs from isolated areas of groundwater development have limited extents of less than $5 \mathrm{mi}$ (fig. 57). Drawdowns in Emigrant Valley, Pahute M esa, and south of Bullfrog Hills are typical examples of isolated pumping. Drawdowns greater than $1 \mathrm{ft}$ were not simulated around Furnace Creek area pumping wells. These pumping wells are close to Travertine and Texas Springs, which has resulted in most of the pumped water being derived from captured spring discharge rather than groundwater storage. Effects from pumping in Indian Springs are not isolated, as conceptualized, and contribute to water-level declines in the megachannel (fig. 57).

\section{Sources of Pumped Water}

Simulation results for sources of pumped water were differentiated between groundwater-storage depletion, return flow, and capture of discharge from springs and ET areas. Cumulative pumping volumes totaled 50,19, and 31 percent from storage depletion, return flow, and capture, respectively, during groundwater development between 1910 and 2018. Sources differed considerably by groundwater basin as groundwater development occurred (fig. 89). Cumulative capture (1913-2018) exceeded cumulative storage depletion in the PDV S groundwater basin, but storage depletion annually exceeded capture during peak pumping between 1952 and 1985. Storage depletion supplied greater than 90 percent of pumped water from AFFCR and A sh M eadows groundwater basins (fig. 89A). These groundwater basins were combined because pumping from either basin can capture predevelopment discharges in both basins. Return flow consisted of water from storage depletion and capture that had been pumped during previous years. Storage depletion and capture constituted 61 and 39 percent of cumulative return flow in the study area, respectively.

Capture was substantial where groundwater development occurred near springs in Pahrump Valley and the A sh $M$ eadows discharge area. Pumping wells in Pahrump Valley mostly were within $5 \mathrm{mi}$ of Bennetts and Manse Springs prior to 1946 (figs. 29 and 32) and pumped water principally was captured spring discharge (fig. 89). Pumping by Cappaert Enterprises was within $5 \mathrm{mi}$ of springs in the $\mathrm{A}$ sh $\mathrm{M}$ eadows discharge area and about one-half of the pumped water was capture.

\section{Reductions in Natural Discharges}

Discharges from springs and ET areas decreased in response to declining groundwater levels from pumping (table 13). Simulated discharges in 2018 were less than 80 percent of discharges prior to development. More than 80 percent of the simulated decline in predevelopment discharge occurred in Pahrump Valley and primarily was capture of discharges from Bennetts and Manse Springs (fig. 62).

Simulated captures in the Franklin Well area and Chicago Valley were both more than 80 percent of predevelopment discharge (table 13), indicating that extinction depths were underestimated. These ET areas were assigned a uniform extinction depth of $5 \mathrm{ft}$. Simulated water levels in the Franklin Well area and Chicago Valley declined between 10 and 15 $\mathrm{ft}$ after 1993, but vegetation appears little changed between 1994 and 2018. Simulating capture of discharge by $\mathrm{ET}_{\mathrm{GW}}$ with a fixed extinction depth is an approximation that does not account for growth of roots. 


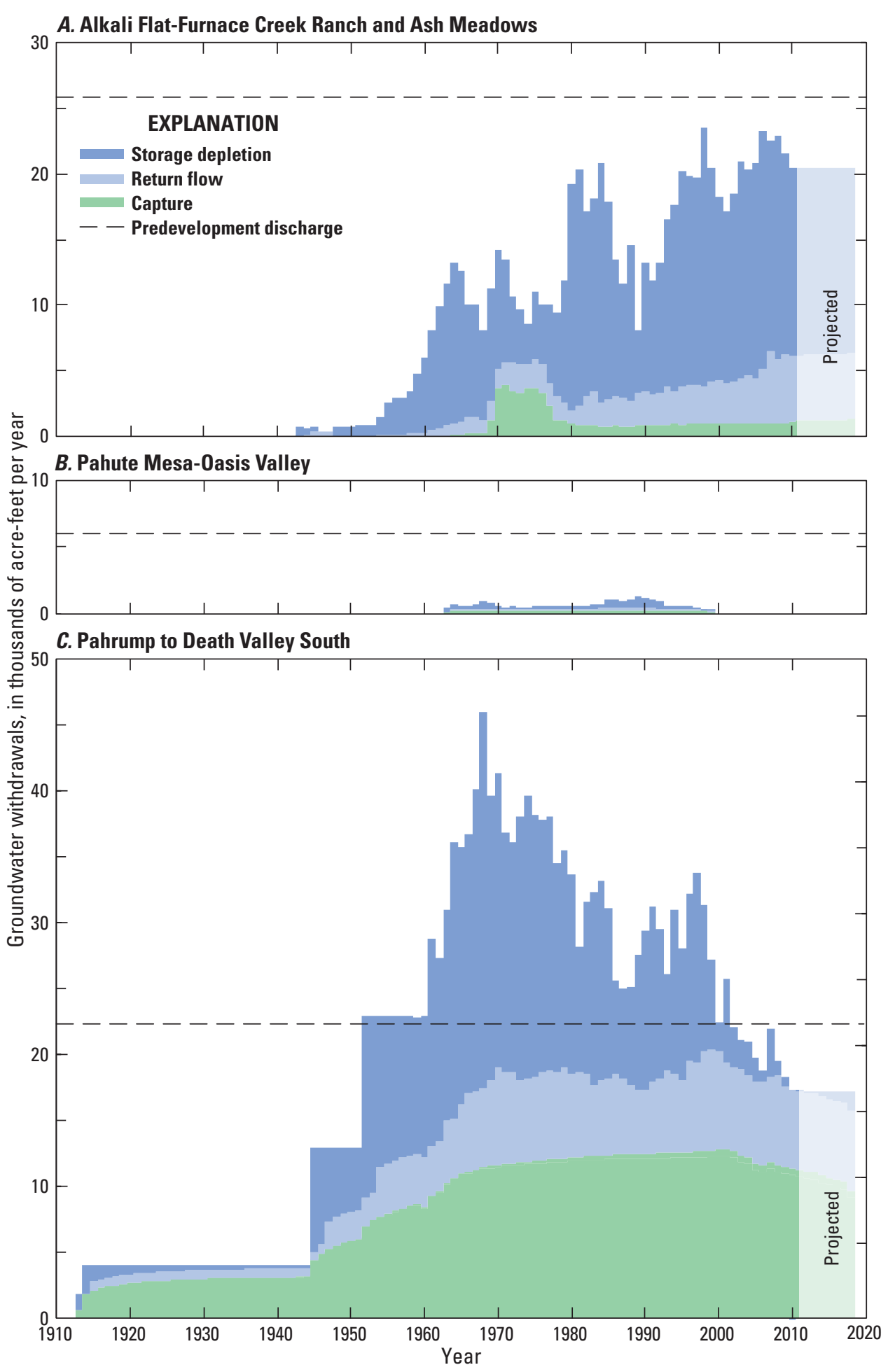

Figure 89. Total annual groundwater withdrawals by groundwater-storage depletion, return flow, and capture of discharge from springs and evapotranspiration areas by groundwater basins Alkali Flat-Furnace Creek Ranch and Ash Meadows $(A)$, Pahute Mesa-Oasis Valley $(B)$, and Pahrump to Death Valley South $(C)$, in the study area, 1910-2018, with withdrawal estimates from 2010 projected to 2018. 
Table 13. Simulated discharges by discharge area for predevelopment (DV3-SS model), 2018 (DV3-AM-AFFCR or DV3-PDVS model), and projected future conditions in 2100 (DV3-PRED model), in the study area, Nevada and California.

[G roundwater basin: AFFCR, Alkali Flat-Furnace Creek Ranch; PDVS, Pahrump to Death Valley South; PMOV, Pahute Mesa-Oasis Valley. Annual simulated discharge- 2018 and 2100: Pumping rates from 2010 were either projected through 2018 or 2100 . Abbreviations: DV 3-A M -A FFCR model, Death Valley version 3 stress-response model simulating groundwater development in the Ash Meadows, Alkali-Furnace Creek Ranch, and Pahute Mesa-Oasis Valley groundwater basins; DV3PDVS model, Death Valley version 3 stress-response model simulating groundwater development in the Pahrump to Death Valley South groundwater basin; DV3-PRED model, Death Valley version 3 predictive model; DV3-SS model, Death Valley version 3 stress-response model simulating steadystate (predevelopment) conditions]

\begin{tabular}{|c|c|c|c|c|}
\hline \multirow{2}{*}{$\begin{array}{c}\text { Groundwater } \\
\text { basin }\end{array}$} & \multirow[t]{2}{*}{ Discharge area } & \multicolumn{3}{|c|}{$\begin{array}{c}\text { Annual simulated discharge } \\
\text { (acre-feet) }\end{array}$} \\
\hline & & Predevelopment & 2018 & 2100 \\
\hline \multirow[t]{4}{*}{ AFFCR } & Furnace Creek area ${ }^{1,2}$ & 6,300 & 6,100 & 5,900 \\
\hline & Franklin Well area ${ }^{3}$ & 330 & 50 & 10 \\
\hline & Franklin Lake ${ }^{1}$ & 300 & 300 & 200 \\
\hline & Death Valley playa ${ }^{1}$ & 100 & 100 & 100 \\
\hline \multirow[t]{2}{*}{ A sh M eadows } & A sh M eadows with A margosa Flat & 18,500 & 18,000 & 17,400 \\
\hline & Indian Springs & 700 & 580 & 530 \\
\hline PM OV & Oasis Valley ${ }^{4}$ & 6,100 & 6,000 & 6,000 \\
\hline \multirow[t]{7}{*}{ PDVS } & Pahrump Valley with Stewart Valley ${ }^{5}$ & 13,200 & 3,300 & 4,900 \\
\hline & Chicago Valley ${ }^{3}$ & 400 & 10 & 0 \\
\hline & Shoshone area & 2,100 & 2,000 & 2,000 \\
\hline & Tecopa/California Valley area & 6,300 & 6,100 & 6,100 \\
\hline & Saratoga Spring area-NET ${ }^{6}$ & 310 & 310 & 310 \\
\hline & Death Valley playa ${ }^{1}$ & 40 & 40 & 40 \\
\hline & TOTAL & 54,700 & 42,900 & 43,500 \\
\hline
\end{tabular}

\footnotetext{
${ }^{1}$ Simulated predevelopment discharges from playas assume groundwater-evapotranspiration rates of 0.001 foot per year.

${ }^{2}$ Simulated discharges from Furnace Creek Wash include diversions.

${ }^{3}$ Simulated discharges in 2018 and 2100 are biased low because extinction depths are underestimated.

${ }^{4}$ Simulated drawdowns of less than 0.5 feet in B eatty captured about 100 acre-feet of discharge in Oasis Valley.

${ }^{5}$ Simulated discharges include Bennetts and Manse Springs and evapotranspiration areas in Pahrump and Stewart Valleys.

${ }^{6}$ Net discharge subtracts 720 acre-feet per year (1 cubic foot per second) of return flow from Amargosa River downstream of Dumont Dunes streamgage (USGS 10251375).
} 
Simulated discharge in 2018 from the A sh M eadows discharge area decreased by 3 percent, or 500 acre-ft/yr, with more than $300 \mathrm{acre}-\mathrm{ft} / \mathrm{yr}$ from springs. Captured spring discharges supplied about one-half of the pumpage for Cappaert Enterprises, but capture varied markedly between springs (fig. 71). Pumping captured all discharge from Jack Rabbit Spring during summer months from 1972 to 1977. However, average discharge from Big Spring decreased by 20 percent and seasonally fluctuated 10 percent owing to pumping by Cappaert Enterprises (fig. 71). M aximum capture of all spring discharge occurred in A ugust 1971 when well Spring Meadows 6 pumped 1,400 gal $/ \mathrm{min}(3.0 \mathrm{ft} / \mathrm{s}$ ) (figs. 37 and 38). M ore than 90 percent of the water pumped from well Spring Meadows 6 was captured discharge from Crystal Pool, which is within 1,000 ft of well Spring Meadows 6 (Dudley and Larson, 1976).

Pumping in the central A margosa Desert minimally affected discharges from Travertine and Texas Springs in the Furnace Creek area (fig. 90). Combined simulated discharges from Travertine and Texas Springs decreased by a total of $0.24 \mathrm{ft}^{3} / \mathrm{s}(170 \mathrm{acre}-\mathrm{ft} / \mathrm{yr})$ between predevelopment and 2018 . Nearly all simulated capture from these springs were caused by local pumping in the Furnace $C$ reek area that started in 2009. M easured discharges were not easily interpreted because of missing records and shifts from earthquakes that introduced ambiguity. Combined measured discharges from Travertine and Texas Springs decreased from $2.4 \mathrm{ft}^{3} / \mathrm{s}$ (1,740 acre-ft/yr) to $2.0 \mathrm{ft}^{3} / \mathrm{s}$ (1,450 acre-ft/yr) between 1964 and 1990. The observed decrease is difficult to attribute to a particular stress because discharges only were measured once during this 25-year period. Discharges were measured continuously for less than 3 years during the 1990s before earthquakes perturbed spring discharges (fig. 90). Combined discharge from Travertine and Texas Springs increased 0.3 $\mathrm{ft}^{3} / \mathrm{s}$ (220 acre-ft/yr) in response to the L anders/Little Skull Mountain earthquake and earthquake effects dissipated after a decade (Cutillo and Ge, 2006). Restoration activities, such as restoring spring runs from Travertine and Texas Springs, in the Furnace $\mathrm{Creek}$ area al so perturbed discharges between 2006 and 2008.

\section{Ash Meadows and Devils Hole}

Effects of individual pumping centers on water levels in Devils Hole were estimated with calibrated DV 3-A M -A FFCR and DV 3-PDV S models. Pumping wells were grouped into 11 pumping centers by geography and NNSS operational units (table 14). The central Amargosa Desert, Pahrump Valley, and Cappaert Enterprises were grouped as major pumping centers (fig. 91). Pumping from A sh M eadows groundwater basin was differentiated further between Crystal, Indian Springs, and the megachannel (fig. 91). Pumping from wells in the megachannel was grouped separately from nearby wells outside the megachannel because of disproportionate effects of pumping on water levels in Devils Hole. Net pumpage from pumping centers and its effect on water levels in Devils Hole between 1968 and 2018 are shown in table 14. Simulated results are not shown prior to 1969 because limited data are available in Devils Hole prior to 1969 and measurable waterlevel declines occurred after 1969.

Water-level changes in Devils Hole were simulated 11 times with pumping and return flows from a single pumping center in each simulation. Individual water-level changes from 11 simulations were summed and compared to the total simulated change from all pumping in the calibrated DV 3 AM-AFFCR model. The summation of individual simulations did not equal total simulated changes from the calibrated DV 3-A M -AFFCR model (fig. 92). Results differed because captures from springs and ET areas were non-linear and depended on total pumpage. The fact that Jack Rabbit Spring went dry during summer from 1970 to 1977 is an example of a non-linear response (fig. 71). Individual water-level changes were scaled so that the summation of individual simulations equaled simulated changes from the calibrated DV 3-A M AFFCR model. Scaling fractions varied with time and ranged from 1.15 to 0.72 during 1984 and 2018, respectively (fig. 92).

Only pumping centers in the central A margosa D esert and Ash Meadows groundwater basin measurably affected water levels in Devils Hole (table 14). Pumping from B eatty, Pahrump Valley, and Pahute and B uckboard M esas did not affect water levels in Devils Hole because areas of low transmissivity intervene (figs. 29 and 72). J ackass Flats did not affect water levels in Devils Hole because pumping was distant and pumped volumes were small relative to aquifer storage (table 14). Furnace Creek area did not affect water levels in Devils Hole because pumping was distant and pumped wells captured nearby discharge from Travertine and Texas Springs.

Pumping by Cappaert Enterprises and the NNSS inside the megachannel predominantly affected water levels in Devils Hole between 1969 and 1980 (fig. 92). However, residual effects of pumping from the megachannel have persisted for decades after pumping ceased. Maximum water-level declines of $2.5 \mathrm{ft}$ occurred during the 1970s, where 80 percent of the decline was due to pumping by Cappaert Enterprises. Pumping by Cappaert Enterprises accounted for 25 percent of the anthropogenic water-level decline in Devils Hole in 2018, 40 years after pumping ceased. Pumping by the NNSS inside the megachannel accounted for, on average, 20 percent of the anthropogenic water-level decline in Devils Hole during the 1970s. Although most of the pumping in the NNSS occurred prior to 1993, NNSS pumping inside the megachannel accounted for 25 percent of the water-level decline in Devils Hole from 1993 to 2018. Water-level declines in 2018 of less than $0.1 \mathrm{ft}$ from Crystal are small (fig. 92), but disproportionately large for average pumping rates of 40 acre-ft/yr (table 14). Pumping in Crystal exaggeratedly affected water levels in Devils Hole because pumpage came from the megachannel (fig. 91). 


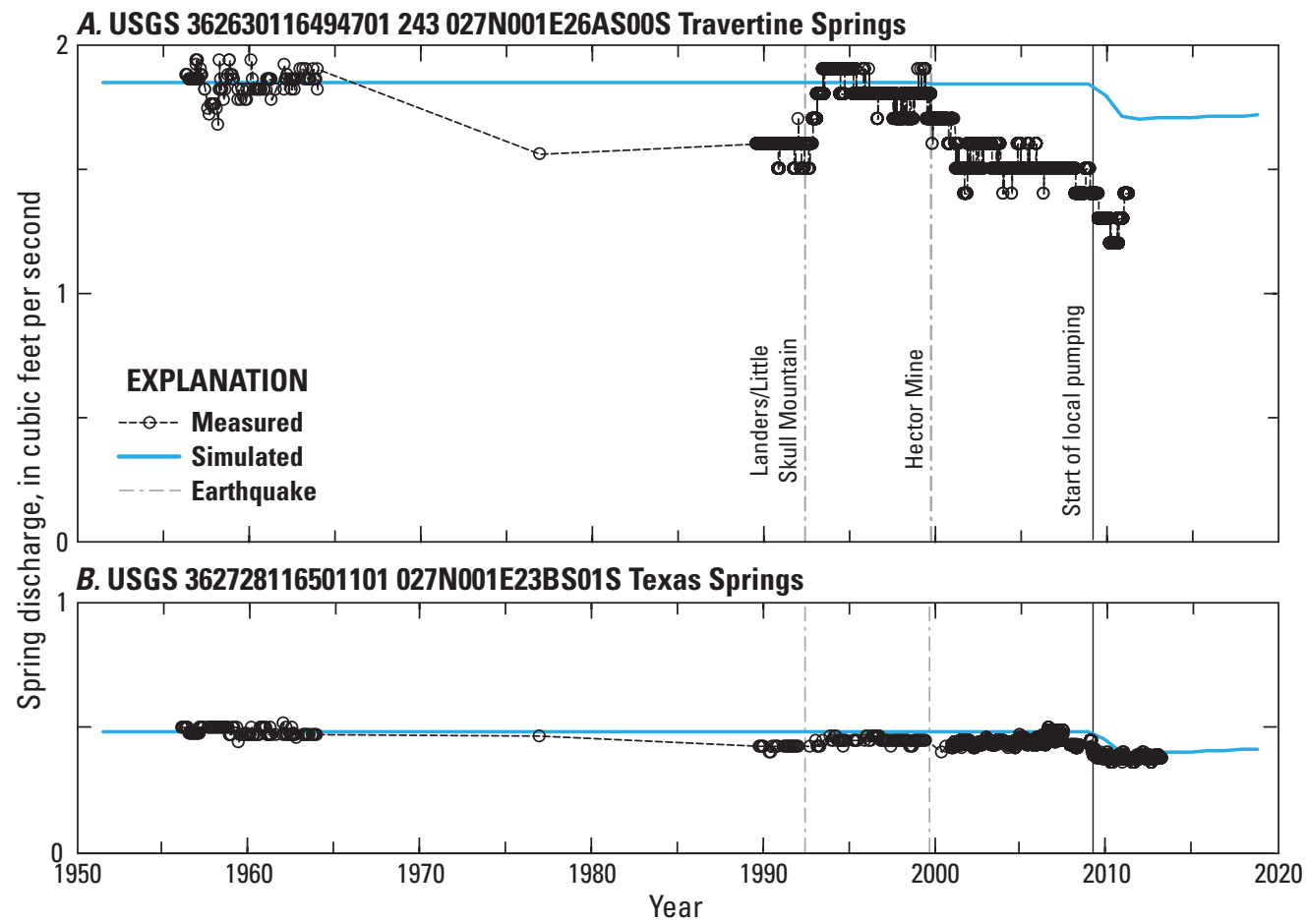

Figure 90. Measured and simulated discharges from Travertine $(A)$ and Texas $(B)$ Springs in the Furnace Creek area, California, 1950-2018. Simulated discharges do not account for earthquake effects.

Table 14. Pumping centers; net pumpage volumes, 1969-2018; and effect of pumping centers on water levels in Devils Hole, in the study area, Nevada and California.

[Groundwater basin: AFFCR, Alkali Flat-Furnace Creek Ranch; PDVS, Pahrump to Death Valley South; PMOV, Pahute Mesa-Oasis Valley. Symbols: $<$, less than; -, not applicable because simulated drawdown was not estimated]

\begin{tabular}{llcccc}
\hline \multirow{2}{*}{$\begin{array}{c}\text { Groundwater } \\
\text { basin }\end{array}$} & \multicolumn{1}{c}{$\begin{array}{c}\text { Pumping center } \\
\text { Volume of net pumpage, }\end{array}$} & $\begin{array}{c}\text { 1969-2018 } \\
\text { (acre-feet) }\end{array}$ & $\begin{array}{c}\text { Simulated water-level decline in } \\
\text { Devils Hole (feet) }\end{array}$ & $\begin{array}{c}\text { Year of maximum } \\
\text { water-level decline } \\
\text { in Devils Hole }\end{array}$ \\
\cline { 4 - 5 } & & 40,000 & $\mathbf{2 0 1 8}$ & Maximum & 1972 \\
A sh M eadows & Cappaert Enterprises & 540,000 & 0.36 & 2.09 & 2018 \\
A FFCR & Central A margosa Desert & 15,000 & 0.48 & 0.48 & 1995 \\
A sh M eadows & Inside megachannel & 2,000 & 0.31 & 0.46 & 1987 \\
A sh M eadows & Crystal & 38,000 & 0.06 & 0.23 & 2007 \\
A sh M eadows & Outside megachannel & 28,000 & 0.12 & 0.14 & 2018 \\
A sh M eadows & Indian Springs & 6,000 & 0.08 & 0.08 & - \\
AFFCR & Jackass Flats & 26,000 & $<0.01$ & $<0.01$ & - \\
AFFCR & B eatty & 11,000 & $<0.01$ & $<0.01$ & - \\
PM OV & Pahute and Buckboard M esas & $1,064,000$ & $<0.01$ & $<0.01$ & - \\
PDVS & Pahrump Valley & 2,000 & $<0.01$ & $<0.01$ & - \\
AFFCR & Furnace Creek area & $<0.01$ & $<0.01$ & - \\
\hline
\end{tabular}




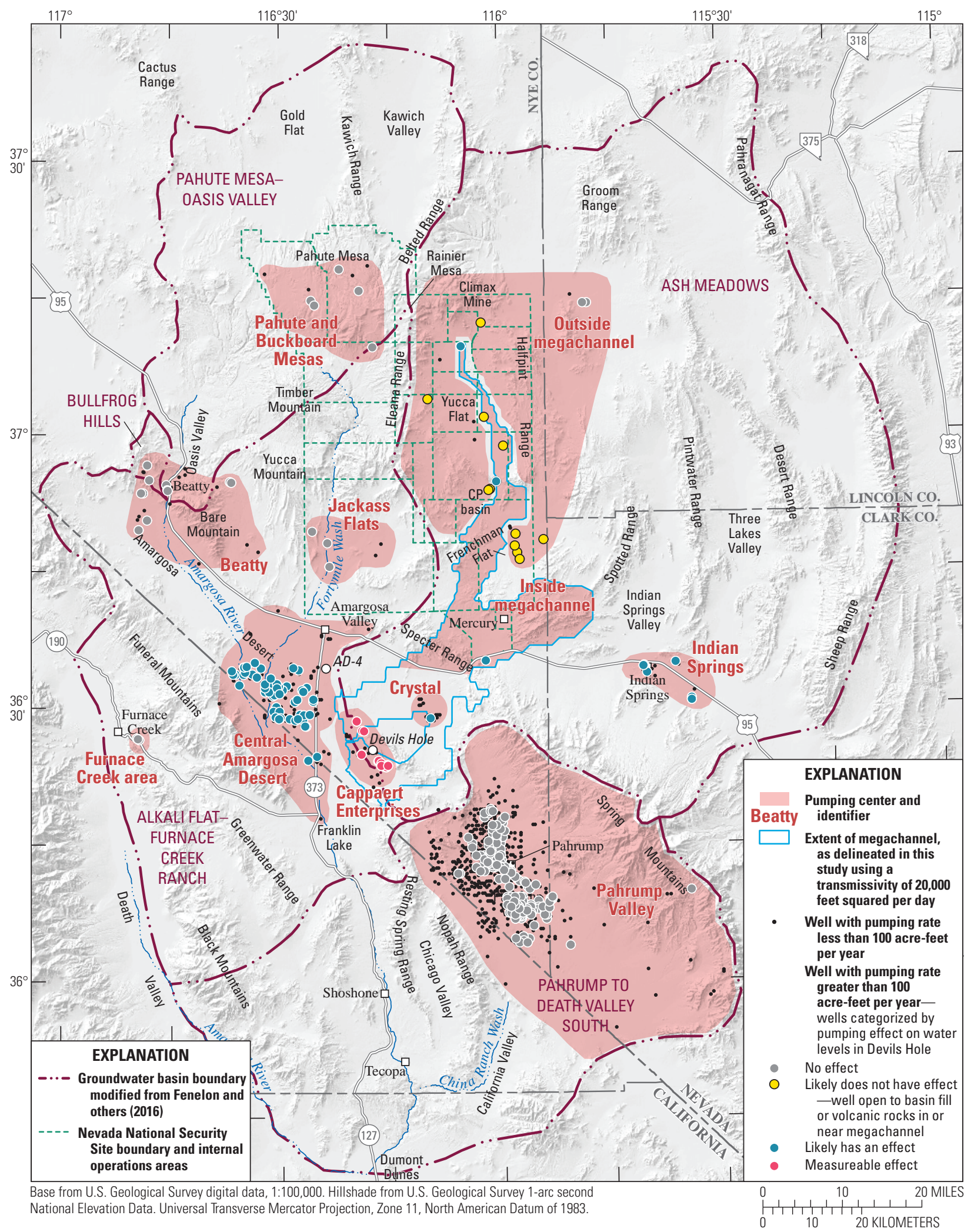

Figure 91. Pumping centers analyzed for affecting water levels in Devils Hole, Nevada and California. 


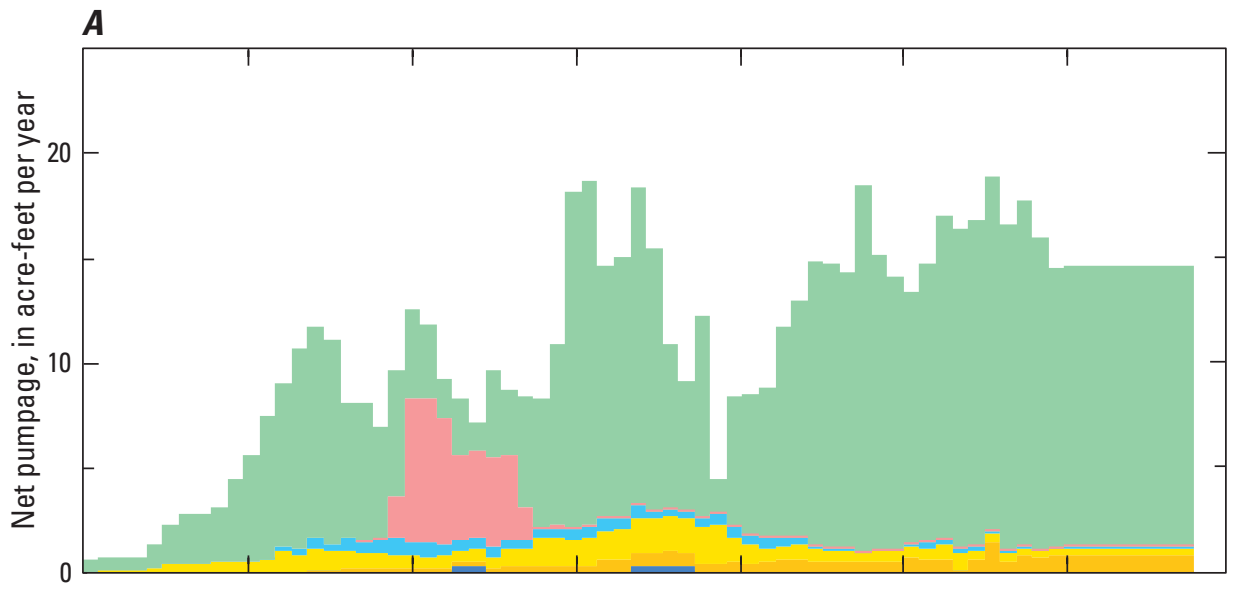

\begin{tabular}{|l}
\multicolumn{1}{c}{ EXPLANATION } \\
Crystal \\
Indian Springs \\
Outside megachannel \\
Inside megachannel \\
Central Amargosa Desert \\
Cappaert Enterprises \\
\hline$\quad$ Measured without natural fluctuations
\end{tabular}

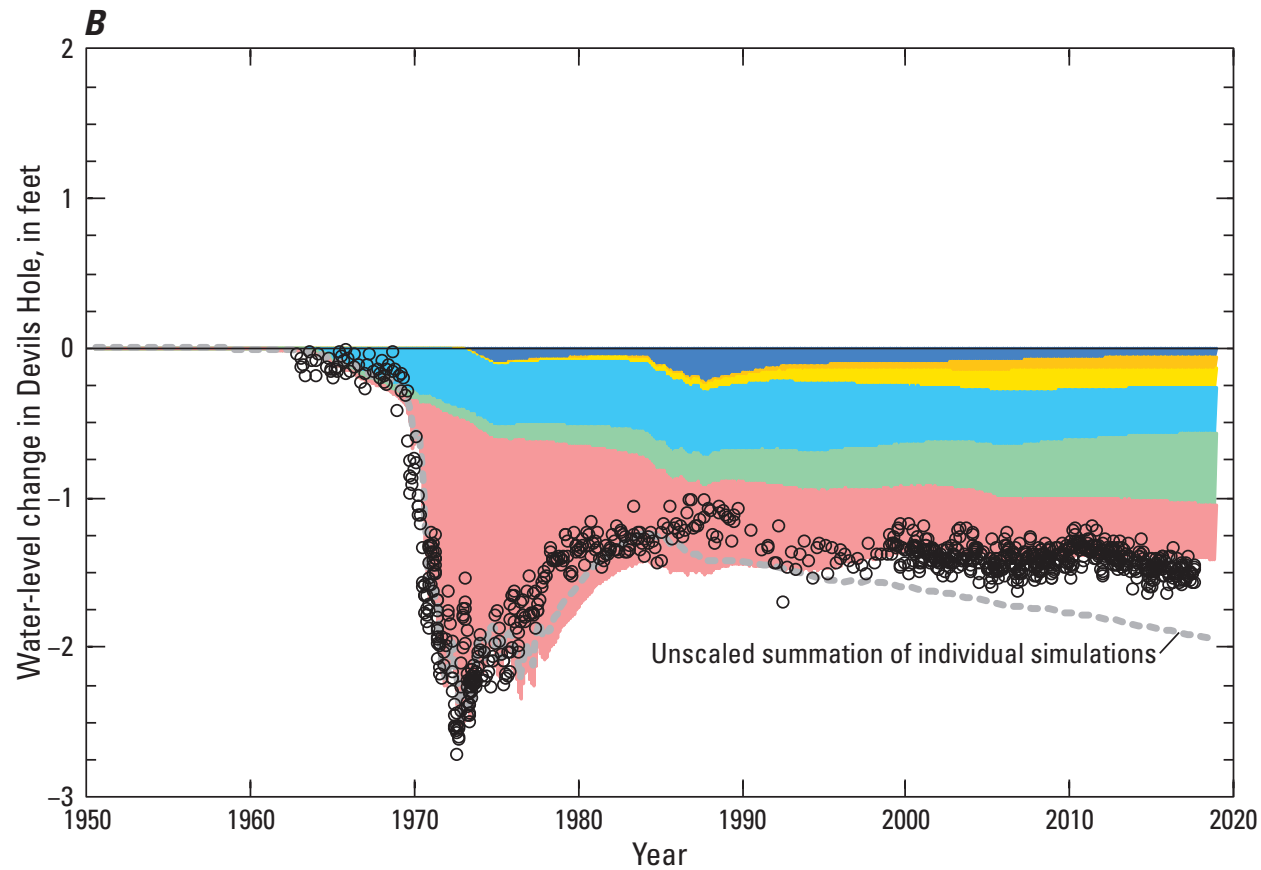

Figure 92. Annual net pumpage by pumping center $(A)$ and water-level changes in Devils Hole by pumping center, as simulated with the Death Valley version 3 stressresponse model simulating groundwater development in the Ash Meadows, Alkali Flat-Furnace Creek Ranch, and Pahute Mesa-Oasis Valley groundwater basins $(B)$, Nevada and California, 1950-2018. 
Water levels in Devils Hole declined rapidly in the early 1970s, recovered through the 1980s, and have declined slowly and steadily since the 1990 s from pumping in the central A margosa Desert (fig. 92). Pumped volumes from the central A margosa Desert were an order of magnitude greater than pumped volumes from Cappaert Enterprises (table 14), but effects on water levels in Devils Hole were attenuated by limited hydraulic connection through the well $A D-4$ corridor. Water levels in Devils Hole have declined at a rate of $0.1 \mathrm{ft}$ per decade from pumping in the central A margosa Desert during 1998-2018. Pumping in the central A margosa Desert accounted for a third of anthropogenic water-level decline in Devils Hole during 2018 (fig. 92).

Injection in Devils Hole Well (AM-5) elevated water levels in Devils Hole about $0.5 \mathrm{ft}$ prior to the discontinuation of injections in 1977 (fig. 93). Effects of injection in Devils Hole Well (AM-5) were estimated by removing injection from the calibrated DV 3-A M -AFFCR model and simulating water-level changes in Devils Hole. Results from the model simulating injection were subtracted from model results without injection to estimate effects of injection in Devils Hole Well (AM-5) on water levels in Devils Hole. Differences in fit between measured and simulated water levels in Devils Hole prior to and during injection suggest that injection rates were more variable than reported (Larson, 1975). This is because measured and simulated monthly water-level changes track well prior to injection and poorly during simulated injection. Water levels in Devils Hole Well (AM-5) also vary greatly (fig. 39), which suggests that the injection rate was not constant with time.

\section{Potential Effects of Future Groundwater Development}

Potential effects of future groundwater development on water levels and spring discharges were estimated with the DV 3-PRED model (Jackson and Halford, 2020). Pumping history and temporal discretization in the DV 3-PRED model differed from the DV3-AM-AFFCR and DV3-PDVS models. Pumping changed annually in all groundwater basins from 1913-2010 in the DV 3-PRED model. A nnual pumping rates during 2011-2018 were projected from pumping rates in 2010 (Elliott and M oreo, 2018). A ll pumping scenarios simulated pumping, water-level changes, and capture of discharges from 1913-2018 before solving for predicted changes. Simulated water-level changes in Devils Hole from DV 3-A M -A FFCR (fig. 92) and DV 3-PRED (fig. 94) models differ because of use of monthly and annual stress periods during pumping by Cappaert Enterprises, respectively. These temporal pumping differences dissipated during recovery between 1980 and 2000, and simulated water levels from both DV3-AM-AFFCR and DV 3-PRED models were quite similar between 2000 and 2018 (fig. 94).
Water-level changes in Devils Hole from pumping were simulated with steady-pumping and no-pumping scenarios that simulated changes from 2019-2100 (fig. 94). Pumping rates from 2010 were projected from 2019-2100 in the steadypumping scenario. All pumping ceased in 2019 and recovery was simulated in the no-pumping scenario. Simulated water levels in Devils Hole declined $1.5 \mathrm{ft}$ and rose $0.1 \mathrm{ft}$ from 2019-2100 in the steady-pumping and no-pumping scenarios, respectively (fig. 94).

Prolonged water-level recovery responses in Devils Hole were observed from Cappaert pumping during 1980-2018 and from results of the hypothetical no-pumping scenario during 2019-2100. Prolonged water-level recovery responses to pumping are typical in the megachannel. For example, prolonged recovery also has been observed in Tracer Well 3 during recovery from Cappaert pumping (fig. 70) and recovery from the ER-6-1-2 main MWAT (fig. 67). Prolonged recovery occurs because large volumes of groundwater were withdrawn from carbonate rocks in the megachannel. Pumping minimally decreases water levels and induces little extra flow from surrounding rocks to offset storage depletion in the megachannel. Substantial groundwater-storage depletion from the A sh M eadows groundwater basin (fig. 89) has resulted in a 2-ft water-level decline throughout the carbonate-rock megachannel by 2018 (fig. 57).

Water-level changes in Devils Hole simulated with the DV 3-PRED model likely are biased towards minimum change for given pumping rates because of assumptions regarding natural fluctuations. Water levels are affected by long-term natural fluctuations; however, simplified assumptions were made to quantify this natural variability so that hydraulic properties could be estimated (fig. 40). Long-term natural fluctuations in Devils Hole were not estimated uniquely and were biased toward a minimum rise of $1 \mathrm{ft}$ between 1973 and 2018. A rise of $1.5 \mathrm{ft}$ between 1973 and 2018 could have been estimated in Devils Hole, which would have caused drawdown estimates to be $0.5 \mathrm{ft}$ greater or total $2 \mathrm{ft}$ in 2018, instead of the $1.5 \mathrm{ft}$ of drawdown currently simulated in 2018 (fig. 94). Simulated water levels in Devils Hole would have declined $2 \mathrm{ft}$ between 2018 and 2100, or $4 \mathrm{ft}$ from predevelopment conditions, in the steady-pumping scenario had an alternative long-term natural fluctuation with a rise of $1.5 \mathrm{ft}$ between 1973 and 2017 been used.

Natural discharges are projected to increase by 1,600 acre-ft/yr in Pahrump Valley and decrease slightly or not change in all other discharge areas between 2018 and 2100 if pumping remains at 2010 rates in the steady-pumping scenario (table 13). Increased discharges were simulated in Manse Spring and are a response to locally rising water levels (fig. 51) that are projected to continue. Simulated discharges in Chicago Valley decreased by $10 \mathrm{acre}-\mathrm{ft} / \mathrm{yr}$ between 2018 and 2100, whereas simulated discharges in the Shoshone and Tecopa/California Valley areas are projected to remain unchanged from 2018 to 2100 . Simulated discharges in the A sh $M$ eadows and AFFCR groundwater basins decreased by about 1,000 acre-ft/yr between 2018 and 2100 (table 13). 


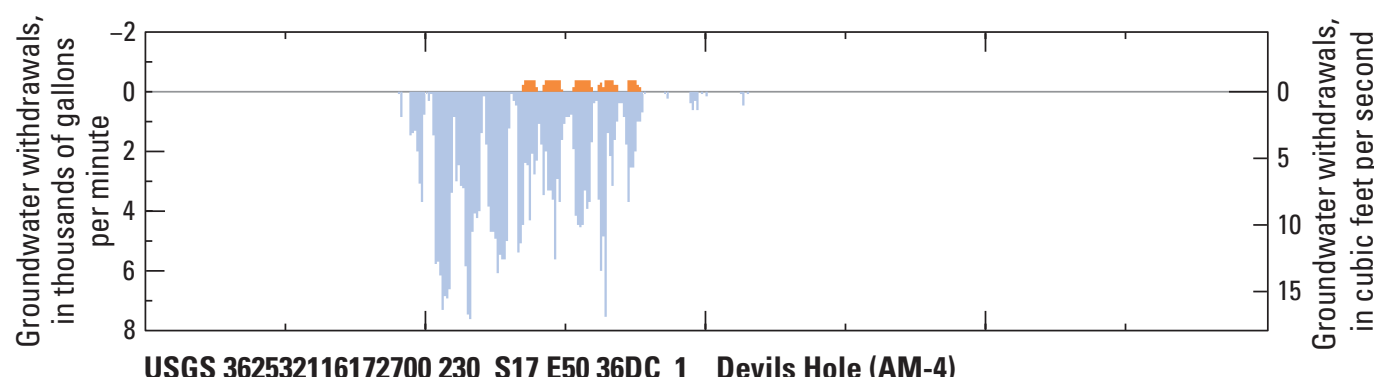

USGS 362532116172700230 S17 E50 36DC 1 Devils Hole (AM-4)

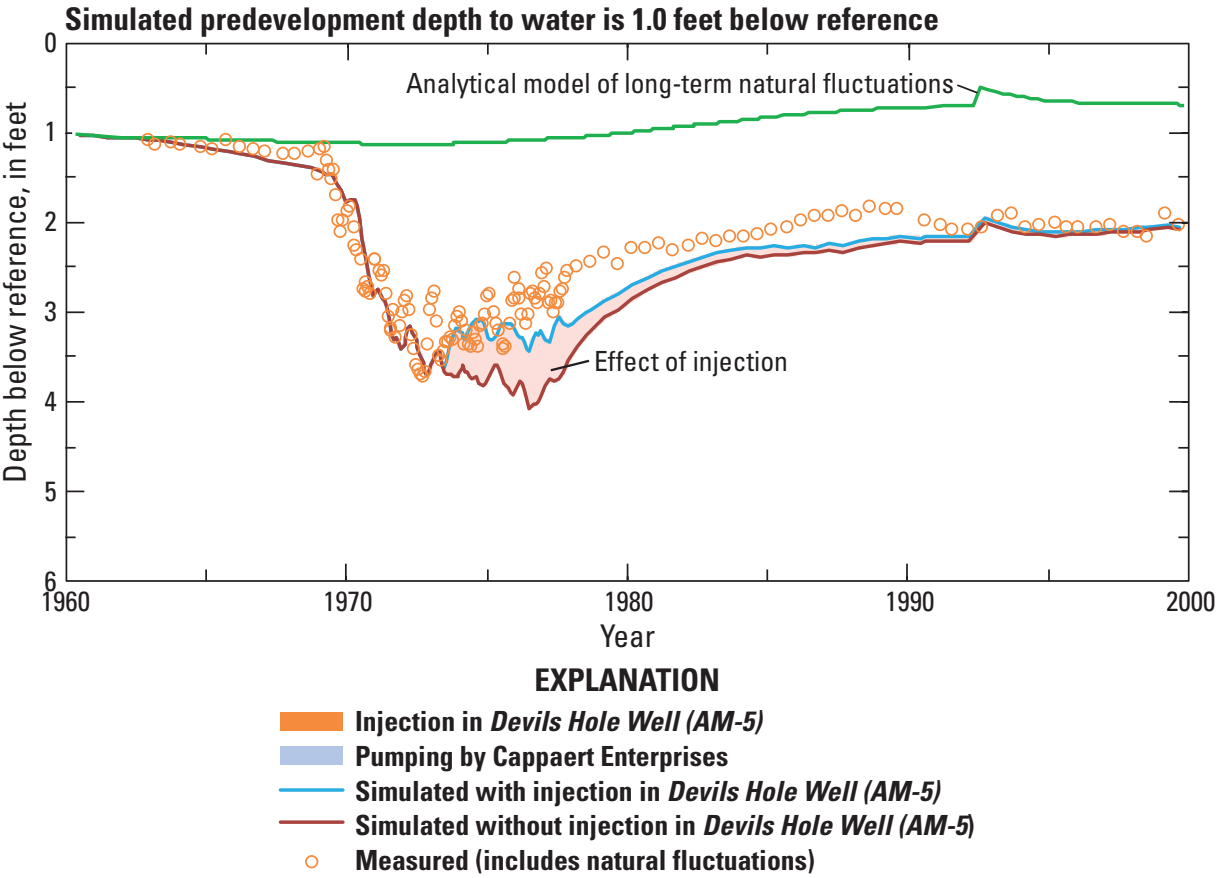

Figure 93. Groundwater withdrawals and injections (top graph); and measured water levels, and simulated water levels with and without injections (bottom graph), in Devils Hole Well (AM-5) (bottom graph), Nevada, 1960-2000.

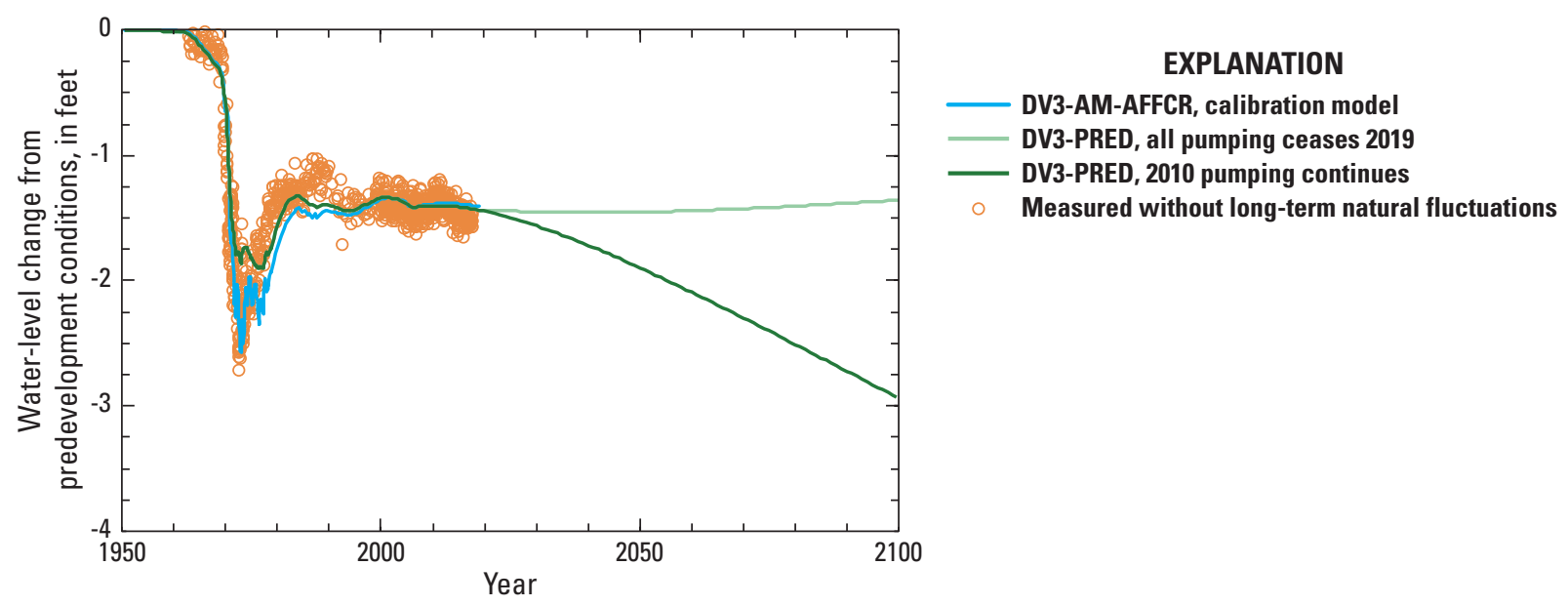

Figure 94. Measured water levels without long-term natural fluctuations from recharge, and simulated water levels from DV3-AM-AFFCR and DV3-PRED models, in Devils Hole, Nevada, 1950-2100. DV3-AM-AFFCR, Death Valley version 3 stress-response model simulating groundwater development in the Ash Meadows and Alkali Flat-Furnace Creek Ranch groundwater basins; DV3-PRED, Death Valley version 3 predictive model. 


\section{Groundwater-Basin Boundary Uncertainty}

B oundary uncertainty was addressed for all internal groundwater-basin boundaries in the study area. Predevelopment groundwater-flow paths, water-level declines from groundwater development, and hydraulic properties were used to determine whether groundwater-basin boundaries are barriers to flow.

The PMOV groundwater basin mostly is isolated from neighboring AFFCR and A sh M eadows groundwater basins. A net rate of 20 acre-ft/yr moves from the Ash Meadows groundwater basin into the PM OV groundwater basin (fig. 88). Limited flow occurs through the Belted Range along this boundary because of low-permeability rocks that form a barrier to flow (fig. 32). The southeastern boundary of the PM OV groundwater basin between B are M ountain and Rainier $M$ esa is a good approximation of the groundwater divide (fig. 88). A small number of flow paths cross the southeastern PM OV boundary (fig. 80). However, the amount of simulated groundwater flow across this boundary is small (230 acre-ft/yr; fig. 88) and accounts for less than 4 percent of total discharge in Oasis Valley. Water-level declines from pumping in the PM OV groundwater basin al so are isolated from declines associated with pumping centers in the AFFCR and $\mathrm{A}$ sh $\mathrm{M}$ eadows groundwater basins.

Low-permeability rocks (fig. 32) hydraulically isolate PDVS groundwater basin from the A FFCR and A sh M eadows groundwater basins (fig. 68). These low-permeability rocks cause pumping in Pahrump Valley to minimally affect water levels in Ash Meadows and AFFCR groundwater basins (fig. 57) because hydraulic connections to PDV S groundwater basin are limited to two locations of saturated basin fill. Saturated basin fill beneath the Amargosa River near Eagle M ountain connects AFFCR and PDV S groundwater basins (fig. 32), where simulated interbasin flow is about 60 acre-ft/ yr (fig. 88). Saturated basin fill between Stewart Valley and the A sh M eadows discharge area connects PDV S and A sh M eadows groundwater basins (fig. 32), where simulated interbasin flow is about 180 acre-ft/yr (fig. 88).

A sh M eadows and AFFCR groundwater basins are coupled and are better considered as a single groundwater basin. The basin boundary extending from the well $A D-4$ corridor northward to Jackass Flats is a groundwater divide that was delineated based on water-level altitudes in wells (Fenel on and others, 2016). Areally extensive drawdowns from pumping in both groundwater basins have coalesced into a 2,200 $\mathrm{mi}^{2}$ area (fig. 57), where these drawdowns have propagated across this boundary. Hydraulic continuity principally occurs through the well $A D-4$ corridor, where predevelopment groundwater flow is about 2,550 acre- $\mathrm{ft} / \mathrm{yr}$ (fig. 88).

B oundary uncertainty was not addressed for external groundwater-basin boundaries, which bound the study area. External groundwater-basin boundaries were simulated as no-flow boundaries in the integrated DV3 model because the study area primarily is isolated from surrounding groundwater basins by low-permeability rocks and groundwater divides (Fenelon and others, 2016). Potential groundwater flow is expected to be limited from north of Kawich, Emigrant, Tikaboo, and Pahranagat Valleys (Winograd and Thordarson, 1975; Harrill and others, 1988; Heilweil and Brooks, 2011; Fenelon and others, 2016). Potential groundwater flow across external boundaries was not precluded by no-flow boundaries because potential lateral flow was accommodated in simulated recharge estimates. Differentiating recharge from lateral flow al ong the study-area boundary was not possible because little data exist.

\section{Evaluation of Advective Flow from Corrective Action Units}

Advective-flow distances (and velocities) from underground nuclear tests are used to evaluate flow rates and boundary conditions in the (regional) DV 3 model. Flow rates and boundary conditions from the DV 3 model need to be evaluated because they support local-scale CAU models of groundwater flow and radionuclide transport. Flow rates and boundary conditions extracted from the DV 3 model and used in a local-scale model highly influence the Darcy velocities of the local-scale model, which affect advective transport calculations. Evaluating advective movement along flow paths is a relevant way to determine the reasonableness of simulated flow rates near nuclear tests in the DV3 model.

Groundwater-flow paths were simulated from all underground nuclear tests detonated near or bel ow the water table at the NNSS using the DV3-SS model. Advective-flow distances and velocities were computed along flow paths using the DV3-SS model. Computing advective velocities along simulated flow paths is a straight-forward calculation that requires an estimated effective porosity of the rocks along the flow path and hydraulic-conductivity and hydraulic-gradient values derived from the calibrated model. The advective velocity was used to calculate the distance a water particle would move in 165 years, which is the time necessary for tritium in a nuclear test cavity to decay to below the Safe Water D rinking A ct (SDWA) standard of 20,000 pCi/L (U.S. Environmental Protection Agency, 2017), assuming an initial concentration of $2.2 \times 10^{8} \mathrm{pCi} / \mathrm{L}$ (Pawloski and others, 2001). An advective-flow distance based on tritium decay is used because tritium is a conservative radionuclide. Computed 165-year advective-flow distances are qualitatively compared to tritium data from wells downgradient from nuclear tests to ensure that the computed distances are consistent with known transport distances. Because the DV 3-SS model was not calibrated to measured tritium concentrations, simulated groundwater-flow paths from nuclear tests are not expected to coincide with exact pathways of known tritium plumes. 
Predevelopment groundwater-flow paths were not simulated for all 828 underground nuclear tests on the NNSS (U.S. Department of Energy, 2015). Flow paths were simulated only for the 296 underground nuclear tests (fig. 95) that were detonated bel ow the water table or less than $328 \mathrm{ft}$ $(100 \mathrm{~m})$ above the water table (Stoller-Navarro Joint Venture, 2004b, 2005b; Navarro-Intera, LLC, 2013; U.S. Department of Energy, 2018). These 296 tests are considered to have the potential to introduce radionuclides directly into the saturated zone (Finnegan and others, 2016). Flow paths originated from model layer 1 for nuclear tests detonated above the water table, whereas flow paths originated in model layer 2, 3, 4 or 5 for nuclear tests detonated bel ow the water table. M odel layer selection for each nuclear test detonated in the saturated zone was based on detonation depth bel ow the simulated water table. Vertical locations of nuclear tests were checked to ensure that they intersected the correct hydrogeologic unit in the DV 3 model. Flow paths were simulated by assigning an effective porosity of 0.01 to fractured volcanic and carbonate rocks, and an effective porosity of 0.1 to basin fill and volcanic-sedimentary rocks, which include the volcanic tuffs in Yucca Flat, F renchman Flat, and R ainier M esa.

The 165-year period used to calculate advective-flow distances along simulated flow paths from 296 underground nuclear tests was based on estimated initial tritium concentrations in nuclear-test cavities and the decay (half-life) coefficient for tritium of 12.3 years (Lucas and Unterweger, 2000). I nitial tritium concentration, in picocuries per liter, was estimated for each nuclear test using methods described in Stoller-Navarro Joint Venture (2005b) for tests in Frenchman Flat CAU, Stoller-Navarro Joint Venture (2004b) for tests in Pahute Mesa CAU, Navarro-Intera, LLC (2013) for tests in Yucca Flat-Climax M ine CAU, and U.S. Department of Energy (2018b) for tests in Rainier M esa-Shoshone M ountain CAU. Initial concentrations ranged from $1.5 \times 10^{4}$ to $2.2 \times 10^{8}$ $\mathrm{pCi} / \mathrm{L}$ and averaged $8.5 \times 10^{7} \mathrm{pCi} / \mathrm{L}$. For each nuclear test, the elapsed time was computed for tritium to radioactively decay from the initial concentration to the SD WA standard of 20,000 pCi/L (U.S. Environmental Protection Agency, 2017). The elapsed time ranged from 7 to 165 years and averaged 120 years. The upper bound of elapsed time was used to calculate the distance traveled from each test, which resulted in calculated distances for tests with low initial concentrations to be overestimated.

The 165-year advective-flow distances from each nuclear-test location are shown in figure 95. Advective-flow distances less than $400 \mathrm{ft}$ are not shown on the figure because distances are too short to easily discern. Calculated advectiveflow distances may be greater than actual tritium migration distances because the calculated distances do not account for dispersive effects. For example, not accounting for dispersion and matrix diffusion will overestimate downgradient migration distances. Because of potential for overestimation from using the upper bound of elapsed time and not accounting for dispersive effects, calculated advective-flow distances likely are biased high relative to the maximum extents of tritium transport above the SDWA standard.
Calculated 165-year advective-flow distances from underground nuclear tests are consistent with tritium migration distances, as determined from well samples and from radionuclide transport studies in Frenchman Flat, Yucca Flat-Climax M ine, and Rainier M esa-Shoshone M ountain CAUs. Calculated advective-flow distances extend less than $0.5 \mathrm{mi}$ from all underground nuclear tests in these CAUs, which is consistent with actual tritium migration distances between nuclear-test cavities and sampled wells. Tritium at concentrations greater than SDWA standards $(20,000 \mathrm{pCi} / \mathrm{L})$ has been measured only in wells within $300 \mathrm{ft}$ of nuclear tests and in post-shot holes drilled into nuclear-test cavities or chimneys in Frenchman Flat and Yucca Flat-Climax $M$ ine CA U s (Smith, 2002) ${ }^{3}$. In the Rainier M esa-Shoshone $M$ ountain CAU, tritium at concentrations greater than SDWA standards has been measured only in water from flooded tunnels where the tests were detonated (U.S. Department of Energy, 2018). M easured tritium migration distances are expected to be shorter than calculated 165 -year advectiveflow distances because only 25-60 years have elapsed from present (2018) since nuclear tests were detonated in these CA Us. Detailed, smaller-scale, model analyses, using conservative assumptions, have been published that support limited downgradient migration from F renchman Flat, Yucca Flat-Climax M ine, and Rainier M esa-Shoshone M ountain CAUs. Simulated tritium at concentrations greater than SDWA standards remained within NNSS boundaries over a 1,000year period for underground nuclear tests in Frenchman Flat (Navarro Nevada Environmental Services, LLC, 2010), Yucca Flat-Climax Mine (Navarro-Intera, LLC, 2013), and Rainier M esa-Shoshone M ountain CA U S (U.S. D epartment of Energy, 2018). These simulated results are consistent with computed advective-flow distances from this study.

Pahute $M$ esa has known tritium plumes migrating from BENHAM/TYBO (Wolfsberg and others, 2002), CHESHIRE (Pawloski and others, 2001), and HANDLEY (Navarro-Intera, LLC, 2015) nuclear tests. The longest measured plumes to date (2018) occur downgradient of the BENHAM/TYBO and HANDLEY tests. Tritium at concentrations greater than the SDWA standard has moved at least $2.6 \mathrm{mi}$ in 50 years from the BENHAM/TYBO test and $1.9 \mathrm{mi}$ in 48 years from the HANDLEY test (Mission Support and Test Services, LLC, 2018). Tritium data indicate that advective transport velocities range from at least $205 \mathrm{ft} / \mathrm{yr}$ from the HANDLEY test to 276 $\mathrm{ft} / \mathrm{yr}$ from the BENHAM/TYBO test. Assuming uniform advective transport velocities along flow paths from these nuclear tests and initial tritium concentrations of $2.2 \times 10^{8}$ $\mathrm{pCi} / \mathrm{L}$, maximum tritium migration at concentrations greater than the SWDA standard ranges from 6.4 to $8.6 \mathrm{mi}$ from HANDLEY and BENHAM/TYBO tests, respectively.

\footnotetext{
${ }^{3}$ Tritium concentrations greater than the SDWA standard only were considered from sites where tritium migrated from the source in the groundwater system through either predevelopment flow or induced flow from pumping. Well UE-5n in Frenchman Flat was not included because tritiated groundwater withdrawn from well RNM-2S was discharged into an unlined ditch, infiltrated basin fill beneath the ditch, and contaminated groundwater in the vicinity of well UE-5n (Smith, 2002).
} 


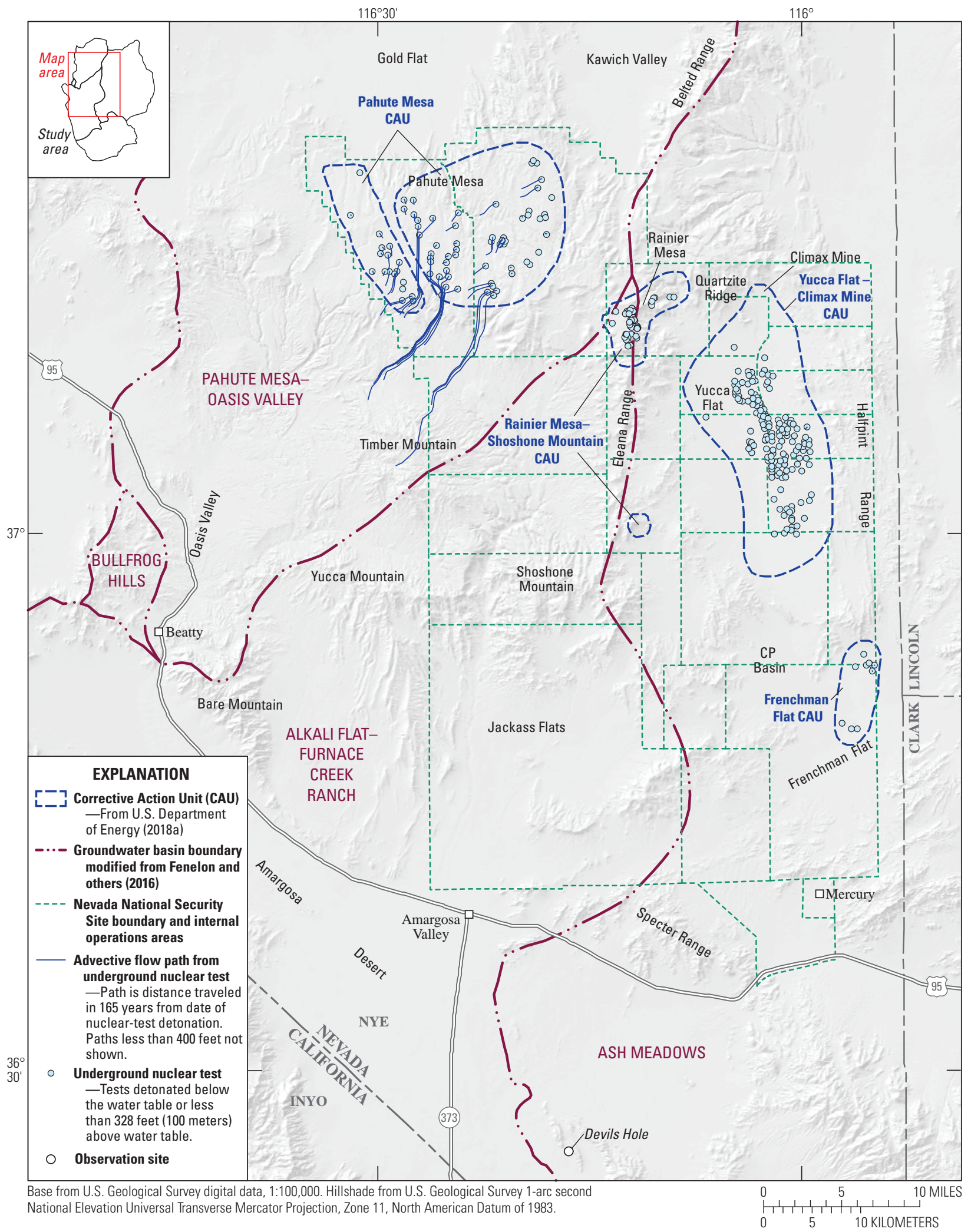

Figure 95. Simulated 165-year advective-flow paths from 296 underground nuclear tests detonated near or below the water table, in the study area, Nevada National Security Site, Nevada. Simulated flow paths do not coincide with tritium plumes and do not represent tritium plumes. 
Calculated 165-year advective-flow distances from underground nuclear tests are consistent with downgradient extents of measured tritium plumes in the Pahute M esa CAU. Advective-flow distances from nuclear tests range from less than 0.1 to $12.6 \mathrm{mi}$ and average $1.8 \mathrm{mi}$. Advective velocities range from 0.03 to $400 \mathrm{ft} / \mathrm{yr}$ and average $60 \mathrm{ft} / \mathrm{yr}$. These calculated advective-flow distances and velocities are within the range of estimated tritium migration distances from HANDLEY and BENHAM/TYBO tests.

Simulated groundwater-flow paths do not coincide with known tritium plumes in the Pahute M esa CA U. Discrepancies are attributed to DV 3-SS model limitations. Computed advective-flow distances from HANDLEY and BENHAM/ TYBO tests are shorter than measured transport distances because advective velocities in the DV3 model are controlled by low (less than $50 \mathrm{ft}^{2} / \mathrm{d}$ ) transmissivities in wells near these tests and the DV 3-SS model was not calibrated to tritium concentrations in downgradient wells. Despite these model errors, computed advective-flow distances for all tests suggest that a limited number of plumes with tritium concentrations greater than SDWA standards exist and that these plumes will migrate only a few miles. This is consistent with the number and migration distance of identified tritium plumes on Pahute Mesa. Furthermore, although simulated flow paths locally do not match observed tritium plumes, simulated flow paths from all tests end in Oasis Valley, which is consistent with the expected discharge location (Fenelon and others, 2010, 2016).

Boundary conditions and flow rates from the DV3 model can be applied to local-scale CAU transport models, where tritium transport migration results can be refined. Advectiveflow distances in Frenchman Flat, Yucca Flat-Climax Mine, and Rainier M esa-Shoshone M ountain CA Us are consistent with expected tritium transport distances based on data and previous numerical studies. Advective velocities from nuclear tests in Pahute M esa CAU are within the range of actual tritium migration velocities from HANDLEY and BENHAM/ TYBO tests. Similarities between measured transport velocities and calculated advective velocities indicate that flow rates in the DV 3 model are reasonable.

A steady-state assumption is appropriate for simulation of flow and transport within CAU-scale models. Advectiveflow distances from underground nuclear tests in Frenchman Flat, Yucca Flat-Climax M ine, and R ainier M esa-Shoshone Mountain CAUs are less than $0.5 \mathrm{mi}$. These flow paths do not extend into shallow carbonate rocks of the regional carbonate aquifer and, therefore, effects of regional pumping on advective transport are negligible. Advective-flow distances are more than $5 \mathrm{mi}$ from several nuclear tests in the Pahute Mesa CAU. However, the PMOV groundwater basin is a hydraulically isolated basin. Water-level declines from pumping in AFFCR and A sh M eadows groundwater basins do not extend into the PM OV groundwater basin (fig. 57). Pumping within the PM OV groundwater basin has withdrawn about 26,000 acre-ft of groundwater from storage between 1945 and 2010 (fig. 89), which has affected water levels only locally (J ackson and Fenelon, 2018).

\section{Model Limitations}

The DV3 model addresses questions about predevelopment groundwater flow, groundwater development, and advective-flow rates in the study area. Veracity of simulated results depends on how well the DV 3 model approximates the actual system. Simplification of underlying conceptual models, uncertainty in estimates of predevelopment groundwater discharges, and errors in pumping estimates are major limitations. These limitations result from insufficient measurements to fully account for variations in hydraulic properties and stresses throughout the model area. Spatial and temporal discretization also affect results, but these numerical limitations are minor relative to data limitations.

Groundwater discharges substantially affect numerical model results but remain poorly defined from Furnace Creek and Lower Amargosa discharge areas. Predevelopment groundwater discharge from the F urnace Creek area totals $8.5 \mathrm{ft}^{3} / \mathrm{s}(6,100 \mathrm{acre}-\mathrm{ft} / \mathrm{yr})$ in this investigation, but likely is overestimated. Measured discharges from springs and diversions were not concurrent and discharge from the alluvial fan below Furnace Creek Wash was estimated with extrapolated $\mathrm{ET}_{\mathrm{GW}}$ rates. Average simulated transmissivities of $30,000 \mathrm{ft}^{2} / \mathrm{d}$ through Furnace Creek Wash are biased high and suggest that discharge from the alluvial fan was overestimated. Groundwater discharge from the L ower A margosa area was estimated exclusively with extrapolated $\mathrm{ET}_{\mathrm{GW}}$ rates. Uncertainty of groundwater discharge from the F urnace Creek and L ower A margosa areas can be reduced by appropriate investigations.

Simulated effects of pumping from the central Amargosa Desert on water levels in Devils Hole depend greatly on the well $A D-4$ corridor. Water-level profiles confirm the existence of the well $A D-4$ corridor, but the degree of hydraulic connection has not been estimated independently. Pumping from carbonate rocks east of well $A D-4$ and observing drawdowns in basin fill around well $A D-4$ would confirm the magnitude of hydraulic connection through the well $A D-4$ corridor.

The area north and east of the NNSS remains poorly defined because less than 24 wells were available (fig. 46). This 3,300 $\mathrm{mi}^{2}$ area encompasses Gold Flat in the northwest, the Pahranagat Range in the northeast, and the Sheep Range in the southeast, and covers 30 percent of the study area. Estimated hydraulic properties of carbonate rocks east and north of well USAF R65N (fig. 49) mostly were uninformed by data. Hydraulic properties of basin fill and carbonate rocks between well Army 1 WW and Indian Springs were minimally informed by water levels (figs. 29 and 46) and aquifer-test results (fig. 19). 
Measured groundwater levels and discharges were not matched perfectly by their simulated equivalents, even after calibration, because errors cumulatively affect model results. These irreducible errors result from simplification of the conceptual model, grid scale, and insufficient measurements. Simulated and measured quantities should be compared to estimate uncertainty of specific simulated results. Plausibility of predicted drawdowns in a well should be evaluated by similarity between simulated and measured water-level changes prior to prediction. For example, simulated water levels in ET areas within Chicago Valley and near Tecopa (fig. 55) show spatial biases because there is a structural model error that cannot be resolved with the limited data available. Clayey Tecopa Lake beds and underlying China Ranch beds remain undifferentiated in the hydrogeologic framework. This conceptual model was not incorporated because differences cannot be defined without wells and well logs. The structural model error does not affect the timing of capture between Pahrump and Shoshone because drawdowns in well Hwy 127 MM21-1 provide information about the hydraulic connection between these areas (fig. 57). However, data are unavailable to provide information about the timing and magnitude of drawdown and capture near Tecopa from pumping in Pahrump.

Simulation results indicate that about $180 \mathrm{acre}-\mathrm{ft} /$ yr of groundwater moves northward from Pahrump Valley to the A sh M eadows discharge area (fig. 88). This result is speculative and uncertain because of a lack of water-level data in wells to constrain flow between Pahrump Valley and the A sh M eadows discharge area. For example, measured water levels in well GS-1 Well (AD-12) (fig. 6) have declined about $0.5 \mathrm{ft}$ since 1996. The DV3-PDVS model simulated less than $0.1 \mathrm{ft}$ of water-level decline from 1913 to 2018 in response to pumping from Pahrump Valley. Most of the water-level decline in well GS-1 Well ( $A D-12)$ may be attributed to poor well construction or slow water-level equilibration following well construction (Fenel on and M oreo, 2002). Well GS-1 Well $(A D-12)$ is a recompleted borehole that initially was drilled for mineral exploration. The USGS cased the existing borehole in 1986, where monitoring well GS-1 Well (AD-12) is a 10-ft interval at the bottom of the borehole open to lowpermeability calcareous mudstone (Fenelon and M oreo, 2002). Slow water-level recovery following well completion likely explains most of the water-level decline in this well.

Lateral discretization of the study area into a rectangular grid of cells and vertical discretization into layers forced an averaging of hydraulic properties. Each cell was assumed to represent a homogeneous block or some volumetric average of the aquifer medium. Discretization errors occurred in every model cell, which includes the smallest model cells. B edding structures in the alluvium and fracture networks in the bedrock were averaged even in the smallest cells, which were $820 \mathrm{ft}$ on a side and $160 \mathrm{ft}$ thick. Flow paths were averaged over lengths of about $0.3 \mathrm{mi}$ because hydraulic properties are averaged.

Errors in hydraulic diffusivity inversely affect the timing of groundwater capture. Hydraulic diffusivity is transmissivity divided by storativity, which functionally is specific yield for unconfined aquifer conditions. Groundwater capture will occur sooner as hydraulic diffusivity increases and will be delayed as hydraulic diffusivity decreases. Errors in hydraulic-diffusivity estimates of 50 percent in the DV 3-PRED model are not unexpected, so 50-percent errors in timing of groundwatercapture estimates can occur.

The spatial distribution of simulated recharge minimally affects model results. Simulated recharge refines hydraulicconductivity estimates; however, most recharge occurs upgradient of areas of interest. For example, hydraulicdiffusivity estimates in the Furnace Creek area, central A margosa Desert, megachannel, and Pahrump Valley primarily were defined by fitting to measured water-level declines from pumping and water-level altitudes from predevelopment discharges. In these areas where hydraulicdiffusivity estimates affect predictions of pumping on water levels, the effect of upgradient recharge is minimal. The total volume of recharge is more important. For example, in Pahute Mesa, the total volume of recharge is well defined because total discharge in Oasis Valley is defined well from detailed micrometeorological measurements ( L aczniak and others, 1999; Reiner and others, 2002). The simulated recharge distribution may be nonunique, but most recharge occurs upgradient of nuclear tests that define the leading edge of transport from Pahute Mesa. Total subsurface flow downgradient of Pahute M esa should be simulated correctly, and this flow is constrained by ensuring a water balance between recharge and discharge in the PM OV groundwater basin. The spatial recharge distribution is most important for Rainier Mesa; however, total recharge is limited by lowpermeability volcanic rocks (tunnel beds).

Changes in recharge in response to climate change were not considered in this study. The steady-state (DV3-SS) model assumes recharge remains unchanged over a timescale of more than a century. Water-level changes from changes in recharge are assumed small, such that transmissivity is not a function of thickness. Therefore, changes in recharge do not affect the hydraulic properties of the groundwater system. Groundwater development (DV3-AM-AFFCR and DV3-PDVS) models and the predictive (DV3-PRED) model do not simulate timevarying changes in recharge and temporal recharge trends were removed from well hydrographs, where appropriate. If future recharge decreases within the next 100 years, then drawdowns will increase. The DV3-AM-AFFCR, DV3-PDVS, and DV3-PRED models simulate water-level declines from pumping only. The estimation of spatially distributed waterlevel changes from historical variations in recharge and likely future changes were beyond the scope of this study. 


\section{Summary}

The study area consists of the Pahute Mesa-Oasis Valley (PM OV), A lkali Flat-Furnace Creek Ranch (AFFCR), A sh $M$ eadows, and Pahrump to Death Valley South (PDVS) groundwater basins in Nevada and California. Radionuclides were introduced into the groundwater system of the study area by underground nuclear testing beneath the Nevada National Security Site (NNSS). Pumping by Cappaert Enterprises in the A sh M eadows discharge area during the 1970s directly affected water levels in Devils Hole, the exclusive habitat of the endangered Devils Hole pupfish, Cyprinodon diabolis. Pumping for irrigation in the central A margosa Desert and Pahrump Valley can adversely affect federally protected groundwater-dependent ecosystems. G roundwaterbasin boundaries were uncertain, which affects potential radionuclide migration directions and the degree of hydraulic connection between pumping centers and groundwaterdependent ecosystems.

To address the above stated problems, the five purposes of this report were to:

1. Characterize predevelopment groundwater flow;

2. Evaluate effects of historical (1913-2018) groundwater development on water levels and discharges;

3. Estimate potential future (2019-2100) effects of groundwater development on water levels and spring discharges;

4. Evaluate advective flow from selected underground nuclear tests to determine if boundary conditions and flow rates from the regional model in this study are reasonable for local-scale flow and transport models; and

5. A ddress groundwater-basin boundary uncertainty in the study area.

Characterization of predevelopment groundwater flow required conceptual models for recharge, discharge, and hydraulic-conductivity distributions within hydrogeologic units. Conceptual models integrated water-level data, transmissivity estimates, geologic data, water availability in recharge areas, and locations and estimates of predevelopment discharge. A hydrogeologic framework was used to distribute hydraulic properties within hydrogeologic units during simulation of predevelopment and groundwater development.

R egional discharge areas were analyzed critically because hydraulic-property estimates and predictions of groundwater capture depend greatly on specified locations and rates of discharges. Virtually all discharge from the A sh $M$ eadows discharge area was attributed directly to springs. The predevelopment water budget from the Furnace Creek area included diversions from Furnace Creek Wash, a major hydrologic feature that conveys groundwater to the alluvial fan at Furnace Creek. Discharges from Pahrump and Stewart Valleys likely totaled 13,300 acre-feet per year (acre-ft/ yr) prior to development, with 9,800 acre-ft/yr (13.5 cubic feet per second) discharging from Bennetts and Manse Springs. Discharge from the L ower A margosa area ceased 2 miles south of Tecopa, where China Ranch beds above the Amargosa River were eroded or unsaturated. Saratoga Spring area is supplied primarily by base flow in the Amargosa River that infiltrates basin fill below Dumont Dunes. Playas were interpreted as low-permeability features that discharged very little groundwater.

Relations between transmissivity, rock type, and depth in the study area were investigated with transmissivity estimates from 271 aquifer tests and specific capacities. Rocks were categorized into four hydraulically distinct hydrogeologic units: (1) basin fill; (2) carbonate rocks; (3) volcanic rocks; and (4) low-permeability granitic and siliciclastic rocks. Thicknesses of hydrogeologic units and their transmissivities were not correlated regardless of rock type. M ore than 90 percent of estimated transmissivity in carbonate and volcanic rocks occurred within 1,600 feet (ft) of the water table. Contributing intervals composed less than 10 percent of open holes in carbonate and volcanic rocks and did not occur predictably with depth.

A hydrogeologic framework was developed with simplified hydrogeologic units that were appropriate for extrapolating hydraulic conductivities. The hydrogeologic framework was divided into five layers and extended from the water table to 3,300 ft below the National Geodetic Vertical Datum of 1929 (NGVD29). Thick sequences of carbonate and volcanic rocks were divided into shallow and deep intervals based on analysis of hydraulic conductivity with depth. Hydrogeologic interpretations from the U nderground Test Area project were incorporated in the framework because drilling 34 new boreholes and completing 119 new wells during 2000-2016 reduced geologic and hydrologic uncertainties. Major hydrologic features, such as Furnace Creek Wash and China Ranch beds, were incorporated explicitly in the hydrogeologic framework.

Pumping in the study area averaged 46,000 acre-ft/yr from 1960-2010 and totaled 38,000 acre-ft/yr in 2010. The $46,000 \mathrm{acre}-\mathrm{ft} / \mathrm{yr}$ of pumping averaged 80 percent of the predevelopment discharge, which totaled about 55,000 acre-ft/yr. A nnual pumping in the PDV S groundwater basin peaked at 46,000 acre-ft/yr in 1968 and exceeded the basin predevelopment discharge of 22,400 acre-ft/yr between 1955 and 2000. Pumping from AFFCR and A sh M eadows groundwater basins gradually increased from 700 acre-ft/yr in 1950 to 21,000 acre-ft/yr in 2010 and has not exceeded the predevelopment discharge of 26,000 acre-ft/yr. Pumping by Cappaert Enterprises in the A sh M eadows discharge area total ed 42,000 acre-ft during 19691977. Water levels declined $2.3 \mathrm{ft}$ in Devils Hole in response to this pumping. Return flows from irrigation, domestic, and metered pumping in the study area averaged 20 percent of the pumping, with a 2-year delay between application and recharge to the water table. 
The central Amargosa Desert and Pahrump Valley were the two primary pumping centers and affected water levels in areas of 300 and 600 square miles $\left(\mathrm{mi}^{2}\right)$, respectively. These broad areas were delineated using dozens of wells, where water levels declined at rates greater than $0.1 \mathrm{ft}$ per decade. Delineation of areas affected by pumping were more tenuous in the Funeral M ountains and L ower A margosa area because observation wells were few or non-existent there. Groundwater levels distant from pumping centers rose between 1980 and 2018 throughout most of the study area in response to a wetter-than-average period from 1970 to 2018.

Water-level changes in Devils Hole have been influenced measurably by long-term natural fluctuations in addition to pumping. These long-term natural fluctuations appear as multiple-decade periods of declining or rising water levels and result from differences between episodic recharge and steady discharge. Water levels in Devils Hole were simulated with an analytical water-level model so that long-term, natural fluctuations from recharge could be estimated and differentiated from pumping effects. Estimated long-term, natural fluctuations suggest that water levels in Devils Hole would have risen about $1 \mathrm{ft}$ between 1973 and 2018 in the absence of pumping.

Recharge and hydraulic-property distributions in the study area were estimated by simultaneously calibrating four numerical, groundwater models. Predevelopment (steadystate) conditions (DV3-SS model); groundwater development in A sh M eadows, AFFCR, and PM OV groundwater basins (DV3-AM-AFFCR model); groundwater development in PDVS groundwater basin (DV3-PDVS model); and the well ER-6-1-2 main multiple-well aquifer test (DV 3-ER 612 model) were simulated with four stress-response models. Stress-response pairs were isolated with separate models so that fewer errors were introduced compared to simulating all responses with a single generalized model. For example, discharge rates were specified at nearly all springs and evapotranspiration areas in the DV3-SS model, whereas discharge was simulated using capture-limited boundaries in DV 3-A M -A FFCR, DV 3-PDVS, and DV 3-ER 612 models, which prevented simulated captures from exceeding measured discharges.

Hydraulic-conductivity, specific-yield, specific-storage, and recharge distributions, as well as extinction depths from springs with known captures were estimated by minimizing a weighted composite, sum-of-squares objective function that included measurement and Tikhonov regularization observations. Measured observations included waterlevel altitudes, water-level differences between wells, transmissivities, selected flow rates, temporal water-level changes, and spring captures. Simulated responses from all four groundwater models were compared to measured observations and the comparisons simultaneously informed revised parameter estimates. Hydraulic conductivity, specific yield, specific storage, and recharge were distributed with pilot points in the groundwater models so that observed spatial variability could be simulated in hydrogeologic units. Simulated responses compare favorably to measured observations for all quantifiable observations.

Simulated water-level changes in Devils Hole were the summation of pumping changes that were simulated with the DV3-AM-AFFCR model and long-term, natural fluctuations from episodic recharge and steady discharge that were simulated with an analytical water-level model. Measured and simulated (numerical + analytical model) water levels in Devils Hole agreed with a root-mean-square error of 0.2 $\mathrm{ft}$. Overall shape of water levels and responses to pumping stresses in Devils Hole agreed through the nearly 70-year period of record.

Eight major hydrologic features were identified in the study area and were simulated correctly:

1. The perched water-table mound beneath Rainier Mesa, which allows for numerical simulation of groundwater flow from nuclear tests in Rainier Mesa.

2. The boundary between PMOV and AFFCR groundwater basins, which affects rates and directions of radionuclide migration from Pahute M esa.

3. The megachannel — a high hydraulic diffusivity feature that causes drawdowns to propagate quickly and recover slowly. The megachannel extends from Ash M eadows discharge area to Indian Springs and from the southernmost part of the NNSS to northern Yucca Flat.

4. The Gravity fault, which forms a flow barrier that juxtaposes low-permeability basin fill downgradient of highly transmissive carbonate rocks. The Gravity fault causes groundwater to move upward and discharge from springs in the A sh M eadows discharge area.

5. The well $A D-4$ corridor, which hydraulically connects A sh M eadows and AFFCR groundwater basins.

6. Alluvial deposits along Furnace Creek Wash, which transmit groundwater above Travertine Springs to the alluvial fan on the floor of Death Valley.

7. Black Mountains and Greenwater Range forming flow barriers, which isolate Death Valley from the central Amargosa Desert and Amargosa River.

8. Carbonate rocks and basin fill forming a continuous aquifer between the Spring M ountains and the A margosa River.

Predevelopment (DV3-SS model) results indicate that the recharge source or sources for most of the major discharge areas are derived from the same groundwater basin. Oasis Valley, A sh M eadows discharge area, Bennetts and Manse Springs, and L ower A margosa area primarily discharge groundwater that was recharged in the same groundwater basin. Discharge from the Furnace C reek area was atypical because more than 40 percent of the discharge was recharged in another groundwater basin. 
The well $A D-4$ corridor is an area of considerable interbasin flow (2,550 acre-ft/yr) that hydraulically connects AFFCR and Ash Meadows groundwater basins. The longest flow paths in the study area pass through the well $A D-4$ corridor. Groundwater flows upward from carbonate rocks in Ash Meadows groundwater basin to basin fill in the well $A D-4$ corridor, moves west through the central Amargosa Desert, flows from basin fill to carbonate rocks in the Funeral Mountains, and continues to flow westward to the Furnace Creek area before discharging. This flow path is consistent with hydraulic and hydrochemical evidence. Results from the DV 3-SS model also are consistent with this conceptual model of connecting recharge and discharge areas through basin fill in the central Amargosa Desert. An alternative conceptual model connects recharge and discharge areas through deep carbonate rocks al ong the Furnace Creek fault zone, but this conceptual model is less probable based on hydraulic and hydrochemical data.

Water budgets were simulated for subareas of groundwater basins in the study area to estimate groundwaterflow rates from corrective action units (CAUs) at the NNSS and to inform water availability in subareas. More than 90 percent of the groundwater discharging in $\mathrm{O}$ asis Valley is derived from recharge sourced at Pahute Mesa and Timber M ountain. A bout 80 percent (17,400 acre-ft/yr) of recharge in Ash Meadows groundwater basin is derived from the Spring M ountains and Sheep Range. Less than 3 percent of the predevelopment flow in Ash Meadows groundwater basin moves through Yucca Flat. Slightly more than one-half $(2,840$ acre-ft/yr) of the recharge in AFFCR groundwater basin is derived from Timber, Yucca, and Shoshone Mountains. Most groundwater that enters the Amargosa Desert moves westward toward Furnace Creek. Total simulated discharge at Franklin Lake is 440 acre-ft/yr, with most of this discharge sourced from the A margosa Desert. M ost recharge to the PDVS groundwater basin occurs in the Spring M ountains.

A sh M eadows and A FFCR groundwater basins are coupled and are better considered as a single groundwater basin. Areally extensive drawdowns from pumping in both groundwater basins have coalesced into a 2,200- $\mathrm{mi}^{2}$ area. Hydraulic continuity principally occurs through the well $A D-4$ corridor. The PDVS groundwater basin functionally is limited to transmissive rocks between the Lower Amargosa area and the Spring M ountains and is hydraulically isolated from other groundwater basins in the study area. The PMOV groundwater basin also is hydraulically isolated from other basins and the DV3 model supports the previously mapped boundary.

Groundwater development in the study area principally has removed water from storage because most of the pumping has been relatively distant from discharge areas. Cumulative pumping volumes totaled 50,31, and 19 percent from storage depletion, capture, and return flow, respectively, during groundwater development between 1910 and 2018. Sources differed considerably by groundwater basin. Storage depletion supplied greater than 90 percent of pumped water from A FFCR and A sh M eadows basins. Storage depletion annually exceeded capture during peak pumping between 1952 and
1985 in the PDV S groundwater basin. Capture was substantial where groundwater development occurred near springs in Pahrump Valley and the A sh M eadows discharge area.

Only pumping centers in the central A margosa Desert and Ash Meadows groundwater basin measurably affected water levels in Devils Hole. Pumping by Cappaert Enterprises and the NNSS inside the megachannel have most affected water levels in Devils Hole and accounted for 50 percent of the anthropogenic water-level decline in 2018. Water levels in Devils Hole have declined slowly and steadily from pumping in the central A margosa Desert, which accounted for a third of the anthropogenic water-level decline in 2018.

Future depths to water bel ow the reference in Devils Hole depend on pumping and long-term natural fluctuations. Water levels in Devils Hole likely will decline between 0.1 and $0.2 \mathrm{ft}$ per decade during the next 80 years, assuming future pumping rates are similar to 2010 rates. A nalytically simulated natural fluctuations between 1900 and 2018 have ranged from declines of $0.1 \mathrm{ft}$ per decade to rises of $0.3 \mathrm{ft}$ per decade.

Natural fluctuations depend on future precipitation and are functionally unknown, but likely will be bound by historical rates of change for the next few decades.

Advective-flow distances and velocities from underground nuclear tests in the DV 3 model are within the range of advective transport calculations from tritium data and previous radionuclide transport investigations. This result indicates that boundary conditions and flow rates from the (regional) DV 3 model are reasonable for local-scale CA U transport models. Simulated 165-year groundwater-flow paths also do not extend into pumping areas and effects of regional pumping on advective transport are negligible. This result indicates that a steady-state (predevelopment) assumption is appropriate for local-scale CAU flow and transport models.

The DV3 model is a major improvement compared to previous regional models of the study area, such as the Death Valley Regional Flow System version 2 (DVRFS.v2) model. Veracity of simulated results depends on how well a model approximates the actual system. Compared to the DVRFS. v2 model, the DV3 model has a better fit between measured and simulated water-level altitudes, water-level differences between wells, transmissivities, discharges, temporal waterlevel changes, and spring captures. The DV3 model also is consistent with conceptual models of predevelopment flow through groundwater-discharge areas and major hydrologic features, unlike the DVRFS.v2 model, which had inconsistencies between conceptual models and numerical results.

Results from the DV 3 model can support future investigations of radionuclide transport and pumping effects in the study area. Boundary conditions and flow rates from the DV 3 model can support boundary conditions applied to local-scale models of flow and radionuclide transport from the Pahute Mesa and Yucca Flat-Climax Mine CAUs. The DV3 model also can estimate potential effects of groundwater development on water levels in Devils Hole and other federally protected groundwater-dependent ecosystems in the study area. 


\section{Acknowledgments}

The authors gratefully acknowledge John Klenke of the Nuclear Waste Repository Project Office in Nye County, Nevada, for providing Pahrump Valley and Amargosa Desert water-level data. The authors also gratefully acknowledge the following U.S. Geological Survey personnel:

- Steven R. Reiner and Peggy E. Elliott for data processing,

- Donald S. Sweetkind for providing geologic insights and technical guidance to revise the Death Valley version 3 (DV3) hydrogeologic framework,

- Nora Nelson for assisting with documentation of the model archive of the data release,

- Rebecca F rus for quality assurance and documentation of transmissivity estimates in Appendix B of the data release,

- Philip Gardner and Steve Van Denburgh for providing technical guidance in evaluation of water-chemistry data, and

- Joseph M. Fenelon for providing conceptual guidance of hydrologic principles developed in this report and for quality assurance of water-chemistry data in A ppendix $G$ of the data release.

The authors gratefully acknowledge the reviewers of this report, model archive, and data release appendixes for their hel pful comments:

- Karl Pohlmann and Chuck Russell of the Desert Research Institute;

- Edward M. Kwicklis of Los Alamos National Laboratory;

- Peter Martian of Navarro, LLC;

- Richard Waddell and Guy Roemer of Tetra Tech;

- Sue Braumiller of the U.S. Fish and Wildlife Service;

- Paula A. Cutillo of the U.S. National Park Service; and

- J oseph M Fenelon, Philip Gardner, L eonard K onikow, and Stanley Leake of the U.S. Geological Survey.

\section{References Cited}

A llander, K.K, Smith, J.L., and Johnson, M.J ., 2009, Evapotranspiration from the Lower Walker River Basin, west-central Nevada, water years 2005-07: U.S. Geological Survey Scientific Investigations Report 2009-5079, 62 p., https://pubs.er.usgs.gov/publication/sir20095079.
A nderman, E.R., and Hill, M.C., 2000, M ODFL OW-2000, the U.S. Geological Survey modular ground-water modelDocumentation of the Hydrogeologic-U nit Flow (HUF) package: U.S. Geological Survey Open-File Report 2000342, 89 p., https://doi.org/10.3133/ofr00342.

Bechtel Nevada, 2002, A hydrostratigraphic model and alternatives for the groundwater flow and contaminant transport model of Corrective Action Units 101 and 102Central and western Pahute Mesa, Nye County, Nevada: U.S. Department of Energy Report DOE/NV /11718-706, 383 p., https://www.osti.gov/biblio/799777.

Bechtel Nevada, 2005a, A hydrostratigraphic framework model and alternatives for the groundwater flow and contaminant transport model of Corrective Action Unit 98: Frenchman Flat, Clark, Lincoln and Nye Counties, Nevada: U.S. Department of Energy Report DOE/NV/11718-1064, 240 p., https://www.osti.gov/biblio/859292.

Bechtel Nevada, 2005b, Completion report for well cluster ER-5-3: U.S. Department of Energy Report DOE/ NV/11718-1093, $202 \mathrm{p}$.

Bechtel Nevada, 2005c, Completion report for well cluster ER-5-4: U.S. Department of Energy Report DOE/ NV/11718-998, $159 \mathrm{p}$.

Bechtel Nevada, 2006, A hydrostratigraphic model and alternatives for the groundwater flow and contaminant transport model of Corrective Action Unit 97-Yucca FlatClimax Mine, Lincoln and Nye Counties, Nevada: U.S. Department of Energy Report DOE/NV/11718-1119, 288 p., https://www.osti.gov/biblio/878649.

Bedinger, M .S., and Harrill, J.R., 2006, A nalytical regression stage analysis for Devils Hole, Death Valley National Park, Nevada: Journal of the American Water Resources Association, v. 42, no. 4, p. 827-839, https://doi. org/10.1111/j.1752-1688.2006.tb04497.x.

B elcher, W.R., ed., 2004, Death Valley regional ground-water flow system, Nevada and California-Hydrogeologic framework and transient ground-water flow model: U.S. Geological Survey Scientific Investigations Report 2004-5205, 408 p., https://pubs.er.usgs.gov/publication/ sir20045205.

Belcher, W.R., Bedinger, M.S., Back, J.T., and Sweetkind, D.S., 2009, Interbasin flow in the Great Basin with special reference to the southern Funeral M ountains and the source of F urnace Creek springs, Death Valley, California, U.S.: Journal of Hydrology, v. 369, nos. 1-2, p. 30-43, https://doi. org/10.1016/j.jhydrol.2009.02.048. 
Belcher, W.R., Elliott, P.E., and Geldon, A.L., 2001, Hydraulic property estimates for use with a transient ground-water flow model of the Death Valley regional ground-water flow system, Nevada and California: U.S. Geological Survey Water-Resources Investigations Report 2001-4210, 28 p., https://doi.org/10.3133/wri014210.

B elcher, W.R., and Sweetkind, D.S., eds., 2010, D eath Valley regional ground-water flow system, Nevada and California-Hydrogeologic framework and transient ground-water flow model: U.S. Geological Survey Professional Paper 1711, 398 p., https://doi.org/10.3133/ pp1711.

Belcher, W.R., Sweetkind, D.S., and Elliott, P.E., 2002, Probability distributions of hydraulic conductivity for the hydrogeologic units of the Death Valley regional groundwater flow system, Nevada and California: U.S. Geological Survey Water-Resources Investigations Report 2002-4212, 24 p., https://doi.org/10.3133/wri024212.

Belcher, W.R., Sweetkind, D.S., Faunt, C.C., Pavelko, M.T., and Hill, M.C., 2017, A n update of the Death Valley regional groundwater flow system transient model, Nevada and California: U.S. Geological Survey Scientific Investigations Report 2016-5150, 74 p., 1 pl., https://doi. org/10.3133/sir20165150.

Belcher, W.R., Sweetkind, D.S., Hopkins, C.B., and Poff, M .E., 2019, Hydrogeology of L ower A margosa Valley and groundwater discharge to the A margosa Wild and Scenic River, Inyo and San Bernardino Counties, California, and adjacent areas in Nye and Clark Counties, Nevada: U.S. Geological Survey Scientific Investigations Report 20185151, 131 p., 1 pl., https://doi.org/10.3133/sir20185151.

Berger, D.L., M ayers, C.J ., Garcia, C.A ., Buto, S.G., and Huntington, J.M ., 2016, Budgets and chemical characterization of groundwater for the Diamond Valley flow system, central Nevada, 2011-12: U.S. Geological Survey Scientific Investigations Report 2016-5055, 83 p., https://doi.org/10.3133/sir20165055.

Blankennagel, R.K., and Weir, J.E., J r., 1973, G eohydrology of the eastern part of Pahute Mesa, Nevada Test Site, Nye, County, Nevada: U.S. Geological Survey Professional Paper 712-B, 35 p., https://doi.org/10.3133/pp712B B redehoeft, J.D., 2002, The water budget myth revisited-Why hydrogeologists model: Groundwater, v. 40, no. 4, p. 340345, https://doi.org/10.1111/j.1745-6584.2002.tb02511.x.

Bredehoeft, J., 2007, It is the discharge: Groundwater, v. 45, no. 5, p. 523.

Buqo, T., 2004, Nye County water resources plan: Tonopah, Nevada, Nye County Department of Natural Resources and Federal Facilities, 136 p., http://www.nyecounty. net/ DocumentCenter/View/145/Nye-County-Water-ResourcesPlan?bidld=.
Byers, F.M., Jr., Carr, W.J., Orkild, P.P., Quinlivan, W.D., and Sargent, K.A., 1976, Volcanic suites and related cauldrons of the Timber Mountain-Oasis Valley caldera complex, southern Nevada: U.S. Geological Survey Professional Paper 919, 70 p., https://doi.org/10.3133/pp919.

Carr, W.J ., Grow, J.A., and K eller, S.M ., 1995, Lithologic and geophysical logs of drill holes Felderhoff Federal 5-1 and 25-1, Amargosa Desert, Nye County, Nevada: U.S. Geological Survey Open-File Report 95-155, 14 p., https:// doi.org/10.3133/ofr95155.

Carson, R.L., 1979, Water-resources data collected in the Devils Hole area, Nye County, Nevada, 1976-77: U.S. Geological Survey Open-File Report 79-742, 22 p.

Castor, S.B., McLaurin, B.T., Ludington, S., and Flynn, K.S., 2006, M ineral resource potential of the A sh M eadows and Amargosa Mesquite Trees Areas of Critical Environmental Concern, Nye County, Nevada, chap. F of L udington, S., ed., M ineral resource assessment of selected areas in Clark and Nye Counties, Nevada: U.S. Geological Survey Scientific Investigations Report 2006-5197, p. F1-F13, http://pubs.usgs.gov/sir/2006/5197/.

Christiansen, R.L., Lipman, P.W., Carr, W.J ., B yers, F.M., Jr., Orkild, P.P., and Sargent, K.A., 1977, Timber M ountain-O asis Valley caldera complex of southern Nevada: Geological Society of America Bulletin, v. 88, no. 7, p. 943-959, https://doi.org/10.1130/00167606(1977)88<943:TMVCCO >2.0.CO;2.

Claassen, H.C., 1973, Water quality and physical characteristics of Nevada Test Site water-supply wells: U.S. Geological Survey Report 474-158, 145 p.

Claassen, H.C., 1985, Sources and mechanisms of recharge for ground water in the west-central Amargosa Desert, Nevada; a geochemical interpretation: U.S. Geological Survey Professional Paper 712-F, 31 p., https://doi.org/10.3133/ pp712F.

Cooper, H.H., and Jacob, C.E., 1946, A generalized graphical method for evaluating formation constants and summarizing well field history: Transactions, American Geophysical Union, v. 27, no. 4, p. 526-534. https://doi.org/10.1029/ TR027i004p00526.

Craig, R.W., and Robison, J.H., 1984, Geohydrology of rocks penetrated by test well UE-25p\#1, Yucca M ountain area, Nye County, Nevada: U.S. Geological Survey WaterResources Investigations Report 84-4248, 57 p.

Cutillo, P.A ., and B redehoeft, J. D., 2011, Estimating aquifer properties from the water level response to earth tides: Groundwater, v. 49, no. 4, p. 600-610, https://doi. org/10.1111/j.1745-6584.2010.00778.x. 
Cutillo, P.A., and Ge, S. 2006, Analysis of strain-induced ground-water fluctuations at Devils Hole, Nevada: Geofluids, v. 6, p. 319-333, https://doi.org/10.1111/j.14688123.2006.00150.x.

Czarnecki, J.B., and Stannard, D.I., 1997, Geohydrology and evapotranspiration at Franklin Lake playa, Inyo County, California, with a section on estimating evapotranspiration using the energy-budget eddy-correlation technique by Stannard, D.I.: U.S. Geological Survey Water-Supply Paper 2377, 75 p., https://doi.org/10.3133/wsp2377.

Czarnecki, J.B., and Waddell, R.K ., 1984, Finite-element simulation of ground-water flow in the vicinity of Yucca Mountain, Nevada-California: U.S. Geological Survey Water-Resources Investigations Report 84-4349, 38 p., https://doi.org/10.3133/wri844349.

Czarnecki, J.B ., and Wilson, W.E., 1991, Conceptual models of the regional ground-water flow and planned studies at Yucca Mountain, Nevada: Hydrological Science and Technology, v. 7, nos. 1-4, p. 15-25.

D’Agnese, F.A., Faunt, C.C., and Turner, A.K., 1998, An estimated potentiometric surface of the Death Valley region, Nevada and California, using geographic information systems and automated techniques: U.S. Geological Survey Water-Resources Investigations Report 97-4052, 15 p., 1 pl., https://doi.org/10.3133/w ri 974052.

D’Agnese, F.A., Faunt, C.C., Turner, A.K., and Hill, M.C., 1997, Hydrogeologic evaluation and numerical simulation of the Death Valley regional ground-water flow system, Nevada and California: U.S. Geological Survey WaterResources Investigations Report 96-4300, 124 p., https:// doi.org/10.3133/wri964300.

D'A gnese, F.A., O'B rien, G.M ., Faunt, C.C., B elcher, W.R., and San Juan, Carma, 2002, A three-dimensional numerical model of predevelopment conditions in the Death Valley regional ground-water flow system, Nevada and California: U.S. Geological Survey Water-Resources Investigations Report 2002-4102, 114 p., https://doi.org/10.3133/ wri024102.

DeM eo, G.A ., Laczniak, R.J ., Boyd, R.A ., Smith, J.L., and Nylund, W.E., 2003, Estimated ground-water discharge by evapotranspiration from Death Valley, California, 1997-2001: U.S. Geological Survey Water-Resources Investigations Report 2003-4254, 27 p., https://doi. org/10.3133/wri034254.

Doherty, J., 2010b, Addendum to the PEST manual: Brisbane, Australia, Watermark Numerical Computing, 235 p.

Doherty, J., 2010a, PEST, Model-independent parameter estimation-U ser manual (5th ed., with slight additions): Brisbane, Australia, Watermark Numerical Computing, $336 \mathrm{p}$.
Doherty, J., and J ohnston, J.M ., 2003, M ethodologies for calibration and predictive analysis of a watershed model: J ournal of the A merican Water Resources A ssociation 39, no. 2, p. 251-265. [Also available at https://doi. org/10.1111/j.1752-1688.2003.tb04381.x.]

Drever, J.I., 1988, The geochemistry of natural waters (2d ed.): Prentice Hall, Upper Saddle River, New Jersey, 437 p.

Dudley, W.W., Jr., and Larson, J.D., 1976, Effect of irrigation pumping on Desert Pupfish habitats in Ash Meadows, Nye County, Nevada: U.S. Geological Survey Professional Paper 927, 52 p., https://doi.org/10.3133/pp927.

Elliott, P.E ., and Fenelon, J.M ., 2010, Database of groundwater levels and hydrograph descriptions for the Nevada Test Site area, Nye County, Nevada: U.S. Geological Survey Data Series 533, version 7.0, October 2016, 16 p., https://doi.org/10.3133/ds533.

Elliott, P.E., and Moreo, M.T., 2011, Groundwater withdrawals and associated well descriptions for the Nevada National Security Site, Nye County, Nevada, 1951-2008: U.S. Geological Survey Data Series 567, 126 p., https://doi. org/10.3133/ds567.

Elliott, P.E., and Moreo, M.T., 2018, Update to the groundwater withdrawals database for the Death Valley regional groundwater flow system, Nevada and California, 1913-2010: U.S. Geological Survey data release, https:// doi.org/10.5066/F 75H7FH3.

Faunt, C.C., D'A gnese, F.A ., and O'B rien, G.M ., 2010, Hydrology, chap. D of Belcher, W.R., and Sweetkind, D.S., eds., Death Valley regional ground-water flow system, Nevada and California-Hydrogeologic framework and transient ground-water flow model: U.S. Geological Survey Professional Paper 1711, p. 161-249, https://doi. org/10.3133/pp1711.

Faunt, C.C., Blainey, J.B., Hill, M.C., D'A gnese, F.A., and O'Brien, G.M., 2010, Transient numerical model, chap. F of B elcher, W.R., and Sweetkind, D.S., eds., D eath Valley regional groundwater flow system, Nevada and CaliforniaHydrogeologic framework and transient groundwater flow model: U.S. Geological Survey Professional Paper 1711, p. 251-344, https://doi.org/10.3133/pp1711.

Faunt, C.C., Sweetkind, D.S., and B elcher, W.R., 2010, Three-dimensional hydrogeologic framework model, chap. E of B elcher, W.R., and Sweetkind, D.S., eds., Death Valley regional ground-water flow system, Nevada and California-Hydrogeologic framework and transient ground-water flow model: U.S. Geological Survey Professional Paper 1711, p. 161-249, https://doi. org/10.3133/pp1711. 
Fenelon, J.M., Halford, K.J., and Moreo, M.T., 2016, Delineation of the Pahute M esa-Oasis Valley groundwater basin, Nevada (ver. 1.1, May 2016): U.S. Geological Survey Scientific Investigations Report 2015-5175, 40 p., https:// doi.org/10.3133/sir20155175.

Fenelon, J.M ., Laczniak, R.J ., and Halford, K.J., 2008, Predevelopment water-level contours for aquifers in the Rainier Mesa and Shoshone Mountain area of the Nevada Test Site, Nye County, Nevada: U.S. Geological Survey Scientific Investigations Report 2008-5044, 38 p., https:// pubs.er.usgs.gov/publication/sir20085044.

Fenelon, J.M., and Moreo, M.T., 2002, Trend analysis of ground-water levels and spring discharge in the Yucca Mountain region, Nevada and California, 1960-2003: U.S. Geological Survey Water-Resources Investigations Report 2002-4178, 97 p., https://doi.org/10.3133/wri024178.

Fenelon, J.M ., Sweetkind, D.S., Elliott, P.E., and Laczniak, R.J., 2012, Conceptualization of the predevelopment groundwater flow system and transient water-level responses in Yucca Flat, Nevada National Security Site, Nevada: U.S. Geological Survey Scientific Investigations Report 2012-5196, 61 p., https://doi.org/10.3133/ sir20125196.

Fenelon, J.M ., Sweetkind, D.S., and Laczniak, R.J ., 2010, Groundwater flow systems at the Nevada Test Site, Nevada - A synthesis of potentiometric contours, hydrostratigraphy, and geologic structures: U.S. Geological Survey Professional Paper 1771, 54 p., https://pubs.usgs. gov/pp/1771/.

Fienen, M., Muffels, C., and Hunt, R., 2009, On constraining pilot point calibration with regularization in PEST: Groundwater, v. 47, no. 6, p. 835-844, https://doi. org/10.1111/j.1745-6584.2009.00579.x.

Finnegan, D.L., Bowen, S.M., Thompson, J.L., Miller, C.M., Baca, P.L., Olivas, L.F., Geoffrion, C.G., Smith, D.K., Goishi, W., Esser, B.K., Meadows, J.W., Namboodiri, N., and Wild, J.F., 2016, Nevada National Security Site underground radionuclide inventory, 1951-1992A ccounting for radionuclide decay through September 30, 2012: Los Alamos National Laboratory Report LA-UR-1621749, 53 p., https://www.osti.gov/biblio/1242909.

French, R. H., J acobson, R.L., and Lyles, B .F., 1996, Threshold precipitation events and potential ground-water recharge: Journal of Hydraulic Engineering, v. 122, no. 10, p. 573-578, https://doi.org/10.1061/(A SCE)07339429(1996)122:10(573).
Frus, R.J., and Halford, K.J., 2018, Documentation of singlewell aquifer tests and integrated borehole analyses using transmissivity estimates, Pahute Mesa and vicinity, Nevada: U.S. Geological Survey Scientific Investigations Report 2018-5096, 22 p. [Also available at https://doi.org/10.3133/ sir20185096.]

Garcia, C.A ., Fenel on, J.M ., Halford, K.J ., R einer, S.R., and L aczniak, R.J., 2011, A ssessing hydraulic connections across a complex sequence of volcanic rocks-Analysis of U-20 WW multiple-well aquifer test, Pahute Mesa, Nevada National Security Site, Nevada: U.S. Geological Survey Scientific Investigations Report 2011-5173, 24 p. [Also available at https://doi.org/10.3133/sir20115173.]

Garcia, C.A., Halford, K.J., and Laczniak, R.J ., 2010, Interpretation of flow logs from Nevada Test Site boreholes to estimate hydraulic conductivity using numerical simulations constrained by single-well aquifer tests: U.S. Geological Survey Scientific Investigations Report 20105004, 28 p., https://doi.org/10.3133/sir20105004.

Garcia, C.A., Huntington, J.M., Buto, S.G., Moreo, M.T., Smith, J.L., A ndraski, B.J ., 2014, Groundwater discharge by evapotranspiration, Dixie Valley, west-central Nevada, March 2009-September 2011: U.S. Geological Survey Professional Paper 1805, 90 p., https://doi.org/10.3133/ pp1805.

Garcia, C.A., Jackson, T.R., Halford, K.J., Sweetkind, D.S., Damar, N.A., Fenelon, J.M., and Reiner, S.R., 2017, Hydraulic characterization of volcanic rocks in Pahute M esa using an integrated analysis of 16 multiple-well aquifer tests, Nevada National Security Site, 2009-14: U.S. Geological Survey Scientific Investigations Report 20165151, 62 p., https://doi.org/10.3133/sir20165151.

Gesch, D., Evans, G., Mauck, J., Hutchinson, J., and Carswell Jr., W.J., 2009, The national map-Elevation: U.S. Geological Survey Fact Sheet 2009-3053, 4 p.

Geter, T., 2015, Amargosa Desert (Hydrographic Basin 14-230) groundwater pumpage inventory - Water year 2015: State of Nevada Department of Conservation and Natural Resources, 126 p.

Greene, L.W., and Latschar J.A., 1981, Death Valley National M onument historic resource study - A History of M ining: National Park Service, Denver, Colorado: Online book, accessed A ugust 14, 2019, at https://www.nps.gov/ parkhistory/online_books/deva/index.htm.

Halford, K ., Garcia, C.A ., Fenelon, J., and M irus, B., 2012, Advanced methods for modeling water-levels and estimating drawdowns with SeriesSEE, an Excel add-In, (ver. 1.1, July 2016): U.S. Geological Survey Techniques and M ethods, book 4, chap. F4, 28 p., https://dx. doi. org/10.3133/tm4F 4 . 
Halford, K.J., 2016, T-COMP—A suite of programs for extracting transmissivity from MODFLOW models: U.S. Geological Survey Techniques and Methods, book 6, chap. A 54, 17 p., https://dx.doi.org/10.3133/tm6A 54.

Halford, K.J., and Plume, R.W., 2011, Potential effects of groundwater pumping on water levels, phreatophytes, and spring discharges in Spring and Snake Valleys, White Pine County, Nevada, and adjacent areas in Nevada and Utah: U.S. Geological Survey Scientific Investigations Report 2011-5032, 52 p., https://doi.org/10.3133/sir20115032.

Halford, K.J ., Weight, W.D., and Schreiber, R.P., 2006, Interpretation of transmissivity estimates from single-well pumping aquifer tests: Groundwater, v. 44, p. 467-471, https://doi.org/10.1111/j.1745-6584.2005.00151.x.

Halford, K.J ., and Yobbi, D.K., 2006, Estimating hydraulic properties using a moving-model approach and multiple aquifer tests: Groundwater, v. 44, no. 2, p. 284-291, https:// doi.org/10.1111/j.1745-6584.2005.00109.x.

Harbaugh, A.W., 1990, A computer program for calculating subregional water budgets using results from the U.S. Geological Survey modular three-dimensional ground-water flow model: U.S. Geological Survey Open-File Report 90-392, 46 p., https://doi.org/10.3133/ofr90392.

Harbaugh, A.W., 2005, M ODFL OW-2005, the U.S. Geological Survey modular ground-water model-The ground-water flow process: U.S. Geological Survey Techniques and Methods, book 6, chap. A16, https://doi. org/10.3133/tm6A 16.

Harrill, J.R ., 1976, Pumping and ground-water storage depletion in Las Vegas Valley, Nevada, 1955-74: Nevada Division of Water Resources Bulletin 44, 70 p., http:// images.water.nv.gov/images/publications/water $\% 20$ resources\%20bulletins/Bulletin44.pdf.

Harrill, J.R ., 1986, G round-water storage depletion in Pahrump Valley, Nevada-California, 1962-75: U.S. Geological Survey Water Supply Paper 2279, 53 p., https:// doi.org/10.3133/wsp2279.

Harrill, J.R., Gates, J.S., and Thomas, J.M., 1988, Major ground-water flow systems in the Great Basin region of Nevada, Utah, and adjacent states: U.S. Geological Survey Hydrologic A tlas 694-C, pls. 1-2.

Heilweil, V.M ., and Brooks, L.E., eds., 2011, Conceptual model of the Great Basin carbonate and alluvial aquifer system: U.S. Geological Survey Scientific Investigations Report 2010-5193, 191 p. [Also available at https://doi. org/10.3133/sir20105193.]
Hershey, R.L., Paces, J B. ., Singleton, M .J ., K wicklis, E.M., Decker, D.L., Fryer, W.M ., and Earman, S., 2008, Geochemical and isotopic evaluation of groundwater movement in Corrective Action Unit 99-Rainier Mesa and Shoshone Mountain, Nevada Test Site: U.S. Department of Energy Report DOE/NV/26383-10, Publication No. 45229, 173 p., https://www.osti.gov/opennet/detail?osti-id=944749.

H sieh, P.A ., and Freckleton, J.R., 1993, Documentation of a computer program to simulate horizontal-flow barriers using the U.S. Geological Survey modular three-dimensional finite-difference ground-water flow model: U.S. Geological Survey Open-File Report 92-477, 32 p., https://doi. org/10.3133/ofr92477.

Hunt, C.B., and Robinson, T.W., 1960, Possible interbasin circulation of ground water in the southern part of the $G$ reat Basin: U.S. Geological Survey Professional Paper 400-B, p. B273-B274, https://doi.org/10.3133/pp400B .

Hunt, C.B., Robinson, T.W., Bowles, W.A., and Washburn, A.L., 1966, Hydrologic basin, Death Valley, California: U.S. Geological Survey Professional Paper 494-B, 138 p., https://doi.org/10.3133/pp494B .

Interagency Wild and Scenic Rivers Coordinating Council, 2018, National Wild and Scenic Rivers System-Amargosa River, California: National Wild and Scenic Rivers System web page, accessed January 2, 2018, at http://www.rivers. gov/rivers/amargosa.php.

Inyo County Yucca Mountain Repository Assessment Office, 2005, Death Valley lower carbonate aquifer monitoring program - Wells down gradient of the proposed Yucca M ountain nuclear waste repository: U.S. Department of Energy Cooperative Agreement DE-FCO8-02RW12162 Final Project Report, 39 p., http://www.inyoyucca.org/ LSNRoot/documents/iny5.pdf.

Inyo County Yucca Mountain Repository Assessment Office, 2007, Inyo County final project report from 2002-2005Death Valley low er carbonate aquifer monitoring programWells down gradient of the proposed Yucca M ountain nuclear waste repository: U.S. D epartment of Energy Cooperative Agreement DE-FC08-02RW12162 Final Project Report, 39 p., Nuclear Regulatory Commission Accession Number ML081070545, http://pbadupws.nrc. gov/docs/ML0810/ML081070525.html.

IT Corporation, 1995, Pre-completion hydrologic testing documentation package for well UE-10j: IT Corporation Report prepared for U.S. Department of Energy Nevada Operations Office, $336 \mathrm{p}$. 
IT Corporation, 1997, Regional groundwater flow and tritium transport modeling and risk assessment of the underground test area, Nevada Test Site, Nevada: Report DOE/NV-477 prepared by the IT Corporation, Las Vegas, Nevada, for the U.S. Department of Energy Nevada Operations Office [variously paged], https://www.osti.gov/biblio/788792.

IT Corporation, 1999, Preliminary water level contours and topographic map of western Pahute M esa and Oasis Valley: Las Vegas, Nevada, IT Corporation, 1 pl.

Jackson, T.R., 2017, AQUIFER TEST PACKAGEDrawdown estimation and analysis of the ER -4-1 m1 multiple-well aquifer test of the lower carbonate aquifer, Yucca Flat, Nevada National Security Site: U.S. Geological Survey, aquifer test package, accessed June 1, 2017, at https://nevada.usgs.gov/aquifertests/ER-4-1m1. cfm?studyname=ER -4-1m1.

Jackson, T.R., and Fenelon, J.M., 2018, Conceptual framework and trend analysis of water-level responses to hydrologic stresses, Pahute M esa-Oasis Valley groundwater basin, Nevada, 1966-2016: U.S. Geological Survey Scientific Investigations Report 2018-5064, 89 p., https:// doi.org/10.3133/sir20185064.

Jackson, T.R., and Halford, K.J. 2019, Estimation of groundwater flow through Yucca Flat based on a multiple-well aquifer test at well ER-6-1-2 Main, Nevada National Security Site: U.S. Geological Survey Scientific Investigations Report 2019-5038, 27 p., https://doi. org/10.3133/sir20195038.

Jackson, T.R., and Halford, K.J. 2020, MODFLOW-2005 model and supplementary data used to characterize groundwater flow and effects of pumping in the Death Valley regional groundwater flow system, Nevada and California, with special reference to Devils Hole: U.S. Geological Survey data release, https://doi.org/10.5066/ P9HIY VG2.

Jackson, T. R., Halford, K. J., Gardner, P. M., and Garcia, C.A., 2018, Evaluating micrometeorological estimates of groundwater discharge from G reat B asin desert playas: Groundwater, v. 56, no. 6, p. 909-920, https://doi. org/10.1111/gwat. 12647 .

J ohannesson, K.H., Stetzenbach, K.J., Hodge, V.F., K reamer, D.K., and Zhou, X., 1997, Delineation of ground-water flow systems in the southern $\mathrm{G}$ reat B asin using aqueous rare earth element distributions: Groundwater, v. 35, p. 807-819, https://doi.org/10.1111/j.1745-6584.1997.tb00149.x.

Kilroy, K.C., 1991, Ground-water conditions in A margosa Desert, Nevada-California, 1952-87: U.S. Geological Survey Water-Resources Investigations Report 89-4101, 93 p., https://doi.org/10.3133/wri894101.
K onikow, L.F., and L eake, S.A ., 2014, Depletion and capture-Revisiting "the source of water derived from wells": Groundwater, v. 52, p. 100-111, https://doi. org/10.1111/gwat.12204.

Kunkel, F., and Robinson, T.W., 1966, A geohydrologic reconnaissance of the Saratoga Spring area, D eath Valley National Monument, California: U.S. Geological Survey Open-File Report 66-74, 25 p., https://doi.org/10.3133/ ofr6674.

Laczniak, R.J., Cole, J.C., Sawyer, D.A., and Trudeau, D.A., 1996, Summary of hydrogeologic controls on ground-water flow at the Nevada Test Site, Nye County, Nevada: U.S. Geological Survey Water-Resources Investigations Report 96-4109, 59 p., https://doi.org/10.3133/wri964109.

Laczniak, R.J ., DeM eo, G.A., Reiner, S.R., Smith, J.L., and Nylund, W.E., 1999, Estimates of ground-water discharge as determined from measurements of evapotranspiration, Ash Meadows Area, Nye County, Nevada: U.S. Geological Survey Water-Resources Investigations Report 99-4079, 70 p., https://doi.org/10.3133/wri994079.

Laczniak, R.J ., Smith, J.L., and DeM eo, G.A., 2006, A nnual ground-water discharge by evapotranspiration from areas of spring-fed riparian vegetation along the eastern margin of Death Valley, 2000-02: U.S. Geological Survey Scientific Investigations Report 2006-5145, 36 p., https://doi. org/10.3133/sir20065145.

Laczniak, R.J ., Smith, J.L., Elliot, P.E., DeM eo, G.A., Chatigny, M .A ., and Roemer, G.J ., 2001, Ground-water discharge determined from estimates of evapotranspiration, Death Valley regional flow system, Nevada and California: U.S. Geological Survey Water-Resources Investigations Report 2001-4195, 51 p., https://doi.org/10.3133/ wri014195.

Larson, J.D., 1974a, Water-resources data collected in the Devils Hole area, Nevada, 1972-73: U.S. Geological Survey Water-Resources Investigations Report 73-61, 20 p. [Also available at https://doi.org/10.3133/wri7361.]

Larson, J.D., 1974b, Water-resources data collected in the Devils Hole area, Nevada, 1973-74: U.S. Geological Survey Open-File Report 74-330, 12 p. [Also available at https://doi.org/10.3133/ofr74330.]

Larson, J.D., 1975, Water-resources data collected in the Devils Hole area, Nevada, 1974-75: U.S. Geological Survey open-file report, $12 \mathrm{p}$.

Leake, S.A., Reeves, H.W., and Dickinson, J.E., 2010, A new capture fraction method to map how pumpage affects surface water flow: Groundwater, v. 48, p. 690-700, https:// doi.org/10.1111/j.1745-6584.2010.00701.x. 
Lucas, L.L., and Unterweger, M.P., 2000, Comprehensive review and critical evaluation of the half-life of tritium: Journal of Research of the National Institute of Standards and Technology, v. 105, no. 4, p. 541-549, https://doi. org/10.6028/jres.105.043.

Malmberg, G.T., 1967, Hydrology of the valley-fill and carbonate-rock reservoirs, Pahrump Valley, NevadaCalifornia: U.S. Geological Survey Water Supply Paper 1832, 47 p., https://doi.org/10.3133/wsp1832.

Maxey, G.B., and Eakin, T.E., 1951, Ground water in Railroad, Hot Creek, Reveille, Kawich, and Penoyer Valleys, Nye, Lincoln, and White Pine Counties, Nevada, in Eakin, T.E., Maxey, G.B., Robinson, T.W., Fredericks, J.C., and Loeltz, O.J., Contributions to the hydrology of eastern Nevada: Nevada Water Resources Bulletin No. 12, p. 127-171.

M axey, G.B., and Jameson, C.H., 1948, Geology and water resources of $L$ as Vegas, Pahrump, and Indian Springs Valleys, Clark and Nye Counties, Nevada: Nevada Water Resources Bulletin No. 5, 121 p. plus 2 appendixes, http:// images.water.nv.gov/images/publications/water $\% 20$ resources\%20bulletins/Bulletin5.pdf.

M iller, G.A., 1977, A ppraisal of the water resources of D eath Valley, California-Nevada: U.S. Geological Survey OpenFile Report 77-728, 68 p., https://doi.org/10.3133/ofr77728.

M irus, B.B., Halford, K.J ., Sweetkind, D.S., and Fenelon, J.M., 2016, Testing the suitability of geologic frameworks for extrapolating hydraulic properties across regional scales: Hydrogeology Journal, v. 24, p. 1133-1146, https://doi. org/10.1007/s10040-016-1375-1.

Mission Support and Test Services, LLC, 2018, Nevada National Security Site-Environmental report 2017: U.S. Department of Energy Report DOE/NV/036240270, 264 p., https://www.nnss.gov/docs/docs LibraryPublications/2017\%20NNSSER.pdf.

Moreo, M.T., Halford, K.J., La Camera, R.J., and Laczniak, R.J., 2003, Estimated ground-water withdrawals from the Death Valley regional flow system, Nevada and California, 1913-98: U.S. Geological Survey Water-Resources Investigations Report 2003-4245, 28 p., https://doi. org/10.3133/wri20034245.

Moreo, M.T., and Justet, L., 2008, Update to the ground-water withdrawals database for the Death Valley regional groundwater flow system, Nevada and California, 1913-2003:

U.S. Geological Survey Data Series 340, 10 p., https://pubs. er.usgs.gov/publication/ds340.
Moreo, M.T., Laczniak, R.J., and Stannard, D.I., 2007, Evapotranspiration rate estimates of vegetation typical of ground-water discharge areas in the Basin and Range carbonate-rock aquifer system, Nevada and Utah, September 2005-August 2006: U.S. Geological Survey Scientific Investigations Report 2007-5078, 36 p., https:// doi.org/10.3133/sir20075078.

Morrison, R.B., 1999, Lake Tecopa-Quaternary geology of Tecopa Valley, California, a multimillion-year record and its relevance to the proposed nuclear waste repository at Yucca Mountain, Nevada, in Wright, L.A., and Troxel, B.W., eds., Cenozoic basins of the Death Valley region: B oulder, Colorado, Geological Society of A merica Special Paper 333, https://doi.org/10.1130/0-8137-2333-7.301.

Naranjo, R.C., Welborn, T.L., and Rosen, M.R ., 2013, The distribution and modeling of nitrate transport in the Carson Valley alluvial aquifer, Douglas County, Nevada: U.S. Geological Survey Scientific Investigations Report 20135136, 51 p., https://doi.org/10.3133/sir20135136.

National Climatic Data Center, 2017, 1981-2010 normals data access: National Oceanic and Atmospheric Administration National Climatic Data Center web page, accessed July 2017, at http://www.ncdc.noaa.gov/data-access/land-basedstation-data/land-based-datasets/climate-normals/19812010-normals-data.

National Security Technologies, LLC, 2007, A hydrostratigraphic model and alternatives for the groundwater flow and contaminant transport model of Corrective Action Unit 99-Rainier Mesa-Shoshone Mountain, Nye County, Nevada: U.S. Department of Energy Report DOE/NV/25946-146, 302 p., https://www.osti.gov/ biblio/934454.

Navarro, 2016b, Pahute Mesa well development and testing analyses for Well ER-20-11, Nevada National Security Site, Nye County, Nevada: Navarro Report N/0002653028-REV. 0, 175 p. [Also available at https://www.osti.gov/ biblio/1464519-pahute-mesa-well-development-testinganalyses-well-er-nevada-national-security-site-nye-countynevada-revision.]

Navarro, 2016a, Response to external peer review team report for Corrective Action Unit 97-Yucca Flat/Climax Mine, Nevada National Security Site, Nye County, Nevada: Navarro Report N/0002653-031-REV. 1, 272 p., https:// www.osti.gov/biblio/1465146.

Navarro-Intera, LLC, 2013, Phase I flow and transport model document for Corrective Action Unit 97-Yucca Flat/Climax Mine, Nevada National Security Site, Nye County, Nevada, Rev. 1: Las Vegas, Nevada, NavarroIntera Report N-I/28091-080, https://www.osti.gov/scitech/ biblio/1094979. 
Navarro-Intera, LLC, 2015, Evaluation of PM-3 chemistry data and possible interpretations of $3 \mathrm{H}$ observations: Navarro-Intera Report N-I/28091-092, 159 p.

Navarro Nevada Environmental Services, LLC, 2010, Phase II transport model of Corrective Action Unit 98-Frenchman Flat, Nevada Test Site, Nye County, Nevada: Navarro Nevada Environmental Services Report N-I/28091-004, $843 p$.

Nevada Division of Water Resources, 2018, Well log database query tool: Nevada Division of Water Resources web page, accessed January 2018, at http://water.nv.gov/.

Nevada State Engineer, 1979, State Engineer's Order No. 724- Designating and describing the A margosa Desert ground water basin, Nye County, Nevada: Carson City, Office of the State Engineer of the State of Nevada, 5 p., http://images.water.nv.gov/images/Orders/724o.pdf.

Nevada State Engineer, 2008a, State Engineer's Order No. 1197: Carson City, Office of the State Engineer of the State of Nevada, 2 p., http://images.water.nv.gov/images/ Orders/11970.pdf.

Nevada State Engineer, 2008b, State Engineer's Ruling 5902- In the matter of applications 69836, 69837, 70383, 72012, 72239, 72962, 73862, 74531, 74532, 74533, 74534, and 74535 , filed to change the point of diversion, place of use and manner of use of underground water previously appropriated under permit 60437 certificate 14999, permit 63235, permit 17417 certificate 5888, permit 31727 certificate 9318 , permit 66057 , permit 20352 certificate 5764, permit 66370, application 70383, application 69837, application 69836, permit 67957, and permit 67956, within the Amargosa Desert hydrographic basin (230), Nye County, Nevada: Carson City, Office of the State Engineer of the State of Nevada, 24 p., http://images.water.nv.gov/ images/Rulings/5902r.pdf.

Noble, D.C., Anderson, R.E., Ekren, E.B., and O'Connor, J.T., 1964, Thirsty Canyon tuff of Nye and Esmeralda Counties, Nevada, Article 126-Short papers in geology and hydrology: U.S. Geological Survey Professional Paper 475-D, p. 24-27.

Noble, D.C., Vogel, T.A., Weiss, S.I., Erwin, J.W., McKee, E.H., and Y ounker, L.W., 1984, Stratigraphic relations and source areas of ash-flow sheets of the Black Mountain and Stonewall Mountain volcanic centers, Nevada: Journal of Geophysical Research, v. 89, p. 8593-8602. [Also available at https://doi.org/10.1029/J B 089iB 10p08593.]

Oatfield, W.J., and Czarnecki, J.B., 1989, Hydrogeologic inferences from drillers' logs and from gravity and resistivity surveys in the Amargosa Desert, southern Nevada: U.S. Geological Survey Open-File Report 89-234, 29 p., https://doi.org/10.3133/ofr89234.
Osterkamp, W.R., Lane, L.J., and Savard, C.S., 1994, Recharge estimates using a geomorphic/distributedparameter simulation approach, Amargosa River basin: Water Resources Bulletin, v. 30, no. 3, p. 493-507, https:// doi.org/10.1111/j.1752-1688.1994.tb03308.x.

Pavelko, M.T., 2004, Estimates of hydraulic properties from a one-dimensional numerical model of vertical aquifersystem deformation, Lorenzi site, Las Vegas, Nevada: U.S. Geological Survey Water-Resources Investigations Report 2003-4083, 35 p., https://doi.org/10.3133/wri034083.

Pawloski, G.A., Tompson, A.F.B., and Carle, S.F., 2001, Evaluation of the hydrologic source term from the underground nuclear tests on Pahute Mesa at the Nevada Test Site-The CHESHIRE Test: Lawrence Livermore National Laboratory Report UCRL-ID-147023, 507 p.

Pistrang, M .A., and K unkel, F., 1964, A brief geologic and hydrologic reconnaissance of the Furnace Creek Wash area, Death Valley National Monument, California: U.S. Geological Survey Water-Supply Paper 1779-Y, 35 p., https://doi.org/10.3133/wsp1779Y.

Pollock, D.W., 2012, User guide for MODPATH version 6-A particle-tracking model for M ODFLOW: U.S. Geological Survey Techniques and Methods, book 6, chap. A41, 58 p. https://pubs.usgs.gov/tm/6a41/.

PRISM Climate Group, 2012, PRISM climate data, 30-year normal, Norm81m data set, created July, 2012: Oregon State University PRISM Climate Group web page, accessed M ay 2014, at http://prism.oregonstate.edu.

Prothro, L.B., and Drellack, S.L., Jr., 1997, Nature and extent of lava-flow aquifers beneath Pahute Mesa, Nevada Test Site: U.S. Department of Energy Report DOE/NV/11718156, 50 p., https://www.osti.gov/biblio/653925.

RamaRao, B.S., de M arsily, G., and M arietta, M .G., 1995, Pilot point methodology for automated calibration of an ensemble of conditionally simulated transmissivity fields - 1, Theory and computational experiments: Water Resources Research, v. 31, no. 3, p. 475-493, https://doi. org/10.1029/94W R 02258.

Reiner, S.R., L aczniak, R.J ., DeM eo, G.A., Smith, J.L., Elliott, P.E., Nylund, W.E., and Fridrich, C.J., 2002, $G$ round-water discharge determined from measurements of evapotranspiration, other available hydrologic components, and shallow water-level changes, Oasis Valley, Nye County, Nevada: U.S. Geological Survey Water-Resources Investigations Report 2001-4239, 65 p., https://doi. org/10.3133/wri014239. 
Rice, W.A ., 1984, Preliminary two-dimensional regional hydrologic model of the Nevada Test Site and vicinity: Albuquerque, New Mexico, Sandia National Laboratories Report SAND83-7466, 89 p., https://www.nrc.gov/docs/ M L 0330/M L 033070362.pdf.

Russell, C.E, 1987, Hydrogeologic investigations of flow in fractured tuffs, Rainier Mesa, Nevada Test Site: Las Vegas, University of Nevada, M.S. thesis, https://www.nrc.gov/ docs/M L 0330/M L 033010264.pdf.

Savard, C.S, 1998, Estimated ground-water recharge from streamflow in Fortymile Wash near Yucca Mountain, Nevada: U.S. Geological Survey Water-Resources Investigations Report 97-4273., 30 p., https://doi. org/10.3133/wri974273.

Sawyer, D .A ., Fleck, R.J ., L anphere, M .A ., Warren, R.G., Broxton, D.E., and Hudson, M.R., 1994, Episodic caldera volcanism in the Miocene southwestern Nevada volcanic field-Revised stratigraphic framework, $40 \mathrm{Ar} / 39 \mathrm{Ar}$ geochronology, and implications for magmatism and extension: Geological Society of America Bulletin, v. 106 , no. 10, p. 1304-1318, https://doi.org/10.1130/00167606(1994)106<1304:ECVITM>2.3.CO;2.

Sheets, R.A., Hill, M.C., Haitjema, H.M., Provost, A.M., and Masterson, J.P., 2015, Simulation of water-table aquifers using specified saturated thickness: Groundwater, v. 53, no. 1, p. 151-157, https://doi.org/10.1111/gwat.12164.

Simonds, F.W., 1989, Geology and hydrothermal alteration at the Calico Hills, Nye County, Nevada: Boulder, University of Colorado, unpublished M.S. thesis, 136 p.

Slate, J.L, B erry, M .E., Rowley, P.D., Fridrich, C.J ., M organ, K.S., Workman, J.B., Young, O.D., Dixon, G.L., Williams, V.S., McKee, E.H., Ponce, D.A., Hildenbrand, T.G., Swadley, W.C., Lundstrom, S.C., Ekren, E.B., Warren, R.G., Cole, J.C., Fleck, R.J ., L anphere, M .A., Sawyer, D.A., M inor, S.A., Grunwald, D.J ., L aczniak, R.J., M enges, C.M., Yount, J.C., and J ayko, A.S., 2000, Digital geologic map of the Nevada Test Site and vicinity, Nye, Lincoln, and Clark Counties, Nevada, and Inyo County, California: U.S. Geological Survey Open-File Report 99-554A, 53 p, scale 1:120,000, https://pubs.usgs.gov/of/1999/ofr-99-0554/.

Smith, D.K., 2002, Evaluation of the radiochemistry of nearfield water samples at the Nevada Test Site applied to the definition of a hydrologic source term: Lawrence Livermore National Laboratory Report UCRL-ID-149049, 55 p.

Smith, D.W., Moreo, M.T., Garcia, C.A., Halford, K.J., and Fenelon, J.M., 2017, A process to estimate net infiltration using a site-scale water-budget approach, Rainier M esa, Nevada National Security Site, Nevada, 2002-05: U.S. Geological Survey Scientific Investigations Report 20175078, 22 p., https://doi.org/10.3133/sir20175078.
Smith, J.L., Laczniak, R.J., Moreo, M.T., and Welborn, T.L., 2007, Mapping evapotranspiration units in the Basin and Range carbonate-rock aquifer system, W hite Pine County, Nevada, and adjacent parts of Nevada and Utah: U.S. Geological Survey Scientific Investigations Report 20075087, 20 p., https://doi.org/10.3133/sir20075087.

Stallman, R.W., 1971, Aquifer-test design, observation, and data analysis: U.S. Geological Survey Techniques of WaterResources Investigations, book 3, chap. B1, 31 p., https:// pubs.usgs.gov/twri/twri3-b1/.

Starkey, H.C., and Blackmon, P.D., 1979, Clay mineralogy of Pleistocene Lake Tecopa, Inyo County, California: U.S. Geological Survey Professional Paper 1061, 40 p., https:// doi.org/10.3133/pp1061.

Steinkampf, W.C., and Werrell, W.E., 2001, Ground-water flow to Death Valley, as inferred from the chemistry and geohydrology of selected springs in Death Valley National Park, California and Nevada: U.S. Geological Survey Water-Resources Investigations Report 98-4114, 37 p., https://doi.org/10.3133/wri984114.

Stoller-Navarro Joint Venture, 2004a, Phase II hydrologic data for the groundwater flow and contaminant transport model of Corrective Action Unit 98-Frenchman Flat, Nye County, Nevada: Las Vegas, Nevada, Stoller-Navarro Joint Venture Report S-N/99205-032, Rev. 0 [variously paged], https://www.osti.gov/biblio/840959.

Stoller-Navarro Joint Venture, 2004b, Unclassified source term and radionuclide data for the groundwater flow and contaminant transport model of Corrective Action Units 101 and 102, central and western Pahute Mesa, Nye County, Nevada: Las Vegas, Nevada, Stoller-Navarro Joint Venture Report S-N/99205-022, $171 \mathrm{p}$.

Stoller-Navarro Joint Venture, 2005a, Analysis of hydraulic responses from the ER-6-1 multiple-well aquifer test, Yucca Flat FY 2004 testing program, Nevada Test Site, Nye County, Nevada: Las Vegas, Nevada, Stoller-Navarro Joint Venture Report S-N/99205-051, 84 p., https://doi. org/10.2172/840943.

Stoller-Navarro Joint Venture, 2005b, Unclassified source term and radionuclide data for Corrective Action Unit 98-Frenchman Flat, Nevada Test Site, Nevada: Las Vegas, Nevada, Stoller-Navarro Joint Venture Report S-N/99205058, $498 \mathrm{p}$.

Stoller-Navarro Joint Venture, 2009, Phase I transport model of Corrective Action Unit 101 and 102 - Central and western Pahute Mesa, Nevada Test Site, Nye County, Nevada: Las Vegas, Nevada, Stoller-Navarro Joint Venture Report S-N/99205-111, Rev. 1, 696 p. 
Stonestrom, D.A., Prudic, D.E., Walvoord, M.A., Abraham, J.D., Stewart-D eaker, A .E., Glancy, P.A ., Constantz, J., Laczniak, R.J ., and A ndraski., B .J ., 2007, Focused groundwater recharge in the A margosa Desert basin, chap. E. of Stonestrom, D.A., Constantz, J., Ferre, T.P.A., and Leake, S.A., eds., Ground-water recharge in the arid and semiarid southwestern United States: U.S. Geological Survey Professional Paper 1703-E, 136 p., https://doi.org/10.3133/ pp1703E.

Sweetkind, D.S., Belcher, W.R., Faunt, C.C., and Potter, C.J ., 2010, Geology and hydrogeology, chap. B of B elcher, W.R., and Sweetkind, D.S., eds., D eath Valley regional groundwater flow system, Nevada and California-Hydrogeologic framework and transient ground-water flow model: U.S. Geological Survey Professional Paper 1711, p. 19-94, https://doi.org/10.3133/pp1711.

Sweetkind, D.S., Dickerson, R.P., B lakely, R., and Denning, P.D., 2001, Interpretive geologic cross sections for the Death Valley regional flow system and surrounding areas, Nevada and California: U.S. Geological Survey M iscellaneous Field Studies M ap M F-2370, 3 pls., 32 p., http://pubs.usgs.gov/mf/2001/mf-2370/.

Taylor, E.M., and Sweetkind, D.S., 2014, Three-dimensional geologic mapping of the Cenozoic basin fill, Amargosa Desert basin, Nevada and California: U.S. Geological Survey Scientific Investigations Report 2014-5003, 40 p., 2 appendixes, accessed September 7, 2017, at http://dx.doi. org/10.3133/sir20145003.

Theis, C.V., 1940, The source of water derived from wellsEssential factors controlling the response of an aquifer to development: Civil Engineering, v. 10, p. 277-280, https:// water.usgs.gov/ogw/pubs/Theis-1940.pdf.

Thomas, J.M., Welch, A.H., and Dettinger, M.D., 1997, Geochemistry and isotope hydrology of representative aquifers in the Great Basin region of Nevada, Utah, and adjacent States: U.S. Geological Survey Professional Paper 1409-C, 100 p., https://pubs.er.usgs.gov/publication/ pp1409C.

Thomasson Jr., H.G., Olmsted, F.H., and LeRoux, E.F., 1960, Geology, water resources and usable ground-water storage capacity of part of Solano County, California: U.S. Geological Survey Water-Supply Paper 1464, 693 p., https://doi.org/10.3133/wsp1464.

U.S. Department of Energy, 2010, Environmental restoration: U.S. Department of Energy Fact Sheet DOE/NV-537, Rev. 4, 2 p, accessed September 2013, at http://nnss.gov/ docs/fact_sheets/DOENV_537.pdf.
U.S. Department of Energy, 2015, U nited States nuclear tests, J uly 1945 through September 1992: U.S. Department of Energy Report DOE/NV-209 REV 16, 129 p. [Also available at https://www.nnss.gov/docs/docs_ LibraryPublications/DOE_NV-209_Rev16.pdf.]

U.S. Department of Energy, 2018, Rainier M esa/Shoshone Mountain flow and transport model report-Nevada National Security Site, Nevada, Rev. 1: U.S. Department of Energy Report DOE/NV-1588, https://www.osti.gov/ biblio/1465819-rainier-mesa-shoshone-mountain-flowtransport-model-report-nevada-national-security-sitenevada-revision.

U.S. Environmental Protection Agency, 2017, National Primary Drinking Water Regulations: Code of Federal Regulations, title 50, part 141, https://www.govinfo.gov/ content/pkg/CFR-2017-title40-vol25/xml/CFR-2017title40-vol25-part141.xml.

U.S. Geological Survey, 2018b, Aquifer tests: Carson City, Nevada, U.S. Geological Survey, Nevada Water Science Center web site, accessed June 2018, at http://nevada.usgs. gov/water/aquifertests/index.htm.

U.S. Geological Survey, 2018a, USGS National Water Information System - Web Interface: U.S. G eological Survey National Water Information System database, accessed December 2018, at https://waterdata.usgs.gov/ nwis.

Waddell, R.K., 1982, Two-dimensional, steady-state model of ground-water flow, Nevada Test Site and vicinity, NevadaCalifornia: U.S. Geological Survey Water-Resources Investigations Report 82-4085, 72 p., 1 pl., https://doi. org/10.3133/wri824085.

Walker, G.E., and Eakin, T.E., 1963, Geology and ground water of Amargosa Desert, Nevada-California: Nevada Department of Conservation and Natural Resources, Water Resources- Reconnaissance Series Report 14, 45 p., http:// images.water.nv.gov/images/publications/recon\%20reports/ rpt14-Amargosa_valley.pdf.

Waring, G.A ., 1921, Ground water in Pahrump, M esquite, and Ivanpah Valleys, Nevada and California: U.S. Geological Survey Water-Supply Paper 450-C, p. 51-86., https://doi. org/10.3133/wsp450C.

Wells, S.G., M CF adden, L.D., Renault, C.E., and Crowe, B.M ., 1990, Geomorphic assessment of late Quaternary volcanism in the Yucca Mountain area, southern Nevada-Implications for the proposed high-level radioactive waste repository: Geology, v. 18, no. 6, p. 549-553. [Also available at https:// doi.org/10.1130/0091-7613(1990)018<0549:GA OLQV >2. 3.CO;2.] 
Westenburg, C.L., 1993, Water-resources data for the Devils Hole area, Nye County, Nevada, July 1978-September 1988: U.S. Geological Survey Open-File Report 90-381, 13 p., https://doi.org/10.3133/ofr90381.

Williams, O.R., A lbright, J.S., Christensen, P.K., Hansen, W.R., Hughes, J.C., J ohns, A.E., M cG lothlin, D.J ., Pettee, C.W., and Ponce, S.L., 1996, Water rights and Devil's Hole pupfish at Death Valley National Monument, in Halvorson W.L. and Davis, G.E. eds., Science and ecosystem management in the national parks: Tucson, University of A rizona Press, p. 161-183.

Winograd, I.J., and Pearson, F.J., Jr., 1976, Major carbon-14 anomaly in a regional carbonate aquifer-Possible evidence for megascale channeling, south-central Great B asin:

Water Resources Research, v. 12, p. 1125-1143, https://doi. org/10.1029/W R 012i006p01125.

Winograd, I.J., Riggs, A.C., and Coplen, T.B., 1998, The relative contributions of summer and cool-season precipitation to groundwater recharge, Spring M ountains, Nevada, USA: Hydrogeology Journal, v. 6, no. 1, p. 77-93, https://doi.org/10.1007/s100400050135.
Winograd, I.J., and Thordarson, W., 1975, Hydrologic and hydrochemical framework, south-central Great Basin, Nevada-California, with special reference to the Nevada Test Site: U.S. Geological Survey Professional Paper 712-C, p. C1-C126. https://doi.org/10.3133/pp712C.

Western Regional Climate Center, 2016, Recent climate in the West: Western Regional Climate Center web page, accessed M ay 2016, at http://www.wrcc.dri.edu/.

Wolfsberg, A., Glascoe, L., L u, G., Olson, A ., Lichtner, P., McGraw, M., Cherry, T., and Roemer, G., 2002, TYBO/ BENHAM-Model analysis of groundwater flow and radionuclide migration from underground nuclear tests in southwestern Pahute Mesa, Nevada: Los Alamos National L aboratory Report LA -13977, 490 p.

Yager, R.M ., M aurer, D.K., and M ayers, C.J ., 2012, A ssessing potential effects of changes in water use with a numerical groundwater-flow model of Carson Valley, Douglas County, Nevada, and Alpine County, California: U.S. Geological Survey Scientific Investigations Report 2012-5262, 73 p., https://doi.org/10.3133/sir20125262. 
Publishing support provided by the U.S. Geological Survey Science Publishing Network, Tacoma Publishing Service Center

For more information concerning the research in this report, contact the Director, Nevada Water Science Center

U.S. Geological Survey

2730 N. Deer Run Road

Carson City, Nevada 89701

https://www.usgs.gov/centers/nv-water 
